Geothermal Energy in Idaho:

Site Data Base and Development Status

Prepared for

U.S. Department of Energy (USDOE)

San Francisco Operations Office

Oakland, California

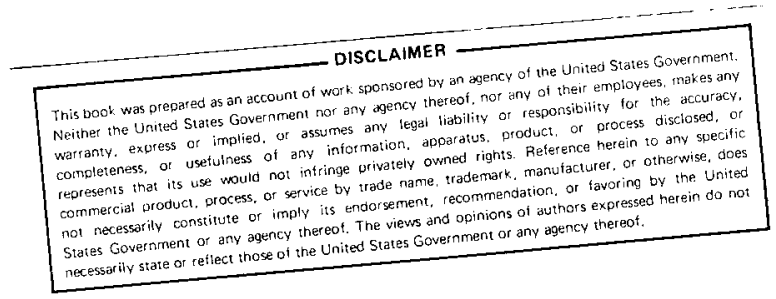

Contract No. DE-AC03-79SF 1049

by

David W. McClain, Research Associate

Geo-Heat Utilization Center

Klamath Falls, Oreaon 97601

July, 1979 


\section{DISCLAIMER}

This report was prepared as an account of work sponsored by an agency of the United States Government. Neither the United States Government nor any agency Thereof, nor any of their employees, makes any warranty, express or implied, or assumes any legal liability or responsibility for the accuracy, completeness, or usefulness of any information, apparatus, product, or process disclosed, or represents that its use would not infringe privately owned rights. Reference herein to any specific commercial product, process, or service by trade name, trademark, manufacturer, or otherwise does not necessarily constitute or imply its endorsement, recommendation, or favoring by the United States Government or any agency thereof. The views and opinions of authors expressed herein do not necessarily state or reflect those of the United States Government or any agency thereof. 


\section{DISCLAIMER}

Portions of this document may be illegible in electronic image products. Images are produced from the best available original document. 
FOREWORD

Among the most critical of problems facing our nation is energy resources. Though there may be minor disagreement about the specifics, magnitude and solutions to these problems there can be no question about their urgency and of the necessity for immediate action. In an effort to in part resolve these questions by accelerating utilization of one of our renewable resources, the U. S. Department of Energy has developed a program of National and Regional Planning and Operations Research of geothermal energy resources.

The OIT Geo-Heat Utilization Center, under contract to USDOE, has evaluated the geothermal energy resource development potential of the six northwest states of Alaska, Idaho, Montana, Oregon, Washington, and Wyoming. Our goal has been to summarize for this region on a site-specific basis the various factors affecting development including resource data base, geological description, reservoir characteristics, environmental character, lease and development status, institutional factors, economics, population and market, and finally potential for development. This report summarizes the known data base for the state of Idaho.

As so little geothermal resource data is available this then represents a progress report in a young but rapidly developing field of knowledge. The continuation of this project now underway is attempting to complete this core of site information and identify data on new significant sites, provide accurate information and recommendations to policy and decision-makers, and ultimately to assist in evolving more effective regional and national geothermal energy programs.

R. P. Koeppen

July, 1979 
$\theta$

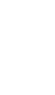
. 
Idaho cannot isolate itself from acknowledging national and regional patterns indicating we are moving more and more out of balance with our indigenous energy resources. In response to the growing need for energy policy coordination, the Idaho Office of Energy was established by an Executive Order 74-2 in October, 1973, by Governor Cecil D. Andrus, and renewed by Governor John V. Evans in July, 1978. The Executive Order concluded that the conservation of energy and natural resources must be viewed as "an effort to save energy, acquire the knowledge, and gain the time, necessary to change to patterns of consumption and economic development consistent with our available resources especially the renewable energy resources available in Idaho."

Pursuant to this goal the United States Department of Energy, and Oregon Institute of Technology, and the Idaho Office of Energy entered into a joint contractual agreement to compile a data base concerning the geothermal energy. development potential of the State of Idaho. The data presented in this text provides the necessary base information to formulate local, state, federal and private development planning affecting geothermal energy resources in Idaho.

This report should not be construed as an advocacy for geothermal development. The information presented is a measure of the geothermal energy production and consumption that is realistically possible for the period between now and the year 2020. Information presented is meant to be used as tools for policy makers, not as a description of destiny.

This project included contributions from the following personnel: Robert Koeppen, Project Coordinator, Charles Higbee, Gene CuIver, John Lund, Bill King, Gordon Bloomquist, Keith Brown, Debra Justus, Don Markle, Rick James, all of Oregon Institute of Technology; Kirk Hall and Marty Montgomery, of Idaho Office of Energy; and John Mitchell of Idaho Department of Water Resources.

Special thanks are given to Marjorie Pratt, Barbara Bassick, and Debbie Allen of the Idaho Office of Energy as well as to Colleen Fry of the Geo-Heat Center for their clerical help. 


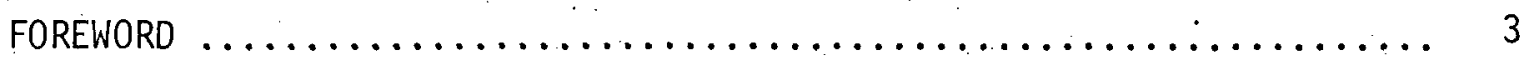

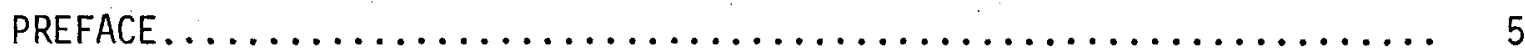

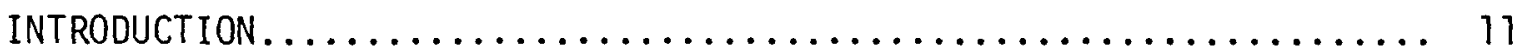

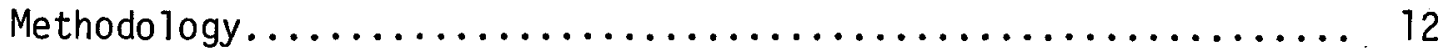

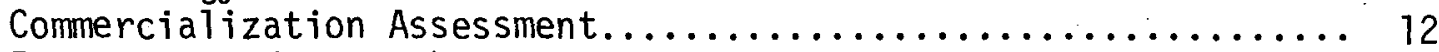

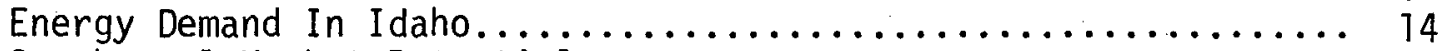

Geothermal Market Potential........................ 17

SUMMARY OF PROJECTED GEOTHERMAL DEVELOPMENT $\ldots \ldots \ldots \ldots \ldots \ldots \ldots \ldots \ldots 19$

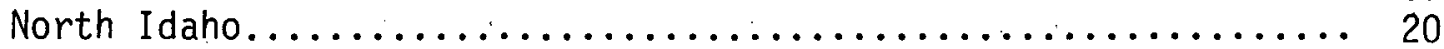

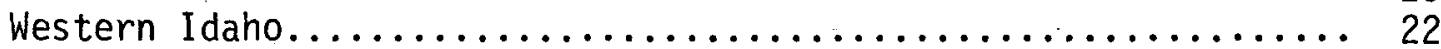

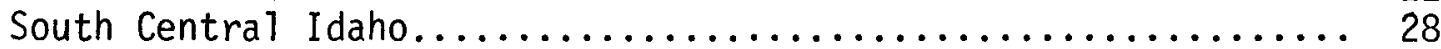

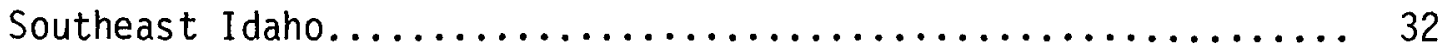

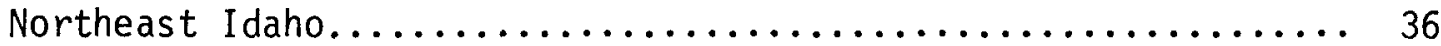

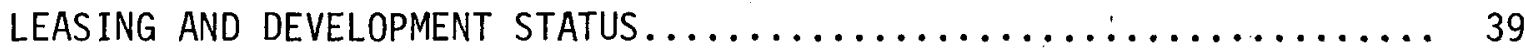

Leasing Status KGRA........................... 40

Leasing Noncompetitive, Federal................... 42

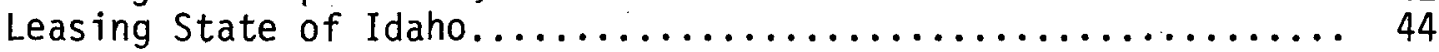

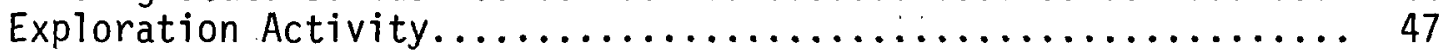

KGRA Development Status ......................... 56

INSTITUTIONAL PARAMETERS $\ldots \ldots \ldots \ldots \ldots \ldots \ldots \ldots \ldots \ldots \ldots \ldots \ldots \ldots$

Institutional. Controls

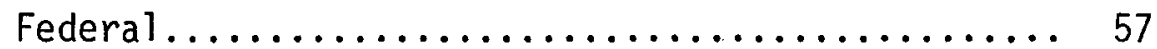

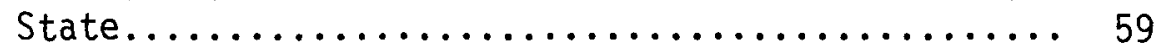

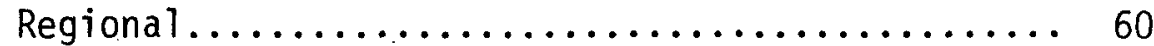

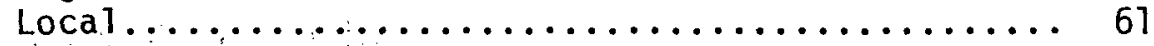

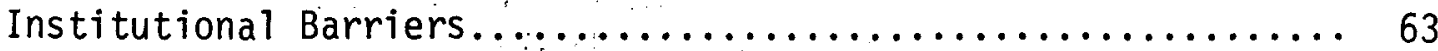

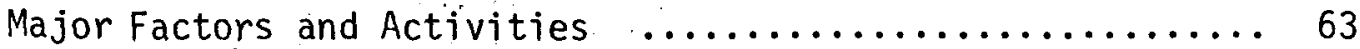

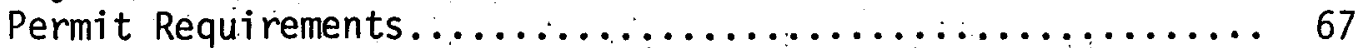

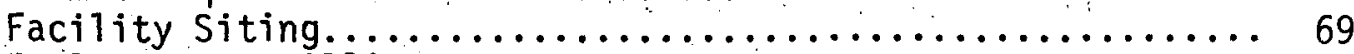

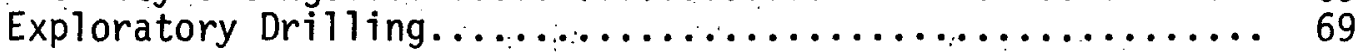

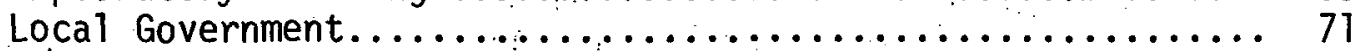

LEGAL OVERVIEW OF GEOTHERMAL RESOURCES IN IDAHO $\ldots \ldots \ldots \ldots \ldots \ldots \ldots \ldots$

Federal Law

Geothermal Steam Act.......................... 73

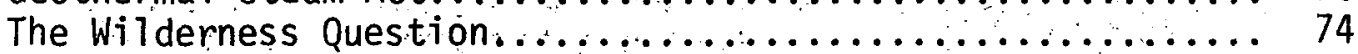

Idaho Law

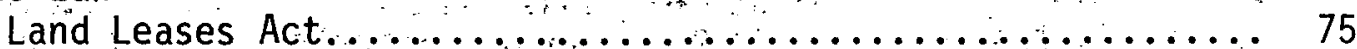

Geothermal Resources Act...................... 76

Appropriation Doctrine........................ 79

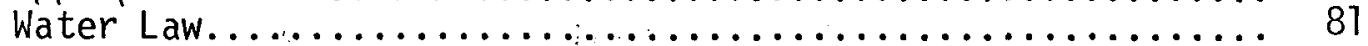


Critical Groundwater Designation.................... 81

Injectional wells ............................. 82

Reservation Doctrine Applied to Geothermal Resource........... 83

The Role of State Regulations in Federal Geothermal Leases..... 84

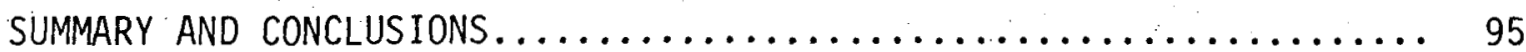

SELECTED BIBLIOGRAPHY $\ldots \ldots \ldots \ldots \ldots \ldots \ldots \ldots \ldots \ldots \ldots \ldots \ldots . \ldots . \ldots \ldots$

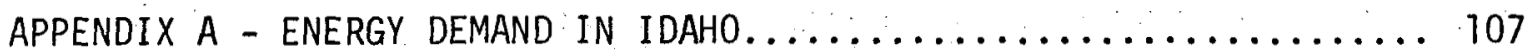

APPENDIX B - GEOTHERMAL DEVELOPMENT REGION I
Northern Idaho..................... 135

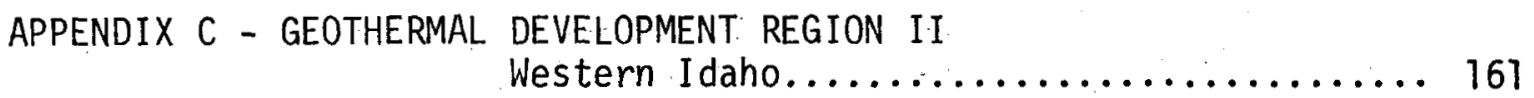

APPENDIX D - GEOTHERMAL DEVELOPMENT REGION III
South Central Idaho................. 343

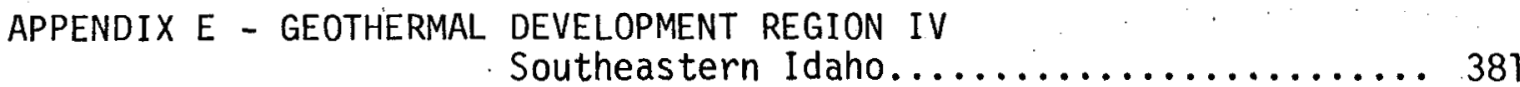

APPENDIX F - GEOTHERMAL DEVELOPMENT REGION $V$
Northeastern Idaho.................. 425

Table 1, Western Intermountain Subregion

Projected Geothermal Development.............. 24

Table 2, Western Snake River Plain Subregion

Projected Geothermal Development.............. 25

Table 3, South Central Idaho Region Projected

Geothermal Development....................... 31

Table 4, Southeast Idaho Region Geothermal

Deve1opment Projections..................... 35

Table 5, Northeast Idaho Region Geothermal

Development Projections................... 38

Table 6, Known Geothermal Resource Areas (KGRA's)

As Classified by the U.S. Geological Survey............ 40

Table 7, Total Acreages of Geothermal Resource Leases

in the State of Idaho (October 1978)............ 40

Table 8, Known Geothermal Resource Areas, Acreages, and Lessees

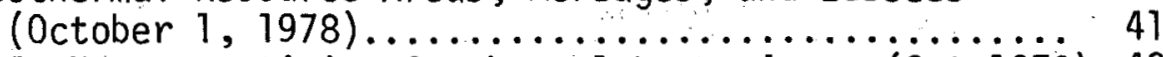

Table 9, Leasing In Non-competitive Geothermal Lease Areas (Oct.1978) 42

Table 10, Non-competitive Geothermal Leasing Summary Status Report, Idaho (October 1,1978 )................ 43 
Table 11, State of Idaho Geothermal Leases, Total Acreage per County Leased, State School and Other State Lands (October 1978).......................... 44

Table 12, Idaho Share Mineral Leasing Collections by Commodity (October 1, 1977 to March 37, 1978)............ 45

Table 13, Idaho Counties Share of Mineral Leasing Monies.......... 46

Table 14, Federal Geothermal Leases in Idaho................... 47

Table 15, Summary of Projected Geothermal Development............ 97

\section{TABLE OF FIGURES}

Figure 1, Idaho Energy Consumption by Sector............... 15

Figure 2, Idaho Total Energy Demand Forecast (Moderate Case)....... 15

Figure 3, Geothermal Resource areas...................... 16

Figure 4, Geothermal Development Region I, Northern Idaho......... 20

Figure 5, Geothermal Development Region II, Western Idaho........ 22

Figure 6, Geothermal Development Region III, South Central Idaho... 28

Figure 7, Geothermal Development Region IV, Southeastern Idaho..... 32

Figure 8, Geothermal Development Region V, Northeastern Idaho...... 36

Figure 9, Institutional Barrier Analysis................... 68 

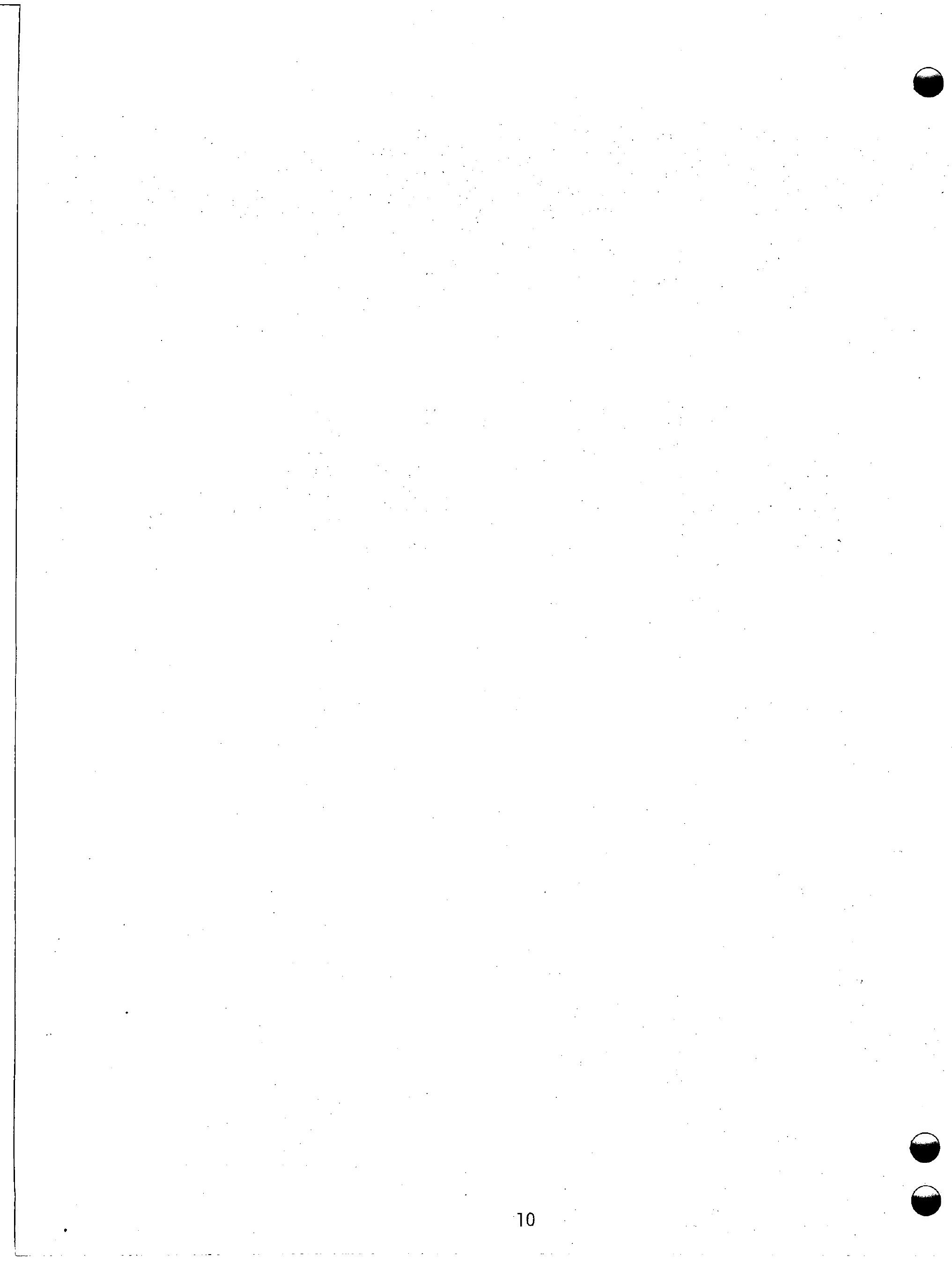
There is considerable potential in Idaho for expanded direct applications of geothermal resource for spaceheating, industrial applications and electric power generation. The following report presents a summary of known information about the nature of the resource, its potential for development, and the infrastructure of government which will guide future development.

Locational data is presented by regions. The regional divisions are designed to be compatible with present Idaho State Planning Regions and Federal Bureau of Land Management regional management districts.

The optimum location in the United States for the development of geothermal energy resources are the volcanic regions of the western states. Tremendous volumes of young volcanic and intrusive rocks exist in the state of Idaho and make it a prime geothermal exploration and development region. More than 200 thermal springs are scattered throughout Idaho and in several areas regional ground water tables are warm to hot. The most extensive thermal ground waters are found in the Snake River Plain region. These thermal waters are indicative of the large geothermal resource potential in Idaho. Against this attractive exploration setting, only a modest amount of development has occurred and this has been largely confined to localized space heating of green houses, swimming pools, and a few buildings. Presently, there is a growing concern, by both private interest and government agencies to expand and accelerate development of geothermal resources within the state. An indication of the extent of development interest is that over 381,688 acres of state and federal 1ands have been leased for geothermal exploration.

The potential for use of geothermal energy resources in Idaho seems to be substantial with the most promising localities located in the Snake River Plain and Basin and Range physiographic provinces. Al though numerous thermal springs are located in the mountainous interior regions of Idaho, the development potential of these isolated localities is limited.

A major conflict that can arise with development of an energy resource is competition for 1 and. New industrialization often permanently changes the present land uses of an area. A most important characteristic of geothermal energy is its potential for utilizing. . local resources instead of competing with local resources. flexibility of this type makes geothermal energy a highly compatible future alternative energy resource.

The predominant land use in the Snake River Plain from Payette to Idaho Falls, Idaho is agriculture. This agriculture is limited by the amount of land that can be successfully irrigated or dry-farmed. If geothermal resources in the Snake River Plain region are developed, they must be compatible with the present land uses of this region, and 
an integrated part of the agricultural economy. The principal land uses in the interior mountainous regions of Idaho are timber management and recreation. If geothermal resources are developed in this region, then it must be done so in a manner sensitive to the recreation potential of the region.

The transfer of geothermal energy over great distances can in most cases best be accomplished by converting it to electrical energy. Since thermal fluids cannot be transported great distances, the spatial extent of the resource's development will generally be limited to site specific areas. Clearly, a major consequence of geothermal resource. development could be the migration of certain industrial plants to the source of the geothermal heat. Should this occur then flowing from this impact is a host of higher order impacts associated with 1 and use changes, demographic shifts, and regional economics. Development of geothermal resources is dependent on the resource: interfacing with the local economic needs and opportunities in the area where the geothermal well is located. Furthermore, the location and degree of geothermal development is dependent upon the legal and institutional framework that governs the proposed development site. "This report presents. detailed site specific data regarding the commercialization potential of the proven, potential and inferred geothermal resource areas in Idaho.

\section{Methodology}

To assess the potential for geothermal resource development in Idaho, several kinds of data were obtained. These include information. regarding institutional procedures for geothermal development, logistical procedures for utilization, energy needs and forecasted demands, and resource data. Area reports, data sheets, and scenarios were prepared that described possible geothermal development at individual sites. In preparing development projections, the objective was to base them on actual market potential ; forecasted growth, and known or inferred resource conditions. To the extent possible, power-on-line dates and energy utilization estimates are realistic projections of the first events. Commercialization projections were based on the assumption that an aggressive development program will prove sufficient known and inferred resources to accomplish the projected event.

The reader is cautioned that this is at best, a rough gauge of the market potential of geothermal energy which could be developed between the present and 2020. Because of a lack of data, it is not possible to estimate the recoverable energy available. This report is an estimate of probable energy developable under an aggressive exploration program and is considered "extremely conservative.

\section{Commercia]ization Assessment}

Several kinds of cultural, environmental, geological institutional 
and legal data were considered in developing commercialization scenarios that would reasonably reflect characteristics specific to each geothermal resource site. These include population, economic conditions, growth rate, energy demand, geological conditions, geochemical temperature estimates, topography, land ownership and legalinstitutional factors.

\section{Population:}

Population estimates were obtained from various local, state and federal reports. In all cases, the most current data available was used. A dwelling-unit occupancy rate of 3.0 was assumed and field inspection was used to determine the estimated number of dwelling units that may be incorporated in a development.

Economic Conditions:

Economic conditions around each resource area were assessed in order to determine what type of geothermal development would be most reasonable. This was in part empirical, derived from field inspections and in part complemented by current economic statistics provided by the Idaho Department of Agriculture.

Energy Demand :

Local energy demand estimates were obtained from current consumption of natural gas, and electricity, field surveys, and direct energy coefficients per employee. Industrial demand was obtained by use of direct energy coefficients. There are two basic pieces of data generally available for industrial plants, the Standard Industrial Classification Code and the number of employees. Direct energy intensity coefficients can be derived in terms of billions of BTU's per employee for each SIC code. The energy intensity coefficients used to determine industrial energy demand estimates, were obtained from Rocket Research Company, Idaho Office of Energy, and the Pacific Northwest Regional Commission.

\section{Geological Conditions:}

Local geological and geochemical information was obtained from various reports. The majority of the most current data concerning geothermal resources was obtained from the Idaho Department of Water Resources: Geochemical data was used to determine assumed geothermat reservoir temperatures. A minimum temperature of $40{ }^{\circ} \mathrm{C}$ was assumed to be the lowest temperature that would be beneficial for direct use. A minimum temperature of $150^{\circ} \mathrm{C}$ was assumed to be the lowest temperature for electrical generation. Geothermal resources are classified in this report as: proven, potential, and inferred. Proven resources have been measured and there is sufficient resource available to accomplish the projected development. Potential resources are indicated from surface manifestations of thermal water and geochemical 
thermometry, but the resource has not been measured and the reservoir field has not been defined. Inferred resources are assumed to exist because of favorable geological and geophysical conditions but the resource has not been substantiated.

Environment:

Local environmental conditions were considered for each site development scenario. Climate, topography, habitat, and critical environmental issues are presented. Data was obtained from U.S. Department of Commerce, U.S. Fish and Wildlife Service, U.S. Forest Service, and field observations.

\section{Legal Institutional:}

Local, State and Federal institutional considerations were incorporated into the scenario matrix and their aggregate effect is expressed into time line sequences of the projected development. Institutional considerations are presented for each resource area in the individual site reports. Although federal and state institutional considerations are generally common to al1 sites, locally institutional factors may substantially vary from one resource area to another.

\section{Energy Demand in Idaho}

A critical issue facing policy makers is the extent it is possible or desirable to change future energy growth.: It is clear that future energy growth in. Idaho will be largely determined by forces outside the control of regional, state, and local policy-makers. Nevertheless, these policy makers can influence the rate of growth in energy supply and to some degree influence or change the type and rate of growth in energy demand.

An array of policy options and their impacts must be available in order for policy makers to make decisions based on careful and systematic analysis of all available information. The aggregate energy demand of Idaho is 230 trillion BTU's per year. Non transportation energy consumption accounts for approximately $67 \%$ of this energy demand (Figure 1). By the year 2000, Idaho's total energy demand is forecasted to exceed 320 trillion BTU's per year, if growth continues at its present moderate rate (Figure 2). This represents a $1.8 \%$ annual rate of growth in energy consumption. Idaho's geothermal resources could contribute to the energy supply. 
FIGURE I IDAHO ENERGY CONSUMPTION BY SECTOR

Source: Idaho Office of Energy

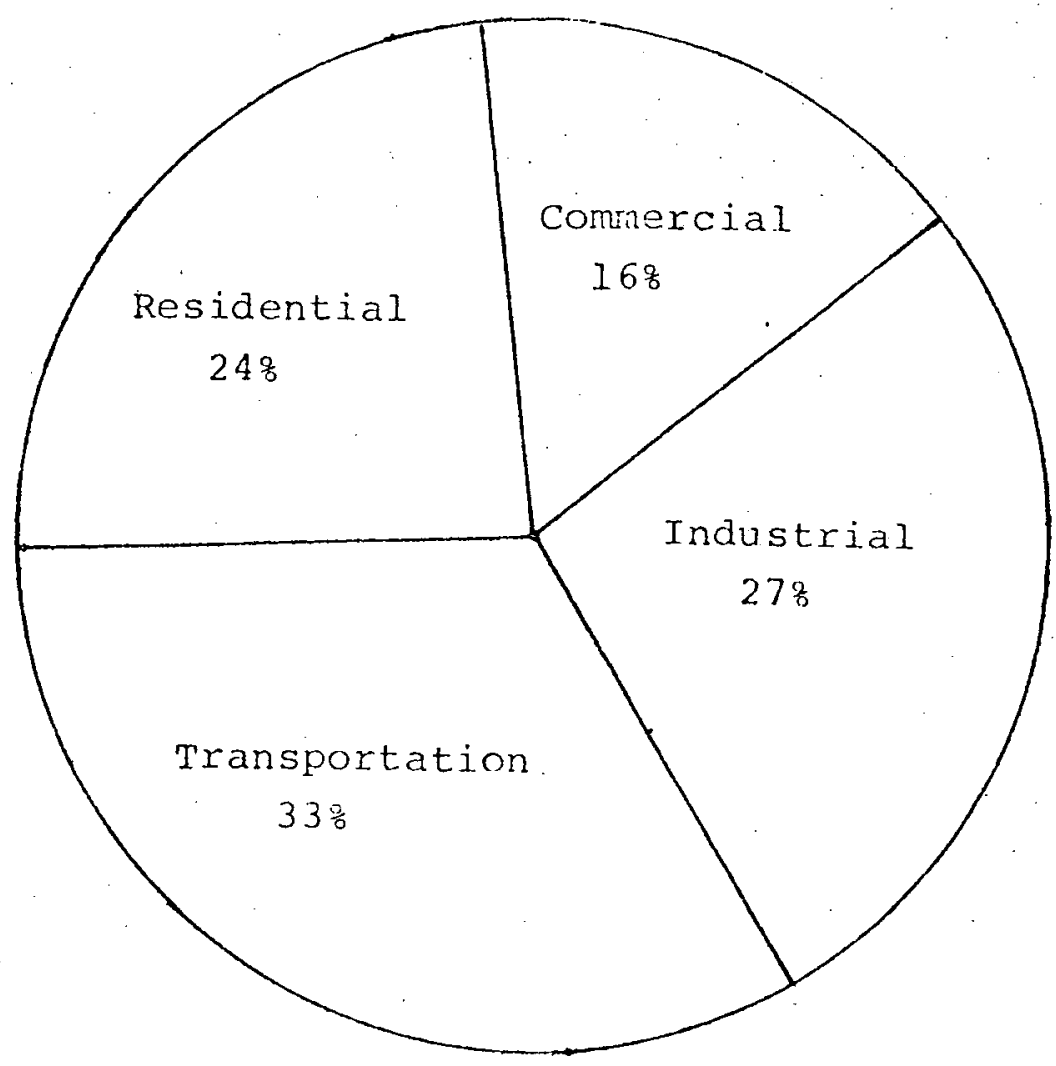

$227.9 \times 1012$ BTUs per year

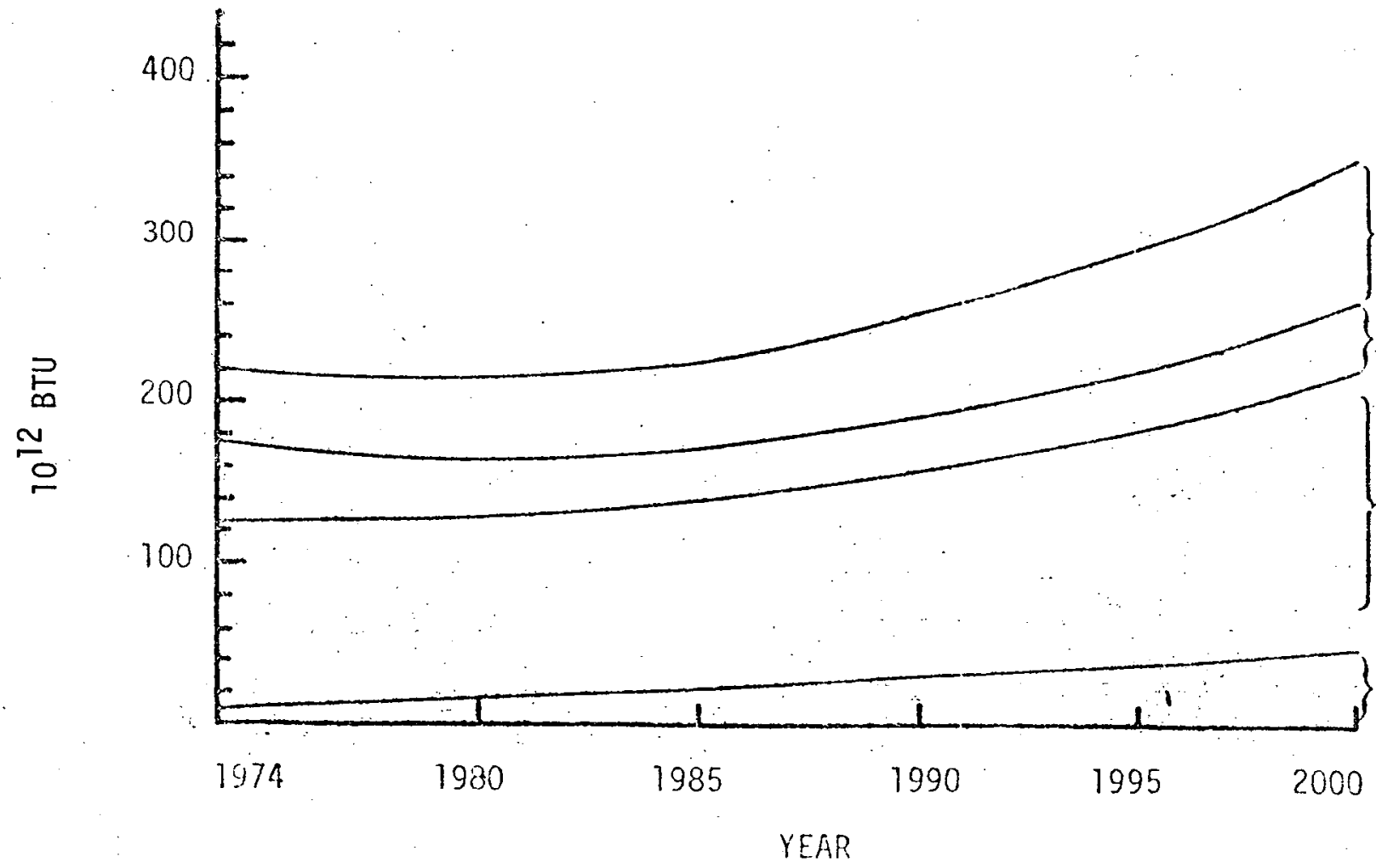

ELECTPICTTY

NATURAL GAS

OIL

COAL.

FIGL'RE 2 IDAHO TOTAL ENERGY DEMAND FORECAST (Moderate Case) Source: Northwest Energy Policy Project, Pacific Northwest Regional Commission 


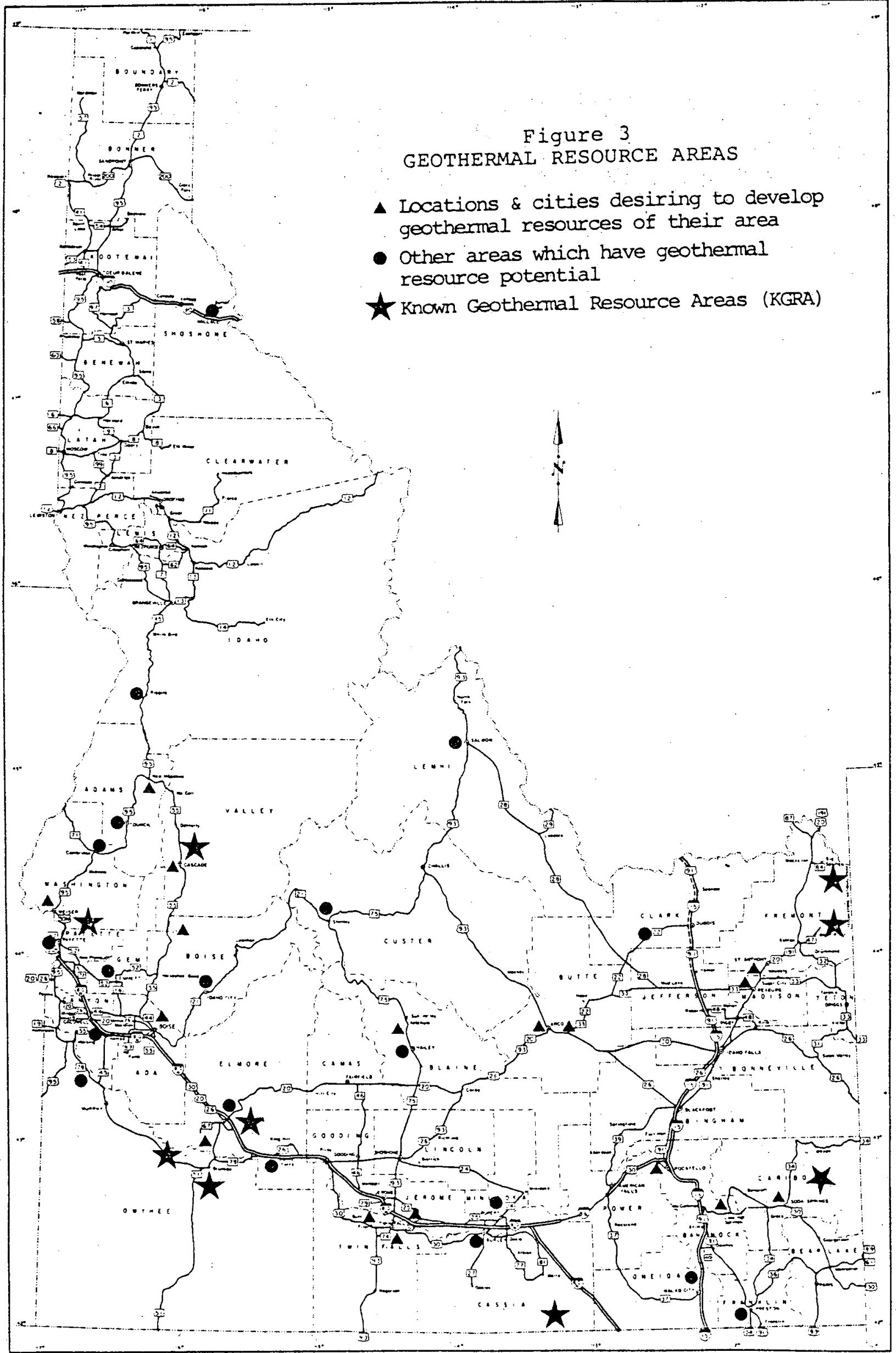


The potential for utilizing geothermal energy in Idaho will be largely confined to the residential, commercial, and industrial sectors. The major impact of geothermal utilization by Idaho consumers will be to deter some of the projected growth in natural gas, electricity, and coal energy. Minor impact can be expected in projected petroleum consumption because the majority of this energy consumption will be in the transportation sector.

The major energy end use in the residential sector is for space heating and water heating. These two end uses account for approximately 89 percent of the total residential energy consumption. It is a well known fact that geothermal energy, when available, can fulfill these energy needs. Seventeen communities in Idaho have contacted the Idaho office of Energy regarding their desire to develop the geothermal energy of their area. An additional fifteen communities have also been identified as having significant geothermal resource potential. This represents a statewide potential of 229,955 people, living in close proximity (less than $20 \mathrm{~km}$ ) of potential geothermal resources. In terms of national population this is not a significant number of people, but in terms of Idaho's population this number represents almost one-third of the State population and onehalf of the urban population (Figure 3 ).

Space heating and water heating in the residential sector account for 20 percent of the total energy consumption in the state. Space heating in the commercial sector accounts for an additional ten percent of Idaho's total energy consumption. Space heating is the largest energy-consuming area which is compatible to direct use of low temperature geothermal resources. In Idaho, space heating in the residential and commercial sectors 'accounts for $68.2 \times 10^{12}$ BTU per year of direct energy consumption. The most logical and obvious use for geothermal resources in the residential and commercial sector is to help meet present and future space heating needs.

The 32 largest industrial plants in Idaho account for 71 percent $(44 \times 1012$ BTU) of the industrial energy. consumption in the state. The food and kindred products industry, the Tumber and paper products industry and chemical products industry are the major industrial consumers of energy in Idaho. The chemical products industry in Idaho is largely phosphate ore reduction to make fertilizers. This industry gets 70 percent of its energy from electrical power and less than 30 percent from natural gas. The use of geothermal resources in phosphate reduction would be very limited. Geothermal energy could contribute to the demand needs of this industry by developing new electrical generation facilities.

The lumber and paper products industry could use geothermal resources but would require high temperature resources. The majority of Idaho!s lumber and paper products industries are located in Northern and Central Idaho and somewhat isolated from the major geothermal areas of the State. Limited uses of geothermal energy in 
this industrial sector are possible but major contributions by geothermal energy resources are not foreseen.

Of the three major industrial sectors in Idaho's economy, the food and kndred products industry is the one industrial section which could directly utilize large quantities of geothermal resources. This industrial sector is the largest natural gas consuming sector in Idaho, accounting for 20 percent of the state's total natural gas consumption. The food products industry has the largest industrial energy demand in Idaho. This demand is approximately $20 \times 10^{12}$ BTU per year and 70 percent of this energy is natural gas and approximately 20 percent is coal.

Twenty-two of the thirty-two largest industrial facilities in Idaho are food processing plants. Twenty, of these food processing facilities are located in the Snake River Plain within $50 \mathrm{~km}$ of known geothermal resources. These twenty plants account for 16.77 $x 10^{12}$ BTU per year of direct energy consumption. These plants are primarily potato, sugar beet and vegetable processing facilities. All of these plants require hot water and could utilize large quantities of geothermal fluids.

The present potential for use of geothermal energy in Idaho industry is in providing hot fluids to present food processing facilities and new electrical generation capacity for the growing phosphate industry.

In the future, long range, industrial geothermal energy development will depend upon utilizing undeveloped geothermal resource localities for siting new industrial facilities. Such facilities will most likely be an extension of an expanding agriculture economy. New food processing facilities, particularly potato processing facilities, will be needed over the next forty year period. The applications of geothermal energy to fulfill the energy needs of this form of industrial expansion is a logical alternative to the present energetics of Idaho's economy.

A detailed energy analysis of Idaho's present energy demand and forecasted energy demand is presented in Appendix $A$. 


\section{PROJECTED GEOTHERMAL DEVELOPMENT}

\section{IN IDAHO}

The following information is a summary of projected geothermal development in Idaho between the present and the year 2020. Selection of commercialization locations is based on known resource data, regional and local socioeconomic data, leasing data, and exploration activity. Projected development at each site is based on a general assumption that the resource is present and could be developed with current and near future technology. The resource is classified as proven, potential or inferred, according to previously outlined criteria, for each development location. Projected electric power developments assume that all potential sites will utilize a binary cycle electric generation facility. The minimum economical generation unit is assumed to be $50 \mathrm{MW}$. Projected nonelectrical developments are a measure of the local market potential which could be satisfied by the proven, potential or inferred geothermal resources of the area. Estimated dates for energy-on-line are given for each site and based on the assumption that current and future interest will diligently pursue exploration and commercialization. Individual site projections are presented by regional divisions which are compatible with Idaho State Planning Regions and Bureau of Land Management Districts. Five geothermal development regions have been designated by this report: North Idaho, Western Idaho, South Central Idaho, Southeast Idaho, and Northeast Idaho. Detailed site specific data regarding the commercialization projections are presented in the regional appendixes of this report. 


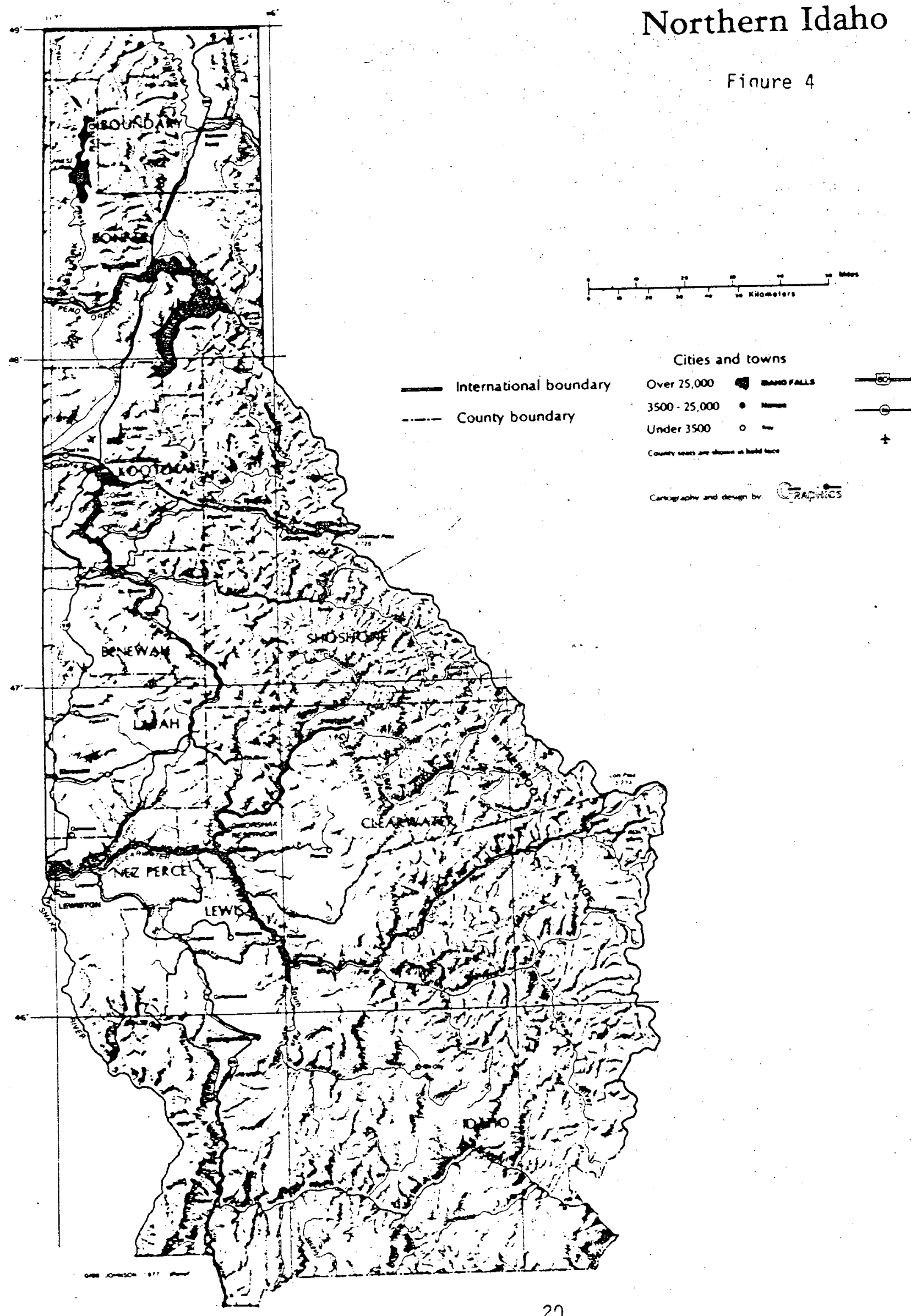


GEOTHERMAL DEVELOPMENT REGION I

NORTH IDAHO

The panhandle region of northern Idaho encompasses all of the counties north of the southern boundary of Idaho County. This large region encompasses about one-third of the state's land mass. Most of the known geothermal occurrences in this region are located in remote mountainous areas. The majority of the known thermal springs are located within the Selway-Bitteroot Wilderness Area, which restricts motorized traffic. The thermal areas of this region are isolated by rough mountainous terrain and the political and economic outlook is unfavorable for any development.

Two geothermal areas, outside of the Wilderness Area, have limited development potential. The two areas are Riggins Hot Springs and Burgdorf Hot Springs. The Riggins area is the only known geothermal area in North Idaho spatially located near a potential market area. Riggins Hot Springs is located near a potential market area. Riggins Hot Springs is located 12 kilometers east of the town of Riggins. Development of geothermal resources for use in this community is unlikely. Burgdorf is an isolated seasonal resort which is not expected to expand. In general, no major geothermal development activity is forecasted for Northern Idaho. 


\section{Geothermal Development Region II}

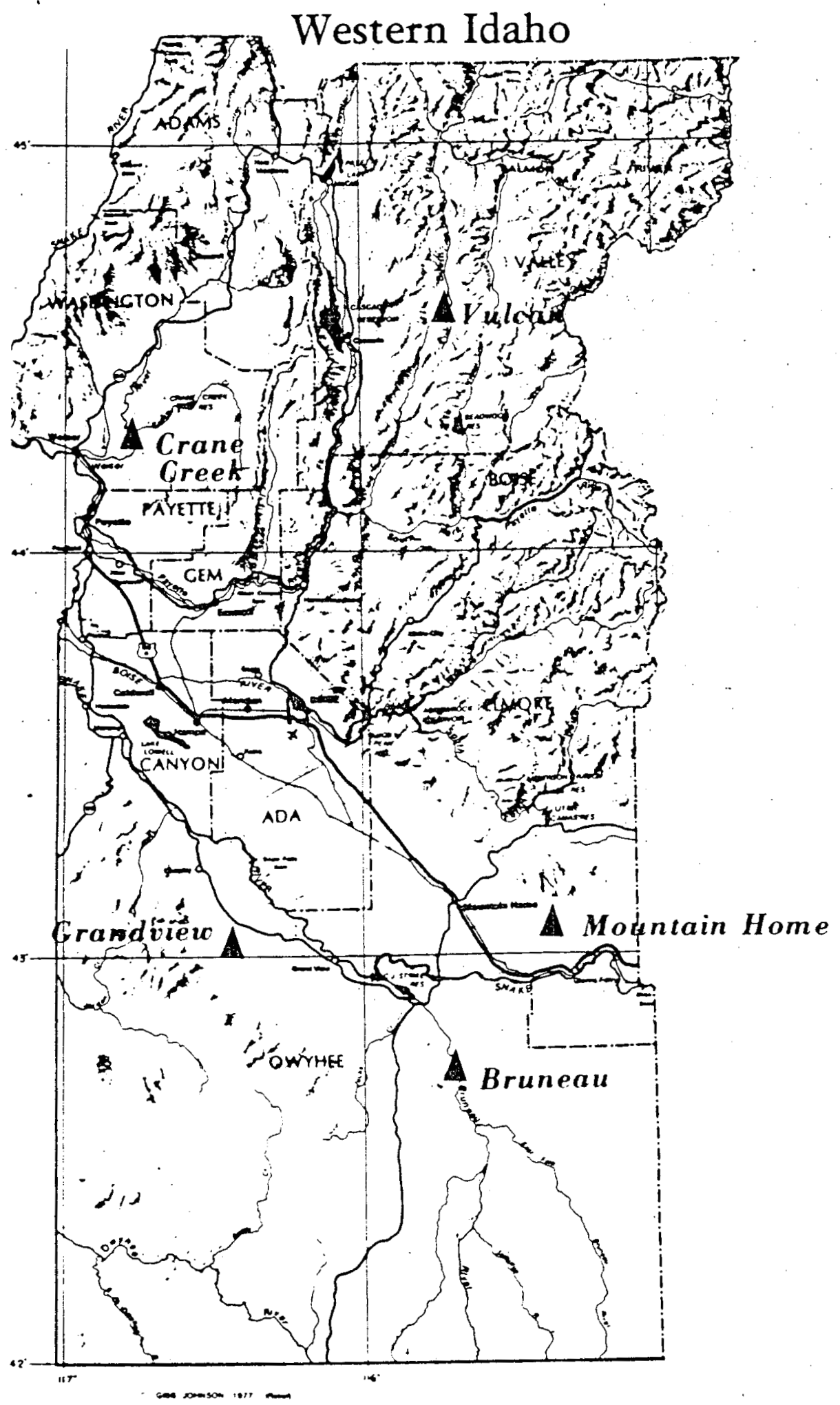

Figure 5 
The Western Idaho Geothermal Development Region has an estimated 1978 population of 300,000 . This represents about 35 percent of Idaho's estimated 1978 total population of 857,000 . Approximately 75 percent of the population within this region resides in Ada and Canyon Counties. Ada County has an estimated 1978 population of 150,000 or 50 percent of the population with in the region. Canyon County, the second most populated county in the region has an estimated 1978 population of 75,000 , accounting for 25 percent of the regional population. These two counties are the primary growth corridor in the Western Idaho Geothermal Development Region. Payette, Gem and Elmore Counties account for an additional 15 percent of the region's population. The remaining ten percent of the region's population is scattered throughout the remaining six counties. Adams, Boise, Gem, Owyhee, Valley, and Washington Counties are remote mountainous counties with isolated small communities and small populations. The most populated counties are those found in the Western Snake River Plain.

The region is experiencing a 20 percent increase in population per year as compared to a 15 percent increase for the state. The region should reach a population in excess of 500,000 people by the year 2000. The growth corridor of Ada and Canyon Counties wil1 account for 75 percent of this growth.

To discuss the potential role of geothermal resource commercialization, as part of the regional growth in Western Idaho, two subregions have been designated.

The Western Intermountain Sub-region includes the northern counties of Adams, Boise, Valley and parts of Washington County. These areas have similar demographic and geologic conditions.

The Western Snake River Plain Sub-region includes the Weiser area of Washington County, Gem, Payette, Ada, Elmore, and Owyhee counties. These counties have similar geological conditions but varying demographic conditions.

\section{Western Intermountain Sub-Region:}

The economy of the intermountain region of western Idaho is based on timber and recreation. The region is demarcated by small 1 isolated communities with the towns of the region centered around either a lumber mill or a recreation area: No single location has a population exceeding 2000 people and the typical community has a population of a few hundred. Major industries which need large amounts of hot water are not located in this region.

Geothermal resources of the intermountain region of western Idaho are generally isolated springs. Locations with commercializa- 
tion potential are listed in Table 1.

\section{TABLE I *}

Western Intermountain Subregion

Projected Geothermal Development

Boise County: Resource is proven

Garden Valley

Residential Space heating/50 × $10^{9}$ BTU/year by 1985

Valley County: Resource is assumed to be adequate and classified as Vulcan KGRA

potenti.al

Electrical Generation Capacity/50 MW by 1990

City of Cascade

Residential \& Commercial Space heating/400 $\times 10^{9}$ BTU/year

by 1985

* Note detailed site specific data is present for each site in Appendix C.

WESTERN SNAKE RIVER PLAIN SUBREGION:

The economy of the Western Snake River Plain is based on agriculture. Outside of the Boise urban area, agriculture is the economic base of the region for it is the regional activity that leads and determines the overal1 regional development. Other activities of the region including commerce, are consequent to the overall growth in agri-industry. The development of nonbasic activities such as establishment of factories is a result of the expansion in the basic agriculture economy of the area.

Geothermal resource development in the Western Snake River Plain could help facilitate future growth in both the agricultural and urban economic spheres. Urban use of geothermal resources will be principally for space heating. Industrial use of geothermal resources will primarily be in the food processing industry. Sites with commercialization potential are listed by County in Table 2 . 


\section{WESTERN SNAKE RIVER PLAIN SUBREGION \\ PROJECTED GEOTHERMAL. DEVELOPMENT}

Ada County: All projected geothermal developments in Ada County are for district geothermal space heating systems. The resource is proven.

Kelly Hot Springs - Barber Area:

Industrial/ $13 \times 10^{9} \mathrm{BTU} /$ year

Commercial/ $2.5 \times 10^{9}$ BTU/year

Residential/ $198.0 \times 10^{9}$ BTU/year

Schools/ $11.6 \times 18^{9}$ BTU/year

TOTAL/ $247.6 \times 10^{9}$ BTU/year al1 by 2000

Penitentiary Grounds

Commercial (State) / $225 \times 10^{9}$ BTU/year by 1985

Warm Springs Water District

Boise Barracks

Residential/ $582.4 \times 10^{9}$ BTU/year by 1982

Capital Mall

Public buildings/ $101.9 \times 10^{9}$ BTU /year by 1985

Public building / $196.0 \times 10^{9}$ BTU/year by 1982

Camels Back Park.

Residential/ $488 \times 10^{9}$ BTU/year by 1990

Boise Central Business District

West Boise Commercial buildings/ $664.2 \times 10^{9}$ BTU/year by 1985

Residential/521 × $10^{9}$ BTU/year by 1990

Canyon County: Assuming 50\% conversion of present food processing industries in Nampa and Caldwel1. Resource is classified as inferred.

Nampa and Cardwe 17

Industrial/ $1777.5 \times 10^{9}$ BTU/year by 2020

Elmore County: Assuming adequate resource is proven by current and near future exploration.

Mountain Home KGRA: Resource is classified as potential.

Electrical Generation Capacity/ 50 MW by 1990

Total field/ 100 . MW by 2020

Industrial/ $200 \times 10^{9}$ BTU/year by 1990

Mountain Home Air Force Base: Resource is classified as inferred. Space heating/ $651 \times 10^{9}$ BTU/year by 1990

City of Mountain Home: Resource is classified as potential. Residential Space Heating/ $50 \times 10^{9}$ BTU/year by 1990 . 
TABLE 2 * (Cont'd.)

Gem County: Assuming adequate resource is proven. Resource is classified as potential.

Roystone Hot Springs

Electrical Generation Capacity/ 50 MW by 2020

Payette County: Assuming adequate resource is proven and assuming $50 \%$ conversion of present food processing facilities by the year 2000. Resource is classified as inferred.

Payette County

Industrial/ $150 \times 10^{9}$ BTU/year

Assuming new processing facilities by the year 2020 .

Industrial/ $250 \times 10^{9}$ BTU/year

Owyhee County: Assuming adequate high temperature resources are proven by current lease holders during the primary term of their leases. Resource is classified as potential.

Bruneau KGRA

Electrical Generation Capacity/50 MW by 1990

Industrial/ $250 \times 10^{9}$ BTU/year by 1990

Castle Creek KGRA

Electrical Generation Capacity/ 50 MW by 1990

Givens Hot Springs

Industrial $150 \times 10^{9}$ BTU/year by 1985

Space heating/50 × $10^{9}$ BTU/year by 1985

Washington County: Assuming high temperature resources are proven by current lease holders within the primary term of their lease. Resource is classified as potential.

Crane Creek KGRA

Electrical Generation Capacity/50 MW by 1985

Total field/100 MW by 1990

Weiser Hot Springs

Electrical Generation Capacity/ 50 MW by 1990

Industrial $/ 250 \times 10^{9}$ BTU/year by 1985

Residential Space heating/ $100 \times 10^{9}$ BTU/year by 1985

*Note: Detailed site specific data is presented for each site in Appendix C. 


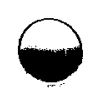

$\odot$

$\theta$ 


\section{Geothermal Development Region III South Central Idaho}

Finure 6
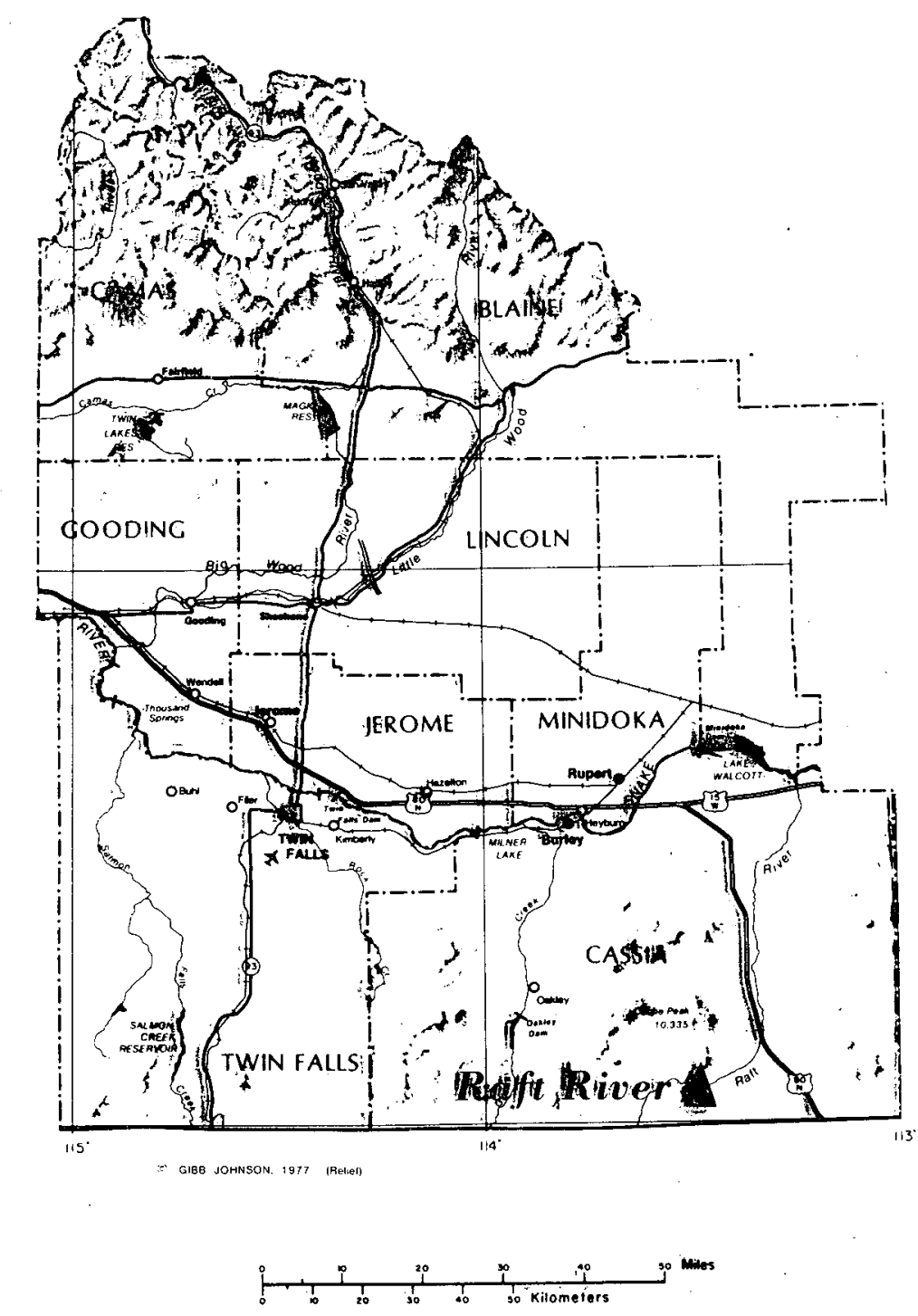

Known Geothermal IResource Area (K:G:R.A.) Cities and 'towns

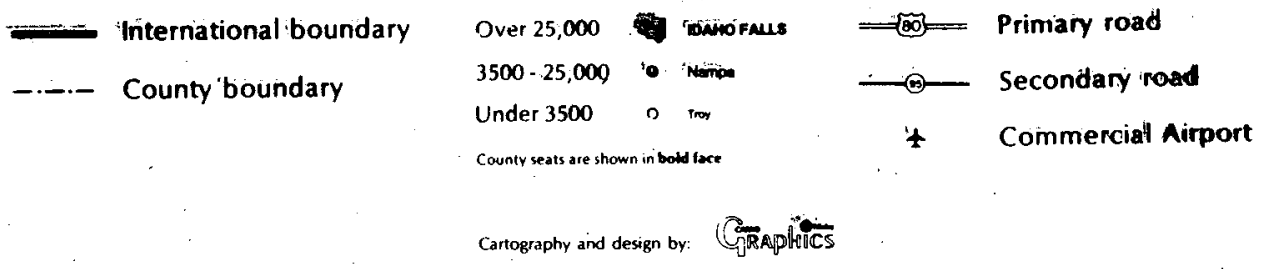


IDAHO GEOTHERMAL DEVELOPMENT REGION III

SOUTH CENTRAL IDAHO

The South Central Idaho region encompasses eight counties: Blaine, Camas, Cassia, Gooding, Jerome, Lincoln, Minidoka and Twin Falls. This area coincides with Idaho State Planning Region IV and the Bureau of Land Management South Central Region. The area is economically dependent on agriculture and food processing. Recent trends in the area indicate that population is growing at a rapid rate, with migration patterns shifting to a substantial net in-migration. Although the region is somewhat isolated from other population centers by long travel distances and expansive deserts, excellent rail and interstate freeway connections provide transportation for exporting and importing products.

The agricultural counties of this region are economically interrelated. Population and industry are concentrated in two locations: Twin Falls, and the Burley-Rupert areas with the principal industries of the region being food processing plants. The major transportation corridors of the state cross through this area. Railroads, freeways, powerlines, oil pipelines and gas pipelines all corverge in the Twin Falls and Burley areas. Adequate transportation services, and expanding agriculture and food processing have made the Twin Falls and Burley-Rupert areas the main growth corridor of South Central Idaho Region.

In general the South Central Idaho Region can be considered rural. The population density of the region is 9 persons per square mile. The total population of the region is approximately 105,000 with approximately 50 percent of the total living in the City of Twin Falls and 15 percent of the population living in the Burley-Rupert area. The remaining 35 percent of the region's population is scattered throughout the agricultural areas.

There are 129 manufacturing units in the South Central Idaho Plain. The majority of these units (33 percent) are in the food and kindred products classification. These facilities are the major industrial consumers of energy and the principal industries of the region.

Regional trade areas and areas of highest population density coincide with the location of the major food processing facilities. The greatest potential market for direct heat utilization of geothermal resources in the South Central Idaho Region is in the food processing facilities. The region also shows the best promise for an early demonstration of electric power generation with geothermal energy from facilities currently being constructed at the Raft River KGRA. Residential and commercial space heating is also possible with projects currently underway in Twin Falls and the Hailey-Sun Valley area.

Four areas were examined in the South Central region: The Raft 
River KGRA, the City of Twin Falls and surrounding area, the HaileySun Valley area and the Camas Prairie area. Sites with projected commercialization potential are listed by county in Table 3. 
TABLE 3 *

SOUTH CENTRAL IDAHO REGION PROJECTED GEOTHERMAL DEVELOPMENT

Cassia County: Resource is proven

Raft River KGRA

Electrical Generation Capacity/ 5 MW by 1982

/50 MW by 1985

Total field/100MW by 2020

Industrial/ $250 \times 10^{9}$ BTU/ year by 1990

Twin Falls County:

College of Southern Idaho: Resource is classified as potential. Space heating/ $25 \times 10^{9}$ BTU/year by 1982

Assuming high temperature resources are proven and assuming

$50 \%$ conversion of present food processing facilities.

Resource is classified as inferred.

City of Twin Falls

Industrial/ $670 \times 10^{9} \mathrm{BTU} /$ year by 1990

City of Buhl

Industrial/ $160 \times 10^{9}$ BTU/ year by 1990

Camas County: Resource is classified as inferred.

Magic Hot Springs: Assuming adequate resource is proven.

Electrical, Generation Capacity/ 50 MW by 2020

Blaine County: Resource is classified as potential

Hailey

Space heating/ $25 \times 10^{9}$ BTU/year by 1990

Ketchum-Sun Valley

Space heating/50 × $10^{9}$ BTU/year by 1990

* Note: Detailed site specific data is presented for each site in Appendix D. 


\section{Geothermal Devellopment Region IV}

\section{Southeastern Wdaho}

\section{Finure 7}
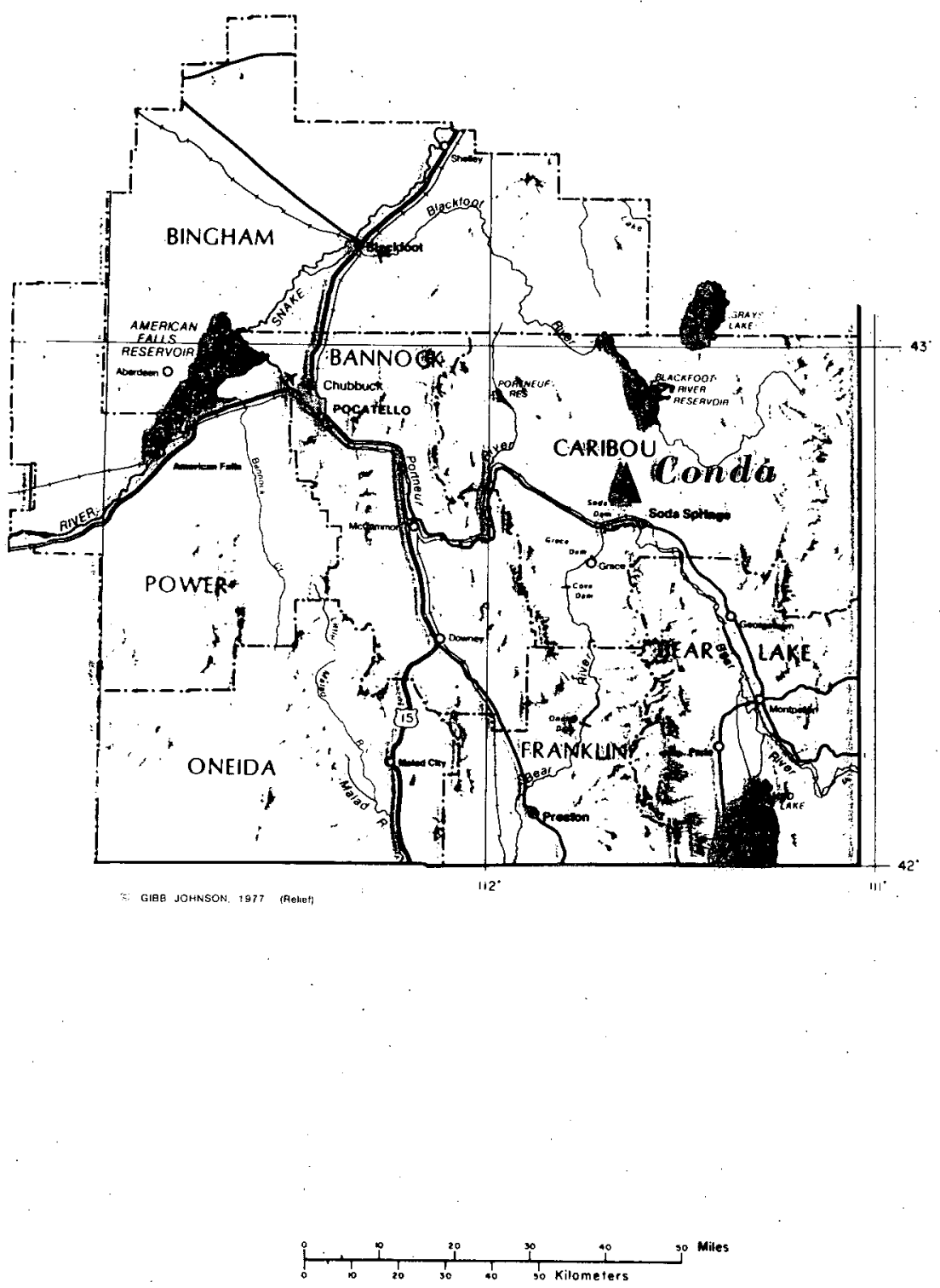

'Known Geothermal Resource Area (K.G.R.A.)

Cities and towns

International boundary

-...- County boundary

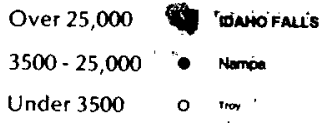

County seats are shown in bootd loce

Cartography and design by: Cin

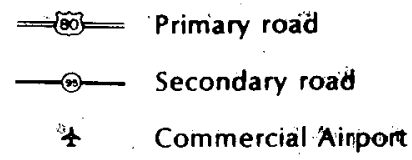

4 Commercial Ainport 
The Southeast Idaho region encompasses seven counties: Bannock, Bear Lake, Gingham, Caribou, Franklin, Oneida, and Power. This region coincides with Idaho State Planning Region $V$ and the Bureau of Land Management's Burley and Idaho Falls Districts. Power, Bannock and Oneida Counties are in the Idaho Falls BLM District. The major surface regulatory agency in this region is the Caribou National Forest.

The region is sparsely settled and population is largely concentrated in a few areas; American Falls-Pocatello, Soda Springs, Preston, and Montpelier. Agriculture, the dominant industry, includes dry and irrigation farming and livestock grazing. Potatoes, alfalfa, wheat and barley are the principal crops. An established phosphate mining and processing industry is the significant industrial development of the region. Major phosphate processing plants are located in Pocatello and Soda Springs. The region also supports several food processing plants.

A reasonably adequate transportation network connects the population centers and secondary roads provide access to more remote areas. Interstate 15, the major arterial, services the center and northern portions of the region. Numerous state highways provide access between the smaller population center. The Union Pacific Railroad owns and operates almost all the trackage in southeast Idaho. Two major routes exist; an east-west rail route along the Snake River Plain between Idaho Falls, Pocatello, and Boise; and a north-south rail route between Salt Lake City, Preston, Soda Springs and Pocatello.

A major petroleum pipeline supplies the Pocatello area and a major natural gas pipeline supplies the Soda Springs and Pocatel1o areas.

In general the region can be considered rural - with a total population estimated at 123,200 people.(1) The majority of this population resides in Pocatello and Soda Springs areas. A11 other communities in the region have populations of less than 2,500 people.

There are nine major industrial energy consumers in South Central Idaho. These nine industries can be broken into two groups: Those plants concerned with ore processing, and those plants concerned with food processing. There are four ore reduction plants of which three are phosphate plants and one is a Portland Cement plant. These four plants are among the top six energy consuming industrial plants in Idaho. The combined total energy demand of these four plants is $12,000 \times 10^{9}$ BTU/year. The majority of this energy demand is in the form of electrical power. There is little market for direct use of geothermal energy in these plants. The only major contribution geothermal energy could make to this energy demand is to provide additional electrical generation capacity. The phosphate mining and processing related loads totals approximately $460 \mathrm{MW}$. Idaho Power 
supplies roughly two-thirds of this load and Utah Power and Light provides one-third.

The five major food process plants of Southeast Idaho are principally concerned with potato processing. The total combined energy demand of these five plants is $2,640 \times 10^{9}$ BTU/year. (4) These plants are located in the Snake River Plain area. These plants could utilize large volumes of geothermal fluids directly.

In addition to the potential industrial market, several communities have potential for direct use of geothermal fluids for space heating. Communities which have space heating potential are: Pocate110, Chubbuck, Lava Hot Springs, Soda Springs, and Preston. Sites with commercialization projections are 7isted in Table 4. 


\section{SOUTHEAST IDAHO REGION GEOTHERMAL DEVELOPMENT PROJECTIONS}

Caribou County: Resource is classified as inferred

Conda KGRA: Assuming adequate resource is proven.

Soda Springs Electrical Generation Capacity/50 MW by 2020

Space heating/25 × $10^{9}$ BTU/year by 1990

Bannock County:

Chubbuck: Resource is classified as potential

Residential Space heating/50 × $10^{9}$ BTU/year by 1985

Industrial/200 × $10^{9}$ BTU/year by 1990

Lava Hot Springs: Resource is proven,

Commercial Space heating/25 x 109 BTU/ year by 1985

\section{Frankl in County}

Preston: Resource is classified as inferred.

Electrical Generation Capacity/50 Mu by 2020

Industrial/200 × $10^{9}$ BTU/year by 1990

* Note: Detailed site specific data is presented for each site in Appendix E. 


\section{Geothermal Development Region V Northeastern Idatho}

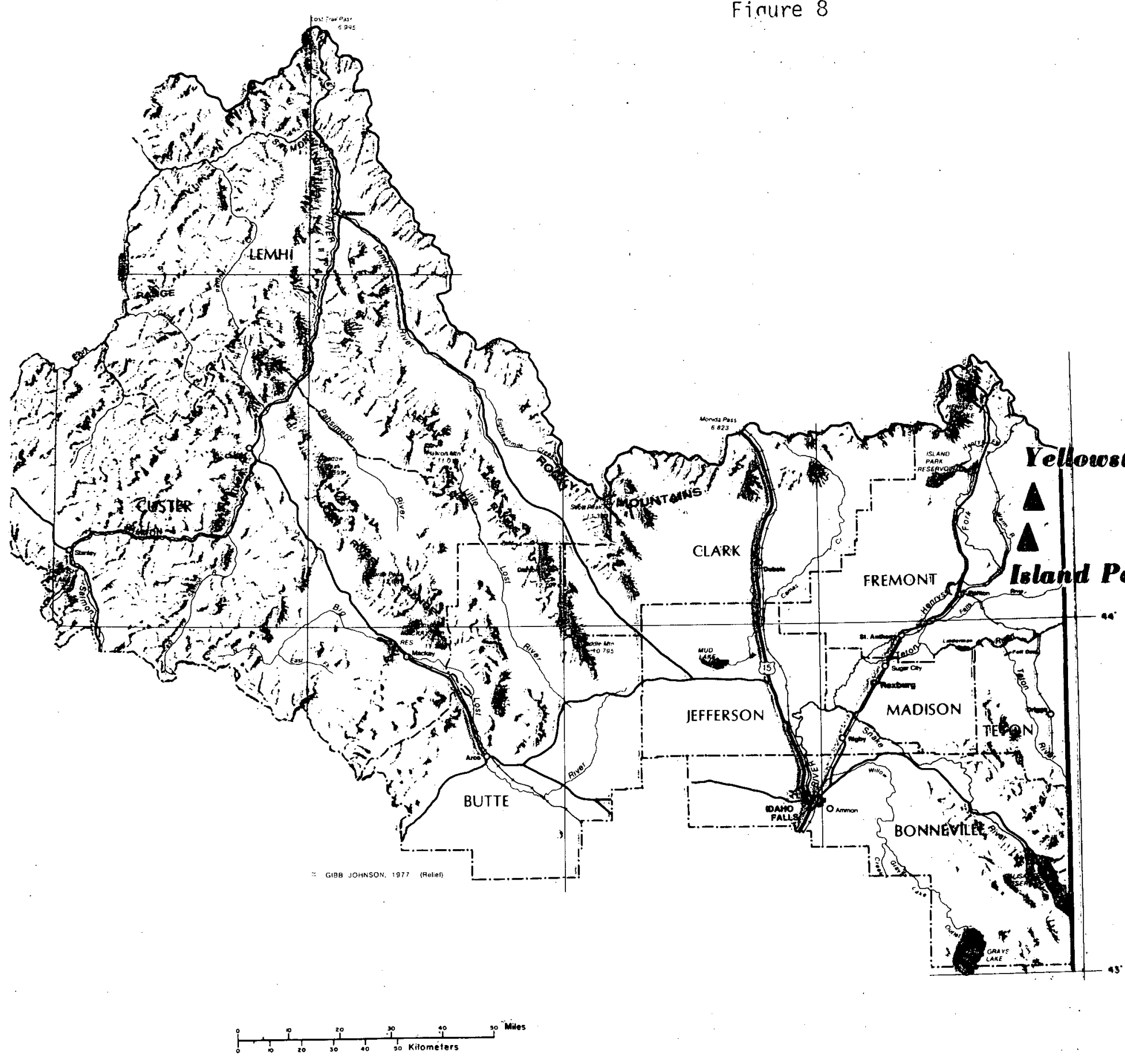

Known Geothermal iResource Area (K.G.R.A.)

Cities and towns
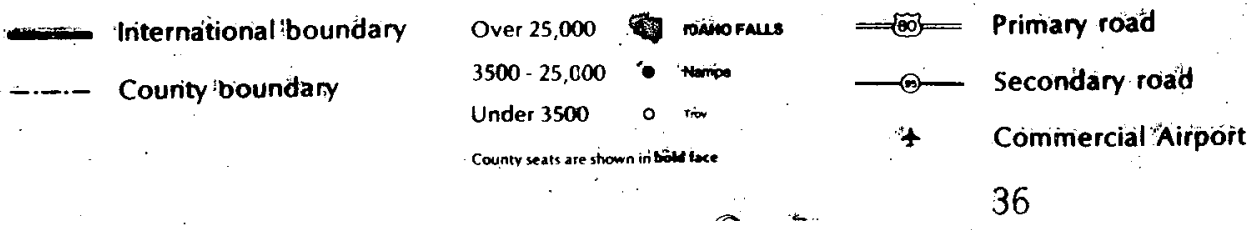
The Northeast Idaho region encompasses nine counties: Bonneville, Butte, Clark, Custer, Freemont, Jefferson, Lemhi, Madison and Teton. The boundaries of this region coincide with the boundaries of the Idaho Falls and Salmon BLM Districts and Idaho State Planning Region VI.

The major economic center for this region is Idaho Falls in Bonneville County. Smaller economic centers are Rexburg in Madison County and Salmon in Lemhi County. The principal economic activities are centered in the Snake River Plain near Idaho Falls and Rexburg. The total population of this nine county region is 114,863. Approximately 86 percent of the population lives in the Idaho FallsRexburg growth corridor. The major employment sectors are government, agriculture, food processing and lumber. Idaho Falls is a center for federal offices concerned with the National Reactor Testing Station. The Idaho Falls-Rexburg corridor is the regional center for agricultural activities. St. Anthony and Salmon are centers for logging and milling operations.

Three geothermal areas were examined in the Northeast Idaho Region: the Island Park-Yellowstone KGRAs, the Madison County area, and Lemhi County. Known thermal areas located in the Island Park KGRA and Lemhi County have moderate potential for electrical power generation. The Madison County area has a large market for direct utilization but undefined resources. The Island Park area has very favorable geological conditions which indicate a geothermal resource, but the area is also considered to be environmentally and politically sensitive. Sites with commercialization projections are listed in Table 5. 
TABLE 5 *

'NORTHEAST IDAHO REGION GEOTHERMAL

DEVELOPMENT PROJECTIONS.

Fremont County: Assuming adequate resources and minimum environmental problems. Resource is classified as inferred.

Island Park and Yellowstone KGRA's

Electrical Generation Capacity/50 MW by 1990

Maximum field development/500 MW by 2020

Lemhi County:

Big Creek Hot Springs: Resource is classified as potential 50 MW by 2020

Madison County: Assuming adequate resources are proven. Resource is classified as inferred.

Rexburg

Space heating/500 $\times 10^{9}$ BTU/year by 1985

Industrial/200 $\times 10^{9}$ BTU/year by 1985

* Note: Detailed site specific data is presented for each site in Appendix F. 
A task of this study was to assess the current status of geothermal leasing and development activity in Idaho. To obtain this information, records of geothermal leases on federal and state lands were obtained. Information regarding geothermal leasing on private lands is included in the individual site reports, whenever such data was available. Leasing data presented in this section is restricted to current leased on public lands in Idaho.

Exploration activity is summarized into "electric and nonelectric" categories. The development status of the ten Known Geothermal Resource Areas (KGRAs) is briefly summarized in this section, while detail reports on present and projected activities are presented in the individual site reports that are found in the appendixes. The following tables ( 6 thru 15) list the current information regarding leasing activity in Idaho on state and federal lands as of October 1978.

\section{Exploration Activity (Electric):}

Union 0il Company and Magma Power Company have filed for and received a drilling permit from the Idaho Department of Water Resources to deepen the Bostic \#1 well. The well is located on private lease holdings near the Mountain Home KGRA.

Phillips Petroleum has completed two deep exploration wells, on in Weiser, Idaho, one in the Grand View area or Owyhee County, Idaho near the Castle Creek KGRA.

The "Christenson A" \#1 well was drilled to 2,439 meters $(8,001 \mathrm{ft}$. at a location 3.2 kilometers ( $w$ miles) south of Crane Creek KGRA in Washington County on private leases.

The "Lawrence D" \#1 well was drilled to 2,846 meters (9,340 ft.) at a location within the Castle Creek KGRA on private lands adjacent to a federal lease that Phillips has held since November, 1975.

Sun 0 il Company is drilling an exploration well near Preston, Idaho.

Gulf $0 i 1$ is conducting heat flow studies in the Albion Valley.

U.S. Department of Energy is drilling production wells at Raft River KGRA. The Idaho National Engineering Lab has drilled the "RRG" \#4 we11 to 865 meters $(2,840 \mathrm{ft}$.) with the original intent of using it as an injection well. Flow test indicate that the well may be a possible production well.

\section{Exploration Activity (Nonelectric):}

Two wells were drilled by the Department of Energy to 350 meters $(1,148 \mathrm{ft}$.$) in the Fort Boise area of Boise, Idaho.$

The College of Southern Idaho in Twin Falls, Idaho is currently drilling an exploration well on campus. 
TABLE 6

IDAHO

Known Geothermal Resource Areas (KGRAs)

As Classified by the U.S. Geological Survey

1. Bruneau

2. Castle Creek

3. Conda

4. Crane Creek

5. Island Park

6. Mountain Home

7. Raft River

8. Vulcan

9. Yellowstone

$$
\begin{array}{r}
5,120 \\
79,722 \\
2,566 \\
4,342 \\
28,539 \\
9,520 \\
30,209 \\
3,836 \\
14,164 \\
\hline 178,018
\end{array}
$$

\section{TABLE 7}

TOTAL ACREAGES OF GEOTHERMAL RESOURCE LEASES

IN THE STATE OF IDAHO

(October 1978)

\section{Federal Leases:}

Total Acreages of Competitive Leases in KGRAs:

A11 BLM

Total Acreages of Noncompetitive Leases

BLM: $277,737.07$

Forest Service: 2,560

\section{State Leases:}

Total Acreages of State Leases:

Total of All Acreages State and Federal

Leased for Geothermal Resources:

381,688 . 
TABLE 8

KNOWN GEOTHERMAL RESOURCE AREAS

ACREAGES, AND LESSEES

October 1, 1978

KGRA

Conda

Yellowstone

Vulcan

Island Park

Crane Creek

Cast Te Creek

Bruneau

Mountain Home

Raft River

TOTAL KGRAs

\section{ACREAGE LESSEES}

2,566 None

$14,164 \quad$ None

3,836 None

28,539 None

4,342 Supron Energy Corp $(1,380)$

79,722 Dow Chemical Co., $(2,080)$

Geothermal Resources International

Inc., $(2,353)$;

Occidental Geothermal Inc.

$(16,412)$;

Phillips Petroleum Co. $(5,025)$;

R.A. Pomeroy $(2,492)$;

L.J. Spangler $(2,560)$.

Total: 30,922

5,120 Occidental Geothermal Inc. $(2,600)$

9,520 Union $0 i 1$ of Calif. and Magma

Energy Inc. $(5,102)$

30,209 Raft River Rural Electrical

Cooperative $(1,883)$

175,452
Total Acres Leased (competitive leases $):(41,877)$ 
TABLE 9

LEASING IN

NON-COMPETITIVE GEOTHERMAL LEASE AREAS

. (October 1978)

\begin{tabular}{|c|c|c|}
\hline COUNTY NAME & TOTAL ACREAGE (FEDERAL) & COMMENTS \\
\hline Blaine & $.6,546$ & $\begin{array}{l}\text { Leases are concentrated near the } \\
\text { Craters of the Moon National } \\
\text { Monument and held by the Hunt } \\
\text { family. }\end{array}$ \\
\hline Bonneville & 2,560 & $\begin{array}{l}\text { Leases are in the Palisades area, } \\
\text { and held by Pacific Energy Corp. }\end{array}$ \\
\hline Camas & 9,724 & $\begin{array}{l}\text { Leases are concentrated near the } \\
\text { Camas Prairie, held by Hunt } \\
\text { family. }\end{array}$ \\
\hline Cassia & 22,986 & $\begin{array}{l}\text { Leases are concentrated near the } \\
\text { Raft River KGRA, the major lease } \\
\text { holder is SUNCO Energy Develop- } \\
\text { ment Company. }\end{array}$ \\
\hline Clark & 1,246 & $\begin{array}{l}\text { Leases are near the Island Park } \\
\text { KGRA and held by E.J. Wilson. }\end{array}$ \\
\hline E.7more & 28,525 & $\begin{array}{l}\text { Leases are concentrated near the } \\
\text { Mountain Home KGRA and held by } \\
\text { Magma Energy Inc. and Union } 0.17 \text {. }\end{array}$ \\
\hline Lincoln & 34,526 & $\begin{array}{l}\text { Leases are located in the center } \\
\text { of the Snake River Plain and held } \\
\text { by the Hunt Family. }\end{array}$ \\
\hline Owyhee & 152,838 & $\begin{array}{l}\text { Leases are concentrated around the } \\
\text { Castle Creek and Bruneau KGRAs. } \\
\text { Major lease holders are: Amax } \\
\text { Exploration, Inc.; Atlantic } \\
\text { Richfield Co.; Dow Chemical Co.; } \\
\text { Earth Power Corp.; Idaho } \\
\text { Geothermal Co.; Gerald Loucks; } \\
\text { 0xy Petroleum; Occidental } \\
\text { Geothermal INC. ; Phillips } \\
\text { Petrolelum Co.; Russel1 Pomeroy; } \\
\text { Robert Smith; Snake River } \\
\text { Geothermal Co. ; Thermal Resources } \\
\text { Inc.; United States Geothermal } \\
\text { Corp. }\end{array}$ \\
\hline Washington & 18,768 & $\begin{array}{l}\text { Leases are concentrated near the } \\
\text { Crane Creek KGRA and Weiser Hot } \\
\text { Springs and held by Phillips } \\
\text { Petroleum Co.; SUPRON Energy Corp. } \\
\text { Union Oil Co. }\end{array}$ \\
\hline
\end{tabular}


TABLE 10

NONCOMPETITIVE GEOTHERMAL LEASING

SUMMARY STATUS REPORT, IDAHO

October 1, 1978

APPLICATIONS

\begin{tabular}{|c|c|c|c|c|c|c|c|}
\hline & & \multirow[b]{2}{*}{ SUBTOTAL } & \multicolumn{2}{|l|}{ 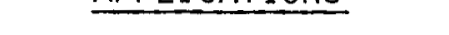 } & \multirow{2}{*}{\multicolumn{2}{|c|}{$\begin{array}{l}\text { AWAITING (1) } \\
\text { ACTION } \\
\end{array}$}} & \multirow[b]{2}{*}{ REFUSED } \\
\hline & $\frac{\text { FILEL }}{\mathrm{FS}}$ & & WITHDRAWN & REJECTED & & & \\
\hline $\begin{array}{l}581 \\
\text { BLM \& }\end{array}$ & $\begin{array}{l}302 \\
\text { FS }\end{array}$ & $\begin{array}{r}883 \\
\frac{16}{899}\end{array}$ & 213 & 166 & $\begin{array}{c}130 \\
\text { BLM \& FS }\end{array}$ & $\begin{array}{l}205 \\
\frac{16}{351}\end{array}$ & 26 \\
\hline
\end{tabular}

LEASES

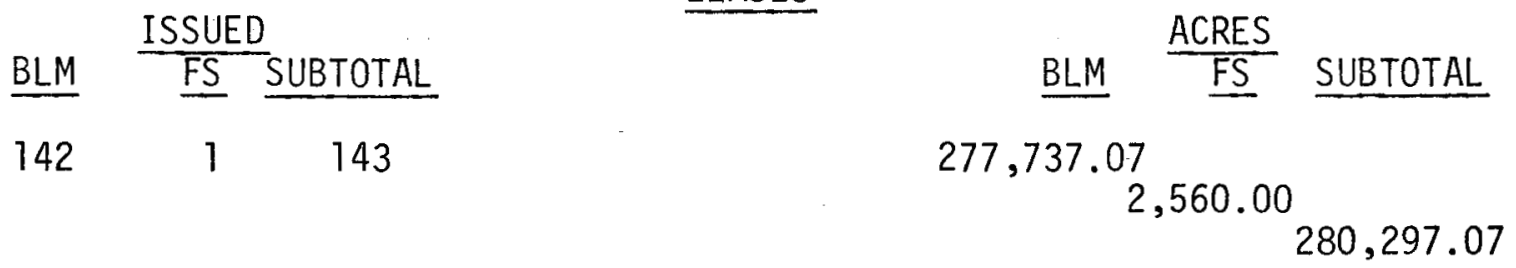

(1) Applications awaiting action for the following reasons:

3 Awaiting KGRA report from USGS

99 Pending preparation of EAR (BLM on 1y)

211 Awaiting comment of other agencies

10 Lease forwarded for signature

28 Processing (Adjudication) - BLM

1 On appeal

(2) 5 Leases relinquished or terminated $(8,005.16$ Acres $)$ 
TABLE 11

STATE OF IDAHO GEOTHERMAL LEASES

TOTAL ACREAGE PER COUNTY LEASED

STATE SCHOOL AND OTHER STATE LANDS

(October 1978)

\begin{tabular}{|c|c|c|}
\hline Owhyee County & 19,137 acres & $\begin{array}{l}\text { Most of these leases are held by } \\
\text { Occidental Geothermal Inc. }\end{array}$ \\
\hline Fremont County & 12,794 acres & $\begin{array}{l}\text { Leases held by Occidental } \\
\text { Geothermal Inc. and Warren } D \text {. } \\
\text { Barrells. }\end{array}$ \\
\hline $\begin{array}{l}\text { Elmore County } \\
\text { Washington County }\end{array}$ & $\begin{array}{l}8,640 \text { acres } \\
5,089 \text { acres }\end{array}$ & $\begin{array}{l}\text { Leases held by Gulf 0il Corp. } \\
\text { Leases held by Phillips } \\
\text { Petroleum Company }\end{array}$ \\
\hline Cassia County & 4,520 acres & $\begin{array}{l}\text { Leases held by Raft River Rural } \\
\text { Electrical Coop. and Sun } 0 \text { il Co. }\end{array}$ \\
\hline . Tark County & 2,553 acres & Leases held by R.L. Bullock \\
\hline Bonneville County & 2,489 acres & Leases held by Chevron U.S.A. Inc. \\
\hline $\begin{array}{l}\text { Camas County } \\
\text { Ada County }\end{array}$ & 1,578 acres & Leases held by R.L. Bullock. \\
\hline Ada County & 1,562 acres & Leases held by Joe Kanta \\
\hline $\begin{array}{l}\text { Madison County } \\
\text { Bannock County }\end{array}$ & $\begin{array}{l}666 \text { acres } \\
240 \text { acres }\end{array}$ & $\begin{array}{l}\text { Leases held by Chevron U.S.A. Inc. } \\
\text { Leases held by sun } 0 \text { il Company }\end{array}$ \\
\hline $\begin{array}{l}\text { Bannock Lounty } \\
\text { Frank } 1 \text { in County }\end{array}$ & 200 acres & Leases held by Chevron U.S.A. Inc. \\
\hline $\begin{array}{l}\text { Tetal State Land } \\
\text { Leased: }\end{array}$ & 59,504 acres & $\begin{array}{l}\text { Drilling requests have been filed } \\
\text { for } 3,021 \text { acres, al1 of which are } \\
\text { in Fremont County. }\end{array}$ \\
\hline
\end{tabular}


TABLE 12

IDAHO SHARE MINERAL LEASING COLLECTIONS BY COMMODITY October 1, 1977 to March 31, 1978

\begin{tabular}{|c|c|c|c|c|c|}
\hline & $\begin{array}{l}\text { OIL and } \\
\text { GAS } \\
\end{array}$ & PHOSPHATE & GEOTHERMAL & OTHER & TOTAL \\
\hline Ada & 119.54 & & & 64.37 & 183.91 \\
\hline Bannock & 2523.55 & & & 75.00 & 2598.55 \\
\hline Bear Lake & 97143.79 & & & 105.75 & 97249.54 \\
\hline Bingham & 28979.75 & 1008.00 & & & 29987.75 \\
\hline Blaine & & & 4197.00 & & 4197.00 \\
\hline Boise & 37.25 & & & & 37.25 \\
\hline Bonneville & 73369.38 & & 1280.00 & & 74649.38 \\
\hline Butte & 26145.25 & & & & 26145.25 \\
\hline Camas & & & 3930.00 & & 3930.00 \\
\hline Canyon & 123.05 & & & 64.37 & 187.42 \\
\hline Caribou & 56786.29 & 364689.28 & & 410.50 & 421886.07 \\
\hline Cassia & 2840.55 & & 9068.70 & 392.63 & 12301.88 \\
\hline Clark & 110395.00 & 736.50 & & & 111131.50 \\
\hline Custer & 340.00 & & & & 340.00 \\
\hline Elmore & 9287.29 & & 18115.65 & 201.88 & 27604.82 \\
\hline $\begin{array}{l}\text { Franklin } \\
\text { Fremont }\end{array}$ & $\begin{array}{l}42260.00 \\
56740.50\end{array}$ & & & & $\begin{array}{l}42260.00 \\
567.40 .50\end{array}$ \\
\hline Gem & 9811.80 & & & 89.37 & 9901.17 \\
\hline $\begin{array}{l}\text { Gooding } \\
\text { Jefferson }\end{array}$ & $\begin{array}{r}486.50 \\
50744.75\end{array}$ & & & & $\begin{array}{r}486.50 \\
50744.75\end{array}$ \\
\hline Kootenai & $(650.50)$ & & & & $(650.50)$ \\
\hline Lemhi & 79964.75 & & & & 79964.75 \\
\hline Lincoln & 2564.50 & & 17267.50 & & 19832.00 \\
\hline Madison & 12513.75 & & & & 12513.75 \\
\hline Minidoka & 630.50 & & & & 630.50 \\
\hline Oneida & 12652.25 & & & 64.38 & 12716.63 \\
\hline Owyhee & 663.25 & & 32884.00 & & 33547.25 \\
\hline Payette & 2763.79 & & & 64.37 & 2828.16 \\
\hline Power & 245.80 & & & & 245.80 \\
\hline Teton & 12048.00 & & & & 12048.00 \\
\hline Twin Falls & 19.54 & & & 64.37 & 83.92 \\
\hline Washington & 4356.75 & & & & 4356.75 \\
\hline Total & 695906.62 & 366433.78 & 86742.85 & 1597.00 & 1150680.25 \\
\hline
\end{tabular}


TABLE 13

\section{IDAHO COUNTIES SHARE OF MINERAL LEASING MONIES}

Counties' $10 \%$ share of Mineral Leasing Monies as per Section 57-1306, Idaho Code, for the payment due the State of Idaho under the provisions of Section 35 of the Mineral Leasing Act of 2-25-20, as the State's $50 \%$ share of bonuses, royalties and rentals received during the period. of October 1; 1977 through March 31, 1978.*

COUNTY

Ada

Bannock

Bear Lake

Bingham

Blaine

Boise

Bonneville

Butte

Camas

Canyon

Caribou

Cassia

Clark

Custer

Elmore

Franklin

Fremont

Gem

Gooding

Jefferson

Kootenai

Lemhi

Lincoln

Madison

Minidoka

Oneida

Owyhee

Payette

Power

Teton

Twin Falis

Washington

TOTALS
TOTAL AMOUNT COLLECTED

BY U.S. GOVERNMENT

$\$$

367.84

$5,197.10$

$194,499.08$

$59,975.50$

$8,394.00$

74.50

$149,298.74$

$52,290.50$

$7,860.00$

374.84

$843,772.12$

$24,603.78$

$220,932.00$

680.00

$55,209.64$

$84,520.00$

$113,481.00$

$19,802.34$

973.00

$101,489.50$

30.00

$159,929.50$

$39,664.00$

$25,027.50$

$1,261.00$

$25,433.24$

$67,094.50$

$5,656.34$

491.58

$24,096.00$

167.86

$8,713.50$

$\$ 2,301,360.50$
AMOUNT PAID

$\$ \quad 18.39$

259.85

$9,724.95$

$2,724.95$

419.70

3.73

$7,464.94$

$2,614.52$

393.00

18.74

$42,188.60$

$1,230.19$

$11,046.60$

34.00

$2,760.48$

$4,226.00$

$5,674.05$

990.12

48.65

$5,074.48$

1.50

$7,996.48$

$1,983.20$

$1,251.38$

63.05

$1,271.66$

$3,354.72$

282.82

24.58

$1,204.80$

8.39

435.68

$\$ 115,068.03$

*MARJORIE RUTH MOON

State Treasurer 


\section{FEDERAL GEOTHERMAL LEASES IN IDAHO}

Lessee: Amax Exploration, Inc.

4704 Harlow Street,

Denver, Colorado 80212

Lease No.

I - 13321

I -13323

I - 13324

Date Issued
$\begin{gathered}7-1-78 \\ 7-1-78 \\ 7-1-78\end{gathered}$

Acreage

$2,560.00$

$2,558.56$

$2,382.59$

Total $\quad 7,501.15$
County

Owyhee

Owyhee

Owyhee

Lessee: Armour, L.H.J.

135 South LaSalle St., Room 1940,

Chicago, I11. 60603

Lease No.

$I-763$
Date Issued

$9-1-76$
Acreage

1,480
County

Cassia

Lessee: Atlantic Richfield Co.

P.0. Box 2819,

Dallas, Texas, 75221

Lease No.

I - 8993

I - 8994

I - 8995

I - 8996

I - 8997

I - 8998

I - 12689

I - 12690

I - 12691

$I-13032$
Date Issued

$7-7-75$

$$
\text { " }
$$

$$
\text { " }
$$$$
\text { " }
$$

"

$"$

$7-1-78$

iI

11
Acreage

$2,272.39$

$2,387.21$

$2,560.00$

$2,379.00$

$2,273.69$

$1,672.03$

$1,807.84$

$1,961.55$

$1,839.47$

160.00
County

Owyhee

II

॥

II

11

Washington

II

II

Lessee: Delta Funds, Inc.

1401 Walnut Street, Room 815,

Philadelphia, PA 19102

Lease No.

I - 9513

I - 9514

I - 9515

I - 9516

Date Iss
10-1-76
$" 1$
11

Date Issued
Acreage

$1,520.00$

$1,920.00$

$1,320.00$

961.25

Total $5,721.25$
County

Cassia

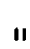

II 
TABLE 14. (cont.)

Lessee: Don Chemical Company

P.0. Box 1398,

Pittsburg, Ca. 94565

Lease No.

I - 8339

I -8341

I -8344

I -8346

I - 8348

I - 10084
Date Issued

$8-1-75$

II

II

11

3-1-76 (Comp.)
Acreage

$1,360.00$

560.00

635.24

640.00

$1,640.00$

$2,080.00$

County

Owyhee

II

II

II

II

Lessee: Earth Power Corporation

P.0. Box 1566

Tulsa, Ok. 74101

Lease No.

Date Issued.

Acreage

County

I - 7688

$11-7-75$

$11-1-75$

$12-1-76$

I - 10074

I - 7992

I - 7994

I - 7995

I - 8780

I - 8049

I - 8045

$6-7-77$

$17-7-75$

$8-1-75$

$8-1-75$

$8-1-77$

$8-7-77$

$8-7-75$

$2,476.76$

$2,440.94$

920.00

640.00

640.00

656.72

$1,294.46$

$1,280.00$

654.08

$1,526.32$

$1,920.00$

$2,543.72$

Owyhee

$2,500.84$

Total $19,493.84$

Lessee: Geothermal Resources International Inc.

4676 Admi ralty Way,

Marina Del Rey, Ca. 90291

Lease No.

Date Issued

Acreage

County

I - 10082

$12-1-75$

$2,353.75$

Owyhee

Lessee: Caroline L. Hunt

1401 Elm Street,

Dallas, Texas 75202

Lease No.

Date Issued

Acreage

County

I - 9869

$3-7-78$

I - 9870

$3-1-78$

$2,560.00$

$2,525.95$

Lincoln

Total $5,085.95$ 
Lessee: Caroline Hunt Trust Estate 2500 First Naional Bank Building, Dallas, Texas 75202

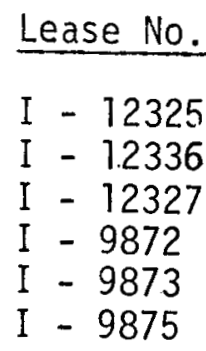

Date Issued $3-7-78$

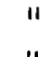

II

II

II
Acreage

240.00

320.00

560.00

$2,219.15$

$2,096.88$

$1,480.00$

County

Camas

Lincoln

BTaine

Camas

Lincoln

Blaine

Lessee: Hassie Hunt, Inc.

2500 First Naional Bank Building, Dallas, Texas 75202

Lease No.

Date Issued

Acreage

County

I - 9815

I -9816

$3-7-78$

$2,374.44$

$2,200.00$

Blaine

I - 9817

$2,352.05$

Camas

Lincoln

Lessee: Lamar Hunt

2500 First National Bank Building,

Dallas, Texas 75202

Lease No.

Date Issued

Acreage

County

I - 9879

I - 9883

3-1-78

$2,398.55$

$2,491.36$

I -9884

I - 9877

I - 9876

$$
\text { " }
$$

$2,112.19$

$2,560.00$

Total

$2,521.14$

$12,083.24$

Lincoin

Blaine

Camas

Lincoln

Lessee: Nancy B. Hunt

1401 E1m Street

Dallas, Texas 75202

Lease No.

Date Issued

I - 9838

I -9839

$3-1-78$

Total

Acreage

County

$2,552.53$

$2,548.67$

Lincoln

$5,101.20$ 
Lessee: Nelson B. Hunt

1401 Elm Street,

Dallas, Texas 75202

Lease No.

Date Issued

Acreage

County

I - 9861

I - 9862

$3-7-78$

$2,343.16$

$2,481.15$

Lincoln

Total $4,824.31$

Lessee: Norma K. (Knoke1) Hunt

1401 Elm Street,

Dallas, Texas 75202

Lease No.

Date Issued

Acreage

County

I - 9823

$3-7-78$

$2,536.18$

$2,505.40$

Lincoln

I - 12025

Total $4,800.00$

Camas

Lessee: Idaho Geothermal Co. 39 Broadway

New York, N.Y. 10006

Lease No.

Date Issued

I - 7629

I - 7793

I - 7846

$8-7-75$

$8-7-75$

$11-1-75$

I -9886

$1-1-77$

I -9887

$1-1-77$

I - 7665

$8-1-75$

I - 8044

$6-1-76$

I -7674

$11-1-75$

I - 7696

I - 10073

I - 10075

$11-1-75$

$12-1-76$

$12-1-76$

Acreage County

$1,200.00$

$2,560.00$

$2,558.70$

$1,638.88$

$1,239.06$

$1,920.00$

$1,158.37$

$2,082.44$

640.00

$2,199.52$

$2,399.80$

Total 19,596.77

Owyhee

II

II

II

"

"

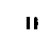

II

II

II

Lessee: Gerald G. Loucks

925 Kohl Street,

Denver, Co. 80020

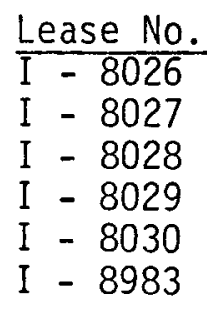

$\frac{\text { Date Issued }}{7-7-75}$

Acreage

$1, \overline{040.00}$

$2,556.56$

$2,524.32$

640.00

$1,760.84$

$1,940.19$

County
Owyhee
"
"
"
" 
Lessee: Gerald G. Loucks, Cont.

\begin{tabular}{|c|c|c|c|}
\hline Lease No. & Date Issued & Acreage & County \\
\hline $\begin{array}{l}I-8984 \\
I-8989 \\
I-8990 \\
I-8991\end{array}$ & $\begin{array}{c}7-1-75 \\
8-1-75 \\
11\end{array}$ & $\begin{array}{r}2,048.82 \\
1,400.00 \\
2,560.00 \\
1,296.28 \\
20,127.01\end{array}$ & $\begin{array}{c}\text { Owyhee } \\
" \\
" \\
"\end{array}$ \\
\hline
\end{tabular}

Lessee: Jerome $P$. McHugh

600 South Cherry Street, Suite 1225,

Denver, Co. 80222

Lease No.

Date Issued

$5-7-76$

I - 8034

Lessee: Magma Energy Inc.

631 So. Witmer Street,

Los Angeles, Ca. 90017

Lease No.

I - 7757

I - 7614

I - 7834

I - 7733

I -7727

I -14208

I - 14209

I -14210

I - 14211

I -14212

I - 14213

I - 14214
Date Issued

$5-1-76$

$6-1-76$

$6-1-76$

$8-7-75$

$8-1-78$

$8-1-78$

$8-1-78$

II

II

"1
Acreage $\quad \underline{\text { County }}$

$1,320.00$

Elmore

Lessee: 0xy Petroleum \& Occidental Geothermal, Inc.

5000 Stockdale Highway

Bakersfield, Ca. 93309

Lease No.

I -9545

I -9546

$I-10080$

I -10081

I - 10083
Date Issued

$\begin{array}{cc}8-7-75 & \text { (Comp) } \\ 11 & (\text { Comp }) \\ 1-1-76 & (\text { Comp }) \\ 1 & \text { (Comp) } \\ 1 & \text { (Comp) }\end{array}$
(50\% interest held by Union 0 il Company)

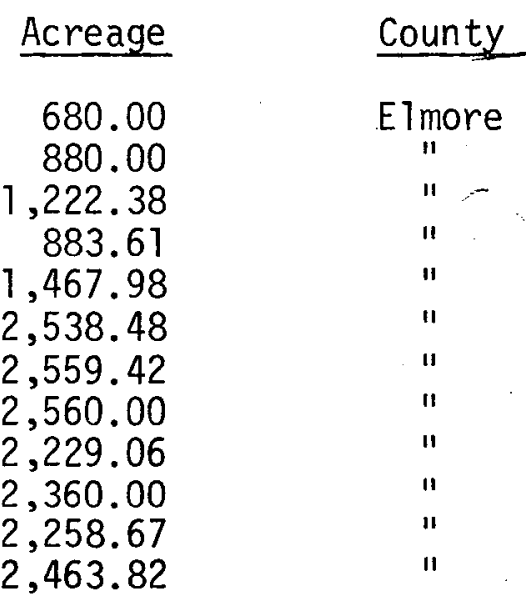

Note: $25 \%$ interest held by Louisiana Land \& Exploration Co. 
Lessee: Pacific Energy Corp.

One Maritime Plaza, Suite 1260

San Francisco, Ca. 94111

Lease No.

Date Issued

Acreage

County

I - 7620

Lessee: Phillips Petroleum Company Geothermal Operations

P.0. Box 239,

Salt Lake City, Utah 84110

Lease No.

$I-10085$

I -10086

I -13443

I - 7792

I -7589

I -7625

I -7717

I -7762

I -7805

I -9989

I - 9990
Date Issued

$$
\begin{aligned}
& 1-1-76 \text { (Comp) } \\
& 1-1-76 \text { (Comp) } \\
& 6-1-78 \\
& 7-7-78 \\
& 7-1-78 \\
& 11
\end{aligned}
$$

11

11

If

11

II
Acreage

$2,480.00$

$2,455.26$

$1,920.00$

$1,600.68$

$2,104.10$

$2,480.00$

$1,976.97$

880.00

$1,040.00$

$1,160.88$

$2,178.66$
County

Owyhee

11

Cassia

Washington

"

II

II

11

II

II

Lessee: Russel1 A. Pomeroy

5449 South Jasmine Street,

Englewood, Co. 80110

Lease No.

I - 8019

I - 8020

I -8022

I - 8023

I - 10079
Date Issued

$11-7-75$

$11-1-75$

$7-1-75$

$7-1-75$

1-1-76 (Comp)
Acreage

$2,558.04$

$2,558.52$

$1,283.63$

$2,480.00$

$2,492.00$
County

Owyhee

!I

II

II

Lessee: Raft River Rural Electrical Coop, Inc. Box 617,

Malta, ID 83342

Lease No.

Date Issued

Acreage

County

$I-14166$

4-1-78 (Comp)

$1,883.10$

Cassia 
Lessee: Robert A. Smith

P.0. Box 1603

Boise, ID 83701

Lease No.

Date Issued

Acreage

County

I - 12849

$6-1-77$

I - 12850

$6-1-77$

I - 12847

$9-1-77$

I - 12848

$9-7-77$

$1,916.91$

$2,560.50$

$2,520.00$

$1,631.50$

Owyhee

"

II

Lessee: Snake River Geothermal Co.

39 Broadway, 31st Floor

New York, N.Y. 10006

Lease No.

Date Issued.

Acreage

County

I - 13208

I - 13209

$10-1-77$

$2,200.62$

$2,040.00$

$1,896.72$

$2,381.80$

I - 13211

I - 13212

11

" $2,560.00$

Owyhee

II

II

Lessee: Dwayne C. Spangler

2827 Venus Place,

Boise, Idaho 83702

Lease No.

Date Issued

Acreage

County

I - 12778

$6-1-77$

$1,575.52$

Owyhee

Lessee: Laura L. Spangler

P.0. Box 1603,

Boise, ID. 83701

Lease No.

I - 12298

I - 12770

I - 12774

I - 12775

I - 12776

I - 12769

I - 12777

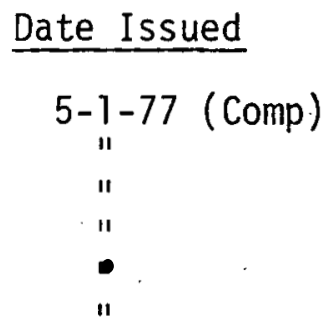

$6-1-77$
Acreage

$2,560.00$

$1,336.70$

$1,965.98$

$2,560.00$

$2,520.00$

1,977:44

$1,680.00$

Total $\quad 14,600.12$
County

Owyhee

11

II

in 
TABLE 14 (Cont.)

Lessee: SUNOCO Energy Development Co.

12700 Park Central Place, Suite 1500 , Dallas, Texas 75251

Lease No.

I -7508

I -7617

I -7781

I -7802

I - 7844

I -7702

I -7720

I - 9376

I -9377

I - 7633

I -7660

I -7710

I - 7634
Date Issúed

$7-7-75$

$"$

i"

iI

8-1-75

$5-1-76$

$9-7-76$

$9-1-76$

$12-1-76$

$12-1-76$

$10-7-77$

$2-1-78$
Acreage

$1,284.50$

640.00

$1,920.00$

$1,280.00$

$1,501.72$

800.00

240.00

$1,708.80$

481.29

$1,096.95$

$1,680.00$

$1,713.74$

$1,441.93$

Total $15,788.93$
County

Cassia

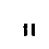

11

11

II.

II

II

11

!1

II

II

11

Lessee: SUPRON Energy Corp. 333 Flint Street,

Reno, Nevada 89501

Lease No.

Date Issued

Acreage

County

I - 12297

1-1-77 (Comp)

$1,380.63$

Washington

Lessee: Thermal Resources, Inc.

39 Broadway,

New York, N.Y. 10006

Lease No.

I -7643

I -7595

$1-7776$

I - 10408

I - 10409

I - 10410

I - 10411

I - 12684

I - 12685

I - 12687

I - 12688
Date Issued

$11-1-75$

11

$6-1-77$

II

It

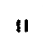

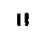

11

II
Acreage

600.00

$1,278.64$

$2,160.00$

$1,920.00$

$1,926.24$

$2,562.80$

$1,925.80$

$1,920.00$

$1,273.56$

$1,929.60$

$1,259.92$

Total $18,756.56$
County

Owyhee

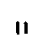

II

II

II

II

!I

II

II

II 
Lessee: Union 0il Company of California Note: Union 0il also holds P.0. Box 7600, 50\% interest in a11 Magma Los Angeles, California 90051 energy, Inc., leases in Elmore County. See Magma Energy, Inc.

\begin{tabular}{lccc} 
Lease No. & Date Issued & Acreage & County \\
\hline I -7808 & $7-1-75$ & 640.00 & Owyhee \\
I -7832 & $7-1-78$ & 640.00 & Washington \\
I -8191 & 1 & $1,242.84$ & " \\
I -8192 & 19 & $2,114.54$ &
\end{tabular}

Lessee: United States Geothermal Corp. 39 Broadway, Suite 3100 , New York City, N.Y. 10006

Lease No.

Date Issued

Acreage

County

I - 12328

I - 12329

$7-1-78$

$1,976.00$

$2,536.24$

$2,560.00$

$2,560.00$

$2,560.00$

$1,920.00$

$1,036.79$

$2,410.79$

$1,276.52$

I - 12336

I - 12338

$1,280.00$

Owyhee

Lessee: Floot R. White

193, The Masters Circle,

Costa Mesa, California 92627

Lease No.

Date Issued

Acreàge

County

I - 14493

I - 14494

$$
7-1-78
$$

941.97

80.00

Owyhee

Lessee: E.J. Wilson and Son

Liddy Hot Springs, Star Route

Dubois, Idaho 83423

Lease No.

Date Issued

Acreage

County

I - 7949

$10-1-77$

$1,246.44$

Clark 
K.G.R.A. Development Status 1978

Bruneau

Approximately one-half of the KGRA area has been leased to Occidental Geothermal Inc. No exploration activity has occurred on these federal leases.

Castle Creek Approximately one-half of the KGRA has been leased to several interest. No exploration drilling has occurred. on public lands. Exploration drilling has occurred on private lands within the KGRA. Wells were drilled by Phillips Petroleum Co.

Crane Creek Approximately one-third of the KGRA area has been leased to SUPRON Energy Corporation. No Exploration activity has occurred on public lands. Exploration activity has occurred on private lands adjacent to the KGRA by Phillips Petroleum Co.

Island Park No lease sales have taken place. Leasing of federal KGRA 1 ands and other national forest lands in the Targhee Naional Forest are awaiting the EIS by the Targhee National Forest. Over 150 lease applications have been recieved. EIS is expected to be complete by Feb. 1979 and lease sâles are expected by July, 1979.

Mountain Home Over half of the KGRA area has been leased to Union $0 i 1$ Co. and Magma Power Co. Exploration activity is being conducted on private leases adjacent to the KGRA by Magma Power Co. in joint venture with Union 0 il Co.

Raft River

One lease has been issued to Raft River Rural Electrical Coop. The D.0.E. is drilling the fourth and fifth production wells at the Raft River test site. Environmental problems regarding pollution of the regional irrigation aquifer are slowing the drilling process.

Vulcan

No lease sales have taken place, and leasing is not expected until the Boise National Forest writes an EIS.

Yellowstone

No lease sales have taken place and leasing is contingent upon the results of the Targhee National Forest EIS which wi11 be completed in Feb., 1979.

Conda

Recently defined as a KGRA by the USGS (8-18-78. A lease sale date has not been set for this area. 


\section{INSTITUTIONAL CONTROLS}

Introduction

A task of this report is to define the institutional parameters related to geothermal resources in Idaho. To accomplish this task, the institutional matrix was divided according to federal, state, regional and local controls. Institutional controls were defined as statutory responsibilities of the various agencies. Definitions of these responsibilities are presented in this section.

\section{Federal Controls}

Federal involvement includes the U.S. Forest Service on reserved National Forest Lands, the Bureau of Land Management on National Resource Lands, and the mineral estate under certain State and privately owned lands. The U.S. Geological Survey has responsibility for supervising operations concerned with discovery, development, and production of geothermal resources from Federal lands and mineral estates. The Fish and Wildlife Service exercises controls over withdrawn wildlife refuges.

Management policy has been extended in greater detail to all these agencies by the National Environmental Policy Act of 1969. Under certain conditions, there is a joint or multi-agency sharing of particular management and control responsibilities.

While the planning activity and its eventual land use controls are being developed, these agencies continue issuance (if feasible) of a variety of leases, permits, and licenses. Controls over these various land uses are of a discretionary nature in the form of stipulations imposes by the responsible agency official.

a. National Forest Lands

Basic land use controls over the national forest lands are conducted under the Organic Administration Act of 1897, and the Multiple Use Sustained Yield Act of 1960. Legislation, policy, and regulation provide firm and specific bases for administration of surface resources, including recreation, forage, timber, wil $l i f e$ and fishery resources. Mineral-resource administration is generally shared between the Bureau of Land Management and the U.S. Geological Survey. Mineral administration is complex and is usually related to the surface-resource values.

Forest Service personnel execute administrative policy and regulations in the national forest lands. District personnel are directed by a directives system of policy and regulations entitled the "Forest Service Manual". In addition, each District is guided by Ranger District Multiple Use Plans (RDMU plans). RDMU Plans are coordination requirements for use of these lands.

RDMU plans were prepared in the early 1960's by Ranger District personnel to implement Public Law 86-517 (Multiple Use Sustained Yield Act of 1960). Plans for each ranger district are in use, but need updating through the land use planning process. These plans are 
currently in accordance with a December 1965 Multiple Use Management Guide for the Intermountain Region of the Forest Service.

b. National Resource Lands

Traditionally, the National Resource Lands under jurisdiction of the Bureau of Land Management have been the subject of various forms of applications under a variety of agricultural land laws, public sales, and exchanges, etc. However with the passage of the Classification and Multiple Use Act of 1964, land areas and specific tracts were classified either for disposition or retention for multiple use management.

Like the Forest Service, the Bureau of Land Management is in various forms of applications under a variety of agricultural land 1 aws, public sales, and exchanges, etc. However, with the passage of the. Classification and Multiple Use Act of 1964, 1and areas and specific tracts were classified either for disposition or retention for multiple use management.

Like the Forest Service, the Bureau of Land Management is in various stages of developing land use plans. The first phase of the planning system (Unit Resource Analysis) consist of: (1) an inventory of the natural-resource base (1and, minerals, water-shed, forage, timber, recreation, wildlife, open space, and visual resource values) through consultation with the public and organized groups; and (2) identification of the potential development of each resource wi thout regard to the influence on or by the other resources. The Bureau of Land Management is currently developing Unit Resource Analys is information. The second phase (Management Framework Plan) identifies and resolves the different resource conflicts, and identifies various management alternatives.

The Mineral Leasing Act of 1920 gives the Bureau of Land Management the responsibility to determine if the federally-owned minerals shall be leased and, if so, under what terms and conditions. Under this authority, it receives and processes permit and lease applications on al1 Federal lands and Federal mineral estate and takes necessary action leading to the issuance or rejection of these applications. The 1970 Geothermal Steam Act gives the BLM similar responsibility regarding geothermal resources.

c. U.S. Geological Survey

The U.S. Geological Survey's Conservation Division has supervisory responsibilities over operations concerned with the discovery, development, and production of geothermal resources from Federal 1ands and the Federal mineral estate from certain private and State-owned lands.

Responsibilities include classifying, investigating, and reporting on applications for leases and prospecting permits and recommending lease terms to the Bureau of Land Management, enforcing compliance with lease terms and regulations governing the conduct of prospecting, mining, and beneficiation; protecting and conserving the natural resource by preventing waste; determining royalty 1 iability; preparing statements; receiving payment of royalties and rentals; and acting in:an advisory capacity to the Secretary of the Interior, other bureaus of the 
Department, and other government agencies .

d. Fish and Wildiife Service.

The Fish and Wildiife Service exercises land use controls over Wildlife Refuges. They also administer the Endangered Species Act of 1973, which provides for the conservation of endangered and threatened species of fish, wildlife, and plants. It also provides, through federal assistance, a system of incentives to develop conservation programs to meet the national and international standards. Section 7 of the Act states that the Secretary of the Interior shall review other programs administered by him and utilize such programs in the furtherance and purpose of the Act. It also states that endangered species and threatened species be protected through such action necessary to insure the continued existence of such endangered species and protection of their habitat as deemed critical in consultation with the appropriate states.

Under the Fish and Wildlife Coordination Act of 1958, the Fish and Wildlife Service investigates various water-related actions which may cause detrimental effects to fish and wildlife resources. It cooperates with other federal, state, and private agencies for the investigation into various fish and wildlife habitat programs. Under the provisions of this Act, the Secretary of the Interior, through the Fish and Wildi ife Service and the Bureau of Mines, is authorized to make such investigations as he deems necessary to determine the effects on wildlife of such impacts as domestic sewage, mine operations, petroleum and other industrial wastes, and silt and other polluting substances.

e. Bureau of Indian Affairs

Lands withdrawn from the public domain for reservoir purposes for the Grays Lake and Blackfoot Reservoir have surface use rights administered by the Bureau of Indian Affairs. Permits or leases are entered into for grazing, farming, public use sites, concessions, and other purposes.

Some of the land in the Grays Lake area is dedicated for both reservoir and wildlife refuge purposes. Surface use of these 1 ands is governed by an agreement between the Bureau of Indian:Affairs and the U.S. Fish and Wildlife Service, with permits issued by the agency responsible for the specific land to be permitted.

\section{State Controls}

The subsurface estate vested in the State or private ownership is governed by applicable statutes of the State of Idaho.

a. The Idaho Department of Lands issues leases and permits governing the use and disposition of a variety of natural resources to individuals, groups, and agencies. Jurisdiction over the various uses are identified by various State Statutes. This department issues geothermal leases for state lands.

b. The Idaho Department of Health and Welfare, Division of Environment, has the following controls and regulating powers:

Septic Tank Permits - the state regulates the installation and use of septic tanks. This authority has been delegated to the district 
health departments.

Sanitary Restrictions on Subdivisions - plans for subdivisions need to be approved by the Department to assure that plans and specifications for sewer systems have been approved.

Review of Plans \& Specifications, all plans and specifications for new and/or modified wastewater collection or treatment facilities must be approved by the state before construction can begin.

Environmental Impact Statement (EIS) Review - the department reviews and comments on the technical and Tegal adequacy of EIS's prepared by Federal agencies.

Non-Point Source Controls - the state will do the planning and develop programs for the control of non-point sources of pollution on areas not designated for 208 planning.:

Certification of Federal Licenses - makes sure issuance of a

Ticense does not violate any state air and water quality standards.

Wastewater Discharge Permits - under new regulations effective January 1, 1977, permits wiT7 be required for wastewater discharge from both point (excluding discharges to surface water) and nonpoint sources.

Antidegradation Requirements - new or increased pallutant discharge from industrial, public, or private projects or developments to either surface or underground high quality waters must be approved by the Idaho Department of Health and Welfare.

c. The Department of Water. Resources has a variety of duties and responsibilities related to administration of the Idaho Geothermal Resources Act, which include:

(1) Provide the data; information, and staff support to the Water Resource Board for the formulation and implementation of the State Water P.Tan.

(2) Administer the water laws and supervise the distribution of surface and ground water.

(3) Supervise the preparation of reports to the District Courts for the adjudication of water rights.

(4) Protect from contamination the groundwater by supervising the construction and use of water wells and waste disposal and injection wells. Issues all drilling permits.

(5) Protect public safety through the approval of plans and specifications of proposed dams and inspection of all existing dams.

(6) Manage and protect the state's geothermal resources.

(7) Protect streams from unnecessary or improperly designed channel alterations through a permit program.

\section{Regional Controls}

District Health Departments exert controls over lot sizes as they relate to individual sewer: (i.e. septic tanks) and water systems. The Division of Environment of the Idaho Department of Health and Welfare has the responsibility of certifying all municipal sewer and water 
systems.

Councils of Government have been organized and are in the process of assisting county governments develop comprehensive plans and zoning ordinances. No implementation authority rests in the Councils of Government.

\section{Local Controls}

In Idaho, counties have been given authority to exercise land use controls over unincorporated private lands. They are required to adopt comprehensive plans and to enact zoning and subdivision ordinances. This is a new requirement of the "Local Planning Act of 1975", which went into effect July 1, 1975 (Tit1e 67, Idaho Code).

Ultimate control jurisdiction rests with the county commissioners, and ultimate control within incorporated municipalities rests with the city councils. 
$\theta$ 


\title{
INSTITUTIONAL BARRIERS
}

\author{
Introduction
}

The time required for the development of geothermal resources on public lands is contingent upon the number of institutional factors involved. Leasing, exploration, drilling, and production all involve complex institutional procedures. Each major development activity requires an environmental report and the processing of a permit. As development proceeds from the pre-lease environmental report through leasing, drilling, and production, a series of parallel institutional steps are required. Each institutional step adds time to the development sequence. The influence of such institutional factors has often been one of delaying the onsite development activities. Such procedures have been labeled by the industry as "institutional barriers". The net effect of the institutional framework has been to extend the time required for any development scenario involving public lands.

Institutional barriers having the greatest impact, are common to all geothermal areas. The translation of these barriers to the development sequence has resulted in stagnation of development on public lands and slowed development on private lands. The aggregation of regulations has in effect created an institutional quagmire. In addition to the infrastructure of current regulations, tax statutes cripple the geothermal industry. The involvement of numerous regulatory agencies and a lack of tax incentives accentuates the uncertainty and risk already inherent to geothermal exploration and development.

Research was conducted to determine the major roles and needs of the various institutitional factors. Institutional barriers were identified through the development of time-line scenarios for each KGRA in the study area and personal interviews with regulators and developers.

\section{Major Institutional Factors}

The major factors in a geothermal development can be divided into two categories, private development sector and public agencies. These broad categories have several subdivisions. The private sector has three functional areas; private land owners, developer/provider activities, and utility/user activities. The public agencies are subcategorized into local, state, and federal government activities.

\section{The Private Land Owner}

The function of the private 1 and owner is the leasing or: sale of his property for geothermal exploration and for the construction of a utilization facility. Development interests are reluctant to construct any major facilities other than the well head on public lands due to restrictive surface occupancy regulations. Thus the private lands in and adjacent to the KGRAs have a double value to the development sector. These lands may possess the resource beneath the surface and are the areas under primary consideration for the construction of utilization facilities. 
The developer does have the right to as much surface area of the pubitic lands as is required for the development of the resources. (2) Under the State and Federal Geothermal: Acts, this right is tempered by conditiona? term leases, rental rates, and major environmental restrictions as to the type and mode of development that will be allowed. The result has been to deter the private sector from considering the construction of utilization facilities on public lands, unless there is no other recourse.

One reason the KGRAs of the Western Snake River Plain have a high potential for an early development is the considerable amount of private land interspersed with the Federal and State lands in the KGRAs. The development of the geothermal resources can occur on the public lands and be piped to the private lands for utilization.

Because there are fewer environmental controls and fewer public agencies involved, the majority of the exploration and development activities currently being conducted have been on private lands. If the resource is proven to be accessible on the private lands, then these lands will most likely be the first areas to develop followed closely by drilling activity on the public lands.

\section{Developer/Provider Activities}

The functions of the geothermal developer can be divided according to the logistics of exploration, drilling and production. The exploratory phase involves geological and geophysical investigations for reservoir assessment and selection of potential drilling sites. This is followed by an exploratory drilling phase, further geophysical investigations and reservoir characterization. Based on this data, the developer must make a decision whether or not to develop. If a commitment to develop is made, then a master plan is constructed and field production drilling takes place. Each of these activities takes a certain amount of time which will vary according to conditions. Typical time sequences were postulated based on drilling activities in other localities and for other resources. (3)

\section{Uti]ity/User. Activities}

The utility/user functions are an extension of the developer/provider's actions, and are often conducted by the same interest. The utility/user is primarily concerned with the construction and operation of a facility that will utilize or market the geothermal resources as delivered by the developer/provider. Certain logistic functions such as plant consiruction and the installation of distribution lines are usually dependent on the completion of one or more production wells." Time projections for each of these development actions were based on construction times for other geotherma 1 development. (4)

Within the private development sector, the activities of the major factors have been outlined in the scenario matrix by the fundamental logictical actions and decision that must be accomplished in order to complete a development project. It is these major development actions which are controlled by the regulatory functions of the public agencies. 


\section{Public Agencies}

It is apparent that the public agencies participate as a regulator of geothermal development. The regulatory process is accomplished through a series of permits at the local, state, and federal levels. In addition, there are several environmental and technical reports which are required by public agencies prior to the granting of the various permits. These reports must be reviewed by the agencies involved and approved before the permits can be justified. The requirements of the public agencies were identified and categorized as to the appropriate responsible agency. The appropriate local, state, and federal concerns were subdivided into fundamental roles which are an integral part of the geothermal development process. Time requirements for these functions were estimated on the basis of similar reports conducted in other areas for other types of resource. management. (5)

\section{Local Government Agencies}

In the Western Snake River Plain the local regulatory concern at the county level is minor. Most of the regulatory concerns at this level involve the issuance of land-use, construction, and other permits. Because 1and-use planning has only just begun for most of the counties in Idaho, there is very little restriction to geothermal development found at this level. Ada County and the City of Boise have the most stringent regulations. (6) Major development conflicts at the county level involve the possibility of incompatibility of a geothermal development with the present land use of the area. For example, geothermal development for industrial purposes in residential areas and in prime agricultural lands could cause land-use conflicts.

The majority of Idaho's counties have county land-use plans, or are developing those plans. None of these land-use plans have zoning ordinances which address geothermal development. Special land-use permits will be required for the construction of utilization facilities in zoned areas. These permits are in addition to the required building permits and sewage disposal permits required by the counties.

\section{State Government Agencies}

The regulation of geothermal development at the state level is the concern of four major state agencies: the Department of Water Resources, the Department of Lands, the Department of Health and Welfare, and the Public Utilities Commission. Through these state agencies the State controls the issuance of public utilities charters, leases, drilling permits, injection permits, and ground water appropriation. The issuance of permits by the State is not considered an institutional barrier. For example, a permit to drill for geotherma 1 resources takes two to four weeks to process." The state does require some-technical information about the type, size, nature, and plan of operation for its permits but does not require any major environmental statements. The major concern of the State with regard to geothermal resources development is to regulate any potential ground water interference problems. (7) 
State Land Board* and

Idaho Department of Lands

Idaho Department of Water Resources

Idaho Department of Health

Public Utilities Commission
Issues leases for state and school lands

Issues: Drilling Permits Water Rights Permits Geothermal Resource Permits

Injection Wel1 Permits Sets standards for drilling and casing

Certifies injection wells

Issues utility charters Certifies plant siting

(*Governor, Attorney General, and Superintendent of Public Instruction, Secretary of State)

Federal Government Activities

There are five major federal agencies which act in a supervisory role on federal lands. The major institutional barriers are in terms of time requirements. The Bureau of Land Management is the surface regulatory agency for the federal geothermà lands. in the Western Snake River Plain. The BL.M issues exploration permits, conducts environmental studies, and leases the land for exploration and development. The U. S. Geological Survey has two major functions. The Geological Division evaluates the land and resource for leasing. Secondly, the USGS Conservation Division is charged with policing geothermal lease areas, to insure that all lease obligations and regulations are met. In particular the Conservation Division processes environmental statements on drilling operations and plant construction, issues drilling permits, certifies plant sites and issues permits for any construction. The Department of the Interior's Fish and Wildlife Service also processes environmental statements and has a major impact on what areas are to be leased and under what conditions. The Environmental Protection Agency also reviews major environmental impact statements and monitors the sites for air and water pollution.

- Responsibilities of Federal Agencies in Relation to Geothermal Resources -

U. S. Forest Service

Bureau of Land Management

USGS Geological. Division

USGS Conservation Division
Surface management, EIS

Leases

Surface management

Resource assessment

Regulatory agency

Issues permits 
U. S. Fish and Wildlife Service

Environmental Protection Agency
Game management

Lease review

Environmental impacts

Pollution control

Inherent in the number of agencies involved at the federal level is the excessive time factor required to process the various reports and permits. Development of geothermal resources on federal lands will be slow due to a reluctance on the part of industry to work within this institutional framework.

\section{Institutional Barriers Resulting from Permit Requirements}

Several local, state, and federal agencies have a major influence on how and when a geothermal lease area will develop. The major institutional factors were identified and used as a matrix for scenario projections of a development sequence. The development sequence was based on the diligent development and primary term requirements of state and federal geothermal leases.

The major roles and needs of the various institutional factors were extrapolated into time requirements and event projections. These time lines indicate when a certain activity can be expected and how long a time period will be required before the next logical activity will commence. The scenarios begin with the pre-lease environmental reports and conclude with a projected first event involving completion of a utilization facility. The resulting scenarios show the influence of institutional factors on the time requirements of exploration and development logistics.

For each KGRA in the study area, development scenarios were constructed. The development of private, state, and federal lands was considered in the scenario construction (refer to Appendix G ). From these scenarios, a representative scenario was constructed to illustrate the time lag between development on private lands versus federal geothermal lease lands.

Permit requirements for exploration and drilling are time consuming and restrictive. Numerous permits result in long delays and curtailment of operations. Development of geothermal resouces is inhibited and the cost of development is unnecessarily increased by delays. The delays are effectively caused by the numerous government entities that must review the operation plan submitted by the developer. Elapse time required for obtaining a permit depends upon the environmental sensitivity of the area and the stage of the exploration/development process. A time period of at least six months and up to eighteen months may elapse before a permit can be obtained for drilling activities from the federal agencies. (8)

Figure 9 illustrates an ideal development sequence for two adjacent parcels of land. One parcel is leased by the federal government under the 1970 Geothermal Steam Act and the other is leased from a private land owner. The assumption is that the developer has an equal interest in developing both parcels and that both parcels have identical geological and environmental 
Figure 9

INSTITUTIONAL BARRIER ANALYSIS

GEOTHERMAL

DEVELOPMENT TIMELINE SENARIO

\begin{tabular}{|c|c|c|c|c|c|c|c|c|c|c|c|c|}
\hline $\begin{array}{l}\text { Operating } \\
\text { Entictes }\end{array}$ & $\vdots$ & ACTIVITIES & 1978 & 1979 & 1980 & 1981 & 1982 & 1983. & 1984 & 1985 & 1986. & 1987 \\
\hline $\begin{array}{l}\text { Private land } \\
\text { owners }\end{array}$ & $\begin{array}{l}1.1 \\
1.2\end{array}$ & $\begin{array}{l}\text { Issue Progpect } \\
\text { Lease land }\end{array}$ & $\Delta$ & $\Delta$ & & & & & : & & & \\
\hline $\begin{array}{l}\text { County/Local } \\
\text { Government }\end{array}$ & 2.1 & $\begin{array}{l}\text { Issue Land Use } \\
\text { ond enstruction } \\
\text { Permits }\end{array}$ & & $\mathbf{A}$ & & & & & & & & \\
\hline $\begin{array}{l}\text { State } \\
\text { Government }\end{array}$ & $\begin{array}{l}3.1 \\
3.2 \\
3.3\end{array}$ & $\begin{array}{l}\text { Isaue Drilling, } \\
\text { Permit Exploration } \\
\text { Issue Drilling } \\
\text { Permit Production } \\
\text { Isoue Utillty } \\
\text { Charter }\end{array}$ & & $\Delta$ & & $\Delta$ & & & & & & \\
\hline $\begin{array}{l}\text { Developer/ } \\
\text { Provider }\end{array}$ & $\begin{array}{l}4.1 \\
4.2 \\
4.3 \\
4.4 \\
4.5\end{array}$ & $\begin{array}{l}\text { Geophysical Expl. } \\
\text { Exploration drili. } \\
\text { Comit to Develop } \\
\text { Master Plan and } \\
\text { Environmental } \\
\text { Data Statement } \\
\text { Development Drill. }\end{array}$ & & $-\frac{2}{4}$ & & & & & & -7 & & \\
\hline $\begin{array}{l}\text { Ut1lity/ } \\
\text { Use: }\end{array}$ & $\begin{array}{l}5.1 \\
5.2 \\
5.3 \\
5.4 \\
5.6 \\
5.7 \\
5.8\end{array}$ & $\begin{array}{l}\text { Comit to Develop. } \\
\text { Master Plan-EIS } \\
\text { Design } \\
\text { Construction Supply } \\
\text { P1peline Install } \\
\text { Construction Use } \\
\text { Application on Line: }\end{array}$ & & & & A & & $\rightleftarrows$ & & 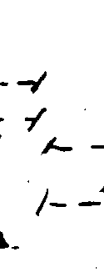 & & $\begin{array}{r}7 \\
-1 \\
\therefore-1\end{array}$ \\
\hline 5) Dor / bux & $\begin{array}{l}6.1 \\
6.2 \\
6.3 \\
6.4 \\
6.5\end{array}$ & $\begin{array}{l}\text { Acieve Laese - } \\
\text { Application } \\
\text { Prelease EIA } \\
\text { Issue Lease } \\
\text { Process BIS for } \\
\text { Drilling and PIpe } \\
\text { Cert1fy Siting } \\
\text { Perrits }\end{array}$ & $\hat{L}$ & & & & & & & A & & \\
\hline $\begin{array}{c}\text { 7) DOI / USGS } \\
\\
:\end{array}$ & $\begin{array}{l}7.1 \\
7.2 \\
7.3 \\
7.4\end{array}$ & $\begin{array}{l}\text { Evaluate Land for } \\
\text { Lease } \\
\text { Issue Prelease } \\
\text { Surface Exploration } \\
\text { Permft } \\
\text { Issue Exploration } \\
\text { Drilling Permit } \\
\text { Issue Production } \\
\text { Drilling Permit }\end{array}$ & & & - & & & •. & & . & & \\
\hline 3) DOI / PWS & 8.1 & EAR-EIS Review & & & & $4-$ & & $A-$ & 4 & -7 & & \\
\hline ?) EPA & $\begin{array}{r}9.2 \\
9: 2 \\
9.3 \\
9.4\end{array}$ & $\begin{array}{l}\text { Review Prelease EAR } \\
\text { Review Exploration } \\
\text { Drilling EAR-EIS } \\
\text { Review Production } \\
\text { Drililng EAR-RIS } \\
\text { Revlew Development } \\
\text { EAR-EIS }\end{array}$ & & & $6-$ & & & & $\mu-$ & -7 & & \\
\hline
\end{tabular}

KEY :

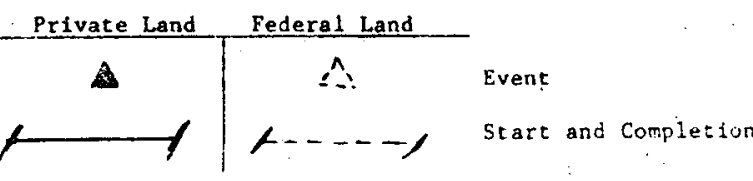


conditions. A developer who begins action on both parcels of land at the same time, with equal diligence, will find that the permit and regulatory process associated with the federal lands adds a minimum of two and one half years to a development sequence compared to the private land. This scenario development is also based on the presumption that the area in question has a low environmental sensitivity and that the permit process proceeds under ideal interagency cooperation.

The reaility of the situation is the federal government does not have ideal interagency cooperation. The delays that have resulted indicated that the leasing and permitting process may require up to five years. (9) This is double the original estimate that was based on ideal institutional conditions.

\section{Institutional Barriers to Facility Siting on Federal Lands}

Private development is detered from exploiting geothermal energy on federa 1 geothermal lease lands by inadequate regulations on surface occupancy. The present geothermal operating regulations provide surface occupancy rights for drilling and for production of the resource. (10) These regulations do not contain procedures that permit construction and opertion of geothermal steam power facilities or other utilization facilities on federal geothermal lease lands. The siting of these facilities is necessary to assure the orderly and timely development of federal leases.

The recent1y enacted BLM Organic Act of 1976,(11) specifically deals with right-of-way and siting permits associated with power plants, but is not clear where the authority lies in the federal government for licensing power plant siting on geothermal lease lands. In addition, the BLM Organic Act does not address the issuance of siting permits for facilities of nonelectrical nature.

\section{RECOMMENDATION}

Regulations concerning geothermal operations on federal public, acquired and withdrawn lands should be revised to permit the construction of geothermal steam power facilities and direct use facilities on lands leased for geothermal resources. Title 30 CFR 270 should be modified to include onsite utilization facilities. The definition of such facilities should include non-electric applications.

\section{Institutional Barriers to Exploration Drilling}

A critical shortage in the availability of large drilling rigs, capable of deep drilling, is perhaps the most significant institutional barrier in the private sector facing geothermal development in Idaho. Drilling depths of one to two kilometers are expected for high temperature production wells. Machinery capable of drilling $30 \mathrm{~cm}$ production well $\mathrm{s}$ to depths of over a kilometer is in short supply. Only three companies capable of drilling 
greater than 600 meters are located in the Snake River Plain Region. A11 three companies are water well drillers who have not drilled deeper than 1,000 meters. Only one of these operators has experience in drilling for geothermal resources.(13) The only equipment capable of deep drilling is operated by the petroleum and gas industry. One large drilling rig, owned by Phillips Petroleum Company is drilling for geothermal resources in the Western Snake River Plain on private lease lands. The majority of the deep drilling rigs operated by the other petroleum companies is tied up with higher priority oil and gas exploration wells.

Although over a quarter million acres of public lands have been leased in Idaho, not one exploration well has been drilled on public lands. The slow drilling activity is in part due to a lack of tax incentives. Two areas of federal taxation need remedial legislation in order to stimulate the exploration and development of geothermal resources. The two areas are intangible drilling cost deductions and depletion allowances.

Drilling Cost Deductions

The Internal Revenue Code of 1954 explicitly allows the operator of $0 i 1$ and gas wells the option of capitalizing intangible drilling and development cost. (14) The deduction generally includes all expenditures for drilling and preparing a production we11. Legislation extending the intangible dri11ing deduction to geothermal resources is of the utmost importance. Traditionally, natural resource development of private and publicly owned resources has been accomplished through private enterprise. Such exploration and development ventures have not occurred for geothermal. Although the level of interest in leasing geothermal resources has been high, exploration drilling activity has not kept pace.

The largest single deterrent is the present federal tax treatment of geothermal exploration expenditures. The lack of favorable tax incentives retards development of this resource by discouraging the investment of risk capital. A combination of the high risk exploration and the extended development time that proceeds initial revenues from the sale of energy makes an unfavorable investment climate. At today's prices and without some form of government cosi-sharing, the internal rate of return of most geothermal projects cannot satisfy the minimum 10 to 20 percent return on invested capital reouired by the investor. (15)

Tax incentives present the most advantageous approach to stimulating investments in geothermal exploration. It places the incentive in the private development sector, which is a tax-paying entity with alternative sources of taxable income and could benefit from tax credits resulting from a large scale capital outlay for exploration and development cost.

\section{RECOMMENDATION}

Section 263 of the Internal Revenue Code should be amended to provide for the deduction of intangible costs of drilling and development for a period of 10 years on geothermal investment projects certified by the Department of Energy. Section 611 
and Section 613 of the Internal Revenue Code should be amended to allow percentage depletion for geothermal resources.

Institutional Barriers at the Local Government Level

Few institutional barriers have materialized at the local government level at this time; however, the potential for conflict between geothermal developers and local government is real and warrants discussion. (23) Local impact will come from county governments' reactions to new growth generated by the construction and operation of geothermal energy facilities. Both the rate and the magnitude of growth will have an effect on the capability of local governments to manage local services. Growth will increase the number of people served and expand the types of services provided. While the existing services increase, the quality of those services that local governments provide may be severely affected.

A large scale geothermal development could cause rapid growth in rural areas which do not have adequate services. Several counties in the Snake River Plain are aware of this potential problem and are presently considering some form of facility siting ordinance to be integrated into their county plans. (24) 
$\bullet$ 


\section{A LEGAL OVERVIEW OF GEOTHERMAL RESOURCES IN IDAHO}

Introduction

The development of geothermal resources within the state of Idaho is controlled by three legislative acts. The statutory authority for the disposition of the geothermal resources that underlie acquired lands, mineral reserved lands, and public domain lands of the United States is the Geothermal Steam Act of 1970.(1) The State of Idaho under the statutory authority of the Idaho Geothermal Resources Act of 1972,(2) has also declared its interest by claiming the right to regulate the development and use of all geothermal resources on all lands within the state. The right to develop geothermal resources on lands owned by the State of Idaho is obtained through a lease that is issued by the State Board of Land Commissioners. (3) The third area of statutory regulation is Idaho water law which requires the water "resources of the state to be devoted to beneficial use in reasonable amounts through appropriation".(4) In order for the development of geothermal resources to proceed in an orderly and economical manner, the participants in the geothermal industry must have a clear understanding of the interrelationship between these three areas of statutory regutation.

\section{Federal Law}

The Federal Geothermal Steam Act

In 1970 the United States Congress passed the Geothermal Steam and Associated Geothermal Resources Act. This Act is the exclusive means of acquiring the right to explore and develop geothermal resources underlying federal lands and on lands subject to a mineral reservation. The geothermal resources are disposed of through a system of privately held leases. The structure of this Act and the legal framework of the leases closely parallel the Mineral Leasing Act of 1920(5) governing oil, gas, and minerals used for energy and fertilizer.

The Secretary of the Interior, through the Offices of the Bureau of Land Management (BLM), is authorized to issue leases for geothermal resources on public lands.(6) Minimum lease size is 640 acres and the maximum lease size is 2,560 acres within an area of six square miles. Departures from the compact area and minimum size restriction are allowed upon the approval of the BLM. (7)

All federal lands open to geothermal leasing fall under two general classifications. Lands in a "Known Geothermal Resource Area".(8) require competitive bidding to acquire the lease rights. Other lands are classified as "Potential Geothermal Resource Areas" and will be leased to the first qualified person applying for a lease.

Special provisions are made in the Act to limit the amount of surface area that can be developed and controlled by the lessee. The lessee may use only "the necessary amount of surface area required for his operation".(9) Geothermal development is specifically prohibited by the Act from interfering 
with or endangering the operation of other interests in the same 1 and. leases cannot interfere with or endanger the operation of the geothermal lease. (10)

The primary term of a federal geothermal lease is ten years. Within this period, the lessee must "prove" his lease by diligent drilling operations. The continuation of a lease without commercial production cannot exceed 40 years. (11)

The revenue raising aspect of the Geothermal Steam Act is secondary to the development of the resource. An annual rent of at least one dollar per acre and a royalty of not less than 10 percent and not more than 15 percent of the gross value of energy derived and sold is required by law. The Secretary of the Interior can waive these payments in the interest of a successful operation. Furthermore the Act requires that royalties must be paid on valuable by-products. The Secretary of the Interior is given wide discretionary powers on placing a value on the by-products. (12)

A bond of $\$ 10,000$ must be maintained, conditioned on compliance with all terms of the lease. An additional $\$ 5,000$ bond for indemnification for a 11 damages that result from the lease operation must also be posted by the lessee.(13)

Lands specifically excluded from the operation of the Federal Act are national parks, natjonal recreation areas, fish hatcheries, wildlife refuges, wildlife management areas and Indian lands. (14) This provision of the Act is of major interest for the development of geothermal resources in Idaho. Major geothermal areas of the state are located near, or with in these specifically excluded areas. Al though no geothermal development within these areas will occur under a federal lease, lessees whose exploration and development is in adjacent areas will encounter. major environmental restrictions.

The potential for environmental conflict between geothermal development and other land uses is greatest in close proximity to wildlife refuges and wild1 ife management areas. Well drilling, testing, and maintenance present local noise pollution problems. Depending on the location of the geothermal field and associated utilization facilities, with respect to a wildlife area, noise pollution control will be a major factor in the application of land-use regulations within individual lease contracts.(14)

The development of a geothermal resource involves a major change in land intensity. Increased noise pollution, sulphur dioxide emissions, and general human activity will affect adjacent wildlife areas. Adoption of mitigating measures during various stages of development can solve most of the environmental problems associated with geothermal development. Regulatory activities will probably focus on conditioning the geothermal development to be compatible with the present land use rather than prohibiting it entirely.

The Wilderness Question

It should be noted that wilderness areas are not specifically excluded under this Act.(15) This has led to speculation that wilderness areas are open to 
leasing. Although wilderness areas are included in the USGS classification of lands with potential geothermal resources, wilderness areas are not open to leasing. (16) Even if the Act is applicable to wilderness areas, it would be an abuse of discretion to issue a lease for a wilderness area. The issuance of a lease by the BLM is a discretionary act. It is within the statutory power of the BLM to reject nominations for leases because of environmental consequences or because other land uses have a higher priority. (17)

The Geothermal Steam Act of 1970 was established to provide statutory authority for leasing public lands for the development of geothermal resources. The Wilderness Act was established to preserve and protect certain public lands in their natural condition. Because Congress did not specifically exclude wilderness areas from exploration and development it cannot be construed that Congress intended the destruction of wilderness values by allowing geothermal development of the surface areas. The Congressional purpose for establishing a wilderness system is not nullified by the language of the Act. Nothing in the Geothermal Steam Act expressly authorizes the issuance of leases in wilderness areas, nor is there any specific statement by Congress to indicate their intent to override the prohibition clauses of the Wilderness Act. (18) Geothermal development will not occur in the wilderness system unless Congress repeals the Wilderness Act or determines that wilderness values are subordinate to geothermal needs. The Wilderness Act will be the controlling legislation regarding wilderness areas, superior to the Geothermal Steam Act of 1970.

\section{Idaho Law}

\section{Idaho Geothermal Resources Land Leases Act}

The disposal of geothermal resources underlying lands owned by the State of Idaho is authorized under the Geothermal Resources Land Leases Act. (19) The State Board of Land Commissioners, through the Idaho Department of Lands, is authorized to issue leases for geothermal resources underlying state and school lands of the state of Idaho. The term of a geothermal lease is ten years and can be continued as long as the geothermal resource is producing "in paying quantities" or as long as the lessee shows diligent good faith in drilling and development. (20)

The lease area is limited to an area no greater than one section is size, but there is no limit on the number of leases that any one person may hold. (21) The annual rental is set at a minimum of twenty-five cents $(25 \phi)$ per acre and the royalty is a minimum of ten percent of the gross value of the resource produced from the lands under lease.(22) These are minimum assessments of royalty and rental, and the state can set higher figures if it wi11 "maximize the public benefits". (23)

In issuing a geothermal. lease, the state does not reserve the right to issue leases for agriculture and other purposes for the same land. The geothermal lease will have paramount rights to as much of the surface area as it needs to accomplish the purpose of the lease. (24) This provision indicates the State's intention for a multipurpose use of its lands particularly with respect to agriculture. Present and future agriculture leases, particularly 
grazing leases, are subordinate to a geothermal lease in terms of access but in no way are other uses excluded from a geothermal area.

A minimum one-thousand-dollar bond is required with the initial lease and an additional six-thousand-dollar bond is required before the construction of any geothermal well.(25) The State of Idaho, through the State Board of Land Commissioners, reserves the right to cancel or modify any geothermal lease. This provision gives the State the authority to manage geothermal resource development on lands under its jurisdiction in an efficient and conservationoriented manner. (26)

\section{Idaho Geothermal Resource Act}

Geothermal development in the state of Idaho 'can occur on federal, state, or private lands. As owners of the pubiic domain and acquired lands, the Federal Government has the supreme authority to determine how these 1 ands will be used and the manner by which the public resources will be disposed. (27) The regulation of land uses and development pursuant to federal geothermal leases is not restricted just to federal jurisdiction.

The State of Idaho has the right to regulate federal geothermal leases, but is confined to regulating the lessee and not the lessor. Federal regulations require that the lessee comply with all federal and state standards with respect to control of all forms of air, land, water, and noise pollution.(28)

The most significant impact of geothermal resource development in southern Idaho will be the effect on water. Any geothermal resource development in southern Idaho witl involve some form of consumptive uitilization of thermal waters for energy conversion. The potential for discord between geothermal development and water resources is considered the most critical legal conflict, next to ownership of the resource, facing future geothermal resource development in Idaho.

The State of Idaho recognizes the unique nature of geothermal resources with respect to water and has declared the geothermal resources of the state to be "sui generous".(29) The "sui generous" desicnation classifies geothermal resources as being neither water nor mineral resource but closely related to and possibly affecting and effected by water and mineral resources. In order to control any possible conflict between geothermal utilization and state water appropriation, the regulatory powers of the State Geothermal Resource Act was placed in the Idaho Department of Water Resources. (30)

Under the Idaho Geothermal Resources Act, any private owner, or holder of a state or federal geothermal lease must first apply to the Director of the Idaho Department of Water Resources for a geothermal resource wel1 permit, before he can drill or alter any well for exploration or production purposes. A filing fee of one hundred dollars $(\$ 100)$ for a well and fifty dollars $(\$ 50)$ for an injection well is required with all permit applications. (31) The permit must be secured before drilling can occur.

An application for appropriation of public waters must al so be made if the proposed well will involve the use of water in the construction or operation of a geothermal we11.(32) For example, water that would be used in drilling 
a well or used to stimulate a hot but dry well would have to be appropiated from some other source. An application for appropriation must also be made if the geothermal well will yield water that will have a beneficial use.

This means that any consumptive use of geothermal water will require appropriation. (33)

If the geothermal well yields water that is used as a "mineral source, an energy source, or as a material medium", an appropriation of public waters is not required. Geothermal resources which can be developed as an energy source, a mineral source or as a material medium,(34) are usually dependent on high temperature geothermal reservoirs. Temperatures hot enough for electrical power generation (above $150^{\circ} \mathrm{C}$ ) can be found beneath Western Snake River Plain at depths of three to four kilometers. (35) Fluids at these depths are sui generous and would be high temperature, high pressure and often highly mineralized. Fluids at these depths are not normally associated with the developed ground waters, but can be affected by or affect the shallower ground water. In addition, high temperature fluids may be encountered at shallower depths than those mentioned, if suitable convective reservoir systems are present. Shallow, high temperature fluids are known to exist in several. locations in southern Idaho, particularly in the Raft River Basin. These high temperature geothermal fluids are directly related to developed regional ground waters.(35a).

High temperature geothermal fluids, developed as an energy source, a mineral source, or as a material medium are exempt from applications to appropriate water if they will not affect any source of developed underground water. $A$ geothermal resource permit will not be issued if the operation of any well, under the proposed permit, will unreasonably decrease the ground water available for prior water rights. (36) The burden of proving the interdependence between geothermal sources and prior ground water rights is with the State of Idaho. The geothermal resource permit will be denied until a valid water appropriation permit has also been obtained.

The statutory intent is to tightly regulate geothermal development which could interfere with a prior appropriation of water. The potential for such a conflict is quite high when considering shallow geothermal sources. Sources of geothermal fluids from depths deeper than two kilometers are generally high temperature sources and could be considered undeveloped and thus unappropriated waters. There would be little difficulty in obtaining an appropriation permit for such deep thermal waters on the grounds of the constitutional guarantee of the State of Idaho, that the appropriation of the unappropriated waters of the state shall not be denied.(37)

In the state of Idaho, any state, private, or federal geothermal operator must obtain a valid geothermal resource permit from Idaho Department of Water Resources before any drilling operations can begin. (38) The prudent geothermal developer in the state of Idaho would be wise to obtain a permit to appropriate deep, high temperature fluids used as an energy source.

This would guarantee him a prior appropriation of the newly developed water source. The acquisition of a valid water right for a geothermal development appears to be the current interpretation for the administration of this Act. 
Certain specific types of geothermal resource utilization are specifically excluded from geothermal resource permit requirements.

\begin{abstract}
"No person operating or proposing to operate a geothermally heated green house, hot house, swimming pool, hot springs bath, or hot water fish propagation facility, space heating plant or similar facility unless such operation is in conjunction with a geothermal resource use not specified in this subdivision, shall be compelled to comply with the geothermal resource permit requirements under this act if such person obtains a valid water right permit for such operation." (39)
\end{abstract}

The operations mentioned above are low temperature uses of geothermal resources. Low temperature thermal waters $\left(80^{\circ} \mathrm{C}\right.$ to $\left.140^{\circ} \mathrm{C}\right)$ with potential for space heating and other low temperature uses are common shallow ground water resources in southern Idaho. Under this part of the Idaho Geothermal Resources Act, any irrigation well which contains thermal water and a valid water right could develop a geothermal heating project without a geothermal resource permit.

Presumably, drilling and development of $10 \mathrm{w}$ temperature thermal we11s for any of the above geothermal operations will be regulated by the ground water appropriation laws and water well drilling regulations of the State of Idaho.

If the operation of a low temperature utilization method is in conjunction with a geothermal resource use not specified under this part of the State Act, then the operation is regulated by the geothermal resource permit regulations. Secondary developments, associated with higher temperature developments, would be governed by the permit regulations of the Geothermal Resources Act. Thus, any high temperature geothermal resource developed for an energy source which also develops a secondary use beyond the primary energy use, would fall under the appropriation clause of the Act.

The implications of the exemptive clauses of the Idaho Geothermal Resources Act are that low temperature geothermal utilization requires only a valid water right permit and such operations would be regulated by the appropriation laws of the state. Higher temperature utilization for an energy source or mineral resource requires a geothermal resource permit, but does not require a water right permit. This latter point is only valid if the well will not interfere with other ground water users. Conjunctive developments of high and low temperature uses from the same geothermal resource well would require both a water right permit and a geothermal resource permit.

Although many low temperature uses do not require a valid geothermal permit, such operations can acquire one. Likewise high temperature geothermal operations developed as an energy source, a mineral resource or a material medium do not require a valid water right permit, but such operations can acquire such a permit. 'A prudent operator would be wise in obtaining both permits for additional protection from third party interference and for avoiding potential conflicts with state agencies. A problem with applying for both permits is that performance bonds, application fees, and damage bonds are required for each. 
Under the general concept of the appropriation doctrine, the individual water user has a guaranteed right to the continued use of water based on the date of his first use of the water. The measure of his certainty to an adequate water supply is his priority date. The appropriation doctrine is the basis of water law in the western United States. In the state of Idaho, the appropriation doctrine included the administration of ground water resources.

Idaho has had a comprehensive Groundwater Act since 1951.(40) Under this Act "the right to groundwater may be acquired only by appropriations. "(41) There is no distinction in the Groundwater Act between categories of ground water. Under this statutory framework, a water right is acquired by diverting the water and applying it to a beneficial use. (42)

The acquisition of ground water rights in the state of Idaho is through a permit system supervised by the Idaho Depariment of Water Resources. (43) Under the permit system, any person intending to appropriate water must apply for a permit prior to commencing work on the diversion and distribution facility.(44) The Department then publishes notice and if anyone files a protest against approval of the application, a hearing must be held. (45) The State can deny a permit or grant one for a lesser quantity of water only under the following conditions.(46)

1) If the proposed use is such that it will reduce the quantity of water under existing rights.

2) If the water supply itself is insufficient for the purpose for which it is sought to be appropriated.

3) If it appears to the satisfaction of the Department that such application is not in good faith.

4) If the applicant has not sufficient financial resources with which to complete the work involved.

After the diversion has been completed and the water put to a beneficial use, a license is granted. The priority of the water right begins on the date the application for an appropriation permit was filed.

The point here is the difference between developed water and appropriated water. Water that is used in the construction of a geothermal well or water that is injected to develop a geothermal system would have to be derived from another source. This would require an appropriation for that purpose. Thus a permit to construct a geothermal well of this nature would be dependent upon both a water appropriation permit and a geothermal resource permit. If the particular system involves the extraction of high temperature water for the purpose of mineral or energy extraction, that water will be considered non-tributary water or developed water, providing that such waters would not be available for use except through the exertion of the development of the geothermal resource. The developer of the water would create a water source and under the appropriation doctrine would be given free rein of disposition of this water provided that no other appropriator could be injured by this action. The geothermal permit does not guarantee the operator a water right to the created water. If the operator wishes assurance against subsequent developers, he would be wise to acquire an appropriation license as prima 
facie evidence of a water right. The geothermal resource permit gives the operator the right to construct a geothermal well and extract the energy or mineral found therein. Anyone diverting water and applying it to a beneficial use without a permit acquires no rights to that water under the mandatory permit system of water appropriation in the state of Idaho. (47)

The Idaho Groundwater Act seeks to promote "full economic development" of the state's ground water resources. (48) The full economic development of ground water is consistent with the constitutional policy of promoting optimum development of the state's water resources. (49) The implications of the phrase "full economic development" to geothermal development is not clear and needs definition. Geothermal resource development, by its very nature, involves the combination of various resources which seek maximum net benefits by efficient economic coordination of those resources. It would seem that geothermal development, particularly multicomponent utilization, would be a justifiable interpretation of "full economic development".

The Idaho Groundwater Act requires "the maintenance of reasonable groundwater pumping levels".(50) The maintenance of reasonable, pumping levels is of concern to geothermal development. The Director of Water Resources can establish ground water pumping levels in areas "having a common groundwater supply". (51) The interpretation of the phrase "common groundwater supply" is not clearly understood and subject to judicial review. Deep thermal aquifers could not be termed a "common groundwater supply", but they may be hydrologically interrelated to shallower common ground water supplies. Excessive withdrawal of thermal waters from these deep sources could be restricted if pumping levels of other prior appropriators were affected. Thermal aquifers which are shared by geothermal developments and other water users, such as irrigation, would fall under the broad term "common groundwater supply". This is particularly true in the Bruneau-Grandview area of northern Owyhee County where irrigation wells yield thermal waters. In all such cases, it would be prudent for the geothermal well operator to have a water right to protect himself against third party interference.

In defining the term "beneficial use", the Idaho Supreme Court held that the use of hot water in the heating of dwelling houses comes within the "domestic purposes" seciion of beneficial use of water. (52) This determination qualifies domestic space heating appropriations for preference rights guaranteed under the articles of the Idaho Constitution. (53) Under the articles of the Idaho Constitution, those using water for domestic purposes have a preference over those claiming water for any other use if no other source of water is available. It is within the perview of the Idaho Constitution for such purposes to acquire waters under a condemnation proceeding, subject to the provision of law regulating the taking of private property for public use. (54)

In the case of an established district space heating system, an interfering well for industrial or irrigation uses could be condemned. But the condemnation of an irrigation well or an industrial hot water well to establish a district space heating system for domestic use is highly questionable. In such a case the preference right of domestic use is limited. If energy can be obtained from some ocher available source (i.e., natural gas) then it is very questionable if the taking of private property for public use could be justified. 
CRITICAL GROUNDWATER DESIGNATION:

The total development of groundwater in the state of Idaho is limited by the restriction that no well may "result in the withdrawing of the groundwater supply at a rate beyond the reasonably anticipated average rate of future natural recharge."(55) Excessive declines in water levels can occur and this provides protection against mining groundwater sources. The rationale behind the natural recharge restriction can be seen where a regional groundwater source which is in danger of over appropriation. This point is clearly recognized by the Idaho Code. The Water Administrator can designate an area as a "critical groundwater area."(56) This designation closes the area to future applications to appropriate groundwater but does not affect any of the existing pumpers or valid outstanding permits. $(57)$ The designation of a critical groundwater area serves notice that no new appropriations will be granted for the area or that appropriations will be granted only for reduced quantities.

Geothermal resource permits would most likely be denied in areas designated as critical groundwater areas. If the geothermal permit was valid prior to the designation the operator would have a right to continue, but could be subjected to pumping level restrictions. It is highly doubtful that a geothermal permit would be issued for a critical groundwater area without a water appropriation permit. Geothermal resource permits could possibly be issued for deep exploratory purposes in critical groundwater areas providing adequate protection and monitoring of the aquifer was provided.

The application of the natural recharge clause to geothermal wells is of particular interest to the geothermal operator. Geothermal developments of a major scale will require a natural reservoir of thermal fluids with sufficient permeability to insure adequate recharge and fluid movement. Such a reservoir would most likely develop from a hydrothermal convective system which is a dynamic circulating water system. The heat that the system possesses is transferred from the earth source to the percolating meteoric waters of the region. This water in turn circulates by convection and deposits or discharges the heat near the surface of the system, creating the high temperature reservoir.

If a natural or artificial discharge occurs at the top of the system, a recharge must occur in order for the dynamics of the convective heat transfer to continue. The natural rate of recharge for most geothermal systems is very slow. Significant withdrawal of water will have to be replaced in a homeostatic geothermal reservoir, in order to avoid depletion, land subsidence, (58) and changes in regional groundwater flow. Large discharges for geothermal systems with naturally slow recharge rates could establish an influent system: which will cause water to flow toward the cone of depression. This could be considered groundwater mining and may have effects on areas of the regional water table and groundwater appropriators. Under Idaho water law, geothermal operations of this nature are at a distinct legal disadvantage and subject to restrictions and cancellation of permits. 
Any geothermal development operation which involves a large consumptive use of thermal groundwater presents numerous legal problems, particularly if the well has a potential for hydrologic disruption. The harmonious development of geothermal resources with other aroundwater appropriations is clearly possible under Idaho law. The Idaho Department of Water Resources has two statutory methods for regulating the harmonious development of geothermal resources and groundwater management.

The primary method of administering the harmonious development of these resources is the issuance of the permits. The director of the Idaho Department of Water Resources can deny a permit for a geothermal operation or require an additional water appropriation permit for that operation. If the director finds that the unappropriated groundwater resource is not available or that other appropriators could be adversely affected, he can deny permits to both geothermal and groundwater development operations. Secondly, the director can regulate wells by declaring critical groundwater areas, establishing pumping lift restrictions and closing wells for excessive withdrawal of water beyond the natural recharge of the system.

INJECTION WELLS :

The development of a homeostatic geothermal reservoir for a major consumptive utilization, such as electrical power generation facility or a major food processing plant, will probably involve the development of injection wells. The development of injection wells in conjunction with geothermal development is a common form of disposal of waste fluids. The injection of spent thermal fluids back into the hydrothermal convection. system will help avoid an early depletion of the resource and mitigate envirorimental problems of hydrological displacement, subsidence, and discharge. restrictions on water quality. The construction of an injection well is subject to regulation by Idaho law. (59) The regulation of injection wells in Idaho is the responsibility of the Department of Idaho Water Resources.

No waste disposal or injection well can be constructed in Idaho unless a permit has been issued by the Director of the Department of Water Resources. Filing fees of twenty-five $(\$ 25)$ dollars for the first well and ten (\$10) dollars for each well thereafter are required. (60) The approval of an injection well permit is contingent upon the investigations of the Director of the Idaho Department of Water Resources and the Director of the Health and Welfare Department. (61) The Department of Water Resources investigates the effect that the well will have on the rights of others who use the water. Also they regulate the standards of well construction. The approval of the injection well depends largely upon the review of the application by the Department of Health and Welfare. The proposed well is reviewed by this department to see if it will unreasonably contaminate or deteriorate the quality of the groundwater below the adopted water quality standards of the state. The Director of Health and Welfare can recommend to the Directior of Water Resources that the permit be disapproved. (62)

Federal water quality regulations also have a major role in regulating reinjection. The Federal Safe Drinking Water Act, the Federal Water Pollution Control Act, and the National Environmental Policy Act have regulations on this subject. (63) Any reinjection of spent thermal fluids will require some form of special permit status to reinject under federal standards. 
The Geothermal Steam Act of 1970, leaves the issue of the reservation of geothermal resources to judicial interpretation. The Act directs the federal justice department to institute litigation to quiet the title for geothermal resources on lands that have the mineral estates reserved to the United States. (64) The resulting litigation (65) holds that geothermal resources are included in a reservation to the United States of "all coal and other minerals" under the Stockraising and Homestead Act of 1916."(66)

The Department of Interior also asserts that geothermal resources were reserved by Executive Order in 1930. Congress in 1910 authorized the President of the United States to temporarily withdraw public lands of the United States"... and reserve the same for water-power sites... or other purposes to be specified in the orders of withdrawals..."(68) President Hoover under the authority of this act withdrew "every smallest legal subdivision of the Public lands surveys...containing a hot spring, or a spring the waters of which possess curative properties... (69) The Department of Interior has taken the position that this Executive Order extends the reseryatjon to hot water systems developed by drilling wells on the public lands. (90)

The Federal government by enacting a comprehensive act controlling the acquisition of geothermal resources on public lands has preempted state power to issue acquisition rights to geothermal resources through water appropriation laws on federal public lands. This does not imply that geothermal development under the National Geothermal Steam Act is exempt from state water laws. Concessions to the states of appropriation powers and other regulatory powers (71) regarding water in the Desert Land Act of 1877 and other federal statutes asserts that states have jurisdiction over geothermal resources regarding their relationship to water resources. The extent to which state laws can regulate geothermal resources on Federal lands is a major jurisdictional issue facing geothermal resource development and conservation in the state of Idaho. To this date, there have been no major challenges to the state's jurisdictional right to regulate geothermal development on federal 7 ands. Questionable areas of jurisdiction between State and Federal government will involve those areas where geothermal development has the potential for conflict with other groundwater users.

The Geothermal Steam Act is the sole procedure for acquiring the rights to develop and ytjlize geothermal resources underlying lands owned by the United States. (72). The Act states that "nothing in this. Act shall constitute an expressed or implied claim or denial on the part of the Federal government as to its exemption from state water laws". (73) "Under the provisions of the Act, the issue of the state's jurisdiction over geothermal development on federal land is left unresolved.

Individual states have been empowered by the Federal government to regulate the acquisition of water rights within their boundaries. By virtue 
of the Desert Land Act of 1877, the power of the state was extended to Federal lands. (74) Judicial interpretation has limited the state's power to public lands which have not been reserved by the federal government. (75) Under the supremacy clause, the Federal government has the freedom to control the use of its properties without regard to state law. (76)

Supervision of geothermal operations on federal lands has been delegated to the United States Geological Survey and other agencies designated by the Secretary of Interior. (77) Nothing in the Geothermal Steam Act authorizes a delegation of jurisdiction to the states. Under the statutory mandate of the Geothermal Steam Act, lessees should not need to secure a state permit for geothermal development on federal Tands. (78)

Although there have been no court tests of this position the potential for conflict between state and federal regulatory control exist. Where Idaho geothermal resources are most promising, existing groundwater supplies are also in great demand by conventional users. If geothermal resource development activities are subjected to state water regulations, these operations may be compelled to seek water rights from competjing users or stopped by other water users from obtaining water rights. (79)

Under the reserved rights doctrine the federal government could claim a right to the water necessary to fulfill the purpose of the reservation. (80) U.S. Court of Appeals has held that the United States rights to necessary groundwater is established by implied reservation in a presidential proclamation removing area from the public domain. (81) The court sustained that the United States may reserve not only surface water but also underground water for the use of any federal enclave. Ay analogy, geothermal resources which have been withdrawn from the public domain by Presidential, (82) and congressional(83) proclamation have a reserved right in groundwater sufficient to maintain the purpose of the reservation. In a recent case, California vs. United States, (83a) federal water development projects were found to be subject to state water appropriation laws. The Court held that the United States is required by the Reclamation Act of 1902 to acquire water rights for its projects under state law. This case implies that federal geothermal development projects may have reserved rights to sufficient groundwater but the acquisition of that water is regulated by state water 1 aws.

THE ROLE OF STATE REGULATIONS IN FEDERAL GEOTHERMAL LEASES

Federal geothermal leasing laws allow the consideration of state regulations in federal geothermal 1eases. The Department of Interior maintains that it will cooperate in federal leases. Other State regulatory acts, similar to the Geothermal Resources Act, have been upheld in the Idaho Supreme Court as reasonably and substantially related to the legitimate police powers of the state. (88) Idaho's highest judiciary has held that permits and bonding requirements of state regulatory acts do not seek to ban federal leasing activities but merely seek to regulate it. Other cases support this argument. (89)

When there is a conflict between state and federal legislation, state legislation which make it impossible to exercise that right would be in conflict with the supremacy clause. The Idaho Geothermal Resources Act would be in conflict with the supremacy clause. The Idaho Geothermal Resources Act would be unenforceable on federal geothermal lands if it restricted 
development to the extent that it rendered it impossible to develop all resource areas. A permit could be denied for a federal geothermal lease by the state without violating the supremacy clause. Also, a permit could be issued by the state, under the police powers, that is very restrictive, thus limiting the scope of the development.

The Idaho Geothermal Resource Act clearly falls within the police powers of the state because it "..... bears a reasonable relationship to the public health, safety, morals and general welfare of the state. "(90) A federal lessee is faced with a situation in Idaho of attaining a state geothermal permit which is based on strict state water appropriation rules. At present, Idaho Department of Water Resources requires all federal lessees to acquire a geothermal resource permit before drilling operations can begin. (97) All drilling operations being conducted at the Federal Department of Energy geothermal test site located at Raft River, Idaho, have complied with the Idaho Geothermal Resources Act by acquiring all the necessary permits from the state. (92) This action by the federal government has been more in the spirit of cooperation than a capitulation by the federal government to the state's right to regulate geothermal resources on federal government lease lands. Although the federal government does not concede that the state has a right to regulate federal leases, by the act of complying at Raft River and Federal government has set a precedence to which all future federal geothermal leases will be held.

Legal restrictions on geothermal resource development in the state will depend upon well interference conflicts. If geothermal operations do not interfere with other water users, then there is little reason to impose restrictions on the geothermal operator, except for those restrictions necessary to prevent the pollution of conventional water resources. If geothermal wells are interfering or have the potential for interfering with conventional water resource users, then geothermal operations must be conducted in harmony with those competing rights according to Idaho water laws.

Jurisdictional conflicts will occur when adjacent land owners (federal, state, private) are developing a common pool geothermal resource or groundwater resource. The application of "first in time and first in right" will probably guide the development of this resource as an energy resource in Idaho. By placing the police powers of the Idaho Geothermal Resource Act within the Idaho Department of Water Resources, (93) the state has made a major accommodation regarding geothermal resources which respects the strong relationship of the resource to other water resources. It is apparent that geothermal resource development can only be accomplished by a compatible relationship to appropriation doctrine.

Water right conflicts and the need for adjudicated rights between geothermal users and water users, will depend largely on the water need of the geothermal operation. The amount of water that will ultimately be used by the geothermal operation will depend on the type of utilization proposed for each site. Non-electrical utilization of thermal waters in the food processing industry could consume thousands of gallons per minute of thermal water. If the theirmal fluids are used for heat extraction and then reinjection back into the thermal aquifer, the potential consumption would not be significant and the potential for water right conflicts would be small. 
The use of geothermal resources for the generation of electricity has the highest potential for consumption. Since the typical generation facility wi 11 be developed from a wet steam or hot water reservoir, it is estimated that there wi.11 be a $20 \%$ consumptive loss by evaporation. (94) The current estimate for the amount of water needed to generate electricity is 48 acre feet/year/megawatt. 95 ) The major problems with geothermal regulations will be the large consumptive users which cause draw down problems with other conventional users of regional groundwater resources. 
1. 30 U.S.C. 1001, The Geothermal Steam Act of 1970.

2. Idaho Code 42-4001 et. seq. (Chapter 40, Geothermal Resources).

3. Idaho Code 47-1610 et. seq. (Chapter 40, Mines and Mining).

4. Idaho Code 42-101 et. sea. (Chapter 1, Appropriation of Water). Idaho Code 42-226, (Appropriation of Groundwater).

5. 30 U.S.C. 181 et. seq., also 30 U.S.C. 35 ?, 358.

6. Bureau of Land Management regulations concerning geothermal resources are found under Chapter 2, Title 43 Code of Federal Regulations 3200.

7. C.F.R. 3203.2. Any one entity must limit its maximum holdings to 20,480 acres. This provision is intended to limit the amount of potential resource areas that any one concern can hold or control. It was the intent of congress to prevent large energy companies from controlling the future development of a competitive form of energy and to encourage smaller interests to become involved in the development of this resource.

8. 30 U.S.C. 1020, A KGRA occurs when geology, discoveries and competitive interest and overlapping applications for leases suggest geothermal resources are present and appear to be a recoverable investment. The U.S. Geological Survey classifies lands as KGRA. Also see U.S.G.S. Cirr. 647.

9. C.F.R. $3200.0-8$.

10. Ibid.

11. C.F.R. $3203.1-3$

12. C.F.R. 3205.3.

13. C.F.R. 3206.T.

14. The most notable example of this potential problem is the Birds of Prey Natural Area. Geothermal leases are not issued in the buffer study area of the natural area and leases that are in the general area have specific stipulations within the lease which protect nesting sites and restrict activity in the area.

15. 43 C.F.R. 3201.1-6.

16. Soko1, Jan D., "Geothermal Leasing in Wilderness," 6 Environmental Law 489, 1975-76.

17. 43 C.F.R. 3200.3. 
18. Izaak Walton League of America v. St. Clair, 353 F. Supp 698, The case considered the question of whether mining activities were compatible with the objectives of the Wilderness Act. The court stated that there is an "inherent inconsistency" in the Wilderness Act and that it was up to the judiciary to decide on which purpose Congress deemed supreme. The court concluded that there are provisions provided for mining in the Wilderness Act, but "if an area is to remain true wilderness, there is no reasonable usage to which the surface can be put and still retain the area's character as a wilderness... In the court's opinion the Wilderness objectives override the contrary mineral right provisions of the statute, otherwise the Congressional Act is a nullity." The conclusion is that the overriding purpose of the Wilderness Act is the preservation of wilderness values. Any use that is inconsistent with this purpose is subordinate to this purpose.

Case reversed on other grounds, 497 F.2d 849.

cert. denied $95 \mathrm{~S}$. Ct. 329 (1974)

For an excellent pro and con discussion of this issue see:

Tarlock, A. Dan, and Waller, Richard L., "An Environmental

Overview of Geothermal Resource Development", Geothermal Resource

Development Institute, Paper 14, pg. 17-19, (Rocky Mt. Min L Fdn, 1977).

19. Idaho Code 47-1601 and 47-1611.

20. Ibid.

21. Idaho code 47-1604.

22. Idaho Code 47-1605.

23. Ibid.

24. Idaho code 47-1606.

25. Idaho Code 47-1608.

26. Idaho Code 47-1611.

27. 43 C.F.R. 3201.1-3.

28. 42 C.F.R. 3204.1 (c), also 3234.2-4.

29. Idaho Code 42-4002, Idaho Geothermal Resource Act: sui generous; being neither water nor mineral resource but closely related to and possible affecting and affected by water and mineral resources.

30. Idaho Code 42-4001, et. seq.

31. Idaho Code $42-4003$ (c).

32. Idaho Code $42-4003$ (b), the appropriation of public waters of the state of Idaho is controlled by Idaho Code 42-227. 
33. AlTred, Steve, Director of Idaho Department of Water Resources, personal communications, March, 1978.

34. Idaho Code $42-4002,4003$.

35. Brott, Charles A., et. al., Heat Flow Study of the Snake River Plain Region, Idaho, Geothermal Investigations in Idaho, Part 8, Idaho Department of Water Resources Information BuT1. 30 (1976), pg. 50-52.

36. Idaho Code 42-4006 (e).

37. Idaho Constitution, Article 15, Section 3. The constitutional aspect of water appropriation in Idaho relates to the declaration in the original constitution of 1889 that "The right to divert and appropriate the unappropriated waters of any natural stream to beneficial uses shall never be denied." In 1928, this sentence was amended by adding the clause "except that the state may regulate and limit the use thereof for power purposes." The effect of the constitutional provision on the acquisition of water riahts for irrigation and other purposes, other than power, was not altered by the amendment. The development of geothermal resources for power generation will be affected by this regulation but other nonelectrical uses presumable are not affected. For further information on the judiciary ruling of a constitutional method of appropriation of water see the following: Pioneer Irr. Dist. V. American Ditch Assn. 50 Idaho 732. Also see: Hutchins, Wells A., Water Rights Law in the Nineteen Western States: Volume 1, U.S. Department of Agriculture Publication No. 1206, pg. 346.

38. Clapp, Darrel, State of Idaho Department of Water Resources, personal communications, December 1977.

39. Idaho code 42-4003 (e).

40. Idaho Code 42-226 et. seq.

41. Idaho Code 42-229.

42. Idaho Code $42-230$.

43. Idaho Code $42-437$.

44. Idaho Code 42-202, 42-229. An application for a permit must be accompanied by information about the project. The permit application must contain information about the project that the Director of Water Resources Department has requested. A plan of operation; a map of proposed facilities and a payment of a fee, which varies with the size of the appropriation also must accompany the application.

45. Idaho Code $42-203$.

46. Idaho Code 42-203. Delay for speculative purposes is included in the good faith clause. Such delays are a violation of Idaho Code. 
47. Tappen v. Smith, 92 Idaho 45.

48. Idaho Code 42-226.

49. Idaho Constitution Article 15, Section 7.

50. Idaho Code $42-226$.

51. Idaho Code 42-237 (a-g).

52. Public Utilities Commission v. Natatorium Co., 36 Idaho 287; 211 Pac. 533; Idaho Code 42-111. Domestic Purposes Defined: Heating of dwelling-houses comes within meaning of "domestic purposes."

53. Idaho Constitution, Article 14, Section 3.

54. Idaho Code 7-701, Eminent Domain.

55. Idaho Code 42-223 (a).

56. Ibid.

57. Ralston, Dale R., et. al., Analys is of the Impact of Legal Constraints on Ground-water Resource Development in Idaho, Idaho Bureau of Mines and Geology Pamphlet No. 158, (1974), pg. 57.

58. Subsidence is a result of reduction of hydrolic support due to extraction of fluids. This is a common environmental problem associated with major geothermal wells and large groundwater we11s.

59. Idaho Code 42-3901 et. seq. chapter 39, Waste Disposal and Injection Wells.

60. Idaho Code 42-3905.

61. Idaho Code 42-30906-7.

62. Idaho Code 42-30906. If the Department of Health and Welfare fails to act on the application within a reasonable time the Director of Water Resources may deem the application recommended for approval.

63. Federal Safe Drinking Water Act of 1974, 42 U.S.C. (A) 300 (F-J). This act is concerned with underground water sources that could be used for a source of domestic water. The act sets standards for wells and well drilling. Federal Water Pollution Control Act of 1972, Under this act the national goal is to attain zero pollution by the year 1985. Groundwater is included under this act. National

Environmental Policy Act, 42 U.S.C. 4331 et. seq.

64. 84 Stat. 1573, sec. 21 (b). 
65. United States V. Union $0 i 1$ of California, 369 F. Supp. 1289 (1973). The original case held that geothermal resources are water and not reserved to the United States. Case Reversed, 549 F. 2nd 1271 (1977). U.S. Court of Appeals Ninth Circuit has held that the geothermal resource was energy. As an energy resource it was reserved under Stockraising and Homestead Act of 1916.

66. The land in question was patented under the Stockraising and Homestead Act of 1916, 39 Stat. 862; amended in 1965, 43 U.S.C. 291.

67. Geothermal Kinetics v. Union $0 i 1$ of California, No. 7514 (Superior Court, Sonoma County, California). The argument that geotherma 1 resources are energy resources, reservable as part of the mineral estate, is given further judicial strength in Geothermal Kinetics $v$. Union 0il. This court held that the surface owner wants the energy which the water carries, not the water itself. Water is essential for the beneficial use of the land. Minerals are considered to be valuable for their endogenous properties and independent of the 1 and. What was involved in this case was energy and who owns it; those who own the mineral estate of those who own the surface estate and the associated water rights. The court found that in this case the energy belonged to the mineral estate.

68. The current version of this Act is 43 U.S.C. 141 (1971); the original Act was passed June 25, 1910, chapt. 421, 36 Stat. 847.

69. Executive Order No. 5389, Ju1y 7, 1930.

70. M-36625, Memorandum from Edward Fisher, Acting Solicitor, Department of Interior, to, the Director of the BLM, August 28, 1961. As cited in footnote 103, Geothermal Resource Development Institute, Paper 3 pg. 14(Rocky Mt. Min L. Fdn, 1977).

71. The police power of the state is granted to the state at statehood.

72. 30 U.S.C. 1022 (b).

73. 40 C.F.R. $3242.2-4$.

74. 43U.S.C. 661 .

75. Federal Power Commission v. Oregon, 349 U.S. 435 (1955). For a far-reaching construction of the principles of Reserved Rights Doctrine, also known as Winters Doctrine, consult 26 Montana L Rev. 154.

76. United States Constitution, Article 4, Section 3, clause 2. When acting within the purview of that authorization, the power of Congress over reserved 1 ands and rights to the use of water is unlimited.

77. 30 U.S.C. 1001-1025; 84 Stat. 1566; 45 C.F.R. 3200-3201.1. 
78. Lindsey, Michael K., Geothermal Energy, Legal Problems of Resource Development, p. 104-108(1975).

79. Allred, Steve, Director, March, 1978, Idaho Department of Water Resources, personal communications.

80. United States v. Cappaert, 508 f. 2d 313 (1974). The Court ruled that the United States may reserve not only surface water but also underground water for the use of any federal enclave. Action was brought by the United States for declaration of rights on underground water appurtenant to Devil's Hole, Death Valley National Monument to maintain a pool and the endangered species of fish therein. The District Court held that the United States was entitled to as much water as it deemed necessary. Upon Appeal, the Federal Ninth Circuit Court of Appeals, said, that the presidential proclamation withdrawing the area from the public domain impliedly reserved rights in groundwater sufficient to maintain the reservation. Related Code: Desert Lands Act, 43 U.S.C. 321 ; 16 U.S.C.A. 431 Also the Endangered Species Act of 1973, 16 U.S.C. 1533.

81. Ibid.

82. Executive Order No. 5389, July 7, 1930.

83. Stockraising and Homestead Act of 1916, 43 U.S.C. 291.

84. Lidsey, Geothermal Energy Legal Problems of Resource Development, p. 104.

85. 43 C.F.R. 3203.6-3204.4. A plan of operation is required prior to entering upon lease lands. This plan can be subject to special requirements. Also all leases are subject to the condition that the lessee in conducting his operation will use all reasonable precautions to prevent waste of geothermal resources and other natural resources found or developed in the lease lands.

86. 43 C.F.R. 3000.5 .

87. 43 C.F.R. 3204.5 .

88. Andrus v. C1ick, 97 Idaho 791; 554 p. 2d 969 (1974), Supreme Court of Idaho. The conclusion of the court was that the Idaho Dredge Mining Act was within the police power of the state. The case dealt with the collision between the state and federal legislation. If there is a collision, then the federal legislation would preempt the state legislation by reason of the supremacy clause. However, state regulation which is more stringent than that under the federal legislation is not the type of conflicting legislation described by the supremacy standard. When considering a right granted by the federal legislation, state regulation which renders it impossible to exercise that right would be in conflict with the supremacy clause. The Idaho Geothermal Resource Act would be unenforceable on federal geothermal leases if it restricted development of the resource to the extent that it rendered it impossible to develop. 
89. Northern States Power Co. V. Minnesota 447 F 2d 1143 (8th Cir. 1971). If the Federal legislation sets low standards of compliance it does not imply that there will be an absence of further regulation by the state.

90. Johnston v. Boise City, 87 Idaho 44, also see Andrus v. Click.

91. Clapp, Darre1, Idaho Department of Water Resources, personal communications, December, 1977.

92. Kunze; Jay, E. G \& G. - Idaho National Engineering Laboratory, personal communications, February, 1977.

93. Idaho Code 42-4001.

94. Hansen, Dee C., "Water Conflict from the Viewpoint of the Regulator," Geothermal Resource Development Institute, Paper 7, pg. 5, (Rocky Mt Min L Fdn 1977).

95. Ibid. 
This twelve-month study has attempted to estimate the potential for geothermal resource development in Idaho. It has attempted to identify those sites with potential market and sufficient resources to support geothermal development. It has also attempted to project a realistic energy range and poweron-line dates for future geothermal developments. As a third objective, it has attempted to identify those institutional conditions which guide and impede that development. As a fourth objective, this study has attempted to interpret the legal parameters which effect geothermal resources in Idaho. An attempt was made to identify actions that seem necessary to advance the development of the resource at individual sites and for the state in general.

The results of this study indicate that the geothermal resources of Idaho do have significant potential for contributing to Idaho's energy supply. By, 1985 an estiliated $150 \mathrm{MW}$ of electrical generation capacity could come from geothermal energy. By 1995, an additional $350 \mathrm{MW}$ of electrical generation capacity could come from geothermal energy. By the year 2020, electrical generation cilpacity from geothermal energy could range from $750 \mathrm{MW}$ to 1,350 MW. The development of these new generating facilities will depend upon an aggressive exploration drilling program proving the resources.

Future industrial utilization of geothermal fluids, particularly for food processing, could account for $600 \times 109$ BTUs/year of direct energy consumption by 1985. By 1990 the industrial direct energy consumption of geothermal energy could account for 2,230 x 109 BTUs/year. By 2020 , the total industrial energy consumption of geothermal energy could account for over five million BTUs/year of direct energy supply. Commercial and residential utilization of geothermal resources in Idaho could exceed $800 \times 10^{9}$ BTUs/year by 1982. By 1985 commercial and residential utilization could be as high as $2,378 \times 10^{9}$ BTUs/year. By.1990, residential and commercial space heating with geothermal resources could exceed $4,134 \times 10^{9}$ BTUs/year. At this rate geothermal energy could supply over ten trilition BTUs/year of direct heat utilization by the year 2020. This is equivalent to ten billion cubic feet of natural gas per year or 1.72 million barrels of oil per year. Table 15 summarizes the geothermal development potential of Idaho.

However, geothermal energy use is limited by the distance it can be economically and thermdynamically transported. For this reason, non-electrical geothermal developments will need to utilize the more remote sites. This is particularly true with reference to new industrial development. If geothermal resources are going to play a major role in Idaho's future energy and economic growth, remote geothermal sites must act as focal points for locating new industries and communities. Present and future industries which are most likely to develop geothermal resources in Idaho are the agriculture processing industries. Agri-industries which could be supplied with geothermal heat and hot water are concerned with potato processing, sugar beet processing, dehydration of other vegetables and fruits, barley malting, alfalfa dehydration, hog pen warming, and livestock slaughter operations.

A significant fact that this report must stress is although over 370,000 acres of state and federal lands have been leased in Idaho not one explo- 
ration well has been drilled on public lands. Several exploration wells have been drilled on private lands. Several impediments to developing geothermal resources seem to be conspicuous. The most important one seems to be federal tax incentives. Development in general would be stimulated if depletion allowances and intangible drilling cost deductions were allowed as incentives.

A secondary impediment to exploration drilling is the regulatory matrix which extends development time. This matrix should be streamlined. At present, it is extremely difficult to obtain geothermal leases on national forest lands and extremely time consuming to pursue permits to develop any federal lands. More efficient procedures are needed if the federal government resource lands are to be developed.

A third constraint is the high risk and expense associated with exploration. Few individuals, communities, industries, and entrepeneurs have sufficient "free" capital to invest in a high expense, high risk venture. Low temperature resources for space heating could be developed with low risk and capital. Sufficient resources are known, but technical assistance for planning and feasibility studies are needed to stimulate individual, community, and commercial ventures. Better drilling technology, geophysical data, and tax incentives are needed to stimulate exploration for high temperatures capable of generating electricity or industrial applications.

A fourth hindrance is a lack of public awareness. There is a general lack of knowledge and a great deal of misinformation about the geothermal resource potential of Idaho. Enlightenment of the lay person, the commerical-industrial sector, the professional-legal sector, and the legislative-institutional sector is essential if the geothermal resource potential of Idaho is to be understood and developed.

Some of Idaho's geothermal resource areas are in the development phase. Leases have been issued for extensive areas, and some exploration activity has occurred. Limited electrical generation can be expected by 1982 . Expanded utilization for space heating and industrial applications is expected by 1985. Interest in and awareness of the energy potential of geothermal resources is growing. Successful development of geothermal projects underway in Boise for space heating, Rexburg for industrial applications, and Raft River for electrical generation will spur development along and contribute to the growing awareness and interest in developing geothermal energy in Idaho. 
TABLE 15

SUMMARY OF PROJECTED GEOTHERMAL

\section{DEVELOPMENT}

\begin{tabular}{lcccc} 
Utilization & Resource & & & Date \\
& Proven & Potential & Inferred & \\
\cline { 2 - 5 } & 5 & & & 1982 \\
Electric & 50 & 50 & 100 & 1985 \\
Power & & 300 & & 1990 \\
Generation & & & 2095 \\
(MW) & & 50 & 500 & 2010 \\
& & 400 & 850 &
\end{tabular}

Total from al1 resources by 2020: 1,355 MW.

Proven Potential Inferred

\begin{tabular}{lrrrr} 
Direct Heat & 803 & & & 1982 \\
Utilization & 1,278 & 1,000 & 700 & 1985 \\
$($ total $)$ & 250 & 1,784 & 2,006 & 1990 \\
$\left(19^{9}\right.$ BTU/yr.) & 13 & & 150 & 1995 \\
& & & & 2000 \\
& & & 2,027 & 2010 \\
\hline Total & 2,344 & 2,784 & 4,883 &
\end{tabular}

Total from al1 resources by 2020: 10,011 x $10^{9}$ BTU/yr.

$\begin{array}{lrrr}\text { Industrial } & 263 & 1,000 & 3,407 \\ \text { Space Heating } & 2,081 & 1,784 & 1,476\end{array}$




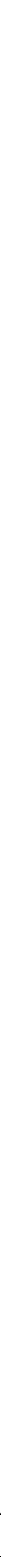


Applegate, J. K., P. R. Donaldson, and K. M. Hollenbaugh. 1975 Boise geothermal project: A progress report: (abs.) Geol. Soc. Amer., Rocky Mountain Section, v. 7 , no. 5, p. 486.

Armstrong, R. L., W. P. Leeman, and H. E. Malde, 1975, K-Ar dating, Quarternary and Neogene volcanic rocks of the Snake River Plain, Idaho: Amer. Jour. Sci., v. 275, no. 3, p. 225-251.

Baldwin, E. M.. 1964, Geology of Oregon: 2nd ed., J. W. Edwards Pub., Inc., Ann Arbor, Mich., p. 225-251.

Blackwe11, D. D.. 1969, Heat flow determinations in the northwestern United State;: Jour. Geophys. Res., v. 74, p. 992-1007.

-.-. 1974, Terrestrial heat flow and its implications on the location of geothermal reservoirs in Washington: Wash. Div. Mines and Geol. Info. Circ., no. 50, p. 21-33.

-.-. 1977, Heat flow and energy loss in the western United States: in Cenozoic Tectonics and Regional Geophysics of the Cordilleran, ed. R. B. Smith and G. P. Eaton, Geol. Soc. Amer. Memoir 152, in press.

Blackwe11, D. D., and E. C. Robertson. 1973, Thermal studies of the Boulder batolith and vicinity, Montana: Soc. Econ. Geologists Guidebook, Butte Field Meeting, Aug. 18-21, p. DI to D8.

Boini, W. E.. 1963, Gravity anomalies in Idaho: Idaho Bur. Mines and Geology Pamphlet 132, $10 \mathrm{p}$.

Bonnichsen, W. B., and W. B. Travers. 1975, Rhyolitic volcanism and structural evolution of the Snake River Plain: (abs.) Geol. Soc. Amer., Rocky Mountain Section, v. 7, no. 5, p. 589-590.

Bowen, R. G., and D. D. Blackwell. 1975, The Cow Hollow geothermal anomaly, MaTheur County, Oregon: The Ore Bin, v. 37, no. 7, p. 109-124.

-.... 1976, Geothermal studies in Oregon: Oregon Dept. Geol. and Min. Industries Bul1., in press.

Bowen, R. G., D. D. Blackwell, D. A. Hull, and N. V. Peterson. 1976, Prooress report on heat-fiow study of the Brothers fault zone, central Oregon: The Ore Bin, v. 38, no. 3, p. 39-50.

Brott, C. A.," D. D. Blackwell, and J. C. Mitche11. 1976, Geothermal investigations in Idaho, Part 8, Heat flow study of the Snake River Plain, Idaho: Idaho Dept. Water Resources Water Info: Bu11. 30,'195 p.

Chapman, S. L., and D. R. Ralston. 1970, Ground-water resource of the B1ue Gulch area in eastern Owyhee and western Twin Falls Counties, Idaho: Idaho Dept. Water Adm. Water Info. Bu11. 20, 36 p. 
Christiansen, R. L.. 1975, Origin and geothermal potential of Island Park eastern Idaho: (abs.) Geol. Soc. Amer. Rocky Mountain Section, v. 7, no. 5 , p. 586 .

Christiansen, R. L., and H. R. Blank, Jr.. 1972, Volcanic stratigraphy of Quarternary rhyolite plateau in Yellowstone National Park: U. S. Geol. Surv. Prof. Paper 729-B, p. B1-B18.

Hamilton, W., and W. B. Meyers. 1966, Cenozoic tectonics of the western United States: Rev. Geophys., v. 4, p. 509-549.

Hamilton, W. S.. 1965, Geology and petrogenesis of the Island Park Caldera of rhyolite and basalt, eastern Idaho: U. S. Geol. Surv. Prof. Paper $504 \mathrm{C}$, . p. C $\mathrm{C}-\mathrm{C} 37$.

Haskett, G. I.. 1972, Ground-water geology of Rexburg-Bench, second phase, lower Teton division Teton Basin project, Idaho: Bur. Reclamation, $21 \mathrm{p}$.

Hi11, D. P.. 1963, Gravity and crustal structure in the western Snake River Plain, Idaho: Jour. Geophy. Res., v. 68, no. 20, p. 5807-5819.

Hi11, D. P., and L. C. Pakiser. 1966, Crustal structure between Nevada test site and Boise, Idaho, from seismic refraction measurements: Amer. Geophys. Union, Geophys. Mono. 10, J. S. Steinhart and T. J. Smith, eds., p. 391-419.

Hoover, D. B., and C. L. Tippens. 1975, Geothermal investigations in Idaho, part $w, A$ reconnaissance audio-magnetotelluric survey: Idaho Dept. Water Resources Water Info: Bul1. 30, p. 53-79.

Howard, K. A., and J. W. Shervais. 1973 Geologic map of Smith Prairie, Elmore County, Idaho: U. S. Geol. Surv., Misc. Inv. Map I-818.

Jaeger, J. C.. 1965, Applications of the theory of heat conduction to geothermal measurements, in W. H. K. Lee, ed., Terrestrial Heat Flow: Geophys. Mono. 8, Washington, D. C., Americal Geophys. Union, p. 7-23.

Kirkham, V. R. D.. 1931, Snake River downwarp: Jour. GeoT., v. 39 , p. 456-482.

Lachenbruch, A. H., and J. H. Sass. 1977, Heat flow in the United States and the thermal regime of the crust, in Amer. Geophys. Union Geophys. Mono. 20 , in press.

Mabey, D. R. 1976, Interpretation of a gravity profile across the western Snake River Plain, Idaho: Geology, v. 4, no. 1, p. 53-55.

Mabey, D. R., D. L. Peterson, and C. W. Wilson. 1974, Preliminary gravity map of southern Idaho: U. S. Geol. Surv., Open-File Report.

MacLeod, N. S., G. W. Walker, and E. H. McKee. 1975. Geothermal significance of eastward increase in age of late Cenozoic rhyolite domes in southeastern Oregon: 2nd U. N. Symp. on Development of Geothermal Potential, San Francisco, May 1975 (in press), also U. S. Geol. Surv. Open-File Report 75-348. 
Madsen, W. W. and I. J. Ingvarsson. 1975, Analys is of binary cycle for geothermal power generation: Aerojet Nuclear Co:, ANCR-1245, $44 \mathrm{p}$.

Malde, H. E., and H. A. Powers. 1962, Upper Cenozoic stratigraphy of western Snake River Plain, Idaho: Geol. Soc. Amer. Bull., v. 73, p. 1197-1220.

Malde, H. E., H. A. Powers, and C. H. Marshal1. 1963, Reconnaissance geologic map of west-central Snake River Plain, Idaho: U. S. Geol. Surv. Misc. Geol. Inv: Map 1-373.

McIntyre, D. H.. 1972, Cenozoic geoloay of the Reynolds Creek experimental water shed, Owyhee County, Idaho: Idaho Bur. Mines and Geology Pamphlet $151,115 \mathrm{p}$.

Mitche11, J. C.. 1976 a, Geotherma 1 investigations in Idaho, part 5, Geochemistry and geologic setting of the thermal waters of the Northern Cache Valley area, Franklin County, Idaho: Idaho Dept. of Water Resources Water 1, fo. Bul1. 30, $47 \mathrm{p}$.

-.--. 1976 b, Geothermal investigations in Idaho, part 6, Geochemistry and geologic setting of the thermal and mineral waters of the Blackfoot Reservoir area, Caribou County, Idaho: Idaho Dept. of Water Resources Water Bul1. 30, in press.

-.-. $1976 \mathrm{c}$, Geothermal investigations in Idaho, part 7, Geochemistry and geologic setting of the thermal waters of the Camas Prairie Area, Blaine and Camas Counties, Idaho: Idaho Dept. of Water Resources Water Info. Bul1. 30, in preparation.

Morgan, P., D. D. Blackwe11, R. E. Spafford, and R. E. Smith. 1977, Heat flow measurements in Yellowstone Lake and the thermal structure of the Yellowstone Caldera: Jour. Geophys. Res., v. 82, p. 3719-3732.

Morgan, W. J.. 1972, Convection plumes and plate motions: Amer. Assoc. Petrol. Geo1. Bul1., v. 56, p. 203-213.

Mundorff, M. J., E. G. Crosthwaite, and Chabot Kilburn. 1964, Ground water for irrigation in the Snake River Plain, Idaho: U. S. Geol. Surv. Water Supply Paper 1654, 224 p.

Newton, V. C., and R. E. Corcoran. 1963, Petroleum geology of the Western Snake River Basin: $0 i 1$ and Gas Invest. no. 1, Oregon Dept. of Geol. and Mineral Industries, $67 \mathrm{p}$.

Pennington, W. D., R. B. Smith, and A. B. Trimble. 1974, A microearthouake study of parts of the Snake River Plain and central Idaho: Bul1. Seism. Soc. Amer., v. 64, no. 2, p. 307-312.

Prostka, H. J., and R. J. Hackman. 1974, Preliminary geologic map of the NWT/4 Driggs $1^{\circ}$ by $2^{\circ}$ quadrangle, southeastern Idaho: U. S. Geol. Surv. Open-File Report.

Ralston, D. R., and S. L. Chapman. 1970, Ground-water resource of southern Ada and western Elmore Counties, Idaho: Idaho Dept. Water Adm., Water Info. Bul1., 15, $52 \mathrm{p}$. 
Renner, J. L., D. E. White, and D. L. Williams. 1975, Hydrothermal convection systems: in Assessment of geothermal Resources of the United States, 1975, D. E. White and D. L. Williams, eds., U. S. Geol. Serv. Circ. 726, p. 5-57.

Rightmier, C. T., H. W. Young, and R. L. Whitehead. 1976, Geothermal investigations in Idaho, part 4, Isotopic and geochemical analysis of water from the Bruneau-Grand View and Weiser Areas, southwest Idaho: Idaho Dept. Water Info. Bul1. 30, $28 \mathrm{p}$.

Ross, C. P., and J. D. Forrester. 1947, Geologic map of the state of Idaho: U. S. Geo1. Surv. and Idaho Bur. Mines \& Geology.

Ross, S. H.. 1971, Geothermal potential of Idaho: Idaho Bur. Mines \& Geology Pamphlet $139,98 \mathrm{p}$.

Sass, J. H., W. H. Diment, A. H. Lachenbruch, B. V. Marsha11, R. J. Monroe, T. H. Moses, Jr., and T. C. Urban. 1976, A new heat flow contour map of the conterminous United States: U. S. Geol. Surv. Open-File Report $76-756,24 \mathrm{p}$.

Sass, J. H., A. H. Lachenbruch, R. J. Monroe, G. W. Greene, and T. H. Moses, Jr.. 1971, Heat flow in western United States: Jour. Geophy. Rex., v. 76 , p. 6376-6413.

Smith, R. B., and M. L. Sbar. 1974, Contemporary tectonics and seismicity of the western United States with emphasis on the Intermountain Seismic . Belt: Geol. Soc. America Bul1., v. 85, p. 1205-1218.

Smithe, R. L., and H: R. Shaw. 1975, Igneous-related geothermal systems: in Assessment of Geothermal Resources of the United States, 1975, D. E. White, and D. L. Williams, eds., U. S. Geol. Surv. Circ. 720, p. 58-83.

Stanley, W. D., J. E. Boeh 1, F. X. Bostick, and H. W. Smith. 1977, Geothermal significance of magnetotelluric sounding in the eastern Snake Piver Plain, Yellowstone region: Jour. Geophys. Res., v. 82, p. 2501-2514.

Stoker, R. C.. 1975, Drilling plan Boise slim (2-3/8 in. diameter) holes demonstration space heating project: Aerojet Nuclear Co., ANCR 1261, $19 \mathrm{p}$.

Swanberg, C. A., and D. D. Blackwe11. 1973, Areal distribution and geophysical significance of heat generation in the Idaho batholith and adjacent instusions in eastern Oregon and western Montana: Geol. Soc. America Bu11., v. 84, p. 1261-1282.

Taubeneck, W. H.. 1971, Idaho batholith and its southern extension: Geol. Soc. Amer. Bul1., v. 82, p. 1899-1928.

U. S. Geological Survey. 1971, Aeromagnetic map of southwestern Idaho: U. S. Geo1. Surv. Open-File Report.

Urban, R. C., and W. H. Diment. 1975, Heat flow on the south flank of the Snake River Rift: (abs.) Geol. Soc. Amer. Rocky Mountain Section, v. 7, no. 5, p. 648. 
Warner, M. M. . 1975, Special aspects of Cenozoic history of southern Idaho and their geothermal implications: Proc. 2nd U. N. Symp. on Development of Geothermal Potential, U. S. Govn. Printing Office, Washington, D. C., p. 653-663.

Young, H. W., and J. C. Mitche11. 1973, Geothermal investigations in Idaho, part 1, Geochemistry and geologic setting of selected thermal waters: Idaho Dept. Water Adm. Water Info. Bul1. 30, $43 \mathrm{p}$.

Young, H. W., and R. L. Whitehead. 1975 a, Geothermal investigations in Idaho, part 3, An evaluation of selected thermal water in Weiser area, Idaho: Idaho Dept. Water Resources Water Info. Bull. 30, $35 \mathrm{p}$.

-... 175 b, Geothermal investigations in Idaho, part 2, An evaluation of thermal water in the Bruneau-Grandview area, southwest Idaho: Idaho Dept. Water Resources Water Info. Bul1. 30, p. 1-50.

Zohdy, A. 1. R., and W. D. Stanley. 1973, Preliminary interpretation of electrical sounding curves obtained across the Snake River. Plain from Blackfcot to Arco, Idaho: U. S. Geol. Surv. Open-File Report.

\section{Legal and Institutional}

Boyce, Shirl C.. 1978, Local Planning Inventory, 1978: Idaho State Planning and Community Affairs, Division of Budget Policy Planning.

Lindsey, Michael K.. 1976, Geothermal Energy, Legal Problems of Resource Development: Stanford University.

Ralston, Dale R., et al.. 1974, Analysis of Legal Constraints on Groundwater Resource Development in Idaho: Idaho Bureau of Mines and Geology Pamphlet no. 158.

Rocky Mountain Mineral Law Foundation. 1977, Proceedings of Geothermal Resource Development Institute.

Sokol, Jan D.. 1976, Geothermal Leasing in Wilderness: 6 Environmental Law 489.

Laws :

\section{Idaho Code}

Chapter. 1, Sec. 42-101, Appropriation of Water.

Chapter 1, Sec. 42-226, Appropriation of Ground-water.

Chapter 3, Sec. 47-401, 0il and Gas Wells.

Chapter 36, Sec. 39-3606, Water Pollution.

Chapter 40, Sec: 42-4001, Geothermal Resources.

Chapter 47, Sec. 47-1610, Mines and Mining.

Idaho Constitution

Article 15, Sec. 1, Use of Water.

Article 15, Sec. 3, Right to Appropriate. 
Laws (continued)

Federal Code

30 U.S.C. 1001, Geotherma 1 Resources.

42 U.S.C. (A) 300, Federal Safe Drinking Water Act.

42 U.S.C. 4331, National. Environmental Policy Act.

43 U.S.C. 291, Stock Raising and Homestead Act.

Idaho Court Cases

Andrus vs. Click, 97 Idaho 791.

Johnston vs. Boise City, 87 Idaho 44.

Public Utilities Commission vs. Natatorium Co., 36 Idaho 287.

Tappen vs. Smith, 92 Idaho 451.

Federal Court Cases

Federal Power Commission vs. Oregon, 349 U. S. 435.

Northern States Power Co. vs. Minnesota, 447, F. 2d. 1743.

United States vs. Cappaert, $508 \mathrm{~F} 2 \mathrm{~d} .313$.

United States vs. Shurbert, 347 F 2d. 103.

United States vs. Union Oil of California, 369 F. supp 1289. Case reversed 549 F. 2 d. 1271.

Related Case

Geothermal Kinetics vs. Union $0 i 1$ of Cal ifornia, Case No. 7514 Superior Court, Sanoma County, California, 1977.

Demographic and Economic

Boise City, Energy Task Force. 1977, Preliminary Plan for Boise Geothermal Energy System: Boise Energy Office, Boise, Idaho.

Bonneville Power Administration. 1974, Agriculture and Food Processing of Pacific Northwest Projection of Production, Employment and Energy Consumption, Portland, Oregon.

Boyce, Shirl C.. 1978, Local Planning Inventory 1978: State Planning and Community Affairs, State of Idaho.

Cenarrusa, Peter T. 1978, Idaho Blue Book: Secretary of State, State of Idaho.

Cornelison, Lauanna C.. 1976, Manufacturing Directory of Idaho: Center for Business Development and Research, University of Idaho.

Donovan, L. E., and A. S. Richardson. 1975, Feasibility and Conceptual Design Study for Boise Geothermal Space Heating Demonstration Project Building Modifications, E.R.D.A./Aerojet Nuclear Company, ANCR-1246.

Fogleman, Sam F., Leonard A. Fisher, and Allan R. Black. 1977, Total Energy Recovery System for Agribusiness: International Engineering Company. 
Geothermal Resource Counci]. 1978, Direct Utilization of Geothermal Energv: A Symposium: Davis, California.

Gerick, Joseph A.. 1977, Industrial Utilization of Geothermal Eneray: Masters Thesis, University of Idaho.

Idaho Crop and Livestock Reporting Service. 1977, Idaho Agricultural Statistics: Idaho Department of Agriculture, Boise, Idaho.

Idaho Department of Employment. 1978, Idaho Economic Indicators: Bureau of Research and Analysis, Boise, Idaho.

Idaho Department of Water Resources. 1978, Population and Employment Forecast, State of Idaho: Boise State University Center for Research.

Idaho Division of Budget, Policy and Planning Coordination. 1978, County Profiles of Idaho, 1978: Office of the Governor, Boise, Idaho.

Idaho Division of Tourism and Industrial Development. 1977, Idaho Almanac: Office of the Governor, Boise, Idaho.

Irvin, Lawrence D.. 1976, Social-Economic Profiles, Idaho BLM Districts: Center for Business and Economic Research, Boise State University.

Lienau, Paul J., (ed.). 1978, Agribusiness Geothermal Energy Utilization Potential of Klamath and Snake River Bas in of Oregon: Geo-Heat LItilization Center, Oregon Institute of Technology, Klamath Falls, Oregon.

N.O.A.A. 1978, Climatological Data, Idaho: U. S. Department of Commerce.

Pearson, Russel1 0.. 1977, Use of Geothermal Heat for Sugar Refining: U. S. Department of Energy, SAN/1317-3.

Reistad, Gordon. 1978, An Evaluation of Uses of Low Temperature Geothermal Fluids in the Klamath Basin, Oregon: Oregon State University Engineering Experiment Station, Bu77. No. 55.

Rocket Research Company. 1977, Industrial Waste Heat for Adjacent Communities and Industrial Applications: Task - 1, Pacific Northwest Regional Commission, RRC-78-H-181.

Rychert, Bob C., Charles W. Baker, and Marcia C. Wicklow-Howard. 1978, Biological Impacts of Geothermal Waste Water Discharge into the Boise River: Boise State University and Idaho Office of Energy.

Southeast Council of Governments. 1975, State of the Region Report, Existing Socia]-Economic Environment: Idaho State University:

Spencer, Sue G., N. E. Stanley, and W. M. Hickamn. 1977; Draft Environmental Report, Raft River Thermal Loop Facility: E. G. \& G. Idaho Inc., Idaho National Engineering Laboratory.

U. S. Department of the Interior. 1976, Final Environmental Impact Statement for Development of Phosphate Resources in Southeastern Idaho: U. S.

Geological Survey. 
Bochenski, Gary L., and Kirk L. Ha17. 1977, Enercy Facts, Idaho - United States - World: Idaho Office of Energy, Office of the Governor.

Bradley, Clifford. 1978, Electricity Demand in Idaho, Recent Trends and Forecast: Idaho Office of Energy, Office of the Governor.

Dames and Moore Company. 1977, Natural Gas Supply Requirements for the State of Idaho: Report to the Idaho Public Utilities Commission.

Drysdale, Frank R., and Charles E. Calef. 1977, The Energetics of the United States of America - An Atlas: Brookhaven National Laboratory, Report 50501 .

Little, Arthur D. . 1977, Idaho Power Company's Need for Additional Generation Capacity: Final Report to the Idaho Public Utilities Commission.

Mackie, William A.. 1976, An Energetics Analysis of Idaho State Economic Concerns in Relation to Energy and Material Resources Involved in the Phosphate Resources of Southeastern Idaho: Institute of Applied Energetics and Idaho Office of Energy.

McHugh, W. Michael. 1978, Northwest Energy Policy Project, Energy Demand Modeling and Forecasting, Final Report: Pacific Northwest Regional Commission.

Rocket Research Company. 1978, Industrial. Waste Heat for Adjacent Communities and Industrial Applications, Task - 1: Pacific Northwest Regional Commission, Report RRC-78-H-181. 


\section{APPENDIX A}

ENERGY DEMAND IN IDAHO

Trends and Forecast

Table of Contents

Page

Text:

INTRODUCTION . . . . . . . . . . . . . . . . . . . 109

IDAHO'S ENERGY SUPPLY . . . . . . . . . . . . . . . . . 109

IDAHO'S ENERGY CONSUMPTION PATTERNS . . . . . . . . . . . . . . . . 113

PROJECTED ENERGY GROWTH . . . . . . . . . . . . . . . . . . . 124

GEOTHERMAL ENERGY MARKET POTENTIAL . . . . . . . . . . . . . . . . 130

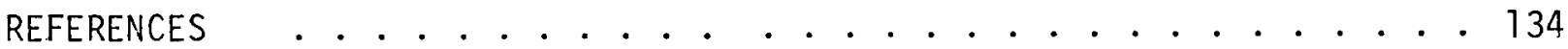

Tables and Figures:

Table 1-A, Idaho's Indigenous Energy Supply . . . . . . . . . . . . 110

Table 2-A, Idaho's County Energy Budgets . . . . . . . . . . . . . . 111

Table 3-A, Petroleum Products . . . . . . . . . . . . . . . . . . . 112

Table 4-A, Sources of Idaho's Natural Gas.............. . . . 114

Table 5-A, Utility Electrical Power Contribution . . . . . . . . . . 116

Table 6-A, Historical Electrical Utilities Sales . . . . . . . . . . 117

Table 7-A, Direct Energy Consumption by Sector . . . . . . . . . . . . 119

Table 8-A, Direct Energy Use by Industrial Code . . . . . . . . . . . . . 121

Table 9-A, Idaho Population Forecast . . . . . . . . . . . . . . 126

Table 10-A, Low Growth Scenario Energy Forecast . . . . . . . . . . . . 127

Table 11-A, Moderate Growth Scenario Energy Forecast . . . . . . . . . . 128

Table 12-A, High Growth Scenario Energy Forecast . . . . . . . . . . . . 129

Table 13-A, Forecasted Rates of Growth in Energy Consumption . . . . . 131

Table 14-A, Major Industrial Energy Consumers . . . . . . . . . . . 133

Figure 1-A, Idaho's Energy Pipelines . . . . . . . . . . . . . . . 115

Figure 2-A, Idaho's Energy Sources . . . . . . . . . . . . . . . . 118

Figure 3-A, Idaho's Energy Consumption by Sector . . . . . . . . . . . 120

Figure 4-A, Residential Direct Energy Consumption . . . . . . . . . . 122

Figure 5-A, Industrial Direct Energy Consumption . . . . . . . . . 123 


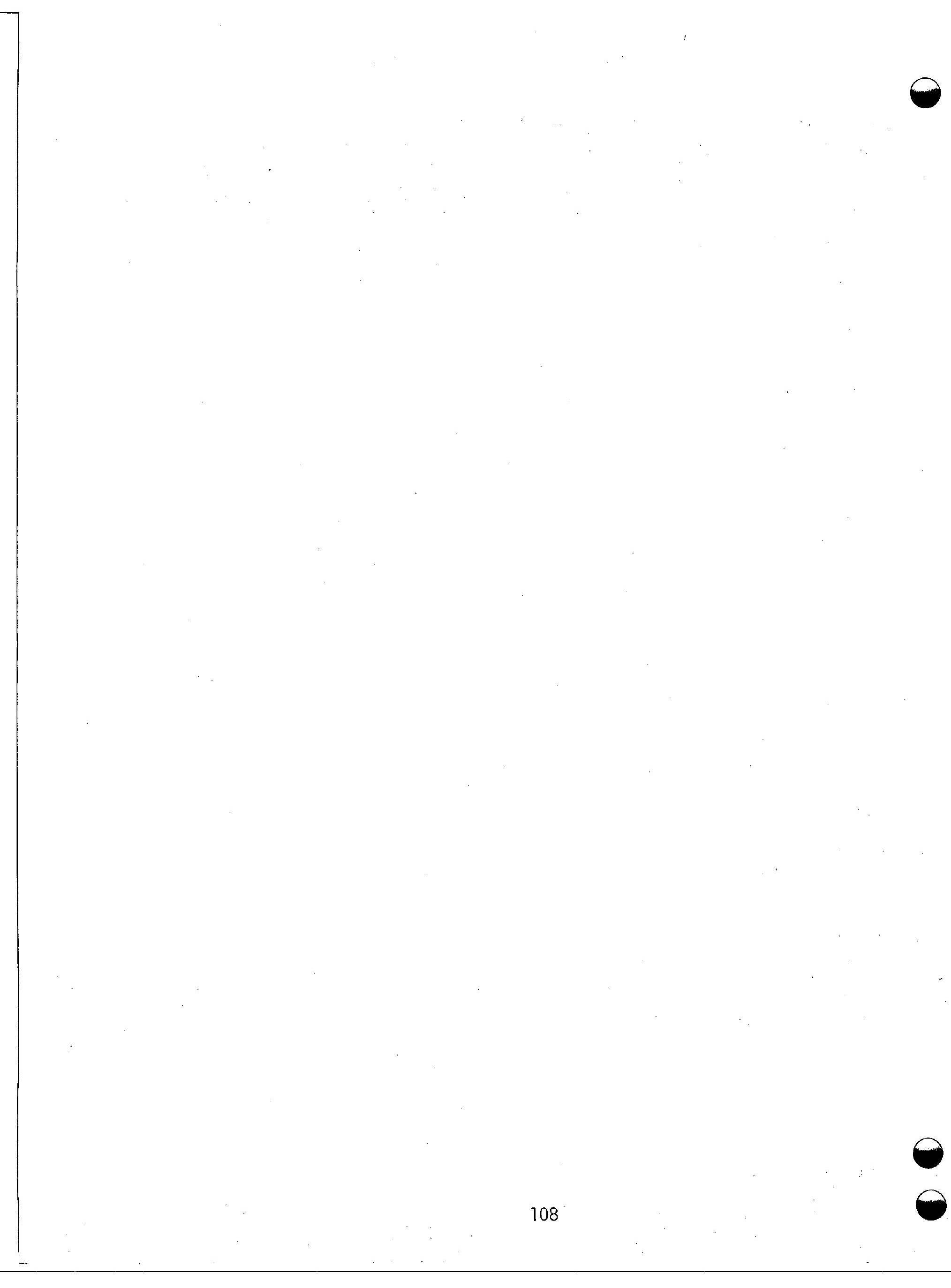




\author{
APPENDIX A \\ ENERGY DEMAND IN IDAHO
}

TRENDS AND FORECAST

\title{
Introduction
}

A critical issue facing policy makers is the extent it is possible or desirable to change future energy growth. It is clear that future energy growth in Idaho will be largely determined by forces outside the control of regional, state and local policymakers. Nevertheless, these policymakers can influence the rate of growth in energy supply and to some degree influence or change the type and rate of growth in energy demand.

An array of policy options and their impacts must be available in order for policymakers to make decisions based on careful and systematic analys is of all available information. The purpose of this chapter is to provide backgiound data on energy supply, consumption patterns, and trends in Idaho and to summarize the various demand forecasts that have been made for the State. An aggregate of energy demand information is presented to illustrate the potential contribution geothermal energy can make to the future energy supply and economic growth of the State.

Idaho's Energy Supply

Table 1 shows Idaho's indigenous energy supply. Hydroelectrical energy is the major source of energy supply from indigenous sources. Wood, solar and geothermal energy presently make only minor contributions to Idaho's energy supply. Conspicuously, hydrocarbons are not an indigenous energy source in Idaho. Although oil exploration is being conducted in Southeast Idaho, no major discoveries are expected.

Those indigenous energy resources with the greatest potential for development are lowhead hydroelectric and geothermal resources. Idaho consumes more energy than jt produces. In 1977, Idaho produced approximately $47.13 \times 10^{12}$ BTU of energy from a11 indigenous energy sources. In the same year, Idaho consumed $227.9 \times 1012$ BTU of energy. (1) Table $2-A$ shows the energy budget of Idaho by county. Idaho has a negative energy budget of $187.77 \times 10^{12}$ BTU. (2). This deficit is made up by importing energy from other regions.

Idaho must import from other regions 100 percent of its coal, oil, natural gas, and gasoline. Idaho also imports 63 percent of its electrical energy. The majority of the coal imported into Idaho comes by rail from coal fields in Wlyoming and Utah. Petroleum products are imported from adjacent western states. Approximately 70 percent of Idaho's petroleum products are imported into the state via major pipelines. Figure 1-A shows the location of the pipelines. The remaining fuel is transported into the state via truck and rail. Table 3-A shows the petroleum product mix and transportation made of Idaho's petroleum energy base. 


\section{IDAHO INDIGENOUS ENERGY SUPPLY}

Gross Deliverable Power

from Indigenous Sources with Present. Technology

\begin{tabular}{lcc}
\hline Energy Type & Present Usage & Potential \\
\hline \hline Hydro & $44.13 \times 10^{12}$ BTU/YR (a) & $158.5 \times 10^{12}$ BTU/YR (a) \\
Gas & None (b) & None (b) \\
Coal & None (b) & None (b) \\
$0 i 1$ & None (b) & None (b) \\
Tar Sands & None (b) & None (b) \\
Oil Shale & None (b) & None (b) \\
Fission & None (b) & Unknown \\
Fusion & None & $2.18 \times 10^{12}$ (c) \\
Waste & Minimal & Not estimable at this tim \\
Wind & Minimal & $47.1 \times 10^{12}$ BTU/YR (d) \\
Wood & $2.3 \times 10^{12}$ BTU/YR (d) & $2.1 \times 10^{18}$ BTU/YR (e) \\
Solar Radiation & $.003 \times 10^{12}$ & $69,100 \times 10^{12}$ BTU/YR (g) \\
Geothermal (Fluid) & $0.7 \times 10^{12}$ BTU/YR (f) & Unknown \\
Geothermal (Hot Rock) & None &
\end{tabular}

(a) Idaho Atlas Project (Annual Average Generation)

(b) U.S. Department of Interior

(c) Adapted from Salvato, using only Residential and Commercial Solid Waste

(d) Estimate by U.S. Forest Service as adapted by Idaho Office of Energy

(e) Total amount of solar radiation reaching ground level in Idaho

(f) Idaho Office of Energy estimate

(g) Circular 726 , U.S. Dept. of the Interior, showing Idaho with more than $85 \%$ of U.S. recoverable geothermal heat

Source: Energy Facts, Idaho Office of Energy (Reference \#1) 
Table 2

COUNMY ENERGY BUDGETS

\begin{tabular}{|c|c|c|c|c|c|c|c|c|c|}
\hline \multirow[b]{2}{*}{$\begin{array}{l}\text { County } \\
\text { Name }\end{array}$} & \multicolumn{5}{|c|}{ Billions of Btu Fuel Use } & \multicolumn{2}{|c|}{ Production $10^{9} \mathrm{Btu}$} & \multicolumn{2}{|c|}{$\begin{array}{l}\text { Electricity thousands } \\
\text { of } \mathrm{MWH}\end{array}$} \\
\hline & Total & Coal & Oil 1 & $\begin{array}{c}\text { Jatural } \\
\text { Gas }\end{array}$ & Gasoline & Total & $\begin{array}{c}\text { Prnduction } \\
\text { less use } \\
\end{array}$ & Seneration & Use \\
\hline Idaho Total & 170687 & 15933 & 37895 & 56630 & 60230 & 44132 & -126554 & 4310 & 11421 \\
\hline Ada & 25750 & 1627 & 5610 & 8384 & 10129 & 0 & 25749 & 0 & 1442 \\
\hline Adams & 768 & 134 & 149 & 222 & 263 & 0 & 767 & 0 & 71 \\
\hline Bannock & 12204 & 559 & 2318 & 3464 & 5863 & 0 & -1.2203 & 0 & 552 \\
\hline Bear Lake & 1472 & 4 & 269 & 402 & 797 & 0 & 1471 & 0 & 41 \\
\hline Benewah & 1712 & 330 & 339 & 506 & 538 & 0 & 1711 & 0 & 172 \\
\hline Bingham & 6324 & 572 & 1546 & 2310 & 1897 & 0 & 6323 & 0 & 435 \\
\hline Blaine & 1185 & 25 & 334 & 499 & 328 & 0 & 1184 & 0 & 59 \\
\hline Boise & 424 & 96 & 76 & 114 & 138 & 0 & 423 & 0 & 47 \\
\hline Bonner & 3407 & 380 & 663 & 991 & 1373 & 10854 & 7447 & 1060 & 239 \\
\hline Bonneville & .12177 & 968 & 2942 & $43 \geq ?$ & 3870 & 6638 & 5538 & 648 & 788 \\
\hline Boundary & 1373 & 154 & 275 & 410 & 533 & 0 & 1372 & 0 & 98 \\
\hline Butte & 829 & 0 & 149 & 222 & 458 & 0 & 828 & 0 & 22 \\
\hline Camas & 148 & 0 & 49 & 73 & 26 & 0 & 147 & 0 & 7 \\
\hline Canyon & 15109 & 1994 & 3591 & 5367 & 4157 & 0 & - 15108 & 0 & 1254 \\
\hline Caribou & 1542 & 0 & 383 & 573 & 585 & 3947 & $2 \mathbf{4 0 5}$ & 385 & 55 \\
\hline Cassia & 5072 & 605 & 1159 & 1731 & 1577 & 0 & 5071 & 0 & 387 \\
\hline Clark & 194 & 0 & 48 & 72 & 75 & 0 & 193 & 0 & 7 \\
\hline Clearwater & 3168 & 818 & 611 & 913 & 827 & 0 & 3167 & 0 & 393 \\
\hline Custer . & 588 & 0 & 128 & 191 & 269 & 0 & 587 & 0 & 19 \\
\hline Elmore. & 3165 & 0 & 742 & 1109 & 1314 & 0 & 3164 & 0 & 109 \\
\hline Franklin & 1406 & 0 & 335 & 501 & 570 & 1346 & 60 & 131 & 48 \\
\hline Fremont & 1981 & 75 & 437 & 653 & 816 & 0 & 1980 & 0 & 91 \\
\hline Gen & 1682 & 0 & 391 & 584 & 706 & 0 & 1681 & 0 & 58 \\
\hline Gooding & 2131 & 0 & 466 & 697 & 968 & 10495 & 8364 & 1025 & 67 \\
\hline Idaho & 3069 & 509 & 679 & 1015 & 866 & 0 & 3068 & 0 & 287 \\
\hline Jefferson & 3347 & 204 & 600 & 896 & 1647 & 0 & 3346 & 0 & 161 \\
\hline Jerome & 2081 & 0 & 594 & 888 & 599 & 0 & 2080 & 0 & 84 \\
\hline Kootenai & 6708 & 680 & 1550 & 2316 & 2162 & 628 & 6079 & 61 & 483 \\
\hline Latah & 5136 & 346 & 1177 & 1758 & 1855 & 0 & 5135 & 0 & 302 \\
\hline Lemhi & 1518 & 96 & 282 & 421 & 719 & 0 & 1517 & 0 & 77 \\
\hline Lewis. & 1045 & 83 & 242 & 362 & 358 & 0 & 1044 & 0 & 66 \\
\hline Lincoln & 704 & 0 & 143 & 214 & 347 & 0 & 703 & 0 & 21 \\
\hline Madison & 3412 & 83 & 608 & 909 & 1812 & 0 & 3411 & 0 & 119 \\
\hline Minidoka & 4068 & 204 & 1028 & 1536 & 1299 & 0 & -4067 & 0 & 220 \\
\hline $\mathrm{Nez}$ Perce & 10915 & 2820 & 2220 & 3317 & 2558 & 538 & -10376 & 53 & 1362 \\
\hline Oneida & 702 & 0 & 148 & 221 & 333 & 0 & 701 & 0 & 21 \\
\hline Owyhee & 1101 & 0 & 31.8 & 474 & 309 & 5741 & 4640 & 561 & 45 \\
\hline Payette & 2597 & 163 & 632 & 945 & 857 & 0 & 2596 & 0 & 152 \\
\hline Power & 3681 & 1385 & 683 & 1021 & 592 & 0 & 3680 & 0 & 607 \\
\hline Shoshone & 3449 & 0 & 747 & 1116 & 1587 & 0 & 3448 & 0 & 114 \\
\hline Teton & 445 & 0 & 109 & 163 & 174 & 179 & 265 & 18 & 16 \\
\hline Twin Falls & 10959 & 1006 & 2591 & 3871 & 3492 & 3767 & 7190 & 368 & 744 \\
\hline Valley & 710 & 0 & 157 & 234 & 320 & 0 & 790 & 0 & 24 \\
\hline Washington & 1233 & 13 & 382 & 570 & 269 & 0 & 1232 & 0 & 59 \\
\hline
\end{tabular}

Source: Energetics of the United States of America - An Atlas (Referance (12). 
Table 3-A

Petroleum Product Mix and Transportation Mode

Energy Type

Gasoline

Aviation

Fuel

Distillate

0 i 1

Residual

$0 i 1$

Total
Chevron

Pipeline

47.6

3.2

28.6

0

79.4
Ship

-

$-$

$-$

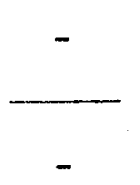

Truck and Rail

10.9

58.5

3.2

20.0

48.6

4.4

4.4

35.3

114.4

A11 figures are expressed in BTUs $\times 10^{12}$

Source: Energy Fact, Idaho Office of Energy (Reference \#1) 
Idaho has no indigenous supply of natural gas. Sources of Idaho's natural gas are Canada and nearby western states. Canada supplies 67 percent of Idaho's natural gas while the remaining 33 percent is domestic import. Table 4-A shows the major sources of Idaho's natural gas supply and Figure $1-A$ illustrates the location of the major natural gas pipelines.

Idaho's major developed indigenous energy resource is hydroelectric power. Idaho's electrical generation facilities account for only 37 percent of the state's electrical needs. The remaining 63 percent is imported into Idaho from generation facilities outside of the State.

Three major investor-owned utilities serve portions of Idaho. Idaho Power Company (IPC), Washington Water Power Company (WWP), and Utah Power and Light Company (UP\&L) account for 90 percent of the electrical power sales in Idaho. Public utilities (Co-ops) account for 10 percent of the sales. Table 5-A shows the percentage contribution each of these utilities makes to Idaho's electrical power needs. Table 6-A shows the historical sales of these utilities for the last ten years. (3)

Approximately one-third of IPC power is imported from the thermal power facilities in Wyoming. Approximately $95 \%$ of UP\&L's electrical power distributed in Idaho comes from thermal power facilities in the Southwestern States. Approximately 90 percent of WWP power is imported into Idaho from hydroelectrical facilities in Washington. There are 23 public utilities in Idaho and 97 percent of this electricity comes from the Bonneville Power Administration. of $14.4 \times 106 \mathrm{MWH}, 37$ percent is generated in the State and 67 percent is imported from out of state.

Overall Idaho has a negative energy budget. The State must import 84 percent of its energy from other "non-Idaho" sources. Foreign imports of natural gas account for 15 percent of Idaho's total energy budget. Domestic natural gas imports account for 7 percent of Idaho's energy budget. Domestic electrical energy imports account for 12 percent of Idaho's energy needs and approximately one-half of this amount is generated from coal fired thermal power plants in Wyoming and Utah. The largest segment of Idaho's energy budget that is imported is petroleum. The importation of petroleum into Idaho accounts for 50 percent of the total energy consumption in the State. Pipeline transported petroleum into Idaho accounts for 69 percent of Idaho oil import. This oil is Alaskan oil. The remaining 31 percent of Idaho's oil imports are transported by truck and rail and the foreign/domestic origin of that petroleum cannot be determined. Figure 2-A illustrates the energy source budget for Idaho.

\section{Energy Consumption Patterns}

Direct energy consumption in Idaho is approximately $227.9 \times 1012$ BTU per year. (1) Table 7-A shows Idaho's energy consumption by sector according to energy source. Figure 3-A illustrates the percent of total energy consumption each energy sector represents.

Residential consumption accounts for 24 percent of the total energy consumption in Idaho. Commercial consumption is 16 percent and industrial consumption accounts for 27 percent of Idaho's energy budget. Transportation is the largest energy consuming sector in Idaho account for 33 percent of the state's total energy use. 
Table 4-A

SOURCES OF IDAHO'S NATURAL GAS

\begin{tabular}{|c|c|c|c|}
\hline & $\begin{array}{l}\text { Daily Average } \\
\text { BTU } \times 10^{9} \\
\end{array}$ & $\begin{array}{r}1975 \\
\text { BTU } \times 10^{12} \\
\end{array}$ & $\begin{array}{r}\text { Percent } \\
\text { of Total } \\
\end{array}$ \\
\hline Indigenous Supply & 0 & 0 & 0 \\
\hline \multicolumn{4}{|l|}{ Domestic Imports } \\
\hline Piceance Basin (Western Colorado) & 9.4 & 3.4 & 7 \\
\hline San Juan Basin (4 Corners) & 18.7 & 6.8 & 13 \\
\hline Big Piney (SW Wyoming) & 18.7 & 6.8 & 13 \\
\hline Sub-Totals & 46.8 & 17.1 & 33 \\
\hline Canadian Import & 93.5 & 34.1 & 67 \\
\hline Total & 140.3 & 51.2 & $100.0 \%$ \\
\hline
\end{tabular}

Source: Energy Facts, Idaho Office of Energy (Reference \#1) 


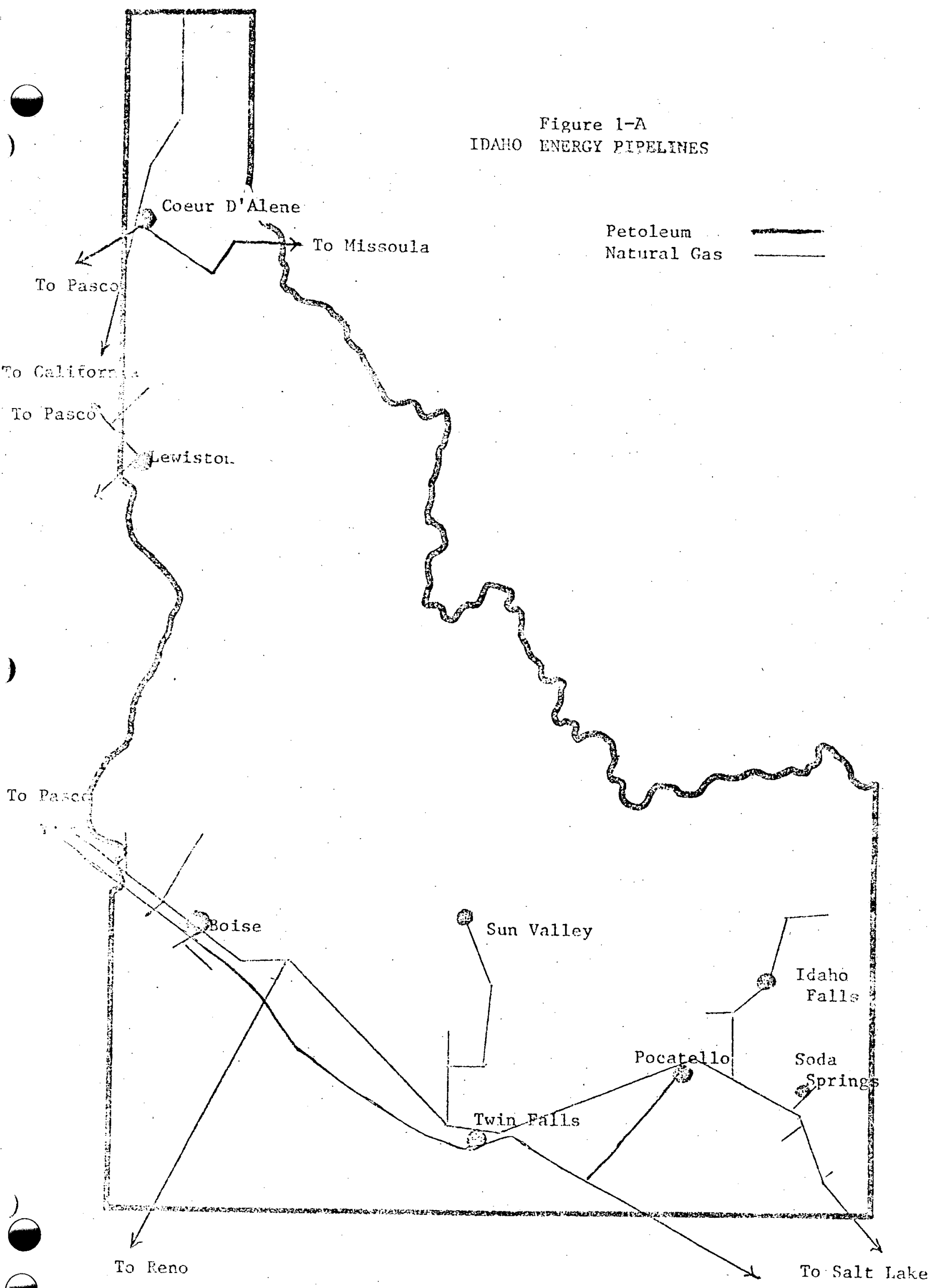


Table 5-A

Idaho Electrical Power Sales/Idaho Utilities

Percentage Contribution

Idaho Power Company

Utah Power and Light

Washington Water Power

Public Co-ops

Pacific Power and Light

Total electrical seales in 1977

$14,316,000 \mathrm{MWH}$

Source: Electricity Demand In Idaho, Idaho Office of Energy 
Table 6-A

Idaho Electricity/Idaho Utilities Sales

Ultimate Customers

MWH (000)

\begin{tabular}{|c|c|c|c|c|c|c|}
\hline Year & IPC* & $\underline{U P \& L}$ & WWP & Publics & Total & Av. MW \\
\hline 1969 & 6097 & 1311 & 1816 & 637 & 9861 & 1126 \\
\hline 1970 & 6305 & 1263 & 1835 & 652 & 10055 & 1148 \\
\hline 1971 & 6618 & 1298 & 1938 & 808 & 10662 & 1217 \\
\hline 1972 & $7: 322$ & 1430 & 2014 & 915 & 11681 & 1333 \\
\hline 1973 & 7355 & 1754 & $207 !$ & 1047 & 12227 & 1396 \\
\hline 1974 & 8081 & 1697 & 2100 & 1115 & 12993 & 1483 \\
\hline 1975 & 8096 & 2079 & 2228 & 1232 & 13635 & 1557 \\
\hline 1976 & 8558 & 1979 & 2366 & 1376 & 14279 & 1630 \\
\hline 1977 & 8384 & 2172 & 2230 & $1530 * \star$ & 14316 & 1634 \\
\hline
\end{tabular}

Av. Annual

Amount

Increase

$4.2 \%$

$7.0 \%$

$2.7 \%$

$11.7 \%$

$4.8 \%$

* IPC data is for the total system plus firm sales for resale

$\star \star 1977$ total sales for publically owned utilities was estimated based on 1974 - 1976 growth rate

Source: Electricity Demand in Idaho, Idaho Office of Energy

(Reference \#3) 
Figure 2-A

IDAHO'S ENERGY SOURCES

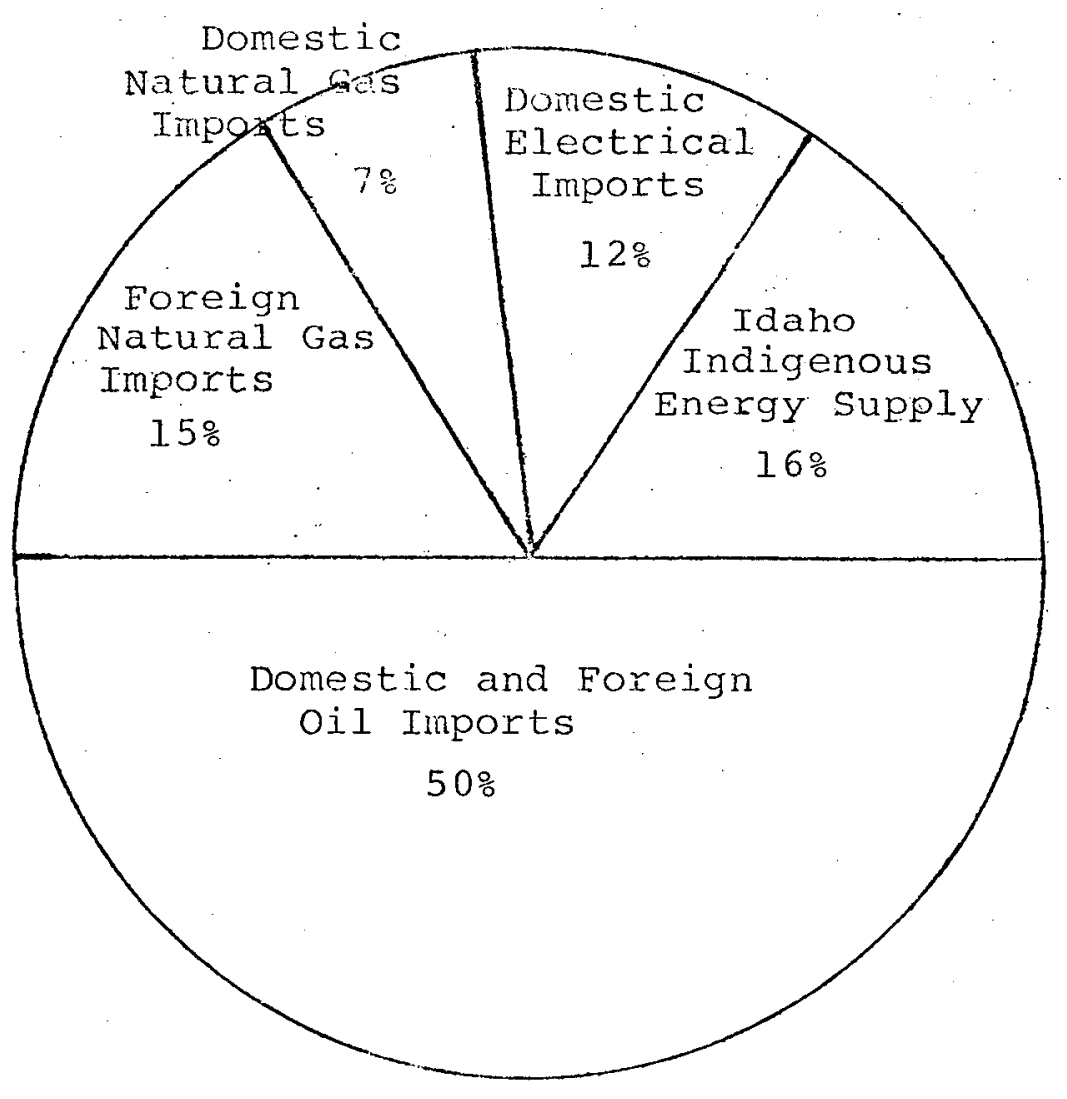

$227.9 \times 10^{12}$ BTús per year 
Table 7-A

Idaho - Direct Energy Consumption by Sector. BTU $\times 10^{12}$

\begin{tabular}{|c|c|c|c|c|c|}
\hline & Natural Gas & Petroleum* & Electricity & Other** & Tota 1 \\
\hline Residential & 10.4 & 22.3 & 12.9 & 7.9 & 53.5 \\
\hline Commercial & 10.3 & 15.5 & 10.1 & 1.2 & 37.1 \\
\hline Industrial & 30.5 & 2.3 & 21.3 & 8.5 & 62.6 \\
\hline Transportaticn & -- & 74.6 & -- & -- & 74.6 \\
\hline Total & 51.2 & 114.7 & 44.5 & 17.5 & 227.9 \\
\hline
\end{tabular}

*Petroleum Usage Consisted of:

$\begin{array}{lrl}\text { Gasoline } & 60.3 \times 10^{12} \text { BTU } \\ \text { Kerosene } & 0.8 & 11 \\ \text { Distillates } & 43.0 & 11 \\ \text { Residual } & 4.4 & " 1 \\ \text { Liq. Pet. Gas } & 4.8 & " \\ \text { Jet Fuel } & 1.4 & \end{array}$

$\star * 0$ ther Usage is:

$\begin{array}{lr}\text { Coal } & 13.4 \\ \text { Wood } & 2.3 \\ \text { Coke } & 1.1 \\ \text { Geothermal } & 0.7\end{array}$

Source: Energy Facts, Idaho Office of Energy (Reference \#1) 
)

Figure $3-\mathrm{A}$

IDAHO ENERGY CONSUMPTION BY SECTOR

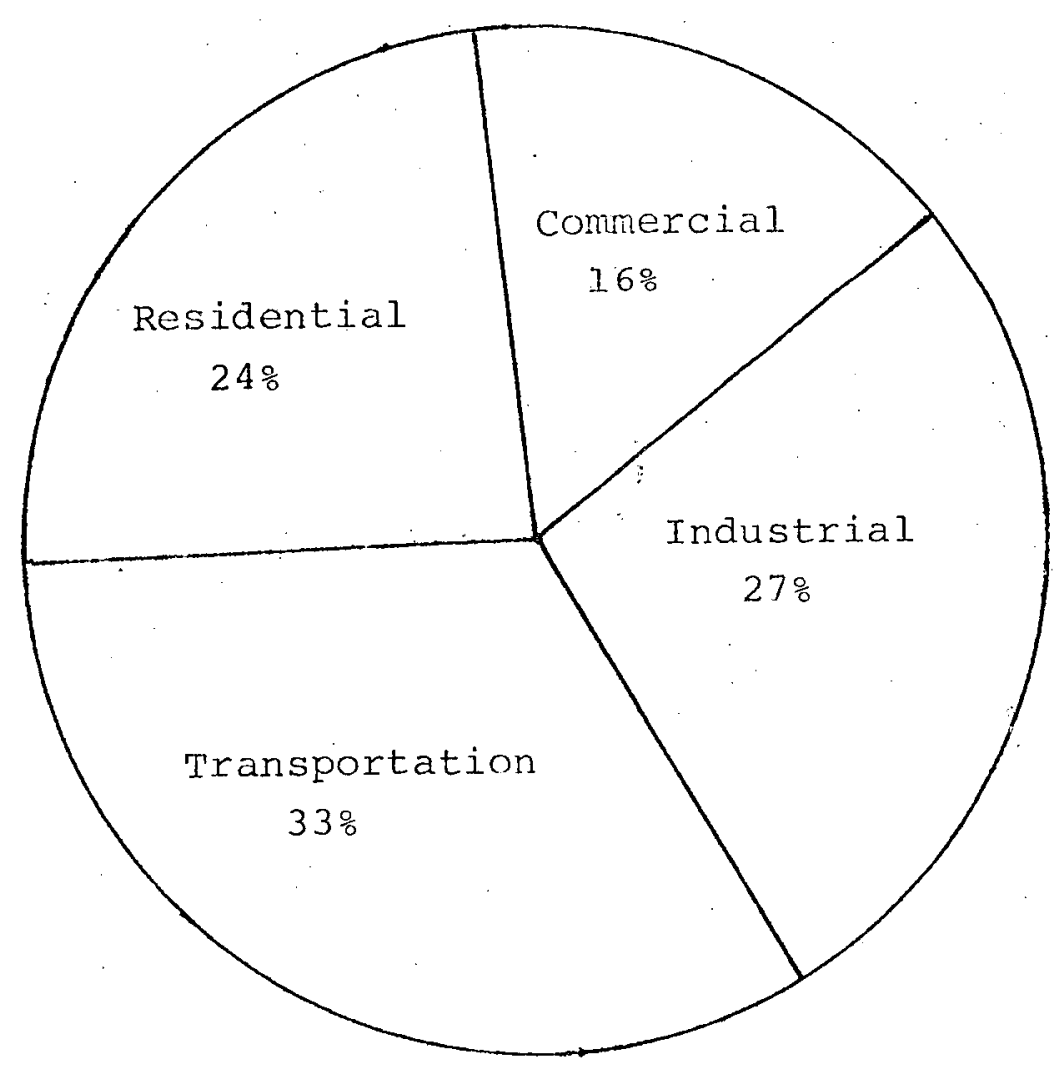

$227.9 \times 10^{12}$ BTUs per year 
In 1977, there were 267,000 occupied housing structures in Idaho of which 37,000 were mobile homes. Space heating accounts for 79 percent of Idaho's residential energy consumption and hot water heating accounts for an additional 10 percent of the residential consumption. (See Figure 4-A). Several types of energy are used for these two functions. Approximately 20 percent of Idaho's homes use natural gas, 38 percent use petroleum, 30 percent use electricity, 12 percent of Idaho's residents use coal and wood, and bottled gas, only 1 percent of Idaho's residences use geothermal energy as the principal energy source in the home. The remaining 11 percent of the energy directly consumed by the residential sector is through lighting and appliances.

The commercial sector involves S.I.C. code numbers $40-93$ which encompasses most trade support services, and government activities. Most of the energy consumed by this sector in Idaho is for space heating and cooling. Less than 20 percent of the commercial consumption of energy is for lighting, appliances and tools.

Industrial direct energy consumption in Idaho is approximately $62.6 \times 1012$ BTUs per year. Forty-eight percent of this energy is natural gas consumption. An additional 34 percent is electrical energy. Coal and wood account for an additional 13 percent of the industrial energy consumption. Petroleum plays a minor role in Idaho's industry accounting for only 3 percent of the energy consumed by this sector. Figure 5-A shows the direct energy consumption in Idaho industry by the industrial class. The food and kindred products industry is the largest industrial consumer of energy. This industry relies on natural gas to supply 70 percent of its energy needs. This one industrial sector accounts for 25 percent of total natural gas consumption in the state and 40 percent of the industrial consumption of natural gas. The remaining 70 percent of Idaho's industrial natural gas consumption is divided between the wood and paper products industries (31 percent), chemical products (13 percent), and other industries (22 percent).

The chemical and allied products industry is the largest industrial consumer of electricity accounting for 50 percent of Idaho's industrial electrical energy consumption. This one industrial sector accounts for 23 percent of Idaho's total electrical energy consumption.

Table 8-A shows the major industrial energy consumption by standard industrial classification.

\section{Table 8-A}

Idaho Industrial Direct Energy Use by Major SIC Codes

$$
\text { (BTU } \times 10^{12} \text { - approximate) }
$$

\begin{tabular}{|c|c|c|c|}
\hline SIC Code & Title & Natural Gas & Electricity \\
\hline 20 & Food \& Kindred Products & 13 & 2 \\
\hline $24-26$ & Wood \& Paper Products & 10 & 2 \\
\hline 28 & Chemicals \& Allied Products & 4 & 11 \\
\hline
\end{tabular}


Figure 4-A

RESIDENTIAL DIRECT ENERGY CONSUMPTION

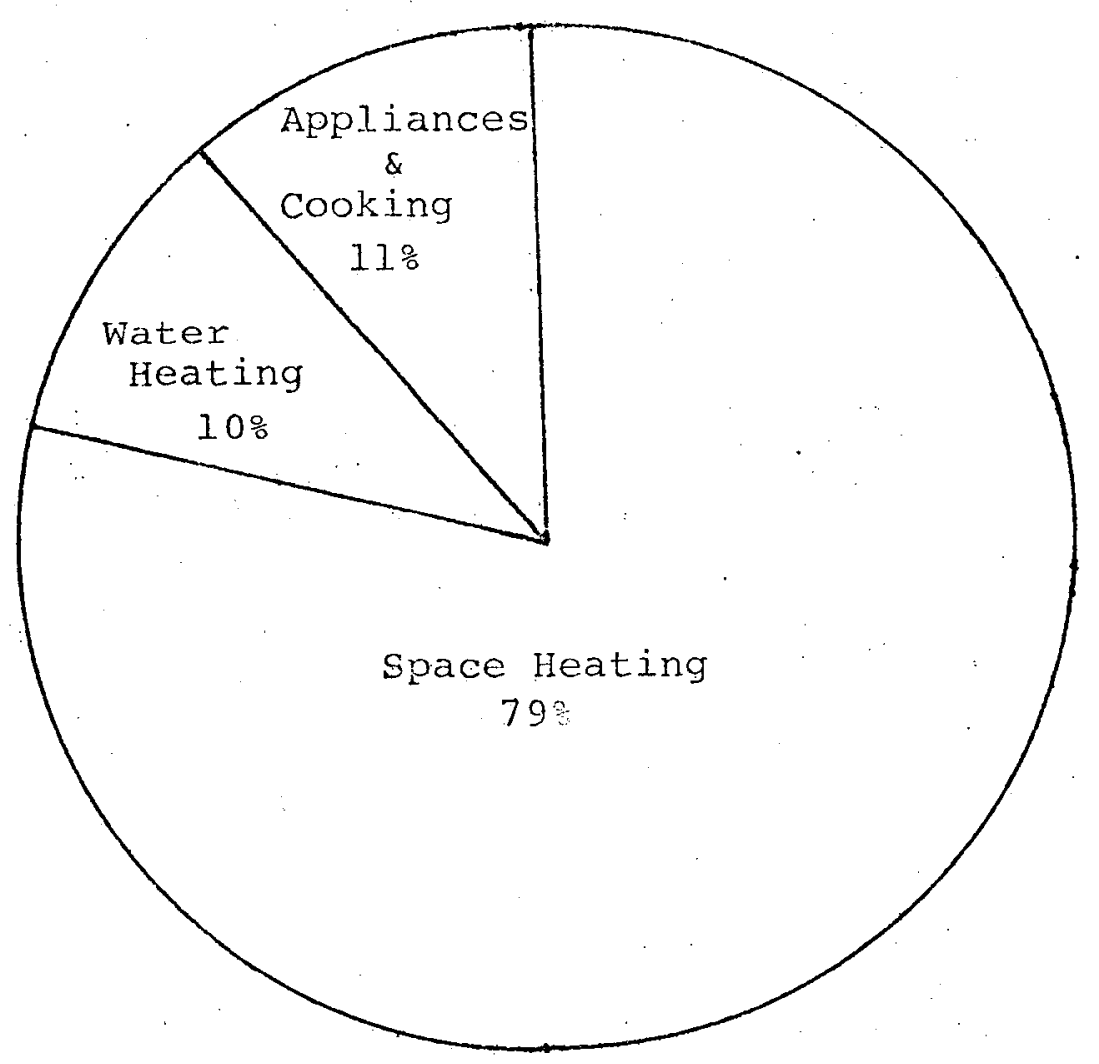

$53.5 \times 10^{12}$ BTUs per year 


\section{Figure 5-A}

\section{INDUSTRIAL DIRECT ENERGY CONSUMPTION}

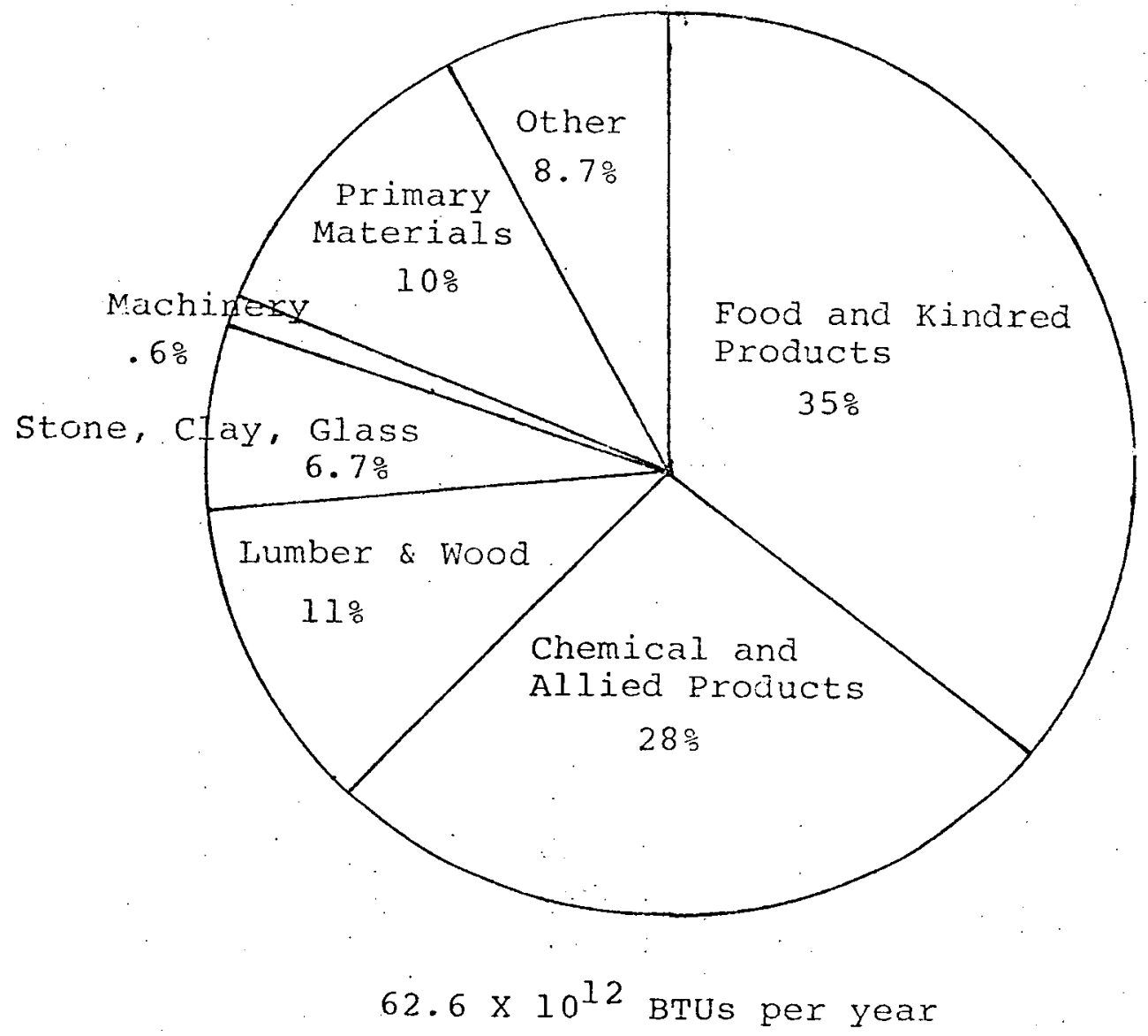


Transportation is the largest energy consuming sector in the state. The consumption of petroleum products accounts for 50 percent of the total energy consumption in Idaho. Transportation accounts for 65 percent of the petroleum consumed in Idaho. The majority of the petroleum consumed in transportation is gasoline and diesel fuel for trucks, autos and farm equipment.

It should be noted that direct energy consumption by agriculture is not separated from the various consuming sectors mentioned above. Data concerning Idaho's present and past consumption of energy does not make a special distinction for agriculture. The direct energy consumption of agriculture is mixed into various categories but principally involves petroleum and electrical consumption. Petroleum consumption by agriculture is classified largely under transportation due to the use of petroleum by farm machinery. Electrical energy consumption by agriculture is classified into residential and industrial sales. The major electrical energy consumption by agriculture is for irrigation. An estimated 13.4 percent of Idaho's electrical energy consumption is for irrigation pumping. (3) Although present consumption patterns do not separate irrigation as a separate consumer section, future demand forecast do make this distinction.

\section{Projected Energy Growth}

Several energy demand forecasting reports have been done for Idaho. The most noticeable aspects of these forecasting models is the large range of forecasted demand. Between the present and the late 1980s or about 10 years from now, the difference between the lowest and the highest forecast exceeds the present total demand for the state. All the forecasting model's examined differed greatly in their intent, methodology and results. The model considered by the Idaho Office of Energy as the most reliable in terms of methodology and unbiased intent is the Pacific Northwest Energy Policy Project (NEPP). (4) The NEPP study was sponsored by the Pacific Northwest Regional Commission.

The purpose of the NEPP Study was to develop an econometric demand forecasting model for all fuels, electricity, oil, natural gas and coal for each of the States of Washington, Oregon and Idaho. The total energy demand was determined in this model for each energy type for each major consuming sector - residential, commercial, industrial, transportation and irrigation. The NEPP model forecast for the period 1975 to 2000 . Three separate scenarios of energy demand growth rates were forecast: A high energy demand forecast, a moderate energy demand forecast, and a low energy demand forecast. The NEPP model forecast are presented in this paper to illustrate Idaho's future energy growth potential.

The difference between the NEPP low and high forecast in the year 2000 for electrical energy is more than 2000 average MW. The difference between the low and high forecast in the year 2000 for natural gas is approximately $20 \times 1012$ BTU. The difference between the low and high forecast in the year 2000 for total energy for all sectors is $104 \times 1012$ BTU. The point to be made here is that forecasts are not going to provide a definitive answer to how much energy Idaho will need in the future. It must be emphasized that forecasting models are merely tools for policymakers and not descriptions of destiny. 
Differences in population forecast are a major factor in varying energy demand forecast. The range of population forecast for Idaho is almost as great as the range of energy demand forecast. Table 9-A summarizes the various population forecast. The highest forecast for Idaho projects a population of 1.7 million people by the year 2000 with a 3.2 percent per year population growth rate. The lowest growth rate projected for the state is an annual increase of .44 percent between 1980 and 1990. The NEPP study takes an econometric approach to energy forecasting which also consider availability, price and economic changes along with population forecasting.

Under a low growth scenario, electrical energy consumption in Idaho wi11 have an annual average rate of growth of 1.72 percent per year. The greatest increase will be in the residential sector which will expand its direct consumption of electrical energy at an average rate of 2.02 percent per year between now and the year 2000. Natural gas use for the same period under a low growth scenario is expected to increase only .75 percent pir year in the residential sector and have up to -.8 percent rate of chunge in the industrial sector. A decline in natural gas consumption is expected between the present and 1990 at which time consumption is forecasted to increase back to the 1980 levels. Industrial cutbacks in natural gas are expected due to conversions of present industries to other energy in response to price, economy and policy regarding gas use. Table 10-A shows Idaho's projected energy consumption by consuming sector and energy type for a low growth scenario.

Under a moderate growth scenario residential energy consumption will show an annual average increase of 3.7 percent in electrical demand and 2 percent per year in natural.gas demand. The industrial sector will show the most significant change in demand. Electricity demand by the industrial sector will increase at 2.9 percent per year under a moderate growth scenario. Natural gas for the same period will show a decrease in demand of -2.29 percent per year in industry. This decrease in natural gas demand is projected to occur between the present and 1990 at which time natural gas consumption will again increase. In response to the projected decrease in natural gas demand by the industrial sector, large increases in industrial consumption of $011,3.4$ percent annually, and coal, 7.41 percent annually, are projected. Table 11-A shows Idaho's projected energy consumption under a moderate growth scenario.

Under a high growth scenario ali consuming sectors will experience sizeable increases in energy demand. The residential sector will experience a projected 5.2 percent annual increase in electricity demand and a 3.46 percent annual increase in natural gas demand between now and the year 2000. Significant decrease in residential use of oil and coal are expected.

Under a high growth scenario the industrial sector will experience significant increases in the use of oil (6.2 percent annually) and coal ( 7.9 percent annually) with only a moderate increase in electricity demand ( 4.3 percent annually) and on ly a moderate decrease in natural gas demand ( -.7 percent annually). Table 12-A shows Idaho's projected energy demand under a high growth scenario. 
Table 9-A

Idaho Population Forecast

$(000)$

Model

1980

1990

2000

Simulating the Energy Economy

928

1188

1700

Idaho Department of Water Resources

926

1200

1410

Bonneville Power Authority

917

1163

Idaho Econometric Model

902

1130

Private Industrial Source (Confidential)

920

1088

1243

U.S. Census

Series I E

761

817

Series II E

807

907

Series III C

830

979

Source: Idaho Office of Energy 
Table 10-A

LOW GROWTH SCENARIO - ALL FACTORS

Idaho

Electricity

Gas

0 i1

Coal

Wood Residue

Total

Idaho

Electricity

Gas

$0 i 1$

Coa 1

Total

Idaho

Electricity

Gas

$0 i 1$

Total

Idaho

Electricity

Gas

0 i]

Coal

Wood Residue

Total

\begin{tabular}{|c|c|c|c|c|c|c|}
\hline 1974 & 1980 & 1985 & 1990 & 1995 & 2000 & AARG \\
\hline 46.6 & 49.49 & 52.30 & 57.35 & 61.78 & 67.99 & $1.72 \%$ \\
\hline & 44 & & & & & -.33 \\
\hline 117. & 96.5 & 98.6 & 103.27 & 109.92 & 119. & .05 \\
\hline & & & & & & 1.50 \\
\hline & & & 5.00 & 6.00 & 6.00 & 1.57 \\
\hline & 208 & 205.42 & 217.61 & 234.83 & 255.02 & 47 \\
\hline
\end{tabular}

LOW GROWTH SCENARIO - RESIDENTIAL SECTOR

\begin{tabular}{|c|c|c|c|c|c|c|}
\hline 1974 & 1980 & 1985 & 1990 & 1995 & 2000 & AARG \\
\hline 12.26 & 13.89 & 15.65 & 17.31 & 18.79 & 20.63 & 2.02 \\
\hline 9.65 & 11.60 & 10.44 & 10.39 & 11.11 & 11.71 & .75 \\
\hline 13.87 & 3.53 & 2.86 & 2.01 & 1.39 & .94 & -9.83 \\
\hline 3.01 & 2.83 & 2.69 & 2.56 & 2.44 & 2.32 & -7.00 \\
\hline 38.79 & 31.85 & 31.65 & 32.27 & 33.74 & 35.59 & -.33 \\
\hline
\end{tabular}

LOW GROWTH SCENARIO - COMMERCIAL SECTOR

\begin{tabular}{rrrrrrr}
$\frac{1974}{5.81}$ & $\frac{1980}{5.71}$ & $\frac{1985}{6.08}$ & $\frac{1990}{7.14}$ & $\frac{1995}{7.85}$ & $\frac{2000}{8.99}$ & $\frac{\text { AARG }}{1.69}$ \\
8.19 & 6.64 & 5.57 & 6.36 & 7.31 & 8.18 & -.00 \\
8.51 & 5.33 & 5.90 & 6.46 & 7.22 & 8.05 & -.21 \\
\hline 22.51 & 17.69 & 17.55 & 19.86 & 22.39 & 25.22 & .44
\end{tabular}

LOW GROWTH SCENARIO - INDUSTRIAL SECTOR

$\frac{1974}{18.43} \quad \frac{1980}{1725} \cdot \frac{1985}{18.17} \quad \frac{1990}{20.82} \quad \frac{1995}{23.55} \quad \frac{2000}{27.42} \quad \frac{\text { AARG }}{1.54}$

$\begin{array}{lllllll}33.03 & 26.73 & 18.69 & 20.43 & 23.81 & 26.79 & -.80\end{array}$

$\begin{array}{lllllll}21.45 & 15.62 & 17.65 & 19.25 & 21.17 & 23.74 & .39\end{array}$

$\begin{array}{lllllll}7.37 & 10.31 & 12.07 & 12.26 & 12.46 & 12.97 & 2.19\end{array}$

\begin{tabular}{rrrrrrr}
4.00 & 5.00 & 5.00 & 6.00 & 6.00 & 6.00 & 1.57 \\
\hline 84.28 & 74.91 & 71.52 & 78.75 & 86.99 & 96.91 & .54
\end{tabular}

LOW GROWTH SCENARIO - IRRIGATION SECTOR

$\frac{\text { Idaho }}{\text { Electricity }} \quad \frac{1974}{7.19} \frac{1980}{12.64} \div \frac{1985}{12.46} \quad \frac{1990}{12.18} \frac{1995}{11.58} \frac{2000}{10.95} \frac{\text { AARG }}{1.63}$

LOW GROWTH SCENARIO - TRANSPORTATION SECTOR

Idaho

$1974 \quad 1980 \quad 1985 \quad 1990 \quad 1995 \quad 2000 \quad$ AARG

Al1 Petroleum Total

(Units in $10^{12}$ BTU)

$\begin{array}{lllllll}73.76 & 72.03 & 72.25 & 75.55 & 80.14 & 86.34 & .61\end{array}$

Source: Northwest Energy Policy Project (Reference \#4) 


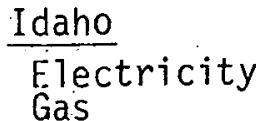

$0 i 1$

Coa 1

Wood Residue

Total

Idaho

Electricity

Gas

0 i1

Coal

Total

Idaho
Electricity
Gas
Oil

Total

I daho

Electricity

Gas

0 il

Coa 1

Wood Residue

Total

Idaho

Electricity

I daho

A11 Petroleum

Total

(Units in $10^{12}$ BTU)
MODERATE GROWTH SCENARIO - TOTAL: ALL SECTORS

\begin{tabular}{|c|c|c|c|c|c|c|}
\hline 1974 & 1980 & 1985 & 1990 & 1995 & 2000 & AARG \\
\hline $\begin{array}{l}43.68 \\
50.87\end{array}$ & $\begin{array}{l}52.52 \\
36.00\end{array}$ & $\begin{array}{l}58.24 \\
29.88\end{array}$ & $\begin{array}{l}67.14 \\
32.88\end{array}$ & $\begin{array}{l}77.04 \\
37.88\end{array}$ & $\begin{array}{l}89.67 \\
43.17\end{array}$ & $\begin{array}{r}2.80 \\
-\quad .63\end{array}$ \\
\hline 177.59 & 108.41 & 174.00 & 127.00 & 145.16 & 169.27 & .1 .47 \\
\hline 10.38 & 18.56 & 24.92 & 3.1 .37 & 39.39 & 49.54 & 6.20 \\
\hline & & 5.00 & 6.00 & 7.00 & & 2.70 \\
\hline 226.52 & 220.49 & 232.04 & 264.39 & 306.47 & 359.65 & $1: 79$ \\
\hline
\end{tabular}

MODERATE GROWTH SCENARIO - RESIDENTIAL SECTOR

\begin{tabular}{|c|c|c|c|c|c|c|}
\hline 1974 & 1980 & 1985 & 1990 & 1995 & 2000 & AARG \\
\hline $\begin{array}{r}12.26 \\
9.65 \\
13.87 \\
3.01 \\
\end{array}$ & $\begin{array}{r}14.94 \\
12.34 \\
4.67 \\
2.83 \\
\end{array}$ & $\begin{array}{r}18.48 \\
11.89 \\
3.23 \\
2.69 \\
\end{array}$ & $\begin{array}{r}22.22 \\
12.67 \\
2.25 \\
2.56 \\
\end{array}$ & $\begin{array}{r}26.38 \\
14.54 \\
1.57 \\
2.44 \\
\end{array}$ & $\begin{array}{r}31.70 \\
16.66 \\
1.08 \\
2.32 \\
\end{array}$ & $\begin{array}{r}3.72 \\
2.12 \\
-9.35 \\
-1.00 \\
\end{array}$ \\
\hline 38.79 & 34.79 & $36.2-$ & 39.70 & 44.93 & 51.76 & 1.12 \\
\hline
\end{tabular}

MODERATE GROWTH SCENARIO - COMMERCIAL SECTOR

\begin{tabular}{|c|c|c|c|c|c|c|}
\hline 1974 & 1980 & 1985 & 1990 & 1995 & $2000^{\circ}$ & AARG \\
\hline $\begin{array}{l}5.81 \\
8.19 \\
8.51\end{array}$ & $\begin{array}{l}5.59 \\
6.54 \\
6.75\end{array}$ & $\begin{array}{l}6.46 \\
5.72 \\
7.07\end{array}$ & $\begin{array}{l}7.52 \\
6.67 \\
8.40\end{array}$ & $\begin{array}{r}8.68 \\
7.94 \\
10.17\end{array}$ & $\begin{array}{r}10.10 \\
9.36 \\
12.33\end{array}$ & $\begin{array}{r}2.15 \\
.57 \\
1.44\end{array}$ \\
\hline 22.51 & 18.87 & 19.25 & 22.59 & 26.79 & 31.79 & 1.34 \\
\hline
\end{tabular}

MODERATE GROWTH SCENARIO - INDUSTRIAL SECTOR

\begin{tabular}{|c|c|c|c|c|c|c|}
\hline 1974 & 1980 & 1985 & 1990 & 1995 & 2000 & AARG \\
\hline 18.43 & 20.06 & 21.73 & 26.44 & 31.96 & 38.79 & 2.90 \\
\hline 33.03 & 17.12 & 12.27 & 13.54 & 15.41 & 17.16 & -2.49 \\
\hline 21.45 & 22.01 & 26.22 & 32.06 & 40.23 & 51.12 & 3.40 \\
\hline 7.37 & 15.73 & 22.23 & 28.87 & 36.95 & 47.22 & 7.41 \\
\hline 4.00 & .00 & 5.00 & 6.00 & 7.00 & 8.00 & 2.70 \\
\hline 84.28 & 79.93 & 87.45 & 106.86 & 137.54 & 162.29 & 2.55 \\
\hline
\end{tabular}

MODERATE GROWTH SCENARIO - IRRIGATION SECTOR

$\frac{1974}{7.19} \frac{1980}{11.93} \frac{1985}{11.57} \quad \frac{1990}{10.96} \quad \frac{1995}{10.03} \quad \frac{2000}{9.08} \quad \frac{\text { AARG }}{.90}$

MODERATE GROWTH SCENARIO - TRANSPORTATION SECTOR

$\begin{array}{llllllll}1974 & \frac{1980}{73.76} & \frac{1985}{74.98} & \frac{1990}{77.48} & \frac{1995}{84.29}: 93.19 & 104.74 & 1.36\end{array}$

Source: Northwest Energy Policy Project, (Reference \#4) 
HIGH GROWTH SCENARIO - TOTAL: : ALL SECTORS

$\frac{\text { Idaho }}{\text { Electricity }}$

Gas

0 i 1

Coal

Wood Residue

Total

Idaho

Electricity

Gas

0 i 1

Coal

Tota 1
Idaho

Electricity

Gas

$0 i 1$

Coa?

Wood Residue

Tota 1

$\frac{\text { Idaho }}{\text { Electricity }}$

Idaho

A11 Petroleum Total

\begin{tabular}{rrrrrrrr}
$\frac{1974}{43.6}$ & $\frac{1980}{54.99}$ & $\frac{1985}{64.31}$ & $\frac{1990}{78.86}$ & $\frac{1995}{99.40}$ & $\frac{2000}{128.57}$ & $\frac{\text { AARG }}{4.24}$ \\
50.87 & 51.17 & 47.52 & 53.32 & 55.69 & 66.23 & 1.02 \\
117.59 & 114.37 & 149.63 & 185.56 & 232.93 & 294.93 & 3.60 \\
10.38 & 16.88 & 21.23 & 28.06 & 39.69 & 55.90 & 6.69 \\
4.00 & 7.00 & 10.00 & 12.00 & 10.00 & 6.00 & 1.57 \\
\hline 226.52 & 244.41 & 292.69 & 357.80 & 437.71 & 551.63 & 3.48
\end{tabular}

HIGH GROWTH SCENARIO - RESIDENTIAL SECTOR

\begin{tabular}{|c|c|c|c|c|c|c|}
\hline 1974 & 1980 & 1985 & 1990 & 1985 & 2000 & AARG \\
\hline 12.26 & 16.05 & 20.28 & 26.27 & $34 .-9$ & 46.61 & 5.27 \\
\hline 9.65 & 13.46 & 14.57 & 17.09 & 19.72 & 23.35 & 3.46 \\
\hline 13.87 & 4.79 & 5.73 & 4.70 & 3.39 & 2.25 & -6.76 \\
\hline 3.01 & 2.83 & 2.69 & 2.56 & 2.44 & 2.32 & -1.00 \\
\hline 38.79 & 37.13 & 43.27 & 50.62 & 60.45 & 74.53 & 2.54 \\
\hline
\end{tabular}

HIGH GROWTH SCENARIO - COMMERCIAL SECTOR

\begin{tabular}{|c|c|c|c|c|c|c|}
\hline 1974 & 1980 & 1985 & 1990 & 1995 & 2000 & AARG \\
\hline 5.81 & 6.34 & 7.68 & 9.81 & 12.54 & 16.25 & 4.04 \\
\hline 8.19 & 7.74 & 8.51 & 10.50 & 12.04 & 15.64 & 2.52 \\
\hline 8.57 & 8.03 & & 19.92 & 27.13 & 36.25 & 5.73 \\
\hline 22.51 & 22.11 & 30.63 & 40.22 & 51.71 & 68.14 & 4.35 \\
\hline
\end{tabular}

HIGH GROWTH SCENARIO - INDUSTRIAL SECTOR

\begin{tabular}{|c|c|c|c|c|c|c|}
\hline 1974 & 1980 & 1985 & 1990 & 1995 & 2000 & AARG \\
\hline $\begin{array}{r}18.43 \\
33.03 \\
21.45 \\
7.37 \\
4.00 \\
\end{array}$ & $\begin{array}{r}20.22 \\
29.97 \\
20.87 \\
14.05 \\
4.00\end{array}$ & $\begin{array}{l}24.08 \\
24.43 \\
37.24 \\
18.54 \\
10.00 \\
\end{array}$ & $\begin{array}{l}31.15 \\
25.73 \\
52.95 \\
25.50 \\
12.00 \\
\end{array}$ & $\begin{array}{l}41.16 \\
23.93 \\
74.50 \\
37.25 \\
10.00 \\
\end{array}$ & $\begin{array}{r}55.61 \\
27.24 \\
102.74 \\
53.58 \\
6.00 \\
\end{array}$ & $\begin{array}{r}4.34 \\
-\quad .74 \\
6.21 \\
7.93 \\
1.57\end{array}$ \\
\hline 84.28 & 92.11 & 114.29 & 147.33 & 186.84 & 245.17 & 4.79 \\
\hline
\end{tabular}

HIGH GROWTH SCENARIO - IRRIGATION SECTOR

$\frac{1974}{7.19} \quad \frac{1980}{12.38} \quad \frac{1985}{12.27} \quad \frac{1990}{11.63} \quad \frac{1995}{10.81} \quad \frac{2000}{10.10} \quad \frac{\text { AARG }}{1.31}$

HIGH GROWTH SCENARIO - TRANSPORTATION SECTOR

(Units in $10^{12}$ BTU)

\begin{tabular}{|c|c|c|c|c|c|c|}
\hline 1974 & 1980 & 1985 & 1990 & 1995 & 2000 & AARG \\
\hline 73.76 & 80.68 & 92.23 & 107.99 & 127.97 & 153.69 & 2.86 \\
\hline
\end{tabular}

Source: Northwest Energy Policy Project, (Reference \#4). 
Table 13-A summarizes the projected rates of change in energy consumption by energy type for low, moderate and high growth scenarios. The moderate growth scenario although not considered totally accurate is considered the most realistic energy demand projection for the State of Idaho. Significant increases in the demand for energy. in the residential sector will cause a major increase in electrical energy demand and moderate increase in naturat gas use. Significant future decreases in demand are expected for oil and coal in the residential sector. The present trend in Idaho is a 7 to 1 ratio of electric vs. natural gas hookups in new housing starts in Idaho. If this present trend continues the moderate growth scenario can be considered as a realistic projection of residential energy demand in Idaho.

Under the moderate growth scenario, the most significant changes in Idaho's energy budget will occur in the industrial sector. Coal is projected to have the most significant increase in energy demand while the use of natural gas is expected to decrease. The demand for coal by Idaho industry is expected to: increase 7.4 percent annually while natural gas demand is expected to decrease 2.5 percent annually under a moderate growth scenario.

\section{Geothermal Market Potentia]}

The major impact of geothermal utilization by Idaho consumers will] be to deter some of the projected growth in natural gas., electricity and coal energy. Minor impact can be expected in projected petroleum consumption because the majority of this energy consumptions will be in the transportation sector.

The major energy end use in the residential sector is space heating and water heating. These two end uses account for 89 percent of the residential energy consumption. Seventeen communities in Idaho have contacted the Idaho Office of Energy regarding their desire to develop the geothermal energy of their area. An additional fifteen other communities have also been identified as having significant geothermal potential. This represents a statewide potential of 229,955 people, living in close proximity (less than $20 \mathrm{~km}$ ) of potential geothermal resources. In terms of national population this is not a significant number of people but in terms of Idaho's population this number represents almost one-third of the State population and one-half of the urban population.

Spaceheating and water heating in the residential sector account for 20 percent of the total energy consumption in the state. Space heating in the commercial sector accounts for an additional 10 percent of Idaho's total energy consumption. Spaceheating is the largest energy-consuming area. which is compatible to direct use of low temperature geothermal resources. In Idaho, spaceheating in the residential and commercial sectors accounts for $68.2 \times 10^{12}$ BTU per year of direct energy consumption. The most logical use for geothermal resources in the residential and commercial sector would be to help meet present and future spaceheating needs.

The food and kindred products industry, the lumber and paper products' industry and chemical products industry are the major industrial consumers: of energy in Idaho. The chemical products industry in Idaho is largely. phosphate ore reduction to make fertilizers. This industry gets 70 percent 
Table 13-A

RATES OF GROWTH IN ENERGY CONSUMPTION

Percentage Annual Average Rate of Change

Forcasted (1964-2000)

\begin{tabular}{|c|c|}
\hline $\begin{array}{l}\text { Historical } \\
(1964-1974)\end{array}$ & $\begin{array}{l}\text { Low } \\
\text { Growth }\end{array}$ \\
\hline
\end{tabular}

Idaho

Electricity

6.66

1.72

$-0.33$

$0 \mathrm{il}$

4.75

4.70

0.05

Coal

$-$

1.50

Wood

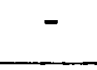

1.57

2.80

$-0.63$

1.41

4.24

6.20

1.02

3.60

2.70

6.69

Total

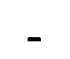

.47

1.79

3.48

Source: Northwest Energy Policy Project, (Reference \#4) 
of its energy from electrical power and less than 30 percent from natural gas. The use of geothermal resources in phosphate reduction would be very limited. Geothermal energy could contribute to the demand needs of this industry by developing new electrical generation facilities.

The majority of Idaho's lumber and paper products industries are (5) located in Northern and Central Idaho and somewhat isolated from the major geothermal areas of the State. Limited uses of geothermal energy in this industrial sector are possible but major contributions by geothermal energy resources are not foreseen.

of the three major industrial sectors in Idaho's economy, the food and kindred products industry is the one industrial sector which could utilize large quantities of geothermal resources directly. This industrial sector is the largest natural gas consuming sector in Idaho accounting for 20 percent of the state's total natural gas consumption. The food products industry has the largest industrial energy demand in Idaho. This demand is approximately 20 x 1012 BTU per year and 70 percent of this energy is natural gas and approximately 20 percent is coal.

The 32 largest industrial plants in Idaho account for 71 percent $(44 \times 1012$ BTU) of the industrial energy consumption in the State. Table 14-A shows these plants in order of their energy demand. Seven of these plants are lumber and paper mills and all seven are located in Northern Idaho. Three plants are phosphate reduction plants. Two other plants are also ore reduction plants. Direct use of geothermal energy in these plants is unrealistic. Geothermal energy could help meet the energy demand of these twelve plants by development of new electric generation capacity.

Twenty of the thirty-two largest industrial facilities in Idaho are food and processing plants. Nineteen of these food processing facilities are located in the Snake River Plan within $50 \mathrm{~km}$ of known geothermal resources. These nineteen plants account for $14.77 \times 1012$ BTU per year of direct energy consumption. Potato, sugar beet and vegetable processing facilities are prime direct energy users which require hot water and could utilize large quantities of geothermal fluids.

The greatest potential for use of geothermal energy in Idaho industry is in providing hot fluids. to present and future food processing facilities and new electrical generation capacity for the growing phosphate industry. 


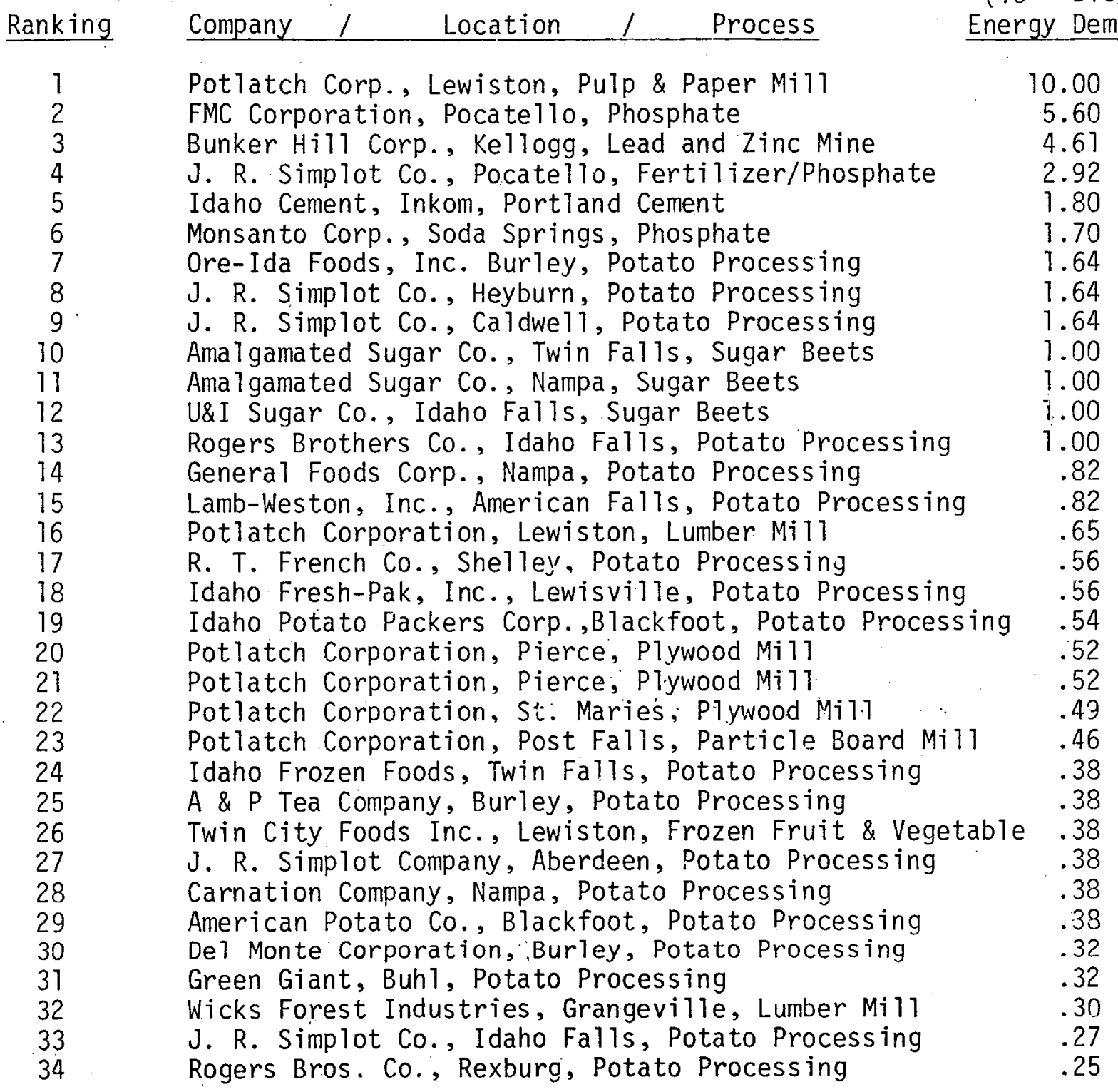

Seven Lumber and Paper Mills (al1 in Northern Idaho) 12.94 Three Phosphate reduction plants

Source: Industrial Waste Heat for Adjacent Communities and Industrial Applications (Reference \#5). 


\section{REFERENCES}

1) Bochenski, Gary L. and Ha11, Kirk L., Energy Facts, Idaho - United States World. Idaho Office of Energy, Office of the Governor, State of Idaho, 1977.

2) Drysdale, Frank R., and Calef, Charles E., The Energetics of the United States of America - An At 1as, Brookhaven National Laboratory, Report 50501-R, 1977 pp. 106-108.

3) Bradley, Clifford, Electricity Demand in Idaho Recent Trends and Forecast, unpublished report, Idaho office of Energy, . Office of the Governor, State of Idaho, 1978.

4) Mclugh, W. Michael, Northwest Energy Policy Project, Energy Demand Modeling and Forecasting, Final Report, Pacific Northwest Regional Commission, 1978.

5) Rocket Research Company, Industrial Waste Heat for Adjacent Communities and Industrial Applications, Task 1, Pacific Northwest Regional Commission Report RRC-78-H-181, 1978.

Other References:

Little, Arthur D., Idaho Power Company's Need for Additional Generating Capacity, Final Report to Idaho Public Utilities Commission, 1976.

Dames and Moore, Natural Gas Supply Requirements for the State of Idaho, Report to Idaho PubTic Utilities Commission, Dec. 1977. 


\section{APPENDIX B}

GEOTHERMAL DEVELOPMENT REGION I

North Idaho Panhandle Region

TABLE OF CONTENTS

Text:

Page

INTRODUCTION . . . . . . . . . . . . . . . . . . . . 137

GEOTHERMAL POTENTIAL . . . . . . . . . . . . . . . . 137

RIGGINS HOT SPRINGS SUB-AREA . . . . . . . . . . . . 137

BERGDORF GEOTHERMAL SUB-AREA . . . . . . . . . . . 146

RED RIVER GEOTHERMAL SUB-AREA . . . . . . . . . . 153

LOCHSA GEOTHERMAL SUB-AREA . . . . . . . . . . . 154

COEUR D'ALENE GEOTHERMAL SUB-AREA . . . . . . . . . . 157

INSTITUTIONAL CONSIDERATIONS

Federal Agencies . . . . . . . . . . . . 157

Local Constraints................. 158

RARE II....................... . . 159

REFERENCES ..................... 160

Tables:

Table 1-B, Site Data Summary for Riggins Hot Springs Sub-Area . . 139

Table 2-B, Site Data Summary for Bergdorf Hot Springs Sub-Area . 147

Table 3-B, Physical Data, Red River Hot Springs Sub-Area . . . 155

Table 4-B, Hot Springs of the Lochsa Geothermal Sub-Area . . . 156

Table 5-B, Local Institutional Framework . . . . . . . . . 158 


\author{
APPENDIX B \\ GEOTHERMAL DEVELOPMENT REGION I \\ NORTH IDAHO PANHANDLE REGION
}

Introduction

The Panhandle region of Idaho described in this chapter encompasses all the counties north of the southern boundary of Idaho County, Idaho. This large region covers about one-third of the state land mass. The boundaries of this region coincide with the boundaries of the coeur d'Alene BLM District and Idaho State Planning Regions I and II. Most of the known geothermal occurences in this region are located in remote mountainous areas.

There are only a limited number of areas in this region with both adequate geothermal resources and local economic demands which could be satisfied by developing the resource.

\title{
Geothermal Potential
}

Five thermal areas were examined in the North Idaho Panhandle Region: the Coeur d'Alene Mining District, the Lochsa Area, the Red River Area, the Bergdorf Area, and the Riggins Area. With the exception of the Coeur d'Alene Mining District, the majority of the thermal springs and seeps in the region are found in a two thousand square kilometer area between the Lochsa and Salmon Rivers in Idaho County.

One geothermal area, Riggins Hot Springs, has limited commercial potential. Of all the geothermal areas in the North Idaho Panhandle region, Riggins Hot Springs is the only geothermal areas spatially located near a potential market area. The Red River, Bergdorf, Lochsa Coeur d'Alene geothermal areas are isolated, mountainous areas with low resource potential and no major market potential.

The majority of the thermal springs known in the Northern Idaho Panhandle geothermal region are located in the Lochsa geothermal area. The Lochsa area is enclosed within the Selway Bitteroot Wilderness area that restricts motorized traffic. The thermal springs of this region are isolated by very rough mountainous terrain. Both the political and economic outlook are unfavorable for any development of the Lochsa geothermal potential.

\section{Riggins Hot Springs Geothermal Sub Area}

Riggins Hot Springs is located 12 kilometers east of the town of Riggins. The hot springs are located on an isolated, small alluvial deposit in the Salmon River Canyon. The on-site development potential is limited by available space. The 80 acre site is bordered by the Salmon River on three sides and by a near verticle, 900 meter high, canyon wall on the fourth side. Access to the site is by U.S. 
Highway 95 to Riggins, then east 12 kilometers along Nez Perce National Forest Road 103 to Allison Creek. The Forest Service road is an all-weather gravel road which follows the north bank of the Salmon River. The hot springs are on the south bank of the river and are accessed by a smal1 private bridge.

Present development of the geothermal potential is 1 imited to a small resort and commercial greenhouse at the site. Except for 640 acres of private land surrounding the hot springs, the remaining 7 and area is owned by public agencies. Most of this land is extremely steep canyon land.

The hot springs are venting from Quarternary alluvium which is les. than 5 meters thick. The surrounding country rock is Mesozoic gneiss. (1) The temperature of the hot springs is $42^{\circ} \mathrm{C}$ and the discharge is approximately $3.5 \mathrm{~L} / \mathrm{S}$ (50 gpm) from four vents. Silica Geochemical thermometry predicts an aquifer temperature of $120^{\circ} \mathrm{C}$ at depth. (2) The location of the hot springs is probably structurally controlled by a major north trending normal fault. It is possible that exploratory driiling into the shear zone of this fault could increase the temperature and flow of the thermal water.

Expansion of the greenhouse operation is handicapped by the shadow effect of the canyon walls. The location has a limited angle of incidence with the sun during the winter months. This limits the productive capabilities of the greenhouses. Any major expansion of the greenhouse operation must consider alternative crops with more tolerance to low light. Present operations have concentrated on tomatoes and flowers.

The market for local produce is limited. Riggins has a population of 580 people and is 80 kilometers from its nearest neighboring community. Two crops appear to be possible alternatives; mushrooms and tree seedlings. Mushrooms require very little 7 ight and are presently imported to Idaho markets from California. Tree seedlings could be used locally. Timber harvesting in this region will require extensive replanting in the near future. A local source of tree seedlings would have an economic advantage due to lower transportation cost.

A fish hatchery is also a feasible future development possibility. The location of the Riggins Hot Springs at an accessible area is the Salmon River Canyon makes it an ideal 1ocation for future hatchery operations. The Salmon River Drainage is a protected fishery habitat under the authorization of the Bonneville Power Administration. No dams will be built in this drainage in order to provide spawning grounds for the Columbia River salmon fishery. Future growth and increasing demand for salmon is increasing the need for more hatcheries. The development of a salmon hatchery at Riggins Hot Springs could help meet future salmon fishery needs.

Large scale geothermal development possibilites will depend on future exploration drilling in the area. No exploration is foreseen at this time. If higher temperature fluids $\left(120^{\circ} \mathrm{C}\right)$ are developed in significant volumes the market potential is fimited by the amount of available space and the isolation of the site. The town of Riggins (12 kilometers from the springs) is a small lumber and resort community located at the confluence of the Saimon and Little Salmon Rivers. 
The town has only 580 people, approximately 150 residential units and 40 commercial buildings. The city could use the geothermal heat for space heating of homes and commercial buildings. The major industry in Riggins is the Salmon River Lumber Company which employs about 100 people. The mill is a major energy consumer which uses approximately $40 \times 10^{9}$ BTU per year of direct energy and could utilize geothermal energy for space heating and kiln drying.

There is very little geological information about the resource area. Exploration for higher volumes and temperatures would be a high risk adventure at this time. Geophysical resource assessment is needed to help determine the potential of the resource. The environmental sensitivity of the Salmon River will limit on-site development to nonindustrial sectors. Table 1-B lists the physical, institutional and economic data that is specific to the Riggins Hot Springs site.

Table 7-B

SITE DATA SUMMARY

Site: Riggins Hot Springs

SITE LOCATION AND PHYSICAL DESCRIPTION

Location:

(3)

.. Latitude: $\quad 45^{\circ} 47^{\prime} 25^{\prime \prime} \mathrm{N}$

..Longitude: $115^{\circ} 11^{\prime} 86^{\prime \prime} \mathrm{W}$

..Rectilinear: Sec. 14, SE, NE, SW; T24 N, R 2 E Boise Meridian

..County: Idaho

..Adjacent Counties: Adams, Clearwater, Lemhi, Lewis, Nez Perce, Valley

.Topography: (3) Riggins Hot Springs are in the narrow deep river canyon of the Salmon River. The Springs are located on a relatively flat alluvial deposit which is surrounded on three side by the Salmon River and the fourth side by a 900 meter high escarpment, of the canyon wal1

..Present Land Use: Commercial land use; greenhouse operation at hot springs. Recreational land use; river is used extensively for recreation.

. Future Land Use Plans: Expanded development of greenhouses.

..Aesthetics: Area has a high aesthetic value and is used extensively for recreation. Area is the low reach of the "River of No Return".

..Historical/Archaeological Significance:

Historical Indian use of the area.

Mining area in 1862 . 
The site is located in the deep narrow gorge of the Saimon River. The Hot Springs are venting from Quaternary Alluvial deposits which overlie Paleozoic and Mesozoic gniess. The area has a major north trending normal fault which is a probable structural control of the thermal fluids. The Salmon River is flowing east-west at the intersection with the fault where the hot springs are found. Area geology was mapped by Hamilton (1969).

..Geophysical Summary:

..Geologic Hazards:
Area is subjected to periodic (100 year) flooding.

\section{RESERVOIR CHARACTERISTICS}

. Reservoir Temperature

. Surface: $45^{\circ} \mathrm{C}$

..Subsurface: No down hole temperatures avajlable

- Geochemical

$\mathrm{SiO}_{2}: \quad 120^{\circ} \mathrm{C}$

$\mathrm{Na}-\mathrm{K}-\mathrm{Ca}: \quad 95^{\circ} \mathrm{C}$

..Flow Rates: (2)

2) Four major springs, total discharge approximately (50 gpm) $3.5 \mathrm{~L} / \mathrm{S}$

..pH: 8.1

..Total Dissolved Solids: (2) $199 \mathrm{mg} / 1$

..Fluid Chemistry:

(2) (milligrams per liter)

$\mathrm{Si}:$

72.0

Ca:

$\mathrm{Mg}:$

$\mathrm{Na}$ :

$\mathrm{K}:$

6.2

$\mathrm{HCO}_{3}$ :

$\mathrm{CO}_{3}$ :

$\mathrm{SO}_{4}$ :

$\mathrm{P}^{4}$ :

C:

$F$ :

$\mathrm{NO}_{3}:$<smiles>[AlH2]</smiles>

160.0

3.4

11.0

25.0

300.0

.02

8.0

2.1

$$
.02
$$

..Estimated Nonelectric Energy Potential (MBtuh 30 years) : .21

(best estimate) $\quad .6$

..Subsurface Area of Reservoir: $1 \mathrm{~km}^{3}$ 
LAND OWNERSHIP AND LEASING

$\begin{array}{lccccc}\begin{array}{ccc}\text { TOTAL AREA } \\ \text { (Acres) }\end{array} & \begin{array}{c}\text { FEDERAL } \\ \text { (Acres) }\end{array} & \begin{array}{c}\text { STATE } \\ \text { (Acres) }\end{array} & \begin{array}{c}\text { PRIVATE } \\ \text { (Acres) }\end{array} & \text { OTHER } \\ * \star \text { Land Ownership } & 7040 & 5760 & 640 & 640 & -- \\ * \star \text { Land Leased } & \text { None } & \text { None } & \text { None } & \text { None } & -- \\ * * \text { Summary of Leasing Status and Needs: No interest shown to lease area }\end{array}$

GEOTHERMAL DEVELOPMENT STATUS

**Present Development Status: A small 80 acre area of flat land is presently used for a small resort and commercial greenhouse operation.

**Projected or Planned Development:

Limited expansion of present use can be expected to space heat more greenhouses and possibly a fish hatchery.

Projected uses: Exploration for high temperatures and greater volumes. The fluids could be transported via pipeline down Forest Service Road \#304 to the City of Riggins which is $13 \mathrm{~km}$ west of the site.

Thermal fluids could be used for space heating in the town or kiln drying in the local lumber mill. 
INSTITUTIONAL CONSIDERATIONS (Federa1)

Institutional Requirements

Federal Geothermal Resource Lease (30 C.F.R. 3000)

National Environmental Policy Act (42-U.S.C. 4331)
Agency and

Public Attitudes

Leases are made pursuant to the Geotherma?

Steam Act of 1970.

(84 Stat. 1566)

(30 USC 1001-1025)

B.L.M., U.S.F.S.

U.S.G.S.
An E.I.A. is required before leases are issued. E.P.A.
Federal Water Pollution Control Act (33-USCA 1251)
The national goal of this act is to attain -0 - pollution by 1985 . E.P.A.

Federal Safe Drinking Water Act

(42 U.S.C. (A) 300)
This Act is concerned with protection of underground water sources that could be used for domestic water. E.P.A.
Status of Requirements (i.e., EIA/EIS Requirements

Area is open to noncompetive leases at this time. Special conditions are required in the leases with regard to potential archaelogical and historical sites, adjacent roadless areas, and critical habitat areas. Nez Perce National Forest and Coeur d'Alene. BLM District are the primary public land agencies.

A preliminary E.A.R. will be required before an exploration drilling projeci. In general an E.I.A. is required for all projects involving exploration and development. An E.I.S. will be required for any major action.

Groundwater is included under this Act and the reinjection of geothermal effluient will require permits.

The Act sets standards for wells and well drilling and could influence future geothermal wells and disposal wells. 
Institutional Requirements

Leases on State lands (Idaho Code 47-601 et. seq. Chapter 16, Geothermal Resources)

Geothermal Resource Permits .

(Idaho Code 42-4001 et. seq. Chapter 40, Geothermal Resources)

Water Appropriation (Idaho Code 42-101 et. seq. Chapter 1 Water Appropriation)

Injection wells (Idaho Code 42-3001 et. seq. Chapter 39 Waste Disposal and Injection Wells)
Agency and Public Attitudes

The State Board of Land Commissioners is authorized to issue leases for geothermal resoures underlying state and school lands.

The regulatory powers of the state Geothermal Resource Act are placed in the Idaho Department of. Water Resources.

The Idaho Department Under the Idaho Geothermal Reof Water Resources issues water appropriation permits and a water right license.

Permits are issued by the Department of Water Resources.
Status of Requirements (i.e., EIA/EIS Requirements

Lease term is 10 years and can be continued with diligent development. Rentals are set by the board. Several leases have been granted on state lands. Lease size is 1 imited to a maximum of 640 acres/lease.

Any private owner, or holder of a state or federal lease of geothermal resources must first apply for a geothermal resource permit from I.D.W.R. before any drilling operations can begin. sources Act, applicants can be required to make an application to appropriate the public waters of the state.

No waste disposal or injection well can be constructed in Idaho unless a permit has been issued by I.D.W.R. The approval of this permit is contingent upon the approval of the Department of Health and Welfare. The proposed well is reviewed to see if it will unreasonably contaminate or deteriorate the quality of the groundwater below the adopted water quality standards of the state. 
(Table 1-B Cont'd.)

ENVIRONMENTAL FACTORS

$* *$ CLIMATE (4)

**Prevailing Winds: East-West

**Precipitation (Annual): Snow: $30.7 \mathrm{~cm}$

Precipitation: $39.34 \mathrm{~cm} / \mathrm{yr}$

$\star \star$ Days of Sunshine (Annual): 300

**Average Temperature

$\left({ }^{0} \mathrm{C}\right)$

$\begin{array}{llr} & \text { Jan. } & \text { July } \\ \text { Minimum: } & 3.2 & 10.45 \\ \text { Maximum: } & 4.9 & 33.5\end{array}$

**Degree Days (Annual): 5097

$\star \star$ Elecation: $\quad 609.6$ meters

**Air Quality: High

**Geologic Factors: Flash flooding of side canyons and falling rock and rock slides are frequent after major storms.

**Water Quality: High

**Noise: Low

$* *$ BIOLOGICAL

**Dominant Flora: Sagebrush, cheat grass ecosystem

**Dominant Fauna: Mule Deer

Coyote

TRANSPORTATION AND UTILITIES

**Utility or Energy Transmission Corridors and Facilities

A 220 volt line services the Riggins Hot Springs Resort.

Right-of-way is owned by Idaho Power Co.

**Transportation Corridors or Facilities

All weather gravel road from Riggins and Highway 95 to Riggins Hot Springs. 
(Table 1-B Cont'd.)

POPULATION

**General Description of Population

Riggins Hot Springs is located 12 kilometers east of the town of Riggins. Riggins is a small community of 580 persons. The town has a growth rate of $8 \%$ per year. The major economic activities of the area are logging, lumber processing, recreation, cattle ranching and mining. The principle industry is the local 1umber mill.

$\star \star$ Economics

The principle economic activity in the Riggins area is lumber and forest products. The local mill is the major employer of the area. The Salmon River Lumber Co., is owned by Brown Industries Inc., and employs approximately 100 people. This industry is also the principle energy consumer in the area. Estimate direct energy consumption by the Salmon River Lumber Mill is $40 \times 10^{9}$ BTU/yr. Recreation and tourism is the second major industry in the area. The Salmon River is famous for its scenic, fishing and boating qualities. 
The Community of Bergdorf and nearby hot springs is located 51 kilometers north of McCal1, Idaho. The geothermal potential of this area is limited and can be considered a low potential development site. No interest has been shown to lease the general area for exploration. The major interest to develop the geothermal resources has been from the local residents to develop the recreation potential of the resource. The hot springs are used for a small pool at the Bergdorf resort.

Most of the land area surrounding Bergdorf is owned by the Federal government. Approximately 120 acres is privately owned and used for summer homes. Most of the structures at Bergdorf are old log buildings which were built in the 1930's. The present potential for geothermal resource development in Bergdorf is spaceheating of present and future cabins.

The major restrictive factors affecting geothermal development at Bergdorf are its remoteness and severe winter. The area has an elevation of 1854 meters and is snowbound up to four months a year. The area typically receives over 2 meters of snow per year.

Bergdorf is located in the northwest quarter of section $1, T .22 \mathrm{~N}$, R.4 E. Boise and Meridian. The population of the area varies by season. The seasonal peak population is 24 in the summer and 6 in the winter. Most of the energy used for heating at Bergdorf is local wood. Local attitudes toward geothermal development are for 7 imited use of the resource for present facilities but against any new developments which would change the nature of the area.

Bergdorf is located in an intermountain valley which is filled with quaternary alluvium. The valley is a relatively flat meadow which is surrounded by steep forested Cretaceous granitic mountains. The hot springs discharge $10.2 \mathrm{~L} / \mathrm{S}(162 \mathrm{gpm})$ of $45^{\circ}$ thermal water. The silica geochemical thermometer indicates that aquifer temperatures of $120^{\circ} \mathrm{C}$ are possible. The hot springs are venting from the quaternary alluvial material which thinly covers the granitic rocks along the valley margins. The surrounding Cretaceous granite is the probable source of the thermal water. This source could be fault controlled. No resource assesment has been conducted in the area other than water analysis. (2) It is possible that drilling in the alluvial fill could increase the temperature and flow of the water.

The only potential utilization of the resource that is feasible is limited spaceheating of homes. Because of the area's remoteness and recreation use, industrial applications are not realistic. A small sawmill did exist in the area at one time but has been abandoned. Timber harvesting in the area is depressed due to overcutting. The major lumber mill of the region was at McCall. This mill was closed due to a lack of timber in 1977 and has been dismantled.

Table 2-B list the physical, institutional, and economic data that is specific to Bergdorf Hot Springs. 
Table 2-B

SITE DATA SUMMARY

Site: Bergdorf Hot Springs

SITE LOCATION AND PHYSICAL DESCRIPTION

Location: (6)

.. Latitude: $\quad 45^{\circ} 16^{\prime} 74^{\prime \prime} \mathrm{N}$

..Longitude: $115^{\circ} 55^{\prime} 19^{\prime \prime} \mathrm{W}$

..Rectilinear: NW SE SW Sec. 1, T. 22 N., R. 4 E. Boise Meridian

..County: Idaho

..Adjacent Counties: Adams, Clearwater, Valley

.. Topography! $!^{(6)}$ Steep, mountainous terrain at hot springs.

Flat meadow area around the community of Bergdori

$1 / 4$ mile east. Elevation of hot springs $1859.2 \mathrm{~m}$

..Present Land Use: Timber management in surrounding area. Small resort developed at hot springs, limited number of summer homes. Large area east of town is under RARE II Study.

..Future Land Use Plans: Continued timber harvesting and expansion of summer homes are expected.

..Aesthetics: Highly aesthetic location

-.Historical/Archaelogical

Signifance: Historical mining in the area in 1812. 


\section{GEOLOGICAL/GEOPHYSICAL DESCRIPTION}

..Geologic description:

Bergdorf lies in a deep valley on quaternarv alluvium of indetermined depth. The hot springs are venting at two locations in close proximity to one another from the alluvium. Surrounding country rock, which forms the valley walls and regional mountains is cretaceous granite. The hot springs may be related to high angle fautting in the area.

..Geophysical Summary:

No geophysical work has been done in the area.

. Geologic Hazards:

Snow avalanches in winter.

\section{RESERVOIR CHARACTERISTICS}

. Reservoir Temperature

..Surface: $\quad 45^{\circ} \mathrm{C}$

. Subsurface: No down hole temperatures

..Geochemical (2)

S.jO $: \quad 120^{\circ} \mathrm{C}$

$\mathrm{Na}-\mathrm{K}-\mathrm{Ca}: 55^{\circ} \mathrm{C}$

.Flow Rates: 10.2 Liters/sec.

.. pH:

8.1

. Total Dissolved Solids:

. Fluid Chemistry:

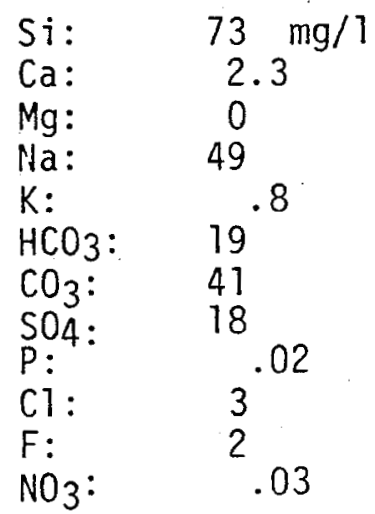


(Table 2-B Cont'd.)

..Estimated Nonelectric Energy Potential (MBtuh 30 years):

.63

.. Subsurface Area of Reservoir:

$1 \mathrm{Km}$ estimated

LAND OWNERSHIP AND LEASING

TOTAL AREA FEDERAL STATE PRIVATE OTHER

(Acres) (Acres) (State) (Acres)

..Land Ownership $7680 \quad$-- $\quad$-- 120

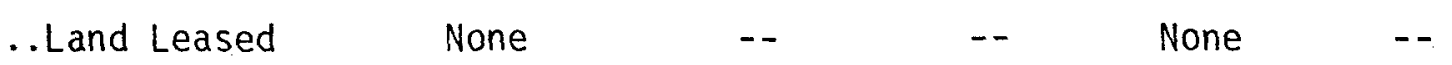

.. Summary of Leasing Status and Needs: No activity as of October 1978.

GEOTHERMAL DEVELOPMENT STATUS

..Present Development Status:

A small resort with 1 imited spaceheating, and timber harvesting are the major development in the area.

..Projected or Planned Developmient:

Expanded development of recreation homes to incorporate geothermal heating is possible by 1985 . 
INSTITUTIONAL CONSIDERATIONS (Federa1)

Institutional

Requirements

Federal Geotherma]

Resource Lease

(30 C.F.R. 3000)
National Environmental Policy Act (42-U.S.C. 4331)
Agency and

Public Attitudes

Leases are made pursuant to the Geothermal Steam Act of 1970.

(84 Stat. 1566)

(30 USC 1001-1025)

B.L.M., USFS

U.S.G.S.

An E.I.A. is required before leases are issued.

E.P.A.
Federal Wäter Poîiution Control Act (33-USCA 1251)

Federal Safe Drinking Water Act

(42 U.S.C. (A) 300)
The national goal of this Act is to attain -0-pollution by 1985 .

E.P.A.

This Act is concerned with protection of underground water sources that could be used for domestic water.

E.P.A.
Status of Requirements (i.e., EIA/EIS Requirements

Noncompetitive lease area. Special conditions are required in the leases with regard to potential archaelogical and historical sites, adjacent roadless areas, and critical habitat areas. Nez. Perce National Forest is the surface regulatory agency.

A preliminary E.A.R. for exploration drilling project. In general an E.I.A. is required for a 11 projects involving exploration and development. An E.I.S. will be required for any major action.

Groundwater is included under this Act and the reinjêction of geothermal effluient will require permits.

This Act sets standards for wells and well drilling and could influence future geothermal well.s. 


\begin{tabular}{l}
$\begin{array}{l}\text { Institutiona } 1 \\
\text { Requirements }\end{array}$ \\
\hline Leases on State \\
lands (Idaho Code \\
$47-601$. et. seq. \\
Chapter 16, Geo- \\
thermal Resources)
\end{tabular}

Institutiona 1

Leases on State lands (Idaho Code

47-601. et. seq.

thermal Resources)

\author{
Agency and \\ Public Attitudes \\ The State Board of \\ Land Commissioners \\ is authorized to \\ issue leases for \\ geothermal resources \\ underlying state and \\ school lands.
}

Geothermal Resource Permits. (Idaho Code 42-4001 et. seq. Chapter 40, Geotherma 1 Resources)

The regulatory powers of the State Geothermal Resource Act are placed in the Idaho Department of Water Resources.

Water Appropriation (Idaho Code 42-101 et. seq. Chapter 1 Water Appropriation)

Injection wells (Idaho Code 42-3001 et.seq. Chapter 39 Waste Disposal and Injection Wel1s)
Permits are issued by the Department of Water Resources.
Status of Requirements (i.e., EIA/EIS Requirements)

Lease term is 10 years and can be continued with ditigent development. Rentals are set by the Board. Severa? leases have been granted on state lands. Lease size is limited to a max. of 640 acres/lease.

Any private owner, or holder of a state or federal lease of geothermal resources must first apply for a geothermal resource permit from I.D.W.R. before any drilling operations can begin.

Under the Idaho Geothermal Resources Act, applicants can be required to make an application to appropriate the public waters of the state.

No waste disposal or injection we 11 can be constructed in Idaho unless a permit has been issued by I.D.W.R. The approval of this permit is contingent upon the approval. of the Dept. of Health and Welfare. The proposed well is reviewed to see if it will unreasonably contaminate or deteriorate the quality of the ground water below the adopted water quality standards of the state. 


\section{ENVIRONMENTAL FACTORS}

. CLIMATE

(4)

..Prevailing winds: $\mathrm{N}-\mathrm{S}$

..Precipitation (Annual): $\begin{array}{rr}74.01 \mathrm{~cm} & (29.14 \text { in rain) } \\ 454.4 \mathrm{~cm} & (178.9 \text { in snow) }\end{array}$

$\therefore$ Days of Sunshine (Annua 1): $240 /$ year

..Average Temperature

Minimum: $\quad 1^{\circ} \mathrm{C} \quad\left(3^{\circ} \mathrm{F}\right)$ January $/ 7^{\circ} \mathrm{C} \quad\left(33.5^{\circ} \mathrm{F}\right)$ July

Maximum: $\quad 0^{\circ} \mathrm{C}\left(32.3^{\circ} \mathrm{F}\right)$ January $/ 25.5^{\circ} \mathrm{C},\left(77.9^{\circ} \mathrm{F}\right)$ July

..Degree Days (Ánnua 1): 10407

Elevation: 1859 meters

..AIR QUALITY:

Excellent

..GEOLOGIC FACTORS:

Shallow soil depth, exception valley fills

.WATER QUALITY:

Surface Quality is high

Ground water is normal for area, high quality

. NOISE

Low levels

..BIOLOGICAL

..Dominant Flora: Lodgepole pine forest

..Dominant Fauna: Deer, bear, elk

... Endangered Species:

Flora: None

Fauna: None 


\section{TRANSPORTATION AND UTILITIES}

.Utility or Energy Transmission Corridors and Facilities

None:

..Transportation Corridors or Facilities

U.S. Highway 95 to McCal1

Warren Wagon Road paved to Bergdorf Junction: $50 \mathrm{~km}$

Forest Service Road (dirt) $1 \mathrm{~km}$ to Bergdorf Hot Springs

\section{POPULATION}

..General Description of Population

Bergdorf is a small resort which supports a seasonal population of 24 in summer and 6 in the winter.

The nearest major population center is McCall, Idaho which is located $51 \mathrm{kilometers}$ to the south. McCall has a population of 2500 people. Access to Bergdorf is cut off in the winter months by heavy snowfall.

..Economics

The present resort development is over 50 years old and in a deteriorated state. New construction is possible but any development would be largely a seasonal operation due to the severe winter.

\section{RED RIVER GEOTHERMAL SUB AREA}

Red River Hot Springs is located in the Nez Perce National Forest in the southeast corner of Section 3, T $28 \mathrm{~N}, \mathrm{R} 10 \mathrm{E}$ Boise and Meridian. The spring has a surface temperature of $55^{\circ} \mathrm{C}$ and a discharge of 2.2 1iters per sec. The silica geochemical thermometery indicates that a temperature of $120^{\circ} \mathrm{C}$ is possible at depth. The springs are venting from Cretaceous granitic rocks into Red River Canyon. (2) The present land use of the spring area is a U.S. Forest Service campground.

The hot springs area can be accessed by traveling 32 kilometers east of Elk City, Idaho, along Forest Service Road 222 to Red River. The hot springs are located near the campground. The area has an elevation of 1520 meters (5000 feet) and receives $314 \mathrm{~cm}$ (124 inches) of snow per year. 
The development potential is negligible. Private placer mining claims located 1 kilometer to the southeast are no longer operational. The nearest economic center is Elk City. Table 3-B.1 ist specific physical data for Red River Hot Springs.

\section{LOCHSA GEOTHERMAL SUB AREA}

Approximately twelve hot spring locations are scattered throughout the mountainous Lochsa Geothermal Area. All of these springs are venting from Cretaceous granite and have surface temperatures less than $50^{\circ} \mathrm{C}$. There appears to be no major geochemical anomalies with these springs. Silica geochemical thermometery indicates $100^{\circ} \mathrm{C}$ is the highest temperature available at depth. The springs often occur in linear clusters over several kilometers which suggest possible structural control.

The Lochsa Geothermal area lies totally within the boundaries of the Selway-Bitteroot Wilderness Area. The area is a rugged mountainous region which is totally isolated from human activity. Motorized equipment is restricted in this area and access is limited by foot or horseback along narrow trails. Both the political and economic outlook for this area indicate that geothermal development is not possible. Jerry Johnson Hot Springs and Weir Creek Hot Springs are representative of the typical geochemistry found in the Lochsa geothermal area. Although the discharge of the various springs in the Lochsa area can vary from a few gallons per minute to several hundred gallons per minute, the geochemistry of these springs is very similar. Table 4-B lists the geochemical information regarding Jerry Johnson and Weir Creek Hot Springs. 
Table 3-B

Physical Data

Red River Hot Springs

T $28 \mathrm{~N}, \mathrm{R} 10 \mathrm{E}$, Sec. 3, SE, Boise Meridian

Chemistry:

(2)

$\begin{array}{lc}\mathrm{Si}: & 76 \\ \mathrm{Ca}: & 2.7 \\ \mathrm{Mg}: & 0 \\ \mathrm{Na}: & 81 \\ \mathrm{~K}: & 1.6 \\ \mathrm{HCO} 0_{3}: & 36 \\ \mathrm{CO}_{3}: & 36 \\ \mathrm{SO}_{4} & 44 \\ \mathrm{P}: & .01 \\ \mathrm{C1}: & 4.4 \\ \mathrm{~F}: & 23 \\ \mathrm{NO}_{3}: & .04\end{array}$

Temperature $55^{\circ} \mathrm{C}$

Discharge $35 \mathrm{gpm}$

Geochemical Thermometer

Si: $120 \mathrm{C}$

$\mathrm{Na-k-Ca:} \quad 95 \mathrm{C}$

Elevation: 1520 meter $(5,000$ feet $)$

Dissolved Solids: $\quad 286 \mathrm{mg} / 1$

$\mathrm{PH}: \quad 8.6$

Springs venting from Cretaceous granite

$\begin{array}{rll}\text { Climate (4) - Elk City Station - January: } & \text { July: } \\ & \text { Max. } 1.1^{\circ} \mathrm{C}\left(34.1^{\circ} \mathrm{F}\right) & 28.3^{\circ} \mathrm{C}\left(83^{\circ} \mathrm{F}\right) \\ & \text { Min. }-11.6^{\circ} \mathrm{C}\left(11^{\circ} \mathrm{F}\right) & 4.1^{\circ} \mathrm{C}\left(39.4^{\circ} \mathrm{F}\right)\end{array}$

Degree days:

8557

Days of Sunshine: 260

Elevation: $\quad 1584.9$ meters

Annual Precipitation: $313.9 \mathrm{~cm}$ (123.6 inch) snow

$65.5 \mathrm{~cm}$ (25.8 inches) rain

Land Ownership: $\quad 100 \%$ Federal for 459. kilometers

Nez Perce National Forest

Private mining claim. 1 kilometer SE. (abondoned)

Access: 20 miles East of Elk City, Idaho on F.S. 222 to Red River, then F.S. 234 to Hot Springs. 
Table 4-B

Hot Springs of the Lochsa Geothermal Sub Area

Jerry Johnson Hot Springs

36 N, R 13 E, Sec. 18, NE Corner, Boise Meridian

Surface Temperature: $48^{\circ} \mathrm{C}$

Geochemical Thermometers: Si: $100^{\circ} \mathrm{C}$

$\mathrm{Na}-\mathrm{k}-\mathrm{C}: \quad 35^{\circ} \mathrm{C}$

Discharge: $300 \mathrm{gpm}$

Geochemistry: (militigrams per liter)

Si:

Ca:

Mg:

Na:

$\mathrm{K}$ :

$\mathrm{HCO}_{3}:$

$\mathrm{CO}_{3}$ :

$\mathrm{SO}_{4}$ :

P:

C]:

$\mathrm{F}$ :

$\mathrm{NO}_{3}$ :

TDS:

$\mathrm{pH}$ :

$$
\begin{array}{r}
49.0 \\
2.7
\end{array}
$$$$
.2
$$$$
37.0
$$$$
24.0
$$$$
25.0
$$$$
25.0
$$

1.9

1.6

155.

8.7

Weir Creek Hot Springs

(2)

T 36N R 11 E Sec. 13 NW Corner, Boise Meridian

Surface Temperature: $47.5^{\circ} \mathrm{C}$

Geochemical Thermometers: $\begin{aligned} \mathrm{S}: 100^{\circ} \mathrm{C} \\ \mathrm{N}-\mathrm{k}-\mathrm{Ca}: 35^{\circ} \mathrm{C}\end{aligned}$

Dischargè: $40 \mathrm{gpm}$

Geochemistry (milligrams per liter)

Si:

Ca:

$\mathrm{Mg}:$

$\mathrm{Na}:$

$\mathrm{K}:$

$\mathrm{HCO}_{3}:$

$\mathrm{CO}_{3}:$

$\mathrm{SO}_{4}$ :

P:

$\mathrm{Cl}:$

$\mathrm{F}$ :

$\mathrm{NO}_{3}:$

TOS:

$\mathrm{pH}$ :

49.0

3.3

0

29.0

27.0

22.0

15.0

.03

2.1

2.2

.03

134.

8.5 
Coeur d'Alene geothermal area is located in $T^{48} \mathrm{NR}^{5} \mathrm{E}$, Boise Meridian. The geothermal energy potential of this geothermal area is unknown due to 1 imited information about the resource. In general, the area does not have major resource potential and very limited development potential. The geothermal resource is unique and does warrant further investigation.

The Coeur d' Alene Mining District is located in the Belt Supergroup series. The Belt Supergroup is an extensive Precambrian Metamorphis belt known for extensive mineralization. The geothermal resource of the area is mine water. Mine water from at least one mine averages $27.6^{\circ} \mathrm{C}$ when discharged at the surface. The Star Morning Mine is presently pumping $700 \mathrm{gpm}$ of $27.6^{\circ} \mathrm{C}$ water out of the main crosscut portal. (7) This main portal is located at the mining town of Burke, Idaho.

The town of Burke has an elevation of 1153 meters and a mean annual temperature of $4.7^{\circ} \mathrm{C}$. Less than 30 people live in Burke. The town consists primarily of mine related buildings. this is not a significant resource, it could provide adequate warm water to heat all the residential and mine related buildings in the area. Water to air heat pumps could be used to raise the temperature.

Recommendation: Mine water from all mines in the Coeur d'Alene Mining District should be surveyed to determine temperature, flow rate and composition of the mine waste water.

\section{Institutional Considerations, Region 1}

In addition to the normal state and federal regulations, several regional institutional factors will impact geothermal development activities in the North Idaho Panhandle Region. Three institutional areas which will constrain geothermal development have been identified. The three areas are: (1) federal agencies, (2) local planning, (3) RARE II. 1. Federal Agencies: The Coeur d'Alene BLM District is the lead agency regarding geothermal leases in the region. The Payette, Nez Perce, and Clearwater National Forest are the major surface regulatory agencies. These federal agencies are presently unprepared to process lease applications. A severe constraint to geothermal development is the inability of developers to obtain the necessary leases from these agencies. The constraint is largely due to a lack of funding in these agencies. Present staff is unfamiliar with geothermal leasing procedures. 2. Local constraints are limited. Compliance with local and county zoning, health and building codes are the major factors. Table 5-B lists the geothermal areas, with local regulations by county jurisdiction. 
Table 5-B

LOCAL INSTITUTIONAL FRAMEWORK

RIGGINS, BERGDORF, RED RIVER, LOCHSA GEOTHERMAL AREAS

KEY :

1973 = EXISTS - DATE OF ORIGIN SHOWN $(X=$ DATE UNKNOWN $)$

$D(1977)=$ IN THE DEVELOPMENT STAGE -- DATE IN PARENTHESIS

$P(1979)=$ PROPOSED - - DATE ALSO IN PARENTHESIS

$=$ DOES NOT EXIST

CEDA $=$ CLEARWATER ECONOMIC DEVELOPMENT ADMINISTRATION

\begin{tabular}{|c|c|c|c|c|c|c|c|}
\hline JURISDICTION P & $\begin{array}{l}\text { PLANNING } \\
\text { AND/OR } \\
\text { ZONING } \\
\text { COMMISSION } \\
\end{array}$ & $\begin{array}{l}\text { REGIONAL } \\
\text { COUNCIL }\end{array}$ & $\begin{array}{l}\text { COMPRE- } \\
\text { HENSIVE } \\
\text { PLAN }\end{array}$ & $\begin{array}{l}\text { ZONING } \\
\text { ORDINANCE }\end{array}$ & $\begin{array}{l}\text { SUB- } \\
\text { DIVISION } \\
\text { ORDINANCE }\end{array}$ & $\begin{array}{l}\text { BUILDING } \\
\text { CODE }\end{array}$ & $\begin{array}{l}\text { AREA } \\
\text { OF CITY } \\
\text { IMPACT }\end{array}$ \\
\hline Idaho County & $x$ & CEDA & $D(1978)$ & & 1974 & & \\
\hline Riggins & & CEDA & & & & $x$ & \\
\hline Grangeville & $x$ & CEDA & 1976 & 1976 & $x$ & $x$ & \\
\hline Bergdorf & & & & & & & \\
\hline Clearwater Co. & 1963 & CEDA & $\begin{array}{l}1962 \\
1976\end{array}$ & 1974 & 1975 & 1971 & \\
\hline Orofino & 1952 & CEDA & 1957 & 1952 & 1963 & 1958 & 1977 \\
\hline Pierce & 1976 & CEDA & $D(1978)$ & $\begin{array}{r}R-1978 \\
1965\end{array}$ & 1964 & & 1977 \\
\hline Elk River & 1976 & CEDA & $D(1978)$ & $\begin{array}{c}\text { Interim } \\
1977\end{array}$ & & $x$ & 1977 \\
\hline
\end{tabular}


(3) RARE II Studies:

Several areas in the North Idaho Panhandle Geothermal Region are presently under study as part of the RARE II inventory. Several roadless areas under consideration for wilderness area status have geothermal potential adjacent to or within the RARE II study areas. RARE II areas with notable geothermal potential are listed below:

1. Weir Creek Hot Springs

Location: $36 n$ 11E Sec. 13, Boise Meridian

Discharge: $40 \mathrm{gpm}$

Temperature: $47.5^{\circ} \mathrm{C}$

Aquifer Estimate: $100^{\circ} \mathrm{C}$

RARE II Area: \#1311, Lochsa Face, (Clearwater National Forest)

No major geothermal potential.

2. Jerry Johnson Hot Springs

Location: 36N T3E Sec. 18, Boise Meridian

Discharge: $300 \mathrm{gpm}$

Temperature: $48^{\circ} \mathrm{C}$

Aquifer Estimate: $100^{\circ} \mathrm{C}$

RARE II Area: NF 074, Selway-Bitteroot Wilderness

Protected under present statures concerning wilderness.

3. Red River Hot Springs

Location: 28N TOE Sec. 3, Boise Meridian

Discharge: $35 \mathrm{gpm}$

Temperature: $55^{\circ} \mathrm{C}$

Aquifer Estimate: $120^{\circ} \mathrm{C}$

RARE II Area: Adjacent to \#1845, Meadow Creek, (Nez Peirce National Forest).

Moderate geothermal potential; area needs to be examined for geothermal energy potential as part of RARE.II.

4. Riggins Hot Springs

Location: $24 \mathrm{~N} 2 \mathrm{E} \mathrm{Sec.} \mathrm{14;} \mathrm{Boise} \mathrm{Meridian}$

Discharge: $50 \mathrm{gpm}$

Temperature: $42.0^{\circ} \mathrm{C}$

Aquifer Estimate: $120^{\circ} \mathrm{C}$

RARE II Area: \#1857, Kelly Mountain, (Nez. Perce National Forest)

Area has high geothermal potential, adjacent private land uses hot springs for commercial operations.

RARE II area should be studied regarding its geothermal potential. 
5. Bergdorf Hot Springs

Location: $22 \mathrm{~N}$ 4E Sec. 1, Boise Meridian

Discharge: $162 \mathrm{gpm}$

Temperature: $45^{\circ} \mathrm{C}$

Aquifer Estimate: $120^{\circ} \mathrm{C}$

RARE II Area: \#4459, Crystal Mountain, (Payette National Forest)

Area is adjacent to City of Bergdorf and the hot springs area.

Increased recreation growth at Bergdorf could utilize local

geothermal area for space heating.

RARE II area should be studied as to its geothermal energy potential.

REFERENCES

(1) Hamilton, Warren; Reconnaissance Geologic Map of Riggins Quad. West Central Idaho U.S. Geological Survey Misc. Geological Inv. Map 7-579, 1969

(2) Young, H.W. and Mitchel1, J.C.; Geothermal Investigations in Idaho, Part 1, Geochemistry and Geological Setting of Selected Thermal Waters: Idaho Department of Water Resources, Water Information Bulletin 30, 1973

(3) U.S. Geological Survey; Riggins Hot Springs, Idaho 7.5 minute series, topographic, 1964.

(4) Rice, K.A.; Climate of Idaho, Climates of the United States, No. 60-10, U.S. Department of Commerce, N.0.A.A., 1971

(5) Howard, Richard; U.S. Fish and Wildlife Service, Department of Interior, Boise, Idaho, personal communications, June, 1978.

(6) U.S. Geólogical Survey; Burgdorf, Idaho, 15 minute series, topographic, 1956

(7) Enderlin, Walter L.; Evaluating Underground Heat Sources in Deep Mines; Masters Thesis, Montana College of Mineral Science and Technology, April, 1973 
APPENDIX - C

GEOTHERMAL DEVELOPMENT REGION II

Western Idaho

\section{Table of Contents}

Text:

Page

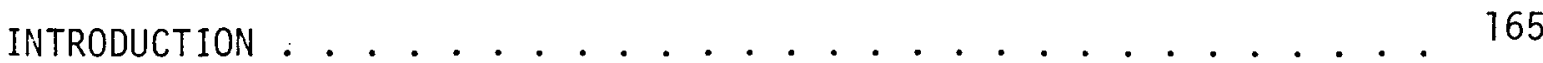

WESTERN INTERMOUNTAIN SUB-REGION . . . . . . . . . . . . . 167

VULCAN KGRA SUB-AREA ..................... . . 167

CASCADE-LONG VALLEY SUB-AREA . . . . . . . . . . . . 176

GARDEN VALLEY SUB-AREA . . . . . . . . . . . . . . . 180

WESTERN SNAKE RIVER PLAIN SUB-REGION . . . . . . . . . . . . 183

POTENTIAL GEOTHERMAL DEVELOPMENT SITES IN ADA COUNTY . . . . . . . 186

KELLEY HOT SPRINGS SUB-AREA . . . . . . . . . . . . . 188

THE BOISE URBAN AREA.................. . . 195

PENITENTIARY CROUNDS SUB-AREA . . . . . . . . . . . . . 195

WARM SPRINGS WATER DISTRICT SUB-AREA . . . . . . . . . 200

BOISE BARRACKS SUB-AREA . . . . . . . . . . . . . . 211

CAMELS BACK PARK SUB-AREA . . . . . . . . . . . . . . 235

DELIVERY SYSTEMS . . . . . . . . . . . . . . . . 238

DISPOSAL SYSTEMS ..................... 238

WEST BOISE AREA........................ 240

CRANE CREEK SUB-AREA . . . . . . . . . . . . . . . 242

STEWART GULCH SUB-AREA. . . . . . . . . . . . . . . 242

POLE CAT GULCH SUB-AREA . . . . . . . . . . . . . . . 243

PIERCE GULCH SUB-AREA . . . . . . . . . . . . . . . . 243

DRY CREEK SUB-AREA . . . . . . . . . . . . . . . . . . . 244 


\section{APPENDIX - C}

(Table of Contents (Cont'd.)

POTENTIAL GEOTHERMAL DEVELOPMENT SITES IN CANYON, PAYETTE

AND GEM COUNTIES . . . . . . . . . . . . . . . . . . . . 259

CANYON COUNTY SUB-AREA . . . . . . . . . . . . . . . . . . 262

PAYETTE AND GEM COUNTIES SUB-AREA . . . . . . . . . . . . 262

POTENTIAL GEOTHERMAL DEVELOPMENT SITES IN ELMORE COUNTY . . . . . . 273

MOUNTAIN HOME KGRA SUB-AREA . . . . . . . . . . . . . . 274

CITY OF MOUNTAIN HOME SUB-AREA . . . . . . . . . . . . . 285

MOUNTAIN HOME AIR FORCE BASE SUB-AREA . . . . . . . . . . . 285

POTENTIAL GEOTHERMAL DEVELOPMENT SITES IN OWYHEE COUNTY . . . . . . 292

BRUNEAU-GRANDVIEW SUB-AREA . . . . . . . . . . . . . . . . 294

ELECTRICAL GENERATION POTENTIAL . . . . . . . . . . . . 310

SPACE HEATING POTENTIAL . . . . . . . . . . . . . . . 311

INDUSTRIAL POTENTIAL . . . . . . . . . . . . . . . . 311

GIVENS HOT SPRING SUB-AREA . . . . . . . . . . . . . . 375

POTENTIAL GEOTHERMAL DEVELOPMENT SITES IN WASHINGTON COUNTY . . . . . 322

CRANE CREEK KGRA SUB-AREA . . . . . . . . . . . . . . . . . 322

WEISER HOT SPRINGS SUB-AREA . . . . . . . . . . . . . . . . . 332 
(Table of Contents, (Cont'd.)

TABLES:

(ADA COUNTY)

Table 1-C, Population Projections, Western Idaha . . . . . . 166

Table 2-C, Data Summary for Vulcan KGRA . . . . . . . . . . . 169

Table 3-C, Data Summary for Cascade-Long Valley Sub-Area . . . . . 178

Table 4-C, Resource Data Summary for Garden Valley-Crouch . . . . 181

Table 5-C, Crop Summary, Western Snake River Plain . . . . . . . 184

Table 6-C, Temperatures for Thermal Wells, Ada County...... 187

Table 7-C, Kelley Hot Springs-Barber Industrial Park,

Energy Needs ....... . 189

Table 8-C, Warm Springs Village, Phase Implementation Plan... 191

Table 9-C, Approximate Cost of a District Heating System for

The Kelley Hot Springs Sub-Area . . . . . . . 192

Table 10-C, Estimated Total Potential Geothermal Heat Utilization,

The Kelley Hot Springs Sub-Area. . . . . . . . . . 194

Table 11-C, Heating Cost Comparison for the Geothermal Demonstra-

tion Project at the Idaho Agricultural/Health

Laboratory . . . . . . . . . . . . . . 198

Table 12-C, Penitentiary Grounds Sub-Area, Geothermal Develop-

ment Projections ............... . . 199

Table 13-C, Geothermal Development Potential, Warm Springs

Water District Sub-Area . . . . . . . . . . 202

Table 14-C, Data Summary for Warm Springs Water District and

Pententiary Grounds Sub-Area . . . . . . . . . . . 203

Table 15-C, Fort Boise Barracks Buildings, Heating Systems . . . . . 212

Table 16-C, Federal Office Building, Historical Energy Demand and Cost................... . . 214

Table 17-C, Veterans Hospital Energy Needs and Cost... . . . . . 217

Table 18-C, Historical Energy Use and Cost, Idaho Elks

Rehabilitation Hospital........... 218

Table 19-C, Idaho Elks Rehabilitation Hospital Twenty-Year

Economic Analysis of Drilling On-site Well to

Depth of 1,500 feet for Space Heating......... 219

Table 20-C, Idaho Elks Rehabilitation Hospital Twenty-Year

Economic. Analys is of Buying Geothermal Water for

Space Heating at $\$ 0.45 / 100 \mathrm{cu}$. ft. . . . . . . . . 220

Table 21-C, Idaho Elks Rehabilitation Hospital Twenty-Year

Economic Analysis of Buying Geothermal Water for

Table 22-C, Space Heating at $\$ 0.29 / 100$ cu. ft. . . . . . . . . 221

Table 23-C,

Estimated Conversion Cost for the Capitol Mal1... . . 223

Table 24-C,

Estimated Geothermal Fluid Needs for Major Public

Buildings at the Capitol Mall and Boise Barracks . . . 225

Table 25-C, Estimated Energy Needs of Boise Barracks and The

Capitol Mal1................... . 226

Table 26-C,

Data Summary for Boise Barracks Sub-Area . . . . . . . 227

Identified Prospective Geothermal Heat Users in

the Boise CBD .................. 237

Table 27-C, West Boise Projected Geothermal Heat Utilization . . . 241

Table 28-C, Data Summary for West Boise Geothermal Sub-Area . . 246

Table 29-C, Major Leases Recorded in Ada County Court . . . . . . . . 254

Table 30-C, Summary of Geothermal Energy Commercialization

Projected by 2020 in Ada County . . . . . . . . . . 256 
(Table of Contents, (Cont'd.)

\section{TABLES}

(CANYON, PAYETTE AND GEM COUNTIES)

Table 31-C, Major Industries Which Need Hot Water, Canyon County. ....... 261

Table 32-C, Cost of Production Test We11, Nampa Idaho . . . . . 263

Table 33-C, Major Industries of Payette County and Their Energy Demands. . . . . 264

Table 34-C, Data Summary for Roystone Hot Springs . . . . . . 267 (ELMORE COUNTY)

Table 35-C, The Bostic 1-A Well (Union 0i] Mounta in Home, ID. . . . 275

Table 36-C, Major Industries of Elmore County and Their

Table 37-C Data Summary for Mounta in Homergy Demands. . . . . 276

Table 37-c, Data Summary for Mountain Home KGRA....... . 278

Table 39-C, Mountain Home Air Force Base, Heating Energy Facts . 287

(OWYHEE COUNTY)

Table 40-C, Selected Thermal. Springs and We 17 s in Bruneau-Grandview Geothermal Area... 293

Table 41-C, Data Summary for Bruneàu KGRA ... . . . . . . . 295

Table 42-C, Data Summary for Castle Creek KGRA . . . . . . . 303

Table 43-C, Data Summary for Givens Hot Springs . . . . . . . . 316

Table 44-C, Geothermal Leasing in Owyhee County . . . . . . . 318

(WASHINGTON COUNTY)

Table 45-C, Data Summary for Crane Creek KGRA . . . . . . . . . 324

Table 46-C, Major Industries Located in Weiser, Idaho . . . . . 333

Table 47-C, Estimated Cost of Delivering Geothermal Fluids to 335

Table 48-C, Data Summary for Weiser Hot Springs . . . . 336 


\section{APPENDIX C}

\section{IDAHO GEOTHERMAL DEVELOPMENT REGION I I}

Western Idaho

\section{Introduction}

The Western Idaho Geothermal Development Region has an estimated 1978 population of 300,000 . This represents about 35 percent of Idaho's estimated 1978 total population of 857,000. Approximately 75 percent of the population within this region reside in Ada and Canyon Counties. Ada County has an estimated 1978 population of 150,000 or 50 percent of the population within the recion. Canyon County, the second most populated county in the region has an estimated 1978 population of 75,000 , accounting for 25 percent of the regional population. These two counties are the primary growth corridors in the Western Idaho Geothermal Development Region. Payette, Gem and Elmore Counties account for an additional 15 percent of the region's population. The remaining 10 percent of the region's population is scattered throughout the remaining six counties. Adams, Boise, Gem, Owyhee Valley, and Washington counties are remote mountainous counties with isolated small communities and small populations. The most populated counties are those found in the Western Snake River Plain.

The region is experiencing a 20 percent increase in population per year as compared to a 15 percent increase for the state. The region could reach a population in excess of 500,000 people by the year 2000 . The growth corridor of Ada and Canyon Counties will account for 75 percent of this growth. (6) Table 1-C is a list of county population projections for western Idaho.

To discuss the potential role of geothermal resource commercialization, as part of the regional growth in western Idaho, in an orderly way, two sub-regions have been designated.

The Western Intermountain Sub-Region includes the northern counties of Adams, Boise, Valley and parts of Washington County. These areas have similar demographic and geologic conditions.

Sub-area reports discuss the development potential of the most promising areas.

The Western Snake River Plain Sub-Region includes the Weiser area of Washington County, Gem, Payette, Ada, Elmore and Owyhee Counties. These counties have similar geological conditions but varying demographic conditions. The sub-area reports are presented by county with several sub-areas in each county. 
Table 1-C

Population Projections, Western Idaho

1980-2000

\begin{tabular}{|c|c|c|c|c|c|}
\hline & 1980 & $\underline{1985}$ & 1990 & 1995 & 2000 \\
\hline $\begin{array}{l}\text { Ada County } \\
\text { Adams County } \\
\text { Boise County } \\
\text { Canyon County } \\
\text { Elmore County } \\
\text { Gem County } \\
\text { Owyhee County } \\
\text { Payette County } \\
\text { Valley County } \\
\text { Washington County }\end{array}$ & $\begin{array}{r}167,810 \\
4,060 \\
4,390 \\
88,780 \\
23,900 \\
12,760 \\
7,850 \\
15,700 \\
5,690 \\
10,060\end{array}$ & $\begin{array}{r}198,840 \\
4,390 \\
5,390 \\
100,700 \\
26,290 \\
14,840 \\
8,590 \\
17,320 \\
6,540 \\
11,920\end{array}$ & $\begin{array}{r}229,010 \\
4,660 \\
6,470 \\
109,900 \\
28,440 \\
16,850 \\
9,380 \\
18,760 \\
7,500 \\
13,660\end{array}$ & $\begin{array}{r}256,280 \\
4,890 \\
7,670 \\
117,070 \\
37,110 \\
18,470 \\
9,110 \\
19,770 \\
8,360 \\
15,220\end{array}$ & $\begin{array}{r}282,590 \\
5,120 \\
8,740 \\
126,800 \\
34,020 \\
19,930 \\
9,040 \\
20,720 \\
9,100 \\
16,810\end{array}$ \\
\hline TOTAL & 341,000 & 394,820 & 444,630 & 487,950 & 532,870 \\
\hline STATE & 970,700 & $1,119,320$ & $1,256,200$ & $1,362,780$ & $1,467,270$ \\
\hline
\end{tabular}


Western Intermountain Sub-Region

Introduction:

The economy of the Western Intermountain Region is based on timber and recreation. The region is demarcated by small isolated communities with the towns of the reaion centered around either a lumber mill or a recreation area. Populated localities are generally high intermountain valleys and river canyons. Total population of the sub-region is less than 12,000 people and no single location has a population exceeding 2,000 people. A typical community has a population of a few hundred.

Geothermal resources of the sub-region are generally isolated springs. Several areas in the sub-region do have limited commercialization potential. Geothermal development could help supply spaceheating energy for residential and commercial buildings of a 1 imited number of locations. Industrial applications of the resource are limited as major industries which need large amounts of hot water are not located in this region. Limited application of geothermal resources in the lumber industry may be possible. Commerical applications of geothermal energy for greenhouses and fish farms are currently developed and could be expanded in the future. Electrical generation from geothermal resources may be possible at the Vulcan KGRA. In all cases, the resource needs to be proven by exploration drilling.

\section{Vulcan KGRA Sub-Area}

Vulcan KGRA is located in T. 14 N., R. 16 E., Valley County, Idaho. Cascade, Idaho, the nearest community, is located 48 kilometers west of the KGRA. The area is characterized by long winters with low temperatures and substantial snow accumulation and by summers with low to moderate temperatures and precipitation. Snow normally covers the ground for about five months per year, from November through March.

The KGRA is located in an intermountain valley through which the South Fork of the Salmon River flows. Peaks in the area rise to elevations ranging from 2000 meters to 2600 meters. The elevation of the KGRA is 1700 meters. Slopes in the mountainous areas vary from moderate to precipitous producing terrain which varies from gentle to very rugged.

The KGRA and all. surrounding acreage is owned by the Federal Government and included within the Boise National Forest. Logging and recreation are the primary land uses in the KGRA area. The Boise National Forest has a long range land use management plan for the area which will control logging and recreation development but this plan does not consider the geothermal potential of the area.

The major lithologic units of the area are granitic rocks of the Idaho batholith. The KGRA is located along the western margin of the Idaho Batholith. An extensive system of north trending faults in this region structurally control the major valleys. Movement along the fault systems appear to be high angle normal faulting. Movement along these faults occurred in the late Micoene and prior to Pleistocene glaciation. Miocene basalts of the Columbia River group have been displaced by the regional fault system, in the Cascade area. Glacial sediments along 
fault traces in the Cascade area indicate no signifant movement has occurred since Pleistocene deposition.

Hot springs in the KGRA are venting from Cretaceous granite. Major Springs flow from fault intersections. Along the South Fork of the Salmon River, a kilometer-long reach is one continous discharge of thermal water from nine springs. The largest discharge is from Vulcan Hot Springs which discharges more than $500 \mathrm{gpm}$ of $89^{\circ} \mathrm{C}$ water. Silica geochemjfal thermometery indicates that temperatures as high as $150^{\circ} \mathrm{C}$ are possible 1 ) at depth.

The KGRA appears technically promising for electrical generation potential. Large quantities of hot water occur at this location and a large number of faults and shear zones are present which can circulate thermal water from depth to the surface. Exploration drilling is needed to prove the existence of a high temperature reservoir at moderate depths.

Because of the remoteness of the site, the only potential utilization of the resource will be for generation of electrical power. A $138 \mathrm{kV}$ power transmission line exists 10 kilometers south of the KGRA and could be expanded to handle additional load.

No leasing activity has occurred at the KGRA and no lease sales are scheduled. There are two major restrictions to leasing and development activity at Vulcan KGRA: (1) Environmental considerations (2) Institutiona) factors.

Environmental considerations will be a major controlling factor effecting geothermal development at Vulcan KGRA. The area has a high aesthetic and recreation value and is critical salmon spawning drainage. Although there is considerable logging activity and numerous roads in the area, Vulcan Hot Springs is in a roadless area with the nearest road 2 kilometers east of the hot springs.

Institutional factors which constrain development are: (1) An Environmental Impact Statement has not been written for the KGRA, (2) Leasing is being held up by the U.S.F.S.

A11 development activities concerning the Vulcan KGRA are awaiting the completion of environmental reports from the Boise National Forest. Fish and wildlife studies are presently being conducted but adequate funding for an Environmentąl Impact Statement is not expected unitil 1980 or 1981.

\section{Scenario Projection}

Scenario projections for Vulcan KGRA are for a maximum 50 megawatts of electrical generation capacity which could be developed by 1988 . A maximum of 50 megawatts is projected because of the limited amount of available space for facility siting and the lack of resource data. Table $2-C$ is a compendium of site specific data regarding Vulcan KGRA. 
Table 2-C

Data Summary for Vulcan KGRA

SITE LOCATION. AND PHYSICAL DESCRIPTION

..Latitude: $\quad 44^{\circ} 34^{\prime} 05 \mathrm{~N}$

..Longitude: $\quad 115^{\circ} 41^{\prime} .53 \mathrm{~W}$

..Rectilinear: $\quad$ T. 14 N., R. 6 E., Boise Meridian

..County: Valley

..Adjacent Counties: Boise, Gem, Adams, Idaho, Custer

..Topography

Flat topography at Vulcan Campground and Stolle Meadows.

Moderate slopes at hot springs area. Very steep slopes

along valley walls.

..Present Land Use:

Recreation and logging are the major land uses.

Logging activity has occurred within 5 kilometers of the KGRA.

..Future Land Use Plans:

Boise National Forest has recently completed its land use management plan for this area. The plan calls for controlled, limited logging and recreation development. No consideration of geothermal resource development is present in the plan. (4)

Aes thetics :

Area is considered highly aesthetic.

..Historical/Archaeological Signifance:

Historical mining activity in the area.

GEOLOGICAL/GEOPHYSICAL DESCRIPTION

..Geologic Description:

Vulcan KGRA is located in an area of faulted cretaceous granite. Major faults of the area are preglacial and post Miocene image.

Thermal waters in the area appear to be fault controlled. The volume of thermal water is significant. Approximately $100 \mathrm{gpm}$ of $80^{\circ} \mathrm{C}$ water is being discharged from several springs. Vulcan Hot Springs alone discharges over $500 \mathrm{gpm}$ of $890 \mathrm{C}$ water. 
..Geophysical Summary:

No data available for the KGRA but areas 19, kilometers west of the KGRA, near Cascade, are seismicly active. (5) In the general area of Vulcan KGRA and Cascade 13 locatable seismic events have been recorded ranging in magnitude from 6.0 to 3.5. "A swarm of six earthquakes occurred near Vulcan KGRA in 1970 in the magnitudes were: $3.5,3.7,3.8,3.9,4.3$ and 4.3

..Geologic Hazards:

Snow avalanches in winter

Flooding

Earthquake area

\section{RESERVOIR CHARACTERISTICS}

. Reservoir Temperature

..Surface: $\quad 89^{\circ} \mathrm{C}(1)$

. Subsurface: No down hole temperatures

. Geochemical

$$
\mathrm{SiO}_{2} \text { : }
$$

$150^{\circ} \mathrm{C}$

$$
\mathrm{Na}-\mathrm{K}-\mathrm{Ca} \text { : }
$$$$
135^{\circ} \mathrm{C}
$$

..Flow Rates:

..pH:

8.5

. Total Dissolved Solids: 362

(1) $(\mathrm{mg} / 1)$

. Fluid Chemistry:

(1)

Milligrams/litre

$\begin{array}{lc}\mathrm{Si}: & 120 \\ \mathrm{Ca}: & 1.8 \\ \mathrm{Mg}: & 0.1 \\ \mathrm{Na}: & 94.0 \\ \mathrm{~K}: & 3.0 \\ \mathrm{HCO}_{3}: & 120.0 \\ \mathrm{CO}_{3}: & 0 \\ \mathrm{SO}_{4}: & 43.0 \\ \mathrm{P}: & .02 \\ \mathrm{Cl}: & 17.0 \\ \mathrm{~F}: & 24.0 \\ \mathrm{NO}_{3}: & .05\end{array}$

..Estimated Electric Energy Potential: $50 \mathrm{mw}$ 
LAND OWNERSHIP AND LEASING

..Land Ownership

$\frac{\begin{array}{c}\text { TOTAL AREA } \\ \text { (Acres) }\end{array}}{3,836^{(3)}}$

FEDERAL

STATE

(Acres)

(Acres)

PRIVATE

(Acres)

.. Land Leased

3,836

None

. Summary of Leasing Status and Needs:

USFS will not issure leases until after an EIS has been completed. The EIS is not expected until the mid 1980's.

GEOTHERMAL DEVELOPMENT STATUS

..Present Development Status:

Prelease EAR by the U.S. Forest Seryjce recommends that an
EIS be completed before leasing. ..Projected Development:

Land is leased by 1981 and exploration drilling begins by 1982 . $50 \mathrm{mw}$ electrical generation capacity by 1988 . 
Table 2-C (Cont'd.)

INSTITUTIONAL CONSIDERATIONS - Federal

Institutional

Requirements

Federal Geothermal

Resource Lease

(30 C.F.R. 3000)

National Environmental Policy Act (42 U.S.C. 4331)
Agency and

Public Attitudes

Leases are made pursuant to the Geothermal Steam

Act of 1970

(84 Stat. 1566)

(30 USC 1001-1025)

An E.I.A. is required Boise National Forest U.S.F.S.
Federal Water Pol- The national goal of lution Control Act. (33 U.S.C. 1231)

Federal Safe Drinking Water Act. (42 U.S.C. (A) 300)

Land Use Plan Regulations this Act is to attain -0- pollution by 1985 .

This Act is concerned with protection of underground water sources that could be used for domestic water.

U.S.F.S., Boise National Forest
Status of Requi rements (i.e., EIA/EIS Requirements)

Leases within the K.G.R.A. are competitive. Special conditions are required in the leases with regard to potential archaelogical and historical sites, adjacent roadless areas, and critical habitat areas.

U.S.F.S. will conduct an EIS prio to leasing for any development project. In general an E.I.A. is required for all projects involvi exploration and development. If a generation facility is to be built and power generated and wold or a large nonelectrical facility constructed, then an E.I.S. will be required.

Ground-water is included under this Act and the reinjection of geothermal effluient will require permits.

The Act sets standards for wells and well drilling and could influence future geothermal wells. The upper aquifer of the basin is the supply of domestic and irrigation water for the area. Reinjection of water for geothermal wells will require permits under this Act.

Area management plan has been developed for the area surface development will be affected. 
INSTITUTIONAL CONSIDERATIONS - State and Local

\section{Institutional} Requirements

Geothermal Resource Permits.

(Idaho Code 42-4001

et. seq. Chapter 40 , Geothermal

Resources)

Water Appropriation (Idaho Code 42-101 et. seq. Chapter 1 Water Appropriation)

Injection wells (I daho Code 42-3801 et. seq. Chapter 39 Waste Disposal and Injection Wel1s)
Agency and Public Attitudes

The regulatory powers of the state Geotherma ] Resource Act are placed in the Idaho Department of Water Resources.

The Idaho Department of Water Resources issues water appropriation permits and a water right license.

Permits are issued by the Department of water Resources.
Status of Requirements i.e., EIA/EIS Requirements

Any private owner, or holder of a state or federal lease of geothermal resources must first apply for a geothermal resource permit from I.D.W.R. before any drilling operations can begin.

Under the Idaho Geothermal Resources Act, applicants can be required to make an application to appropriate the public waters of the state.

No waste disposal or injection well can be constructed in Idaho unless a permit has been issued by I.D.W.R. . The approval of this permit is contingent upon the approval of the Department of Health and Welfare. The proposed well is reviewed to see if it will unreasonably contaminate or deteriorate the quality of the ground-water below the adopted water quality standards of the state.

Building Code
County Building

Permit
Valley County

Commissioners 


\section{ENVIRONMENTAL FACTORS}

CLimATE (4)

..Prevailing Winds: N-S

.Precipitation (Annual): $127 \mathrm{~cm}$ (snow)

.. Average Temperature

Minimum:

$\begin{array}{cr}\text { January } & \text { JuTy } \\ -20^{\circ} \mathrm{C} & 20^{\circ} \mathrm{C} \\ & \\ 20^{\circ} \mathrm{C} & 30^{\circ} \mathrm{C}\end{array}$

Maximum:

AIR QUALITY: $\quad$ Generally High.

GEOLOGIC FACTORS: Earthquake activity in area Snow avalanches in winter.

WATER QUALITY: $\quad$ Springs have high $\mathrm{F}, \mathrm{SO}_{4}$, and $\mathrm{Na}$. Other surface waters are of high quality.

NOISE: $\quad$ LOW levels.

ELEVATION: 1700 meters

ENVIRONMENTAL FACTORS

. BIOLOGICAL

..Dominant Flora: Fir-Pine Forest

..Dominant Fauna: Deer, elk, bear

Salmon and Trout spawning grounds.

.. Endangered Species

(4)

. Fauna:

Historical Peregrine Falcon Nesting area.

\section{TRANSPORTATION AND UTILITIES}

..Utility or Energy Transmission Corridors and Facilities;

A $138 \mathrm{kv}$ line from Cascade to Warm Lake is located 10 kilometers south of the KGRA. The right-of-way is owned by Idaho Power Company.

..Transportation Corridors or Facilities;

Paved County Road from Cascade to Warm Lake: $40 \mathrm{~km}$ Forest Service Road 427 from Warm Lake to Vulcan KGRA: $8 \mathrm{~km}$ 
Table 2-C (Cont'd.)

\section{POPULATION}

..General Description of Population

Approximately 50 summer homes are located at Warm Lake 10 kilometers south of Vulcan KGRA.

Cascade, Idaho, population 1,000, is located 40 kilometers west of the KGRA.

..Economics

The KGRA area is isolated from all industrial and commercial activity. Development at the site will be for electrical generation facilities only, providing adequate temperatures are developed with limited environmental impact. The principal economic activities are recreation at Warm Lake and Logging in the general area. 
The Cascade-Long Valley geothermal area consists of four north-south valleys surrounded by mountainous terrain. The four valleys are Meadows Valley, Long Valley, Cascade Valley and Round Valley. All four of these valleys have gently sloping floors with elevations of 1500 meters to 2500 meters. Long Valley, Cascade Valley and Round Valley form a major topographic depression which is 75 kilometers long and 2 to 8 kilometers wide. Valley floors have gentle slopes while the surrounding mountains have very rugged slopes.

The major population centers are McCal1 (2020), Cascade (1000), and New Meadows, (620). Logging and sawmi 11 operations have been the major industry basic to this area. Logging is done on U.S. National Forest lands and private timber lands owned by the Boise Cascade Corporation. A larqe sawmill in McCall recently halted operations because of a lack of public timber in that area. A large sawmill in Cascade is the major industry located in the area. Several small sawmill operations are also currently working in this area.

Cattle ranching is the major agricultural activity. Several large ranches raise pasture and feed crops for winter feed. The raising of cattle feed requires extensive summer irrigation and several of these irrigation wells show above average temperatures.

The fastest growing economic enterprises in the Cascade-Long Valley area are related to recreation and tourism. Summer recreation activities are centered around Payette Lake, Cascade Reservoir and the general area's excellent hunting and fishing. The major winter recreational activities are skiing at Brundage Mountain near McCall and snowmobiling near Cascade.

The major energy need of the area is for spaceheating. Sub-Zero temperatures are common during the winter months but the summer temperatures are moderate. The area has an average of 9000 heating degree days. (7) The major energy types used for heating in the Cascade-Long Valley area are bottled gas and fuel oil. Both of these energy types are transported into the area by truck.

Geothermal commercialization potential of the area is limited as no new industrial growth is expected for the area. The market potential for geothermal resources is spaceheating commercial and residential buildings. Limited utilization of geothermal resources for fish farming, greenhouse and animal husbandry are also possible. Two development projects have been proposed for the Cascade-Long Valley area.

Zimm's Hot Springs in Meadows Valley is planning to develop àgriculture operation utilizing thermal water to raise catfish. Construction of this project and exploration drilling is planned to begin in 1979 .

The City of Cascade proposes to geothermally heat the new high school which will be constructed in 1979. Therrmal springs are located in the general area but exploration drilling is needed to develop sufficient resource. The school will be designed for easy retrofit to geothermal resources of $60^{\circ} \mathrm{C}$ to $80^{\circ} \mathrm{C}$ range. If adequate resources are developed at Cascade it is possible that several major buildings in the town could utilize the resource. 
Scenario Projections: A district heating system could be developed in the City of Cascade by 1985 providing exploration drilling proved the resource by 1981. Such a system could provide approximately $400 \times 10^{9}$ BTU/year of. direct geothermal heat to residential and commercial buildings. Table 3-C is a summary of known data regarding the Cascade geothermal area. 
Table 3-C

Data Summary for the Cascade-Long Valley Area

Valley County, Idaho

Location: T. 13, 14, 15, 16, N., R. 1, 2, 3, E., Boise Meridian

County: Valley

Land Ownership, Valley County:

$\begin{array}{lr}\text { Federa }: & 2,070,583 \text { acres (Boise National Forest) } \\ \text { State: } & 67,436 \text { acres } \\ \text { Private: } & 213,447 \text { acres }\end{array}$

Geotherma] Leases: None

Present Land Use: $84 \%$ Forest Land, 10\% Rangeland, 3\% Agricultural 1and, $3 \%$ other.

Geological Description:

Meadows Valley, Long Valley, Cascade Valley and Round Valley are all fault bounded structures. The major faults of the area trend north-south and northeast. These valleys form a series of graben structures along the western boundary of the Idaho Batholith. The major 1ithological units of the area are the Cretaceous granite of the Idaho Batholith overlain by Miocene Basalts of the Columbia River Group. These rock units have been faulted into high relief and glaciated. Surfacial deposits in (5) the valleys are largely glacial outwash and quarternary al liuvium.

Two hot springs are located in Meadows Valley and eleven hot springs are located within Cascade and Long Valleys. The hot springs in Meadows Valley are located along the faults which control the valley walls. Five hot springs in Cascade Valley are located along or close to the Cascade fautt. (5) Surface discharge temperatures range from $31^{\circ} \mathrm{C}$ to $70^{\circ} \mathrm{C}$ and silica geochemical thermometers

indicate subsurface temperatures of $150^{\circ} \mathrm{C}$ to $160^{\circ} \mathrm{C}$ are possible.

The area is considered to be technically active; experiencing continous microscismic activity

Geophysical Description: (3)

There are 13 locatable events and four additional reported events for the area. The most significant events are:

1945: magnitude 6.0 , located $45 \mathrm{~km}$ east of Cascade.

1966: magnitude 3.5 , 1ocated $20 \mathrm{~km}$ north of Cascade.

1970: a swarm of six, magnitudes $3.5,3.7,3.8,3.9$,

4.3 , and 4.3 , Jocated $40 \mathrm{~km}$ east of Cascade

near Vulcan $K G R A$.

1977: magnitude 4.3, 10cated at Cascade 
Resource Characteristics: ${ }^{(5)}$

Hot Springs Location (Boise Meridian) Silica ppm

Silica ppm Surface Mixing- Model

Cabarton SWO, Sec. 31, T13N, R4E $68.0 \quad 71.0^{\circ} \cdot 147^{\circ}$

Arling NW0, Sec. 13, T15N, R3E $\quad 56.6 \quad 40.0 \quad 179$

Gold Fork SW0, Sec. 35, T16N, R4E $62.3 \quad 50.5 \quad 165$

$\begin{array}{lllll}\text { Flat Creek SW } & \text { S Sec. 21, T15N, R4E } & 47.5 & 38.0 & 158\end{array}$

Cascade $\quad$ NE$^{\circ}$, Sec. 36, T14N, R3E $\quad 42.9 \quad 38.5 \quad 140$

Little Creek NE ${ }^{\circ}$, Sec. 5, T14N, R5E $\quad 48.6 \quad 36.0 \quad 168$

Belvidere $\quad$ NE$^{\circ}$, Sec. 13, TI3N, R3E $\quad 60.0 \quad 49.5 \quad 163$

(7)

Climate:

Elevation: 1,492 meters

Precipitation: $264 \mathrm{mc}$ snow annually

$54 \mathrm{~cm}$ precipitation annualiy

Average Temperature:

$\begin{array}{llr}\text { Minimum: } & \text { January } & \text { July } \\ \text { Maximum: } & -71.0^{\circ} \mathrm{C} & 6.4^{\circ} \mathrm{C} \\ & -2.8^{\circ} \mathrm{C} & 28.1^{\circ} \mathrm{C}\end{array}$

Heating Degree Days Annually: 8832

Population: Cascade, 1,004

Long Valley rural, approximately 300

Percent change since 1970, 20.5\%

Median Income: $\$ 12,500$ 
Garden Valley geothermal area is located in T. 3 N., R. 4 E., Boise Meridian, Boise County, Idaho. Garden Valley is a fault controlled structure which is probably related to the same north trending faults which control the Long Valley and Vulcan Hot Springs geothermal areas. The major city and approximately 500 persons living in outlying areas of Garden Valley. The major economic activities in Garden Valley are logging, cattle ranching, recreation and tourism. Historically, the land use of the valley has been rural agriculture. In recent years the land has been subdivided for recreation and year-round homes.

The geothermal resources of the area are isolated hot springs along the Middle and South Forks of the Payette River and along Warm Springs Creek. Surface temperatures of these springs range from $55^{\circ} \mathrm{C}$ to $80^{\circ} \mathrm{C}$ and silica geochemical thermometers indicate $1100 \mathrm{C}$ to $1500 \mathrm{C}$ temperatures are possible at depth. (1) Table 4-C list a summary of resource data for the Garden Valley Sub-area.

Hot Springs near Crouch have been developed to supply heat energy to the following complexes:

(1) A private resort heats an olympic size swimming pool, tennis courts, and fire station garage from a nearby hot spring.

(2) A 22,000 sq. ft. commercial greenhouse utilizes the same hot springs for heating. The greenhouse is a major wholesale producer of cut flowers marketed in the Boise area.

(3) A maintenance garage for a small logging company is heated by geotherma 1 water.

(4) Five residential buildings adjacent to the hot springs are also heated by geothermal water.

In general, the geothermal development potential in Garden Valley is to supply heat energy for residential and commercial structures. A geothermal district heating system developed at Crouch could utilize shallow wells supplying $80^{\circ} \mathrm{C}$ water to over 150 potential customers.

\section{Scenario Projections:}

A district heating system for the Terrace Lakes Subdivision and the Community of Crouch could be operational by 1985 provided sufficient capital could be obtained to initiate development. The projected system would have a deliverable heat capacity of approximately $50 \mathrm{x}$ $10^{9}$ BTU/year. 
Table 4-C

Resource Data Summary for Garden Valley-Crouch

Boise County, Idaho

Location: Sec. 33, T. 10 N., R. 4 E., Boise Meridian

Geological Description:

Several hot springs are located in Garden valley along the south and middle forks of the Payette River. Major hot springs located along the Middle Fork of the Payette River show a linear pattern which suggest fault control. A series of hot springs can be traced from near the community of Crouch to Vulcan KGRA along the Middle Fork of the Payette River. Several of these hot springs are located near crouch. The hot springs are venting from cretaceous granite which is the major 7ithological unit of the area. Schultz's Hot spring is the major hot spring of the area and the spring that is currently being used for limited space heating.

Schultz's Hot Springs:

Discharge: $\quad 600 \mathrm{gpm}$ from 14 springs and seeps.

Temperature:

Surface: $55^{\circ}$ to $80^{\circ} \mathrm{C}$.

Subsurface: $68^{0}$ from existing 26 meter well

Silica geothermometry: $135^{\circ} \mathrm{C}$ to

$1500 \mathrm{C}$. Estimated temperatures of

$80^{\circ} \mathrm{C}$ are expected from shallow

160 meter wells.

Elevation: 1,485 meters

climate: (7)

Heating Degree Days: 7573 annual

Temperature: January / July

Minimum: $-8.7^{\circ} \mathrm{C} \quad 6.5^{\circ} \mathrm{C}$

Maximum: $0.6^{\circ} \mathrm{C} \quad 34.0^{\circ} \mathrm{C}$

Precipitation: $180 \mathrm{~cm}$ snow (annual)

$54 \mathrm{~cm}$ precipitation (annual) 
(1) John Mitche11, Norm Young, Geotherma] Investigations in Idaho Part 1, Geology and Geochemistry, Idaho Department of Water Resources Bulletin No. 30, 1973.

(2) U.S.G.S., Warm Lake Quadrang7e 1:62000, 1954.

(3) Memorandum from Chief, Conservation Division, U.S.G.S., to State Director, Bureau of Land Management, July 23, 1975. Definition of the Vulcan Hot Springs, Idaho KGRA.

(4) EAR Reports to Supervisor, Boise National Forest from the Cascade Ranger; on Vulcan Hot Springs KGRA pre lease.

(5) Wilson, M.D., Applegate, J.K., Chapman, S.L., and Donaldson, P.R. Geothermal Investigations of the Cascade, Idaho Area, Boise State University, 1976.

(6) Irvin, Lawrence D. , Social Economic Profile Southwest Idaho, Region III Boise (BLM) District, Center for Business and Economic Research, Boise State University, 1976

(7) N.0.A.A., Climate of Idaho, Climate of the United States No. $60-10$, U.S. Department of Commerce, 1977 
Western Snake River Plain Subregion:

Introduction

The economy of the Western Snake River Plain is based on agriculture, the food processing industry and government. The region is demarcated by its broad agriculture base and large urban centers. In general the region is a surplus supply center for agricultural products and a center for food processing industries. The major urban centers are Boise, Nampa, Caldwell, and Mourtain Home. Boise is the regional trade center for southern Idaho and the center for State and Federal government. Nampa and Caldwell are industrial food processing centers. Mountain Home is a service center for agriculture and the Mountain Home Air Force Base. The total population of the subregion is approximately 327,400 with $75 \%$ of this population located in the growth corridor of Ada and Canyon Counties. With the exception of Mountain Home and Boise, the economy of the region is based on agriculture and agricultural industries.

The Western Snake River Plain is the Targest producer of sugar beets and potatoes in Idaho and the Nampa-Caldwell area supports the largest sugar beet and potato processing plants in the Western United States. Agriculture is the basic activity in the Western Snake River Plain that leads and determines the regions overall economic development. 0ther activities of the regional economy are consequent to the overall growth in agri-industry. Table 5-C list the 1977 agricultural crop statistics for the Western Snake River Plain. An estimated 60 to 80 percent of these crops are processed before shipping.

Geothermal resource development could help supply direct heat energy needs for residential and commercial buildings in several major urban centers. High temperature geothermal fluids are possible and could be a major energy source for the food processing facilities of the region. The more remote but accessible geothermal areas could become focal points for new industrial development based on food processing. Electrical generation could be possible at several sites. 
Table 5-C

CROP SUMMARY WESTERN SNAKE RIVER PLAIN (21)

Alfalfa Hay

County

Ada

Canyon

Elmore

Gem

Owyhee

Payette

Washington
Acres Harvested

27,241

32,202

22,226

11,129

31,672

13,127

32,807
Production (Tons)

112,775

146,583

71,338

35,863

117,069

50,331

79,671

Potatoes (1975)

County

Canyon

Elmore

Owyhee

Other Counties

TOTAL
Acres Harvested

6,500

17,000

7,000

$\frac{2,500}{33,000}$
Production (CWT)

$$
\begin{array}{r}
2,210.000 \\
5,220.000 \\
2,205.000 \\
10,360.000 \\
\hline 0,395.000
\end{array}
$$

Sugar Beets

County

Ada

Canyon

Elmore

Gem

Owyhee

Payette

Washington
Acres Harvested 744

23,285

2,743

108

4,657

1,628

1,679
Production (Tons)

16,926

586,653

46,767

1,580

92,506

37,805

37,505

A11 Wheat (1976)

County

Ada

Canyon

Elmore

Gem

Owyhee

Payette

Washington

TOTAL
Acres Harvested

$$
6,000
$$

23,300

13,000

2,200

9,300

400

16,300

70,500
Total Production (Bushels)

$$
\begin{array}{r}
277,500 \\
1,968,100 \\
894,300 \\
156,800 \\
680,600 \\
12,000 \\
722,000 \\
\hline 4,711,300
\end{array}
$$


Table 5-c (Cont'd.)

Barley (1976)

County

Ada

Canyon

Elmore

Gem

Owyhee

Payette

Washington

TOTAL
Acres Harvested

9,000

24,000

10,500

3,000

11,000

3,000

$\frac{7,400}{67,900}$

Corn for Grain (1974)
Total Production (Bushels)

$\begin{array}{r}687,000 \\ 2,208.000 \\ 847,200 \\ 229,500 \\ 770,000 \\ 188,000 \\ 405,800 \\ \hline 5,326,500\end{array}$
County

Ada

Canyon

Elmore

Gem

Owyhee

Payette

Washington
Acres Harvested

2,319

5,675

1,070 705

2,787

1,008

1,173
Production (Bushels)

191,998

479,523

48,675

47,626

241,843

66,850

109,610

Oats

County

Ada

Canyon

Elmore

Gem

Owyhee

Payette

Washington
Acres Harvested

489

1,076

462

255

565

260

904
Production (Bushels)

41,057

83,956

19,106

19,243

24,630

17,664

55,502

REPORTED ONION ACREAGE

WESTERN IDAHO - 1978

$$
\begin{gathered}
\text { Yellows } \\
4,400
\end{gathered}
$$

Whites

705

Reds

288

Source: Idaho Agriculture; Statistics 1:977, Idaho Dept. of Agricultures. 
Geothermal resources are found at several locations in Ada County along the Boise Front Fault. This broad fault front trends Northwest along the base of the Boise foothills. The resource is known to exist at several locations from just east of Table Rock in Boise to the Eagle area in western Ada County. The local geology is a transition zone between the Snake River Plain and the Idaho Batholith. The Boise Front Fault is the dominant structural feature which creates the topographic break between the plain and the batholith. The local geology of the Boise foothills consist of tertiary sediments and volcanic rocks of the Glenns Ferry Formation unconformably overlying Mesozoic quartz monzinite of the Idaho Batholith. A series of north, northeast trending linears can be distinguished leading from the fault front back into the batholith. These structural linears are distinguished by topographic expressions. It is along these north, northeast trending features that the hot water resources have been found. The highest production zones and prime exploration and development areas are at the intersections of the Boise Front Fault and the linear features. The highest temperature wells $\left(75^{\circ} \mathrm{C}\right)$ are found at these intersection locations which are believed to be structurally controlled geothermal aquifers (1). Ninety wells along the Boise Front have temperatures greater than $200 \mathrm{C}$ and twenty of these wells have temperatures greater than $40^{\circ} \mathrm{C}$ but less than $80^{\circ} \mathrm{C}$. (2) Table 6-C list the twenty-two highest temperature wells in Ada County.

The utilization of the resources will be limited by the type of 1 and use and type of market found at the geothermal areas. Four seperate potential geothermal development areas have been identified in Ada County. Each area is different in character with different possible utilization scenarios. The four geothermal development areas are described in this chapter in the order of their occurrence from east to west along the Boise Front Fault. The four major development areas are: (1) The Kelley Hot Springs - Barber Area, (2) the Boise Urban Area, (3) The West Boise Area, (4) The Dry Creek Area. The Dry Creek Area is the only geothermal development area not within or adjacent to the Boise city limits.

The Kelley Hot Springs area is located adjacent to the eastern city limits of Boise. This area is also known as the Barber Industrial Park. Although largely undeveloped at this time, this locality has been designated as a future growth center for Boise by local planning commissions.

The Boise Urban Area is the major geothermal development locality in Ada County. The market area encompasses the Boise Central Business District, the State Capitol Mall, and over one-third of the city's residential area. The Boise Urban Area is divided into four subareas. These four subareas are resource localities which will serve different sectors of the city. The subareas are presented in the order of their occurrence from east to west along the Boise Front Fault. Separate development scenarios are presented for each subarea, with some market 
No. Location Name

1 3N2E 11 ba ERDA -BHW- 1

2 12cdd Warm Springs Water Dist.

$3 \quad$ 12cdd Warm Springs Water Dist.

4 11ba ERDA - BEH-1 (BLM)

$5 \quad 11 \mathrm{ba}$ BSU - BSH-2

6 3N3E 20ca Dallas Harris

7 3N2E 10ab State of Idaho

8

2cb H.L. Koch

\section{9}

4N2E 29acd Edwards Greenhouse

10

$28 \mathrm{cbb}$ Hunt Brothers Floral

11 28abc Victor Nibler

12

29bad 4401 Castlebar-Ryan

13

$$
\text { 29daa Robert Hunt }
$$

14 3N2E 10abb Hotel Boise

15 4N2E 29daa Robert Hunt

16 5NIE 35aca J. Jeker

17 4N2E 17ba City of Boise

18

22bcd J. Terteling

$19 \quad 22 \mathrm{cbb}$ J. Terteling

20

29acd W.F. \& Kerry Church

21

8dc Lilian Barnes

22 5N1E 35aca J. Jeker

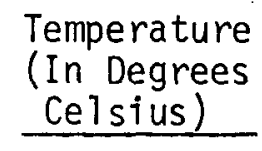

78.4

77

77

74

56

56

54

50

49

48

47.3

46.5

45.5

43.6

43.5

43.5

43

43

43

42.4

40.5

40
Depth

(In

Feet)

1283

400

400

1222

650

450

1075

1160

1295

1240

1300

1100

1250

1250

1700

595

600

1390

1685
100

Discharge (In Gallons Per Minute)

750

900

900

250

300

80

378

190

270

378

500

400

36

73

, 22

Source: Idaho Department of Water Resources 
area common to all subareas. The four resources subareas within the Boise Urban Area, from east to west are: the Penitentiary Grounds, the Warm Springs Water District, the 01d Fort Boise Military Reservation, and Camel's Back Park.

The West Boise Geothermal Development Area is the Northwest Boise residential area. Three subareas are described in the West Boise section. The three subareas are separate resource locations with different scale associated market areas. The three areas are from east to west, Crane Creek, Stewart Gulch and Pierce Gulch.

The Dry Creek Geothermal Development Area is the only major non-urban potential development area in Ada County. This area is largely an undeveloped agricultural locality which is 5 kilometers from the Boise City Center.

\section{Kelley Hot Springs Sub-Area}

The Kelley Hot Springs-Barber Area is located at the mouth of Warm Springs Creek Canyon, just east of Table Rock, $2 \mathrm{~km}$ east of the Boise city limits. Historically, thermal waters have been known to exist in this area. Kelley Hot Springs was developed as a resort in 1908. The hot springs served as resort for a number of years before going dry. The water temperature was reported to be between $300^{\circ} \mathrm{C}$ and $60^{\circ} \mathrm{C}$ with a filow of $250 \mathrm{gpm}$. (4) Several explanations have been offered as to why the hot springs went dry. Earthquake damage and well interference have been suggested but not substantiated.

In addition to historical occurrence to thermal water, the area has two additional geological indicators of a geothermal aquifer. The Kelley Hot Springs area has a similar structural: relationship as other known geothermal areas in Ada County. The site of the old hot springs is at the intersection of the Boise Front Fault and a north trending linear which forms Warm Springs Creek canyon. The area north of the Hot Springs site has a substantial resistivity low. (5)

Present 1 and use in the Kelley Hot Springs area is a mixture of residential, agricultural and industrial development. Most of the area is zoned agricultural. Of Approximately 2,000 acres, 400 acrea are zoned industrial and 100 acres are in residential zone, and the rest is agricultural.

The Barber Industrial Park is located .4 kilometers from the old Kelley Hot Springs site. The Barber industrial area is the only industrial site in Boise, fortuitously located at a geothermal resource area. Two small lumber mills and a large brick manufacturing company are the heavy industries at the site. Other industries (3) located in the industrial park are wholesale warehouses. The location does have rail service and access to a major truck route and the freeway is only $4 \mathrm{~km}$ from the site. Major powerlines also service the industrial site. Table 7-C lists the industries and their energy requirements.

Geothermal resources could be utilized in the dry kiln operations at both mills. Ponderosa Pine is the major lumber being ki in dried at the Barber Mills. A standard kiln is capable of handling 75,000 board feet every four days. Ponderosa Pine can be satisfactorily kiln dried at. temperatures less than $70^{\circ} \mathrm{C}$. (16) A geothermal dry kiln of this type 
Boise Cascade Barber Mill: employment 100

S.I.C. Code C 2421

Energy Intensity Coefficient: .4

Approximate Energy Consumption: $40.0 \times 10^{9}$ BTU/year.

Producers Lumber Company: employment 25

S.I.C. Code: B 2421

Energy Intensity Coefficient: .4

Approximate Energy Consumption: $10.0 \times 10^{9}$ BTU/year

Pullman Brick Co.: employment 10

S.I.C. Code: A 3259

Energy Intensity Coefficient: 1.6
Approximate Energy Consumption: $16 \times 10^{9}$ BTU/year

Pre Cote Industries: employment 10

S.I.C. Code: A 2491

Energy Intensity Coefficient: .15

Approximate Energy Consumption: $1.5 \times 10^{9}$ BTU/year

Total Approximate Energy Requirements for Industrial Park:

$67.5 \times 10^{9}$ BTU/year.

Approximate temperature geothermal resource required: $100^{\circ} \mathrm{C}$

Projected residential units in the Barber area by 1990: 500 to 1000 .

Approximate temperature geothermal resource required: $80^{\circ} \mathrm{C}$

Energy Intensity Coefficient: Source, Industrial Waste Heat for Adjacent Communities and Industrial Applications. 
requires a $82^{\circ} \mathrm{C}$ resource. A geothermal resource would have to supply $300 \mathrm{gpm}$ to sustain the heat requirement of a 75,000 board foot dry ki1n. (7) The geothermal resource of the Boise area may be capable of providing an $820 \mathrm{C}$ resource.

Space heating of industrial buildings could be accomplished with lower temperature geothermal fluids. The advent of geothermal heating at this industrial location could stimulate the location of secondary processing industries and warehouse to this area. Space heating of large manufacturing facilities with low temperature geothermal fluids $\left(44^{\circ} \mathrm{C}\right)$ has been demonstrated in K1amath Fal1s, Oregon where a large furniture manufacfuring building is realizing a $60 \%$ reduction in heating cost. (8) The principal attraction to locate industries at this site will be the availability of low cost geothermal heat.

Primary manufacturing industries such as the lumber mills are not likely to expand at the Barber Industrial site. This is due to increasing pressure by local city/county planning officials to encourage heavy industry to locate in the Boise Airport Industrial Park. (9)

Present land use planning calls for expanded residential growth in the Barber area. The Boise City Planning Department is encouraging growth in the general direction of the Barber area. It is hoped that by encouraging growth in the Kelley-Hot Springs-Barber Area, the city will be able to curb some of the sprawling growth southwest of the city. By encouraging growth to the northeast, the center of population distribution will be drawn back toward the Central Business District. In order to facilitate growth in the Kelley Hot Springs-Barber Area, the city plans to extend a major sewage line into the area by 1980.(10) Both the city and the county plan to rezone the area from agriculture to residential zoning as soon as development plans are approved.

Present plans call for the construction of Warm Springs Villaqe at the Kelley Hot Springs-Barber Area. Warm Springs Village is an ambitious development which plans to construct 3669 homes between now and 2000 . Table 8-C lists the construction timetable projected for Warm Springs Village. The Warm Springs Village Plan is a twenty-one year phased growth plan. There will be three major phases to the development. Each phase is planned to take seven years to fully implement. Over 11,000,people are expected to live in Warm Springs Valley by the year 2000.

The advent of expanding sewer services into the area will facilitate rapid development. Because geothermal resources are also known in this area, a rapid development of this resource for space heating is logical. Space heating of residences with geothermal fluids is technically possible and with escalating natural gas and electrical cost, geothermal space heating is an economical alternative. The combination of sewer service, close proximity to downtown Boise and geothermal heat will make this area a focal point for future growth.

Table 9-C lists the approximate development cost of installing a geothermal district heating system at Warm Springs Village. The following figures are based on assumed conditions which are considered realistic for the area. These figures do not reflect the exact development plans of Warm Springs Village. Exploration drilling for geothermal resources has begun and is expected to continue through 1980 at which time construction is expected to begin. Table 10-C list the projected geothermal utilization for the Kell ey Hot Springs-Barber Sub-Area. 
Table 8-C

WARM SPRINGS VILLAGE

Phase Implementation

21 year development plan

3 phase development

7 years per phase

\begin{tabular}{ccc}
1987 & 1994 & 2001 \\
Phase I & Phase II Phase III Total \\
\hline
\end{tabular}

Public Facilities Plan

Elementary Schools

Pre-schools

Junior High Schools

1
2

1
2
1

1

3

2

6

Business Plan

Village Center

Office Center

Convention Center

Part Part Part

Part Part

Business and Warehouse

Complex

Part Part Part

Housing Plan

Single Family Units

Townhouse \& Patio Houses

558

300

350

300

553

400

1469

400

400

400

1000

Apartment Units

TOTAL

1258

1058

1353

$\underline{1200}$

3669

Total Population

3,873

$3 ; 179$

4,163

11,215

Source: Warm Springs Village Plan, 1976, A Dallas Harris Development. 
Table 9-C

Kelley Hot Springs-Barber Area

Approximate Cost of A District Heating System

Assumption: Well is drilled to provide $70-80^{\circ} \mathrm{C}$ water for spaceheating industries and homes.

Drilling Cost: Approximately well depth: 1500 feet - 2000 feet

We11 Program: 12" diameter hole with 10" casing to 500 feet;

Average Well cost:

10 " hole with 8 " casing to 2000 feet.

$\begin{array}{rrr}\text { Depth } & 1000 \text { feet } & 2000 \text { feet } \\ \text { Drilling Cost } & \$ 17,000 & \$ 34,000 \\ \text { Casing Cost } & \$ 9,000 & \$ 17,000 \\ \text { Total Cost: } & \$ 26,000 & \$ 51,000\end{array}$

Range of Cost:
All Soft Rock
$\$ 20,500$
$\$ 41,000$
A11 Hard Rock
$\# 37,000$
$\$ 75,500$

Assumption: Average home is 1800 square feet, modern construction and well insulated.

Average flow per house on a peak load day $6.6 \mathrm{gal} / \mathrm{min}$.

1985: 500 homes $\times 6.6 \mathrm{gal} . / \mathrm{Min} .=3330 \mathrm{gpm}$

1990: 1000 homes $\times 6.6 \mathrm{gal} . / \mathrm{Min} .=6660 \mathrm{gpm}$

TRANSMISSION COST:

$$
\begin{array}{cc}
\text { Distance } & \text { (Feet) } \\
5,000^{\circ} & 10,000
\end{array}
$$

Distance Feet

$5,000^{\prime}-10,000^{\prime}$

$\begin{array}{ll}\text { Pipe Size } & 10 " \\ \text { GPM Range } & 600-2500 \\ \text { Heat Loss } & 1500 \\ \quad 0.01 \mathrm{ft} / \mathrm{ft} . & \\ \begin{array}{c}\text { Insulated Pipe } \\ \text { List } \$ / \mathrm{ft} .\end{array} & 23 \\ \begin{array}{c}\text { Trenching Cost } \\ \quad 1 / \mathrm{ft} .\end{array} & 1.25 \\ \begin{array}{c}\text { Fitting Cost } \\ \quad \$ / \mathrm{ft} .\end{array} & 5.75 \\ \begin{array}{c}\text { Total Cost } \\ \quad \$ / \mathrm{ft} .\end{array} & 30.00 \\ +30 \% & \end{array}$

\begin{tabular}{rrlrr} 
& \multicolumn{5}{c}{$14 "$} \\
$825-$ & & \\
& & 5000 & & \\
115,000 & 230,000 & 4000 & 200,000 & 400,000 \\
6,250 & 12,500 & 1.50 & 7,500 & 15,000 \\
28,750 & 57,500 & 10.00 & 50,000 & 100,000 \\
150,000 & 300,000 & 51.50 & 258,000 & 515,000 \\
45,000 & 90,000 & & 77,100 & 154,500 \\
195,000 & 390,000 & & & 669,500
\end{tabular}


Range oc Cost

$$
\begin{aligned}
& 1985 \text { - } 500 \text { Homes } \\
& 3,330 \mathrm{gpm} \\
& 2 \text { we } 11 \mathrm{~s} 1600 \mathrm{gpm}
\end{aligned}
$$

Drilling Cost:

$$
\begin{array}{r}
1,000 \mathrm{ft} . \\
\$ 26,000 \\
\$ 52,000
\end{array}
$$

Deep we 11 pumps cost o $\$ 33,000$

$$
\begin{array}{r}
2,000 \mathrm{ft} . \\
\$ 51,500 \\
\$ 103,000
\end{array}
$$

Transmission Cost 14' pipe, 5,000 ft.

Cost Range

Two Shallow Wells

$$
\begin{array}{cr}
\begin{array}{l}
\text { Drilling } \\
\text { Pumps }
\end{array} & \$ 52,000 \\
\text { Pipes } & \$ 66,000 \\
& \$ 335,500 \\
\hline \text { TOTAL } & \$ 454,000
\end{array}
$$

GEOTHERMAL ENERGY COST:

Hook-Up Charge -

$$
\frac{\text { Cost of System }}{\# \text { of Users }}
$$

$\$ 505,000=\$ 1010 /$ unit

System Maintenance Cost: Approximate $\$ 50,000 /$ year

Revenues using Icelandic System for 500 units

Monthly Rate $\$ 150 /$ unit/year $=\$ 75,000$

$$
\text { Yearly capital } \quad(\$ 25,000)
$$

30 Year Life Cycle Cost:

$\begin{array}{ll}\text { Hook-up Charge } & \$ 1,010 \\ 30 \text {-year a } \$ 150 / y r & \$ 4,500 \\ \text { Cost over 30-year Life } & \$ 5,510 \\ \text { Heat Cost Per Year - } & \$ 183.66\end{array}$


Table 10-C

Estimate Total Potential Geothermal Heat Utilization

The Kelley Hot Springs-Barber Sub-Area

\section{Industrial}

** Assuming: $10 \%$ energy replacement at present lumber mills

$50 \%$ energy replacement at present brick factory

Barber Mi11 Boise Cascade: $4 \times 10^{9}$ BTU/year

Ponderosa Lumber Company: $1 \times 10^{9}$ BTU/year

Pullman Brick Company: $\quad 8 \times 10^{9}$ BTU/year

TOTAL: $\quad 13 \times 10^{9}$ BTU/year

\section{Commercial}

$\star \star$ Assuming construction of ten new commercial buildings

Ten commercial buildings a approximately

$25 \times 10^{9}$ BTU/year: $25 \times 10^{9}$ BTU/year

Residential (For Warm Springs Village)

**Assuming 5.4 × $10^{7}$ BTU/year/homes

1987:

$67.9 \times 10^{9}$ BTU/year

New Additions by 1994: $57.1 \times 10^{9}$ BTU/year

New Additions by 2001: $73.0 \times 10^{9}$ BTU/year

TOTAL: $198.0 \times 10^{9}$ BTU/year

Schools

Four School Buildings a approximately

$2.9 \times 10^{9}$ BTU/year: $\quad 11.6 \times 10^{9}$ BTU/year

Total A11 Sectors: $\quad 247.6 \times 10^{9}$ BTU/year by 2001 
Hot water resources have been developed in the Boise Urban Area for over 90 years. The oldest organized geothermal heating district in the United States is the Warm Springs Water District. This system presently services 175 homes and businesses in Boise. In the 1940's this system served up to 400 residential and commercial buildings.

In addition to the Warm Springs Water District, there are several other known geothermal areas in Boise. To discuss the geothermal potential in an orderly way, four subareas have been desiginated for the Boise Urban Area. Penitentiary Grounds, Warm Springs Water District, Fort Boise, Camels Back Park. All four subareas lie with in the corporate limits of Boise, Idaho. The four subareas were segregated according to resource location and development potential. The resources locations are all along the Boise Front Fault and have similar geological conditions. All four subareas are adjacent to high density urban development but the potential drilling sites are largely located in open space areas. The potential utilization senarios for the subareas discussed for each area in the subarea reports.

\section{PENITENTIARY GROUNDS SUBAREA}

The old Idaho State Penitentiary grouns are located on the eastern city limits of Boise, at the end of Warm Springs Avenue. This 300 acre site is on the Boise Front Fault and adjacent to the main production wells of the Warm Springs Water District. The area was used as the State Penitentiary and prison farm until 1973. With the construction of a new penitentiary outside of Boise, this facility was abondoned and is presently a state historical park. The area around the old penitentiary is largely open space which was used as the prison farm. The topography of the site varies from near vertical along the fault escarpment of flat bottomland away form the escarpment to the south. Presently the old penitentiary grounds are under construction for future development as the majority of the 300 acre site is open space. Part of the grounds is being used for new state office buildings.

The Warm Springs Water District!s main pipeline lies along the western property line of the old penitentiary. In 1976, the State of Idaho purchased a maximum allocation of $400 \mathrm{gpm}$ from the Warm Springs Water District for the purpose of space heating new state office buildings constructed on the old penitentiary grounds.

The heating system for the State of Idaho Health-Agriculture Laboratory has been successfully converted from natural gas to geothermal water. This retrofit was funded through the Pacific Northwest regional commission. The project was undertaken to demonstrate the feasibility of heating a large state office building with geothermal water. Although the project is considered a pilot operation, it is a proven, successful demonstration which is being expanded to serve other office buildings on the penitentiary grounds. At present geothermal water charges, the Health-Agriculture Laboratory is operating at significantly lower energy cost than it did when using natural gas. The yearly heating cost has been reduced approximately $50 \%$. (12) Table 11-C list the comparison heating cost between the natural gas heating system and the geothermal heating system. 
The State of Idaho plans to expand the geothermal heating system to the new Department of Agriculture Office Building which is presently under construc tion adjacent to the Health-Agriculture Laboratory. This building is designed for geothermal heating and will use the same heat exchanger as the Laboratory because the heat exchanger at the Laboratory is capable of heating two additional buildings. With the addition of the new Department of Agriculture Office Building the state expects to be utilizing less than one quarter of its allocation from the Warm Springs Water District. A third building could be construced adjacent to the Health-Agriculture Laboratory and utilize the same central heat exchanger.

In addition to the Warm Springs Water District geothermal resource, the State of Idaho also has a geothermal well located on the old penitentiary grounds. This well was originally drilled as an irrigation well for the prison farm. The well has a slotted casing which allows both cold and warm water aquifers to enter the wel1. The temperature of the Pen we 11 is $58^{\circ} \mathrm{C}$ compared to the $77^{\circ} \mathrm{C}$ temperature of the Warm Springs Water District weljs. The State of Idaho is considering utilizing this well in the future.

The fortuitous advantage of state land ownership and the avajlability of geothermal resource makes the penitentiary grounds an ideal location for new state office buildings. Limited available space for new construction in the Capitol Mall is already forcing new construction to outlying areas. The availability of low cost geothermal heat and the successful demonstration of its utilization at the old penitentiary grounds has made this site a high priority location for agglomerating new state buildings.

There are two areas of institutional problems associated with a major development and utilization of geothermal resources at the old penitentiary grounds. The two areas are resource ownership and environmental impact.

The State of Idaho has leased the penitentiary grounds and additional adjacent state lands to a private party for the purpose of geothermal exploration. (14) The leases were issued in March 1975 pursuant to Idaho Code 47-1610 which deals with geothermal leases on state lands. The lease gives the lessee the right to explore for geothermal resource on the leased state land. The lease does not give the lessee the right to the present thermal well on the state property as the state still retains the ownership of the well and its water rights. If the private. lease holder does pursue exploration on the penitentiary grounds, his right to develop the geothermal resource will be limited to non-interference of present thermal weils in the area, which include the penitentiary well and the Harm Springs Water District wells. If the State utilizes the penitentiary well, it must also respect the water levels of the Uarm Springs Water District wells which have a prior appropriation dating from a 1894 water right.

The major environmental impact will be from the disposal of the thermal water. Presently, the thermal affluent from the Health-Agriculture Laboratory geothermal heating system is cooled via a spray pond and disposed of in the Boise River. Maximum discharge is approximately $100 \mathrm{gpm}$, with actual columns varying with heating demand. The major environmental parameters of concern with regard to disposal of geothermal waste water are the impact of temperature and fluoride on the biology of the Boise River. 
In terms of public drinking water supplies, the U.S. Public Health Service has set $1.4-2.4 \mathrm{ppm} F$ as the maximum permissible 7 imits. The Warm Springs Water District wells have a fluoride content of 14 to $18 \mathrm{ppm}$. Vegetation, animals and humans are susceptible to fluoride to fluoride toxicity. Thus there is a major concern over the disposal of geothermal water.

The Idaho Office of Energy and Boise State University has been monitoring the Biological impacts of geothermal waste water discharge into the Boise River. The results of this study have shown that under present discharge conditions the temperature and fluoride effects were negligible. From the standpoint of fluoride and thermal pollution, several more projects of the size of the Health Agriculture Laboratory could be handled in an environmentally sound fashion. However any large scale development,which would discharge greater than $100 \mathrm{gpm}$ would be ecologically unsound.

Scenario Projections:

Table 12-C presents the projected timetable for geothermal direct heat applications at the Penitentiary Grounds. A resource data summary is presented in the Warm Springs Water District Sub Area section, in Table 14-C, as the resource for both subareas comes from the Warm Springs Wells. 
TABLE 17-C

HEATING COST COMPARISON FOR THE

CURRENT GEOTHERMAL DEMONSTRATION PROJECT AT THE

STATE OF IDAHO AGRICULTURAL/HEALTH LABORATORY:

Agricultural/Health Laboratory (Approx. 30,000 sq. ft.)

Retrofit cost in 1976:

Average yearly heating cost (natural gas):

Estimated geothermal cost documented by the University of Idaho Engineering Department:

Additional outside air sensor being installed next week will achieve another $20 \%$ savings.

Approximate payoff of retrofit system: 6.4 years

Actual fuel cost comparisons at Health/Agriculture Laboratory

76-77 (Heating Season)

Natural Gas

Oct.

Nov.

Dec.

Jan.
$\$ 2,313$

3,109

3,870

4,478
77-78 (Heating Season) Geothermal

$\$ 1,715$

2,317

2,212

Note: Late in December a 11 mechanical problems were worked out of the system.

Source: Idaho Office of Energy 
Table 12-C

PENTENTIARY GROUNDS SUB-AREA

GEOTHERMAL DEVELOPMENT PROJECTIONS

Geotherma1 Development

On line: $\quad$ State of Idaho Health Agriculture

Laboratory ....... $100 \times 10^{9}$ BTU/yr.

Idaho Department of Agriculture

Building........ $25 \times 10^{9}$ BTU/yr.

Projected: $\quad 30,000 \mathrm{sq}$. ft State Office

Building (1982)..... . $25 \times 10^{9}$ BTU/yr.

$30,000 \mathrm{sq}$. ft. State Office

Building (1985)..... . $25 \times 10^{9}$ BTU/yr.

Penitentiary Historical Park . $50 \times 10^{9}$ BTU/yr.

$\overline{225 \times 10^{9} \text { BTU/yr. }}$ 
The Boise residential area known as Warm Springs Avenue has an extensive history of geothermal energy experience. The historical development of geothermal energy in Boise began with the drilling of two warm water wells in 1892 . Located near the 0ld State Penitentiary, these wells are now part of the Warm Springs Water District geothermal heating system. These wells have continuosly provided hot water for space heating of homes and commercial buildings in Boise for almost 90 years. At one time, the wells provided geothermal fluids for space heating in 400 residences, part of the commercial business district, and a large recreational facility known as the Boise Natatorium. With the advent of cheap natural gas and electricity in the 1950's, many customers converted to the new energy systems for better reliability. By 1973 the number of customers 96 ftilizing geothermal energy for space heating had dwindled to less than 150 .

In 1973, the 01d Natatorium Company, which at that time owned and operated the system, notified customers that the system would be abandoned due to maintenance cost. In. 1974, the remaining customers took over the system and set up the Warm Springs Water District. The creation of the district required a special legislative Act. Under the authorization legislation, the Warm Springs Water District is not considered a public utility and is not under the Public Utility Commission jurisdiction. (17)

Since 1974 the Warm Springs Water District has been active in rehabilitating the system and stimulating interest to gain new customers. The present system provides hot water for 150 residential and commercial buildings. In addition to these customers, the State of Idaho Health-Agriculture Laboratory and the Department of Agriculture Office. Building are on the Warm Springs Water District system. During peak load periods, the total energy supplied to these customers is estimated to be approximately $28 \times 10^{6} \mathrm{BTH} / \mathrm{h}$.

The original hot water system was designed as a flow-through system requiring each homeowner to dispose of the spent hot water. Discharges to sanitary sewers, storm sewers, the City canal, and shallow wells are typical methods of disposal. Continued use of the sanitary sewer for discharge may be discontinued by the city. The environmental effects of the other disposal practices have not been observed, or seriously studied.

The Warm Springs Water District has two production wells less than 10 meters apart which are approximately 250 meters deep and have a water temperature of $71^{0} \mathrm{C}$. One we 11 is used for the base load and the other for peaking. Both wells experience a 50 meter draw down under peak load conditions. When the wells are allowed to sit for 48 hours, the we $17 \mathrm{~s}$ will begin to flow artesian. The production zone of these two wells is the shear zone of the Boise Front Fault.

Two wells supply the system with a combined peak historical capacity of 6,800 liters per minute (1800) gpm). Depletion in the quantity of the resource has not been observed in the wells even during the peak usage which occurred in the first half of the century. (18)

The wel1s are located on 10 acres of land adjacent to the old Penitentiary grounds. Warm Springs Water District owns both the surface and subsurface rights to this property and the District has preferential right-of-ways for its pipelines and water rights to 7,267 liters per minute $(1,920 \mathrm{gpm})$ dating 
back to 1899, This is one of the oldest water rights in the city of Boise. Warm Springs Water District has an application on file with the State Water Resource Board for an additiona] 6,813 1iters per minute $(1300 \mathrm{gpm})$ which would come from future wells.

A rapid future expansion of the Warm Springs Water District is expected. Several prospective users have expressed serious interest to hook-up to the geothermal system and are working diligently to complete this goal. Several other potential customers have expressed an interest in expanding the system.

Twenty-one single family residential units on Mobley Drive have recently been added to the system and an additional 15 units will be added as soon as retrofitting is completed. The Warm Springs Hollow Condominium Development is a 60-unit development only 100 meters from the Warm Springs Water District mainline. The condominium units are 2,000 sq. ft. units and are designed for geothermal heating. Warm Springs Hollow is expected to be completed and connected to the geothermal system by January, 1979 .

The River Run Development and the Morning Side Heights Development have also expressed a desire to expand the geothermal system to their areas. River Run Development is a 700-unit multi-unit residential and commercial development with an average unit size of 2,000 sq. ft. The River Run Development is located approximately one kilometer from the present main hot water line. Construction began on this development in 1978. Morning Side Heights is a 180-unit multi-residential development with 3,000 sq. ft. individual units. The development is also located within 1 kilometer of the present Warm Springs Water District system. Both of these developments have expressed a serious desire to be part of the geothermal system. The addition of these two developments will depend on the Warm Springs Water District developing an additional supply capacity.

In addition to these developments, the Warm Springs Water District is considering a cooperative adventure with the City of Boise to provide geothermal water to the Central Business District and Capital Mall area. The downtown area is a common market target for several geothermal resource locations in the Boise Urban Area. The market potential of the downtown and Capital Mall will be discussed separatelylater in this chapter. Table 13-C list the on line and projected direct heat applications of geothermal resources in the Warm Springs Water District Sub-area. Table 14-C is a compendium of data regarding the Warm Springs Water District and Penitentiary Grounds Sub-areas. 
Table 13-C

WARM SPRINGS WATER DISTRICT SUB-AREA

Geothermal Development Potential

On Line:

Projected 1979:

1982:
Warm Springs Water District

150 residential units

Warm Springs Hollow (100 units)

Mobley. Drive (50 units)

Morning Side Heights (180 units) River Run Development (700 units) Boise State University Morrison-Knudsen Boise CBD (part)
BTU

$16.2 \times 10^{9}$

$5.4 \times 10^{9}$

$2.7 \times 10^{9}$

$9.7 \times 10^{9}$

$37.8 \times 10^{9}$ $225.4 \times 10^{9}$

$65.3 \times 10^{9}$

$219.9 \times 10^{9}$

$582.4 \times 10^{9}$ 
Table 14-C

Data Summary for Warm Springs Water District and

Penitentiary Grounds Sub-Areas.

SITE LOCATION AND PHYSICAL DESCRIPTION

..Latitude: $\quad 43^{\circ} 37^{\prime} 30: \mathrm{N}$

..Longtitude: $\quad 116^{\circ} 10^{\prime} 30^{\prime \prime} \mathrm{W}$

. Rectilinear: T. 3 N, R. 2 E., Boise Meridian

..County: Ada

..Adjacent Counties: Elmore, Canyon, Owyhee, Boise

..Topography: The Boise Front Fault creates a major topographic break at the well site. South of the well site lies the flat flood plain of the Boise River. North of the we11 site slopes range from $12 \%$ to near vertical.

..Present Land Use: Land adjacent to the well site is largely undeveloped State land. South and west of the we 11 site, 400 meters away, the principal land use is high density residential housing.

..Future Land Use Plans: The State of Idaho will develop State lands for State Office Buildings.

..Aesthetics: Low

...Historical/Archaeological Signifance:

Site of the first geothermal well drilled in the United States for space heating. Wells were first drilled in 1892 to supply heat to homes along Warm Springs Avenue. State Penitentiary Buildings are a State Historical Park. 
Table 14-C (Cont'd.)

GEOLOGICAL/GEOPHYSICAL DESCRIPTION

..Geologic Description:

(29)

Rock types range from Cretaceous to Pleistocene in age. The older rocks, those of the Idaho Batholith, have been uplifted, faulted and eroded. The granitic rocks are overlain by clastic beds and interrelated basalt flows of the Glenns Ferry Formation of the Idaho group. The geothermal system may be related to the water of the deep artesian system in the Boise area. The warm water of the geothermal system has been found to be associated with major structural features, linears, major faults of the area. The water is heated at depth in deep fracture systems within the Idaho Bath$01 i$ th and moves along fault and fracture zones upward mixing and heating the water found in the Glenns Ferry Formation. This water is then intersected in wells tapping the Glenns Ferry sediments. The present wells are located at the intersection of the Boise Front Fauit and a major NE trending linear structure. Highest production comes from wells drilled into the fracture zone of the fault.

..Geophysical Summary:

Draw/down recovery test have been conducted on the two wells at the Boise Barracks Property. Interference testing with Warm Springs Water District wells 2 kilometers away shows no interference between the Warm Springs wells and the Boise Barracks wells. A 3.5 psi draw down between the Boise Barracks wells is attributed to seasonal variations in the water table.

...Geologic Hazards:

Historical micro-seismic activity appears to be coincident with construction in the Boise Area. The area is thought to be aseismic by Applegate and considered potentially seismic by Idaho Department of Water Resources.

The major geological hazard at the Warm Springs wells is occasional rock slides from the old prison quarry and talus slope of the Boise Front Fault. 
RESERVOIR CHARACTERISTICS (25)

..Reservoir Temperature

..Surface: $72^{\circ} \mathrm{C}$

..Subsurface: $77^{\circ} \mathrm{C}$

..Geochemical: $\mathrm{SiO}_{2}: 125^{\circ} \mathrm{C}$

$\mathrm{Na}-\mathrm{K}-\mathrm{Ca}: \quad 80^{\circ} \mathrm{C}$

Flow Rates: $400 \mathrm{gpm}$ to $1000 \mathrm{gpm}$

$\mathrm{pH}: \quad 8.6$

..Total Dissolved Solids: 293

..Fluid Chemistry: mg/litre

$\begin{aligned} & \mathrm{S}_{1} \mathrm{O}_{2}: 105 \\ & \mathrm{Ca}: 2.0 \\ & \mathrm{~K}: 1.3 \\ & \mathrm{Mg}: 1 \\ & \mathrm{Na}: 17 \\ & \mathrm{Cl} \vdots 8.6 \\ & \mathrm{~F}: 14 . \\ & \mathrm{CO}^{3}: 14 . \\ & \mathrm{HCO}_{3}: 105 \\ & \mathrm{NO}_{3}: 1.0 \\ & \mathrm{SO}_{4}: 23.0\end{aligned}$

LAND OWNERSHIP AND LEASING

TOTAL AREA FEDERAL STATE PRIVATE OTHER (Acres) (Acres) (Acres) (Acres)

..Land Ownership

$1,562 \quad 10$

..Land Leased

1,562

..Tentative Lease Sale Dates: In 1985 the State Leases are up for renewal. ..Summary of Leasing Status and Needs: State Leases have not been developed. No exploration activity known. 
GEOTHERMAL DEVELOPMENT STATUS

..Present Development Status:

Warm Springs Water District serves approximately 150 residences and two 30,000 square foot state office buildings. During peak load periods the total energy demand supplies to these customers is estimated to be approximately 28 million BTU/hr.

..Projected or Planned Development:

Projected development plans include refurbishing existing wells and transmission main lines currently operated by the District, and extending the main line to the Boise Central Business District. Additional well production is needed. At least one new production we 11 is expected by 1985 .

\section{ENVIRONMENTAL FACTORS}

..CLIMATE (32),

..Prevailing Winds: 8 to $10 \mathrm{mph}$ from SE in winter, from NW in summer.

..Precipitation (Annual): $27 \mathrm{~cm} 911$ inches)

..Days of Sunshine (Annua1): 310 days a year

..Average Temperature: Mean January July

Minimum: $\begin{array}{llll}3.33^{\circ} \mathrm{C} & \left(38.1^{\circ} \mathrm{F}\right) & -6.2^{\circ} \mathrm{C} & 14.7^{\circ} \mathrm{C}\end{array}$

Maximum: $17.22^{\circ} \mathrm{C} \quad\left(63.1^{\circ} \mathrm{F}\right) \quad 2.2^{\circ} \mathrm{C} \quad 32.4^{\circ} \mathrm{C}$

... Degree Days (Annua 1): $\quad 5,809$

..Relative Humidity (Seasonal Peaks)

Summer: 22

Winter: 76

..AIR QUALITY: Measured at Bureau of Air Quality, State Health and Welfare Department adjacent to Military Reserve Park. Area has same air quality as the city of Boise, which can be described as good to. poor depending on the time of year and wind. Copollution: auto, $19 \mathrm{ppm}$ bad day, $4 \mathrm{ppm}$ good day. Particulate pollution: dust, 150 micro-grams bad day, 50 micro-grams good day.

..GEOLOGIC FACTORS:

Exploration area is located at the base of the Boise Front Fault escarpment. 
..WATER QUALITY:

Thermal ground waters have high fluoride concentrations of 14-18 ppm.

INSTITUTIONAL CONSIDERATIONS - Federal

Institutional

Requirements

National Environmental

Policy Act

(42-U.S.C. 4331 )

Federal Water Pollution Control Act (33-USCA 1251)

Federal Safe Drinking Water Act

(42 U.S.C. (A) 300)
Agency and

Public Attitudes

The mational goal of this Act is to attain -0-pollution by 1985 . E.P.A.

This Act is concerned with protection of underground water sources that could be used for domestic water. E.P.A.
Status of Requirements (i.e., EIA/EIS Requirements)

An E.I.S. will be required for any major action which will require disposal of thermal water.

Groundwater is included under this Act and the reinjection of geothermal effluent will require permits.

The Act sets standards for wells and well drilling and could influence future geothermal wells in the Boise area. The upper aquifer of the basin is the supply of domestic and irrigation water for the area. Reinjection of water for the area. Reinjection of water for geothermal wells will require permits under this Act. 
INSTITUTIONAL CONSIDERATIONS - State

Institutional

Requirements

Leases on state lands (Idaho Code 47-601 et. seq. Chapter 16, Geothermal Resources)

Geothermal Resource Permits.

(Idaho Code 42-4001

et. seq. Chapter 40, Geothermal Resources)

Water Appropriation (I daho Code 42-101

et. seq. Chapter 1

Water Appropriation)

Injection wells (I daho Code 42-3001 et. seq. Chapter 39 Waste Disposal and Injection Welis)
Agency and

Public Attitudes

The State Board of Land Commissioners is authorized to issue leases for geothermal resources underlying state and school lands.

The regulatory powers of the State Geothermal Resource Act are placed in the Idaho Department of Water Resources.

The I daho Department of water Resources issues water appropriation permits and a water right license.

Permits are issued by the Department of Water Resources.
Status of Requirements (i.e., EIA/EIS Requirements

Lease term is 10 years and can be continued with diligent development. Rentals are set by the board. Several leases have been granted on state lands. Lease size is limited to a max. of 640 acres/lease.

Any private owner, or holder of a state or federal lease of geothermal resources must first app1y for a geothermal resource permit from I.D.W.R. before any drilling operations can begin.

Under the Idaho Geotherma1 Resources Act, applicants can be required to make an application to appropriate the public waters of the state.

No waste disposal or injection well can be constructed in Idaho unless a permit has been issued by I.D.W.R. The approval of this permit is contingent upon the approval of the Department of Health and Welfare. The proposed well is reviewed to see if it will unreasonably contaminate or deteriorate the quality of the groundwater below the adopted water quality standards of the state. 
Table 14-C (Cont'd.)

INSTITUTIONAL CONSIDERATIONS - LOCAI

Institutiona 1

Requirements

County Code and Zoning

City Code and

City Zoning

Right of Ways
Agency and

Public Attitudes

Ada County Planning Department

Boise City Planning Department

Ada County Highway Commission
Status of Requirements

(i.e., EIA/EIS Requirements)

Permits needed for all construction, special land use permits needed for all non-conforming land uses.

Permits needed for all construction. Special use permits needed for non-conforming land uses.

Grants right-of-ways for a11 streets and roads in Ada County including intercity streets. 
Table 14-C (Cont'd.)

..NOISE :

Low noise levels

TRANSPORTATION AND UTILITIES

..Utility or Energy Transmission Corridors and Facilities

Two $230 \mathrm{kv}$ lines are within 5 kilometers of the site, owned by

Idaho Power Company. Natural gas and water lines are located

on the site.

..Transportation Corridors or Facilities

Warm Springs Avenue and Penitentiary Road service the area. Al1 right-of-ways along city streets and county roads are controlled by the Ada County Highway District.

\section{POPULATION}

..General Description of Population

The City of Boise has an approximate population of 100,000 people. High density urban population center at the resource site is a mix of residential and business development.

...Economics

The City of Boise has experienced an 18\% growth rate for the last five years. This trend is expected to continue. The city is experiencing a period of major re-development. The Boise Central Business District is the site of the Boise Re-development Project. This planned revitalization of Boise City's downtown core has stimulated the private sector to initiate several projects. Buildings have been rehabilitated, reinforcing the concept of a Renaissance in the Central Business District. Several new office buildings have been completed and a regional shopping center and mall complex is proposed for one six block area. Tapping Boise's geothermal resource is a factor in developing a downtown regional center into the first geothermally heated shopping mall in the nation. Wider use of the hot ground water for space heating is being studied. The State Capitol Mall is also undergoing a major construction period. New office complexes and parking. garages are presently under construction. Geothermal heat is also being considered for the new and old buildings of the Capitol Mal1. 
The Fort Boise Military Reservation is located near the city center of Boise at the mouth of Cottonwood Creek Canyon. The Boise Front Fault crosses the property forming a major topographic discordant. The land area south of the fault escarpment is a flat flood plain of Cottonwood Creek. North of the escarpment, the topography is typical of the Boise foothills with slopes averaging ten per cent. Present land use of this geothermat area is a mixture of developed and undeveloped open park land and public buildings.

The Fort Boise Military Reservation was withdrawn from the public domain on April 9, 1873 by Executive order. On April 5, 1979, the fort was redesignated Boise Barracks and Army units were stationed there unti 1 1912. Later, it was determined that all of the lands withdrawn for the Boise Barracks were not needed by the military. As a result, administration of portions of the original area were transferred to the Veterans Administration and the General Service Administration. The GSA transferred title to the Department of Interior several tracts of the Boise Barracks property. The Bureau of Land Management then patented the majority of this property to the city of Boise for recreation and public purposes. In addition to the above title transfers, several small tracts of land within the original Fort Boise Military Reservation have been transferred to the State of Idaho.

As outlined above, the surface estate of the original reservation has been slit between several titles. The subsurface estate reservation has been kept intact and reserved to the federal government. The mineral reservation list included the geothermal resources until October 1978 when the City of Boise acquired the geothermal rights from Congress.

In 1977, the Federal Department of Energy (ERDA) drilled two exploration wells on the property to prove the existence of the resource. The two wells have bottom hole temperatures of $77^{\circ} \mathrm{C}$ and pump test temperatures of $740 \mathrm{C}$. The depths of the wells is approximately 250 meters. Pump test conducted in 1978 indicate that a large geothermal reservoir exists under the Fort Boise Military Reservation. The chemistry of this water is similar to the other geothermal wells in Boise with high fluoride content (18 ppm) being the only major potential pollutant. (20).

The energy potential of this geothermal area is considered to be adequate for meeting the space heating needs of the Capitol Mal1 and portions of the Central Business District. Three major market areas have been identified which could be served by geothermal resources development in the Fort Boise Military Reservation. The market areas are: (1) present buildings located on the Boise Barracks Property, (2) Idaho State Capitol Mal1, and (3) Boise Central Business District. The market potential of the Boise Barracks Property and the Capitol Mall are examined in this section. The market potential of the Central Business District will be examined in the section covering the Camel Back. Butte Park Subarea.

Several major public buildings are located on the Fort Boise Barracks Property. Table 15-C lists the buildings, ownership, type of heating system and energy type. All of the buildings surveyed with the exception of those with resistant heating are considered compatible to geothermal retrofits. 
Table 15-C

Fort Boise Barracks Buildings, Heating Systems

Building

Ownership

Heating System

Fuel

Federal office

General Service

Steam/forced air

Natural Gas

Building

Administration

Fort Boise

Veteran's

Veteran's Hospital

Administration

Steam/hot water

radiators

Elk's Hospital

B.P.O.E.

Hot water

Natural Gas

Veteran's Home

State

Steam/hot water radiators

Lincoln School

Boise School

District

Idaho Children's

State

Hot water

Hot water

Natural Gas

Home

Boise BLM District

Dept. of Interior

Hot water/base

board

Gas and Electric

Boise Community

City

Electric

Center

Col. Pinkney

Army Reserve Station

U.S. Army

Gas 
The four major energy consuming buildings were examined for geothermal space heating potential. Those buildings are: (1) Federal office Building, (2) Veterans Hospital, (3) Idaho Veterans Home, and (4) the Idaho Elks Rehabilitation Hospital. The other buildings on the Boise Barracks property were not examined in any detail.

Initial reconnaisance indicates that the Federal office Building, Idaho State Veteran's Home and Elks Rehabilitation Hospital could be retroffited to geothermal space heating systems. The Veterans Hospital could utilize geothermal fluids but its mechanical systems would require major study before any retrofit can be estimated.

The economic considerations for conversion to geothermal energy fall into two categories: (1) Annual energy costs, (2) System conversion cost. Both of these require detailed evaluation and a completed design prior to exacting. Based on initial and limited information, general conversion feasibility can be estimated.

\section{(1) Federal Office Building}

The Federal Office Building is a $271,000 \mathrm{sq}$. ft., five story structure which used approximately 150,000 CCF of natural gas per year. Natural gas, the primary source of heating and cooling for this facility, is used to generate steam in two boilers. The steam is used directly in heating coils and through heat exchangers with hot water in the air handling equipment. The absorption chillers and domestic hot water heat exchangers also utilize steam. Table 16-C list the historical energy needs and cost of the Federal Office Building.

A preliminary study on systems conversion to a geothermal heating system has been conducted by the General Services Administration. The results of this study indicate that the present boiler system could be trimmed down to provide hot water instead of steam and would provide adequate backup and peaking for a geothermal system. The geothermal system would utilize a heat exchanger with the building loop water. Air handling equipment would need to be retrofitted if a geothermal system were installed. The steam absorption coolers would also need to be replaced with electrical centrifugal chillers.

The estimated cost of conversion to geothermal energy is $\$ 205,318$. Present annual heating and cooling costs for the building are $\$ 35,000$ per year. By converting to geothermal energy an estimated 140,000 therms of natural gas per year would be conserved. At 1977 natural gas prices, this conservation has an approximate net value of $\$ 35,000$. 
Federal Office Building/Historical Energy Demand and Cost

Special Uses: Federal Agencies Offices, operates 8 hours a day/5 days a week.

Gross Sq. Ft.: $\quad 277,370$

Net Sq. Ft. : 172,560

Heat System : Natural Gas boilers

cooling system: Steam absorption (natural gas boilers)

Cost and Consumption:

FY 1977:

\begin{tabular}{lrr} 
Month & CCF & Amount \\
\hline Oct. & 6454 & $\$ 1,495.72$ \\
Nov. & 10831 & $2,891.22$ \\
Dec. & 16292 & $4,340.74$ \\
Jan. & 20718 & $5,516.18$ \\
Feb. & 10537 & $2,789.96$ \\
Mar. & 9260 & $2,453.10$ \\
Apri1 & 7468 & $1,867.13$ \\
May & 4002 & $1,025.52$ \\
June & 13691 & $3,385.16$ \\
July & 15560 & $3,855.60$ \\
Aug. & 17720 & $4,400.80$ \\
Sept. & 6625 & $1,661.72$ \\
\hline TOTAL: & $139,165 \mathrm{CCF}$ & $\$ 35,682.96$
\end{tabular}

FY 1978 (incomplete)

\begin{tabular}{lrr} 
Oct. & 3628 & $\$ 1,009.73$ \\
Nov. & 8722 & $2,369.80$ \\
Dec. & 10795 & $2,895.78$ \\
Jan. & 13604 & $3,491.90$ \\
Feb. & 10179 & $2,589.68$ \\
Mar. & 6934 & $1,779.83$ \\
Apri1 & 4861 & $1,295.10$ \\
May & 4373 & $1,194.95$ \\
\hline & & \\
TOTAL: & 6,3036 CCF & $\$ 16,626.79$
\end{tabular}

Other Years:

Year FY $1976 \quad$ FY $1975 \quad$ FY 1974

CC̈̈ $\quad 132,054 \quad 146,498 \quad 186,466$

Cost $27,784 \quad 24,959 \quad 20,258$

Note: Higher fuel bills in summer months is due to the steam absorption cooling Source: GSA, Boise Federal Office Building Heating Records. 
Natural gas prices in Idaho are essentially unregulated and escalating at an average of $24 \%$ per year. Based on the initial information, the payout period for conversion could be as little as eight years.

In summary, geothermal energy appears to be a feasible alternative for this facility. A complete engineering design study is required for verification of this potential. It should be noted that the resultant savings in natural gas consumption will be slightly offset by an increase in electrical consumption due to the addition of the electrical centrifugal chillers and larger air handling fans.

(2) State of Idaho Veteran's Home:

The Idaho State Veteran's Home, a 30,000 sq. ft. structure, presently utilizing a natural gas boiler to produce steam for steam/water exchangers which heat the water and air in the building. An initial engineering study on the feasibility of conversion to geothermal energy indicates that this building could retrofit to geothermal heating utilizing $75^{\circ} \mathrm{C}$ thermal water. Presently, the domestic hot water system is part of the space heating system. The domestic laundry/kitchen water would have to be boosted by electrical heaters to obtain the needed temperature, if the present system was converted to geothermal heat.

The separation of the building space heating system and the higher temperature domestic water can be accomplished by installation of two water to water heat exchangers. One heat exchanger could be tied in parallel to the present system to provide space heating and the other could preheat the domestic water which would then be increased in temperature by electrical units.

The best estimate on building conversion cost is $\$ 29,000$ in 1975 dollars which does not include contingency. The present cost of heating the State Veteran's Home is $\$ 21,400$ per year. Conversion of this system could have a payback period as short as two years.

\section{(3) Veterans Hospital:}

The Fort Boise Veteran's Hospital is a large structure totaling approximately $600,000 \mathrm{sq}$. ft.. The Hospital complex consists of a central hospital building and several service buildings which include a laundry, central heating plant and several maintenance shops. All of the hospital's buildings are heated from the central, heating plant. The central heating plant utilizes three natural gas boilers to provide high temperature steam at 110 pounds per square inch pressure. The pipelines to the buildings vary in size. The building heating systems can be divided into two types: in older buildings, space heating is accomplished by old steam radiators; in the newer wings of the hospital, space heating is accomplished by steam/ water heat exchangers which supply hot water to the water/air space heating system.

No engineering studies have been conducted on conversion of the hospital heating system to geothermal energy. The new wing of the hospital has the most feasible system for retrofitting. The older buildings use steam radiators which create major retrofit probiems. No conversion cost estimates are available for this facility. 
The Veteran's Hospital's average annual consumption of natural gas is $4300 \mathrm{MCF}$ per year. In 1973, the unit cost for natural gas was $\$ .58 / \mathrm{MCF}$ but in 1977. the unit cost of natural gas for the hospital was $\$ 2.31 / M C F$. This represents a $400 \%$ increase in four years. Without substantially increasing its consumption of natural gas, the Veteran's Hospital energy cost has risen from $\$ 25,000$ in 1973 , to approximately $\$ 104,000$ in 1977 . Table 17-C lists the historical energy consumption and cost of heating the Veteran's Hospital.

Recommendation:

The D.0.E. and the Veteran's Administration should undertake an engineering study of the systems conversion feasibility at this facility. The hospital is located along the Boise Front Fault and has considerable potential for successful exploration drilling at the hospital site.

\section{(4) Idaho Elk's Rehabilitation Hospital:}

The Idaho Elk's Rehabilitation Hospital is a 70,000 sq. ft., privately operated medical facility which specializes in therapy treatments. This facility is presently considering a 33\% expansion of its floor space. Design of the new wing will begin in 1979 with construction to begin in 1979 with construction to begin by 1980 .

The present heating system utilizes a natural gas boiler for a hot water heating system. The boiler water temperature is $82^{\circ} \mathrm{C}\left(180^{\circ} \mathrm{F}\right)$ and the comfort heating untis are designed for a twenty degree drop in temperature. Deliverable geothermal temperatures of $74^{\circ}$ could be supplied. This temperature water could be used for space heating but is not hot enough for the domestic hot water system of the hospital.

Conversion to geothermal energy would require installation of a heat exchanger which could be fitted parallel to the present heating system and the present boiler would be a backup unit. The domestic hot water is presently seperated from the heating water by a tube and shell heat exchanger. Retrofit of this system to geothermal would require an electrical booster to increase the domestic water temperature to $180^{\circ} \mathrm{F}$.

The present annual natural gas cost for the hospital is $\$ 15,000$ for 56,892 CCF of gas per year. Table 18-C 1ists historical energy costs and consumption for the hospital by month. Conversion cost of the present heating system to geothermal energy is approximately $\$ 11,900$. The payback for converting to geothermal energy will depend upon the type of supply system and the price of thermal water. Table 19-C lists the projected annual savings if the hospital were to drill its own well on site. "This cost does not consider the cost of the well. The estimated cost of a 450 meter well is $\$ 28,600$. Total conversion cost under this scenario is $\$ 40,500$ and the payback period is four years. Table 20-C lists the comparative cost of heating the hospital over twenty years by buying water at $\$ 0.45 / 100 \mathrm{ft} .{ }^{3}$, which is the price charged by the Warm Springs Water District. Under this price structure it would not be profitable for the hospital to retrofit to geothermal heating. Table 21-C lists the comparative economic analysis of heating the hospital by buying thermal water at $\$ 0.29 .6 / 100 \mathrm{ft} .{ }^{3}$ assuming the same return on investments as before and a retrofit cost of $\$ 11,900$ the annual savings is $\$ 11.800$. This example indicates that an analysis of price structure for thermal water is needed. 
Table 17-C

Veterans Hospital Energy Needs and Cost

Very large V.A. Hospital and Administration Complex.

Total Sq. Ft.

Heating System:

Natural Gas boilers/high temp. steam/high pressure, 1110 psi/central heating plant.

The steam is delivered to the building by pipe. Space heating is done by a combination of radiant heat and heat exchangers for water/air system.

01der buildings have steam radiators, newer buildings have water/ air systems with the water going through a heat exchanger with the steam.

Estimate that 90 psi could be used for heating purposes but 110 psi stem is needed for the laundry dry cleaning and presses.

Laundry uses about 250 Mibs/month.

Cost:

1977 Degree days: 5833

Month gas consumed MCF

Unit Cost \$/MCF

Cost $\$$

$\begin{array}{llrr}\text { July } & 1671 & 2.59 & \$, 328 \\ \text { August } & 1705 & 2.54 & 4,331 \\ \text { Sept. } & 2548 & 2.37 & 6,039 \\ \text { Oct. } & 3630 & 1.98 & 7,187 \\ \text { Nov. } & 5074 & 2.33 & 11,822 \\ \text { Dec. } & 5668 & 2.32 & 13,150 \\ \text { Jan. } & 6293 & 2.31 & 14,537 \\ \text { Feb. } & 4772 & 2.35 & 11,119 \\ \text { Mar. } & 4821 & 2.33 & 11,329 \\ \text { Aprit } & 3481 & 2.22 & 7,728 \\ \text { May } & 3347 & 2.25 & 7,531 \\ \text { June } & 1940 & 2.47 & 4,792 \\ & & & \end{array}$

TOTAL : $\quad 44,950$

Ave. 2.31 TOTAL: $\$ 103,839$

Year: $\quad \underline{1976} \underline{1975} \quad \underline{1974} \underline{\underline{1973}}$

Gas (MCF)

Consumed $44012 \quad 42792 \quad 45166 \quad 44049$

Unit Cost

\$MCF $\$ 1.85 \therefore \quad \$ 1.37 \quad \$ 0.93 \quad \$ 0.58$

Total Cost $\$ 81,285 \$ 58,423 \quad \$ 41,838 \quad \$ 25,537$

Source: Veterans Administration 
Table 18-C

Historical Energy Use and Cost

Idaho Elks Rehabilitation Hospital

\begin{tabular}{|c|c|c|c|}
\hline & CCF & THERMS & DOLLARS \\
\hline $\begin{array}{l}\text { June } 10,1975 \\
\text { Ju1y } 10,1975 \\
\text { August } 10,1975 \\
\text { September } 10,1975 \\
\text { October } 10,1975 \\
\text { November 10, } 1975 \\
\text { December 10, 1975 }\end{array}$ & $\begin{array}{l}4508 \\
2435 \\
2151 \\
\text { Not Available } \\
2136 \\
3266 \\
5498\end{array}$ & $\begin{array}{l}4377 \\
2347 \\
2020 \\
\\
2036 \\
3168 \\
5744\end{array}$ & $\begin{array}{r}771.57 \\
435.84 \\
381.76 \\
399.33 \\
439.88 \\
657.93 \\
1192.13\end{array}$ \\
\hline 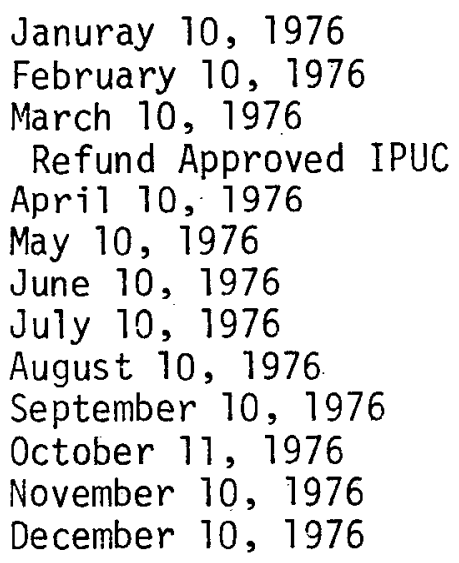 & $\begin{array}{l}6488 \\
4837 \\
3440 \\
2743 \\
1968 \\
1778 \\
2344 \\
3504 \\
5750\end{array}$ & $\begin{array}{l}6598 \\
4852 \\
3347 \\
2650 \\
1860 \\
1694 \\
2241 \\
3409 \\
5750\end{array}$ & $\begin{array}{r}1515.96 \\
1618.02 \\
1668.33 \\
(14.87 \\
1380.97 \\
1028.16 \\
724.03 \\
583.19 \\
423.55 \\
390.08 \\
500.53 \\
755.87 \\
1526.54\end{array}$ \\
\hline $\begin{array}{l}\text { January } 10,1977 \\
\text { February 10, } 1977 \\
\text { March 10, 1977 } \\
\text { Apri1 11, 1977 } \\
\text { May 10, 1977 } \\
\text { June 10, } 1977 \\
\text { Ju1y 11, 1977 } \\
\text { August 10, } 1977 \\
\text { September } 9,1977 \\
\text { October 10, } 1977 \\
\text { November 9, } 1977 \\
\text { December 10, } 1977\end{array}$ & $\begin{array}{l}7898 \\
9385 \\
7695 \\
6312 \\
4447 \\
3055 \\
2148 \\
2220 \\
2150 \\
2681 \\
3306 \\
5595\end{array}$ & $\begin{array}{l}8182 \\
9901 \\
7880 \\
6318 \\
4349 \\
2969 \\
2043 \\
2036 \\
2017 \\
2563 \\
3213 \\
5567\end{array}$ & $\begin{array}{r}2148.86 \\
2589.01 \\
2070.74 \\
1600.19 \\
1110.06 \\
764.65 \\
541.76 \\
540.08 \\
535.51 \\
666.93 \\
875.51 \\
1510.40\end{array}$ \\
\hline $\begin{array}{l}\text { January } 10,1978 \\
\text { February 10, } 1978 \\
\text { March 10, } 1978 \\
\text { Apri1 10, } 1978 \\
\text { May 10, 1978 }\end{array}$ & $\begin{array}{l}6290 \\
8044 \\
6277 \\
4980 \\
3962 \\
\end{array}$ & $\begin{array}{l}6353 \\
8213 \\
6352 \\
4920 \\
3903\end{array}$ & $\begin{array}{l}1772.24 \\
2591.92 \\
1605.93 \\
1250.22 \\
1029.62\end{array}$ \\
\hline
\end{tabular}

Source: Idaho Elk's Rehabilitation Hospital Records. 
TABLE 19-C

IDAHO ELKS REHABILITATION HOSPITAL

TWENTY-YEAR ECONOMIC ANALYSIS OF DRILLING

ON-SITE !UELL TO DEPTH OF 1,500 FEET FOR SPACE HEATING

Projected Cost

of Natura? Gas for Present System

Year

1979

1980

1981

1982

1983

1984

1985

1986

1987

1988

$\begin{array}{ll}\sim & 1989 \\ 0 & 1990\end{array}$

1991

1992

1993

1994

1995

1996

1997

1998

$52,711.56$

\begin{abstract}
Projected Cost
of Eleciricity

for Geothermal

System

See Note (2)
\end{abstract}

$$
\begin{gathered}
\$ 1,147.93 \\
1,245.50 \\
1,351.37 \\
1,466.24 \\
1,590.87 \\
1,726.09 \\
1,872.81 \\
2,032.00 \\
2,186.02 \\
2,351.73 \\
2,529.99 \\
2,721.76 \\
2,928.07 \\
3,150.02 \\
3,388.79 \\
3,645.66 \\
3,922.00 \\
4,219.29 \\
4,539.11 \\
4,833.17
\end{gathered}
$$

Projected Cost

of Operation and

Maintenance for

Geothermal System

See Note (3)

\$ 349.80

370.79

393.04

416.62

441.67

468.11

496.20

525.97

557.53

590.98

626.44

664.02

703.87

746.10

790.86

838.32

888.62

941.93

998.45
, 058.35
Annual Savings

$\$ 9,385.23$

$11,878.58$

$14,989.23$

$18,866.86$

$19,962.21$

$21,720.77$

$22,344.23$

$23,638.06$

$25,024.24$

$26,491.16$

$28,043.47$

$29,686.10$

$31,424.27$

$33,263.46$

$35,209.50$

$37,268.52$

$39,447.03$

$41,757.89$

$44,190.33$

$46,770.04$

TOTAL

$\$ 560,754.57$
Present Worth a $10 \%$

$\$ 8,532.03$ $9,817.01$

$11,261.63$

$12,886.32$

$12,394.96$

$11,921.79$

$11,466.12$

$11,027.33$

$10,612.72$

$10,213.49$

$9,829.06$

$9,458.91$

$9,102.49$

$8,759.31$

$8,428.87$

$8,170.72$

$7,804.38$

$7,509.44$

$7,225.47$

$6,952.07$

TOTAL

$\$ 193,314.12$

(1) Natural gas is assumed to inflate at $24 \%$ through 1983 and at 6\% thereafter.

(2) Electricity is assumed to inflate at $8.5 \%$ through 1936 and at $7.58 \%$ thereafter.

(3) Operation and maintenance cost is assumed to inflate at $6 \%$ annually.

Source: Chuck Highee, Oregon Institute of Technology, Geo-Heat Utilization Center. 
IDAHO ELKS REHABILITATION HOSPITAL

TWENTY-YEAR ECONOMIC ANALYSIS OF BUYING GEOTHERMAL WATER FOR SPACE HEATING

Elks Rehab.

Projected Annual Cost of

Year Natural Gas

Present Cost $\$ 8,776.58$

Geothermal

Cost of Buying at $\$ 0.45 / 100 \mathrm{ft}^{3}$

Annual Savings

Present Cost

$\$ 12,536.33$

$\$$

Present Worth

1979

$9,759.56$

$13,288.51$

$14,085.82$

$14,930.97$

1981

$10,852.63$

$12,068.12$

1982

$15,826.83$

$16,776.44$

$17,783.02$

1984

$14,922.76$

$16,594.11$

$18,452.65$

$18 ; 850.01$

$19,981.01$

$21,179.87$

$22,058.30$

$22,450.66$

$23,797.70$

$25,491.13$

$25,225.56$

$26,739.09$

$28,343.44$

$30,044.04$

$31,846.69$

$33,757.49$

$35,782.94$

$37,929.91$

$40,205.71$

$$
\begin{array}{r}
-3,528.95 \\
-3,233.19 \\
-2,862.85 \\
-2,407.08 \\
-1,853.67 \\
-1,188.91 \\
-\quad 397.35 \\
538.35 \\
878.44 \\
1,262.02 \\
1,693.43 \\
2,177.40 \\
2,719.09 \\
3,324.11 \\
3,998.57 \\
4,749.12 \\
5,583.00 \\
6,508.09 \\
7,532.94 \\
8,666.86
\end{array}
$$

TOTAL

$\$ 34,159.40$ (c $10 \%$ $\$$

$-3,208.14$

$-2,672.06$

$-2,150.90$

$-1,644.07$

$-7,150.99$

-671.11
$-\quad 203.90$

- 203.90

251.14

372.54

486.56

593.54

693.79

787.62

875.34

957.23

$1,033.55$

$1, .104 .57$

$1,170.54$

$1,231.70$

$1,288.27$

TOTAL

\$- 854.78

Source: Chuck Higbee, Oregon Institute of Technology, Geo-Heat Utilization Center. 
IDAHO ELKS REHABILITATION HOSPITAL

TWENTY-YEAR ECONOMIC ANALYSIS OF BUYING

GEOTHERMAL WATER FOR HEATING AT $\$ 0.29 / 100 \mathrm{cu} . \mathrm{ft}$.

Year

1979

1980

1981

1982

1983

1984

1985

1986

1987

1938

19,89

1990

1991

1992

1993

1994

1995

1996

1997

1998
Projected Costs
of Natural Gas

$9,759.56$

$10,852.63$

$12,068.12$

$13,419.75$

$14,922.76$

$16,594.11$

$18,452.65$

$20,519.35$

$22,058.30$

$23,712.67$

$25,491.13$

$27,402.96$

$29,458.18$

$31,667.55$

$34,042.61$

$36,595.81$

$39,340.49$

$42,291.03$

$45,462.86$

$48,872.57$

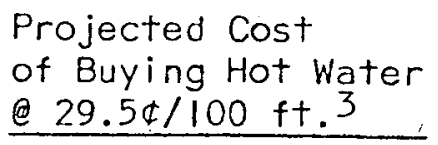

e 29.5 $4 / 100 \mathrm{ft} .3$

$8,711.36$

$9,234.05$

$9,788.09$

$10,375.37$

$10,997.90$

$11,657.77$

$12,357.24$

$13,098.67$

$13,884.59$

$14,717.67$

$15,600.73$

$16,536.77$

$17,528.97$

$18,580.71$

$19,695.56$

$20,877.29$

$22,129.93$

$23,457.72$

$24,856.19$

$26,357.10$

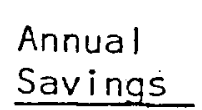

$1,048.19$

$1,618.58$

$2,280.03$

$3,044.38$

$3,924.87$

$4,936.34$

$6,095.42$

$7,420.68$

$8,173.71$

$8,995.01$

$9,890.40$

$10,866 \cdot 19$

$11,929.21$

$13,086.83$

$14,347,06$

$15,718.52$

$17,210.57$

$18,833.31$

$20,597.67$

$22,515.47$

TOTAL

$202,532.44$
Present

Worth

$30.5 \%$

803.21

950.42

$1,025.91$

$1,049.68$

$1,036.99$

999.41

945.65

882.19

744.60

627.91

529.05

445.40

374.69

314.98

264.61

222.15

186.39

155.29

130.98

109.72

TOTAL

$11,800.22$

Source: Chuck Higbee, Oregon Institute of Technology, Geo-Heat Utilization Center. 
The Capitol Mall is located less than $1 \mathrm{~km}$ from the Fort Boise geothermal we11s. The mall is considered a major market area for utilizing geothermal resources. Idaho's State Capitol Mall consists of six major office buildings, all of which are heated from a central heating plant. The present system is a natural gas fueled steam plant. The buildings presently use either hot water pumped to converters or forced air systems.

To modify the aforementioned buildings to geothermal space heating, two distinct retrofit concepts are apparent. The existing hot water system could be modified by installation of a water/heat exchanger in series with the existing steam/water heat exchanger. Modification of the forced air systems would require installation of geothermal water heating coils in the present duct work. The modification required for existing forced air systems vary from minor to major retrofits with the individual buildings.

A preliminary feasibility and conceptual design sfudy for geothermal space heating was conducted by ERDA (DOE) in 1975. (21). Initial examination indicates that with the exception of the Len B. Jordan Building, the physical conversion to geothermal heating appears to be relatively straighforward modification. Table 22-C lists by building, the estimated conversion cost and annual fuel cost. These estimates are in 1977 dollars.

The Twin Towers office building, presently under construction, is designed for an easy retrofit to geothermal energy. The major cost of this retrofit is the installation of a heat exchanger. The State Capitol Building has been partially retrofitted and also requires a heat exchanger. Both of these buildings could be retrofitted to geothermal heat as soon as the thermal fiuids are deliverable. The State of. Idaho has taken the position that geothermal energy is a realistic future option and that the state is an interested customer. 
CAPITOL MALL COMPLEX:

(Capitol Building, Len B. Jordan Building, Supreme Court, State Library, New State Office Building)

Estimated Conversion Cost in 1977 dollars

1. Len B. Jordan

$\$ 33,740$

2. Supreme Court

29,100

3. State Library

19,700

4. Ha1l of Mirrors Office Building 19,800

5. Capitol Building

$12,000^{*}$

*Because of work completed in 1977, additional conversion cost would be relatively low.
Total for (5) buildings
$\$ 114,340$

1977. Natural Gas Heating cost for the complex was $\$ 107,038$

(This number also includes the Blind Commission Building which was not considered in the initial report from INEL).

A $60 \%$ savings would pay off the conversion cost in less than 3 years. A 25\% savings would provide a payback of less than 5 years.

Source: Idaho Office of Energy 
There have been major legal and institutional barriers associated with developing geothermal resources at the Fort Boise Military Reservation. The question of resource ownership at this location has obstructed a rapid develop ment of this geothermal area. The surface estate has been split between sever titles with the city of Boise owning most of the surface estate. The city has also filed for water rights to 20,520 liters per minute on these tracts. The Federal Government held a reservation on the subsurface estate for the mineral. rights to Fort Boise Military Reservation. Under the mineral reservation the geothermal resources were also reserved to the Federal Government.

In October 1978, Congress passed a bill transferring the ownership of the geotherma resources to the City of Boise thus clearing the way for development. The City plans to begin exploration drilling by 1980. Table 23-C gives the estimated geothermal water needs of public buildings projected for geothermal space heating from the Boise Barrack geothermal field.

\section{Scenario Projections:}

Approximately $300 \times 10^{9}$ BTU/year of direct geothermal heat energy could be utilized by public buildings in the Boise Barracks and Capitol Mall areas by 1985. Table 24-C Tists the approximate direct energy needs of these buildings. This projection is based on the assumption that a district heating system providing $70^{\circ} \mathrm{C}$ water is developed using the Boise Barracks geothermal field. Table 25-C is a compendium of data regarding the Boise Barracks geotherma 1 resource area. 
Table 23-C

ESTIMATED GEOTHERMAL FLUID NEEDS FOR MAJOR PUBLIC BUILDINGS AT THE CAPITOL MALL AND THE BOISE BARRACKS

$\underline{\text { GPM }}$

Boise Barracks:

GSA Federal Building 300

State Veterans Home 438

Veterans Hospital 600

Elks Rehabilitation Hospital 200

Capitol Ma11:

State Capitol Building 227

Ha11 of Mirrors

Len B. Jordan Building 265

Supreme Court 150

State Library 170

Twin Towers

$25 \%$ Contingency 
Table 24-C

Estimated Energy Needs of Boise Barracks and

The Capitol Ma 11

Boise Barracks:

Energy Need Per Year (BTU)

GSA Building

$6.3 \times 10^{9}$

Veterans Hospital

$45 \times 10^{9}$

Elks Hospital

$5.6 \times 10^{9}$

Veterans Home

$38 \times 10^{9}$

Idaho Children's Home

$2 \times 10^{9}$

Boise BLM Office

$2 \times 10^{9}$

Co1. Pinkney Center

$\frac{3 \times 10^{9}}{101.9 \times 10^{9}}$

Capitol Mal1:

Statehouse

$21.9 \times 10^{9}$

Len B. Jordan Office

$55.8 \times 10^{9}$

Idaho Supreme Court

$28.0 \times 10^{9}$

Idaho State Library

$44.6 \times 10^{9}$

New State Office Building

$15.7 \times 10^{9}$

Health and Welfare

(approx.) $\frac{30.0 \times 10^{9}}{196.0 \times 10^{9}}$ 
Table 25-C

Data Summary for Boise Barracks Sub-Area

SITE LOCATION AND PHYSICAL DESCRIPTION

..Latitude:

$43^{\circ} 37^{\prime} 30^{\prime \prime} \mathrm{N}$

...Longi tude :

$116^{\circ} 10^{\prime \prime} 30 " \mathrm{~W}$

..Rectilinear:

T 3 N, R 2 E, Boise Meridian.

County:

Ada

Adjacent Counties:

Gem, Canyon, Elmore Owyhee

Topography: (26)

Present Land Use:

Terrain ranges from flat topography in the flood plain the Freestone Canyon steep slopes of the Boise Front Fault and Freestone Canyon. The geothermal exploration area is at the base of the fault escarpment in the flood plain.

Half of the Boise Barracks Property is open land in Freestone Canyon. Half of the property is deve1oped for a Boise City park, State Children's Home, Veterans Administration Hospital, and rest home and several small Federal Office Buildings. The property is surrounded by developed residential areas.

..Future Land Use Plans: Geothermal development is the major planned future development for the area in combination with a further development of the city park.

.. Aes thetics:

A portion of the Boise Barracks Property is deeded to the city of Boise and has been designated as the Eagle Ridge Park and Military Reserve Park. Both parks do have aesthetic natural settings. Development has occured in the flood plain area. The canyon areas occured in the flood plain area. The canyon areas are in a natural state but cut by numerous jeep trails.

..Historical/Archaeological Significance:

A historical military cemetery is located in Freestone Canyon and the Fort Boise site is a historical land mark. Possible archaeological sites are located on the property. Before any drilling or surface disturbance is allowed, a cultural resource inventory will be conducted to determine significant values. 
GEOLOGICAL/GEOPHYSICAL· DESCRIPTION

..Geologic Description:

Rock types range from Cretaceous to Pleistocene in age. The older rocks, those of the Idaho Batholith, have been uplifted, faulted and eroded. The granitic rocks are overlain by clastic beds and interrelated basalt flows of the Glenns Ferry Formation of the Idaho group. The geothermal system may be related to water of the deep artesian system in the Boise area. The warm water of the geothermal system has been found to be associated with major structural features, Tinears and major faults of the area. The water is heated at depth in deep fracture systems within the Idaho Batholith and moves along fault and fracture zones upward, mixing and heating the water found in Glenns Ferry Formation. This water is then intersected in wells tapping the Glenns Ferry sediments. The present wells are located at the intersection of the Boise Front Fault and a major NE trending linear structure. Highest production comes from wells drilled into the fracture zone of the fault.

..Geophysical Summary:

Draw down/recovery tests have been conducted on the two wells at the Boise Barracks Property. Interference testing with Warm Springs Water District wells 2 kilometers away, shows no interference between the Warm Springs wells and the Boise Barracks wells. A 3.5 psi draw down between the Boise Barracks wells is attributed to seasonal variations in the water table.

..Geologic Hazards:

Historical micro-seismic activity appears to be coincident with construction in the Boise Area. The area is thought to be aseismic by Applegate and considered potentially seismic by Idaho Department of Water Resources.

Major geologic hazard in the Boise Barracks Property is the 100 year flood cycle. The prime exploration areas are in the flood plain of Freestone and Cottonwood Canyons. 
Table 25-C (Cont'd.)

\section{RESERVOIR CHARACTERISTICS}

.. Reservoir Temperature

..Surface:

$$
77^{\circ} \mathrm{C}
$$

..Subsurface

..Geochemical :

$$
\begin{gathered}
\mathrm{SiO}_{2}: \\
\text { Na-K-Ca: } 77^{\circ} \mathrm{C}
\end{gathered}
$$

..Flow Rates: 194 to 220 gpmartesian flow during free flow test,

..pH:

8.6

. Total Dissolved Solids:

230

..Fluid Chemistry:

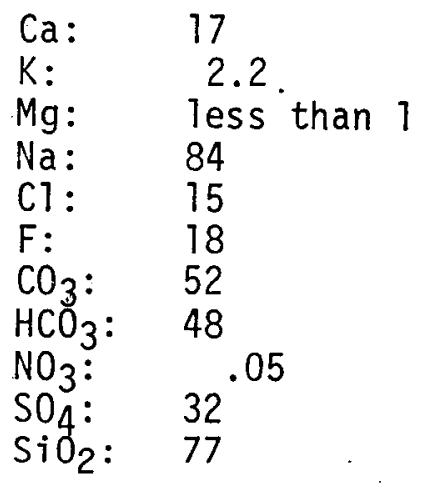

\begin{tabular}{|c|c|c|c|}
\hline $\begin{array}{l}\text { TOTAL AREA } \\
\text { (Acres) }\end{array}$ & $\begin{array}{l}\text { FEDERAL } \\
\text { (Acres) }\end{array}$ & $\begin{array}{l}\text { STATE } \\
\text { (Acres) }\end{array}$ & $\begin{array}{l}\text { PRIVATE } \\
\text { (Acres) }\end{array}$ \\
\hline
\end{tabular}

Table 25-C (Cont'd.)

LAND OWNERSHIP AND LEASING:

..Land Ownership 485

..Land Leased

.. Number of Bids Rejected:
485

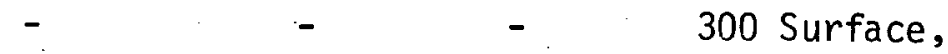
450 Subsurface File No. I-8193

..Summary of Leasing Status and Needs: No leases have been let on the federal lands due to legal problems regarding KGRA designation. The city of Boise has acquired the geothermal rights to 450 acres via an Act of Congress. 
Table 25-C (Cont'd.)

GEOTHERMAL DEVELOPMENT STATUS

..Present Development Status:

Two wells were drilled and tested by the Department of Energy to determine the nature of the resource and the size of the reservoir. Test we11 \# 1 (Beard) was completed in August, 1976, to a depth of 391 meters. The well was drilled into the fracture zone of the Boise Front Fault. Artesian flow of $195 \mathrm{gpm}$ was experienced for 12 hours. Test wel1 \# 2 (BLM) was stepped out 300 meters and drilled to a depth of 372 meters. Artesian flow of $50 \mathrm{gpm}$ was experienced for a brief period.

The U.S. Geological Survey has nominated this area for KGRA status but the Department of Interior has delayed action on the KGRA designation until further information about the site is presented. Presently the site has a split estate. The surface rights are deeded to the city of Boise and the mineral rights are reserved by the Federal Government. Boise State University has applied for a lease of the geothermal resources. The city of Boise has applied for water rights in Military Reserve Park. The Beard well is located in Military Reserve Park. The BLM well is located in the Boise District, Bureau of Land Management, utility yard. The BLM we 11 is owned totally by the Federal Government. The ownership of the resource (water) in the Beard well is unclear. No further development is expected in this area until the ownership question is resolved.

..Projected or Planned Development:

The city of Boise and the State of Idaho project development of the geothermal resources at Military Reserve Park for space heating of the Capitol Mall and the Boise Central Business District. The potential market area for the geothermal resource is within 500 meters of the site. Field development drilling is projected to begin by 1980 . 
INSTITUTIONAL CONSIDERATIONS - Federal

Institutional Requirements

Federal Geotherma1 Resource Lease (30 C.F.R. 3000)

National Environmental Policy Act (42-U.S.C. 4331)
Agency and Public Attitudes

Leases are made pursuant to the Geothermal Steam Act of 1970.

(84 Stat. 1566)

(30 USC 1001-1025)

B.L.M.

U.S.G.S.

An E.I.A. is required before leases are issued.

E.P.A.
Federal Water Pollution Control Act (33-USCA 1251)

Federal Safe Drinking Water Act (42 U.S.C. (A) 300)
The national goal of this Act is to attain -0- pollution by 1985 . E.P.A.

This Act is concerned with protection of underground water sources that could be used for domestic water. E.P.A.
Status of Requirements (i.e., EIA/EIS Requirements

Leases within the K.G.R.A. are competitive. Special conditions are required in the leases with regard to to potential archaeological and historical sites, adjacent roadless areas, and critical habitat areas.

A preliminary E.A.R. has been completed for the exploration drilling project. In general an E.I.A. is required for all projects involving exploration and development. An E.I.S. will be required for any major action.

Groundwater is included under this Act and the reinjection of geothermal effluent will require permits.

The Act sets standards for wells and well drilling and could influence future geothermal wells in the Boise area. The upper aquifer of the basin is the supply of domestic and irrigation water for the area. Reinjection of water for geothermal wells will require permits under this Act. 
Table 25-C (Cont'd.)

INSTITUTIONAL CONSIDERATIONS - LOCa1

Institutional Requirements

Special Use Permit

County Code and Zoning.

City Code and City Zoning.

Right-0f-Ways
Agency and Public Attitudes

Boise City Parks Department

Ada County

Planning Dept.

Boise City Planning Department.

Ada County Highway Commission.
Status of Requirements (i.e., EIA/EIS Requirements)

Military Reserve Park is under the jurisdiction of the City Parks Department. Any surface disturbance of the park will require a special use permit.

Permits needed for a 11 construction. Special land use permits needed for all non-conforming land uses.

Permits needed for all construction. Special use permits needed for non-conforming 1 and uses.

Grants right-of-ways for all streets and roads in Ada County including inter city streets. 


\section{ENVIRONMENTAL FACTORS}

..Prevailing Winds: 8 to $10 \mathrm{mph}$ from SE in winter, from NW in summer.

.Precipitation (Annua1): $27 \mathrm{~cm}$ (11 inches)

. Days of Sunshine (Annual): 3.10 days a year.

.. Average Temperature: Mean

January

JuTy

\begin{tabular}{|c|c|c|c|}
\hline Minimum: & $3.33^{\circ} \mathrm{C}$ & $\left(38.1^{\circ} \mathrm{F}\right)$ & $-6.2^{\circ} \mathrm{C}$ \\
\hline Maximum: & $17.22^{\circ} \mathrm{C}$ & $\left(63.7^{\circ} \mathrm{F}\right)$ & $2.2^{\circ} \mathrm{C}$ \\
\hline
\end{tabular}

..Degree Days (Annual): 5,809

.. Relative Humidity

(Seasonal Peaks)

Summer:

Winter:

..AIR QUALITY: Measured at Bureau of Air Quality, State Health and Welfare Department adjacent to Military Reserve Park. Area has same air quality as the city of Boise, which can be described as good to poor depending on the time of year and wind. Co-pollution: Auto, $19 \mathrm{ppm}$ bad day, 4 ppm good day. Particulate pollution: Dust, 150 micro-grams bad day, 50 micro-grams good day.

.. GEOLOGIC FACTORS :

Exploration area is a flood plain.

..WATER QUALITY:

Water quality is generally good. Surface water is run off from Cottonwood and Freestone Creeks drainages. Subject to seasonal floods and dry periods. Water is diverted into the irrigation network. Groundwater has high fluoride: $14 \mathrm{ppm}$.

.. Noise:

Noise levels in Military Reserve Park are low.

. BIOLOGICAL (33)

..Dominant Flora: Sagebrush-grass ecosystem, willows and elms along creeks.

..Dominant Fauna: Birds and small mammals.

..Endangered Species:

..Flora: Alesae (wild onion) 
Table 25-C (Cont'd.)

\section{TRANSPORTATION AND UTILITIES}

..Utility or Energy Transmission Corridors and Facilities

Two, $230 \mathrm{kv}$ lines are within 5 kilometers of the site, owned by Idaho Power Co. One $138 \mathrm{kv}$ line is at the site also owned by Idaho Power Co. Residential lines are adjacent to property. Telephone, natural gas and water lines are within 100 meters of the site.

\section{. Transportation Corridors or Facilities}

Several paved city streets lead to the area. Reserve Street is the main access to the area. Mountain Cove Road and Cottonwood Canyon Road are unimproved roads that extend into the nonurban area. Numerous jeep trails lead off these roads.

A11 right-of-ways along city streets and county roads are controlled by the Ada County Highway District.

\section{POPULATION}

\section{.General Description of Population}

The city of Boise has an approximate population of 100,000 people. High density urban population center at the resource site is a mix of residential and business development.

\section{.. Economics}

The City of Boise has experienced an $18 \%$ growth rate for the last five years. This trend is expected to continue. The city is experiencing a period of major redevelopment. The Boise Central Business District is the site of the Boise Redevelopment Project. This planned revitalization of Boise city's downtown core has stimulated the private sector to initiate several projects. Buildings have been rehabilitated, reinforcing the concept of a Renaissance in the Central Business District. Several new office buildings have been completed and a regional shopping center and mall complex is proposed for one six block area. Tapping Boise's geothermal resource is a factor in developing a downtown regional center into the first geothermally heated shopping; all in the nation. Wider use of the hot ground water for space heating is being studied. The State Capitol. Mall is also undergoing a major construction period. New office complexes and parking garages are presently under construction. Geothermal heat is also being considered for new and old buildings of the Capitol Mall. 
Camels Back Park is a 150 acrea which lies at the mouth of Hull's Gulch. Hull's Gulch is a northeast trending linear structure which can be traced for two kilometers. The park lies directly over the trace of the Boise Front Fault and at the intersection of the fault and the Hull's Gulch linear structure. The fault forms a major topographic break between the Boise Foothills and the Boise River Flood Plain.

North of the fault, the stratigraphy is typical of the Glenns Ferry Formation. South of the fault the stratigraphy is typical of the Snake River Plain. This fault scarp also marks a major change in land use. South of the fault scarp the park is a developed, high intensity use area. This part of the park is surrounded by high density single family housing. North of the fault the park area and surrounding land are largely undeveloped foothills.

Reconnaissance geology indicates that the structural geology of this area is similar to the structure of other geothermal areas along the Boise Front Fault. Although no thermal waters are known at this site; the intersection of the Hull's Gulch linear feature and the Boise Front Fault make this area a logical exploration site. Thermal wells of the Boise Military Reservation are located 2.4 kilometers southwest of Camels Back Park. Thermal wells of the Stuart Gulch area are located 2 kilometers northwest of Camels Back Park. These thermal wells were drilled into the shear zone of the Boise Front Fault at linear intersections.

The similarity of structural geology between known geothermal production zones supports the probability of successfully intersecting of the resource elsewhere along the Boise Front Fault. Camels Back Park exhibits those structural characteristics which indicate a probable drilling site.

Because the city of Boise owns both the surface and subsurface rights to Camels Back Park, the city has selected the park as a well field site. Future geothermal wells developed at the park could be used for space heating Boise's Central Business District. In addition to mineral ownership, the city has filed water right applications for 2.28 liters per second from three productions wells to be drilled in the park. (34) At present there is no known resource data for this area.

Boise's Central Business District is presently undergoing a major urban redevelopment. Clearing of old structures has already taken place and new constructions will begin by 1980 . Local planning calls for geothermal heating of new structures in the redevelopment area. In addition to future structures, several existing buildings have been identified as potential retrofit customers. These buildings are listed in Table 26-C 
In addition to the market potential of the Central Business District, there are approximately 7,000 residential structures located between the Boise Front Fault and the central business area which could be potential customers for a geothermal heating district. Table 26-C identifies the Central Business District Buildings which are prospective users of a geothermal district heating system and their approximate direct heat energy needs.

Scenario Projection:

Approximately $665 \times 10^{9}$ BTu per year of direct heat utilization of geothermal resources could be accomplished by 1985 provided geothermal well field development begins by 1980 . 
Table 26-C

IDENTIFIED PROSPECTIVE GEOTHERMAL HEAT USERS IN BOISE CBD

Boise City Hall

Idaho Employees Credit Union Building

Ada County Courthouse

Ada County Administration Building

Boise Cascade Corporate Headquarters

Hotel Boise

East Junior High School

First National Bank Office Building

North Junior High School

Adams Elementary School

Boise High School

St. John's Cathedral

St. Luke's Hospital

Approximate Energy Needs $200 \times 10^{9}$ BTU/yr.

Boise Redevelopment Area- 15 acre Redevelopment:

New Construction- Ma11 Retail Shops $\quad 447,000 \mathrm{sq}$. ft.

Civic Center $\quad 90,000 \mathrm{sq}$. ft.

Hotel $200,000 \mathrm{sq}$. ft.

Offices $\quad 200,000 \mathrm{sq}$. ft.

Energy Needs $\quad 242.8 \times 10^{9}$ BTU/yr.

11 Other Downtown Businesses

$221.4 \times 10^{9} \mathrm{BTU} / \mathrm{yr}$.

TOTAL:

$664.2 \times 10^{9}$ BTU/yr. 
This report has identified four major resource locations in the Boise Urban Area. Legal institutional relationships and market potential vary with each location. All four of these locations could be developed. Initial development scenarios could be targeted toward adjacent market areas with the Boise Central Business District being a common market area. Pipelines leading from the various geothermal fields along the Boise Front Fault could be designed for a pooled delivery system in the Central Business District.

Future wells developed on the Penitentiary Grounds could service state buildings at this site and excess production could be tied into the Warm Springs Water District main line. The Warm Springs Water District will continue to service the residential area of northeast Boise. Additional new wells at Warm Springs and Penitentiary Grounds would allow the Water District to extend its lines into the Central Business District and Boise State University. Wells developed on the Fort Boise Military Reservation could service public buildings in the Boise Barracks property, the Capitol Mall area and St. Luke's Hospital. Excess flow from this system could logically be tied into the Warm Springs Water District lines to service the Central Business District. Wells developed in Camels Back Park should be used to service residences in north Boise and the Central Business District.

\section{Disposal Systems}

Any development scenario for the Boise Urban Area should have a disposal system which parallels the delivery system. The disposal system could collect the geothermal fluid after it is utilized by the primary customers. The collected fluids could then be utilized for heat pumps in additional residential and commercial buildings.

With respect to ultimate disposal of geothermal waste water, temperature and fluoride constitute two of the major parameters influencing ecological systems. A third major parameter is the recharge needs of the aquifer. Three disposal methods are possible: (1) disposal into the Boise River, (2) injection of the fluids into the ground, and (3) disposal into the irrigation canal system.

The use of the Boise River for disposal could have a major effect on the aquatic environments. An increase in temperature can alter the behavior and development of aquatic species. Feeding and reproductive behavior in relation to food-chain species could be damaged. The sensitivity of aquatic life to toxic materials is generally enhanced by higher temperatures. Increased temperature wi11 result in a decrease in dissolved oxygen which can damage the reproduction and behavior of cold-water fish and other aquatic species. Algae growth can be enhanced by increase in temperature. Blue-green algae are the dominate producers at temperatures above $35^{\circ} \mathrm{C}$ and blue-green algae produce compounds which are toxic to fish, lives tock and humans.

Fluorine, chemically bound as fluoride is common in the thermal wells of the Boise Urban Area. Vegetation, animals and humans are susceptible to fluoride toxicity. Fluorides present a particular hazard to animals 
since vegatation may accumulate fluoride in amounts sufficient to cause fluorosis. Fluoride concentrations of water as low as 2-7 ppm can cause discoloring of tooth enamel in humans. The U.S. Public Health Service has set 1.4 to $2.4 \mathrm{ppm}$ as the maximum permissible limits of fluoride in public drinking water. Boise wells have fluoride concentrations of 8 to $22 \mathrm{ppm}$ in thermal waters.

With regard to fluoride and thermal pollution, disposal into the Boise River would be an ecologically unsound alternative. The Boise geothermal system when fully constructed would be discharging geothermal water at a rate greater than 5,000 gal/min. Even if this water was cooled sufficiently, the average fluoride count of $20 \mathrm{ppm}$ would require a river flow rate greater than $400 \mathrm{cfs}$ for the fluoride level to be diluted to $1 \mathrm{ppm}$. Winter flow rates in the river will coincide with the maximum disposal rate, $(35)$ and dispersal of the fluoride waters in the river would be unrealistic.

Injection of the thermal fluids into the ground will depend upon two factors: (1) Cost, (2) Aquifer recharge needs. The cost of injection must consider not only the cost of drilling injection wells but the energy cost of injection. Net energy must be considered. Aquifer recharge needs may require that thermal fluids be injected into the same geothermal systems from which fluids were withdrawn. In the areas of potential well interference, this may be the only alternative which is feasible.

The third alternative is to discharge the fluids into a storage pond for irrigation. Direct discharge into an irrigation system in the winter may have the same ecological problems as discharge into the Boise River. Discharge into a storage area would avoid major ecological problems. The stored geothermal waste water could then be dilluted with spring and summer irrigation flows. Sufficient area already exists near the Boise city sewer treatment plant for the construction of one storage facility and additional areas along the irrigation canals could also be used for storage. 
The West Boise geothermal area is divided into four subareas. The subareas are Crane Creek Gulch, Stewart Gulch, Polecat Gulch and Pierce Gulch. These four gulches are linear features which trend northeast from the Boise Front Fault into the Boise Foot Hills. These linear features are rather straight ground trends which are controlled by some form of planar discontinuity related to the granite bedrock of the region. Thermal waters are known to exist in Crane Creek, Stewart and Pierce Gulches. The highest temperature thermal waters are found at the intersection of Stewart Gulch and the Boise Front Fault. All four areas are considered potential geothermal exploration areas with the highest potential geothermal exploration areas with the highest potential areas being located at the intersection of the Boise Front Fault and the northeast trending linear features. The Boise Front Fault forms a major topographic break which separates the Boise Foothills from the Boise River Flood plain. North of the fault, the geology is dominantly Glenns Ferry Formation sediments. South of the fault the geology is primarily Snake River Plain stratigraphy.

Land use in the area also shows marked contrast along the fault scarp. North of the fault, the area is largely undeveloped open space. South of the fault, the area is largely low density residential. Present county zoning ordinances limit construction in the foothills to areas with less than 12 degree slope which has limited construction in the foothills to the stream valieys. Increased residential growth south of the Boise Front Fault is beginning to expand into the foothill's gulches. The gulches near the Boise Urban Area are experiencing rapid development and plans have been submitted to develop the other gulches. Table 27-C 1ists the projected geothermal resource development for West Boise.

Thermal waters in the area have temperatures of $40^{\circ} \mathrm{C}$ to $50^{\circ} \mathrm{C}$. Most of the thermal wells are shallow irrigation wells and domestic water wells. Expanded use of these thermal waters for space heating of new residential developments is logical. The geothermal development potential of the four subareas is presented by area, in the order of the locations occurence alang the Boise Front Fault, from east to west. Table 28-C is a compendium of data regarding the geothermal energy commercialization potential of the West Boise Geothermal Area. 
West Boise Projected Geothermal Heat Utilization

Crane Creek

El Pelar 200 units

250 other units

Stewart Gulch

2 greenhouses

1 school

100 residential units

Pole Cat Gulch

100 units

200 units

Pierce Gulch

100 units

$$
\text { TOTAL: } \quad \frac{54 \times 10^{9}}{521 \times 10^{9}}
$$

(BTU)

$108 \times 10^{9}$

$135 \times 10^{9}$

$5 \times 10^{9}$

$3 \times 10^{9}$

$54 \times 10^{9}$

$54 \times 10^{9}$

$108 \times 10^{9}$

Projected Completion Data: 1990 
The Crane Creek Gulch geothermal area is located within the city limits of Boise, Idaho at the north end of Harrison Boulevard. The area is presentiy undergoing rapid residential development. The one thermal well which is located in Crane Creek Gulch is an old oil and gas exploration well drilled in the 1930's along Cartwright Road. It has a water temperature of $48^{\circ} \mathrm{C}$ but was poorly cased and has a mixing of thermal and cold water aquifers. The well is approximately 1000 meters deep. Cold water enters the well at 137 meters and hot water enters the well at 427 meters. The well has a pump test temperature of $48^{\circ} \mathrm{C}$ and the temperature of the hot water aquifer is estimated to be in the $70^{\circ} \mathrm{C}$ range. Recently, the well was reworked and recased and cement plug was placed in the well at 230 meters to cut off the hot water. The upper portion of the well has a perforated casing for cold water. Approximately $1700 \mathrm{gpm}$ of cold water can be produced from the upper portion of the well.

This well is presently used as the domestic water source for the El Pelar Estates subdivision, located at the well head. (37) Approximately 50 homes are under construction at the location. Plans call for an additional 150 homes to be built at El Pelar in the next five years. All of the present structures use air to air electrical heat pumps for heating and cooling. Present homes could be retrofitted to water to air heat pumps using the thermal water. Future homes in the area could be geothermally heated with water to air heat pumps utilizing the existing well. Drilling of additional thermal wells in the area is not expected. The present developer does not consider the geothermal potential an option. In addition to the El Pelar Estates subdivision, there are over 500 residential structures in the Crane creek Gulch area.

\section{Stewart Gulch Subarea}

The Stewart Gulch geothermal area is located at the intersection of $\mathrm{Hi} 11$ Road and North $36 \mathrm{th}$ Street. Geothermal resources have been used at this location since 1940. Thermal wells in this area are presently used to heat two large commercial greenhouse operations and an apartment house. The greenhouses raise cut flowers and bedding plants for the Boise area. It is estimated that these greenhouses save approximately $\$ 20,000 /$ year in heating costs.

The area has the same structural geology as the other geothermal areas along the Boise Front Fault. Stewart Gulch is a north trending linear which intersects the Boise Front Fault at the location of the thermal wells.

The area south the Hill Road is a high density housing area. An expansion of the geothermal resource for space heating is possible in this area. Any expansion of the resource will be 7 imited by prior appropriations of thermal water for the present greenhouses and for agricultutal irrigation wells north of Hill Road. 
The area north of Hill Road is presently used for agriculture with a large cattle ranch as the principle land holder. Present land owners are reluctant to develop the area for high density housing. If residential development does occur, the geothermal resources of the area could be used for space heating. Irrigation wells north of the fault have temperatures of $43^{\circ} \mathrm{C}$.

\section{Pole Cat GuTch Subarea}

Pole Cat Gulch is located along Hill Road, $2.5 \mathrm{~km}$ west of Stewart Gulch. No drilling has occurred in this area and there are no known occurences of thermal water. The geological similarity and close proximity to other geothermal areas makes this area a prime exploration area. Thermal waters are known to exist in Pierce Gulch $2.5 \mathrm{~km}$ east of Pole Cat Gulch. Like other geothermal areas in the Boise area, Pole Cat Gulch is a northeast trending linear feature leading away from the Boise Front Fault.

Pole Cat Gulch is presently undergoing rapid residential development. Approximately 50 homes have been constructed in the Gulch and an additional 100 apartment units have been constructed at the mouth of the Gulch along the Boise Front Fault. A large market for residential space heating also exists south of the gulch where several new subdivisions (approximately 400 homes) are presentiy under construction.

Exploration drilling is needed in the Pole Cat Gulch area to prove the resource. Discovery of an $80^{\circ} \mathrm{C}$ geothermal resource could lead to large scale geothermal space heating. Sewer services were extended into this area in 1978 and a rapid development of residential areas is expected in the near future.

\section{Pierce Gulch Subarea}

Located $2.5 \mathrm{~km}$ west of Pole Cat Gulch, Pierce Gulch is a north trending linear feature along the Boise Front Fault, with similar structural geology as other geothermal areas in the Boise area. Thermal waters are known to exist in six private wells located in the Gulch, These wells are shallow water wells with temperatures of around $30^{\circ} \mathrm{C}$.

Less than a dozen homes have been built in Pierce Gulch. Residential development in this area has been restricted due to the agricultural zoning and the Boise Foot Hills Ordinance which limits construction to areas with less than a 12 degree slope.

Future development in the Gulch is not expected until, adequate sewer services have been expanded to the area. The Boise Master Sewer Plan calls for extending the State Street trunk line to Pierce Gulch when the demand for the line has provided all the financial commitments. (10). Increased residential growth is expected south of $\mathrm{Hill}$ Road at the mouth of Pierce Gulch. Developers have submitted plans to subdivide this area and development is expected between 1979 and 1985. (9)

The advent of this growth will create a demand for sewer services and a market for development of geothermal resources for space heating. 
The Dry Creek geothermal area is located outside of the Boise Urban area, $5 \mathrm{~km}$ north of Eagle, Idaho, at the confluence of Spring Valley Creek and. Dry Creek. State Highway 1.5 passes directly through the area. Present land use is primarily agricultural in Dry Creek Valley, residential in Spring valley and residential in the foothills surrounding the area. Dry Creek valley and Spring Valley are structurally controlled and the known thermal waters of the area are thought to be associated with this structural control. Faulting in the area is probably related to the Boise Front Fault.

Known thermal waters in the area are associated with domestic water wells in the Spring Valley Subdivision and irrigation wells in Dry Creek valley. Four thermal wells are used for space heating and one well is utilized for a commercial greenhouse operation. These wells are low temperature, $26^{\circ} \mathrm{C}$, thermal wells. Wells in this area are probably capable of producing higher temperature water if cased properly to prevent mixing of cold and hot waters.

The types of uses that are feasible are limited by the legal parameters and market density. Increased residential growth is expected but geothermal heating will probably be on an individual basis. Present zoning in the area calls for a minimum lot size of 5 acres as a district heating system has limited practicality in such low density developments. High density housing. will not be allowed in this agriculturally zoned area, unless all the utilities, sewer, and streets are provided by the developer. Subdivisions are also limited by the $12 \%$ slope restrictions in the Boise Foothills Ordinance, and county zoning which restricts zone changes to 50 acre minimum blocks. If a developer is capable of building a subdivision of approximately 50 acres in' size and owns land in the flatter areas of Dry Creek Valley, then a.geotherma: district heating system would be possible and logical. One major property owner in: the Dry Creek Valliey is considering drililing for geothermal resources with the intent to develop the resource for space heating a low density cluster home development. The concept involves one well providing a cluster of homes with hot water space heating with several. clusters to a subdivision of 50 acres. (9)

The Dry Creek Valley geothermal area has a high potential for developing an agricultural related geothermal utilization. The development of a geothermally heated cattle feed lot would be advantageous at this location. Such an enterprise would be in compliance with the zoning which allows for agriculture related industries. The area has a unique combination of factors which indicate that a geothermally heated feedlot operation would be possible. These factors are:

(1) The present 017 and gas well which yields $43^{\circ} \mathrm{C}$ thermal water is capable of providing the energy for space heating.

(2) This well is located $.4 \mathrm{~km}$ from Highway 15.

(3) The local agriculture already supports a major cattle operation.

(4) The present open air feed lot for the cattle operation is $.2 \mathrm{~km}$ from the geothermal we 11 . 
(5) Technical studies have shown that geothermally heated feed lots will increase cattle weight and shorten production time.

(6) Local alfalfa production can provide the necessary feed.

(7) The same land owner owns the cattle operation and the thermal we11. 
Table 28-C

Data Summary for the West Boise Geothermal Area

SITE LOCATION AND PHYSICAL DESCRIPTION:

..Latitude: $\quad 43^{\circ} 36^{\prime} \mathrm{N}^{(26)}$

..Longitude: $116^{\circ} 12^{\prime} \mathrm{W}(26)$

..Rectilinear: $T 3 N, R 2 E$, Boise Meridian

..County: Ada

..Adjacent Counties: Boise, Canyon, Elmore, Gem, Owyhee

..Topography: (26) South of the Boise Front Fault is an area which has a flat topography. North of the Boise Front Fault slopes of the Boise Foothills typicallv range from 10 to 20 percent. Stewart Gulch and Dry Creek Valley are wide flat bottomed stream valleys in the Boise Foothills. Pierce and Pole Cat Gulches are steep narrow stream valleys.

..Present Land Use:

The area north of the Boise Front Fault is largely undeveloped. South of the Boise Front Fault the land area is dominantly high density housing.

..Future Land Use Plans:

Existing agricultural areas in Dry Creek and Stewart Gulch will remain stable. All other areas are subject to residential expansion.

..Aesthetics: High aesthetic values in Stewart Gulch and Dry Creek. Moderate aesthetic value in other areas.

GEOLOGICAL/GEOPHYSICAL DESCRIPTION

..Geologic Description: (1)

Pleistocene Basalts and Sandstones of the Glenns Ferry Formation are the major rock types of the area. The Glenns Ferry Formation unconformably overlies Cretaceous Granite of the Idaho Batholith. Known thermal waters of the West Boise Area are found at the intersection of the Northwest trending linear features.

. Geophysical Summary:

No geophysical data available.

. Geologic Hazards:

No major hazards. 
(Table 28-C (Cont'd.)

RESERVOIR CHARACTERISTICS

.. Reservoir Temperature

.. Surface: $27^{\circ} \mathrm{C}$ to $40^{\circ} \mathrm{C}$

. Subsurface: $76^{\circ} \mathrm{C}(1)$

..Flow Rates: $10 \mathrm{gpm}$ to $1000 \mathrm{gpm}$

..pH:

$8.6(1)$

..Total Dissolved Solids: 200 to 250

LAND OWNERSHIP AND LEASING

$\begin{array}{llccc}\begin{array}{c}\text { TOTAL AREA } \\ \text { (Acres) }\end{array} & \begin{array}{l}\text { FEDERAL } \\ \text { (Acres) }\end{array} & \begin{array}{c}\text { STATE } \\ \text { (Acres) }\end{array} & \begin{array}{c}\text { PRTVATE } \\ \text { (Acres) }\end{array} & \text { OTHER } \\ & & & \end{array}$

..Land Ownership

$1280 \quad 20,000$

..Land Leased

$--\quad 6,640$

.. Summary of Leasing Status and Needs:

Approximately 6,640 acres of private geothermal leases have been filled with the Ada County Recorder.

GEOTHERMAL DEVELOPMENT STATUS

..Present Development Status:

Wells in Stewart Gulch are used for space heating two commercial greenhouses of approximately 22,000 square feet each, and an apartment house. 3 wells in Pierce Gulch and one well in Dry Creek Valley are used to spaceheat individual homes.

..Projected or Planned Development:

Extensive development of the geothermal resource for space heating is projected for all areas. At present the Boise West Area is undergoing rapid residential development of about $20 \%$ per year. 
INSTITUTIONAL CONSIDERATIONS -(Federa 1 )

Institutional

Requirements

Federal Water Pollution Control Act (33-USCA 1251)

Federal Safe Drinking Water Act

(42 U.S.C. (A) 300)
Agency and

Public Attitudes

The national goal of this

Act is to attain -0pollution by 1985 . E.P.A.

This Act is concerned with protection of underground water sources that could be used for domestic water.

E.P.A.
Status of Requirements (i.e., EIA/EIS Requirement

Groundwater is included under this Act and the reinjection of geotherma? effluent will require permits.

This Act sets standards for wells and well drilling and could influence future geothermal wells ir the Boise area. The uppe aquifer of the basin is th supply of domestic and irrigation water for the area. Reinjection of wate for geothermal wells will require permits under thi Act. 
INSTITUTIONAL CONSIDERATIONS - (State)

Institutional

Requirements

Leases on state lands

(Idaho Code 47-601

et. seq. Chapter 16, Geotherma 1 Resources)

Geothermal Resource

Permits.

(Idaho Code 42-4001

et. seq. Chapter 40, Geothermal Resources)

Water Appropriation (Idaho Code 42-101 et. seq. Chapter 1 Water Appropriation)

Injection wells (Idaho Code 42-3001 et. seq. Chapter 39 Waste Disposal and Injection Wells.)
Agency and

Public Attitudes

The state board of Land Commissioners is authorized to issue leases for geothermal resources underlying state and school lands.

The regulatory powers of the State Geotherma1 Resource Act are placed in the Idaho Department of Water Resources.

The Idaho Department of Water Resources issues water appropriation permits and a water right license.

Permits are issued by the Department of Water Resources.
Status of Requirements (i.e., EIA/EIS Requirements)

Lease term is 10 years and can be continued with diligent development. Rentals are set by the board. Several leases have been granted on state lands. Lease size is limited to a maximum of 640 acres/lease.

Any private owner, or holder of a state or federal lease of geothermal resources must first apply for a geothermal resource permit from I.D.W.R. before any drilling operations can begin.

Under the Idaho Geothermal Resources Act, applicants can be required to make an application to appropriate the public waters of the state.

No waste disposal or injection well can be constructed in Idaho unless a permit has been issued by I.D.W.R.. The approval of this permit is contingent upon the approval of the Department of Health and Welfare. The proposed well is reviewed to see if it will unreasonably contaminate or deteriorate the quality of the groundwater below the adopted water quality standards of the state. 
Table 28-C (Cont'd.)

INSTITUTIONAL CONSIDERATIONS - LOCa 1

Institutional

Requirements

County Code

and Zoning.

City Code and

City Zoning.

Right-Of-Ways
Agency and

Public Attitudes

Ada County Planning

Department.

Boise City Planning Department.

Ada County Highway Commission.
S.tatus of Requirements (i.e., EIA/EIS Requirements)

Permits needed for all construction. Special land use permits needed for all nonconforming land uses.

Permits needed for all construction. Special use permits needed for nonconforming land uses.

Grants right-of-ways for all streets and roads in Ada County including intercity streets. 
ENVIRONMENTAL FACTORS

. . CLIMATE (32)

..Prevailing winds: $\quad 8$ to $10 \mathrm{mph}$ from southwest in winter, from northwest in summer.

..Precipitation (Annual): $26 \mathrm{~cm}$

..Days of Sunshine (Annual): 320

.. Average Temperature:

...Min imum:

January July

...Maximum:

$-6.2^{\circ} \mathrm{C}$

$14.7^{\circ} \mathrm{C}$

$22^{\circ} \mathrm{C}$

$32.4^{\circ} \mathrm{C}$

..Degree Days (Annua T)

5,835

. Relative Humidity

(Seasona 1 Peaks)

Summer :

$20 \%$

Winter:

$70 \%$

..AIR QUALITY: High to moderate quality depending on the air quality in Boise.

..GEOLOGIC FACTORS: Erosion problems on steep slopes.

..WATER QUALITY: High Fluoride count in thermal wells in Boise Area 14-18ppm.

..NOISE: $\quad$ Low noise levels.

BIOLOGICAL:

..Dominant Flora: Sagebrush - grass ecosystem

..Dominant Fauna: Deer and small mammals.

TRANSPORTATION AND UTILITIES:

..Utility or Energy Transmission Corridors and Facilities

One $138 \mathrm{kv}$ line is located at the area, access is owned by Idaho Power.

Two $238 \mathrm{kv}$ lines are located 2 kilometers from the area, access is owned by Idaho Power.

.. Transportation Corridors or Facilities:

Hill Road-paved

Cartwright Road-gravel 
Table 28-C (Cont'd.)

POPULATION

..General Description of Population:

The high density urban residential housing area south of the Boise Front FauTt has an estimated population of 30,000 people. North of the Boise Front Fault the population density drops off sharply. Scattered homes exist in Dry Creek Valley, Pierce, Pole Cat and Stewart Gulches. Crane Creek Gulch has been developed into a major moderate density residential area.

\section{.. Economics :}

The west Boise Area is one of the fastest growing residential areas of Boise. Rapid expansion of residential housing in this area has already begun. Limited space close to Boise and planning restrictions to growth south of the city have made the West Boise Area a primary development area. All areas in West Boise are growing at a rate of $20 \%$ per year. 
Ada County has a large number of recorded private geothermal leases. The majority of these leases are located along the Boise Front Fault although some are recorded for southern Ada County. Approximately 25,000 acres of land in Ada County has been leased for geothermal resource, $0 i 1$ and gas resources, and mineral resources. Table 29-C 1ists the energy leases that have been recorded in Ada County.

\section{Summary Ada County}

Development of the geothermal resources of Ada County could make a significant contribution to Boise's direct energy needs. The geothermal resources could be used for space heating of commercial, and residential buildings with an estimated 2.5 trillion BTU/year of direct heat utilization realistically obtainable by the year 2020. Table 30-C is a summary of the estimated geothermal development that is projected for each Subarea. The major restrictive factors that could hinder this development are aquifer recharge needs and disposal of waste fluids. The geothermal fluids of the area have high concentrations of fluoride which will limit surface disposal. Alternative disposal methods are needed. 
Table 29-C

MAJOR LEASES RECORDED IN ADA COUNTY COURT

\begin{tabular}{|c|c|}
\hline Lessee & Lease \\
\hline Joe Kanta & $\begin{array}{l}\text { Geothermal State } \\
\text { Land Lease }\end{array}$ \\
\hline Joe Kanta & Geo.St. Land Lease \\
\hline Gutf $0 i 1$ & Steam 1 \\
\hline Gulf $0 i 1$ & Steam \\
\hline Joe Kanta & $\begin{array}{l}\text { Geothermal Ida. St. } \\
\text { Land Lease }\end{array}$ \\
\hline Gulf $0 i 1$ & Steam ${ }^{1}$ \\
\hline $\begin{array}{l}\text { Gulf } 0 i 1 \\
\text { Gulf } 0 i 1\end{array}$ & $\begin{array}{l}\text { Steam } \\
\text { Steam }\end{array}$ \\
\hline Joe Kanta & $\begin{array}{l}\text { Geothermal State } \\
\text { Land Lease }\end{array}$ \\
\hline Gulf $0 i 1$ & Steam ${ }^{1}$ \\
\hline $\begin{array}{l}\text { Oxy Petroleum } \\
\text { 0xy Petroleum } \\
\text { 0xy Petroleum } \\
\text { Oxy Petroleum }\end{array}$ & $\begin{array}{l}\text { Geothermal Lease } \\
\text { Geotherma1 Lease } \\
\text { Geothermal Lease } \\
\text { Geothermal Lease }\end{array}$ \\
\hline $\begin{array}{l}\text { Oxy Petroleum } \\
\text { Oxy Petroleum }\end{array}$ & $\begin{array}{l}\text { Geothermal. Lease } \\
\text { Geothermal Lease }\end{array}$ \\
\hline $\begin{array}{l}\text { 0xy Petroleum } \\
\text { 0xy Petroleum } \\
\text { 0xy Petroleum } \\
\text { Oxy Petroleum }\end{array}$ & $\begin{array}{l}\text { Geothermal Lease } \\
\text { Geothermal Lease } \\
\text { Geothermal Lease } \\
\text { Geothermal Lease }\end{array}$ \\
\hline Standard $0 i 1$ & 0il, Gas, Mineral \\
\hline Standard $0 i 1$ & 0il, Gas, Mineral \\
\hline $\begin{array}{ll}\text { Standard } & 0 i 1 \\
\text { Standard } & 0 i 1\end{array}$ & $\begin{array}{l}\text { 0i1, Gas, Mineral } \\
\text { 0i1, Gas, Mineral }\end{array}$ \\
\hline Oxy Petroleum & Geothermal Lease \\
\hline Gulf $0 i 1$ & Steam ${ }^{1}$ \\
\hline
\end{tabular}

Nancy Anschutz

$0 i 1$ \& Gas
$3 \mathrm{~N} 2 \mathrm{E} \quad 12 \mathrm{dC}$

$13 a, b a, p t . c$

3N3E lab,ac,bd, lot 4 $2 \mathrm{a} a, \mathrm{ab}, \mathrm{da}, \mathrm{bd}, \mathrm{ca}$ Lots $2,3,4,5,6$ Joe Aldape e

$6 b b, b c, c, b d, a c$, $a d, d a, d b$

$7 d$

$8 c, d, a c, a d, b a, b c$,

$b d, a b b$

$9 b, c a, c b$

Joe Aldape

Joe Aldape
$17 a b, a c, a d, b a, b b$, $b d, d$

State of Ida

$18 a a, a b, a c$

4N1W 15 lots 7.8

15 ptc

16 lot 3

1630 acres by lot

21 lot 1,ad,da

$21 a, b b, b c, p t c$

$22 a b b, a b c, a c b$, $a c c, b b, b c, 1$ ot 1

$22 b b, b c, c b$

$22 a a b, a a a$

$22 \mathrm{aac}, \mathrm{a} a \mathrm{c}$, dod, ad,

4NTW 22aca,acb

23 lot 2, ac,ac, $b c, b d, c$ 26bb, bcaa, bcab, bcba, bcbb

4N1W $26 \operatorname{tax} 2$

$28 a b, a c$

4N2E 1 lots $1,2, a c, b d a$,

Joe Aldape

Pete Anchust

Elias Aldape

Elsie Duncan

Elias Aldape

Elias Aldape Hattie Broge

Flias Aldape Elsie Duncan Lee Ows ley Helen Simpso

Helen Simpso

Helen Simpso

Helen Simpsol Jimmie Jämes

Travis Duncal

bdd, cb,cc

1 lots $1-4$, ac, ad

$b c, b d, c d, d b, d c$

2 lots 2,3,4,ac,
Joe Aldape e

U.S. BL 


\begin{tabular}{|c|c|}
\hline Lessee & Lease \\
\hline Nancy Anschutz & $0 i 1$ \& Gas \\
\hline Nancy Anschutz & 011 \& Gas. \\
\hline $\begin{array}{ll}\text { Gulf } & 0 i 1 \\
\text { Gulf } & 0 i 1\end{array}$ & Steam ${ }^{1}$ \\
\hline Gulf $0 i 1$ & Steam \\
\hline Gulf $0 i 1$ & Steam \\
\hline Gulf $0 i 1$ & Geotherma 1 \\
\hline Gulf $0 i 1$ & Geotherma \\
\hline $\begin{array}{l}\text { Gulf } 0 i 1 \\
\text { Gulf } 0 i 1 \\
\text { Gulf } 0 i 1\end{array}$ & $\begin{array}{l}\text { Geothermal } \\
\text { Geothermal } \\
\text { Geothermal }\end{array}$ \\
\hline Gulf $0 i 1$ & Geotherma 1 \\
\hline Gulf $0 i 1$ & Geotherma 7 \\
\hline Gulf $0 i 1$ & Steam ${ }^{1}$ \\
\hline $\begin{array}{l}\text { Gulf } 0 i 1 \\
\text { Gulf } 0 i 1\end{array}$ & $\begin{array}{l}\text { Steam } 1 \\
\text { Steam }\end{array}$ \\
\hline
\end{tabular}

Transcontinental

$0 i]$
Mining

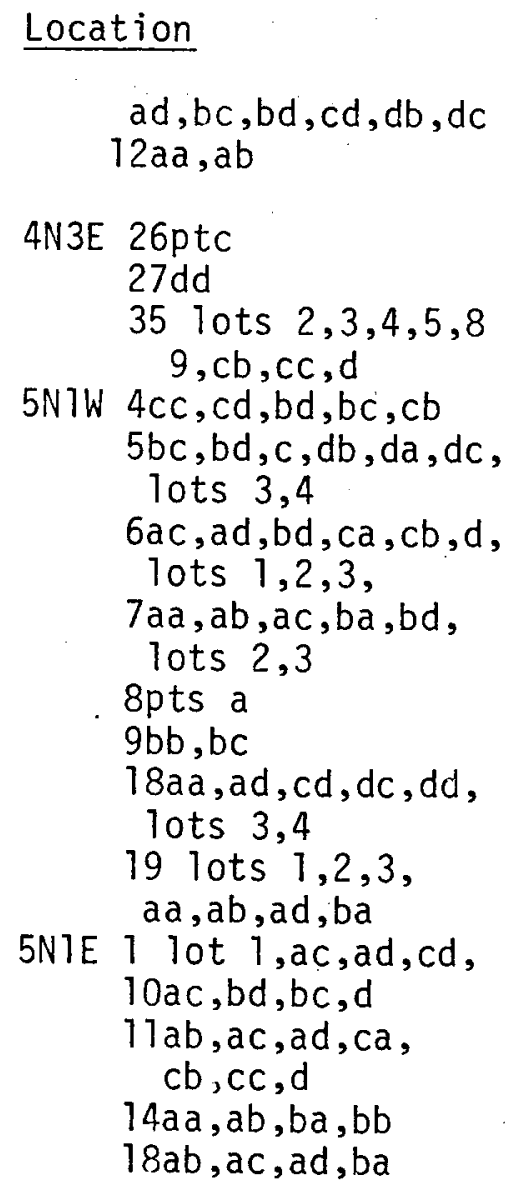

Lessor

U.S. BLM

U.S. BLM

Joe Aldape et al

Joe Aldape et al

Little Cattle Co.

Little Cattle Co.

Little Cattle co.

Little Cattle Co.

Little Cattle Co.

Little Cattle Co.

Little Cattle Co.

Little Cattle Co.

Arthur Bollar

Arthur Bollar

Arthur Bollar

Sec. 1

Sec. ?

Sec. 3

Sec. 4

Sec. 7

Sec. 8 .

Sec. 10

Sec. 11

Sec. 12

Sec. 13

Sec. 19

Sec. 24
Col in McLeod Spring Valley Livestock

Col in McLeod Spring Valley Lives tock

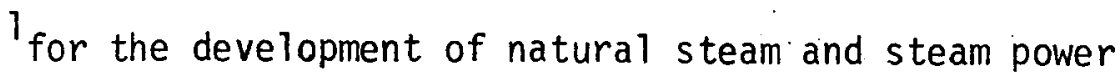


Projected Summary of Geothermal Energy Commercialization by 2020 in Ada County, Idaho

Area 1, Kelly Hot Springs

Area 2, Boise Urban Area

Penitentiary Ground Sub-Area

Warm Springs Water District Sub-Area

Fort Boise Military Reservation Sub-Area

Camel Back Park Sub-Area
$247.6 \times 10^{9}$ BTU/year

$225.0 \times 10^{9}$ BTU/year $582.4 \times 10^{9}$ BTU/year $297.9 \times 10^{9}$ BTU/year $664.2 \times 10^{9}$ BTU/year $243.0 \times 10^{9}$ BTU/year $62 \times 10^{9}$ BTU/year $162 \times 10^{9}$ BTU/year $54 \times 10^{9}$ BTU/year $2538.1 \times 10^{9}$ BTU/year 
1) Mink, Leland L. and Graham, David L., Geothermal Potential of West Boise Area, Idaho National Engineering Laboratory Report, TREE 1762, 1977.

2) Johnson, Linda, Idaho Department of Water Resources, person communications, Juiy, 1978.

3) Idaho Department of Water Resources well files for Ada County.

4) Waring, Gerald A., Thermal Springs of the United States and other countries of the world. A summary, U.S.G.S. - Prof. Paper 492, 1965, pp. 66-31.

5) Applegate, James K. and Donaldson, Paul R., "Characteristics of Geothermal Systems in Idaho", The Earth's Crust, Geophysical Monograph 20, American Geophysical Union, 1970

6) Reistad, Gordon, An Evaluation of Uses for Low Temperature Geothermal Fluids in the Klamath Basin, Oregon. Oregon State University Engineering Experiment Station, Bu77. No. 55, 1978.

7). Ibid, p. 67 .

8) Maywood Industries, Klamath Falls, Oregon, personal communications, April 1978.

9) OTien, Irvin, Ada County Planner, personal communications, June 1978.

10) Boise Metropolitan Area, Master Sewer Plan 1977, Boise City Department of

11) Harris, Dallas, Warm Springs Village Plan, 1976.

12) Ha11, Kirk, Idaho Office of Energy, personal communications, July 1978.

13) Ha11, Ken, Idaho Department of Administration, personal communications, July 1978.

14) Idaho Department of Lands, Geothermal Resource Leases, H-718, H-479, H-720, H-721, H-482. Total acreage: 1562 acres, Lessee: Joe Kanta, Boise, Idaho.

15) Rychert, Robert C., Baker, Charles W., and Wicklow-Howard, Marcia C., Biological Impacts of Geothermal Waste Water Discharge into the Boise River, Boise State University-Idaho Office of Energy, 1978.

16) Post, Lee, Boise City Office of Energy, personal communications, Ju1y 1978.

17) Idaho Code 42-3201.

18) Griffiths, Robert H., Engineer, Warm Springs Water District, personal communications, June 1978.

19) Ibid.

20) Stoker, R.C., E.G.\&G. Idaho Inc., The Boise, Idaho Geothermal Reservoir INEL unpublished report, July 1978. 
21) Donovan, L.E. and Richardson, A.S., Feasibility Conceptual Design Study for Boise Geothermal Space Heating Deomonstration Project Building Modification, INEL Report, ANRC 1246, 1975.

22) Idaho Department of Water Resources, News Release, Apri1 19, 1978.

23) Idaho Code Chapt. 2, Title 56, Sec. 204-205.

24) 43 U.S.C. $852(d)$.

25) Young, H.W. and Mitche11, J.C., Geothermal Investigations in Idaho, Part 1, Geochemistry and Geological Setting of Selected Thermal. Waters: Idaho Department of Water Resources, Water Information Bu71. 30, 1973.

26) U.S. Geological Survey, Boise North Quadrangle, Idaho, 7.5 minute series 1972 .

27) Post, Lee, Boise Office of Energy, personal communications June 1978.

28) Mitche 11, John C., Idaho Department of Water Resources, personal communications, July 7978.

29) Stoker, R.C., E.G.\&G., Idaho, Inc., The Boise, Idaho Geothermal Reservoir, Idaho National Engineering Lab., JuTy 1978.

30) BLM Lease file No. I-8193.

31) Hal1, Kirk, Idaho Office of Energy, personal communications, July 1978.

32) Rice, K.A., Climate of Idaho; Climates of the United States, NOAA, U.S. Department of Commerce, 1971.

33) Howard, Richard, Fish and Wildlife Service, Department of Interior, personal communications, July 1978.

34) Idaho Department of Water Resources, News Release, April 19, 1978.

35) Rychert, Robert C., Baker, Charles W. and Wicklow-Howard, Marcia C. Biological Impacts of Geothermal Waste Water Discharge into the Boise River. Boise State University - Idaho Office of Energy, 1978.

36) Mink, Leland L. and Graham, David L., Geothermal Potential of the West Boise Area. INEL Report TREE-1162, October 1977.

37) Griffith, John, well driller, Boise, Idaho, personal communications, June 1978. 
POTENTIAL GEOTHERMAL DEVELOPMENT

Canyon, Payette and Gem Counties

Introduction:

Very little is known about the geothermal geology of the western most counties of the Snake River Plain. 0il and gas wells give some hint as to the stratigraphy of the area. Near surface indications of hot water are scarce. The surface geology in the center of the Snake River Plain from Nampa to Payette is rather simple and featureless. No major structures, linements or attitudes are present that would suggest deformation. Thousands of meters of volcanic and lacustrine deposits and recent fluviatile deposits cover this area. These deposits may be over 4 Kilometers thick in the Nampa area and 2.5 Kilometers thick in the Payette area.

Heat flow studies in the center of the Western Snake River Plain indicate that temperatures of $100^{\circ} \mathrm{C}$ and $200^{\circ} \mathrm{C}$ would be reached at 1.7 and 4.1 kilometers respectively. (1) The general geothermal gradient calculated for this region is $52.7^{\circ} \mathrm{C} / \mathrm{km}$ depth. (2) Over 20 oil and gas exploration holes have been drilled in the counties of Gem, Canyon and Payette, Depths of these wells vary from less than $500 \mathrm{~m}$ to greater than $3,500 \mathrm{~m}$. (3) The deepest well is located in southern Payette County halfway between the cities of Payette and Nampa. This well was drilled by Chevron 0il Company to a depth of $3,646 \mathrm{~m}$. (4) An overal1 geothermal of $61.2^{\circ} \mathrm{C} / \mathrm{km}$ has been obtained for this we 11. (5) A down-hole femperature of $210^{\circ} \mathrm{C}$ has been measured in this wel1 at a depth of $3,246 \mathrm{~m}$. (6) The Chevron well suggests a slightly higher than average heat flow.

Shallow hole temperature gradients for Ontario, Oregon, $8 \mathrm{~km}$ southwest of Payette suggest a heat flow gradient of $80^{\circ} \mathrm{C}$ to $90^{\circ} \mathrm{C} / \mathrm{km}$ of depth. (7) Estimated gradients for Ontario indicate temperatures exceeding $150^{\circ} \mathrm{C}$ should be encountered at depths of around 2000 meters. $(8)$

Known occurrences of thermal water are scarce. Several wells (25 to 50) in southern Canyon County are warmer than $20^{\circ} \mathrm{C} / \mathrm{kmt}$ only one we 11 is reported to be thermal $\left(51^{\circ} \mathrm{C}\right) .(9)$ Some irrigation wells in $\mathrm{Gem}$ and Payette Counties are warm but not hot. One hot spring in Gem County has a surface temperature of $55^{\circ} \mathrm{C}$.

Because there is limited geological evidence of known geothermal potential in this area of the Western Snake River Plain, exploration for geothermal resources would be a high risk venture. Drilling conditions are difficult as evidenced by the number of abandoned oil and gas wells. The limited geophysical evidence does support a possible high temperature resource $\left(200^{\circ} \mathrm{C}\right)$ at depths of approximately 2 kilometers. The lack of known structural features in the center of the Snake River Plain will probably limit the permeability of any geothermal aquifers. Any intragraben faults, horsts and small grabens which could act as nighly permeable shear fracture aquifers are buried by overlying tertiary sediments and basalts. Certain buried stratigraphic units such as the Columbia River Basalt may be excellent high temperature thermal aquifers, if adequate joints and fractures exist for permeability. Regional 
seismic and gravity surveys are needed to identify any buried structural features and anomalously high gravity zones. In general, the regional geothermal model for the Snake River Plain of Canyon, Gem, and Payette counties is limited. The higher than normal heat flow does support the presence of a heat source but there is limited data to support a hot water system at this time. The heat may be present but there is no data to support the existence of an aquifer.

The market characteristics for utilization of geothermal resources are favorable. Canyon and Payette Counties have highly concentrated population centers and an agglomeration of food processing industries. Table 31-C.1ists the major food processing industries of Canyon and Payette Counties. (10) Gem County has a smaller population and no food processing industries. Two general market areas are described regarding the geothermal development potential:

1) Canyon County, 2) Gem and Payette Counties. 
Major Industries Which Need Hot Water, Canyon County

SIC Code Name/City

Meat Packing

Plants Armour \& Company/

$2011 \quad$ Nampa

2011 H. H. Keim Co./

Nampa

2077

Idaho Meat Packing/

Caldwell

Creamery \&

Dairy

2021

Swiss Village Co./

Nampa

25

.52

2022

Dairy Creamery

Assoc. Inc.l

Caldwell

50

.52

2026

Home Dairies Co./

Caldwel1

50

.52

Dehydrated

Fruit-Vegetables

2034 \&

2037

J. R. Simplot/

Caldwell

1000

.8

1640

Frozen Foods

\& Vegetables

2037

Carnation Co./

Nampa

500

.9

450

2037

Western Idaho

Potato Processors/

Nampa

200

.9

180

2037

General Foods

Corp./Nampa

Sugar

Amalgamated Sugar/

Nampa
900

.9

1100
26

26

200

100

200

3


The population of Canyon County $(72,172)$ is concentrated in two urban centers. Nampa $(23,940)$ and Caldwe $11(15,442)$ account for more than $50 \%$ of the county population distribution. (12) The remaining population is rural in nature. The high population of Nampa and Caldwell is the result of the location of major food processing industrial. Twelve major food processing industries are located in Canyon County with seven in Nampa and five in Caldwel1. Those industries with the largest employment and greatest energy needs are potato processing plants which are either involved with dehydration or frying and freezing potato products. These are the plants that could use geothermal resources in food processing.

One production test well drilled in the Nampa-Caldwell area would cost between an estimated one-half to two million dollars for the respective resource depths of 2.5 and 5 kilometers. See Table 32-C exploration cost estimates. (3) No single company could afford this high a cost at such a high risk. The application of geothermal energy to present industries in Canyon County on an individual basis is at best economically marginal. The economics could improve if a multiple use system were employed. Simultaneous use of a geothermal source by several industries and home heating could reduce the source development cost and spread the risk to several individuals.

Because the location and nature of the resource is a major unknown factor it is highly unlikely that exploration drilling will be considered by any of the present industries. If any of these industries decide to dri11, they will most likely drill their exploration wells at the plant site to reduce pipeline cost. Geothermal resource development at the present industrial parks would have a great potential for cascade use for other industries and space heating of nearby businesses and homes. Before any exploration wells are drilled in the Nampa-Caldwell industrial area, the resource would have to be proven and used economically at nearby locations such as Ontario, Oregon. The successful development and use of geothermal enercy for food processing at ontario could provide incentive for exploration drilling at other food processing plants in Canyon County.

Scenario Projection:

Natural gas is the major energy source used by food processing facilities in Canyon County. Assumed adequate geothermal resources become available to convert $50 \%$ of the energy needs for the eleven largest food processing facilities, an estimated $232.7 \times 10^{9}$ BTU/year of fossil fuel energy could be conserved.

Payette and Gem Counties Subarea:

Payette County:

The major population centers of Payette County $(14,404)$ are New P1ymouth $(1,089)$, Fruitland $(1,066)$ and Payette $(5,240)$. These urban centers account for more than $50 \%$ of Payette County's population distribution. The remaining population is rural in nature and active in farming and ranching. Four industries in Payette County could use geothermal hot water. Table 33-C lists the major industries and their energy demands. Only one is a food processing industry which requires large volumes of hot water. This industry 
Table 32-C

Cost of Production Test Wells, Nampa

\section{5 kilometer well}

We 11 program: 16 inch hole to 160 feet, setting 12 inch casing, 8 inch casing to 3300 feet, 6 inch casing to 8200 feet $(2.5 \mathrm{~km})$.

Mobilization and demobilization

Drilling a $\$ 31 / \mathrm{ft}$.

Casing a $\$ 11 / \mathrm{ft}$.

$\$ 100,000$

250,000

$\underline{87,500}$

437,500

Contingencies a $30 \%$

$\underline{131,240}$

Total

$\$ 568,740$

Approximate cost per ft.: $\$ 71 / \mathrm{ft}$.

\section{5 kilometer well}

Well program: 20 inch hole to 160 feet, setting 16 inch casing, 16 inch hole to 3000 feet 12 inch casing, 8 inch casing to 8200 feet, 4 inch casing to 16,000 feet $(5 \mathrm{~km})$

Mobilization and demobilization

Drilling at $\$ 61 / \mathrm{ft}$.

Casing at $\$ 22 / \mathrm{ft}$.

$$
\begin{array}{r}
\$ 100,000 \\
976,000 \\
352,000 \\
\hline 1,428,000
\end{array}
$$

Contingencies

428,400

Tota 1

$\$ 1,856,400=\$ 116 / \mathrm{ft}$. 
Table 33-c

Major Industries of Payette County and Their Energy Demands

\begin{tabular}{|c|c|c|c|c|}
\hline SIC Code & Name/City & $\begin{array}{l}\text { Number of } \\
\text { Employees }\end{array}$ & $\begin{array}{l}\text { Energy } \\
\text { Coefficient }\end{array}$ & BTU/year $\left(10^{9}\right)$ \\
\hline $\begin{array}{l}\text { Canned Vegetable } \\
2033 \& \\
2034\end{array}$ & $\begin{array}{l}\text { American Fine } \\
\text { Food Inc./ } \\
\text { Payette }\end{array}$ & 300 & .45 & 135 \\
\hline $\begin{array}{l}\text { Meat Packing } \\
2011\end{array}$ & $\begin{array}{l}\text { Wells \& Davis } \\
\text { Inc./Payette }\end{array}$ & 50 & 2.0 & 100 \\
\hline $\begin{array}{l}\text { Prepared Foods } \\
2099\end{array}$ & $\begin{array}{l}\text { Henaggeler } \\
\text { Packing Co./ } \\
\text { Fruitland }\end{array}$ & 50 & .33 & 16 \\
\hline 2086 & $\begin{array}{l}\text { Payette Vinegar } \\
\text { Co./Payette }\end{array}$ & 25 & .56 & 14 \\
\hline
\end{tabular}

Gem County

Saw Mi11

Boise Cascade/

500

.4

200

2421

Emmett 
is a vegetable cannery and is located in Payette. Development of a geothermal resource in Payette could provide the hot water energy needs for this cannery and supply heat for homes and businesses in the area.

Significant exploration in the Payette area is not expected until exploration results in ontario, $8 \mathrm{~km}$ southeast, and Weiser, $22 \mathrm{~km}$ north, have proven the resource. Payette County does have potential for establishing new food processing facilities using geothermal energy if the resource is proven in Ontario, Oregon. The similarity in geology between Ontario and Payette will reduce the risk in exploration. High heat flow data from oil and gas wells in southern Payette County near New Plymouth indicate that high temperature geothermal resources are possible.

Onion dehydration is one food processing industry which could utilize local geothermal resources and could be supported in the Gem-Payette area by local agriculfure. Commercial dry onion production for the state in 1976 was 2,831,000 Cwt. (16) The majority of this crop is raised in Payette, Gem and Canyon Counties. Currently there is only one onion dehydration plant in the Western Snake River Plain and this plant is located in Oregon. The location of such a facility at an Idaho geothermal area would require a resource temperature of $100^{\circ} \mathrm{C}$ to $150^{\circ} \mathrm{C}$ and a substantial production of raw onions from the local area.

Onion dehydration inyglves low temperature hot air dryers in the temperature range of $40^{\circ} \mathrm{C}$ to $100^{\circ} \mathrm{C}$. (17) A typical onion dehydration plant processes 10,000 pounds of raw product per hour where the process reduces the moisture content from $83 \%$ to $4 \%$. The finished product weight is approximately 1,500 pounds. Operation of this type of plant is seasonal and present plants in California use approximately $\$ 200,000$ in fuel during a 180 day operation period.

A geothermal onion dehydration plant of equivalent capacity would require a $100^{\circ} \mathrm{C}$ geothermal resource and wells capable of producing $950 \mathrm{gpm}$. (18) A cost analysis study conducted by Oregon Institute of Technology(19) investigating the cost difference between establishing a geothermal onion dehydration plant and a conventional onion dehydration plant is $\$ 5,775$ capital amortization plus $\$ 210$ per hour for energy cost. Total annual equivalent cost for a geothermal onion dehydration system is $\$ 42,255$ capital amortization plus $\$ 7.11$ per hour for electricity and natural gas. Although a geothermal system is more capital intensive and has a higher initial cost, the per hour operation energy cost is only $3.7 \%$ of a conventional natural gàs system. A geothermal operation would have to operate on $1 y$ 180 hours per year to break even with a conventional natural gas operation. (20)

A conventional plant operating 24 hours a day for 180 days would require 21,600 tons of raw onions per year. Almost $1.5 \mathrm{million}$ tons of onions are produced in Idaho each year. There is more than enough raw agricultural products to supply an onion dehydration plant with raw product: The development of such a plant at a geothermal resource site of $100^{\circ} \mathrm{C}$ would reduce operation costs substantially. A conventional plant operating 4,320 hours per year has an energy cost of $\$ 210 /$ hour or $\$ 907,200$ per year of operation. A geothermal plant has an energy cost of $\$ 7.74 / \mathrm{hr}$. or $\$ 33,436$ per year. A. cost difference of $\$ 873,776$ is realized and a cost savings of $\$ 837,357$ is gained by a geothermal onion dehydration plant. A geothermal operation would have to operate only 7.5 days of 24 hour operation to break even with a natural gas dehydration plant. 
The location of an onion dehydration plant in the Western Snake River Plain will be determined by the resource location. Successful development of the geothermal resources in Ontario, Oregon and/or Weiser, Idaho would help prove the existence of the resource in the Payette-Fruitland area of Payette County. The area has adequate rail and freeway service, cheap abundant land, and adequate fresh water resource, plus a large production of raw onions. If the geothermal resource is proven, then a new food processing plant would be a logical extension of the local economy.

Scenario Projection:

An onion processing plant which uti]izes approximately $150 \times 10^{9}$ BTU/year of direct geothermal heat is projected for the Payette area by 1995.

Gem County:

The major population center of Gem County $(10,650)$ is Emmett $(3,976)$. Although the Emmett area is known for its fruit and vegetable production the area does not have a processing center. Produce which is processed is sent to packing and processing centers in Payette and Canyon Counties. "The principle industry in Emmett which could use geothermal energy is the Boise Cascade Mill which generates most of its own energy by burning wood waste.

Roystone Hot Springs, located 18 kilometers east of Emmett, is the only major thermal occurrence in Gem County. The hot spring is venting from a thin layer of quaternary alluvium which is covering miocene basalts. High angle faulting in the area may be a structural control for the thermal water. The spring is discharging an estimated $20 \mathrm{gpm}$ of $55^{\circ} \mathrm{C}$ water. (9). Both the silica and sodium-potassium-calcium geochemical thermometers indicate deep aquifer temperatures of $150^{\circ} \mathrm{C}$. Table $34-\mathrm{C}$ is a compendium of data regarding Roystone Hot Springs. Exploration drilling at this site may produce a significant high temperature resource. Private land ownership at this resource site has adequate space for facilities siting. However, future commercialization at this resource site will depend upon exploration drilling proving a high temperature resource. The site does have excellent access located on State Highway 51 with railroad and powerlines within 1 kilometer of the site.

Scenario Projection:

A. 50 MW power plant is projected for the Roystone Hot Springs area by 2020 provided the resource is proven by exploration drilling by the year 2000 . 
Table $34-c$

Data Summary for Roystone Hot Springs

SITE LOCATION AND PHYSICAL DESCRIPTION

..Rectilinear: Sec. 8, T $7 \mathrm{~N}, \mathrm{R} 1 \mathrm{E}$, Boise Meridian

..County: Gem

..Adjacent Counties: Ada, Boise, Canyon, Payette, Washington.

.. Topography

The area has a flat topography at the hot springs. The general area is a fault blocked valley with a flat valley floor and steep walls.

..Present Land Use: The present land uses are grazing, limited crop production and recreation.

..Future Land Use Plans: Continuance of present land uses.

..Aesthetics:

Area has moderate to high aesthetic values, with extensive recreation use of the Payette River.

..Geologic Description:

Roystone Hot Springs is located along the fault trace of a major north trending fault located along the western margin of the Idaho Batholith. Although granitic rocks are not exposed in the area, they are present a few kilometers to the east and could be present at depth. The hot springs are venting from quarternary alluvium which covers miocene basalts. Faulting has displaced the basalts several hundred meters. The hot springs are located at the intersection of two major valleys which suggest possible structural control. 


$$
\begin{aligned}
& \text {. Reservoir Temperature } \\
& \text {.. Surface: } 55^{\circ} \mathrm{C} \\
& \text {.. Subsurface: } 150^{\circ} \mathrm{C} \text { estimated } \\
& \text {.. Geochemical } \\
& \qquad \mathrm{SiO}_{2}: 150^{\circ} \mathrm{C} \\
& \text { Na-K-Ca: } 150^{\circ} \mathrm{C} \\
& \text {.. Flow Rates } 20 \mathrm{gpm} \\
& \text {.. PH } 7.5 \\
& \text {.. Total Dissolved Solids: } 577 \\
& \text {.. Fluid Chemistry: }
\end{aligned}
$$

. . Total Dissolved Solids: 577

$\begin{array}{lcc}\mathrm{Si}: & 120 \\ \mathrm{Ca}: & 8.7 \\ \mathrm{Mg}: & .6 \\ \mathrm{Na}: & 160 \\ \mathrm{~K}: & 7.7 \\ \mathrm{HCO}_{3}: & 187 \\ \mathrm{CO}_{3}: & 0 \\ \mathrm{SO} 4 & 110 \\ \mathrm{P} & : & .04 \\ \mathrm{C} 1 & : & 62 \\ \mathrm{~F} & : & 16 \\ \mathrm{NO} 3 & : & 0\end{array}$

..Estimated Electric Energy Potential (30 years): $50 \mathrm{MW}$ LAND OWNERSHIP AND LEASING

..Land Ownership

TOTAL AREA

(Acres)

23040

..Land leased

None

FEDERAL
(Acres)
1920
None

STATE

(Acres) 640

None
PRIVATE

(Acres) 20480

$$
\text { None }
$$


INSTITUTIONAL CONSIDERATIONS - (Federal)

\section{Institutional \\ Requirements}

Federal Geothermal

Resource Lease

(30 C.F.R. 3000)
Agency and

Public Attitudes

Leases are made pursuant to the Geothermal Steam

Act of 1970

(84 Stat. 1566)

(30 USC 1001-1025)

B.L.M.

U.S.G.S.
Status of Requirements

(i.e., EIA/EIS Requirements)

Leases are noncompetitive. Special conditions are required in leases with regard to potential archaelogical and historical sites, adjacent roadless areas, and critical habitat areas.
National Environmental Policy Act (42-U.S.C. 4331)
An E.I.A. is required before leases are issued. E.P.A.
A preliminary E.A.R. could be required before leasing and drilling. In general an E.I.A. is required for all action involving exploration and development. An E.I.S. will be required for any major action.

Ground water is included under this Act and the reinjection of geothermal effluent will require permits.

The Act sets standards for wells and well drilling and could influence future geothermal wells.
Federal Safe Drinking Water Act (42 U.S.C. (A) 300)
This Act is concerned with protection of underground water sources that could be used for domestic water.

E.P.A.
The national goal of this pollution by 1985 . E.P.A. tion Control Act (33-USCA 1251) 
INSTITUTIONAL CONSIDERATIONS - State

Institutional

Requirements

Leases on State Lands

(Idaho Code 47-601

et. seq. Chapter 16, Geotherma 1 Resources)

Geothermal Resource

Permits.

(Idaho Code 42-400)

et.seq. Chapter 40, Geothermal Resources)

Water Appropriation (Idaho Code 42-101

et. seq. Chapter 1 Water Appropriation)

Injection wells

(Idaho Code 42-3001

et. seq. Chapter 39

Waste Disposal and

Injection Wel1s)
Agency and

Public Attitudes

The state board of Land Commissioners is authorized to issue leases for geotherma] resources underlying state and school lands.

The regulatory powers of the state Geotherma? Resource Act are placed in the Idaho Department of Water Resources.

The Idaho Department of Water Resources issues water appropriation permits and a water right license.

Permits are issued by the Department of Water Resources.

Status of Requirements (i.e., EIA/EIS Requirements)

Lease term is 10 years and can be continued with diligent development. Rentals are set by the board. Several leases have been granted on state lands. Lease size is limited to a maximum of 640 acres/lease.

Any private owner, or holder of a state or federal lease of geothermal resources must first apply for a geothermal resource permit from I.D.W.R. before any drilling operations can begin.

Under the Idaho Geothermal Resources Act, applicants can be required to make an application to appropriate the public waters of the state.

No waste disposal or injection wel can be constructed in Idaho unless a permit has been issued by I.D.W.R. The approval of this permit is contingent upon the approval of the Department of Health and Welfare. The proposed well is reviewed to see if it will unreasonably contaminate or deteriorate the quality of the ground water below the adopted water quality standards of the state.

INSTITUTIONAL CONSIDERATIONS - LOCa 1

Gem County Comprehensive Plan
Gem County Planning

Commission
Permits for building. 
..Present Development Status:

The hot springs was used for a swimming pool at one time, but this pool has since been closed to the public. The spring is currently privately owned and used for a private pool. At present there has been no interest shown to lease this area for exploration.

...Projected or Planned Development:

A 50 M electrical generation plant is projected for this site by 2020 providing adequate geothermal resources are proven by the year 2000.

\section{TRANSPORTATION AND UTILITIES}

..Utility or Energy Transmission Corridors and Facilities:

Two $138 \mathrm{kv}$ lines owned by Idaho Power Company are located within $1 \mathrm{kilo-}$ meter of the site.

..Transportation Corridors or Facilities:

State Highway 58 provides access to the site.

\section{ENVIRONMENTAL FACTORS}

\section{CLIMATE}

..Prevailing Winds: North-South

..Precipitation (Annua 1): (11-31 inches) $28.7 \mathrm{~cm}$

..Days of Sunshine (Annual): 304

..Average Temperature

$\begin{array}{lcc} & \text { January } & \text { July } \\ \text { Minimum } & -11^{\circ} \mathrm{C} & 13.6^{\circ} \mathrm{C} \\ \text { Maximum } & 2.2^{\circ} \mathrm{C} & 34.5^{\circ} \mathrm{C}\end{array}$

..Degree Days (Annual): $\quad 5746$

..Relative Humidity (Seasonal Peaks)

$\begin{array}{ll}\text { Summer: } & 10 \% \\ \text { Winter: } & 50 \%\end{array}$

..Air Quality: Generally high quality.

.Geologic Factors: Site is partially in the flood plain 


\section{REFERENCES}

(Gem, Payette, Canyon Counties)

1) Brott, Charles A., Blackwe11, David D.,, and Mitche11, J.C., Heat Flow Study of the Snake River Plain Region, Idaho, Geothermal Investigations in Idaho, Part 8, Water Info. BullTetin No. 30, Idaho Department of Water Resources, 1976 , p. 36.

2) Ibid

3) Idaho Department of Lands, 0il and Gas Drilling Activity Register, 1978.

4) Ibid. p. 9.

5) Ore-Ida Foods Inc., A Field Experiment Food Processing Industry, Geothermal Energy, Department of Energy, PON-EG-77-N-03-153

6) Bowen, R. G. and Blackwe11, D.D., "Cow Hollow Geothermal Anomally, Malheur County, Oregon". The ORE-BIN, V0.1 37, No. 7, July 1975.

7) Ibid.

8) Ibid.

9) Young, H.W., and Mitchell, J.C., Geochemistry and Geological Setting of Selected Thermal Waters, Geothermal Investigations in Idaho, Part 1 , Water Information Bulletin, No. 30, Idaho Department of Water Resources 1973 , p. 24.

10) Cornelison, Laurna C., Edt. Manufacturing Directory of Idaho, 1976, University of Idatio 1976 .

ii) Röcket Research Company, Industrial Waste Heat for Adjacent Communities and Industrial Applications, Task 1, Pacific Northwest Regional Commission: RRC-78-H-181, Dec. 1977. Energy demands for industries were obtained by using direct energy coefficients calculated by Rocket Research Company, and Washington and Oregon State Energy Offices.

12) Irvin, Lawrence D., Social-Economic Profile,; Boise BLM District, Center for Business and Economic Research, Boise State University, 1976, p. 17.

13) Irvin, Lawrence D., Op. Cit.; p. 18.

14) Ibid.

15) Idaho Crop and Livestock Reporting Service, Idaho Agricultural Statistics 1977, Idaho Dept. of Agriculture, p. 69.

16) Lienau, Paul J., 1978, "Agribusiness Geothermal Energy Utilization Potential of the Klamath Basin, and Snake River Plain of Oregon". Proceedings Direct Utilization of Geothermal Energy: A Symposium, Geothermal Resourcé Council, pp. 13-33.

17) Ibid.

i8) İbid.

19) The break-even point is determined by taking the difference between fixed cost and dividing by the difference between the per hour energy cost. The resultant is the number of hours required to run a geothermal system before the difference in fixed cost has been saved by a reduction in energy cost. 


\section{POTENTIAL GEOTHERMAL DEVELOPMENT SITES}

Elmore County

\section{Introduction}

Geothermal resources are found at several locations in Elmore County. The most promising geothermal resource areas are located close to the city of Mountain Home where several wells south of the city are warm to hot. Four thermal wells and two large thermal springs northeast of Mountain Home yield hot artesian water. These wells are 180 meters to 300 meters deep and have temperatures of $56^{\circ} \mathrm{C}$ to $67^{\circ} \mathrm{C}$. ( 1 ) $0 i 1$ and gas exploration wells in the Mount Bennett Hills, northeast of Mountain Home, have high down-hole temperatures. A11 of these wells have been drilled into fractured volcanic rocks.

The local geology of the area is a transition between the central Idaho tertiary and cretaceous granitics, and the tertiary and quaternary rocks of the Snake River Plain. Mountain Home lies on a northwest-southeast trending fault that marks the relatively abrupt transition zone between the Snake River Plain and the mountains. The major hot springs in the area are controlled by faulting. (2) The lithologic types found in the Mountain Home area are pliocene and pleistocene sediments, pleistocene basalts, and tertiary silicic volcanics overlying cretaceous granite. The silicic volcanics are miocene rhyolites. The Idavada volcanics underlying the Idaho group is considered to be the most important aquifer and source of hot water. (3) The Idavada volcanics are miocene silicic volcanics, which generally produced higher temperatures water than nearby wells from overlying units.

The area has above normal geothermal ingredients. The temperature gradients range from $4^{\circ}$ to about $10^{\circ} \mathrm{C}$ per 100 meters. The heat flow in this area is of the order of 1 to 8 heat flow units. (4) The origin of the geothermal water in this area is presumed to be due to deep circulation.

The development potential of the geothermal areas in Elmore County will be limited by the type of land use, the type of market found at each geothermal area, and the magnitude of the resource. Four separate potential geothermal development areas have been identified in Elmore County. Each area is different in character with varying possibilities of geothermal development.

Four geothermal development subareas are presented in the order of highest to lowest development potential. The four major development subareas are: (1) Mounta in Home KGRA, (2) City of Mountain Home, (3) Mountain Home Air Force Base, (4) Atlanta. The Mounta in Home KGRA and the City of Mounta in Home are located along a series of northwest trending faults which possibly control the geothermal system in these areas. The Mountain Home Air Force Base is located in the center of the Snake River. Plain, half-way between the Mountain Home KGRA and the Bruneau KGRA. The Atlanta geothermal subarea is a broad mountainous region in northern Elmore County where the known thermal waters are isolated hot springs. 
Mountain Home KGRA Subarea

The U.S. Geological Survey has declared 9520 acres of federal lands in the Mount Bennett Hills area northeast of Mountain Home a known geothermal resource area. (5). This KGRA is known as the Mountain Home KGRA. Only 5102 acres of the KGRA have been leased. (6) The remaining area has been withheld from lease for environmental reasons:(7) Union 0il Company and Magma Power Company are joint owners of these federal leases.

The State of Idaho has leased 8000 acres adjacent to the federal KGRA to Gulf $0 i l$ Company. (8) Approximately 135 private leases have been recorded with Elmore County for over 9,000 acres of private lands. The majority of the private leases are also concentrated in the Mt. Bennett Hills area.

No geothermal exploration activity has occurred on the federal and state leases. One exploration well was drilled on private leases in 1973. (9) This well was later reworded for geothermal resource production. Table 35-C 7 ists pertinent information about this we11. The we11, 10cated approximately 17 kilometers east of Mountain Home, was originally acquired by the Gulf Energy and Mineral Company but recently the ownership has been transferred to Magma Power and Union 0il Companies. A temperature survey taken approximately one year after the well was drilled showed a maximum temperature of $188^{\circ} \mathrm{C}$ at 8,898 feet. Initially the well was reported flowing at about 1,000 gallons per minute (gpm) but the flow stopped within a few weeks. (10) It appears that the well was heavily damaged by mud invasion during drilling and the well has not flowed since. Chemical treatment such as acidizing or fracturing by hydraulic (or explosive) means could be used to stimulate the well. Union $0 i 1 \mathrm{Co}$. is planning to reopen the wel1 (11) and state permits for deepening this well have been issued by Idaho Department of Water Resources. (12)

Historically, Union 0il Company, Magma Power Company and Gulf 0il Company have been interested in geothermal resource areas for electrical generation potential. The limited amount of geological evidence available indicates that high temperatures are possible at depth in the KGRA. If electrical generation is feasible, then the KGRA is fortuitously located close to the Bonneville Power Administration and Idaho Power Company transmission grid with three 250 kv power lines crossing the KGRA. (13)

Industrial utilization of the resource would involve transporting the hot fluids by pipeline to a nearby market. The closest markets are the cities of Glenns Ferry $17 \mathrm{~km}$ to the south, and Mountain Home $13 \mathrm{~km}$ to the west of the KGRA. The present industrial market is 7 imited. Only five industries are listed in the Idaho Manufacturing Index for the City of Mountain Home and only one major industry is located in Glenns Ferry. (14) Table 36-C lists these industries, their approximate energy consumption and potential geothermal use. (15) Only one of these industries, Magic West Industries, of Glenns Ferry, needs large volumes of hot water in its processing. (16) Magic West is a vegetable and fruit processing plant. In order to fulfill the non-mechanical and electrical energy needs of this type of processing plant a $65^{\circ} \mathrm{C}$ to $100^{\circ} \mathrm{C}$ geothermal resource is needed. (1.7) The major economic limiting factor to utilizing the geothermal resources of the Mountain Home KGRA for existing industries is the piping distance. Piping distances for food processing plants which exceed $8 \mathrm{~km}$ will lower the return on investment to less than $20 \%$. 18 ) 


\author{
Table 35-C \\ Bostic 1-A Well (Union 0i1) \\ Mountain Home, Idaho
}

Location: SE $1 / 4$ SW $1 / 4$ Sec. $25, T 4$ S, R 8 E, Boise Meridian

Elevation: 970 meters

Total Depth: 2950 meters

We11 Program: $27 \mathrm{~cm}$. cased first 325 meters,

$22 \mathrm{~cm}$, no casing remaining depth

Drilistem Test:

Final Shut-in Pressure

8-27-73: $\quad 3752$ psi

Temperature: (1974) $188^{\circ} \mathrm{C}$ o 2712 meters

Flow Rate: Initially flowed at approximately 1,000 gpm. No significant flow after initial tests.

Severe wellbore skin damage suspected. 
Major Industries of Elmore County (14) and Their (15) Energy Demands

Mountain Home

Conchemco: Mobil Home Manufacturing, Employment 50-99

S.I.C.: D 2451

Energy Intensity Coefficient: .5

Estimated Energy Needs: 25 Billion BTU/year

Modular Insulated Building Systems: Employment 5

S.I.C.: A 2493

Energy Intensity Coefficient: .5

Estimated Energy Needs: 2.5 Billion BTU/year

Mountain Home News: Pringing, Employment 10

S.I.C.: B 2711

Energy Intensity Coefficient: .05

Estimated Energy Needs: .5 Billion BTU/year

Purego Company: Fertilizer Mixing, Employment 5

S.I.C.: A 2875

Estimated Energy Needs: Less than .1 Billion BTU/year

Sawtooth Lumber Company: Saw Mi11, Employment 100

S.I.C.: D 2427, 2499

Energy Intensity Coefficient: .4

Estimated Energy Needs: 200 Billion BTU/year

\section{Glenns Ferry}

Magic West: Dehydrated Fruit and Vegetable Soups, Employment 150

S.I.C.: E 2034

Energy Intensity Coefficient: .8

Estimated Energy Needs: 124 Billion BTU/year

Source: Idaho Manufacturing Index, (Reference 14).

Scenario Projections:

The following projections are made on the assumption that current and near future exploration will prove a high temperature geothermal resource. Commercialization projections for the Mountain Home KGRA and adjacent areas are: A 50 MW power plant by 1990, and 50 MWs of additional generation capacity by 2020 . Also, industrial development in conjunction with the first power plant utilizing $200 \times 10^{9}$ BTU/year of direct heat energy by 1990 . 
This could limit industrial use of the geothermal resource to on-site facilities in the KGRA.

There are major institutional road blocks to constructing on-site utilization facilities in the KGRA. Federal ownership requires an Environmental Impact Statement. Present regulations limit the size and type of "individual we 11 facility" to electrical generation(19) and non-electrical utilization facilities are presently excluded. Any development on a federal KGRA would be on a lease basis with no title to the land or resource. This type of relationship discourages investors from building facilities on federal land. The private lands adjacent to the federal KGRA have a greater potential for early development. The development and/or utilization of geothermal resources on private lands entails fewer encumbrances. County jurisdiction is the principal institutional factor affecting private lands. Elmore County's long range comprehensive plan calis for agricultural use of the private lands in the KGRA area. (20) A special use permit from the Elmore County Planning and Zoning Commission is necessary before any lands in the KGRA area can be developed. SEE Table 37-C for a compendium of data regarding the Mountain Home KGRA.

Commercialization at the Union well could occur by 1990. The 1 and area is privately owned agricultural land which has a flat topography and adequate space for facility siting. A major drawback to the Union well site is road access as present roads are unpaved light duty roads. The nearest railroad and freeway access is at Glenns Ferry, 12 kilometers south of the site.

The Union well site would be a logical area for locating a new industrial park between Mountain Home and Glenns Ferry. Types of commercialization that are realistically possible must be oriented toward agriculture. Local agricultural inputs could support a controlled animal breeding facility and slaughter facility. A food processing facility could be an integrated part of this type of operation. 
Table $37-c$

Data Summary for Mountain Home KGRA

SITE LOCATION AND PHYSICAL DESCRIPTION

.. Latitude: ${ }^{(34)} 43^{\circ} 10^{\prime} 00^{\prime \prime} \mathrm{N}$

..Longitude: $115^{\circ} 20^{\prime} 15^{\prime \prime} \mathrm{W}$

.. Rectilinear: T 3 and $4 N, R 8$ and 9 E, Boise Meridian

..County: Elmore

..Adjacent Counties: Gooding, Camas, Owyhee, Ada

. Topography (34)

Elevation, slope and aspect very greatly with the KGRA. The southern portion of the KGRA has an elevation of 914 meters and slope less than $2 \%$. The northern portion of the KGRA has a range of elevation and slope which increases to the north. Elevations range from 1100 meters in the foothills and slopes range from over 10\% to near vertical along the mountain front.

..Present Land Use:

Private lands are used as a base for ranching and farming operations, with most of the private lands in potato crops and pasture. Public lands are used for grazing and logging. Numerous power lines and a major natural gas pipeline are also present.

..Future Land Use PTans:

Local planning calls for continuance of present land uses. The area is being considered for industrial zoning if the geothermal resource is proven.

\section{..Aesthetics:}

The area is cut by high voltage transmission lines and timber areas have numerous clearcuts.

..Historical/Archaeological Significance:

Little Canyon Creek has numerous petroglyphs. The Oregon Trail, Kelton Wagon Road, and Overland Wagon Trail are located within 3 kilometers of the KGRA. 


\section{GEOLOGICAL/GEOPHYSICAL DESCRIPTION}

\section{.Geologic Description: (1). (10)}

Mountain Home KGRA lies on a northwest trending fault system that marks the abrupt transition zone between the geology of the Snake River Plain and the geology of the Idaho Batholith. Lithologic types found in the KGRA are pliocene and pleistocene sediments and basalts underlying tertiary miocene silicic volcanics which overlay cretaceous granite. The $p$ liocene and younger rocks are considered the Idaho group of which the Glenns Ferry Formation is the major unit. The Idavada volcanics underlying the Idaho group are miocene rhyolites. The Idavada volcanics is the major thermal aquifer.

.. Geophysical Summary:

Temperature gradients range from $4^{\circ}$ to $10^{\circ} \mathrm{C}$ per 100 meters. The heat flow in this area is of the order of 1 to 8 heat flow units. (26) (10)

. Geologic Hazards: (7)

Soil erosion on steep slopes in the Mt. Bennett area is a major concern.

\section{RESERVOIR CHARACTERISTICS}

. Reservoir Temperature

..Surface: $55^{\circ} \mathrm{C}, 62^{\circ} \mathrm{C}, 68^{\circ} \mathrm{C}$

. Subsurface: $188^{\circ} \mathrm{C}$

-Geochamical: $\mathrm{SiO}_{2}: 135^{\circ} \mathrm{C}, 130^{\circ} \mathrm{C}, 130^{\circ} \mathrm{C}$

$$
\mathrm{Na}-\mathrm{K}-\mathrm{Ca}: 135^{\circ} \mathrm{C}, 70^{\circ} \mathrm{C}, 80^{\circ} \mathrm{C}
$$

..Flow Rates: $700 \mathrm{gpm}^{(1)}$

..Ph: 8.5

. Total Dissolved Solids: $297^{(1)}$

..Fluid Chemistry: (1) milligrams per litre

Si: $\quad 86$

Ca: $\quad 1.5$

$\mathrm{Mg}: \quad 0$

$\mathrm{Na}: \quad 8 \%$

$\mathrm{K}: \quad .8$

$\mathrm{HCO}_{3}: 74$.

$\mathrm{CO}_{3}: 50$

$\mathrm{SO}_{4}: \quad 14$

$P: \quad .04$

Ci : $\quad 4.5$

$\mathrm{F}: \quad 17.0$

$\mathrm{NO}_{3}: \quad .06$

..Estimated Nonelectric Energy Potential: 100MW 
LAND OWNERSHIP AND LEASING

$\begin{array}{lccccc} & \begin{array}{c}\text { TOTAL AREA } \\ \text { (Acres) }\end{array} & \begin{array}{c}\text { FEDERAL } \\ \text { (Acres) }\end{array} & \begin{array}{l}\text { STATE } \\ \text { (Acres) }\end{array} & \begin{array}{r}\text { PRIVATE } \\ \text { (Acres) }\end{array} & \text { OTHER } \\ \text {. L Land Ownership } & 18,520 & 9,520 & 8,000 & 10,000 & \\ \text {..Land Leased } & & 5,102 & 8,000 & 5,000 & \end{array}$

.Highest Priced Leases (Dollars/Acre)

$\frac{\$ / \text { Acre }}{\$ 2.00} \quad \frac{\text { Lessee }}{\begin{array}{l}\text { Union 0il of Calif. } \\ \text { \& Magma Power Co. }\end{array}}$

..Tentative Lease Sale Dates: 1985: State

1987: Federal

Number of Bids Rejected Three on Federal lands for environmental reasons. Resulting in No Lease:

..Summary of Leasing Status and Needs:

A11 State lands have been leased to Gulf $0 i 1$; these leases are up for renewal in 1985. Union $0 i 1$ and Magma Power hold the only leases on Federal lands. 
Institutional

Requirements

Federal Geothermal

Resource Lease

(30 C.F.R. 3000)
Agency and

Public Attitudes

Leases are made pursuant to the Geothermal Steam Act of 1970

(84 Stat. 1566)

(30 USC 1001-1025)

An E.I.A. is required before drilling. An EAR may be sufficient. BLM. USGS
Status of Requirements (i.e., EIA/EIS Requirements)

Leases within the KGRA are competitive. Special conditions are required in the leases with regard to potential archaelogical and historical sites, adjacent roadless areas, and critical habitat areas.

National Environmental Policy Act. (42 U.S.C. 4331 )
An EAR for prelease has been completed, will review before drilling project. In general an E.I.A. is required for all projects involving exploration and development. If a generation facility is to be built and power generated and sold or a large nonelectrical facility constructed, then an E.I.S. will be required.

The national goal of this Act is to attain -0pollution by 1985 .
Ground water is included under this Act and the reinjection of geothermal effluent will require permits.
Federal Safe Drinking Water Act (42 U.S.C. (A) 300)
This Act is concerned with protection of underground water sources that could be used for domestic water.
The Act sets standards for wells and well drilling and could influence future geothermal wells in the Mt. Bennett Hills. The upper aquifer of the basin is the supply of domestic and irrigation water for the area. Reinjection of water for geothermal wells will require permits under this Act. 
INSTITUTIONAL CONSIDERATIONS - State and Local

Institutiona 1

Requirements

Leases on State Lands

(Idaho Code 47-601

et.seq. Chapter 16 ,

Geotherma 1 Resources)

Geothermal Resource

Permits.

(Idaho Code 42-4001

et. seq. Chapter 40, Geotherma 1 Resources)

Water Appropriation (Idaho Code 42-101 et. seq. Chapter 39 Waste Disposal and Injection We 11s)

Injection wells (Idaho Code 42-3001 et. seq. Chapter 39 Waste Disposal and Injection Wells)
Agency and Public Attitudes

The state board of Land Commissioners is authorized to issue leases for geotherma 1 resources underlying state and school lands.

The regulatory powers of the state Geothermal Resource Act are placed in the Idaho Department of Water Resources.

The Idaho Department of Water Resources issues water appropriation permits and a water right license.

Permits are issued by the Department of water Resources.
Status of Requirements (i.e., EIA/EIS Requirements)

Lease term is 10 years and can be continued with diligent development. Rentals are set by the board.

Several leases have been granted on state lands. Lease size is limited to a maximum of 640 acres/lease.

Any private owner, or holder of a state or federal lease of geothermal resources must first apply for a geothermal resource permit from I.D.W.R. before any drilling operations can begin.

Under the Idaho Geothermal Resources Act, applicants can be required to make an application to appropriate the public waters of the state.

No waste disposal or injection well can be constructed in Idaho unless a permit has been issued by I.D.W.R. The approval of this permit is contingen upon the approval of the Depart ment of Health and Welfare. The proposed well is reviewed to see if it will unreasonably contaminate or deteriorate the quality of the ground-water below the adopted water quality standards of the State.

County will have a comprehensiv plan by late 1978. Drilling will need permits for land use variance if in agricultural areas. Any building or construction will need a building permit. Health permits may be required. No EIS requirements.
Elmore County Permits for building and land use.
County Commission \& Planning Committee 
GEOTHERMAL DEVELOPMENT STATUS

..Present Development Status:

Leases have been issued to Union $0 i 1$ and Magma Power in a joint venture for 5,102 agres of federal KGRA lands. No drilling has taken place within the KGRA. $(6)$

Leases have been issued for 8000 acres of state lands to Gulf 0il Corp. (8) No exploration activity has occurred on these lands as of March, 1978. An old oil-gas exploration well on private lands adjacent to the KGRA will be reopened by Magma Power in 1978.

Bottom hole temperatures of $188^{\circ} \mathrm{C}$ are recorded for this we11. (12)

..Projected Development

The State of Idaho will begin exploration for heat flow data in 1979. Union $0 i 1$ and Magma Power will reopen the Bostic 1-A well in 1978-1979. If sufficient high temperature resources are proven, the Bostic area is projected to become an industrial park and a possible electrical generation site with $50 \mathrm{MW}$ projected by 1990 and $100 \mathrm{MW}$ total projected for 2020.

ENVIRONMENTAL FACTORS

. CLIMATE $^{(35) \quad(7)}$

..Prevailing Winds: 5 to $20 \mathrm{mph}$ from west-northwest gust to $60 \mathrm{mph}$.

..Precipitation (Annual): $22 \mathrm{~cm}$ at Glenns Ferry, $46 \mathrm{~cm}$ at Bennett Mtn.

..Days of Sunshine (Annual): 302

.. Average Temperature

Minimum:

January

$-7.3^{\circ} \mathrm{C}$

Juty

Maximum:

$3.3^{\circ} \mathrm{C}$

$12.7^{\circ} \mathrm{C}$

$33.5^{\circ} \mathrm{C}$

..Degree Days (Annua1):

(7)

5978 Mountain Home 6419 KGRA

..Relative Humidity (Seasonal Peaks)

Summer: $30 \%$

Winter: $70 \%$

AIR QUALITY: ${ }^{(7)}$ High Quality. Particulate matter is from natural causes.

GEOLOGIC FACTORS: (7) Soil erosion problems have occurred steep slopes. We1l interference is known in the area.

WATER QUALITY: (7) Quality high. Total surface flow is $800 \mathrm{cfs}$, Bennett Creek accounts for $500 \mathrm{cfs}$. All surface waters are diverted for irrigation.

NOISE: (7) Low Levels.

Elevation: 970 meters to 1100 meters.

BIOLOGICAL

(7) 
..Dominant Flora: Douglas Fir and Ponderosa Pine above 1500 meters elevation Sagebrush-grass ecosystem below 1500 meters.

..Dominant Fauna: Deer, Elk, small mamals and game birds.

..Endangered Species:

.. Fauna (7) Prairie Falcon

TRANSPORTATION AND UTILITIES

..Utility or Energy Transmission Corridors and Facilities

Two $250 \mathrm{kv}$ Lines located at the KGRA and owned by Idaho Power Company.

Two $138 \mathrm{kv}$ Lines located at the KGRA and owned by Idaho Power Company.

El Paso Gas Pipeline is located 6 kilometers south of KGRA operated by Pacific Pipeline Co. and Intermountain Gas Co.

Chevron II 0 il Pipeline is located 4 kilometers south of KGRA operated by Salt Lake Pipeline Co.

. Transportation Corridors or Facilities

Idaho State Highway is located 12 kilometers from KGRA.

Interstate 80 is located 17 kilometers from KGRA.

County Paved Roads are located 4 kilometers from KGRA.

Gravel light duty roads are at KGRA.

POPULATION

Site: Mountain Home KGRA

. General Description of Population

Population density of KGRA and surrounding area is less than 1 per square

kilometer. Total population of KGRA area is approximately 20 people.

Nearest Cities: Glenns Ferry, population 1389 located 19 kilometers south. Mountain Home; population 6900 located 12 kilometers west.

..Economics

The economy of the Mountain Home area is dependent on the continuation of active status at Mountain Home Air Force Base. New industrial growth is needed. Local agriculture could supply sufficient feed for slaughter facilities and sufficient potatoes for food processing. 
The City of Mountain Home is located close to geothermal resources inel1s approximately $10 \mathrm{~km}$ north of the City have temperatures exceeding $58^{\circ} \mathrm{C}(21)$ and several domestic and irrigation water wells just south of the city are also thermal but in the lower temperature $\left(15^{\circ}\right.$ to $\left.25^{\circ} \mathrm{C}\right)$ range. The minimum economic water temperature for direct use space heating on a large scale is approximately $60^{\circ} \mathrm{C}$. (22) Lower temperature, waters can be used for space heating on a large scale is approximately $60^{\circ} \mathrm{C}$. (22) Lower temperature waters can be used for space heating on individual bases by utilizing heat pumps to obtain the heat energy from the lower temperature resource. (23)

\section{Scenario Projection:}

New growth in the greater Mountain Home area could stimulate development of the present high temperature resources by shifting high density population to the resource site. Table 38-C lists the population projections for Elmore County which is experiencing a $9 \%$ growth rate. $(25)$ Geothermal areas in close proximity to Mountain Home $(8 \mathrm{~km})$ are marginal agricultural areas. The relocation of a portion of the expected growth to these geothermal sites is a possible alternative. County ordinances restrict this type of spot development to planned developments which can provide the necessary sewer, water and road services. A smali district geothermal heating system of $50 \times 109$ BTU/year could occur by 1990 .

Mountain Home Air Force Base Subarea

The Mountain Home Air Force Base (AFB) is located in the center of the Snake River Plain half way between the Mountain Home KGRA to the north and the Bruneau KGRA to the south. Although geological evidence is scarce, there is sufficient information to indicate that the subarea does have geothermal resource potential. Heat flow studies in the center of the Western Snake River Plain indicate that temperatures of $100^{\circ} \mathrm{C}$ and $200^{\circ} \mathrm{C}$ could be reached at 1.7 and 4.1 kilometers depth respectively. (26) Several irrigation wells just southeast of the base are warmer than $200 \mathrm{C}$ and thermal waters are likely within the Base's compound.

Over 3.5 million square feet of floor space on the base is presently being space heated with fossil fuels. (27) Base housing for over 9,000 personnel is presently heated with natural gas and fuel oil. Approximately 500 military buildings are heated with natural gas and coal is used in a central heating plant which heats the base hospital and central compound. The base is presently undergoing significant renovation and construction. A new cafeteria, officers club, and housing were constructed in 1977 and new family housing units will be constructed in late 1978. Expanded new housing on base in anticipated jn the near future and an expansion of hangar facilities is also expected. (29)

Energy costs and availability are critical factors effecting the continued presence of active status for Mountain Home AFB. As a federal installation, the Base has been ordered to reduce its energy consumption. (30) As a result of this order, a conservation plan is in effect at the Base. Despite conservation efforts, the energy needs and cost at the Base are still high and expected to rise. Fable 39-C lists the average monthly energy consumption and cost for the Air Base. Fossil fuels used for space heating account for $40 \%$ of the non-transportation energy consumption of the Air Base. (31) A geothermal resource of $600 \mathrm{C}$ could supply $100 \%$ of this energy need. 
Table 38-C

Elmore County Population Projections

\begin{tabular}{lrrcc} 
Location & 1975 & 1978 & 1980 & Growth Rate \\
\hline Mountain Home & 6,811 & 7,955 & 8,870 & $5.6 \%$ \\
Mountain Home AFB & 6,038 & 10,000 & -- & -- \\
Glenns Ferry & 1,449 & 1,644 & 1,850 & $4.5 \%$ \\
Elmore County & 18,962 & 21,737 & 23,900 & $9.0 \%$
\end{tabular}

Source: Social-Economic Profile, Southwest Idaho, (Reference \#24). 
Table 39-C

Mountain Home Air Force Base

Energy Facts: Heating
(Ref. 29)

Amount of square feet space heated:

Group 1: Industrial sector: 1,678,000 sq. ft. served by central heating plant: Coal

Group 2: Base housing and buildings: 1,852,000 sq. ft. natural gas and diesel

Heat requirements:

(average $-100 \mathrm{C}$ winter day)

Minimum temperature requirements for utility buildings: $50 \mathrm{C}$

Maximum temperature requirements for hospital buildings: $240 \mathrm{C}$

Average temperature requirements for general buildings: $180 \mathrm{C}$

Average Monthly Energy Load:

Type Structure /Type of Energy /Consumption of Energy /BTU Equivalent /Cost (approx)

Housing /Diesel fuel / $/ 99,914$ gal/month $/ 14,953$ MBTU $/ \$ 49,957 /$ month

Housing and

Military Units /Natural Gas / 5,421,000 cuf./month / 5,862 MBTU / \$14,040/month

Central Units,

Offices, Mess,

Etc.

/Coal

/ 1,384 Tons/month

$/ 36,688$ MBTU

$1 \$ 24,219 /$ month

Related

Electrical /Electrical /13,715 kwh/month

/ 46.7 MBTU / $\$ 400 /$ month

57,550 MBTU $\$ 88,616.00 / \mathrm{mo}$

Energy Consumption for January 1978:

Space Heating: $\quad 51.133 \times 10^{9}$ BTU

Electrical: $\quad 77.647 \times 10^{9}$ BTU

Total: $\quad 128.780 \times 10^{9}$ BTU

Energy equivalents for Jan. Space Heating Load:

51.133 Billion BTU $=1710 \mathrm{MW}=9204$ Barrels of 011 
High energy cost and close proximity to other known geothermal resource locations has prompted the Mountain Home AFB to study the possibility of develoning geothermal resources on the base. The air base applied to the Department Defense for funds to drill an exploration wel1. The advent of geothermal energy for space heating could reduce fossil fuel energy consumption significantiy and a producing geothermal well would provide the air base with a degree of energy independence. Such independence has a high strategic value.

Scenario Projections:

A geothermal spaceheating system, delivering approximately $650 \times 10^{9}$ BTU/ year is projected for the base by 1990 .

\section{Atlanta Subarea}

The Atlanta geothermal area encompasses most of northern ETmore County. Several isolated thermal springs are scattered throughout this area. Two thermal locations are noteworthy: thermal springs along the middle fork of the Boise River; thermal springs near the community of Featherville. All of these springs are venting from cretaceous granitic rocks. Middle Fork, Boise River:

Neinmeyer and Dutch Frank's Hot Springs are located along the Middle Fork of the Boise River approximately 100 kilometers North of Mountain Home.

Several springs are located at both sites with each location having a total discharge of approximately $300 \mathrm{gpm}$ each. The temperature of the water ranges from $65^{\circ} \mathrm{C}$ to $75^{\circ} \mathrm{C}$. Geochemical thermometers indifate that $120^{\circ} \mathrm{C}$ to $135^{\circ} \mathrm{C}$ is the maximum temperature available at depth.

These springs are in a-relatively isolated, mountainous area. Both springs are venting from cretaceous granite into the Middle Fork of the Boise River. The area can be accessed by a narrow dirt Forest Service Road. Because. of this area's isolation, no commercialization of the area is considered possible.

\section{Featherville:}

Several small thermal springs are located near Featherville, Idaho. Paradise Hot Springs is located on the South Fork of the Boise River near Featherville and is typical of the springs in the area where discharge temperatures are $50^{\circ} \mathrm{C}$. All springs are venting from cretaceous granite. (33) Several springs and a few wells between Featherville and Atlanta are reported to be low temperature thermal water but are not considered to be of commercial value. The area is isolated and the major economic activities in the area are timber harvesting, recreation and small farms. The total population of Featherville and Atlanta is less than 50 people. Because of the area's isolation and a lack of resource data, commercialization of geothermal resources is not considered possible.

\section{Summary Elmore County:}

At best, the geothermal development potential of Elmore County is moderate. High temperature, known geothermal resources are structurally controlled by 
northwest trending faults in the Mt. Bennett Hills. Exploration drilling into the fault systems may produce large volumes of high temperature resources. If the temperature is high enough to generate electricity, then the probability of development in the KGRA is high. The relative isolation of the resource area will limit the type of geothermal energy utilization possible but high temperature wells may act as a center for new industrial and residential development. This will depend on continued growth and stability for the Mountain Home area. Mountain Home AFB could use geothermal resources for space heating, but deep exploration drilling must be conducted to prove the resource. 


\section{REFERENCES \\ (Elmore County)}

1) Ross, Sylvia H., 1971, Geothermal Potential of Idaho, Idaho Bureau Idaho Bureau of Mines \& Geology, Pamph. 150, p.17.

2) Ralston, D. R. and Chapman, S. L., 1968, Groundwater Resources of the Mountain Home Area, Elmore County, Idaho: Idaho Department of Water Reclamation, Information BuTletin 4, $63 \mathrm{p}$.

3) Ibid.

4) Young, H.W. and Mitche11, J. C., 1973, Geothermal Investigations in Idaho, Part 1: "Geochemistry and Geological Setting of Selected Thermal Waters": Idaho Department of Water Ad. Water Information Bulletin No. 30 , p. 12, 25.

5) Conservation Manager, Western Region, U. S. Geological Survey. Memorandum to State Director, Bureau of Land Management, Boise, Idaho; Subject: Definition of the Mountain Home KGRA., March 21, 1975.

6) Bureau of Land Management, Geothermal Lease File. Numbers: I-14167, I-14168, I-14169 - Jan., 1978.

7) Bureau of Land Management, Boise District, Idaho: Prelease EAR Report Geothermal Leases, I-14167 through I-14169; Union $0 i 1$ Co., and Magma Power Co., 1975.

8) Idaho Department of Lands, Geothermal Resource Lease Files, No. H-612 through H-626, March 1, 1975, Updated March 1, 1979.

9) Idaho Department of Lands, $0 i 1$ and Gas Log, Bostic \#1 We11.

10) Sanyal, Subir K., Econogist, EMMA Ltd., personal communications July 1978.

11) Smithe, Warren A., Union $0 i 1$ Company, Geothermal Division, personal communications, July 1978.

12) Mitchel1, John C., Idaho Department of Water Resources, personal communications, JuTy 1978.

13) Idaho Electrical Transmission Corridors (unpublished map), Idaho Energy Office, 1977.

14) Cornelison, Launna C., Ed., Manufacturing Directory of Idaho, Center for Business Development and Research, University of Idaho, 1976.

15) Rocket Research Company, Industrial Waste Heat for Adjacent Communities and Industrial Applications, Pacific Northwest Regional Commission, RRC-78-H-181, December 1977. Energy Intensity Coefficient by SIC category to expressed as Billion BTU/Empl./ Yr. 
16) Magic West is a food processing plant specialized in dehydrated fruit, vegetables and soups. (Ref. 12).

17) Gerick, Joseph A., Industrial Utilization of Geothermal Energy, University of Idaho, p. 111.

18) Gerick, Op. Cit., p. 54

19) 30 CFR $270.2(r)$, Individual well facility means an electric power generation facility of not more than 10 MN net capacity located on a Federal Geothermal lease for which energy is supplied by a single well.

20) Boyce, Shirl C., Ed. Local Planning Inventory 1978: State Planning and Community Affairs, State of Idaho 1978, p. 53.

21) Young, H. W. Op. Cit., p. 31

22) E.R.D.A., Rules of Thumb for Direct Geothermal Applications: Information Pamphlet Geothermal Program, INEL - EG\&G, Idaho Inc. 1978.

23) Keller, J. G., Heat Pumps, Primer for Use With Low Temperature Geothermal Resources. INEL Report GP 178, Nov. 1977, $21 \mathrm{p}$.

24) Irvin, Lawrence D., Social-Economic Profile, Southwest Idaho, Region III Boise BLM District: Center for Business and Economic Research, Boise State University - 1976, p. 20.

25) Ibid.

26) Brott, C. A., Blackwe11, D.D. and Mitchel1, J.C., Heat Flow Study of the Snake River Plain Region, Idaho: Water Information Bulletin 30, Geotherma Investigations in Idaho, Part 8, 1976.

27) Personal Communications with Lt. Col. Ginnette, U.S.A.F., Mountain Home Air Base 1978.

28) Personal Communications with Robert Nelsion, Mountain Home Air Base, 1978.

29) Personal Communications, Capt. Talbort, U.S.A.F., Washington D.C., 1978.

30) Personal Communications with Robert Ne1sion, Mountain Home Air Base, 1978.

31) Young, H. W. , Op. Cit. p. 31.

32) Ibid.

33) U.S. Geological Survey, Bennett Mtn. Quadrangle, 15 minute series (Topographic), Elmore County, Idaho 1948.

34) N.0.A.A., Climate of Idaho, Climates of the United States No. 60-10, U.S. Dept. of Commerce, NOAA; 1977. 
Introduction:

The most extensive occurrence of geothermal resources in Idaho is found in northern Owyhee County along the southern edge of the Western Snake River Plain. Three geothermal resource areas are located in thjs broad region. The three locations are Bruneau KGRA, (1) Castle Creek KGRA, (2) and Givens Hot Springs (3). These geothermal areas form an elongated, northwest trending, geothermal anomaly. The axial trend of the anomoly is oriented along the topographic break between the Owyhee Front and the Snake River Plain.

Along the Owyhee Front from Bruneau to Givens Hot Springs almost all we17s are thermal. Most wells are over $300 \mathrm{~m}$ deep and range in temperature from $25^{\circ} \mathrm{C}$ to $80^{\circ} \mathrm{C}$. (See Table $40-\mathrm{C}$ ) Almost al1 wells have artesian pressure and several wells flow artesian. Aquifer temperatures from geochemical thermometers indicate that temperatures exceeding $150^{\circ} \mathrm{C}$ are possible. (5)

Hydrological studies in the Bruneau-Grandview area indicate the primary thermal water aquifers are tertiary basalts and sediments. The aquifers have been classified into two groups: (6) sedimentary rock aquifers of the Pleistocene Idaho Group (7) and older volcanic rock aquifers of the Pliocene Idaho Group and Idavada Volcanics. (8) Meteoric recharge of the aquifers is believed to be from snowfall in the Owyhee Mountains. However, recharge to the upper sedimentary aquifers is believed to be chiefly from vertical movement of water from the underlying volcanic rock aquifers.

Some faulting is evident in the area but the hydrological nature of these faults is not clearly understood. (10) The Western Snake River Plain is generally believed to be a graben in which many faults and fractures permit waters to migrate across stratigraphic boundaries. The strong correlation between the topographic break of the Owyhee front and the axial orientation of the geothermal anomaly suggest that a major fault structure does exist. This structure is the probable conduit which supplies thermal water to the upper aquifers.

The rhyolite series of the Idavada Volcanics is reported to be the major thermal aquifer. (11) Total thickness of the rhyolite is unknown, but thermal wells haye penetrated $520 \mathrm{~m}$ into the rhyolite without reaching the lower contact. (12) The highly jointed and fractured character of these rocks make them a good aquifer. Wells drilled into this formation are thermal and have good yields.

Several types of geothermal energy application are possible considering the range of temperatures available. The scale and type of use, from generation of electricity to space heating, will depend upon a number of site specific conditions. Future development of the resource in the BruneauGrandview depend upon: 1) the character of the proven resource, 2) ownership of the resource, 3) the need for local inputs, 4) access to markets and 5) local environmental conditions. 


$$
\begin{gathered}
\text { Table } 40-\mathrm{C} \\
\text { Selected } \\
\text { Thermal Springs and Wells } \\
\text { in } \\
\text { Bruneau-Grandview Geothermal } \\
\text { Area }
\end{gathered}
$$

Location

4S 2E 32 NW, SW 30

5S $3 E 26$ NW, SW 280

6S 3E 2 SW, SW 489

6S 5E $10 \mathrm{SE}, \mathrm{SE}$

6S 5E 29 SE, SW

6S 6E $12 \mathrm{SW}, \mathrm{SW}$

$7 S 5 E \quad 7 \mathrm{NE}$, NW

8S $6 E \quad 3$ NW, SSE 458

IN $4 W 12$ NW, SW 410

IS $2 W 7 \mathrm{SE}, \mathrm{SE}$

169

4S IE 34 NW, NE

5S 1E 24 NW, SE 1060

$5 S 2 E \quad 1 \mathrm{NW}$, NW 30

$786 \mathrm{E} 9 \mathrm{NW}, \mathrm{NE}$
Water Temp.

42.0

135

145

135

175

135

135

125

120

85

85

125

125

115

135

45.5

75.0

66.0

49.5

50.0
$\mathrm{Na}-\mathrm{K}-\mathrm{Ca}$ Temp.

165

90

150

145

165

175

190

185

40

130

The major aquifers reported for the majority of these wells are the Banbury Basalts of the Idaho Group and the Idavada Volcanics.

Source: Idaho Department of Water Resources Information Bullet in 30 . (Ref. \#5) 
In Owyhee County the principle land use is agriculture. The area is sparsely populated and its economy relies primarity on large ranches and farms which produce livestock, feed grains, hay, potatoes and sugarbeets. Those areas with the highest agricultural yields coincide with the known geothermal areas due to the development of thermal aquifers for irrigation.

Areas of concentrated population are limited and small in scale. The communities of Bruneau (pop. 50), Grandview (pop. 370) and Oreana (pop. 35) are service centers providing grocery, postal, and gas station services. Grandview is the major community of the geothermal area and is the location of the regional school and government office buildings.

Because the Bruneau KGRA and the Castle Creek KGRA are in close proximity to one another and have similar resource, environmental and market characteristics, they will be described as a single unit. Whenever possible the individual facts particular to either area will be described. Table 4l-C is a compendium of site specific data regarding the Bruneau KGRA and Table 42-C is a compendium of site specific data regarding the Castle Creek KGRA. These areas will be described as the Bruneau-Grandview geothermal subarea. The Givens Hot Springs geothermal subarea in northwestern Owhyee County is described separately.

Bruneau-Grandview Subarea

Several conceptual development scenarios are possible in the Bruneau-Grandview area. Generation of electricity has been suggested as the highest priority potential use. Processing agricultural products and space heating are realistic alternatives.

Aquifer temperatures exceeding $190^{\circ} \mathrm{C}$ have been estimated using sodiumpotassium-calcium geochemical thermometers. (13) Heat flow studies indicate temperatures exceeding $200^{\circ} \mathrm{C}$ are possible af $2 \mathrm{~km}$ depth. (14) known thermal wells have temperatures as high as $80^{\circ} \mathrm{C}$. (15) $0 i 1$ and gas exploration we 17 in the area have encountered high downhole temperatures greater than $150^{\circ} \mathrm{C}$. $(16)$ tricity is possible in this area.

Several factors affect the feasibility of exploration and development of high temperature geothermal resources in the Bruneau-Grandview Subarea.

\section{1) Resource Ownership}

Federal geothermal 1eases have been issued for 2,600 acres in the Bruneau KGRA. These leases are located at the south end of the Bruneau Valley in the vicinity of Bruneau Hot Springs. Occidental Petroleum Company and Louisiana Land and Exploration Company own these federal leases in a joint venture, (17) known as 0ccidental Geotherma?, Inc. The leases were issued in 1975 and as of October 1978, no attempt has been made to develop these leases. Under the 10-year primary term of the lease, diligent exploration must occur by the sixth year (1981) of the lease. Occidental Geothermal, Inc. is the major KGRA leaseholder in Owyhee County. Occidental owns leases for 16,412 acres in the Castle Creek KGRA and 19,000 acres of state leases near Bruneau KGRA. (18) In addition to 0ccidental's leases in the Castle Creek KGRA, 16,975 acres of federal KGRA lands have been leased to several other interests. An additional 150,000 
Table 41-C

Data Summary for Bruneau KGRA

SITE LOCATION AND PHYSICAL DESCRIPTION

..Latitude: $47^{\circ} 30^{\prime} 00^{\prime \prime} \mathrm{N}$

..Longitude: $115^{\circ} 42^{\prime} 34^{\prime \prime} \mathrm{W}$

..Rectilinear: Sec. 14, 15, 21, 22, 23, 26, 27, 28 T 7 S, R 6 E, Boise Meridian

..County: Owyhee

.. Adjacent Counties: Ada, Elmore, Twin Falls.

Topography: Plateau area dissected by the Bruneau and Snake Rivers. Slopes range from less than $2 \%$ in the Bruneau Valley to near vertical in the Bruneau Canyon. Elevations range from 743.7 meters to 975 meters.

..Present Land Use:

Irrigation agriculture dominates the land use of private lands in the Bruneau Valley. Grazing and pasture are the other major land uses on public and other private lands. Ranching and farming are based along the Bruneau River and Little Valley Creek. Public lands are primarily used for grazing. Bruneau Dunes State Park is located on the northern boundary of the KGRA.

. Future Land Use Plans:

Continued agricultural land uses in all areas. The upper Bruneau River Canyon is being considered for a Wild and Scenic River Classification.

.. Aesthetics:

Highly aesthetic area with the Upper Bruneau River considered to be one of the major natural areas in the State. Bruneau Dunes State Park is located on the northern border of the KGRA and is considered a major scenic area. The Bruneau Valley is a rural agricultural zone in an area of high desert environment.

..Historical/Archaeological Significance:

The Bruneau Valley contains recorded prehistoric archaeological sites. The Little Valley and Bruneau River Valley contain historical settlements. The Oregon Trail crosses through the KGRA. There are numerous areas in the N.E. corner of the KGRA where wagon ruts are still visible. 
GEOLOGICAL/GEOPHYSICAL DESCRIPTION

. Geologic Description:
$(5)$
$(6)$
(10) (11)

Hydrological studies in the Bruneau KGRA indicate that the primary thermal water aquifers are the tertiary basalts and sediments. The aquifers have been classified into two groups: sedimentary rock aquifers of the Pleistocene Idaho Group which make up the upper aquifers: and volcanic rock aquifers of the Pliocene Idaho Group and Miocene Idavada Volcanics which make up the deep aquifers. Meteoric recharge of the upper aquifers is believed to be from snow pack in the Owyhee Mountains to the south of the KGRA. Thermal recharge of the upper aquifers is believed to be from vertical movement of water from the underlying volcanic rock aquifers. The Idavada Volcanics is an unknown thickness of rhyolite which is reported to be the major aquifer. Wells drilled into this formation are thermal and have good yields. This rhyolite formation serves to transmit recharge water to the area and thence upward to overlying units. Faulting in the area shows thermal water to migrate upward across stratigraphic boundaries.

..Geophysical Summary:

Heat flow studies indicate temperatures exceeding $200^{\circ} \mathrm{C}$ are possible at 2 kilometers depth. Reconnaissance audio magnetotelluric survey reveals a northwest-southeast trending, broad conductive anomaly with low resistivities (22 ohm-meters or less) being associated with the areas of highest ground water temperatures $\left(68^{\circ}\right.$ to $\left.80^{\circ} \mathrm{C}\right)$. Aeromagnetic data parallels the resistivity low in the Grandview area shown by the audio-magnetotelluric survey.

RESERVOIR CHARACTERISTICS

.. Reservoir Temperature (5)

.. Surface: $30^{\circ}$ to $50^{\circ} \mathrm{C}$

. Subsurface: $70^{\circ} \mathrm{C}$

..Geochemical

$$
\begin{aligned}
\mathrm{SiO}_{2}: & 135^{\circ} \mathrm{C} \\
\mathrm{Na}-\mathrm{K}-\mathrm{Ca}: & 160^{\circ} \text { to } 190^{\circ} \mathrm{C}
\end{aligned}
$$

.. Flow Rates ${ }^{(13)} 100$ to $750 \mathrm{gpm}$ of $30^{\circ}$ to $70^{\circ} \mathrm{C}$

..pH: $8.2^{(13)}$

..Total Dissolved Solids: ${ }^{(13)} 150$ to $550 \mathrm{ppm}$ 
.Fluid Chemistry: milligrams per litre

Temp: $\quad 50^{\circ} \mathrm{C}$

Si : 93

$\mathrm{Ca}: \quad 1.6$

Mg. : 0

$\mathrm{Na}: 99$

$\mathrm{K}: \mathrm{.6}$

$\mathrm{HCO}_{3}: \quad 72$

$\mathrm{CO}_{3}: \quad 30$

$\mathrm{SO}_{4}: 24$

$\mathrm{P}: \quad .04$

C1 : 8.4

$\mathrm{F}: \quad 14$

N03 : $\quad 0.06$

..Estimated Electric Energy Potentia 1: $100 \mathrm{MW}$

GEOLOGICAL/GEOPHYSICAL DESCRIPTION

SITE: Bruneau KGRA, OWYHEE COUNTY, IDAHO

..Geologic Description: (5) (6) (10) (11)

Hydrological studies in the Bruneau KGRA indicate that the primary thermal water aquifers are the tertiary basalts and sediments. The aquifers have been classified into two groups: sedimentary rock aquifers of the Pleistocene Idaho Group which make up the upper aquifers: and volcanic rock aquifers of the Pliocene Idaho Group and Miocene Idavada Volcanics which reach the deep aquifers. Meteoric recharge of the upper aquifers is believed to be from snow pack in the Owyhee Mountains to the south of the KGRA. Thermal recharge of the upper aquifers is believed to be from vertical movement of water from the underlying volcanic rock aquifers. The Idavada Volcanics is an unknown thickness of rhyolite which is reported to be the major thermal aquifer. Wells drilled into this formation are thermal and have good yields. This rhyolite formation serves to transmit recharge water to the area and thence upward to overlying units. Faulting in the area allows thermal water to migrate upward across stratigraphic boundaries.

.. Geophysical Summary:

Heat flow studies indicate temperatures exceeding $200^{\circ} \mathrm{C}$ are possible at 2 kilometers depth. Reconnaissance audit magnetotelluric survey reveals a northwest-southeast trending, broad conductive anomaly with low resistivities ( $2.2 \mathrm{ohm}$-meters or less) being associated with the areas of highest ground water temperatures $\left(68^{\circ}\right.$ to $\left.80^{\circ} \mathrm{C}\right)$. Aeromagnetic data parallels the resistivity low in the Grandview area shown by the audio-magnetotelluric survey.

..Geologic Hazards: Unknown. 
Table 41-C Cont'd.

\section{RESERVOIR CHARACTERISTICS}

SITE: Bruneau KGRA, Owyhee County, Idaho

..Reservoir Temperature

(5) (13)

.. Surface: $30^{\circ}$ to $50^{\circ} \mathrm{C}$

.. Subsurface: $70^{\circ} \mathrm{C}$

..Geochemical ${ }^{(13)}$

$$
\begin{array}{cl}
\mathrm{SiO}_{2}: & 135^{\circ} \mathrm{C} \\
\text { Na-K-Ca: } & 160^{\circ} \text { to } 190^{\circ} \mathrm{C}
\end{array}
$$

..Flow Rates: 100 to $750 \mathrm{gpm}$ of $30^{\circ}$ to $70^{\circ} \mathrm{C}$

..pH: $8.2^{(13)}$

..Total Dissolved Solids: 150 to $550 \mathrm{ppm}$

\begin{tabular}{|c|c|}
\hline Temp : & $50^{\circ} \mathrm{C}$ \\
\hline & 93 \\
\hline $\mathrm{Ca}$ : & 1.6 \\
\hline $\mathrm{Mg}$ & 0 \\
\hline $\mathrm{Na}$ & 99 \\
\hline & .6 \\
\hline $\mathrm{HCO}_{3}:$ & 72 \\
\hline $\mathrm{CO}_{3}:$ & 30 \\
\hline $\mathrm{SO}_{4}:$ & 24 \\
\hline $\begin{array}{l}P \quad: \\
P 1\end{array}$ & .04 \\
\hline $\begin{array}{l}C 1 \\
F\end{array}$ & $\begin{array}{l}8.4 \\
14\end{array}$ \\
\hline $\mathrm{NO}_{3}:$ & \\
\hline
\end{tabular}

..Fluid Chemistry: milligrams per litre

GEOTHERMAL DEVELOPMENT STATUS

..Present Development Status:

A total of 4160 acres of federal and state lands have been leased and approximately 2000 acres. of private lands have been leased. No exploration drilling has occurred on any geothermal leases. Present development is limited to a small swimming pool and thermal irrigation wells.

..Projected or Planned Development:

The prime lease interest is for electrical generation. The area does have potential for direct use of thermal fluids. Controlled environment breeding of hogs and poultry is possible with present irrigation wells. Long range projections are for the development of high temperature fluids for alfalfa drying, and food processing. No planned developments are evident at this time. 
INSTITUTIONAL CONSIDERATIONS - Federal

\author{
Institutional \\ Requirements \\ Federal Geothermal \\ Resource Lease \\ (30 C.F.R. 3000)
}

National Environmental Policy Act (42 U.S.C. 4331)
Agency and

Public Attitudes

Leases are made pursuant to the Geothermal Steam

Act of 1970

(84 Stat. 1566)

(30 USC 1001-1025)

An E.I.A. is required or an EAR for all exploration activity. BLM and USGA.
Federal Water Pollution Control Act (33 U.S.C. 1251)

Federal Safe Drinking Water Act (42 U.S.C. (A) 300).
The national goal of this Act is to attain -0pollution by 1985 .

This Act is concerned with protection of. underground water sources that could be used for domestic water.
Status of Requirements (i.e., EIA/EIS Requirements)

Leases within the K.G.R.A. are competitive. Special conditions are required in the leases with regard to potential archaeological and historical sites, adjacent roadless areas, and critical habitat areas.

An EAR will be conducted and the FWS will review any major project. In general an E.I.A. is required for all projects involving exploration and development. If a generation facility is to be built and power generated and sold or a large nonelectrical facility constructed, then an E.I.S. will be required.

Groundwater is included under this Act and the reinjection of geothermal effluent will require permits.

The Act sets standards for wells and well drilling and could influence future geothermal wells in the Owyhee area. The upper aquifer of the basin is the supply of domestic and irrigation water for the area. Reinjection of water for geothermal wells will require permits under this Act. 
Table 47-C Cont' $d$.

INSTITUTIONAL CONSIDERATIONS - State and Loca 1

Institutional

Requirements

Leases on State lands

(Idaho Code 47-601

et.seq. Chapter 16 , Geotherma 1 Resources)

Geothermal Resource Permits.

(Idaho Code 42-4001

et. seq. Chapter 40 , Geothermal Resources)

Water Appropriation (Idaho Code 42-101

et. seq. Chapter 1

Water Appropriation)

Injection wells

(Idaho Code 42-3-01

et. seq. Chapter 39

Waste Disposal and

Injection We11s)
Owyhee County

Building permits.
Agency and

Pubiic Attitudes

The state Board of Land Commissioners is authorized to issue leases for geothermal resources underlying state and school lands.

The regulatory powers of the state Geotherma 1 Resource Act are placed in the Idaho Department of Water Resources.

The Idaho Department of Water Resources issues water appropriation permits and a water right license.

Permits are issued by the Department of Water Resources.

Owyhee County Court Commissioners.
Status of Requirements (i.e., EIA/EIS Requirements)

Lease term is 10 years and can be continued with diligent development. Rentals are set by the Board.

Several leases have been granted on state lands. Lease size is limited to a maximum of 640 acres/lease.

Any private owner or holder of a state or federal lease of geothermal resources must first apply for a geothermal resource permit from I.D.W.R. before any drilling operations can begin.

Under the Idaho Geothermal Resources Act, applicants can be required to make an application to appropriate the public waters of the state

No waste disposal or injection well can be constructed in Idaho unless a permit has been issued by I.D.W.R. The approval of this permit is contingent upon the approval of the Department of Health and Welfare. The proposed well is reviewed to see if it will unreasonably contaminate or deteriorate the quality of the groundwater below the adopted water quality standards of the state.

Building permits will be required for structures. No other 7 and use requirements. 


\section{ENVIRONMENTAL FACTORS}

. CLIMATE

.Prevailing winds: 5 to $20 \mathrm{mph}$ following the river canyons, gust of $60 \mathrm{mph}$ from $W-N W$ in summer, from E-SE in winter.

..Precipitation (Annual): $18 \mathrm{~cm}$ per year

. Days of sunshine (Annual): 320

..Average Temperature

Minimum:

Maximum:

$$
\begin{aligned}
\text { January } & \text { July } \\
-6.2^{\circ} \mathrm{C} & 12.7^{\circ} \mathrm{C} \\
7.1^{\circ} \mathrm{C} & 33.2^{\circ} \mathrm{C}
\end{aligned}
$$

..Degree Days (Annual): 5057

..Relative Humidity (Seasonal Peaks)

Summer: $30 \%$

Winter: $70 \%$

..AIR QUALITY: Quality is generally good. Levels of particulate matter are unknown. The major pollutant in the area is dust from farming activities and anatural causes.

..GEOLOGIC FACTORS: The Bruneau Valley is subjected to occasional minor flooding and 100 year floods. There is no flood control along the Bruneau River.

..WATER QUALITY: Quality is generally good. Most of the areas water comes from wells. Almost all of the surface water of the Bruneau River is used for irrigation. Some wells have high fluoride concentrations.

..WATER QUALITY: Quality is generally good. Most of the areas water comes from wells. Almost all of the surface water of the Bruneau River is used for irrigation. Some wells have high fluoride concentrations.

..NOISE: Low levels of noise are occasionally broken by low flying mi Titary jets from the Mountain Home Air Force Base.

\section{. BIOLOGICAL (22)}

..Dominant Flora: Sagebrush grass ecosystem

.Dominant Fauna: Mule deer, raptors, bobcat, coyote

.. Endangered Species

Fauna: State has proposed that the Ferruginous Hawk be placed on the threatened 1ist. Numerous nesting sites are located in the Bruneau KGRA. 
TRANSPORTATION AND UTILITIES

. Utility or Energy Transmission Corridors and Facilities

$45 \mathrm{kV}$ line at Bruneau KGRA, Idaho Power Company.

$138 \mathrm{kv} 1$ ine 12 kilometers northwest of KGRA, Idaho Power Co.

63 megawatt hydroelectric facility at J. C. Strike Dam;

12 kilometers northwest of KGRA, Idaho Power Co.

22 inch natural gas Iine, at KGRA, Southwest Gas Co., El Paso Line.

$500 \mathrm{kv}$ line is proposed by the BPA and will cross southern sections of KGRA, no construction of this line is planned at this time.

\section{. Transportation Corridors or Facilities}

The Junction of

State of Idaho Highway 51 and Highway 78 is located at Bruneau KGRA. Improved paved and gravel heavy duty roads service the Bruneau Valley. Jeep trails and light duty dirt roads provide access to undeveloped areas of KGRA, several areas have no roads.

\section{POPULATION}

. General Description of Population

Bruneau is a very small community of approximately 20 people. An additional 100 people may live with in the KGRA.

The nearest major community is Mountain Home, 6,880, located 25 kilometers north of the KGRA.

Over half of the structures in Bruneau are abandoned. The major commercial structures are two service stations and a general store. Most of the residents of Bruneau are retired and living on fixed incomes. Other residents of the KGRA are located on isolated farms and ranches.

\section{..Economics}

In the Bruneau Valley the principal land use is agriculture. The area is sparsely populated and its economy relies primarily on large ranches and farms which produce livestock, feed grains, alfalfa, potatoes and sugar beets. There are no industrial facilities located in this area. 
Table 42-C

Data Summary for Castle Creek KGRA

SITE LOCATION AND PHYSICAL DESCRIPTION

...Latitude: $42^{\circ} 56^{\prime}, 00^{\prime \prime} \mathrm{N}$

..Longitude: $115^{\circ} 56$ ! $00^{\prime \prime} \mathrm{W}$

..Rectilinear: $T$ 4, $5 \mathrm{~S}, \mathrm{R}$ 1,2, 3 E, Boise Meridian

..County: Owyhee

..Adjacent Counties: Elmore, Ada, Canyon

. Topography

Plateau areas dissected by steep walled canyons, slopes range from $2 \%$ to $5 \%$ and elevations range from 740 meters to 1000 meters.

Most of the area in Castle Creek and Catherine Creek drainages is relatively flat.

..Present Land Use:

Irrigation agriculture and ranching are based in Castle Creek and Catherine Creek, and along the Bruneau and Snake Rivers. The private lands are used to produce potatoes, sugar beets, corn, beans, and alfalfa. Public lands are used for stock grazing. Lands within the Snake River Birds of Prey Natural Area are left in a natural state whenever possible, some areas have been cultivated.

. Future Land Use Plans:

Continuance of present agricultural land uses, possible expansion of the Birds of Prey Natural Area.

\section{..Aesthetics:}

The canyon country of the Birds of Prey Natural Area are considered of high aesthetic and recreational value.

..Historical/Archaeological Significance:

Some historical Indian camps are known in the Snake River Canyon. GEOLOGICAL/GEOPHYSICAL DESCRIPTION

..Geologic Description: (5) (6) (10) (11)

Hydrological studies in the Grandview area indicate that the primary thermal water aquifers are the tertiary basalts and sediments. The aquifers have been classified into two groups: sedimentary rock aquifers of the Pleistocene Idaho Group which make up the upper aquifers; and volcanic rock aquifers of the Pliocene Idaho Group and Miocene Idavada Volcanics which make up the deep aquifers. Meteoric recharge of the upper aquifers is believed to be from snow pack in the Owyhee Mountains to the south of the KGRA. Thermal recharge of the upper aquifers is believed to be from vertical movement of water from the underlying 
volcanic rock aquifers. The Idavada Volcanics is an unknown thickness of rhyolite which is reported to be the major thermal aquifer. Wells drilled into this formation are thermal and have good yields. This rhyolite formation serves to transmit recharge water to the area and thence upward to overlying units. Faulting in the area slows thermal water to migrate upwasd across stratigraphic boundaries.

-.Geophysical Summary:

Heat flow studies indicate temperatures exceeding $200^{\circ} \mathrm{C}$ are possible at 2 kilometers depth. Reconna issance audio magnetotelluric survey reveals a northwest-southeast trending, broad conductive anomaly with low resistivities (22 ohm meters or less) being associated with the areas of highest ground water temperatures $\left(68^{\circ}\right.$ to $\left.80^{\circ} \mathrm{C}\right)$. Aeromagnetic data parallels the resistivity low in the Grandview area shown by the audio-magnetotelluric survey.

\section{RESERVOIR CHARACTERISTICS}

. Reservoir Temperature

. Surface: $35.5^{\circ} \mathrm{C}$

..Subsurface: $42^{\circ}$ to $84.5^{\circ} \mathrm{C}$

.. Geochemical

$\mathrm{SiO}_{2}: 135^{\circ} \mathrm{C}$ and $145^{\circ} \mathrm{C}$

Na-K-Ca: $160^{\circ} \mathrm{C}$ and $90^{\circ} \mathrm{C}$

..Flow Rates: Thermal wells are capable of producing 700 to $1000 \mathrm{gpm}$

..pH: 7.1 to $8.2^{(13)}$

. Total Dissolved Solids: $320(\mathrm{mg} / 1)$

..Fluid Chemistry: (13) milijgrams per litre

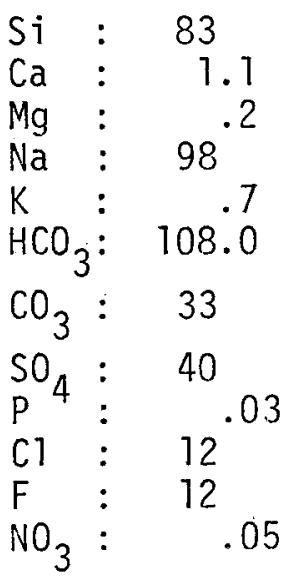

..Estimated Nonelectric Energy Potential: $100 \mathrm{MW}$ 
Table 42-C Cont'd.

\section{LAND OWNERSHIP AND LEASING}

SITE: Castle Creek

.. KGRA: Castle Creek

TOTAL AREA
(Acres)

.. Land Leased in KGRA:

$\begin{array}{lcc}\text { FEDERAL } & \text { STATE } & \text { PRIVATE } \\ \text { (Acres) } & \text { (Acres) } & \text { (Acres) } \\ 79,722 & 5,335 & 50,000 \\ 72,722 & 5,335 & 12,000 \text { (est) }\end{array}$

..Highest Priced Leases

(Dollars/Acre)

$\$ /$ Acre Lessee

35.6 The Anschutz Corp 1,720

12.47 Phillips Petroleum Co. 2,480

8.09 Nancy P. Anschutz 2,475

8.09 Nancy P. Anschutz 2,218

. Tentative Lease SaTe Dates:

Leases are up in 1985

. Summary of Leasing Status and Needs:

Some 1 and has been withheld from leasing for the BLM raptor study area. Anschutz transferred Tand to Occidental Petroleum and the Louisiana Land Corp. in a $75 / 25$ ratio. Continued leasing interest for other areas outside the KGRA in the Castle Creek area. (5) Occidental

Petroleum and the Louisiana Land Corp. are now known as 0ccidental Geotherma 1 Corp. Inc., and Louisiana Land Corp. Other leases are held by Geothermal Resources International, Inc. (2,352 acres).

The Dow Chemical Co.

Phillips Petroleum

(2080 acres)

Russel1 A. Pomeroy

( 2545 acres)* in addition to the above

Laura J. Spangler

(2492 acres)

$(2560$ acres $)(5)$

State geothermal leases are held by Occidental Geothermal Inc. and Louisiana Land and Exploration Co. in a $75 / 25$ ratio (16)

Private leases are held by several companies, Phillips Petroleum is the only firm which has conducted any exploration. Phillips has drilled one exploration well on private leases.

\section{GEOTHERMAL DEVELOPMENT STATUS}

-.Present Development Status:

One well has been drilled under an oil and gas drilling permit by Anschutz Corp. to a depth of $3,353 \mathrm{~m}(11,000$ feet). Hot water was encountered at 1,524 and $2,135 \mathrm{~m}$ with temperatures of 70 to $80^{\circ} \mathrm{C}$. The rest of the wel1 was nonproducing but with temperatures exceeding $200^{\circ} \mathrm{C}$. This well was drilled on state lands prior to 
the KGRA designation. This 1 and has been transferred to 0ccidental Geothermal

Numerous irrigation wells in the area have temperatures of 70 to $80^{\circ} \mathrm{C}$ and are drilled to a depth of about $300 \mathrm{~m}$ (1000 feet). (17)

Heat flow studies carried out by the Idaho Department of Water Resources indicate that temperatures hot enough for space heating can be found at shallow depths ( $7-2$ kilometers anywhere in this area. Temperatures hot enough for electrical generation $\left(200^{\circ} \mathrm{C}\right)$ can be found at depths of 3-4 ki lometers. (12)

Phillips Petroleum has drilled one exploration well on private leases.

..Projected or Planned Development:

Drilling will continue on private lands until discoveries are made of significant magnitude to warrant drilling on federal lands. No deep drilling is expected for the federal lands until 1980's depending on exploration drilling on non-federal lands.

Private and state lands are expected to develop exploration activity in the 1978-79 primarily due to minimal problems related to acquiring drilling permits from the state. 
Table 42 - Cont'd.

INSTITUTIONAL CONSIDERATIONS - FederaI

Institutional

Requirements

Federa] Geotherma 1

Resource Lease

(30 C.F.R. 3000)
National Environmental Policy Act (42 U.S.C. 4331)
Federal Water Pollution Control Act (33 USC 1251)

Federal Safe Drinking Water Act

(42 U.S.C. (A) 300)
Agency and

Public Attitudes

Leases are made pursuant to the Geothermal Steam Act of 1970

(84 Stat. 1566)

(30 USC 1001-1025)
Status of Requirements (i.e., EIA/EIS Requirements)

Leases within the K.G.R.A. are competitive. Special conditions are required in the leases with regard to potential archaeological and historical sites, adjacent roadless areas, and critical habitat areas.

An E.I.A. is required or An EAR will be conducted and an EAR for all exploration activity. BLM and USGA.

The national goal of this Act is to attain -0- pollution by 1985 .

This Act is concerned with protection of underground water sources that could be used for domestic water. the FWS will review only major projects. In general an E.I.A. is required for all projects involving exploration and development. If a generation facility is to be built and power generated and sold or a large non-electrical facility constructed, then an E.I.S. will be required.

Ground water is included under this Act and the reinjection of geothermal effluent will require permits.

The Act sets standards for wells and well drilling and could influence future geothermal we $11 \mathrm{~s}$ in the Owyhee area. The upper aquifer of the basin is the supply of domestic and irrigation water for the area. Reinjection of water for geothermal wells will require permits under this Act. 
INSTITUTIONAL CONSIDERATIONS - State and Loca1

Institutional

Requirements

Leases on State Lands (Idaho Code 47-601 et. seq. Chapter 16, Geothermal Resources)

Geotherma] Resource Permits.

(Idaho Code 42-4001 et. seq. Chapter 40 , Geotherma 1 Resources)

Water Appropriation (Idaho Code 42-101 et. seq. Chapter 1 Water Appropriation)

Injection we $17 \mathrm{~s}$ (Idaho Code 42-3001 et. seq. Chapter 39 Waste Disposal and Injection We11s)

Owyhee County building permits.
Agency and

Public Attitudes

The state Board of Land Commissioners is authorized to issue leases for geotherma 1 resources underlying state and school lands.

The regulatory powers of the state Geothermal Resource Act are placed in the Idaho Department of Water Resources.

The Idaho Department of Water Resources issues water appropriation permit and a water right Ticense.

Permits are issued by the No waste disposal or injection Department of Water Resources.

Owyhee County Court Commissioners
Status of Requirements (i.e., EIA/EIS Requirements)

Lease term is 10 years and can be continued with diligent development. Rentals are set by the Board. Several leases have been granted on state lands. Lease size is limited to a maximum of 640 acres/lease.

Any private owner, or holder of a state or federal lease of geothermal resources must first apply for a geothermal resource permit from I.D.W.R. before any drilling operations can begin.

Under the Idaho Geothermal Resources Act, applicants can be required to make an application to appropriate the public waters of the state:

wel1 can be constructed in Idaho unless a permit has been issued by I.D.W.R. The approval of this permit is contingent upon the approval of the Department of Health and Welfare. The proposed well is reviewed to see if it will unreasonably contaminate or deteriorate the quality of the ground water below the adopted water quality standards of the state.

Building permits will be required for structures. No other 1 and use requirements. 


\section{ENVIRONMENTAL FACTORS}

..CLIMATE ${ }^{(4)}$

..Prevailing Winds: 5 to $20 \mathrm{mph}$ from West to Northwest following the River Canyons, gust up to $60 \mathrm{mph}$.

..Precipitation (Annual): $18.4 \mathrm{~cm}$

..Days of Sunshine (Annua 1): 320

.. Average Temperature

$\begin{array}{lrc} & \text { January } & \text { July } \\ \text { Minimum: } & -7.3^{\circ} \mathrm{C} & 13.6^{\circ} \mathrm{C} \\ \text { Maximum: } & 3.3^{\circ} \mathrm{C} & 35.7^{\circ} \mathrm{C}\end{array}$

..Degree Days (Annual): 5089

. Relative Humidity (Seasonal Peaks)

Summer: $\quad 30 \%$

Winter: $\quad 70 \%$

..AIR QUALITY:

Level of particulate matter is unknown, the major pollutant is dust from natural causes and farming activity. No measuring stations in the area. Air quality is generally considered good.

..GEOLOGIC FACTORS :

Well interference problems may be a major factor. Upper irrigation aquifers are recharged from lower strata.

..WATER QUALITY:

Actual supply of the ground water is unknown. Deep thermal we 1 is have fluoride counts of 8 to $17 \mathrm{ppm}$. Most wells in the area have licensed water rights.

..NOISE: Low noise levels.

..BIOLOGICAL (22)

..Dominant Flora: Sagebrush-grass ecosystem with overstory of large sagebrush and understory of cheat grass and brome grass.

..Dominant Fauna: Mule deer, marrmot, coyotes, bobcat, and ráptors. Also, game birds.

..Endangered Species

Fauna: Prairie Falcons and Furgenous Hawk are proposed for endangered list in Idaho. The largest nesting area in North America for Prairie Falcons is in the Snake River Birds of Prey Natural Area along the northern sections of the KGRA. 
acres of non-KGRA federa] lands have been leased in areas adjacent to the Castle Creek and Bruneau KGRAs. (19) Despite the fact that over 200,000 acres of federa and state lands have been leased in Owyhee County for geothermal exploration, no exploration wells had been drilled on any of these leases as of October, 1978. The lack of drilling activity can be attributed to three principle factors:

1. Speculative investment by leaseholders.

2. Institutional and environmental regulations which accompany federal geothermal leases slow and deter the exploration process.

3. A lack of tax incentives for geothermal exploration.

Exploration drilling has occurred on private leases held by Phillips Petroleum Company in the Grandview area. The well was drilled in March 1978 and the results are confidential. The Phillips well is indicative of the institutional factors which retard exploration of public lands. Phillips was able to obtain the required Geothermal Resources drilling permit from the state in less than one month. (20) Permits for exploration drilling on federal BLM lands presently take from six months to over a year. (21)

2) Environmental Conditions:

The Bruneau KGRA is located between two environmentally protected areas. The northern border of the KGRA is adjacent to the Bruneau Dunes State Park. South of the KGRA, the Bruneau River has been nominated as a Wild and Scenic River. Any development within the Bruneau KGRA will require restricted environmental impact procedures. The northern border of the Castle creek KGRA is in the Snake River Birds of Prey Natural Area. Any development in this area will be restricted within one mile of known nesting areas and ingeneral there is a 5 -mile buffer zone along the borders of the bird reserve. (22) In general, both the Bruneau and Castle Creek KGRAs are adjacent to environmentaliy protected areas and any development of federal leases in these areas will require an Environmental Impact Statement.

\section{3) Aquifer Recharge:}

Declining water levels have been noted in at least one major thermal irrigation well adjacent to the Bruneau KGRA and one well in the Castle Creek KGRA. In certain areas, declining water levels suggest that current recharge to the upper aquifer is not sufficient to replace ground water extracted. Protection of the upper aquifer from pollution and ground water mining will restrict electrical generation and other large consumptive uses. Injection of waste fluids will most likely be required.

\section{Electrical Generation Potential}

The electrical generation potential for the Bruneau and Castle Creek KGRAs is moderate. The technology for generation of electrical power with $150^{\circ} \mathrm{C}$ geothermal fluids is still being developed. Experiments at Raft River, Idaho are providing this technology but the commercial feasibility is not expected until the mid 1980s. (23) High temperature steam may be encountered at depths of 2 kilometers. Deep drilling is needed to prove the resource for electrical generation feasibility. 
Space heating of human habitation will be limited. District heating systems for the communities of Bruneau and Grandview is technologically possible but economically limited. Bruneau is a very small community with approximately. 40 residential structures and 10 commercial structures. One quarter of these buildings, including half the commercial structures are two service stations and a general store. Most of the residents are retired and Tiving on fixed incomes.

In its present socio-economic state Bruneau could not afford to develop a geothermal heating system. Future development of a district heating system in Bruneau is dependent on increased growth. Such growth could occur if industry could be attracted to locate in the area.

Grandview's socio-economic state and higher population could support a geothermal space heating system. The community is undergoing a $38 \%$ growth rate per year(24) and growth is expected to continue as long as the agricultural base of the area continues to expand. Irrigation wells within $8 \mathrm{~km}$ of the city have temperatures of $80^{\circ} \mathrm{C} .(25)$ These wells could provide all the heat energy for Grandview. The location of new industries into this area would increase the growth rate substantially. The major environmental and legal-institutional restriction to increased growth in Grandview is adequate sewer services.

\section{Industrial Potential}

There are clear advantages and disadvantages to locating new industry in the Bruneau-Grandview area. The major incentives for location of new industries in the Bruneau-Grandview area are:

1. Abundant, proven, $80^{\circ} \mathrm{C}$ geothermal resources.

2. Potential for high temperature $\left(150^{\circ} \mathrm{C}\right)$ geothermal resources.

3. Abundant cheap land.

4. Natural gas service in the area.

5. A new BPA $500 \mathrm{kV}$ power line is planned to cross the area by 1985.

6. State highway service to the area.

7. Abundant local agricultural products.

The major deterrents to locating new industry in the Bruneau-Grandview are are:

1. Limited highway access; State Highways 51 and 78 are narrow and $01 d$ roads.

2. Nearest rail service is $32 \mathrm{~km}$ from the area.

3. Present power lines are limited to two $138 \mathrm{kv}$ lines at C. J. Strike Dam and rural service lines.

4. Present communities are isolated and sma11. The nearest major retail service center is Mountain Home, $32 \mathrm{~km}$ from the area.

Industries which would be attracted to this area are those which need hot water for primary processing of agricultural products. The Bruneau-Grandview geothermal area produces over 2 million cwt of potatoes, 117,069 tons of alfalfa, 92,506 tons of sugarbeets, 770,000 bushels of barley and 24,630 bushels of oats per year. (26) Those crops with the highest potential for attracting 
processing plants to the Bruneau-Grandview area are potatoes and alfalfa. crops were selected for the following reasons:

1. Temperature requirements for processing match those available from the local geothermal resources.

2. These crops undergo the greatest weight reduction during processing.

3. Potatoes and alfalfa are the main crops of the area.

4. These crops are presently shipped in bulk to processing markets in Twin Falls and Canyon Counties.

5. These crops are also the main crops of Elmore County which presentiy ship to processing centers in Twin Falls and Canyon Counties.

Alfalfa Drying:

Currently there are no alfalfa dehydration plants in the Western Snake River Plain. The location of such a plant at a geothermal area would require at least a $104^{\circ} \mathrm{C}$ resource and a production of $500 \mathrm{gpm}$ of the thermal water. In addition to a high temperature geothermal resource, the plant will require 5 tons of raw alfalfa per ton of finished product. (27)

The rationale for rapid drying of alfalfa instead of complete sun wilting in the field is to retain a higher percentage of Vitamin $A$ and xanthrophy 11. By fuel drying fresh cut alfalfa, a minimum $17 \%$ of the protein and $44 \%$ of the Vitamin $A$ are retained. (28) The end product is a bright green, hard, pellet of feed. Production cost of pelletized feed is about $\$ 20$ per harvested ton of alfalfa of which $\$ 2.50 /$ ton is fossil fuel energy. (29) Complete dehydration with geothermal does not appear to be economical at this time when compared to fuel $0 i 1$ and natural gas dehydration processing. (30) Field-Wilting alfalfa to $60 \%$ moisture prior to drying offers an alternative. By using a field-wilting geothermal dehydration process the harvesting and processing cost could be reduced from $\$ 20 /$ ton to less than $\$ 16 /$ ton. (3T) A geothermal alfaifa dehydration facility that has an annual output of 25,000 tons of pellets would realize an estimated $\$ 100,000$ per year savings over other conventional fuel plants. (32)

A facility that has an annual output of 25,000 tons of pellets would require 125,000 tons of raw product per year. The annual production of alfalfa in Owyhee County is only 117,000 tons. The combined production of Owyhee and Elmore counties is 188,400 tons annually.

A large alfalfa dehydration plant does not appear feasible at this time because of a lack of raw product. A small operation of one-half to one-quarter the size illustrated could be practical. A plant producing 12,000 tons of pellets per year would require 60,000 tons of raw alfalfa. This scale plant would still realize a $\$ 50,000$ per year cost savings over a fuel plant.

\section{Potato Processing:}

In 1976, Idaho produced $76,865,000$ cwt of potatoes of which 10,395,000 cwt were produced in the Western Snake River Plain. Approximately $60 \%$ of Idaho's potato crop was processed. (33) The production of potatoes is expected to increase to $95,000,000$ cwt by 1990 and approximately $73 \%$ of that crop wi11 be processed. (34) 
Owyhee County produced 2,205,000 cwt of potatoes in 1976. (35) These potatoes were shipped to processing centers in Canyon County and Twin Falls County by truck with the main transportation route through Bruneau-Grandview. Approximately $60 \%$ of Owyhee County's potatoes were processed in 1977 . Owyhee County by itself does not produce enough potatoes to warrant locatina a potato processing facilitv in the Bruneau-Grandview geothermal area. The combined production of Owvhee and Elmore Counties is $7,425,500 \mathrm{cwt}$ of $10 \%$ of the state production and $72 \%$ of the Western Snake River Plain production. (36) The maiority of this potato production occurs within $40 \mathrm{~km}$ of the Bruneau-Grandview qeothermal area. Potatoes produced in this area are presently shipped more than $60 \mathrm{~km}$ for processina.

Potato processina involves freezino or dehydration of the potato. In the frozen french fry process the potato is peeled in a hot solution, blanched, dried and then fried, frozen and packaged. In the dehydration process the potato is washed, cooked and dehydrated to form potato flakes or potato granules. Engineering studies conducted by the University of Idaho, (37) Oregon Institute of Technology, (38) and $\mathrm{CH}_{2} \mathrm{MH} \mathrm{H}_{11}$ (39) on converting present potato processing facilities to geothermal energy require a geothermal resource of $130^{\circ} \mathrm{C}$ to $190^{\circ} \mathrm{C}$, depending on the type of operations. A geothermal resource of $150^{\circ} \mathrm{C}$ could provide up to $50 \%$ of the process energy for frozen potato products. (4T) (42)

Ore-Ida Foods, Inc., located in Ontario, Oregon, expects to replace 55\% of the process energy requirements of their frozen potato products plant with a $148^{\circ} \mathrm{C}$ geothermal resource. (43) The company expects to realize a quarter of a million dollar savings using geothermal resources. With as $10 \mathrm{w}$ as $33 \%$ confidence level of successful driliing, the company expects to have a $20 \%$ return on investment over a 15 year project 1 ife. (44) In the Ore-Ida example the resource is at the plant and the piping costs are minimal.

The above data concerns the conversion of an existing plant to geothermal energy. Assuming construction of a new plant using geothermal energy would have approximately equal basic cost as a gas energized plant, (except for the well and piping cost) the plants location would be determined by the geothermal site. The feasibility of that location is related to the location of the potato crops. As shipping distance for potatoes increases, the transportation costs increase and the economic feasibility of a new plant decreases. Potatoes shipped more than $160 \mathrm{~km}$ have transportation costs of more than $\$ .25 / 1001 \mathrm{~b}$., and potatoes shipped less than $40 \mathrm{~km}$ cost less than $\$ .13 / 100 \mathrm{lb} .(45)$ Potatoes in the Bruneau-Grandview area are presently shipped 60 to $80 \mathrm{~km}$ at an approximate cost of $\$ .20 / 100 \mathrm{1b}$. The location of a potato processing plant at the BruneauGrandview geothermal area would reduce shipping cost to less than $\$ .13 / 1001 \mathrm{~b}$.

The unique combination of high temperature geothermal resources, natural gas service and abundant local agricultural production makes the BruneauGrandview area a prime site for the location of new processing facilities. However, inadequate railroad transportation at the Bruneau-Grandview geothermal area will deter industry from locating in the area. Major processing industries may not consider this location until rail transporation is extended into the area. The nearest railroad spur-line is located 32 kilometers north of Bruneau at the Mountain Home Air Force Base. Any industrial direct-use scenarios for the Bruneau-Grandview area must include construction of a rail transportation system. This is particularly true when considering potato processing facilities where an adequate access to national markets is a primary potato marketing requirement. 
Scenario Projections:

Bruneau KGRA: 50 MW electrical generation capacity by 1990

$250 \times 10^{9}$ BTU/year Industrial utilization by 1990

Future incremental developments are not projected due to a lack of data on availability of geothermal resources.

Castle Creek KGRA:

$150 \times 10^{9}$ BTU/year industrial utilization by 1985

50 MW electrical generation capacity by 1990

Future incremental development of $50 \mathrm{MW}$ every 20 years is projected providing adequate resource is proven. 
The Givens Hot Springs geothermal area is located in northwestern Owyhee County along the Snake River, $40 \mathrm{~km}$ south of Nampa. This geothermal area is the most northwestern manifestation of the Bruneau-Grandview geothermal anomaly. Little is known about the hydro-geology of this thermal. locality. (46) The temperatures of the springs and we $11 \mathrm{~s}$ are greater than $35^{\circ} \mathrm{C}$ and geochemical thermometers predict aquifer temperatures of $85^{\circ} \mathrm{C} .(47)$ Present information about the resource potential indicated that future high temperature utilization prospects are not possible at this time. Present thermal wells do have considerable potential for expanded use for space heating.

At present, the hot springs are used to heat the pool at Givens Hot Springs Resort. This year-round facility is very popular with the local population and received moderate to heavy use throughout the year. Thermal wells in the area are used for irrigation.

The development of commercial greenhouses in this area could be possible. The geothermal resource of the present irrigation wells could provide the necessary heat for the greenhouse's year-round operation and the Nampa-Caldwe 11 market area is $40 \mathrm{~km}$ away. The Boise market area is within $80 \mathrm{~km}$ of Givens Hot Springs. The commercial crops are tomatoes and house plants. (48) Commercial tomato crops have been successfully grown in geothermal greenhouses using $60^{\circ} \mathrm{C}$ or above resources. Two commercial greenhouse operations in Boise use $45^{\circ} \mathrm{C}$ water to raise cut flowers and house plants.

Engineering studies conducted by Oregon State University (49) and Oregon Institute of Technology have shown that the principle difference in capital cost between a gas heated greenhouse and a geothermal heated greenhouse is the cost of the geothermal we11. In both cases, the annual operation cost is equal in al1 areas except heat energy cost. Over $\$ 20,000$ per year cost savings are realized for a three acre greenhouse operation using geotherma 1 energy over natural gas. (51) If lower temperature geothermal water (below $60^{\circ} \mathrm{C}$ ) is used, then larger volumes are required to supply the necessary heat. The Givens Hot Springs area has several irrigation wells which could supply this energy.

Because these wells already exist the higher capital investment for a geothermal heating system is lowered to equal cost of a natural gas system. The pumping demand for these wells is during the opposite season as the demand for geothermal heat for the greenhouse. Thus, competition for the resource is minimal and the opportunity for an out of season winter crop exists.

The second major potential use of geothermal energy in the Givens Hot springs area is space heating of homes. The area has high recreation potential. The hot springs is located along the Snake River in a scenic area known for its good fishing. As growth continues in the Nampa-Caldwell-Boise area, there will be increasing demand for recreation homes in the Givens Hot Springs Area. The area has a mild winter climate and the hot springs provides yearround recreation. Present thermal irrigation wells could provide heat for new homes built in the area. Table $43-C$ is a compendium of data regarding the Givens Hot Spring Subarea. 
Table 43-c

Data Summary for Givens Hot Springs

SITE LOCATION AND PHYSICAL DESCRIPTION

.. Latitude: $43^{\circ} 30^{\prime} 00^{\prime \prime} \mathrm{N}$

..Longitude: $116^{\circ} 46^{\prime} 00^{\prime \prime} \mathrm{W}$

. Rectilinear: Sec. 21, T $1 \mathrm{~N}, \mathrm{R} 3 \mathrm{~W}$, Boise Meridian

..County: Owyhee

..Adjacent Counties: Ada, Canyon, Twin Falls

..Topography: Flat

..Present Land Use:

Agriculture is the major land use of the area. Wheat, potatoes, and alfalfa are the major irrigation crops with cattle grazing on other lands. A small swimming resort at Givens Hot Springs is the only non-agricultural activity in the Givens area.

..Future Land Use Plans:

Continuation of present land uses.

...Aesthetics:

Area is located along the Snake River in a rural agricultural area and can be considered to have moderate to high aesthetic values.

..Historical/Archaeological Significance:

The Oregon Trail crosses this area and Givens Hot Springs was a major stop along that trail.

some archaeological sites do exist in the area. 
Table 43-C Cont'd.

\section{RESERVOIR CHARACTERISTICS}

. Reservoir Temperature (5) (6)

. Surface: $49^{\circ} \mathrm{C}$

..Subsurface: Unknown

. Geochemical

$$
\begin{array}{rr}
\mathrm{SiO}_{2}: & 85^{\circ} \mathrm{C} \\
\mathrm{Na}-\mathrm{K}-\mathrm{Ca}: & 40^{\circ} \mathrm{C}
\end{array}
$$

..Flow Rates: 650 gpm

$\ldots \mathrm{pH}: \quad 7.2$

. Total Dissolved Solids: 302 to $334(\mathrm{mg} / \mathrm{T})$

..Fluid Chemistry: ${ }^{(6)} \quad(\mathrm{mg} / 1)$

$$
\begin{array}{lc}
\mathrm{Si}: & 40 \\
\mathrm{Ca}: & 2.2 \\
\mathrm{Mg}: & 0 \\
\mathrm{Na}: & 110 \\
\mathrm{~K}: & .3 \\
\mathrm{HCO}_{3}: & 214 \\
\mathrm{CO}_{3}: & 0 \\
\mathrm{SO}_{4}: & 8.6 \\
\mathrm{P}: & .01 \\
\mathrm{Cl} & 28 \\
\mathrm{~F} & \mathbf{2} \\
\mathrm{NO}_{3}: & .04 \\
&
\end{array}
$$


Approximately $50 \%$ of the total acreage of federal and state geothermal leases in Idaho are located in Owyhee county. The majority of these leases are located in and around the Bruneau and Castle Creek KGRAs. The total amount of acres leased from private land owners is unknown but estimates range from 25,000 to 50,000 acres. Although approximately 170,000 acres of state and federal lands have been leased for geothermal exploration. Exploration drilling activity has been limited to the private leases. The majority of the state and federal leases were issued between 1970 and 1975. The primary term of these leases will begin to expire in 1980 through 1985. Table 44-C summarizes the leasing activity in Owyhee County.

Table 44-C

\section{GEOTHERMAL LEASING IN OWYHEE COUNTY}

Federal Lands

Bruneau

5,120 acres

Occidental Geothermal Inc. $(2,600$ acres $)$

Castle Creek

79,722 acres

Dow Chemical Co., $(2,080)$; Geothermal

Resources Internationa] Inc., $(2,353)$;

Occidental Geothermal Inc. $(16,472)$;

Phillips Petroleum Co. $(5,025)$;

R. A. Pomeroy $(92,492)$;

L. J. Spangler $(2,560)$.

Tota 1: 130,397 acres

Other Non-Competitive Geothermal Leases

Federal Lands

152,838 acres Leases are concentrated around the

Castle Creek and Bruneau KGRAs.

State Lands 19,137 acres Most of these leases are held by

Occidental Geothermal Inc.

Estimated Private Leases: $\quad 25,000-50,000$ acres

Summary Owyhee County

The geothermal development potential of Owyhee County is moderate to high. Moderate temperature geothermal resources are known to exist in the area and deep exploration drilling may prove high temperature geothermal resource capable of electrical generation and industrial applications. The major development deterrents of the area are: the remoteness of the area, and its close proximity to environmentally sensitive areas such as the Birds of Prey Natural Area. 
1) U.S. Geological Survey, Conservation Manager Western Region, Memorandum: To State Director; Bureau of Land Management, Boise, Idaho; Subject: Definition Bruneau KGRA, Feb. 10, 1975.

2) U.S. Geological Survey, Conservation Manager, Western Region, Memorandum; To State Director of Bureau of Land Management, Boise, Idaho; Subject: Definition of Castle Creek KGRA, June 12, 1975.

3) Ross, Sylvia H., 1971, Geothermal Potential of Idaho: Idaho Bureau of Mines and Geology, Pamph. 150, p. 17.

4) Rice, R. A., Climate of Idaho, Climates of the United States, No. 60-10, U.S. Dept. of Commerce, NOAA, 1977.

5). Rightmire, C. T., Young, H.W., Whitehead, R.L. Isotopic and Geochemical Analysis of Water for Bruneau-Grandview and Weiser Areas, Southeast Idaho, Water Info. Bu11. 30, Geothermal Investigations in Idaho, Part 4, Idaho Department of Water Resources, 1976.

6) Young, H.W. and Whitehead, R.L., An Evaluation of Thermal Water in the Bruneau-Grandview Area, Southwest Idaho, Geotherma 1 Investigation in Idaho Part 2, Idaho Dept. Water Resources Info. Bu11. 30, 1975.

7) Sedimentary Aquifer of the Idaho Group: Poorly to well stratified fluvial and lacustrine deposits of unconsolidated to consolidated gravel, sand, silt, and clay with layers of ash and basalts. Poor to good aquifers, locally $1000 \mathrm{~m}$ thick.

8) Idaho Volcanic Group, Banbury Basalt; Lava Flows, mostly vericular, poor to excellent aquifers depending upon degree of alteration present. An unaltered unit is a good aquifer. Locally $5 \mathrm{~m}$ to $300 \mathrm{~m}$ thick. Idavada Volcanics are highly jointed tuffs and rhyolitec rocks, good aquifers, generally thermal.

9) Rightmire, Op. Cit.

10) Littleton, R.T., and Crosthwaite, E.G., 1957 Groundwater geology of the Bruneau-Grandview Area, Owyhee County, Idaho: U.S. Geological Survey Water Supply Paper 1460-D, p. 147-198.

11) Ralston, D. R. and Chapman, S. L., 1969, Groundwater resources of northern Owyhee County, Idaho: Idaho Department of Reclamation Water Information Bu11. 14, $85 \mathrm{p}$.

12) Brott, Charles A., and Glackwe11, David D., Mitche11, John C., 1976, Heat Flow Study of the Snake River Plain Region, Idaho Water Info. Bull. No. 30, Geothermal Investigation in Idaho, Part 8, p. 39.

13) Young, H.W. and Mitche11, J.C., 1973, Geochemistry and Geological Setting of Select Thermal Waters, Geothermal Investigations in Idaho, Part 1, Water Info. Bul1. No. 30, Idaho Department of Water Resources, p. 33.

14) Brott, Op. Cit. 
15) Young, op. Cit. p. 33

16) Idaho Department of Lands, $0 i 1$ and Gas Log, Anschutz Corp. No. 1 we11,

17). Bureau of Land Management, Geothermal Resource Leases.

I-9545, I-9546, Occidental Geothermal, Inc. (Oxy Petroleum Inc.

75\% interest and Louisiana Land and Exploration Co. 25\% interest.

18) Bureau of Land Management Geothermal Leases I-10083, I-10080, I-10087, Occidental Geothermal Inc.,

Also, State of Idaho Geothermal Lease H-257, Occidental Geothermal Inc.

19) Bureau of Land Management, Idaho BLM, Geothermal Lease File, Boise, Idaho.

20) Mitche 11, John C., Idaho Dept. of Water Resources, Boise, Idaho personal communication.

21) Graetzer, Inez, Boise District, Bureau of Land Management, Boise, Idaho personal communication.

22) Howard, Richard, U.S. Fish and Wildlife Service, Boise, Idaho, personal communication.

23) Kunze, Jay, Edt., Geothermal R \& D Project Report for Oct., 1976 to March 1977. TREE T134, Idaho National Engineering Lab, Idaho Fal1s, Idaho, May, 1977.

24) Cenarrusa, Peter T., Secretary of State, Idaho Blue Book, 1978, p. 238.

25) Young, H.W. and Mitche11 J.C., Op Cit., p. 33.

26) Idaho Crop and Livestock Reporting Service, Idaho Agricultural Statistics 1977, Idaho Department of Agriculture, Boise, Idaho.

27) Wright, Thomas C., "Crop Drying with Geothermal Energy." Direct Utilization of Geothermal Energy: A Symposium, Geothermal Resource Counci1, February 1978, p. 5-12.

28) Lienau, Paul J., "Agribusiness Geothermal Energy Utilization Potential of Klamath Basin, Oregon." Direct Utilization of Geothermal Energy: A

Symposium, Geothermal Resource Council, Feb. 1978, p. 18.

29) Ibid.

30) Wright, Op. Cit., p. 6

31) Lienau, Paul J., Op. Cit., p. 19.

32) Ibid.

33) Idaho Crop and Livestock Reporting Service, Op. Cit., p. 59.

34) Bonneville Power Administration, Agriculture and Food Processing of Pacific Northwest Projection of Production, Employment, and Energy Consumption to 1990, Portland, OR., 1974.

35) Idaho Crop and Livestock Reporting Service, Op. Cit., p. 59.

36) Ibid. 
37) Gerick, Joseph A., Industrial Utilization of Geothermal Energy, Masters Thesis, University of Idaho, 1977.

38) Lienau, Paul J., Edt. Agribusiness Geothermal Energy Utilization Potential of Klamath and Snake River Basin of Oregon, Geo-Heat Utilization Center, Oregon Institute of Technology, 1978.

39) ORE-IDA Foods, Inc., A Field Experiment Food Processing Industry - Geothermal Energy, Dept. of Energy PON, EG-77-N-03-1533, 1978.

40) Gerick, Joseph A., Op. Cit.

41) Lienau, Paul J., Op. Cit. p. 21

42) ORE-IDAHO, Op. Cit. p.

43) Lienau, Paut J., Op. Cit., p. 20.

44) Ibid.

45) Gerick, Joseph, Op. Cit. p.

46) Ross, Sylvia H., Op. Cit., p. 17

47) Young and Mitche 11 , Op. Cit., p. 33.

48) Havens, Lamar D., Geo-Solar Growers Inc., Weiser Hot Springs Greenhouse Development, personal communication.

49) Culver, Gene, Geo-Heat Utilization Center, Oregon Institute of Technology, personal communications.

50) Reistad, Gordon M.

Schmisseur, Wilson E., Shay, J. Ralph, Fitch, James B.,

An Evaluation of Uses for Low to Intermediate Temperature Geothermal Fluids in the Klamath Basin, Oregon. Oregon State University Engineering Experiment Station, Bu71. No. 55, 1978.

51) Ibid.

52) U.S. Geological Survey, 15 minute series Topographic Map, Hot Springs Idaho, Quadrangle, 1949.

53) Bureau of Land Management, Boise District, Idaho, EAR Prelease Report, Bruneau KGRA, June 1975.

54) State of Idaho, Department of Lands, Geothermal Lease Files, Lease Numbers $\mathrm{H}-311, \mathrm{H}-319, \mathrm{H}-320, \mathrm{H}-321$. Current as of March 1978.

55) U.S. Dept. of Interior, U.S.G.S., Assessment of Geothermal Resources in the United States - 1975, USGS Cir. 726, D.E. White, ed. 1975.

56) Idaho Energy Office Utilities Map, 1977, unpublished. 
POTENTIAL GEOTHERMAL DEVELOPMENT SITES

Washington County

\section{Introduction}

The Weiser geothermal area of Washington County comprises about 320 square kilometers. Two major subareas of intense interest are: The crane Creek KGRA located 20 kilometers east of Weiser, Idaho and Weiser Hot Springs located 8 kilometers northwest of Weiser, Idaho. The land use of both areas is dominantly agricultural. Both areas are rural locations with low populations. Major mail service exists at both sites and the existence of rail service enhances the commercialization potential of these sites.

The geology of Crane Creek KGRA and Weiser Hot Springs differs locally but the general stratigraphy and structure of the region is similar for both sites. Both Hot Springs are structually controlled by the northwest trending faults of the region. Geophysical data suggests that an anomalous conductive zone is present at shallow depths in both areas. Surface discharge temperatures range from $77^{\circ} \mathrm{C}$ to $92^{\circ} \mathrm{C}$ and geochemical aquifer temperature estimates range from $150^{\circ} \mathrm{C}$ to $270^{\circ} \mathrm{C}$. (1)

Crane Creek KGRA Subarea

The Crane Creek KGRA encompasses seventeen square miles of land. The local geology is a complex transition zone between the cretaceous granite of the Idaho batholith to the east and the Snake River Plain to the west. The oldest exposed rocks in the KGRA are iocene-basalts and andesites. A series of north trending faults have broken this sequence of volcanic rocks into tilted blocks. These tilted blocks were subsequently buried by a sequence of iocene volcaniclastic sedimentary rocks. Interbedded coarse grained arkosic sandstones are also present. Continued deformation along the north trending faults of the area has gently folded the sedimentary sequence. This deformation was accompanied by emplacement of intrusive rocks and large scale hydrothermal activity. The intrusives are estimated to be 10 million years old. (2)

Subsequent subsidence of the Snake River Plain has truncated structures in the sedimentary sequence and is thought to be the last major structural event in the area. Valley floors are typically filled with holocene gravels and flood plain deposits.

In Crane Creek Canyon two active hot springs and a hot mud seep are located in gravel deposits and sand stones which cover miocene lava outcrops. The hot springs at crane creek are probably controlled by the north trending faults zones which cut the miocene volcanic rocks. The surface discharge of the hot springs is $3.3 \mathrm{~L} / \mathrm{S}$ and the temperature is $77^{\circ} \mathrm{C}$. (2) Both the silica and sodium-potassium-calcium geochemical thermometers indicate aquifer temperatures greater than $150^{\circ} \mathrm{C}$ are possible at depth.

A rugged topography was carved on this landscape by the Weiser River Drainage. Crane Creek forms a deep narrow canyon through the eastern section of the KGRA. The on ly hot springs in the KGRA are located in crane creek 
Canyon. At the confluence of Crane Creek and the Weiser River, the topography of the area abruptly changes to a broad flat flood plain. Located one kilometer west of Crane Creek Hot Springs, Echo Dell flat is the only location within the KGRA which has sufficient open space to site facilities. A primary railroad line exists at Echo Dell flat and the area is serviced by all weather county roads.

Land use in the KGRA is largely agricultural with cattle grazing in the hills and limited irrigation farming along stream channels. The population of the KGRA is less than one person per sq. kilometer. Weiser, the major population center of the area, $(4,600)$ is located 16 kilometers west of Crane Creek Hot Springs and only 4 kilometers from the KGRA boundary.

The geothermal resource potential of the Crane Creek KGRA is unknown. Exploration drilling is needed to prove the capabilities of the geothermal reservoir. Based on the geochemical analysis, the potential utilization range is high temperature. Industrial and electrical generation commercialization scenarios are possible.

Environmental considerations in the area of Crane Creek Canyon could constrain well field development. The Federal Fish and Wildlife Service is concerned about erosion problems on some of the steep land but the major concern is that drilling activity will increase siltation of the streams. The Crane Creek drainage is considered critical habitat for sage grouse, some species of raptors and mule deer. (10) Environmental concerns have limited leasing activity on almost $3 / 4$ of the federal KGRA lands. A maximum field development scenario could be limited to $50 \mathrm{mw}$ or less as a result of environmental constraints. Industrial development will have to be passive in terms of its environmental impact.

Leasing activity has been limited by environmental concerns. Southern Union Production Company hold federal leases on 1,381 acres in the KGRA. (4) This is the only federal lease issued in Crane Creek KGRA. Phillips Petroleum holds a State of Idaho lease on 640 acres adjacent to the Federal KGRA lands. (5) No Federal lands outside of the KGRA have been leased for geothermal. The U.S. Geological Survey will be drilling a series of test holes in the area in 1979.(7) Table 45-C presents a compendium of data regarding the Crane Creek KGRA.

Scenario Projections:

A $50 \mathrm{MW}$ plant is projected for private land adjacent to the KGRA by 1985, and an additional $50 \mathrm{MW}$ plant is projected for the KGRA by 1989 providing current exploration on private leases prove the resource. No future incremental capacity is projected for the Federal KGRA due to limited space for facility siting. Total carrying capacity for the area is estimated to be $100 \mathrm{MW}$. 
SITE LOCATION AND PHYSICAL DESCRIPTION

. Latitude: $44^{\circ} 17^{\prime} 54^{\prime \prime} \mathrm{N}$

..Longitude: $116^{\circ} 30^{\prime} 54^{\prime \prime} \mathrm{W}$

..Rectilinear: T $11 \mathrm{~N}, \mathrm{R} 3 \& 4 \mathrm{~W}$, Boise Meridian

..County: Washington

..Adjacent Counties: Idaho, Payette, Gem, Adams, Oregon: Baker, Malheur

. Topography (11)

Topography in the eastern part of the KGRA is rugged canyon lands; in the western part of the KGRA there are a series of steep rolling hills (slope greater than $12 \%$ )

..Present Land Use: ${ }^{(9)}$

Subhumid grassland and semi-arid grazing land. Principal land uses are grazing, irrigation farming on the flat areas along the creek, and recreation.

..Future Land Use Plans: Continuing present land use.

.. Aes thetics:

crane Creek area has high aesthetic value. The area within the canyon is steep and accessible only by foot.

..Historical/Archaeological Significance:

Six archaeological sites have been identified but have not been explored. All are located within the canyon area.

GEOLOGICAL/GEOPHYSICAL DESCRIPTION

. Geologic Description:

The exposed rocks in the KGRA are miocene basalts and andesites. A series of north trending faults have broken this sequence of rock into tilted blocks which have been subsequently buried by a sequence of miocene volcaniclastic sediments. Continued deformation has folded the entire series into broad gentle folds. Large scale hydrothermal activity and tertiary intrusives accompanied this period of deformation. The major north-northwest trending features of the area have been truncated by faulting related to the Snake River Plain subsidence. The subsidence of the Plain is considered to be the last major tectonic event of the area. Hot springs of crane Creek Canyon appear to be structurally controlled by the north trending faults of the area.

..Geologic Hazards: Flooding along Crane Creek. 
LAND OWNERSHIP AND LEASING

$\begin{array}{lllcc} & \begin{array}{c}\text { TOTAL AREA } \\ \text { (Acres) }\end{array} & \begin{array}{l}\text { FEDERAL } \\ \text { (Acres) }\end{array} & \begin{array}{c}\text { STATE } \\ \text { (Acres) }\end{array} & \begin{array}{c}\text { PRIVATE } \\ \text { (Acres) }\end{array} \\ \text {.. KGRA: Crane Creek } & 4,342 & 3,240 & 640 & 462 \\ \text {..Land Leased in KGRA; } & & 1,381 & 640 & \\ \begin{array}{l}\text {. Highest Priced Leases: } \\ \text { (Do17ars/Acre) }\end{array} & & & & \\ & & \text { \$/Acre } & \text { Lessee } & \\ & \text { bid. } & \begin{array}{l}\text { Southern Union } \\ \text { Production Co. }\end{array} & \end{array}$

. Tentative Lease Sale Dates:

1985 March for State Lands

.. Summary of Leasing Status and Needs:

Because of environmental concerns from the FWS, the BLM rejected non-competitive lease applications for Arco and Union. No Federal land has been leased for geothermal activity outside of the KGRA. (4) State lands near the KGRA have been leased to Phillips Petroleum which is drilling a 3,000 meter exploration well on private lands outside of the KGRA. (14) 


\section{RESERVOIR CHARACTERISTICS}

.. Reservoir Temperature

. Surface: $77^{\circ} \mathrm{C}(1) 92^{\circ} \mathrm{C}$

..Subsurface: Unknown

..Geochemical:

$\mathrm{SiO}_{2}: 170^{\circ} \mathrm{C}$

Na-K-Ca: $\quad 165^{\circ} \mathrm{C}$

Mixing Mode 1: $270^{\circ} \mathrm{C} ; 76 \%$ cold water( 2 )

..Flow Rates: 3.33 1/s

..pH: 7.1 to 8.0

..Total Dissolved Solids 1,070 (2) $\mathrm{mg} / 1$

..Fluid Chemistry: ${ }^{(2)}$ Milligrams per litre

$\begin{array}{rrr}\mathrm{SiO}_{2}: & 180 \\ \mathrm{Ca}: & 26 \\ \mathrm{Mg}: & 3 \\ \mathrm{Na}: & 290 \\ \mathrm{~K} \mathrm{~K}_{3}: & 18 \\ \mathrm{HCO}_{3}: & 197 \\ \mathrm{CO}_{3}: & 0 \\ \mathrm{CaCO}_{3}: & 162 \\ \mathrm{SO}_{4}: & 240 \\ \mathrm{Cl} & 200 \\ \mathrm{~F} & \vdots\end{array}$

Micrograms per 1itre

As:

B : $\quad 11,000$

Li: $\quad 660$

$\mathrm{Hg}$ :

0.1

.. Estimated Electric Energy Potential:

$100 \mathrm{MW}$

GEOTHERMAL DEVELOPMENT STATUS

..Present Development Status:

No private exploration drilling as of Sept. 28, 1978.

A series of 610 meter (2000 feet) stratigraphic test holes are currently being drilled by USGS. USGS work on reservoir confirmation may continue until 1979.(7)

...Projected or Planned Development:

Deep exploration drilling by 1985 . Industrial commercialization may occur by 1990. Electrical generation may occur by 1990, 50 to $100 \mathrm{MW}$. 
INSTITUTIONAL CONSIDERATIONS - Federal

Institutiona 1

Requirements

Federa T. Geotherma 1

Resource Lease

(30 C.F.R. 3000)
Agency and

Public Attitudes

Leases are made pursuant to the Geothermal Steam

Act of 1970.

(84 Stat. 1566)

(30 USC 1001-1025)

B.L.M.

U.S.G.S.

National Environmental Policy Act

(42-U.S.C. 4331)
An E.I.A. is required before leases are issued. E.P.A.
Status of Requirements (i.e., EIA/EIS Requirements)

Lease within the KGRA are competitive. Special conditions are required in the leases with regard to potential archaeological and historical sites, adjacent roadless areas, and critical habitat areas.

A preliminary E.A.R. could be required for any exploration drilling project. In general an E.I.A. is required for all projects involving exploration and development. An E.I.S. will be required for any major action.

The national goal of this Act is to attain -0pollution by 1985 . E.P.A.

(33-USCA 1251)

Federal Safe Drinking This Act is concerned Water Act (42 U.S.C. (A) 300)
Ground water is included under this Act and the reinjection of geothermal effluent will require permits.

The Act sets standards for wells and well drilling and could influence future geothermal wells. with protection of underground water sources that could be used for domestic water.

E.P.A. 
INSTITUTIONAL CONSIDERATIONS - State

\author{
Institutional \\ Requirements
}

Leases on State lands

(Idaho Code 47-601

et. seq. Chapter 16, Geothermal Resources)

Geotherma1 Resource Permits.

(Idaho Code 42-4001

et. seq. Chapter 40, Geotherma 1 Resources)
Water Appropriation (Idatio Code 42-101 et. seq. Chapter 1 Water Appropriation)
Injection we $11 \mathrm{~s}$ (Idaho Code 42-3001 et. seq. Chapter 39 Waste Disposal and Injection Wel1s)
Agency and Public Attitudes

The State Board of Land zed to issue leases for geothermal resources underlying state and school lands.

The regulatory powers of the state Geothermal Resource Act are placed in the Idaho Department of Water Resources. Commissioners is authori-

Status of Requirements (i.e., EIA/EIS Requirements)

Lease term is 10 years and can be continued with diligent development. Rentals are set by the board. Several leases have been granted on state lands. Lease size is limited to a maximum of 640 acres/lease.

Any private owner, or holder of a state or federal lease of geothermal resources must first apply for a geothermal resource permit from I.D.W.R. before any drilling operations can begin.

The Idaho Department of Water Resources issues water appropriation permits and a water right Ticense.

Permits are issued by the Department of Water Resources.
Under the Idaho Geothermal Resources Act, applicants can be required to make an application to appropriate the public waters of the state.

No waste disposal or injection well can be constructed in Idaho unless a permit has been issued by I.D.W.R. The approval of this permit is contingent upon the approval of the Department of Health and Welfare. The proposed well is reviewed to see if it will unreasonably contaminate or deteriorate the quality of the ground water below the adopted water quality standards of the state. 
Table 45-c Cont'd.

INSTITUTIONAL CONSIDERATIONS - LOCAI

Institutional

Requirements

Comprehensive $\mathrm{Plan}$

Building Code

Subdivision

Ordinance
Agency and

Public Attitudes

County Planning and

Zoning Commission
Status of Requirements

(i.e., EIA/EIS Requirements)

Special use permits

Permits

Siting permits. 


\section{ENVIRONMENTAL FACTORS}

..CLIMATE (14)

..Prevailing Winds: $N-S$

.Precipitation (Annual): 40.6 to $61.0 \mathrm{~cm}$. $(16-24$ inches)

..Days of Sunshine (Annua 1): 304

.. Average Temperature

$\begin{array}{lrr}\text { Minimum: } & -7 \text { to }-1^{\circ} \mathrm{C} \quad\left(20^{\circ} \text { to } 30^{\circ} \mathrm{F} .\right)(9) & \text { January } \\ \text { Maximum: } & 21^{\circ} \mathrm{C}\left(70^{\circ} \mathrm{F}\right) & -17^{\circ} \mathrm{C} \\ & & 2^{\circ} \mathrm{C}\end{array}$

..Degree Days (Annua 1): Approx. 6000

..Relative Humidity (Seasonal Peaks)

Summer: 40 to $50 \%(9)$

Winter: 70 to $80 \%$

..AIR QUALITY:

Good, no major pollutants in the area. Measuring Station at Weiser

..GEOLOGIC FACTORS: Periodic flooding in stream valleys.

..WATER QUALITY:

Water quality is generally good. Crane Creek KGRA is just west of Crane Creek Reservoir which has a capacity of 52,000 acre feet. The principle use of water in the area KGRA (in the order of quantities used) are irrigation, domestic, stock, industrial. Owner of the reservoir is the Crane Creek Reservoir Administration Board. Some $49.5 \mathrm{ft}$.

$3 / 5$ have been allocated.

. NOISE :

Low noise levels in the area due to a lack of industrial or urban development. No measuring stations at the KGRA.

. BIOLOGICAL (9) (10)

. Dominant Flora: Sagebrush - grass ecosystem.

..Dominant Fauna: Mule deer, prong horn antelope, upland game birds. (10)

.. Endangered Species

. Fauna: Raptor Species:

Ferrugenous Hawk, Prairie Falcon, Pigeon Hawk, Semi-Palmated Plover, Long Billed Curlew, and Spotted Bat. 
TRANSPORTATION AND UTILITIES

..Utility or Energy Transmission Corridors and Facilities

1. There is a substation and a $138 \mathrm{kv}$ line owned by Idaho Power Co. at Weiser

2. A $250 \mathrm{kV}$ line cuts through the NE corner of the KGRA and is owned by Idaho Power

. Transportation Corridors or Facilities

U.S. 95 is within 8 kilometers of the KGRA (12) and gravel county roads are located at the KGRA.

A primary rail line is within 8 kilometers of the KGRA.

A major $26 \mathrm{~cm}$ (10 inch) oil pipe 1 ine is within $16 \mathrm{ki}$ lometers of the KGRA.

A $56 \mathrm{~cm}$ (22 inch) natural gas line is within 24 kilometers of the KGRA.

\section{POPULATION}

..General Description of Population

Population density is less than 1 person per square mile. The nearest population centers are Weiser (population 4,538) 16 kilometers West; Midvale 32 kilometers N. (population 409).

\section{..Economics :}

The Weiser area (S.W. Washington County) is a growing agricultural region. Principle crops are onions, potatoes, applies, pears. Continued expansion of the potato and onion crops will require a parallel expansion of processing facilities. Present processing facilities are located $30 \mathrm{kilo-}$ meters to the South of Crane Creek. Adequate rail service exist at the site. 
Weiser Hot Springs is located in Section 10, T 11 N, R 6 E, Boise Meridian. The topography at the hot springs area is a transition between the flat flood plain of the Snake River Plain and the Weiser foothills. Slopes are generally about 5 to $7 \%$ dipping to the south. Principle land use surrounding Weiser Hot Springs is agriculture. The hot springs are located at a major transition zone between the prime irrigated agriculture lands of the Snake River Plain and the open grazing lands of the foothills.

The City of Weiser is located 5 kilometers southeast of Weiser Hot Springs. The major industry located in weiser is a mobile home factory. Agricultural products grown in the area are shipped to processing facilities in Ontario, Oregon, and Nampa-Caldwel1, Idaho. Spaceheating of homes and commercial-industrial buildings is the major non-transportation energy need of the Weiser area. Table 46-C list the major industries in Weiser and their approximate direct energy needs. Natural gas presently supplies approximately $60 \%$ of the space heating energy needs in the Weiser area with $0 i 1$ and electricity supplying the remaining $40 \%$.

The geothermal development potential of the Weiser Hot Springs area is one of the highest in the State of Idaho. General reconnaissance geology, geochemical thermometers, and exploration wells all indicate that a high grade geothermal resource exists at depth. The thermal waters of Weiser Hot springs are pumped from a shallow well. A series of four wells were drilled at the hot springs in an area of 50 square meters. The wells are over twenty years old and poorly cased less than 100 meters deep. Only one well is presently used and this well pumps approximately $15 \mathrm{gpm}$ of $70^{\circ} \mathrm{C}$ water.

Geochemical temperature estimates from these wells indicate a maximum aquifer temperature of $157^{\circ} \mathrm{C}$ from the silica method and $145^{\circ} \mathrm{C}$ the $\mathrm{Na}-\mathrm{K}-\mathrm{Ca}$ method. Mixed water temperatures estimate a maximum temperature range of $200^{\circ} \mathrm{C}$ to $280^{\circ} \mathrm{C}$ with the cold water component making up, 70 to 97 percent of the water sample. (6)

Local geology is structurally complex. The oldest exposed rocks are miocene basalts which have been broken by a series of Northwest trending faults. The basalts are covered by miocene sediments in the foothills and a holocene gravels near the hot springs. A major northwest trending fault zone passes through the hot springs area. This north trending fault zone controls the local topography north of the hot springs. A series of east trending fractures related to subsidence of the Snake River Plain, truncate the north trending faults of the area at Weiser Hot Springs. It is likely that the intersection of these fracture zones act as a conduit for the upward circulation of deep hot ground water. (6) Deep exploration drilling is needed to prove the capabi.lities of the geothermal reservoir.

Adequate railroad access exists at Weiser Hot Springs. A major east-west primary rail line exists 2 kilometers south of Weiser Hot Springs. This key transportation element when combined with the geothermal potential of the area makes Weiser Hot Springs an ideal location for siting new industrial facilities. 
MAJOR INDUSTRIES LOCATED IN WEISER, IDAHO

$\begin{array}{lc} & \text { (BTU/yr) } \\ \text { Weiser Community Cannery } & \\ \text { SIC A 2032 } 2033 \\ \text { Approximate Energy Needs } & 6.4 \times 10^{9} \\ & \\ \text { Champion Homebuilders Company } & 40 \times 10^{9} \\ \text { SIC F 2451 } & \\ \text { Ron's Meat Service } & \\ \text { SIC A 2011 } & \\ \text { Approximate Energy Needs } & 10 \times 10^{9}\end{array}$


Local resource input will limit industrial utilization of geothermal resources at Weiser Hot Springs. The major agricultural input which could utilize geothermal resources in food processing is the onion crop. The Weiser area produces $20 \%$ of Idaho's onion crop. These onions are presently sold fresh on the market or shipped for processing to Ontario, Oregon which is $30 \mathrm{ki}$ iometers south of Weiser. Onion production in the Weiser area is approximately 566,000 cwt. per year.

Hot water, developed at Weiser Hot Springs, could be transported to the City of Weiser. Two transmission distances are possible. If transmission lines follow the existing road right-of-ways the distance is 10 kilometers. If transmission 1 ines follow a direct line of sight across agricultural fields the distance is a 5.5 kilometers. Table 47-C shows approximately cost of development of an exploration well and the difference in cost for the two pipeline distances.

If sufficiently high resource temperatures for generation of electrical power are discovered, then a cascading intergraded industrial complex is not only possible but logical. No major environmental or legal restrictions have developed but high boron concentrations in some wells in the area could be a possible environmental problem if found in higher concentrations associated with geothermal waters.

Scenario Projections:

Several utilization scenarios are possible for Weiser Hot Springs. A small resort presently exists at the hot springs and the owners wish to expand this facility. Short term development goals of the present owners are to develop a geothermally heated commercial greenhouse operation, a large fish farm and a subdivision. Large scale development scenarios include supplying hot water to the City of Weiser, establishment of an industrial plant and generation of electricity. Projected geothermal developments are:

Electrical Generation: 50 MW by 1990

Industrial Utilization: $250 \times 10^{9}$ BTU/year by 1985

Spaceheating (residential and commercial): $100 \times 10^{9}$ BTU/year by 1985

Table $48-C$ is a compendium of data regarding the site specific nature of the Weiser Hot Springs site. 
Estimated Cost of Delivering Geothermal Fluids to Weiser, Idaho

3,900 foot production well

We11 program: $10^{\prime \prime}$ to $160^{\prime}$, setting $8^{\prime \prime}$ casing

6" casing to total depth

Mobilization and demobilization cost

Drilling a $\$ 12 / \mathrm{ft}$.

Casing a $\$ 8 / \mathrm{ft}$.

$\$ 10,000$

48,000

30,000

88,000

Contingencies a $30 \%$

26,400

Total

$\$ 114,400$

Average cost per foot: $\$ 30 / \mathrm{ft}$.

8,200 foot production well

Well program: $16^{\prime \prime}$ to $160^{\prime}$, setting $12^{\prime \prime}$ casing, 8 " casing to 3,300 feet, $6 "$ casing to 8,200 feet.

Mobilization and demobilization Drilling a $\$ 31 / \mathrm{ft}$.

Casing a $\$ 1.1 / \mathrm{ft}$.

$\$ 100,000$

250,000

87,500

437,500

Contingencies $@ 30 \%$

$\underline{131,250}$

Total

$\$ 568,700$

Average cost per foot $\$ 70 / \mathrm{ft}$.

TRANSMISSION COST

5.5 kilometers

$(46,464)$ feet

10 inch pipe diameter

Insulated pipe cost $0 \$ 23 / \mathrm{ft}$.

Trenching cost $\propto \$ 1.25 / \mathrm{ft}$.

Fitting cost $\$ 5.75 / \mathrm{ft}$.

Total cost of piping a $\$ 30 / \mathrm{ft}$.

cost

$$
\$ 1,393,930
$$

Range of cost:

Drilling Cost:

Transmission Cost

Pumps @ $\$ 33,000$
3,900
$\$ 114,400$
$5.5 \mathrm{~km}$

$$
\begin{array}{r}
\$ 1,393,920 \\
33,000 \\
\$ 1,541,320
\end{array}
$$

10 kilometers

$(84,480$ feet $)$

10 inch pipe diameter

Cost $\$ 2,534,400$

$$
\begin{aligned}
& \frac{8,200}{\$ 568,700} \\
& 10 \mathrm{~km} \$ 2,534,400 \\
& 33,000 \\
& \$ 4,677,420
\end{aligned}
$$


Table 48-C

Data Summary for Weiser Hot Springs

SITE LOCATION AND PHYSICAL DESCRIPTION

..Latitude: $44^{\circ} 17^{\prime} 90^{\prime \prime} \mathrm{N}$

..Longitude: $117^{\circ} 02^{\prime} 90^{\prime \prime} \mathrm{W}$

. Rectilinear: Sec. 10, T $11 \mathrm{~N}, \mathrm{R} 6 \mathrm{~W}$, Boise Meridian.

..County: Washington

..Adjacent Counties: Adams, Payette, Gem

. Topography: Flat topography at site of Hot Springs

slopes to north, east and west vary from $5 \%$ to $7 \%$.

..Present Land Use: Agriculture

..Future Land Use Plans: Agriculture

..Aesthetics: Rural agricultural setting. Low recreation use.

..Historical/Archaeological Significance: No archaeological sites known at this time. Historical Indian cam sites are nearby.

GEOLOGICAL/GEOPHYSICAL DESCRIPTION

. Geologic Description:

01 dest rocks are miocene basalts which have been broken into tilted blocks of a series of northwest trending faults. The basalts are covered by Miocene Volcanaclastic sediments which have been folded by movements along the northwest trending faults. Major east-west faults related to the Snake River Plain subsidence truncate the north trending structures. The hot springs are located at the intersection of these feature zones.

-. Geophysical Summary:

Gravity survey indicates Weiser area is on the northwest edge of a regional gravity high associated with the Snake River Plains. Area also has a magnetic low. (2)

. Geologic Hazards:

Last flood was in 1975. 


\section{RESERVOIR CHARACTERISTICS}

..Reservoir Temperature

. Surface $77^{\circ} \mathrm{C}$

..Subsurface: No downhole data

..Geochemical: $\mathrm{SiO}_{2}: \quad 157^{\circ} \mathrm{C}(1)$

$$
\text { Na-K-Ca: } 145^{\circ} \mathrm{C}
$$

Mix Methods: $228^{\circ} \mathrm{C}$ with $72 \%$ cold water ( 1 )

. Flow Rates $.01 \mathrm{cfs} . \quad(.33 \mathrm{~L} / \mathrm{S})$

..pH: 7.2 to 9.3

.. Total Dissolved Solids: 2.25 to $852 \mathrm{mg} / 1$

. Fluid Chemistry: (2) $\mathrm{mg} / 1$

\begin{tabular}{|c|c|}
\hline & $\begin{array}{c}140 \\
2.6\end{array}$ \\
\hline & \\
\hline $\mathrm{Na}$ & 140 \\
\hline $\begin{array}{l}\mathrm{K} \\
\mathrm{HCO}_{3}\end{array}$ & $\begin{array}{c}4 . \varepsilon \\
32\end{array}$ \\
\hline $\mathrm{CO}_{3}$ & 37 \\
\hline $\mathrm{CaCO}_{3}$ & 83 \\
\hline $\mathrm{SO}_{4}$ & 150 \\
\hline $\mathrm{Cl}^{4}$ & 56 \\
\hline 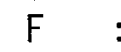 & 2.5 \\
\hline As & 4.0 \\
\hline B & 2100. \\
\hline Li & 50 \\
\hline $\mathrm{Hg}$ & 0 \\
\hline
\end{tabular}

All thermal and no thermal wells at Weiser Hot Springs Area have high Boron concentrations.

..Estimated Nonelectric Energy Potential (MBtuh 30 years):

. Subsurface Area of Reservoir: $9^{3} \mathrm{~km}$ (2) 
INSTITUTIONAL CONSIDERATIONS - Federa?

Institutional

Requirements

National Environmental Policy Act

(42-U.S.C. 4331)

Federal Water Pollution Control Act (33-USCA 1251)

Federal Safe Drinking Water Act

(42 U.S.C. (A) 300)
Agency and

Public Attitudes

An E.I.A. is required before leases are issued.

E.P.A.

The national goal of this Act is to attain -0-pollution by 1985 . E.P.A.

This Act is concerned with protection of underground water sources that could be used for domestic water.

E.P.A.
Status of Requirements (i.e., EIA/EIS Requirements)

An E.I.S. could be required for any major action requiring federal actions.

Ground water is included under this Act and the reinjection of geothermal effluent will require permits.

The Act sets standards for wells and well drilling and could influence future geothermal wells. 
Institutional

Requirements

Geothermal Resource permits.

(Idaho Code 42-4001

et. seq. Chapter 40,

Geothermal Resources)

Water Appropriation

(Idaho Code 42-101

et. seq. Chapter 1

Water Appropriation)

Injection wells

(Idaho Code 42-3001

et. seq. Chapter 39

Waste Disposal and

Injection Wells)
Agency and

Public Attitudes

The regulatory powers of the state Geothermal Resource Act are placed in the Idaho Department of Water Resources.

The Idaho Department of Weiser Resources issues water appropriation permits and a water right license.

Permits are issued by the Department of Water Resources.
Status of Requirements (i.e., EIA/EIS Requirements)

Any private owner, or holder of a state or federal lease of geothermal resources must first apply for a geothermal resource permit from I.D.W.R. before any drilling operations can begin.

Under the Idaho Geotherma 1 Resources Act applicants can be required to make an application to appropriate the public waters of the state.

No waste disposal or injection well can be constructed in Idaho unless a permit has been issued by I.D.W.R. The approval of this permit is contingent upon the approval of the Department of Health and Welfare. The proposed well is reviewed to see if it will unreasonably contaminate or deteriorate the quality of the ground water below the adopted water quality standards of the state.

Subdivision Ordinance

Comprehensive Plan

City Comprehensive Plan Applies out to 5 miles. Subdivision Ordinance Zoning Building Code. 
Land Ownership: $100 \%$ private land for six square miles.

. Summary of Leasing Status and Needs:

Phillips Petroleum holds private leases on lands adjacent to the hot springs. Owners of Weiser Hot Springs own geotherma? rights to 200 acres surrounding the hot springs.

\section{GEOTHERMAL DEVELOPMENT STATUS}

. Present Development Status:

A small resort at the hot springs consists of two greenhouses, a swimming pool, camping area and cabins.

Phillips Petroleum completed an exploration well to approximately 1800 meters, 2 kilometers south of Weiser Hot Springs in 1978. No data available on this well.

..Projected or Planned Development:

Weiser Hot Springs is located on 80 acres of prime agricultural 1 and. The site has four serviceable wells capable of producing $77^{\circ} \mathrm{C}$ water. New wells are expected at the site. Short term development plans call for the development of a major health spa, a geothermally heated subdivision and an aquaculture facility. Long term development projections are for an industrial plant and an electrical power plant. 
ENVIRONMENTAL FACTORS

. CLIMATE (14)

..Prevailing Winds: North-south

..Precipitation (Annual): (11-31 inches) $28.7 \mathrm{~cm}$

...Days of Sunshine (Annual): 304

.. Average Temperature

January July

Minimum:

$-17^{\circ} \mathrm{C}$

Maximum:

$2.2^{\circ} \mathrm{C}$

$13.6^{\circ} \mathrm{C}$

$34.5^{\circ} \mathrm{C}$

. Degree Days (Annual): 5746

..Relative Humidity (Seasonal Peaks)

$\begin{array}{ll}\text { Summer: } & 10 \% \\ \text { Winter: } & 50 \%\end{array}$

..AIR QUALITY: Generally high quality.

..GEOLOGIC FACTORS: Site is partially in the flood plain.

.. WATER QUALITY:

Warm Springs Creek, Scott Creek and Galloway Canal surface waters are generally of high quality. Subsurface water has high boron and low dissolved solids.

. NOISE: LOW

. BIOLOGICAL:

..Dominant Flora: Sagebrush, Cheat grass ecosystem

...Dominant Fauna: Mule deer, upland game birds

\section{TRANSPORTATION AND UTILITIES}

..Utility or Energy Transmission Corridors and Facilities

Rural electrical distribution system at site: Idaho Power Co.

..Transportation Corridors or Facilities (12)
U.S. Highway 95 to Weiser:
$10 \mathrm{Kilometers}$ from site
U.S. Interstate 80:
32 Kilometers from site
County Roads (Paved):
at Site
Union Pacific Rail System:
2 Kilometers from site

POPULATION

..General Description of Population

The population of Weiser is 4,600 . The population density at Weiser

Hot Springs is less than 1 per sq kilometers.

\section{.. Economics}

The economy of the area is based on agriculture. The principle crops are onions, potatoes and fruit (apples and pears).

The major non-agricultural industry is a large mobile home factory in Weiser. This factory employs approximately 300 people. 


\section{REFERENCES}

(Washington County).

1) Young, H.W. and Mitche 17, J.C., Geothermal Investigations in Idaho, Part 1, "Geochemistry and Geological Setting of Selected Thermal waters" Idaho Dept. Water Resources, Water Inf. Bu11. 30., 1973, p. 18, 34.

2) Young, H.W. and Whitehead, R.L., Geothermal Investigations in Idaho, Part 3, "An Evaluation of Thermal Water in the Weiser Area, Idaho; Idaho Dept. of Water Resources, Water Inf. Bu11. 30, 1975.

3) Memorandum: To State Director of BLM, Boise Idaho; From Conservation Manager, Western Region, U.S.G.S.; Subject: Definition of Crane Creek KGRA, June 1975.

4) Bureau of Land Management, Geothermal Lease: I-12297, Supron Energy Corp. Jan. 1978.

5) State of Idaho, Department of Lands, Geothermal Lease: H-727, Phillips Petroleum Co. Issued March 1975, Current Jan. 1978.

6) Rightmire, C.T., Young, H.W., and Whitehead, R.L., Geothermal Investigations in Idaho, Part 4,: Isotopic and Geochemical Analysis of Water from the Bruneau-Grandview and Weiser Areas, Southwest Idaho", Idaho Dept. of Water Resources, Water Inf. Bu11. 30, 1975, p. 20.

7) Mitche11, John C. personal communications, July, 1978.

8) Counts, Mary, Washington Co. Clerk, personal communications, Feb. 1978.

9) Bureau of Land Management, Boise District, EAR prelease report, Crane Creek KGRA, Jan. 1975.

10) Howard, Richard, U.S. Fish and Wildlife Service, personal communications Feb. 1978.

11) U.S. Geological Survey, 15 minute series topographic map, Crane Creek Reservoir and Mann Creek Quadrangles, 1975.

12) Idaho Dept. of Highways, Washington County Road Map.

13) Young, H.W., Harenberg, W.A. and Seitz, H.R., Water Resources of the Weiser River Basin, West Central Idaho, Idaho Dept. of Water Resources Water Inf. Bull. 44, 1977.

14) N.0.A.A., Climatological Data, Idaho, 1977, U.S. Dept. of Commerce, 1978. 


\author{
APPENDIX D \\ GEOTHERMAL DEVELOPMENT REGION III \\ South Central Idaho
}

Table of Contents

Text:

$\underline{\text { Page }}$

INTRODUCTION . . . . . . . . . . . . . . . . . . . . 345

GEOTHERMAL MARKET POTENTIAL. . . . . . . . . . . . . . . . 346

RAFT RIVER KGRA SUBAREA. . . . . . . . . . . . . . . . . . 349

TWIN FALLS SUBAREA . . . . . . . . . . . . . . . . . . . . . 360

CAMAS PRAIRIE SUBAREA. . . . . . . . . . . . . . . . . . . . 368

HAILEY-SUN VALLEY SUBAREA. . . . . . . . . . . . . . . . . . . . . . 374

STATUS OF LEASING ACTIVITY . . . . . . . . . . . . . . . . . . . 376

RARE II CONFLICTS. . . . . . . . . . . . . . . . . . . . . 377

REFERENCES . . . . . . . . . . . . . . . . . . . . 378

Tables:

Table 1-D: Business and Industries in Cassia and Minidoka

Table 2-D: Food Processing Industries in Cassia and

Minidoka Counties, Idaho. . . . . . . . . . . . . 348

Table 3-D: Data Summary for Raft River KGRA, Idaho. . . . . . . . . . 352

Table 4-D: Major Industries in South Central Idaho and

Their Annual Energy Demands. . . . . . . . . . . 361

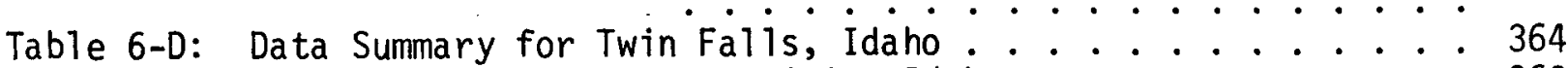

Table 7-D: Data Summary for Camas Prairie, Idaho. . . . . . . . . . . . 369

Table 8-D: Data Summary for Hailey-Ketchum-Sun Valley, 
$\theta$ 


\author{
APPENDIX D \\ GEOTHERMAL DEVELOPMENT REGION III \\ South Central Idaho
}

INTRODUCTION

The South Central Idaho region encompasses eight counties: Blaine, Camas, Cassia, Gooding, Jerome, Lincoln, Minidoka, and Twin Falls. This area coincides with Idaho State Planning Region IV and the Bureau of Land Management South Central Region. The area is heavily dependent on agriculture and food processing. Recent trends in the area indicate that population is growing at a faster rate, and migration patterns have shifted to a substantial net in migration. Although the region is somewhat isolated from other population centers by long travel distances and extensive deserts, excellent rail and interstate freeway connections provide transportation for exporting and importing products.

The region can be geographically divided into three subareas: the northern mountainous areas of the Idaho Batholith; the central plateau area of Snake River Plain; and the southern intermountain area of the Basin and Range.

The northern mountainous area has some of the highest mountains and some of the most appealing beauty of the state. This area boasts some of the highest recreation potential in Idaho. The world-famous Sun Valley Ski Resort is located in Blaine County and the general mountainous area is also endowed with many beautiful lakes and reservoirs.

The central Snake River area is a vital agricultural location. The agricultural counties of this area are economically inter-related. Population and industry are concentrated in two locations: Twin Falls and the Burley-Rupert areas. The principal industries of the region are food processing plants. The major transportation corridors of the state cross through this area. Rail, freeway, powerlines, oil pipelines, and gas pipelines converge in the Twin Falls and Burley areas. Adequate transportation services and expanding agriculture and food processing have made the Twin Falls and Burley-Rupert areas the main growth corridor of the South Central Idaho Region.

The southern bas in and range intermountain area is an isolated and undeveloped area with a low population. Major population centers are small farming and ranching areas located in isolated intermountain valleys. Ranching the and raising of feed products are the major agricultural activities.

In general, the South Central Idaho Region can be considered rural. The population density of the region is nine persons per square mile. The total population of the region is approximately 105,000 with approximately 50 percent of the total living in the city of Twin Falls and 15 percent of the population living in the Burley-Rupert area. The remaining 35, percent of the region's population is scattered throughout the agricultural areas. 
There are 129 manufacturing units in the South Central Idaho Plain. The majority of these units ( 33 percent) are in the food and kindred products classification. These facilities are the major industrial consumers of energy and the principal industries of the region. Food processing facilities are concentrated in Twin Falls, Buhl, Rupert, and Burley. All of these locations are located along the southern margin of the Snake River Plain in areas with potential geothermal resources.

Regional trade areas and areas of highest population density coincide with the location of the major food processing facilities. Twin Falls city is the regional trade center. Twin Falls has 40.5 percent of the reta 11 establishments, Burley has 15.2 percent, Ruperf has 12.8 percent, and the Hailey-Sun Valley area has 10 perce of the retail trade. (2) See Table $1-D$ for a list of businesses and industries. The greatest potential for direct utilization of geothermal resources in the South Central Idaho Region is in the food processing facilities. The principal plants are concerned with sugar beet, potato, and pea processing. All of these processes could utilize geothermal energy. See Table 2-D for a list of the major food processing facilities and their energy demand. The location of the resource, the character of the resource, and the cost of development will determine which present facilities could retrofit to geothermal resources. Growth in agriculture and the need for more processing facilities will determine when known, but isolated, geothermal areas will be developec to support new food processing plants.

Residential and commercial spaceheating with geothermal resources is also possible. The cities of Buhl, Twin Falls, Burley, and Hailey have low temperature geothermal fluids nearby which could be developed for spaceheating.

Raft River KGRA in Cassia County has the greatest potential in the state for an early development of a geothermal electrical generation facility. Generation of $5 \mathrm{mw}$ of electrical power is expected by 1980 .

Four areas were examined in the South Central Region: the Raft River KGRA, the city of Twin Falls and surrounding area, the city of Hailey, and the Camas Prairie area. 
Table 7-D

BUSINESSES AND INDUSTRIES IN CASSIA AND MINIDOKA COUNTIES, IDAHO

The Burley and Rupert area is the retail trade center of Cassia and Minidoka Counties. Cassia County has 202 retail establishments. Minidoka County has 171 retail establishments.

Classification of No. of Establishments Business type Cassia Minidoka

Building Material, Hardware Garden Supply - General Merchandise

$\begin{array}{rr}11 & 7 \\ 13 & 5 \\ 21 & 22 \\ 16 & 17 \\ 23 & 25 \\ 16 & 4 \\ 10 & 6 \\ 43 & 38 \\ 7 & 3 \\ 42 & 44\end{array}$

Food Stores

Automotive

Service Stations

Apparel and Accessory Stores

Furniture and Equipment Stores

Eating and Drinking Places

Drug Stores

Miscellaneous

42

7

5

22

17

25

4

6

38

44

Manufacturing and industry located in and around the Burley area

Type of Manufacturing or Industry Cassia Minidoka

Food and Kindred Products

Textile

9

Lumber and Wood Products

Paper and Allied Products

Printing and Publishing

1

Chem ical

Stone and Glass Products

Fabrication of Metal Products

Nonelectrical Machinery

Transportation Equipment

Miscellaneous Manufacturing

Central Administration Offices

Source: Manufacturing Directory of Idaho, 1976 (Reference 8) 
Table 2-D

FOOD PROCESSING INDUSTRIES IN CASSIA AND MINIDOKA COUNTIES, IDAHO

Manufacturing in Cassia and Minidoka Counties is concentrated largely in the Burley-Heyburn-Rupert retail trade area. Thirteen major food and kindred products industries are located in this area. The following is a breakdown of the energy use and employment of the major industries of the area within 50 miles of the Raft River KGRA.

Company Location (pop.)

Employment

Energy Use

Fuel Split \% (1012 BTU)

(P)

(C) (G)

A. Frozen Vegetables

Ore-Ida Foods, Inc.

Burley $(8,079) \quad 1,000+$

1.64

(4)

(0)

(47)

(49)

J. R. Simplot Heyburn $(1,736)$ 500-1,000

1.64

"1

A \& P Tea Company Burley $(8,079) \quad 300-500$

0.38

11

B. Dehydrated \& Canned Vegetables

$A$ \& P Tea Company Heyburn $(1,637) \quad 300-500$

1.0

(14) (0)

(70) (16)

Del Monte Corporation Burley $(8,079)$

500

0.32

"I

Walbet Foods, Inc.

Burley

0.24

(14) (0)

(79) (16)

Clover Club Foods Co. Burley

0.17

11

C. Dairy

Kraft Corp.

Rupert $(4,563)$

0.05

(14) (0)

(41) (45)

D. Miscellaneous

Magic Valley Foods

Rupert $(4,563)$

0.08

(4) (0)

(69) (27)

Source: Industrial Waste Heat in Idaho, Rocket Research Corporation (Reference 9) 
The Raft River geothermal development area is located in Cassia County, near the Idaho-Utah border. The KGRA is in the upper end of the valley of the Raft River; a tributary of the Snake River. The nearest population centers are Malta (196), 24 kilometers to the north and Burley $(8,820), 83$ kilometers to the northwest.

The Raft River Valley is a down faulted basin, bordered by uplifted, tilted block mountains. Typical of formations in the basin and range province, the Raft River Valley is structurally controlled by north trending high angle normal faults. The floor of the main Raft River Valley overlies a westward tilted block of consolidated rock whose depressed western margin is filled with a westward thickening blanket of sedimentary and volcanic formations. (4) The geological framework of the KGRA is made up of complexly faulted stratigraphy ranging in age from precambrian to tertiary age. The tertiary rocks unconformably overlay the Paleozoic and Precambrian rocks. (5)

Approximately 5,000 acres within the Raft River KGRA have been withdrawn by the Department of Energy for experiments and the development of a pilot low temperature electric generation facility. (6) The nature of the geothermal resource and the limits of the geothermal reservoir remain undefined. Numerous warm wells are present in the irrigation areas. Four high temperature production wells have been drilled in the KGRA by the Federal Department of Energy. These wells have supplied as much as 48 litres per second (760 gpm) of $140^{\circ} \mathrm{C}$ water.

In preparation for a $5 \mathrm{mw}$ power plant (under construction) the D.O.E. is expanding the number of supply and injection wells, which will include three new wells. The $5 \mathrm{mw}$ plant will require seven wells: three production wells, two injection wells, and a reserve well of each type.

The electrical generation facility under construction at Raft River KGRA is a research and development project. The objective is to study the economics and provide the technical demonstration of a dual boiling binary cycle facility. The $5 \mathrm{mw}$ plant is expected to be operational by 1982 .

In addition to producing electricity, several direct application experiments are being conducted at the Raft River Site. The most notable experiment is an attempt to dry both activated sludge biomass slurry and waste potato solids from the food processing plants at Burley, Idaho. Additional experiments are being conducted in aquaculture and agriculture.

A major limitation to direct use commercialization at Raft River KGRA is the isolation of the site. The KGRA is located in the southern portion of Cassia County. The area is primarily rural with the two nearest communities, Malta and Albion, having populations of 192 and 226 respectively. Maita is 24 kilometers from the KGRA and Albion is 52 kilometers away. The KGRA is 30 kilometers from Interstate $80 \mathrm{~N}$ and the Chevron $0 i 1$ pipelines are 83 kilometers away from the nearest natural gas pipeline.

Nearly all major economic activity is centered in the northern section of the county. It is in the Burley area that one finds the richest agricultural lands; major transportation routes, the pipelines; the manufacturing, retail, and government centers; and the Snake River. 
Agriculture is the principal activity in the Raft River Valley. Because of increasing elevation, and soil composition, the land is not devoted to potato and sugarbeet crops which predominate the Burley area. Alfalfa and barley are the principal source of income for Raft River residents.

The major cattle and farm operation in the Raft River Valley is the J. R. Simplot Company. Three separate agriculture operations are conducted by Simplot Company in the Raft River area: 1) a cattle company with 800 cows and 2.000 calves; 2) a dairy herd of 2,500 heads; and 3) farmlands of 10,000 acres planted in barley and alfalfa. The Simplot Company is also the major potato processor in the Burley area.

Transportation access to the KGRA is by Idaho Highway 81 from Malta to Bridge. This road is a light duty paved highway. The KGRA is 12 kilometers west of Bridge along a light duty gravel BLM road.

Scenario Projections

A small electrical generating station of 5 to $20 \mathrm{mw}$, is projected for the D.0.E. Raft River Site by 1.982. By 1985, the generating capacity is projected to reach $50 \mathrm{mw}$ with additional non-electrical facilities being integrated with the generating stations. A manure processing plant, a feed lot, a greenhouse complex, and a fish farm are projected for the site by 1990. The entire complex would be an intergrated cascading system. In the long-term period of 1990 to 2020 the geothermal field is expected to reach a maximum generation capacity of $100 \mathrm{mw}$. A potato processing facility is also projected for the Raft River Site by 1985-1990. Advances in technology may increase the generation capacity but the groundwater availability of the area is a major limiting factor to the amount of geothermal fluids which can be extracted from the field.

Non-electrical commercialization of geothermal resources at Raft River KGRA and nearby areas could encompass a number of agriculturally-related activities. Because of the area's isolation any industrial application would have to depend upon local inputs. Several local products could be processed with geothermal energy. The major local products are: livestock, potatoes, alfalfa, bariey, and milk. Possible developments are:

1) A potato starch dehydration plant, which could utilize waste products from potato processing facilities located in the Burley area is possible by 1985-1990.

2) A large feed lot and slaughter facility could also be possible by 1990. Such a facility would be an extension of the present cattle feed lot operations.

3) An alfalfa dehydration plant could be possible with present geothermal temperatures if a partial field wilting-drum drying mode of operation is employed. Local alfalfa production would have to be tripled before a dehydration plant would be feasible.

4) A barley malting plant at Raft River would be dependent on increased production of barley. Present production is insufficient to sustain a barley malting plant.

Several of these operations could be combined into an integrated industrial development centered around the electrical generation facility. Secondary use of geothermal fluids after electrical generation is logical and could help to defer 
production cost. If secondary operations were sequential throughout the year, then several small operations could use the same production wells. For example, alfalfa production coincides with the peak demand for electricity due to irrigation pumping. Therefore, alfalfa dehydration could be the primary secondary utilization of waste fluids from the electrical generation facility during that period.

Potato starch extraction could occur after the alfalfa dehydration season ended and continue throughout the winter. This would coincide with the peak processing of potatoes in the Burley area. Other operations such as a feed lot and a barleysprouting operation could be intergrated.

Table 3-D list the site-specific data describing the Raft River KGRA. 
Table 3-D

SITE DATA SUMMARY

Site: Raft River KGRA

SITE LOCATION AND PHYSICAL DESCRIPTION

Location:

.. Latitude:

$42^{\circ} 06^{\prime} 06^{\prime \prime} N(12)$

.. Longi tude:

$113^{\circ} 23^{\prime} 48^{\prime \prime} \mathrm{W}$

. Rectilinear:

T. 14 S. R $25 \mathrm{E}$.,

(6) Boise Meridian

.. County:

Cassia

..Adjacent Counties: Idaho: Twin Falls, Jerome, Minidoka, Blaine, Power, Oneida; and Elko, Nevada

..Land Ownership: Federal (BLM), State, and Private

- . Topography:

...Present Land Use:

- Future Land Use Plans:

Basin and range type topography with high fault block mountains and hills separated by flat-bottom valleys. The area around the geothermal wells is generally flat with a 4 percent slope away from the center of the valley to the north and south toward the foot of the mountains. (4

The area is almost exclusively agricultural with some light industry focusing on potato processing. BLM land is used primarily for grazing and recreation. Private lands are in irrigation agriculture. Almost every farm has an irrigation well. (4)

Continuance of irrigation agriculture is dependent on low pumping cost. No major changes in land use for the area are expected, except in the expansion of the geotherma 1 potential of the area.

.. Aesthetics:

Federal roadless-area lands are given high aesthetic values in those areas. Local attitudes toward aesthetic: This area has no extraordinary aesthetic value compared to other areas of the region. The Raft River basin is a rural agricultural area. The rural nature of the area is of high value to the local people.

..Historical/. Archaeological

The area is of minor archaeological significance and no major archaeological sites are expected in the area, Significance: although some potential sites have been identified. The area is of major historical significance in that there are several historical trails in the area: Oregon Trail (South Alternate), the California Trail, and the Kelton Road. (4) 
.. Reservoir

Temperature
$(7)$

- Surface: $96^{\circ} \mathrm{C},\left(205^{\circ} \mathrm{F}\right)$

- Subsurface: $145^{\circ} \mathrm{C}, 150^{\circ} \mathrm{C}\left(284^{\circ} \mathrm{F}\right)$

- Geochemical: $\mathrm{SiO}_{2}$ : $136^{\circ} \mathrm{C}\left(276^{\circ} \mathrm{F}\right)$

$\mathrm{Na}-\mathrm{K}-\mathrm{Ca}: 139^{\circ} \mathrm{C}\left(282^{\circ} \mathrm{F}\right)$

..Total Dissolved Raft River geothermal wells \#1 and \#2 have less than
Solids
(PPM):
$2,000 \mathrm{ppm}$ dissolved solids, well \#3 had 4,100 ppm.

...Estimated

Electric

Energy

Potential: $\quad 100 \mathrm{nw}$

..Type of Over-

laying Rock $(7)$ :

Alluvium (sediments and tuffs), schist and quartzite with a quartz monzonite basement.

..Estimated Depth

to Top of

Reservoir:

$1,500 \mathrm{~m}(4,921$ feet $)$. Fault controlled circulation of warm water.

..Seismic Activity: Three historic seismic events have been recorded within $100 \mathrm{~km}$ of the area. All three events were located along major fault systems to the west of the KGRA.

$1934 M=5.1$

$1937 \quad M=5.4$

$1973 M=1.5-2.5$

A microseismic telemetry station is now operating at the environmental station at the site. Three locations were established for the microseismic systems and the geophones temporarily set at a depth of 3 meters ( 10 feet). Results from an initial monitoring period will determine where the fourth station will be located and how deep the geophones should be (permanentiy set to reduce surface "noise" effects. (4) 
Table 3-D (cont.)

WATER CHEMISTRY OF RAFT RIVER WELLS

(4)

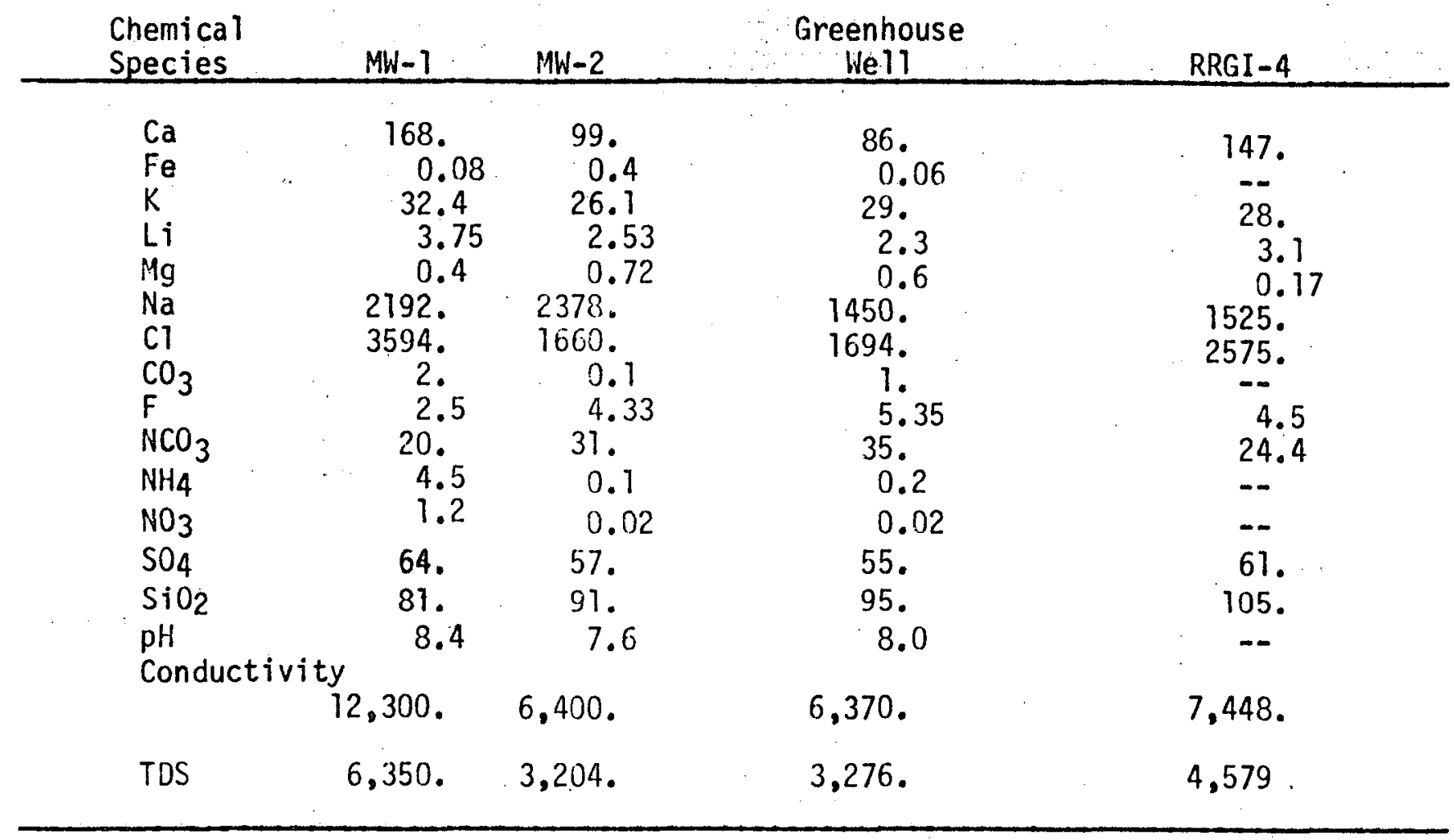

GEOLOGICAL/GEOPHYSICAL DESCRIPTION

...Geologic Description:

Raft River Valley represents a downfaulted basin bordered by uplifted block mountains typical of the Basin and Range province. The Raft River Valley lies at the northern extreme of the Basin and Range Province. Present mountains and valleys were formed by middle to late tertiary block faulting. North trending high angle normal faults bound the tilted blocks which form the valley walls. The valley floor is a westward tilted and is blanketed by westward thickening wedges of sediments and volcanic formations. Complex east-west and north-south faulting intersect at the Raft River site. Rocks in the area range in age from Precambrian to middle Tertiary. The basement rocks are intruded Precambrian quartz monzonite overlain by a metamorphosed Precambrian series of shists and quartzites. These rocks are uncomformably overlain by valley-filling volcanic and sedimentary rocks accumulated from early or middle tertiary time to present.

..Geophysical Summary:

Geophysical surveys indicate two areas of low resistivity and a closed gravits high near the mouth of the Narrows area in the KGRA. Predicted and located faults seemed to intersect in the low resistivity areas. 
Table 3-D (cont.)

GEOLOGICAL/GEOPHYSICAL DESCRIPTION (cont.)

..Geologic Hazards: (4)

Area is classified as Zone 3 for seismic risk. Subsidence north of Malta, Idaho, has resulted from excessive withdrawal of ground waters, areas of maximum subsidence are east of the site. Areas along the Raft River have been classified by the USGS as flood-prone areas. Blowing dust is an occasional hazard, with wind gusting to $22 \mathrm{~m} / \mathrm{second}$ ( $50 \mathrm{mph}$ ).

LAND OWNERSHIP AND LEASING

$\begin{array}{cccc}\text { TOTAL AREA } & \text { FEDERAL } & \text { STATE } & \text { PRIVATE } \\ \text { (Acres) } & \text { (Acres) } & \text { (Acres) } & \text { (Acres) }\end{array}$

(Acres) (Acres) (Acres) (Acres)

** KGRA: Raft River -

Cassia County,

Idaho

30,209

25,110

2,600

2,500

** Land Leased in KGRA

$1,884 \quad 2,600$

** Summary of Leasing Status and Needs:

D.0.E. has withdrawn 3,200 acres to construct a 5 mwe power facility and for other pilot projects of a non-electrical nature. Eight leasing units for a total of 15,921 acres were offered in llovember, 1977. Only one bid was received. Raft River Rural Electric Cooperative, Inc., was the successful bidder for unit 7 for a total of $1,883.10$ acres $\$ \$ 2.35$ /acre. The other units will be reoffered again in 1979. Approximately 31 noncompetitive lease applications for land outside of the KGRA have been received and 18 have been approved for a total of 20,284 acres. Leases have been granted to Suneco, Sun 0il, Delta Funds, L.H. Armour, and Raft River Rural Electrical Cooperative. State lands have been leased to Sun 0 il and Raft River Corp. also has private leases in the KGRA.

\section{GEOTHERMAL DEVELOPMENT STATUS}

-. Present Development Status:

D.0.E. has drilled three wells to an average depth of $1,500 \mathrm{~m}$. Bottom hole temperature of $146^{\circ} \mathrm{C}-149^{\circ} \mathrm{C}$ are common. The drilling of multiple legs in the barefoot section of production well. The drilling of \#3 enhanced production three to five times for 20 percent increase in cost. Test for deposition on heat exchanger tubing has shown negligible difference between stainless steel and titanium tubing. Asbestos-cement pipe has been shown to be used successfully at $150^{\circ} \mathrm{C}\left(300^{\circ} \mathrm{F}\right)$. Agriculture irrigation with geothermal water successful the first year. No difference in mineral uptake compared to controlled crops. Aquaculture experiments have shown that fish raised were unusually disease resistant. Faster growth with virtually zero disease mortality of catfish, perch, and tilapia offers major advantages for fish culture. Fluidized bed heat exchanger experiments have shown a high and constant heat transfer coefficient with no fouling of tubes under most adverse conditions. A 5 mwe thermal loop facility is under construction as a pilot geothermal generation plant. (7) 
.. Projected or Planned Development:

A thermal loop, possible with a turbine generator to make 5,000 kw to be operating at least by 1982 . This unit will use present wells. Reinjection wells will be drilled for disposal of spent geothermal waters. The following experiments will be continued for the next two years.

1. Experiments to increase power production efficiency.

2. Tests to develop better and cheaper heat exchangers and condensors.

3. Reinjection practices, putting the used and cooled geothermal water back into the ground to maintain the pressure in the reservoir. A reinjection well will be drilled in the spring of 1979.

4. Heat removal with reduced consumptive use of water.

5. Continued experiments on direct uses of geothermal water in:

a. Agriculture - for irrigation and soil warming.

b. Forestry - biomass production enhancement.

c. Aquaculture - maintain a flowing warm water environment for maximum protein production.

6. Continued study of possible direct heat uses in agri-industry.

7. By 1985 electrical production could reach $50 \mathrm{mw}$ and non-electrical utilization for potato processing could reach $250 \times 10^{9}$ BTU per year by 2020.

\section{INSTITUTIONAL CONSIDERATIONS (Federal)}

Institutional Requirements

Federa? Geotherma 1

Resource Lease

(30 C.F.R. 3000)

National Environmental Policy Act (42 U.S.C. 4337 )
Agency and Public Attitudes
Status of Requirements (i.e., EIA/EIS Requirements)
Leases are made pursuant to the Geothermal Steam Act of 1970

(84 Stat. 1566)

(30 USC 1001-1025)

An E.I.A. is required for D.0.E.'s $R$ \& D projects.
Federal Vater Pollution Control Act (33 U.S.C.A. 1251)

Federal Safe Drinking Water Act

(42 U.S.C. (A) 300)
The national goal of this Act is to attain -0- pollution by 1985 .

This Act is concerned with protection of underground water sources that could be used for domestic water.
Leases within the KGRA are competiti Special conditions are required in $t$ leases with regard to potential archaelogical and historical sites, adjacent roadless areas, and critica habitat areas for sage grouse and species of raptors.

A baseline E.I.A. has been completed by E.G.\&G. for the D.O.E. R \& D project. In general an E.I.A. is required for a 11 projects involving exploration and development. If a generation facility is to be built and power generated and sold or a large nonelectrical facility constructed, then an E.I.S. will be required.

Groundwater is included under this Act and the reinjection of geotherma effluent will require permits.

The Act sets standards for wells and well drilling and could influence future geothermal wells in the Raft River basin. The upper aquifer of $t$ basin is the supply of domestic irrigation water for the area. jection of water for geotherma will require permits under this Act. 
Table 3-D (cont.)

INSTITUTIONAL CONSIDERATIONS (State)

Institutional

Requirements

Leases on State Lands

(Idaho Code 47-601

et.seq. Chapter 16,

Geotherma1 Resources)

Geothermal Resource

Permits

(Idaho Code 42-4001

et.seq. Chapter 40,

Geothermal Resources)

Water Appropriation

(Idaho Code 42-101

et.seq. Chapter 1

Water Appropriation)

Injection Wells

(Idaho Code 42-3901

et. seq. Chapter 39

Waste Disposal and

Injection Wel1s)
Agency and Public Attitudes

The State Board of Land Commissioners is authorized to issue leases for geothermal resources underlying state and school lands.

The regulatory powers of the state Geothermal Resource Act are placed in the Idaho Department of Water Resources.

The Idaho Department of Water Resources issues water appropriation permits and a water right license.

Permits are issued by the Department of Water Resources.
Status of Requirements (i.e., EIA/EIS Requirements)

Lease term is 10 years and can be continued with diligent development.

Rentals are set by the board. Several leases have been granted on state lands. Lease size is limited to a maximum of 640 acres/lease.

Any private owner or holder of a state or federal lease of geotherma 1 resources must first apply for a geothermal resource permit from I.D.W.R. before any drilling operations can begin.

Under the Idaho Geothermal Resources Act, applicants can be required to make an application to appropriate the public waters of the state.

No waste disposal or injection well can be constructed in Idaho unless a permit has been issued by I.D.W.R . The approval of this permit is contingent upon the approval of the Department of Health \& Welfare. The proposed well is reviewed to see if it will unreasonably contaminate or deteriorate the quality of the groundwater below the adopted water quality standards of the state. 
Table 3-D (cont.)

INSTITUTIONAL CONSIDERATIONS (Loca1)

Institutiona 1

Requirements

Planning and

Zoning Commission

ENVIRONMENTAL FACTORS

. CLIMATE: (4)
Agency and

Public Attitudes
Status of Requirements (i.e., EIA/EIS Requirements)

Cassia County

Comprehensive Plan

..Prevailing Winds: Out of the West gusting up to $22 \mathrm{~m} / \mathrm{s}$

..Precipitation (Annual): 20.3 to $40.6 \mathrm{~cm} / \mathrm{yr}$ (8-16 inches)

..Average Temperature:

Minimum: $\quad-12$ to $-7^{\circ} \mathrm{C}\left(10-30^{\circ} \mathrm{F}\right)$

Maximum: 21 to $27^{\circ} \mathrm{C}\left(70-80^{\circ} \mathrm{F}\right)$

..Relative Humidity (Seasonal Peaks):

Summer: 30 percent

Winter: 70 percent

..AIR QUALITY: (4) Windblown dust from farming is the ma in airborne pollutant in summer. The University of Utah Research Institute operated an air quality monitoring trailer downwind of RRGE-1 and RRGE-2 in December for a two-week period to measure "pollutants." Relatively low concentrations of constituents were found; concentrations that would be expected in background measurements.

.WATER QUALITY: (4) On-site measurements of toxic materials including mercury, hydrogen sulfide, ammonia, fluoride, and arsenic were made by the Battelle Northwest Lab. The mercury, arsenic, hydrogen sulfide, and ammonia were quite low. The fluoride may be the only potentially harmful effluent.

.. NOISE: (4)

Ambient noise is very low. Considerable noise is associated with production test of wells for short periods of time.

. BIOLOGICAL ENVIRONMENT

..Dominant Flora: Sage subclimax type with sagebrush, greasewood, and juniper
being dominant flora.

..Dominant Fauna: Rabbit, deer, coyote, squirrels, snakes, numerous bird species also trout, suckers, and minnows are found in streams.

.. Endangered

Species

Fauna:

Four species of birds that are found in the area on the endangered species list. These include: the greater Sandhill Crane, the Prairie Falcon, the Peregrine Falcon, and the Ferigenous Hawk. A few species may inhibit development. Land within the KGRA have been identified as critical habitat for the sagegrouse. Unless it.can be demonstrated that a propocad activity associated with geothermal leases will not adverse affect the sagegrouse habitat, special measures for their protection will be required. The species of raptors found in area are also given special protection under lease requirement 
...Endangered

Species

Fauna (cont.)
Depending on the classification of the raptor involved and the nature of the operations contemplated, special restrictions may be required from March to July. Nesting sites are generally given a one-mile buffer zone where drilling and major surface disturbances may be prohibited or restricted.

\section{POPULATION, TRANSPORTATION, AND UTILITIES}

..General Description of Population at the Reservoir:

Scattered farms and ranches are located in the area with three small private homes in the near vicinity of which two are trailer homes and one large ranch house with a large geothermal greenhouse operation. The greenhouse is used for vegetables and flowers. Population density is less than one/square mile.

..Closest Population Centers
1. Burley
2. Oakley
3. Bridge
4. Malta

$$
\begin{gathered}
\text { Distance from } \\
\text { Resource }
\end{gathered}
$$

$64 \mathrm{~km}$ (40 miles)

$45 \mathrm{~km}$ (28 miles)

$12 \mathrm{~km}$ (7 miles)

$16 \mathrm{~km}$ (10 miles)
Population 1976

8,489
822
10
288

.Power Plants and Transmission Lines Near the Site: (4)

The Bridge Substation is at the Raft River site. It is owned by the U.S. Bureau of Reclamation.

- The Bridge Substation is a $138 \mathrm{kv}$ capacity line operating at $34 \mathrm{kv}$ from the north. $64 \mathrm{~km}$ to the north are the main E-W transmission lines of Idaho Power Company, a private power utility; two lines of less than $230 \mathrm{kv}$ and one main set of lines of 230-287 kv. No other lines and no plants within $80 \mathrm{~km}$.

- Raft River Rural Electric Cooperative is located in Malta.

.. Roads Servicing Area

1. Interstate $80 \mathrm{~N}$

2. State Highway 81

3. County and BLM gravel roads at site area.

- Distance from the Site: Is within $40 \mathrm{mk}$ of site with a major interchange approximately $60 \mathrm{~km}$ to the north 7 miles from site.

..Other Utilities or Rights of Way (4)

1. 0 il pipeline greater than $25 \mathrm{~cm}$ in size.

2. Railroads in Oakley and Burley.

. Distance from the Site: Within $40 \mathrm{~km}$ of site (25 miles). 
The city of Twin Falls, Idaho, is located in the Twin Falls County along the southern margin of the Snake River plain. Twin Falls is the largest urban center in southcentral Idaho with a population of approximately 24,000 people. Approximate 40 percent of the region's retail trade establishments, 50 percent of the total regional population, and 50 percent of the food processing plants of the region are located in the Twin Falls area.

The city of Twin Falls is located on the south side of the Snake River. The area is underlain from the surface to a depth of several hundred feet by volcanic rocks of the Snake River plain. Undifferentiated flows of the Snake River Basalt are exposed to a depth of 500 feet in the walls of the Snake River Canyon just north or the city. The Snake River Basalt of Pliestocene to recent age consists of individual flows as much as 50 feet or more in thickness.

The Banburry Basalt of late Pliocene age underlines the Snake River Basalts. The Banburry Basalt is exposed in the bottom of the Snake River Canyon and is 300 to 500 feet thick. These basalts are generally of low permeability except where fractured. Numerous hot springs are found along the Snake River Canyon from Bliss to Artesian City. Most of the hot springs along the canyon issue from fractures and faults.

Underlying this sequence is a series of Miocene silicic rocks of undetermined thickness. This group consists primarily of flows of andesite and rhyolite. These rocks, generally referred to as the Idavada Volcanics, dip north and are believed to be disturbed by faulting related to the Snake River downwarp. (14)

Numerous wells in the Twin Falls have encountered hot water $\left(40^{\circ} \mathrm{C}\right)$ at depths of 360 meters to 450 meters, from rhyolite flows of the Idavada sequence. Wells producing thermal water flow under artesian pressure.

The character of the geothermal resource in the Twin Falls area is unknown. No wells in the area have penetrated through the Idavada sequence and geological information is only known imperfectly from records of the few wells drilled into the contact of the Banburry Basalts and the upper flows of the Idavada sequence.

Industrial development of geothermal resources in the Twin Falls area will depend upon higher temperature fluids being discovered. Deep exploration driliing is needed to prove the existence of a high temperature resource. The market potenti for such a resource could be large. Eleven industries which could use geothermal fluids are located in Twin Falls, two such jndustries are located in Filer, and seven such industries are located in Buh1. (8) See Table 4 for a 1ist of major industries in southcentral Idaho, their approximate annual energy demands.

Amalgamated Sugar Company, which processes sugarbeets, and Idaho Frozen Foods, Inc., which processes potatoes, are two of the largest food processing plants in Idaho and are located in Twin Falls. Green Giant Company, which cans vegetables, is another major food processing plant and is located in Buhl. The total yearly energy consumption of these three plants is $1,700 \times 10^{12}$ BTU per year. (9) Assuming a 50 percent energy conversion of these plants to geothermal resources, an estimated $750 \times 10^{12}$ BTU per year of nonelectrical geothermal energy consumption is projected for 1990. 
Twin Falls

C.U.I. International

SIC 2077-B

Animal By-Products

Colonial Concrete, Inc.

SIC 3273-B

3272

3295

Ready-Mix Concrete

Idaho Frozen Food, Inc.

Frozen Potatoes

SIC 2037-G .43

Independent Meat Company

SIC 2011-D

Meat Packing

Monroe, Inc.

SIC 3273-C

Concrete-Ready Mix

Regal Manufacturers, Inc.

SIC 2452-D

Mobile Home Manufacturing

Swift Dairy and Poultry Company

SIC 2022-C

Cheese Factory

Amalgamated Sugar Company

SIC 2063-H

Beet Sugar

Triple C Concrete

SIC 3272

Ready-Mix Concrete, Pipe

Twin Falls Feed, Inc.

SIC 2094 2048-D

Manufactured Ice

Young's Dairy Products Company, Inc. SIC 2026-D

Fluid Milk Processing
Annual Energy Demand (BTU)

$8.3 \times 10^{6}$

$21.0 \times 10^{6}$

$380,000 \times 10^{6}$

$41.5 \times 10^{6}$

$21 \times 10^{6}$

$35 \times 10^{6}$

$21 \times 10^{6}$

$1,000,000 \times 10^{6}$

$21 \times 10^{6}$

$41.5 \times 10^{6}$

$41.5 \times 10^{6}$ 
Table 4-D (cont.)

Filer

Quality Wood Products

SIC 2439-A

Laminated Timbers

Twin Falls County Canning Kitchen, Inc.

SIC 2033, 2035, 2032

Canned Fruits and Vegetables

Buh1

Green Giant Company

SIC 2037, 2033-H

Canned Vegetables

Pet, Inc.

SIC 2023-D

Evaporated Milk

Rangen, Inc.

SIC 2077, 2875-D

Animal Fats and $0 i 1 s$

Smith's Dairy Products

SIC 2024-H

Fluid Milk

Thousand Springs Trout Farms, Inc.

SIC 2092-E

Frozen Packaged Fish

Clear Springs Trout Company, Inc.

SIC 2092-E

Frozen Packaged Fish

Fish Breeders of Idaho

SIC 2092-E

Frozen Packaged Fish
Annual Energy Demand (BTU)

$3.5 \times 10^{6}$

.43

$4.5 \times 10^{6}$

$320,000 \times 10^{6}$

$41.5 \times 10^{6}$

$121 \times 10^{6}$

$41.5 \times 10^{6}$

$41.5 \times 10^{6}$

$41.5 \times 10^{6}$

$41.5 \times 10^{6}$ 
Known low temperature thermal fluids $\left(50^{\circ} \mathrm{C}\right)$ in the Twin Falls area are suitable for spaceheating. Development of these waters for aquaculture has occurred for several years and spaceheating applications are being developed.

The College of Southern Idaho, a large community college in Twin Falls, is drilling an exploration well on campus for the purpose of developing geothermal fluids. The long-range goal is to utilize the geothermal energy to heat the one-half million square-foot campus. (15) As of September 1978, the exploration well was approximately 250 meters deep. The Idavada geothermal aquifer is anticipated at a depth of 350 meters. Thermal wells adjacent to the campus produce $40^{\circ} \mathrm{C}$ water from the upper contact of the Idavada sequence. The CSI well will penetrate deep into the Idavada sequence in hopes of increasing the water temperature to the $80^{\circ} \mathrm{C}$ range.

The campus utilizes electric furnaces to heat water for water/air heating coils. This type of system is compatible to a geothermal retrofit. In 1977, the College of Southern Idaho consumed $5,685,000 \mathrm{kw} \mathrm{hr}$ of electricity. The majority of this demand can be attibuted to heating. Percent energy cost for CSI is $\$ 172,200$ per year.

CSI has reduced its energy consumption 20 percent since 1972. In the same period of time, the cost of energy for CSI has increased 100 percent. Table 5 lists the historical energy demand and cost for the college. If electrical rates increase an additional 30 percent, as predicted over the next two years, CSI's energy bill will increase $\$ 33,600$.

The cost of drilling and casing a 600-meter production well in the Twin Falls area will range between $\$ 51,000$ and $\$ 72,500$. Retrofit costs are unestimatable until a water temperature is known. But at the present rate of energy inflation, the costs of exploration and retrofiting for geothermal spaceheating is a logical economic alternative for the College of Southern Idaho.

In addition to the CSI geothermal experiment, the Villa Del Rio Condominium development just northwest of the CSI campys is considering the use of low temperature geothermal water for spaceheating. (19) A water to air heat pump system is being considered. The development involves sixteen 4,000 square-foot condominium duplexes on 16 acres of land. The development will utilize $40^{\circ} \mathrm{C}$ water and the development is expected to be completed by mid-1979.

Successful development of low temperature geothermal fluids for spaceheating at CSI and other locations is needed before large-scale development can be anticipated. The Idavada rhyolite, which is the principal-known thermal aquifer, underlies most of the Twin Falls area, from Twin Falls to Buhl. Irrigation and domestic water wells have encountered this formation at several localities in the city of Twin Falls. The limited information indicates that the entire city is underlain by a geothermal aquifer which could be a major spaceheating energy source. Exploratory drilling is needed to prove the extent of the geothermal resource.

Table 6-D lists the site specific data describing the Twin Falls area. 
Table 6-D

DATA SUMMARY FOR TWIN FALLS, IDAHO

\section{SITE LOCATION AND PHYSICAL DESCRIPTION}

..Latitude: $42^{\circ} 28^{\prime} 55^{\prime \prime}$

..Longitude: $114^{\circ} 29^{\prime} 12^{\prime \prime}$

..Rectilinear: T 10 S.R. 17 E., Boise Meridian

..County: Twin Falis

..Adjacent Counties: Owyhee, Cassia, Jerome, Gooding, Elmore

..Topography: The topography of the area is generally flat except where the plateau area has been cut by the Snake River and its tributaries Canyon walls of the Snake River are over 150 meters (500 feet) deep and near vertical. Several coulees cut into the lava platea in the city of Twin Falls. These coulees are generally 50 meter deep and have near vertical walls.

. Present Land Use: The general land area surrounding the city of Twin Falls is pre. dominantly in agricultural production. The principal crops are potatoes, sugar beets, peas, and barley. The city of Twin Fal is a growing urban center approximately 6,000 acres in size.

. Future Land Use Plans:

Areas adjacent to the city of Twin Falls will continue to chang from agricultural land use to urban residential land use.

A broad agricultural area southeast of the city near Buhl will continue to reclaim desert lands through irrigation from both surface and groundwater sources.

..Aesthetics: The area is highly aesthetic, particularly along the Snake River Canyon.

..Historical/

Archaeological

The Kelton Wagon Road and the Oregon Trail crossed through this

Significance: area.

\section{GEOLOGICAL/GEOPHYSICAL DESCRIPTION}

..Geologic Description:
The city of Twin Falls is located on the south side of the Snake River Canyon along the southern margins of the Snake River plair The area is underlain by a thick sequence of volcanic rocks of undetermined depth, The major units are: The Snake River Basal ( 150 to 200 meters thick); the Banburry Basalt (average thicknes 150 meters); Idavada volcanics (drilling to depths of in excess of 350 meters both east and west of the city has failed to reach the base of this series of volcanic rocks). Ages range from Miocene to present. South of the city, 10 to 20 kilometers the area is deformed by high angle normal faulting of the basin and range provinces. Some faulting is evident in the Snake Rive Canyon but major displacement is not evident. The Idavada volcanics sequence dips generally to the north approximately 10 20 degrees. This formation may be locally displaced by fault related to the Snake River plain downwarp. 


\section{RESERVOIR CHARACTERISTICS}

.. Reservoir Temperature (14)

Surface: $30^{\circ}$ to $43^{\circ} \mathrm{C}$

Subsurface: $40^{\circ}$ to $45^{\circ} \mathrm{C}$ from shallow irrigation wells

..Flow Rates: (14) 120 to $350 \mathrm{gpm}$ from present wells. Wells drilled in the bottom of the Snake River Canyon $3 \mathrm{~km}$ north of the CSI campus have an artesian pressure of 212 PSI.

..pH: 8

..Total Dissorved Solids: 150 to $200 \mathrm{ppm}$

..Fluid Chemistry: (14) Fluoride content of deep well waters in the vicinity of Twin Falls range from $1.5 \mathrm{ppm}$ to $4 \mathrm{ppm}$.

\section{GEOTHERMAL DEVELOPMENT STATUS}

..Present Development Status:

Several wells in the vicinity of Twin Falls. Buhl and Filer have encountered 33 to $40^{\circ} \mathrm{C}$ water at depths of 150 to 200 meters. These wells are generally used for irrigation and to supply domestic water. No heating applications have occurred. Some thermal wells in the Snake River Canyon are used for raising catfish. The College of Southern Idaho is drilling an exploration well on campus. The well is expected to encounter low temperature fluids at a depth of 150 meters, deeper drilling may produce significantly higher temperature.

..Projected or Planned Development:

The College of Southern Idaho would convert 85 percent of its present energy load to geothermal spaceheating by 1982. Assuming 50 percent conversion of present food processing facilities, approximately $850 \times 10^{9}$. BTU/year of direct geothermal energy could be achieved by 1990 .

\section{ENVIRONMENTAL FACTORS (18)}

..Climate: Prevailing Winds: $E-W$

Precipitation (Annual): $23 \mathrm{~cm}$

Days of Sunshine (Annual): 310

Average Temperature:

$\begin{array}{lcr}\text { Minimum: } & \text { January } & \text { July } \\ \text { Maximum: } & -8.44 & 12.38 \\ & 2.33 & 31.88\end{array}$

Degree Days (Annual): 5990

Relative Humidity (Seasonal Peaks): Summer: 30

Winter: 70

..Air Quality: Generally high.

..Water quality: (16) Groundwater has 1.5 to $4 \mathrm{ppm}$ fluoride.

.Noise: Low. ..Elevation: 1,149 meters 
..Utility or Energy Transmission Corridors and Facilities

El Paso Natural Gas Pipeline is located on the city limits. Chevron 8 oil pipeline is located at the city limits.

- Transportation Corridors or Facilities

Interstate Freeway $80 \mathrm{~N}$ located $10 \mathrm{kilometers} \mathrm{north} \mathrm{of} \mathrm{the} \mathrm{city} \mathrm{limits.} \mathrm{The} \mathrm{junction}$ of Idaho Highways 30 and 93 is located in Twin Falls. Major east-west rallroad lines service Twin Falls.

POPULATION

Site: Twin Falls, Idaho

- General Description of Population (1)

$\begin{array}{ccccc}1940 & 1950 & 1960 & 1970 & 1977 \text { est. } \\ 11,965 & 17,600 & 20,126 & 21,914 & 24,500\end{array}$

Twin Falls is the regional urban center. The city has 40 percent of the retail trade and 50 percent of the industrial base of the South Central Idaho Region. The Twin Falls School District serves an area of approximately 100 square miles.

There are seven grade schools, two junior high schools and one high school. The college of Southern Idaho is the regional community college. There are 55 churches and two hospitals.

\section{..Economics (1) (9)}

The industrial base of the area is dependent on agriculture. The dominant crops of the area are sugar beets, potatoes, alfalfa, and feed corn. The major manufacturing units are in the food and kindred products classification. Twenty-two such industries are located in Twin Falls. Two of the largest food processing plants in Idaho are located in Twin Falls--Amalgamated Sugar Company and Idaho Frozen Foods, Inc. These two industries consume approximately $1,360 \times 10^{12}$ BTUs of energy per year and employ approximately 1,500 to 2,000 people. 
..Geophysical Summary: Landsat false color infrared satellite imagery reveals several curvilinear features near Magic Reservoir. These could be surface expressions of major fault systems. A geothermal gradient of $92^{\circ} \mathrm{C}$ per $\mathrm{km}$ has been calculated from measurements of water wells in the prairie. The normal geothermal gradient for this area should be $33^{\circ} \mathrm{C}$ per $\mathrm{km}$. Geochemical thermometers indicate that temperatures exceeding $150^{\circ} \mathrm{C}$ are possible near Magic Hot Springs.

\section{RESERVOIR CHARACTERISTICS}

. Reservoir

Temperature:

.. Flow Rates:

..pH:

..Total Dissolved Solids:

..Fluid Chemistry:(19) Wells in the Camas Prairie are typified by:

High silica contents (50 to $90 \mathrm{mg} / 1$ ). $\mathrm{pH}$ averages 8.5 .

High fluoride contents ( 3 to $17 \mathrm{mg} / 1$ ).

High carbonate.

Low calcium.

Low magnesium.

Low potassium.

Low Chloride.

Waters are typically high in sodium bicarbonate..

.. Estimated

Electrical Energy

Potential:

$50 \mathrm{mw}$.

LAND OWNERSHIP AND LEASING

..Land Ownership

Camas County:

TOTAL AREA

(acres)

FEDERAL

STATE

(Acres)

PRIVATE

(Acres)

OTHER

674,302

440,763

20,059

211,160

2,320

..Land Leased:

11,142

9,564

1,578 Unknown

..Summary of Leasing Status and Needs: All federal leases in the area are held by the Hunt family of Dallas, Texas. 
The Camas Prairie is located in Camas and Blaine Counties in South Central Idaho. The prairie is approximately 65 kilometers long and 16 kilometers wide. A large east-west trending basin, the Camas Prairie lies at the transition zone between the geology of the Snake River Plain to the south and. the Idaho Batholith to the north.

Cretaceous granitic rocks of the Idaho Batholith form the northern border and Pliocene Idavada volcanic rocks are found along the southern margins of the prairie. Holocene basalts are found in the southeast corner of the basin. The Holocene flows extend southward onto the Snake River Plain. The basin is filled with PliocenePleistocene sediments. The Prairie Basin is thought, $f 8$, be a fault-controlled graben structure with displacement in excess of 300 meters. (19)

Thermal water occurrences in the Camas Prairie are sparsely distributed over the area. Measured surface temperatures range from $26^{\circ} \mathrm{C}$ to $72^{\circ} \mathrm{C}$ and average $52^{\circ} \mathrm{C}$. The higher temperature thermal occurrences seem to be concentrated in the western regions of the basin near the Mt. Bennett Hills. This may be due to the higher number of wells in the western region of the basin. (20)

The possibility of a large thermal reservoir within the sedimentary fill of the basin is thought to be negligible by the Idaho Department of Water Resources. This is because 300 meter irrigation wells penetrating the entire thickness of sediments near the basin's center have encountered cretaceous granite and no evidence of a geothermal reservoir. Temperatures from exploration wells are not expected to be greater than $100^{\circ} \mathrm{C}$ for most of the basin. The area around Magic Hot Springs may prove higher temperatures from localized fault zones which allow deeper circulation of fluids. Temperatures exceeding $150^{\circ} \mathrm{C}$ may be possible near Magic Hot Springs. This high temperature is indicated by the quartz geochemical thermometery.

Temperatures of the $100^{\circ} \mathrm{C}$ magniture would be sufficient for some industrial applications such as drying of grain, alfalfa, and vegetables, environmentallycontrolled animal husbandry, and animal slaughter operations. The main industry in the Camas Prairie is agriculture, principally hay, wheat, and cattle.

The largest community is Fairfield which has a population of 400 . (3) Fairfield, elevation 1,544 meters, has gver 8,538 heating degree day a year and over $210 \mathrm{~cm}$ of snowfall during the winter. (18) The community depends on local wood, and truckedin bottled gas and heating oil for spaceheating. The development of a $100^{\circ} \mathrm{C}$ thermal well in Fairfield could provide energy for a new industry and spaceheat the town.

The thermal water geochemistry and recent basalt flows near Magic Hot Springs show definite promise of high temperature waters. This area needs further geophysical work and deeper drilling to prove the existence of a high-temperature reservoir. Temperature estimates indicate that temperature of $150^{\circ} \mathrm{C}$ to $200^{\circ} \mathrm{C}$ may be possibie. At these temperatures electrical generation is a possible future development.

Scenario Projection

Assuming an adequate resource is proven, an estimated $50 \mathrm{mw}$ of electrical generation capacity could be developed at Magin Hot Springs by 2020 . Table 7-D 1ist the site specific data describing Magic Hot Springs and the Camas Prairie Subarea. 
Table 7-D

DATA SUMMARY FOR CAMAS PRAIRIE, CAMAS COUNTY, IDAHO

SITE LOCATION AND PHYSICAL DESCRIPTION

.. Latitude:

$43^{\circ} 21^{\prime}$

..Longitude:

$114^{\circ} 47^{\prime}$

. Rectilinear:

T 1 S, R 17 E, Boise Meridian

-. County:

Camas

..Adjacent Counties: Elmore, Blaine, Gooding, Lincoln

.. Topography:

The relatively flat plain slopes very gently from west to east with an elevation of 1,520 meters in the western area and 1,483 meters in the eastern portions. To the north the Soldier Mountains rise abruptly from the prairie to heights of 3,048 meters. These mountains are very rugged.

..Present Land Use: Principally agriculture.

..Future Land Use Continuation of the present land uses.

Plans:

..Aesthetics:

Area is a highly aesthetic mountain prairie area.

. Historical/

Archaeological

Significance:

\section{GEOLOGICAL/GEOPHYSICAL DESCRIPTION}

- Geologic

Description:

The prairie area itself consists of alluvium and colluvium of Pliocene to Holocene age. The thickness of the sedimentary material is generally less than 350 meters. The Camas Prairie is thought to be a graben structure located at the transition zone between the Idaho Batholith to the north and the Snake River plain to the south. The basin trends east-west and normal faults of the northwest portions of the priarie have a distinct enechelon relationship to the Mount Bennett Hills fault structures to the west. The northern border of the basin consist of Cretaceous granitic rocks of the Idaho batholith and Eocene volcanic rocks of the challis formation, which are rhyolites and andesites. Lower Pliocene Idavada volcanic rocks are found along the southern margin of the prairie and middle Pleistocene basalts are found along the southwestern and southeastern edges. Holocene basalts are found south of Magic Reservoir and these flows extend south into the Snake River Plain. 
GEOTHERMAL DEVELOPMENT STATUS

..Present

Development

Status:

..Projected or Planned

Development:
Federal leases have been issued, but there has been no exploration activity.

Exploration for high temperatures near Magic Hot Springs is projected for the $1990^{\prime} \mathrm{s}$ and a $50 \mathrm{mw}$ electrical generation facility could be on line by 2020 .

INSTITUTIONAL CONSIDERATIONS (FederaI)

Institutional Requirements

Federal Geothermal

Resource Lease

(30 C.F.R. 3000)

National Environmental Policy Act (42-U.S.C. 4331)

Federal Water Pollution Control Act (33 U.S.C.A. 1251)

Federal Safe Drinking Water Act (42 U.S.C.(A) 300)
Agency and Public Attitudes

Leases are made pursuant to the Geothermal Steam Act of 1970 (84 Stat. 1566) (30 USC 1001-1025)

B.L.M., U.S.F.S.

An E.I.A. is required before leases are issued. E.P.A.

The national goal of this Act is to attain - 0 -

pollution by 1985. E.P.A.

This Act is concerned with protection of underground water resources that could be used for domestic water. E.P.A.
Status of Requirements (i.e.. EIA/EIS Requirements)

Leases are non-competitive. Specia conditions are required in the leas with regard to potential archaelogi and historical sites, adjacent road less areas, and critical habitat ar

A preliminary E.A.R. could be requi before an exploration drilling proj In general an E.I.A. is required fo all projects involving exploration and development. An E.I.S. will be required for any major action.

Groundwater is included under this and the reinjection of geothermal effluent will require permits.

The Act sets standards for wells an well drilling and could influence future geothermal wells. 
INSTITUTIONAL CONSIDERATIONS (State)

Institutional

Requirements
Agency and Public Attitudes
Status of Requirements (i.e., EIA/EIS Requirements)
Leases on state lands (Idaho Code 47-601 et.seq. Chapter 16, Geothermal Resources)

Geothermal resource permits (Idaho Code 42-4001 et.seq. Chapter 40 , Geothermal Resources)

Water Appropriation (Idaho Code 42-101 et.seq. Chapter 1 Water Appropriation)

Injection wells (Idaho Code 42-3001 et.seg. Chapter 39 Waste Disposal and Injection Wells)
The State Board of Land Commissioners is authorized to issue leases for geothermal resources underlying state and school lands.

The regulatory powers of the state Geothermal Resource Act are placed in the Idaho Department of Water Resources.

The Idaho Department of Water Resources issues water appropriation permits and a water right license.

Permits are issued by the Department of Water Resources.
Lease term is 10 years and can be continued with diligent development. Rentals are set by the Board. Several leases have been granted on state lands. Lease size is limited to a maximum of 640 acres/lease.

Any private owner, or holder of a state or federal lease of geothermal resources must first apply for a geothermal resource permit from I.D.W. before any drilling operations can begin.

Under the Idaho Geothermal Resources Act, applicants can be required to make an application to appropriate the public waters of the state.

No waste disposal or injection well can be constructed in Idaho unless a permit has been issued by I.D.W.R. The approval of this permit is contingent upon the approval of the Department of Health and Welfare. The proposed well is reviewed to see if it will unreasonably contaminate or deteriorate the quality of the groundwater below the adopted water quality standards of the state. 
Table 7-D (cont.)

INSTITUTIONAL CONSIDERATIONS (Local)

Institutional

Requirements

Comprehensive

Plan

Zoning Ordinance

Subdivision

Ordinance

Planning and Zoning

Commission

ENVIRONMENTAL FACTORS

..Climate (18)

..Percipitation

(Annual):

.. Days of Sunshine

(Annual):

.. Average

Temperature:

.. Degree Days

(Annual):

..Air Quality:

..Geologic Factors:

..Water Quality:

..Noise:

..Elevation:

..Endangered Species(22)
Agency and Public Attitudes

Camas County

Commission
Status of Requirements (i.e., EIA/EIS Requirements)
Special Use Permits for constructi and nonconforming use.
$211.3 \mathrm{~cm}$ snow annually

$39.7 \mathrm{~cm}$ precipitation annually

300

$\begin{array}{lcc} & \text { January } & \text { July } \\ \text { Mininum: } & -16^{\circ} \mathrm{C} & 7.7^{\circ} \mathrm{C} \\ \text { Maximum: } & -2.4^{\circ} \mathrm{C} & 29.3^{\circ} \mathrm{C}\end{array}$

8575

High

High fluoride in groundwater.

Low.

1,520 meters.

Flora: Antemisa papposa - threatened Astnagalus antratus - endangered 
Table 7-D (cont.)

TRANSPORTATION AND UTILITIES

..Utility or Energy Transmission Corridors and Facilities:

Natural gas lines are located in the Wood River drainage $15 \mathrm{~km}$ east of Magic Reservoir and $33 \mathrm{~km}$ east of Fairfield. Rural power lines service the agricultural areas of Camas Prairie.

.. Transportation Corridors or Facilities:

State Highway 68 services the area, junction of Highways 68 and 48 is at Fairfield. Union Pacific rail service to Magic Reservoir and Fairfield from Twin Falls.

POPULATION

..General Description of Population (3)

The community of Fairfield is the only major community and its population is only 400 . The population density of the area is less than one person per square mile.

...Economics (3)

The principal economic activity in the area is agriculture. The major agricultural activities are cattle, alfalfa, and winter wheat. Secondary industries are largely related to recreation. 
The Hailey-Sun Valley area is located in the northern portion of South Central Idaho, along the Big Wood River. The Big Wood River forms a deep broad valley leading from the Snake River Plain north into the Boulder Mountains.

The area's geology is characteristically a highly glaciated topography carved out of Paleozoics limestones and other sediments which are unlain by Paleozoic quartzite. Northwest and north-trending faults are present. Early Cenozoic challis volcanic rocks outcrop in the northern areas near Sun Valley and are the youngest rock in the area. The Big Wood River Valley is partially filled with glacial and alluvial deposit

Isolated hot springs are generally found along the major east-west-trending tributary valleys of the Big Wood River. The springs generally are venting from the base of the Paleozoic limestone and quartzite block which forms the western border of the Big Wood River Valley. Temperatures of the hot springs range from $47^{\circ}$ to $80^{\circ} \mathrm{C}$ and siljca geochemical thermometers indicate $130^{\circ} \mathrm{C}$ is the maximum temperature at depth. (23)

Three thermal locations in the Hailey-Sun Valley Subarea are of commercial importance for spaceheating: Sun Valley-Guyer Hot Springs, Clarenden Hot Springs, and Hailey Hot Springs. All three areas are being developed for spaceheating.

The expanding recreation industry in the Sun Valley area has created a growing demand for secondary recreation homes and had rapidly increased the local population of the Big Wood River Valley. Hot springs in the Ketchum area near Sun Valley are being used for spaceheating homes and at least one floral shop. Most of the developme is occurring along Warm Springs Creek near the base of the ski area. The water temper ture is $55^{\circ}$ to $70^{\circ} \mathrm{C}$.

Clarendon Hot Springs is located approximately 10 kilometers north of Hailey alon Deer Creek. Numerous springs and at least three shallow wells in the area have $42^{\circ}$ to $47^{\circ} \mathrm{C}$ water. A recent subdivision development at Clarendon Hot Springs is planning on utilizing this water to spaceheat some of the area's homes.

Hailey Hot Springs is located along Cory Creek approximately 8 kilometers from Hailey. The temperature of this spring is $59^{\circ} \mathrm{C}$. In addition to this hot springs, several wells in the Hailey area are reported to be thermal. Expanded development of these thermal fluids for spaceheat may be possible with the use of water to airheat pumps.

The Hailey-Sun Valley area is one of the more rapidly-growing areas in the state. The 1970 population of this area was 3049. In 1973 the population had risen to 4,151 and in 1977 the population was over 5,000 people. (3) This represents a 43 percent change in the permanent residential population but does not include the season or winter weekend population which can double and triple the local population. The large growth has occurred in the Hailey and Ketchum areas where major condominium and recreation home developments have been centered. In 1976, 195 building permits were issued in Ketchum and 28 were issued in Hailey. (3) 
Table 8-D

DATA SUMMARY FOR HAILEY-KETCHUM-SUN VALLEY

HAILEY :

Hailey Hot Springs, sec. 18, T 2 N, R 18 E, Boise Meridian

Discharge: $70 \mathrm{gpm}$

Temperature: $59^{\circ} \mathrm{C}$

Fluoride Count: 12 milligrams per litre

TDS: 273

$\mathrm{pH}: \quad 8.6$

Environment:

Elevation: 1,624 meters

Mean Temperatures:

$\begin{array}{llr} & \text { January } & \text { July } \\ \text { Maximum: } & -7^{\circ} \mathrm{C} & 27.8^{\circ} \mathrm{C} \\ \text { Minimum: } & -16.7^{\circ} \mathrm{C} & 2.7^{\circ} \mathrm{C}\end{array}$

Heating Degree Days: 8070

Mean Precipitation: $230 \mathrm{~cm}$ of snow annually

Population: 1,980 (1978)

$37.7 \mathrm{~cm}$ precipitation annually

KETCHUM-SUN VALLEY:

Guyer Hot Springs, Ketchum, sec. 15, T 3 N, R 17 E, Boise Meridian Discharge: $1,000 \mathrm{gpm}$

Temperature: $70.5^{\circ} \mathrm{C}$

Fluoride Count: 16 milligrams per litre

TDS: 334

$\mathrm{pH}: \quad 8$

Clarendon Hot Springs, sec. 27, T 3 N, R 17 E, Boise Meridian

Discharge: 100 to $250 \mathrm{gpm}$ (estimated)

Temperature: $47^{\circ} \mathrm{C}$

Fluoride Count: 15 milligrams per litre

TDS: 303

$\mathrm{pH}: 8.2$.

Environment:

Elevation: 1,771 meters

Mean Temperature:

$$
\begin{array}{lcr} 
& \text { January } & \text { July } \\
\text { Maximum: } & -.7^{\circ} \mathrm{C} & 27.8^{\circ} \mathrm{C} \\
\text { Minimum: } & -16.7^{\circ} \mathrm{C} & 2.7^{\circ} \mathrm{C}
\end{array}
$$

Heating Degree Days: 9986

Mean Precipitation: $309 \mathrm{~cm}$ snow

$44.2 \mathrm{~cm}$ precipitation

Population: 3,000 permanent residents and approximately 10,000 seasonal 
Leasing activity in South Central Idaho increased sharply in 1978. Approximately 52,600 acres of federal lands were recently leased to several members of the Hunt fami of Dallas, Texas. These leases were concentrated in Camas, Blaine, and Lincoln Counti One competitive lease was issued for 1,383 acres in the Raft River KGRA to the Raft River Rural Electrical Coop, Inc.

All other federal leases were issued prior to 1978 and are concentrated in Cassia County, for a total of 25,000 acres.

Total federal acreage leased in south central Idaho in 1978 is 77,505 acres.

Total state acreage leased in south central Idaho in 1978 is 6,098 acres.

State Leases:

Cassia County

8,640 acres held by Raft River Rural Electrical Coop and Sun 0il Conpany. Camas County

1,578 leases held by R. L. Bullock.

Fecieral Geothermal Leases:

Blaine County

2,040 acres Caroline Hunt, Trust Estate

2,394 acres $H$. Hunt, Inc.

$\underline{2,112}$ acres Lamar Hunt

Total: 6,546 acres

Camas County

2,459 acres Caroline Hunt

2,040 acres $\mathrm{H}$. Hunt, Inc.

2,560 acres Lamar Hunt

2,505 acres Norma Hunt

Total: 9,564 acres

Cassia County

1,480 acres L. H. Armour

5,723 acres Delta Funds, Inc.

1,883 acres Raft River Electrical Coop. Inc.

15,787 acres Sunoc0 Energy Development Company

Total: 26,873 acres 
Lincoln County

5,086 acres Caroline Hunt

2,416 acres Caroline Hunt, Trust Estate

2,352 acres $H$. Hunt, Inc.

7,417 acres Lamar Hunt

5,101 acres Nancy Hunt

4,824 acres Nelson B. Hunt

2,536 acres Horma Hunt

4,800 acres W. H. Hunt

Total: 34,522 acres

\section{RARE II CONFLICTS}

The following RARE II areas are also possible geothermal resource areas.

Cassia County

Area 1:

No Name for geothermal area

Location: Sec. 22, T 15 S, R 24 E, Boise Meridian

Discharge: $100 \mathrm{gpm}$

Termperature: $38^{\circ} \mathrm{C}$

Aquifer Estimate: $95^{\circ} \mathrm{C}$

RARE II AREA: \#4582, Cache Peak, (Sawtooth National Forest). High interest in this area for expioration.

Area 2:

No Name for geothermal area

Location: Sec. 34, T 14 S, R 21 E, Boise Meridian

Discharge: $\quad 50 \mathrm{gpm}$

Temperature: $43^{\circ} \mathrm{C}$

Aquifer Estimate: $95^{\circ} \mathrm{C} 115^{\circ} \mathrm{C}$

RARE II AREA: \#4576, Lane Cedar, (Sawtooth National Forest). High interest in this area for exploration. 
1. Irvin, Lawrence D., Social Economic Profiles, South Central Idaho Region IV Burley (BLM) District, Center for Business and Economic Research, Boise State University, 1976.

2. Ibid.

3. Idaho Division of Budget, Policy Planning and Coordination, County Profiles of Idaho 1978, State of Idaho, 1978.

4. Spencer, S.G., Stanley, N. E., Hickman, W. W., Draft Environmental Report Raft River Thermal Loop Facility, Idaho National Engineering Laboratory, 1977.

5. Ibid.

6. Memorandum to: State Director, BLM, Boise, Idaho. From: Conservation Manager, Western Region, U.S.G.S. Subject: Definition and Description of Raft River KGRA. Formeriy frazier KGRA, February 21, 1976.

7. Kunze, Jay F., Idaho Geothermal Development Projects Annual Report for 1976, Idaho National Engineering Laboratory, January, 1977.

8. Cornelison, Launa C., Manufacturing Directory of Idaho, 1976, University of Idaho Center for Business Development and Research, 1977.

9. Ornum, Joel Van, Industrial Waste Heat for Adjacent Communities and Industrial Applications, Rocket Research Company Report RRC-78-H-181, Pacific Northwest Regiona 7 Commission, December, 1977.

10. Bureau of Land Management, Geothermal Lease Files, Serial Number I-14166, January 1, 1978.

11. State of Idaho, Department of Lands, Geothermal Lease Files. Leases Numbers $\mathrm{H}-753$ through H-755, H-758, H-759 through H-791, as of March 1, 1978.

12. U.S. Geological Survey, 15-Minute Series Topographic Map Quadrangle, 19.

13. Idaho Almanac, Idaho Division of Tourism and Industrial Development, 1977.

14. Brockway, C. E., Feasibility of Thermal Water Development Near Twin Falls, Idaho, 1970. Unpublished data on file at the Idaho Office of Energy.

15. Taylor, Dr. James, President, College of Southern Idaho, personal communications, JuTy, 1978.

16. McManaman, Bob, Director of Administrative Services, College of Southern Idaho, personal communications, July, 1978.

17. Threlkeld, Jack, personal communications, July, 1978.

18. N.0.A.A., Climatological Data, Idaho, U.S. Department of Commerce, 1978.

19. Mitche11, John C., Geothermal Investigations in Idaho, Part 7, "Geochemistry and Geological Setting of the Thermal Waters of Camas Prairie Area, Blaine and Counties, Idaho," Idaho Department of Water Resources Water Inf. Bul1. 30, September, 1976. 
0 REFERENCES (cont.)

20. Ibid.

21. Mitche11, John C., personal communications, August, 1978.

22. Henderson, D. M., et al, Endangered and Threatened Plants of Idaho, University of Idaho, Forest and Wildlife and Range Experiment Station, 1977.

23. Young, H. W., and Mitche11, J. C., Geothermal Investigations in Idaho, Part 1, "Geochemistry and Geological Setting of Selected Thermal Water," Idaho Department of Water Resources Inf. Bu11. 30, 1973. 


\author{
APPENDIX E \\ GEOTHERMAL DEVELOPMENT REGION IV \\ Southeastern Idaho
}

Table of Contents

Text:

$\underline{\text { Page }}$

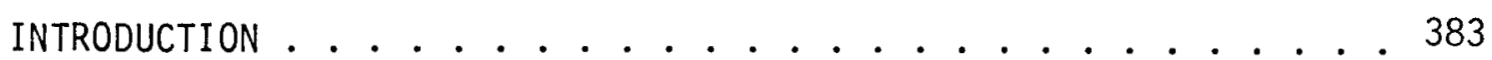

CONDA KGRA AND SODA SPRINGS SUB-AREA ............ 387

POCATELLO-CHUBBUCK SUB-AREA . . . . . . . . . . . 393

LAVA HOT SPRINGS SUB-AREA . . . . . . . . . . . . . 403

CACHE VAlleY SUb-AREA .................. 416

REFERENCES ................... 423

Tables:

Table 1-E: Population of Southeast Idaho by Counties . . . . . 384

Table 2-E: Industrial Energy Consumers, Southeast Idaho . . . . 386

Table 3-E: Data Summary for Conda KGRA and Soda Springs, Idaho . 389

Table 4-E: Population Projections for Pocatello and Chubbuck . . 395

Table 5-E: Data Summary for Pocatello and Chubbuck, Idaho . . . 396

Table 6-E: Survey of Utility Use in the Central Business

District, Lava Hot Springs, Idaho ........ 405

Table 7-E: Economic Analysis for Geothermal Conversion of Smal1 Swimming Pool, Lava Hot Springs Foundation. . . 407

Table 8-E: Data Summary for Lava Hot Springs, Idaho . . . . . . 408

Table 9-E: Data Summary for Cache Valley, Idaho . . . . . . 417 


\author{
APPENDIX E \\ Geothermal Development Region IV \\ Southeast Idaho
}

\title{
Introduction
}

The Southeast Idaho region encompasses seven counties: Bannock, Bear Lake, Bingham, Caribou, Franklin, Oneida, and Power. This region coincides with Idaho State Planning Region V and the Bureau of Land Management, Burley and Idaho Falls Districts. Power, Bannock and Oneida Counties are in the Burley BLM District and the other counties are in the Idaho Falls BLM District. The major surface regulatory agency in this region is the Caribou National Forest.

The region is sparsely settled and population is largely concentrated in the American Falls-Pocate110, Soda Springs, Preston, and Montpelier areas. Agriculture, the dominant industry, includes dry and irrigation farming and livestock grazing. Potatoes, alfalfa, wheat and barley are the principal crops. An established phosphate mining and processing industry is the significant industrial development of the region. Major phosphate processing plants are located in Pocatel10 and Soda Springs. The region also supports several food processing plants.

An adequate transportation network connects the population centers and secondary roads provide access to more remote areas. Interstate 15 , the major arterial, services the center and northern portions of the region. Numerous state highways provide access between the smaller population centers. The Union Pacific Railroad owns and operates the trackage in southeast Idaho where two major routes exist, an east-west rail route along the Snake River Plain between Idaho Falls, Pocatello and Boise; and a north-south rail route between Salt Lake City, Preston, Soda Springs and Pocatello.

A major petroleum pipeline supplies the Pocatello area and a major natural gas pipeline supplies the Soda Springs and Pocatello areas. Electric Power is distributed by two public utilities: Utah Power and Light Co. and Idaho Power Co. The Lower Valley Power and Light Cooperative serves rural customers along the eastern State border in Caribou and Bear Lake Counties. The City of Soda Springs has a municipal power system.

The Southeastern Idaho region consists of two geographical provinces. The Snake River Plain province includes the northern portions of Power, Bannock and Bingham Counties. The Basin and Range Province includes Franklin, Bear Lake, Caribou, Oneida, and Southern Bannock Counties. In general the region can be consijdered rural - with a total population estimated at 123,200 people. (1) The majority of this population resides in Pocatello and Soda Springs areas. All other communities in the region have populations of less than 2,500 people. Table 1-E lists the population of Southeastern Idaho by county. 
Table 1-E

Population of Southeast Idaho, by Counties

County-Region

Total Population

\begin{tabular}{lllll}
1950 & 1960 & $1970 \quad 1973$ & $1974 \quad 1977$ \\
\hline
\end{tabular}

Bannock

$41,745 \quad 49,342 \quad 52,200 \quad 54,500 \quad 55,200 \quad 58,000$

Bear Lake

$6,834 \quad 7,148$

5,801

5,900

5,800

6,700

Bingham

$23,271 \quad 28,218$

$29,167 \quad .30,800$

31,900

33,200

Caribou

5,576

5,976

6,534

6,500

7,000

8,000

Frankl in

9,867

8,457

7,343

7,500

7,600

8,200

Oneida

4,387

3,603

2,864

2,900

3,300

3,300

Power

3,988

4,111

4,864

4,900

5,000

5,800

1) Sources: U.S. Bureau of the Census, Number of Inhabitants, Idaho (1960\& 1970)

Idaho Bureau of Vital Statistics, February 1975 (1973 \& 1974)

2) Source: County Profiles of Idaho, 1978, Idaho Division of Budget Policy Planning and Coordination. 
There are nine major industrial energy consumers in South Central Idaho. Table 2-E lists the annual total energy demand of these industries. These nine industries can be broken into two groups: Those plants concerned with ore processing, and those plants concerned with food processing. There are four ore reduction plants; three are phosphate plants and one Portland Cement plant. These four plants are among the top six energy consuming industrial plants in Idaho. The combined total energy demand of these four plants is $12,000 \times 10^{9}$ BTU/year. (2) The majority of this energy demand is in the form of electrical power. There is no market for direct use of geothermal energy in these plants. The only major contribution geothermal energy could make to this energy demand is to provide additional electrical generation capacity. The phosphate mining and processing related loads totals approximately $460 \mathrm{MW}$. Idaho Power supplies roughly two-thirds of this load and Utah Power and Light provides one-third. Natural gas provides the additional energy required.

The five major food process plants of Southeast Idaho are principally concerned with potato processing. The total combined energy demand of these five plants is 2,640 BTU/yr. (4) These plants are located in the Snake River plain and could utilize large volumes of geothermal fluids directly.

In addition to the potential industrial market, several communities have potential for direct use of geothermal fluids for spaceheating. Communities which have spaceheating potential are: Pocatel10, Chubbuck, Lava Hot Springs, Soda Springs, and Preston.

Four subareas were examined in the Southeast Idaho region: the Soda Springs-Conda area, the Pocatello-Chubbuck area, the Northern Cache Valley area, and the Portneuf River area near Lava Hot Springs. 
Table 2-E

MAJOR INDUSTRIAL ENERGY CONSUMERS

Southeast Idaho

(109 BTU/yr.)

Total Energy Demand

FMC Corporation, Pocate110

5,600

J.R. Simplot Fertilizer Plant

2,920

Idaho-Portland Cement

Inkom, Bannock County

1,800

Monsanto Corporation

Soda Springs, Caribou County

1,700

Lamb-Weston, Inc.

American Falls, Power County

820

R.T. French Company

Shelley, Bingham County

520

Idaho Potato Packers Corporation

Blackfoot, Bingham County

540

J.R. Simplot Co.

Aberdeen, Bingham County

380

American Potato Co.

Blackfoot, Bingham County

380

Source: Industrial Waste Heat for Adjacent Communities, Rocket Research Co. (Ref. 2). 
In August 1978, the Western Region, Conservation Manager of the U.S. Geological Survey declared 2,566 acres of federal BLM lands near Conda, Idaho, a KGRA. The Conda KGRA is Sec. 1,2, 11, and 12, T. 8S., R 42 E, Boise Meridian. (5) The area was declared a KGRA because of overlapping lease application. The Conda KGRA is in the Idaho Falls BLM District, and is 8 kilometers north of Conda and 12 kilometers northeast of Soda Springs.

The Conda KGRA and the City of Soda Springs lie in a northwest trending valley of the Basin and Range physiographic province. The valley is flanked by the Aspen Range to the east and the Chesterfield Range to the west. The Snake River Plain physiographic province is 30 kilometers to the north.

Mountain ranges to the east are complexly faulted anticlines consisting of Upper Paleozoic and Mesozoic marine sediments. Mountain Ranges to the west are also complexly faulted folds of lower to middle Paleozoic marine sedimentary rocks. (6) The area is thought to be within a wide zone of thrust faults. Overthrusting is thought to have occurred from late Jurassic to early cretaceous. The faulted and thrusted mountain ranges are upthrown fault blocks which form the Aspen and Chesterfield Ranges. The Blackfoot lava field area is thought to be a downthrown graben structure. Left lateral strike-slip faults are also present. (7) The most recent rocks in the area are Quaternary basalt and rhyolitic cones which fill the graben floor near Blackfoot Reservoir. These rhyolitic cones are a favorable indication of a geothermal heat source at depth. (8)

Travertine mounds cover extensive areas from Blackfoot Reservoir to Soda springs. These mounds are also indicative of past hydrothermal activity. Several springs in the area are associated with travertine deposits. The major mounds seem to be intimately associated with major fault zones.

Thermal springs of the area have surface temperature which range from $30^{\circ}$ to $58^{\circ} \mathrm{C}$. With average discharge $2151 / \mathrm{min}$. (8) Published estimates of temperature gradients suggest that low temperature thermal water could be encountered at depths of 1100 meters. Geophysical surveys indicate geothermal reservoirs are absent above 2 kilometers depth. High temperature resources may be present at depths greater thap 2 kilometers as attested by Quarternary Basalts flows and rhyolitic cones. (9) Deep exploration drilling is needed to prove high temperature resources capable of generating electrical power. Low temperature (less than 750C) fluids may be encountered at shallow depth in the fault zone near travertine mounds.

A well drilled into a travertine mound near the center of the City of Soda Springs produces $5 \mathrm{l} / \mathrm{min}$. of $580 \mathrm{C}$ water. (10) The well was originally drilled to supply hot water heating for the downtown area but the water temperature was too low and the project was abandoned. There are 114 commercial buildings in Soda Springs and 1190 residential units. (11) Local use of this thermal water would require the use of heat pumps. Travertine deposition is still very active at the well site and pipe scaling is a potential problem. 
Soda Springs, the county seat and commercial nucleus for Caribou County, historically has grown related to expansion in the phosphate industry. Future expansion of the phosphate industry is expected to double the population of the city to over 6,350 people by the year 2000.(11) Expanding residential development at Soda Springs should consider drilling for thermal waters near the large travertine mounds. Deep drilling may prove higher temperature along fault systems associated with the travertine mounds.

Table 3-E is a summary of the site specific data regarding the Conda KGRA and the city of Soda Springs. 
Table 3-E

Data Summary for Conda KGRA and Soda Springs, Idaho

\section{SITE LOCATION AND PHYSICAL DESCRIPTION}

.. Latitude: $42^{\circ} 35^{\prime}$

..Longitude: $111^{\circ} 35^{\prime}$

..Rectilinear: T.85., R.42E., Boise Meridian

- County: Caribou

..Adjacent Counties: Bannock, Bingham, Conneville, Bear Lake

. Topography: Valley floor gently dips to the west. The valley floor has generally mild slopes and elevations of 1800 meters. Surrounding black mountains have steep slopes with elevations of 2700 meters.

..Present Land Use: The major land uses are agriculture in the valley and mining in the mountainous areas. Several areas have extensive strip mines.

..Future Land Use Plans: Continued expansion of strip mining for phosphate area.

..Aesthetics: Because of the area's industrial nature, the strip mining and aesthetic values are moderate.

\section{GEOLOGICAL/GEOPHYSICAL DESCRIPTION}

..Geologic Description:(16) The area is a north-south structural depression, possibly a graben. The area can be divided into three geological realms: Lower Paleozoic marine sedimentary rocks on the western margins of the valley; Upper Paleozoic and Mesozoic sedimentary rocks on the eastern margins of the valley; and Quaternary lava and alluvium in the central portions of the area. Near the center of the Blackfoot Lava field, three prominent volcanic cones, are situated along a northeast linear trend which suggest a fault. The structural framework of the Blackfoot Reservoir area is highly complex. Paleozoic and Mesozoic rocks have been faulted and thrusted into mountain ranges. The southern half of the Blackfoot lava field occupies a graben structure. Major thrust faulting has placed Paleozoic formations up over lower Triassic formations. The trace of the thrust faults trend northwest. Transverse vaults offset mountain blocks along east-west strike-slip faults. High angle normal faulting has created several horst structures. 
GEOLOGICAL/GEOPHYSICAL DESCRIPTION Cont'd

Geothermal springs and travertine cones, and terrace structures cover extensive areas and have a close relationship to faults of the area.

\section{..Geophysical Summary: (6)}

Audio-magnetotelluric work in the Blackfoot lava field area indicates that there is no low resistivity region. This has been interpretated by the FMC Co. As indicating that the warm wells and springs occupy a restricted volume within the upper 2 kilometers of the rock and if any geothermal potential exist it must be deeper than 2 kilometers.

\section{RESERVOIR CHARACTERISTICS}

..Reservoir Temperature (6)

Surface: 230 to $580 \mathrm{C}$.

.Subsurface:

-Geochemical (6)

Si02: 800 to $3600 \mathrm{C}$. depending on assumed quartz equitibrium $\mathrm{Na}-\mathrm{K}-\mathrm{Ca}: 330^{\circ} \mathrm{C}$ to $360^{\circ} \mathrm{C}$.

..Flow Rates: (6) 400 to $5,000 \mathrm{l} / \mathrm{min}$

..pH: $\quad 5.9$ to 6.8

. Total Dissolved Solids:(6) 1,000 to 4,900

..Fluid Chemistry: (6) Corral Creek Well mg/litre

$\begin{array}{llr}\mathrm{SiO}_{2} & : & 28 \\ \mathrm{Ca} & : & 701 \\ \mathrm{Mg} & : & 263 \\ \mathrm{Na} & : & 101 \\ \mathrm{~K} & : & 237 \\ \mathrm{HCO}_{3} & : & 2,845 \\ \mathrm{CO}_{3} & : & 0 \\ \mathrm{SO}_{4} & : & 898 \\ \mathrm{PO} 4 & : & 0 \\ \mathrm{C} 1 & : & 41 \\ \mathrm{~F} & : & 2.3 \\ \mathrm{NO} & : & .16 \\ \mathrm{~B} & : & .52 \\ \mathrm{NH}_{3} & : & 1.2\end{array}$

Specific conductance: 4,519

..Estimated electric Energy Potential: $.50 \mathrm{mw}$ 
Table 3-E Cont'd.

LAND OWNERSHIP AND LEASING

$\begin{array}{lccccc} & \begin{array}{c}\text { TOTAL AREA } \\ \text { (Acres) }\end{array} & \begin{array}{c}\text { FEDERAL } \\ \text { (Acres) }\end{array} & \begin{array}{c}\text { STATE } \\ \text { (Acres) }\end{array} & \begin{array}{c}\text { PRIVATE } \\ \text { (Acres) }\end{array} & \text { OTHER } \\ \text {..Land Ownership } & 1,140,000 & 450,192 & 112,517 & 551,847 & 2,556 \cdot \text { KGRA } \\ \text {..Land Leased } & \text { No geothermat leases, } 350,000 \text { acres of phosphate leases }\end{array}$

..Summary of Leasing Status and Needs:

Conda KGRA designation became effective in August 1978.

No lease sale date has been set.

\section{GEOTHERMAL DEVELOPMENT STATUS}

..Present Development Status:

An explorition well was drilled into a travertine mound in the city of Soda Springs in the 1940's. The well produces a highly carbonated, artesian $30^{\circ} \mathrm{C}$ fluid.

..Projected Development: $50 \mathrm{MW}$ of electrical generation capacity by 2020 .

\section{ENVIRONMENTAL FACTORS}

$$
\text { .. CLIMATE (13) }
$$

..Prevailing Winds: $\mathrm{N}-\mathrm{S}$

..Precipitation (Annual): $\quad \begin{array}{r}460 \mathrm{~cm} \text { Snowfall } \\ 45 \mathrm{~cm} \text { Precipitation }\end{array}$

..Days of Sunshine (Annual): 285

..Average Temperature

$\begin{array}{lll} & \text { January } & \text { July } \\ \text { Minimum: } & -13.60 \mathrm{C} & 70 \mathrm{C} \\ \text { Maximum: } & -1.90 \mathrm{C} & 280 \mathrm{C}\end{array}$

..Degree Days (Annua1): 8,944

..AIR QUALITY: (11) Records show frequent violations of secondary air quality standards and frequent violations of the maximum $24 \mathrm{hr}$. average for particulates. The area has the lowest air quality in the state for particulates but only a few violations of the $24 \mathrm{hr}$. average for sulphur dioxide. 
Table 3-E Cont'd.

ENVIRONMENTAL FACTORS (Cont'd)

..WATER QUALITY:

High fluoride in some ground water.

..NOISE: High noise levels near industrial and mining areas.

...ELEVATION:

1889 meters at Conda KGRA

1800 meters at Soda Springs

..BIOLOGICAL

Endangered Species:

. Fauna:

Northern Rocky Mountain Wolf - Canis Wpis inremotus

American penegrine falcon - Falco perregrinus anaturn

The Whooping Crane - Grus Americana

TRANSPORTATION AND UTILITIES:

..Utility or Energy Transmission Corridors and Facilities:

Natural Gas Pipeline at Soda Springs and,Conda plants.

$138 \mathrm{kv}$ lines at Soda Springs

..Transportation Corridors or Facilities:

Junction of Idaho Highway 30 and 34 at Soda Springs.

State Highway 34 to Conda.

Secondary roads are generaliy gravel and dirt.

Union Pacific Railroad services Soda Springs, the Conda Mine and the FMC Company plant.

POPULATION:

..General Description of Population:

The population of Caribou County is approximately 5,500 with the majority of that population living in Soda Springs (pop. 4,000). Approximately $25 \%$ of the county population lives on farms. Population projections call for an additional 2,000 people to live in Soda Springs by 2000 .

.. Economics:

The economy of the Conda KGRA and Soda Springs Area is dependent on agriculture and phosphate mining and processing. The major employment in the area is related to phosphate extraction and refining. The phosphate industry is expected to grow rapidly between now and 2020. The result will be increased growth and economic stimulation in Caribou County. 
The Pocatello-Chubbuck area is located along the southern margin of the Snake River Plain at the interface between the Snake River Plain and the Basin and Range physiographic provinces. The City of Pocatello and the City of Chubbuck lie in close proximity to one another at the mouth of the Portneuf River Valley.

The Portneuf River Valley is a major north trending structural valley which is truncated by the east-west faults of the Snake River downwarp at Pocate110. The upper stratigraphy of the plain area consist of Pliocene and Pleistocene sediments and Holocene alluvium. The deepest water wells in the Chubbuck area reached a depth of 180 meters and have not penetrated the valley fill. The area is suspected to be underlain by Miocene and Pliocene Basalts.

Thermal wells in the area have temperatures of $20{ }^{\circ} \mathrm{C}$ to $400^{\circ} \mathrm{C}$. Geothermal gradients of thermal wells in the Chubbuck area suggest a temperature of at least $121^{\circ} \mathrm{C}$ at a depth of 760 meters. Geochemical analys is of existing wells show a reservoir temperature of $1150 \mathrm{C}$ (13) and heat flow data indicates that temperatures of $1000^{\circ} \mathrm{C}$ and $2000^{\circ} \mathrm{C}$ can be obtained at depths of 1-2 kilometers and 3-4 kilometers respectively. (14)

Four types of energy soúrces are readily available and currentiy used in Pocatello: electricity, natural gas, 017 and some coal with electricity being the major form of energy consumed. High electrical demand is due to the location of FMC Corporation phosphate reduction plant and the J.R. Simplot Fertilizer plant which use electrical furnaces to refine the ore. The second greatest demand for electrical energy is for irrigation. Irrigation is a priority use and industry is cut back when power shortages occur. The FMC plant ran at 50\% of capacity in the summer of 1977 due to the lack of electricity. (1)

Major natural gas consumers in Pocatello are the J.R. Simplot Company fertilizer plant and residential consumption for spaceheating. Other major natural gas consumers in the area are Lamb-Weston, a potato processing plant in American Falls, and the American Potato Company processing plant in Blackfoot. The Lamb-Weston Company consumes natural gas in excess of $\$ 200,000$ per month in the winter and $75 \%$ that figure in the summer. The American Potato Company consumes natural gas at a rate of $\$ 300,000$ per month during the winter. (15) Both of these plants could use large quantities of geothermal fluids.

The Pocatello-Chubbuck area is an ideal location for locating new industries. The Union Pacific Railroad serves the area with a major east-west line and a major north-south line. Interstate 15 and Interstate $15 \mathrm{~W}$ intersect at Pocatello. The area is the trade center of the region and the center of agriculture. New industries, particularly new food processing facilities, which locate in the Pocatello area, should consider geothermal energy. The geothermal resources need to be proven before industry will consider the geothermal energy option. 
A second major market for geotherma 7 resources is for spaceheating new residential homes. The major population center of Bannock County is the Pocate170-Chubbuck area.

Both communities are expected to double in population by 1990. Table 4-E lists the 20 year population projections for Pocatello and Chubbuck. New subdivisions in the area should consider geothermal spaceheating. 
Table 4-E

POPULATIONS PROJECTIONS (16)

$\begin{array}{ccc}\text { Year } & \frac{\text { Pocate } 110}{1977} & \text { Chubbuck } \\ 1980 & 42,702 & 4,242 \\ 1985 & 56,462 & 5,920 \\ 1990 & 64,566 & 6,920 \\ 1995 & 72,695 & 7,918 \\ 2000 & 80,848 & 9,018 \\ & .89,999 & 10,130\end{array}$

Scenario Projections:

Residential utilization of geothermal energy for space heating in the Pocatel10-Chubbuck area could reach $50 \times 109$ BTU per year by 1985 . Successful development of the first geothermal space heating project could lead to incremental development of geothermal space heating systems at a rate of $50 \times 10^{9}$ BTU every five years until the year 2000. This would closely parallel the predicted population growth for the area.

Industrial utilization of geothermal energy will be closely tied to the expansion of the area's agricultural economy. New food processing plants are expected to be built in Idaho in the future and the Pocatello area is a central location. New industrial plants will most likely be located in the Chubbuck area where there is sufficient available space. Industrial utilization of geothermal energy in the Chubbuck area is projected to reach up to $200 \times 109$ BTU/year by 1990 .

Table 5-E is a summary of site specific data regarding the PocatelloChubbuck geothermal area. 
SITE LOCATION AND PHYSICAL DESCRIPTION

. Latitude: $\quad 42^{\circ} 56^{\prime} 30^{\prime \prime} \mathrm{N}$

..Longitude: $112026^{\prime} 00^{\prime \prime}$

..Rectilinear: T 6 S, R 34 E, Boise Meridian

..County: Bannock

..Adjacent Counties: Power, Oneida, Franklin, Caribou, Bingham

- Topography

The Pocatello-Chubbuck area is a relatively flat area located at the mouth of the Portneuf River Valley. The area is characteristically the flood plain of the Portneuf and Snake Rivers.

.Present Land Use:

The major land uses in the Pocatello area are urban residential and commercial, and industrial areas located west of the city.

The major land uses in the Chubbuck area are agriculture with sugar beets, potatoes and alfalfa being the principal crops.

.Future Land Use Plans:

The City of Chubbuck is rapidly becoming the bedroom community of Pocatel10. Rapid residential development is expected. New food processing industries will most likely be sited in this area due to adequate spaces.

\section{GEOLOGICAL/GEOPHYSICAL DESCRIPTION}

\section{..Geologic: Description: (13) (17)}

The area is generally located along the southern margin of the Snake River Plain. The stratigraphy of the area is dominated by Pliocene and Pliestocene sediments and Holocene alluvium. Fault block mountains to the south of Pocatello are massive Paleozoic marine sediments. The area shows strong structural control. North-south trending faults of the Basin and Range system are truncated by east-west trending faults of the Snake River Plain in the area of Pocatello. The Portneuf River valley is a major north trending structurally controlled valley. The north-south faults of this valley are truncated by east-west faults at Chubbuck. 
Table 5-E Cont'd.

\section{RESERVOIR CHARACTERISTICS}

SITE: Poca tello-Chubbuck

..Reservoir Temperature (13) - We11 at Chubbuck

. Surface: $\quad 40.5^{\circ} \mathrm{C}$.

..Subsurface:

..Geochemical

Si02: $650 \mathrm{C}$

Na-K-Ca: $185^{\circ} \mathrm{C}$

..Flow Rates: $15 \mathrm{gpm}$

..pH: (14) 7.7

..Total Dissolved Solids: (13) 706

..Fluid Chemistry:

$\begin{array}{lcc}\mathrm{Si} & \vdots & 20 \\ \mathrm{Ca} & \vdots & 70 \\ \mathrm{Mg} & \vdots & 25 \\ \mathrm{Na} & \vdots & 150 \\ \mathrm{~K} & \vdots & 21 \\ \mathrm{HCO} & \vdots & 478 \\ \mathrm{CO}_{3} & \vdots & 0 \\ \mathrm{SO}_{4} & \vdots & 95 \\ \mathrm{P} & \vdots & 0 \\ \mathrm{CL} & \vdots & 87 \\ \mathrm{~F} & \vdots & 3.2 \\ \mathrm{NO}_{3} & : & .02\end{array}$

GEOTHERMAL DEVELOPMENT STATUS

..Present Development Status: None

..Projected or Planned Development: (18)

Whitewater Corporation proposes to develop a residential industrial park based on cascading temperatures of geothermal fluids.

Project projections are based on a $120^{\circ}$ to $748^{\circ}$ resource being developed. Currently there is one we 11 which produces $410 \mathrm{C}$ water.

Projected developments include: 350 residential units and 5 acres of commercial units, a feed yard, vitamin and wheat germ plants, potato processing plant, greenhouses, and irrigation projects. 
Table 5-E Cont'd.

INSTITUTIONAL CONSIDERATIONS - Federa1

Institutiona 1

Requirements

Federal Geothermal

Resource Lease

(30 C.F.R. 3000)
Agency and

Public Attitudes

Leases are made pur-

suant to the Geother-

mal Steam Act of 1970

(84 Stat. 1566)

(30 USC 1001-1025)

B.L.M.

U.S.G.S.

An E.I.A. is required before leases are issued.

E.P.A.
Status of Requirements (i.e. EIA/EIS Requirements)

Leases are non-competitive.
National Environmental Policy Act (42-U.S.C. 4331)
Federal Water Pol-

lution Control Act

(33-USCA 1251)

Federal Safe Drinking Water Act

(42 U.S.C. (A) 300)
The national goal of this Act is to attain -0-pollution by 1985. E.P.A.

This Act is concerned with protection of underground water sources that could be used for domestic water.

E.P.A.
A preliminary E.A.R. could be required before exploration drilling. In general an E.I.A. is required for al1 projects involving exploration and development. An E.I.S. will be required for any major action.

Groundwater is included under this act and the reinjection of geothermal effluent will require permits.

The Act sets standards for wells and well drilling and could influence future geothermal wells. The upper aquifer of the basin is the supply of domestic and irrigation water for the area. Reinjection of water for geo. thermal wells will require permits under this Act: 
INSTITUTIONAL CONSIDERATIONS - State

Institutional

Requirements

Geothermal Resource

Permits.

(Idaho Code 42-4001

et.seq. Chapter 40.

Geothermal Resources)

Water Appropriation

(Idaho Code 42-101

et.seq. Chapter 1

Water Appropriation)

Injection wells

(Idaho Code 42-3001

et.seq. Chapter 39

Waste Disposal and

Injection Wells)
Agency and

Public Attitudes

The regulatory powers Any private owner, or holder of of the state Geother- a state or federal lease of geoal Resource Act are placed in the Idaho Department of Water Resources. thermal resources must first apply for a geothermal resource permit from I.D.W.R. before any drilling operations can begin.

The Idaho Department Under the Idaho Geothermal Reof Water Resources issues water appropriation permits and a water right license. sources Act, applicants can be required to make an application to appropriate the public waters of the state.

Permits are issued by No waste disposal or injection the Department of Water Resources. well can be constructed in Idaho unless a permit has been issued by I.D.W.R. The approval of this permit is contingent upon the approval of the Department of Health and Welfare. The proposed well is reviewed to see if it will unreasonably contaminate or deteriorate the quality of the groundwater below the adopted water quality standards of the state. 
Table 5-E Cont'd.

INSTITUTIONAL CONSIDERATIONS - LOCA 1

Institutional

Requirements

Comprehensive

Plan

Subdivision and Zoning Ordinances Building Codes
Agency and

Public Attitudes

Bannock County

Planning and Zoning

Commission

Pocatello

Planning \& Zoning

Commission

Bannock County

Planning and Zoning Commission

Pocatel10 Planning \& Zoning Commission

Chubbuck Planning \&

Zoning Commission
Special use permits for non-

conforming uses

Permits are needed to develop subdivisions and non-conforming structures in zoned areas. Building permits are needed and buildings must be built to code.
Status of Requirements
(i.e. EIA/EIS Requirements)

\section{)}


Table 5-E Cont'd.

ENVIRONMENTAL FACTORS:

..CLIMATE (12)

..Prevailing Winds: E-W $10-20 \mathrm{mph}$

gusts up to $50 \mathrm{mph}$

..Precipitation (Annual): $91 \mathrm{~cm}$ Snowfall

$26 \mathrm{~cm}$ Precipitation

..Days of Sunshine (Annua 1): 300

..Average Temperature January July

Minimum: $\quad-10^{\circ} \mathrm{C} \quad 12.6^{\circ} \mathrm{C}$

Maximum: $\quad 0^{\circ} \mathrm{C} \quad 31.6^{\circ} \mathrm{C}$

..Degree Days (Annual): 6993

..AIR QUALITY: Air quality is generally moderate to good with occasional poor days depending on weather inversions. The major pollutants are particulates and soy.

..NOISE: High levels of noise are associated with the industrial areas, airport and freeways.

TRANSPORTATION AND UTILITIES:

..Utility or Energy Transmission Corridors and Facilities:

Chevron 8 petroleum pipeline at Pocatello

El Paso Natural Gas Pipline at Pocatello

$138 \mathrm{kv}$ lines Idaho Power Co. at Pocatello

$138 \mathrm{kV}$ lines Utah Power and Light at Pocate110

..Transportation Corridors or Facilities:

U.S. Interstate 15 at Pocatello

U.S. 30 at Pocatel 10

U.S. 91 at Chubbuck

Union Pacific Railroad east-west lines and north-south lines at Pocatello. 
Table 5-E Cont'd.

POPULATION:

..General Description of Population

The Pocate110-Chubbuck area has an approximate population of 45,000 with 41,000 residing in Pocatel10. The major employment is in the industrial sector. Present growth rates for the two cities are: Pocate $1102.4 \%$ per year, Chubbuck $40.0 \%$ per year.

The urban population is concentrated in 1 i 7,000 acre area at the mouth of the Portneuf River Valley. The surrounding areas are largely agricultural lands.

An estimated 10,000 additional people live outside of the City of Pocatel10.

..Economics

There are 1,210 business establishments in Bannock County, the majority of these businesses are located in Pocatel10. The median family income is $\$ 12,875$. The unemployment rate is $4.9 \%$ Pocatello is a rapidly growing community. Much of this growth can be attributed to the location of phosphate and other industrial facilities in the area. In addition to the large industrial base, Pocatello is the home of Idaho State University. ISU is the second largest college in the State with an enrollment of 7,000 students.

As a result of this new growth, housing starts have shown marked increase in the Pocatello and Chubbuck areas. 
Lava Hot Springs is located along the Portneuf River in central Bannock County, a smal1 resort community of 700 people, Lava Hot Springs has a long history of geothermal water production and use. The geothermal resources of the area have been utilized for space heating, health and recreation for decades.

The historic use of the thermal water dates back to early historical times when the Indian tribes of the region used the site for bathing and cleaning of hides. Lava Hot Springs became a rest stop along the Oregon Trail. The area began to grow rapidly. When the Oregon Short Line Railway extended its mainline through Lava Hot Springs at the turn of the century. By 1925 the area supported a smal1 resort community. In 1935, the State of Idaho created the Lava Hot Springs Foundation. The purpose of the Foundation was to provide health and recreation facilities for the public. The Foundation has provided these services for over 45 years. The Foundation is self-supporting and relies on revenue generated from its recreational facilities. (19) The Foundation is the major industry of the community and the supportative services of the community are relevant to the tourist trade of the spas.

Geologically, the Lava Hot Springs area is a complicated stratigraphic and structural location. Units representing Cambrian through Pennsylvanian systems are present in the area. Most of these rocks are carbonites. A major uncomformity exists between the upper Paleozoic units and Tertiary units of the area with Pliocene units consisting of sedimentary and volcanic breccias, tuffs, ash, and lava flows. Most of the Portneuf River valley is underlain by the intervalley Pleistocene basalt flow. (17)

In the City of Lava Hot Springs, two major fault linears intersect. The Lava Hot Springs fault is a major north-south trending linear that is typical of the Basin and Range province. Vertical displacement along this fault is 600 meters. A second fault cuts east-west through the Lava Hot Springs area offsetting the Lava Hot Springs fault, to the east, one hundred meters.

It is at the intersection of these two faults that the thermal waters of the area are venting. The relationship of the thermal waters to the thrust plain of the region is unclear.

The hot water of the Lava Hot Springs area range in temperature from $210 \mathrm{C}$ to $60^{\circ} \mathrm{C} .(17)$ The major springs feeding the Foundation Spa are $430 \mathrm{C}$. These thermal waters are most logically associated with deeper sources circulating up through the Paleozoic units along the fault intersection. Most of the thermal springs and wells in the area occur from the basaltic rocks which underlie the Portneuf River Valley. Several shallow wells have been dug with backhoes to depths of less than 6 meters. Hot fluids are intersected along the bottom contact of the basalts. This indicates that thermal water is rising along the fault zones and spreading horizontally along the basalt contact. Some hotels in Lava Hot Springs use these shallow thermal wells for hot baths and heating.

There is a considerable amount of local interest in developing a system for the use of geothermal energy for light industry and home heating. 
Because Lava Hot Springs is primarily a recreation oriented cormunity, its population and economic year fluctuate greatly during the winter and summer. With such a seasonal economy, Lava Hot Springs has experienced considerable problems in maintaining a stable economic and community environment. It is the hope of the community that development of light industries which could use the thermal water will help stabilize the economy and provide employment opportunities that are less affected by seasonal fluctuations. Light industries being considered by the Foundation are greenhouses, mushroom growing, and livestock raising.

There are over 50 businesses in Lava Hot Springs and approximately 500 homes. The business district is highly concentrated around the Foundation's facilities and is the best target for a spaceheating district. A survey of commercial buildings in Lava Hot Springs indicates that the spaceheating energy demand of the business district could be satisfied with a geothermal district heating system. See table 6-E for a list of buildings and their energy demand. The estimated energy load of such a system would be approximately $25 \times 10^{9}$ BTU/year. Provided adequate funding could be obtained by the community, a district geothermal space heating system could be operational by 1985 .

In the short term, the Lava Hot Springs Foundation could convert its small swimming pool from a natural gas boiler to a geothermal heat exchanger. The conversion cost for the swimming pool is estimated to range from $\$ 7,000$ to $\$ 10,000$. Considering the present annual cost of operating the boiler exceeds $\$ 10,000$, and considering the present rate of natural gas inflation in Lava Hot Springs exceeds $11 \%$, the conversion of the smal1 pool could be paid back in one year of operation. Table 7-E lists the annual savings the Foundation could receive over a five year period from converting the small pool to geothermal energy. A range of annual savings are forecasted to account for variation in predicted natural gas cost under two price inflation scenarios.

Table 8-E is a summary of the site specific data regarding the Lava Hot Springs geothermal area. 
Table 6-E

Survey of Utility Use in the Central Business District Lava Hot Springs, Idaho

\begin{tabular}{|c|c|c|c|c|c|c|}
\hline Building & $\begin{array}{l}\text { Type of } \\
\text { Heating }\end{array}$ & $\begin{array}{l}\text { Building } \\
\text { Sq. Ft. }\end{array}$ & $\begin{array}{r}\text { (Ave } \\
\text { Gas } \\
\end{array}$ & erage & $\begin{array}{r}\text { Monthiy } \\
\text { Ele }\end{array}$ & $\begin{array}{l}\text { Cost) } \\
\text { ectric }\end{array}$ \\
\hline Foster Hardware & Gas & 2,700 & $\$$ & 60 & $\$$ & 25 \\
\hline Portneuf Building & Steam & 3,500 & & 200 & & 100 \\
\hline Laundromat & Steam & 1,800 & & 300 & & 70 \\
\hline Library & Gas & 800 & & 30 & & 20 \\
\hline Senior Citizens Center & Gas & 1,000 & & 62 & & 25 \\
\hline Kingston's House of Style & Gas & 1,000 & & 50 & & 30 \\
\hline Lava Real Estate & Gas & 3,200 & & 85 & & 35 \\
\hline *Gates IGA & Gas & 2,700 & & 75 & & 350 \\
\hline Bocek Garage \& Apts. & Gas & 5,400 & & 350 & & 150 \\
\hline Berti's Market & Gas & 7,500 & & 29 & 1, &, 000 \\
\hline Lava Ambulance Service & Electric & 960 & & & & 60 \\
\hline Village Auto Parts & Gas & 1,800 & & 00 & & 55 \\
\hline Guys 'n Gals & Gas & 2,000 & & 40 & & 60 \\
\hline Chuck Wagon Cafe & Gas & 2,400 & & 130 & & 440 \\
\hline Tumbling Waters Motel & Gas & 3,500 & & 90 & & 66 \\
\hline Lava Spa Motel & Electric & 7,000 & & 300 & & 128 \\
\hline KOA Campground & Gas & 3,000 & & 50 & & 400 \\
\hline Harvey's Amoco & $0 i 1$ & 400 & & 50 & & 160 \\
\hline Lava Hot Springs Foundation & \multicolumn{2}{|c|}{$\begin{array}{l}\text { Forced air } 5 \text { bldgs. } \\
\text { ft. not available) }\end{array}$} & 1,50 & 500 & &, 000 \\
\hline *Home Hotel \& Motel & \multicolumn{2}{|l|}{ Hot Water } & & ne & & 15 \\
\hline
\end{tabular}

*Using thermal water from shallow well to heat hotel and cabins. 
Table 6-E Cont'd.

Building

Hot Springs Village

Condominiums

Riverside Inn

Lava Motel Apartments

Wagon Whee 1 Lounge

Bank of Idaho

Silver Grill Restaurant

Idaho Liquor Store

Wild Hair Salon

Lava Drug

U.S. Post Office

Utah Power \& Light

B \& B Texaco Service

Lava Service

Friede]'s

Lava Lounge \& Restaurant

Hillcrest Apartments

Lava Elementary School
Type of

Heating

Gas

14,768

Coal

Gas

Gas

Gas

Gas

Gas

Gas

Gas

Gas

$0 i 1$

Gas

Gas

Gas

Gas

Coal \& Gas

Gas

3,500

4,000

4,500

3,000

900

900

1,800

1,500

1,800

1,800

2,500

2,900

6,600
Building

Sq. Ft.

Gas

$\$ 2,080$

$\$ 1,120$

\section{0}

150

60

60

200

70

385

122

50

291

25

50

25

75

50

30

39

75

125

40

40

35

74

60

70

400

350

174

50

200

Note: In addition to the above businesses 1 isted, there are three churches and five businesses on whom statistics were not available because of various reasons including; manager out of town, did not wish to participate in survey, or business too new to have adequate records. These include:

Lava LDS Church Lava Community Church Lava Catholic Church
Mountain View Trailer Court

Lindsey's Water Conditioning Larene's Pizza House

Marvel Apartments 


$$
\text { Table 7-E }
$$

- Lava Hot Sprịngs Foundation

5 Year Economic Analysis for Geothermal Conversion of Small Swimming Pool

\begin{tabular}{|c|c|c|c|c|}
\hline Year & $\begin{array}{l}\text { Natural Gas } \\
11.2 \% \text { Inflation } \\
\end{array}$ & $\begin{array}{c}\text { Present Worth } \\
9 \% \\
\end{array}$ & $\begin{array}{l}\text { Natural Gas } \\
17 \% \text { Inflation }\end{array}$ & $\begin{array}{c}\text { Present Worth } \\
9 \% \\
\end{array}$ \\
\hline 1979 & $10,408.32$ & $9,548.92$ & $10,951.20$ & $10,046.97$ \\
\hline 1980 & $11,574.05$ & $9,741.65$ & $12,812.90$ & $10,784.36$ \\
\hline 1981 & $12,870.35$ & $9,938.27$ & $14,991.10$ & $11,575.88$ \\
\hline 1982 & $14,311.82$ & $10,138.86$ & $17,539.58$ & $12,425.48$ \\
\hline 1983 & $15,914.75$ & $10,343.49$ & $20,521.31$ & $13,337.45$ \\
\hline & & TOTAL & & TOTAL \\
\hline & & $49,711.19$ & & $58,170.14$ \\
\hline
\end{tabular}

Source: Chuck Higbee, Geo-Heat Utilization Center, Oregon Institute of Technology 
Data Summary for Lava Hot Springs, Idaho

\section{SITE LOCATION AND PHYSICAL DESCRIPTION}

..Latitude: $\quad 42^{\circ} 34^{\prime} 50^{\prime \prime}$

..Longitude: $112000^{\prime} 00^{\prime \prime}$

..Rectilinear: T 9 S, R 38 E, Boise Meridian

..County: Bannock

..Adjacent Counties: Power, Oneida, Franklin, Caribou, Bingham

.. Topography: Lava Hot Springs is located in the narrow river gorge formed by the Portneuf River. The community fills the entire valley which slopes moderately to the west. Fault block mountains which form the valley walls rise abruptly with steep slopes. The elevation of Lava Hot Springs is 1,667 meters and peaks of the area have elevations of 2,970 meters.

..Present Land Use: The major non-urban land uses in the Lava Hot Springs area are agricultural, primarily grazing and winter wheat.

..Future Land Use Plans: Rapid residential expansion is expected for Lava Hot Springs. This growth will be a result of better access to the area due to the new highway between Lava Hot Springs and Soda Springs, 40 kilometers to the west.

..Aesthetics: The Lava Hot Springs area and the Portneuf River Valley are known for their high recreational value.

..Historical/Archaeological Significance:

The Lava Hot Springs area is a historical Indian camp ground and a major stop along the Oregon Trail. 
GEOLOGICAL/GEOPHYSICAL DESCRIPTION

..Geologic Description (17)

Precambrian and Lower Cambrian Bingham Quartzite forms the lower units of the stratigraphic section. These rocks have no porosity or permeability except where fractured. Units representing Cambrian through Pennsylvanian systems are present in the area. Most of these rocks are carbonates. The Paleozoic units may be of sufficient local porosity to act as local reservoirs for fluids. Tertiary rocks present in the area are Pliocene volcanics. These materials are generally valley filling materials which have been deeply eroded by the Portneuf River. Pleistocene Lava flows underlie the Portneuf River in the Lava Hot Springs area and fill valleys to the east.

Late Cretaceous thrust faulting has displaced the Precambrian and Paleozoic units considerable distance eastward. Late Miocene and Pliocene Normal, high angle faulting has broken the area into a series of blocks. The high angle faulting probably to a large extent controls the locations of thermal springs. East-west trending strike-slip faults have offset these blocks several hundred meters. Lava Hot Springs is venting from the fault zone. At the intersection of a major north-south high angle fault and a east-west trending strike-slip fault that off-sets the Lava Hot Springs fault eastward about 1500 meters.

..Geophysical Summary: (17)

Microseismic survey of the Portneuf Valley detect significant microseismic activity.

..Geologic Hazards:

In 1960 the City of Lava Hot Springs was badly damaged by flooding of the Portneuf River. 
Table 8-E Cont'd.

RESERVOIR CHARACTERISTICS

. Reservoir Temperature

(13)

..Surface: $\quad 430 \mathrm{C}$

..Subsurface: $80^{\circ} \mathrm{C}$

..Geochemical (13)

$\mathrm{SiO}_{2}: \quad 80^{\circ} \mathrm{C}$

$\mathrm{Na}-\mathrm{K}-\mathrm{Ca}: \quad 210^{\circ} \mathrm{C}$

..Flow Rates: $100-90 \mathrm{~m}$

..pH: $\quad 6.6$

..Total Dissolved Solids:(13) 430

..Fluid Chemistry:

\begin{tabular}{llc}
$\mathrm{Si}$ & $:$ & 32 \\
$\mathrm{Ca}$ & $:$ & 120 \\
$\mathrm{Mg}$ & $:$ & 32 \\
$\mathrm{Na}$ & $\vdots$ & 170 \\
$\mathrm{~K}$ & $\vdots$ & 39 \\
$\mathrm{HCO}$ & $:$ & 542 \\
$\mathrm{CO}_{3}$ & $:$ & 0 \\
$\mathrm{~S} 05$ & $\vdots$ & 110 \\
$\mathrm{P}$ & $\vdots$ & \multicolumn{2}{c}{.04} \\
$\mathrm{C} 1$ & $:$ & 180 \\
$\mathrm{~F}$ & $:$ & \multicolumn{2}{c}{.7} \\
$\mathrm{NO}_{3}$ & $:$ & .38
\end{tabular}

\section{GEOTHERMAL DEVELOPMENT STATUS}

..Present Development Status:

Several hotels in Lava Hot Springs use the thermal water for hot baths and space heating. The Lava Hot Springs Foundation utilizes the thermal water in three large hot pools and an 01ympic size swimming pool.

..Projected or Planned Development:

1) Development of a district space heating system for the downtown area by 1985 .

2) Development of secondary industry which will utilize the hot water, such as a mushroom farm, greenhouses, and livestock and poultry raising. 
Table 8-E Cont'd.

INSTITUTIONAL CONSIDERATIONS - Federa 1

Institutional

Requirements

National Environmental

Policy Act

(42-U.S.C. 4331)

Federal Water Pollu-

tion Control Act

(33-USCA 1251)

Federal Safe Drinking

Water Act

(42 U.S.C. (A) 300)
Agency and Public Attitudes

E.P.A.

The national goal of this Act is to attain -0- pollution by 1985 .

E.P.A.
Status of Requirements (i.e., EIA/EIS Requirements)

A preliminary E.A.R. has been completed for the exploration drilling project. In general an E.I.A. is required for all projects involving exploration and development. An E.I.S. could be required for any major action.

Groundwater is included under this Act and the reinjection of geothermal effluent will require permits.
This Act is concern- The Act sets standards for wells ed with protection of underground water sources that could be used for domestic water.

E.P.A. and well drilling and could influence future geothermal wells. The aquifer of the basin is the supply of domestic and. irrigation water for the area. Reinjection of water for geothermal wells will require permits under this Act. 
INSTITUTIONAL CONSIDERATIONS - State

Institutional

Requirements

Leases on State lands

(Idaho Code 47-601

et. seq. Chapter 16, Geothermal Resources)

Geotherma1 Resource

Permits.

(Idaho Code 42-4001

et.seq. Chapter 40, Geothermal Resources)

Water Appropriation (Idaho Code 42-101 et.seq. Chapter 1 Water Appropriation)

Injection wells (Idaho Code 42-3001 et. seq. Chapter 39 Waste Disposal and Injection We11s)
Agency and

Public Attitudes

The state Board of Land Commissioners is authorized to issue leases for geothermal resources underlying states \& school lands.

The regulatory powers of the state Geothermal Resource Act are placed in the Idaho Department of Water Resources.

The Idaho Department of Water Resources issues water appropriation permits and a water right license.

Permits are issued by the Department of Water Resources.
Status of Requirements (i.e., EIA/EIS Requirements)

Lease term is 10 years and can be continued with di]igent development. Rentals are set by the Board. Several leases have been granted on state lands. Lease size is 7 imited to a maximum of 640 acres/lease.

Any private owner, or holder of a state or federal lease of geothermal resources must first apply for a geothermal resource permit from I.D.W.R. before any drilling operations can begin.

Under the Idaho Geothermal Resources Act, applicants can be required to make an application to appropriate the public waters of the state.

No waste disposal or injection well can be constructed in Idaho unless a permit has been issued by I.D.W.R. The approval of this permit is contingent upon the approval of the Department of Health and Welfare. The proposed well is reviewed to see if it will unreasonably contaminate or deteriorate the quality of the groundwater below the adopted water quality standards of the state. 
Table 8-E Cont'd

INSTITUTIONAL CONSIDERATIONS - LOCa 1

Institutiona 1

Requirements

County Plan

City of Lava

Hot Springs
Agency and

Public Attitudes

Bannock County

Planning Commission

City Planning

Commission
Status of Requirements

(i.e., EIA/EIS Requirements)

Regional Plan for county zoning ordinance, has a subdivision ordinance, and a building code.

Zoning Ordinance, Subdivision Ordinance, Building Code. 
Table 8-E Cont'd.

\section{ENVIRONMENTAL FACTORS}

..Climate (12)

..Prevailing Winds: E-W $10-20 \mathrm{mph}$

.Precipitation (Annua 1): $34.6 \mathrm{~cm}$

..Days of Sunshine (Annual): 300

.. Average Temperature

$\begin{array}{lrc} & \text { January } & \text { July } \\ \text { Minimum: } & -0.8^{\circ} \mathrm{C} & 9.38^{\circ} \mathrm{C} \\ \text { Maximum: } & 3.4^{\circ} \mathrm{C} & 31.8^{\circ} \mathrm{C}\end{array}$

..Degree Days (Annual): 7180

..Relative Humidity (Seasonal Peaks)

Summer: 30

Winter: 70

..Air Quality:

Generally good air quality is due to a lack of industry in area. Particulate matter that does exist comes from farming and natural causes.

..Geologic Factors:

Area is subject to periodic flooding.

..Water Quality:

Water quality is generally good. Thermal wells and springs have high particulate and TDS counts.

..Noise:

Low 
ENVIRONMENTAL FACTORS (Cont'd.)

..Biological:

..Dominant Flora: Sagebrush - grass juniper ecosystem with pine in the mountainous areas.

..Dominant Fauna: Mule deer, coyote, and game birds

TRANSPORTATION AND UTILITIES:

..Utility or Energy Transmission Corridors and Facilities

A major natural gas pipeline services Lava Hot Springs.

A $138 \mathrm{kv}$ line services Lava Hot Springs

..Transportation Corridors or Facilities

The Union Pacific Railroad main line services Lava Hot Springs.

Interstate 15 is located 16 kilometers west of Lava Hot Springs.

Idaho Highway 30 is the main access route to Lava Hot Springs.

POPULATION

..General Description of Population (16)

Major population centers are: McCammon, population 800, located 17.6

kilometers west of Lava Hot Springs; Soda Springs, population 3,775, located 44 kilometers east of Lava Hot Springs; and Pocatello, population 40,980 , located 56 kilometers north of Lava Hot Springs.

Lava Hot Springs has a population of approximately 700 people, a $15 \%$ growth rate in the last 10 years, and a large seasonal population associa- . ted with the summer spa season. The population of the area is principally composed of ranchers, farmers and retired people.

... Economics

The local economy is dependent on recreation and cattle grazing. The major industry in the area is the Lava Hot Springs Foundation. Over 250,000 tourists utilize the Foundation's facilities each year. The community is primarily composed of secondary service facilities which are aimed at this tourist trade. The economy is geared heavily toward the summer months. 
CACHE VALLEY SUB-AREA

Cache Valley is a north-south trending graben structure which lies astride the Idaho-Utah border in Southeastern Idaho. The Valley is a low, flat plain, 40 by 4 kilometers in area, which lies within the Great Basin Physiographic Province and the Great Salt Lake Basin.

The surrounding mountain ranges are massive upthrown fault blocks composed of rock masses of Paleozoic through Cenozoic age. The downthrown blocks of the graben strycture have been buried by Cenozoic rocks and unconsolidated alluvium. (21)

Thermal springs and wells are scattered throughout the Valley. The springs in the area appear to be fault related. Thermal wells penetrate only alluvial deposits. Measured surface temperatures increase from $35^{\circ} \mathrm{C}$ in the north to $84^{\circ} \mathrm{C}$ in the south part of the Valley. Geochemical thermometers indicate reservoir temperatures ranging from $1000^{\circ} \mathrm{C}$ to $2500^{\circ} \mathrm{C}$ are 1 ikely to be found in the area. (21) Geochemical data and surface temperatures indicate that the hottest waters are found 3 to 4 kilometers north of the town of Preston.

The Bear River enters the northeastern part of Cache Valley and meanders through a wide flood plain on the Valley floor. This area supports a vigorous agricultural industry. The principal crops are sugar beets, corn, potatoes, grain, and alfalfa. The area also raises livestock and poultry, and produces dairy products.

The population of Franklin County is approximately 8,200 with the largely rural population living in small towns and on farms. The major population center is Preston, population 3,600. The area has adequate roads and excellent railroad service. The high temperatures indicated by geochemical analysis are sufficient for several industrial applications including electric power production. The development of these fluids could lead to the location of major food processing facilities in the Cache Valley. Sun $0 i 1$ Company is currently exploring for high temperature fluids just north of Preston. 
Table 9-E

Data Summary for Cache Valley, Idaho

SITE LOCATION AND PHYSICAL DESCRIPTION

..Latitude: $42005^{\prime} \mathrm{N}$

..Longitude: $111^{\circ} 58^{\prime} \mathrm{W}$

..Rectilinear: $T$ 15, $16 \mathrm{~S}, \mathrm{R} 39,4 \mathrm{E}$. , Boise Meridian

..County: Franklin

..Adjacent Counties: Gear Lake, Caribou, Bannock, Oneida

. Topography: The Cache Valley is relatively flat lake bottom into which the Bear River has cut a gentle stream valley and flood plain.

..Present Land Use: The major land use in the area is devoted primarily to agricul ture.

..Future Land Use Plans: Continuation of present land use.

..Aesthetics: The area is a typical agricultural area in the Great Salt Lake Basin. Moderate to high aesthetic values.

GEOLOGICAL/GEOPHYSICAL DESCRIPTION

- Geologic Description: (21)

The Cache Valley is a complexly faulted graben structure.

Upthrown tilted fault blocks are composed of Precambrian through

Cenozoic rocks. Downthrown fault blocks have been buried by a thick

sequence of Cenozoic rocks and unconsolidate alluvium. In general, two sets of faults are evident. One set trends northeast and the other northwest. The northeast trending faults are associated with the major movements associated with the Basin and Range province. The northwest faults appear to be strike-slip, transverse faults. Thermal springs in the area are closely related to fault traces.

..Geophysical Summary: (21)

A gravity survey conducted in the Cache Valley indicates a gravity low near Preston which indicated a thickness of Cenozoic fill of about 5,500 feet $(1,700$ meters $)$. 
Table 9-E Cont'd.

\section{RESERVOIR CHARACTERISTICS}

. Reservoir Temperature

. Surface: $35^{\circ}$ to $84^{\circ} \mathrm{C}$

.. Subsurface:

..Geochemical

$\mathrm{SiO}_{2}$ : $100^{\circ}$ to $200^{\circ} \mathrm{C}$ depending on assumed quartz equilibrium $\mathrm{Na}-\mathrm{K}-\mathrm{Ca}: \quad 255^{\circ} \mathrm{C}$

..Flow Rates: (13) 10 to $450 \mathrm{l} / \mathrm{min}$

..pH: 6.6 to 6.9

..Total Dissolved Solids: 1000 to $10,000 \mathrm{ppm}$

..Fluid Chemistry:
Si : 109
$\mathrm{Ca}: 174$
$\mathrm{Mg}: 19$
$\mathrm{Na}: 3,161$
$\mathrm{K}: 552$
$\mathrm{HCO}_{3}: 696$
$\mathrm{CO}_{3}: 0$
$\mathrm{SO}_{4}: 35$
$\mathrm{PO}_{4}: \quad .01$
$\mathrm{Cl}^{4}: 5,241$
$\mathrm{F}: 6.0$
$\mathrm{NO}_{3}: \quad .06$
$\mathrm{B}: 3.5$
$\mathrm{NH}_{3}: 7.6$

\section{GEOTHERMAL DEVELOPMENT STATUS}

..Present Development Status: None

..Projected or Planned Development:

Exploration drilling for high temperature geothermal fluids and $0 i 1$ and gas. 
INSTITUTIONAL CONSIDERATIONS - Federal

Institutional

Requirements

Federal Geothermal

Resource Lease

(30 C.F.R. 3000)
Agency and

Public Attitudes

Leases are made pur-

suant to the Geothermal

Steam Act of 1979.

(84 Stat. 1566)

(30 USC 1001-1025)

B.L.M. U.S.G.S.

An E.I.A. is required before leases are issued.

E.P.A.

The national goal of this Act is to attain -0 - pollution by 1885. E.P.A.

Federal Safe Drinking Water Act

(42 U.S.C. (A) 300 )

Federal Water Pollution Control Act (33-USCA 1251)
This Act is concerned with protection of underground water sources that could be used for domestic water. E.P.A.
Status of Requirements (i.e., EIA/EIS Requirements)

Leases are non-competitive. Special conditions are required in the leases with regard to potential archaelogical and historical sites, adjacent roadless areas, and critical habitat areas.

A preliminary E.A.R. could be required before leasing. In general an E.I.A. is required for all projects involving exploration and development. An E.I.S. wi 71 be required for any major action.

Groundwater is included under this Act and the reinjection of geothermal effluent will require permits.

The Act sets standards for wells and well drilling and could influence future geothermal wells. The upper aquifer of the basin supplies domestic and irrigation water for the area. Reinjection of water for geothermal wells will require permits under this Act. 
INSTITUTIONAL CONSIDERATIONS - State

Institutional

Requirements

Leases on State lands

(Idaho Code 47-601

et.seq. Chapter 16,

Geothermal Resources

Geotherma 1 Resource

Permits.

(Idaho Code 42-4001

et.seq. Chapter 40 ,

Geotherma 1 Resources)

Water Appropriation

(Idaho Code 42-101

et.seq. Chapter 1

Water Appropriation)

Injection wells

(Idaho Code 42-3001

et.seq. Chapter 39

Waste Disposal and

Injection Wells)
Agency and

Public Attitudes

The State Board of Land Lease term is 10 years and can

Commissioners is author-be continued with diligent ized to issue leases for geothermal resources underlying state and school lands.

The regulatory powers of the State Geothermal Resource Act are placed in the Idaho Department of Water 'Resources.

The Idaho Department of Water Resources issues water appropriation permits and a water right license.

Permits are issued by the Department of Water Resources.
Status of Requirements (i.e., EIA/EIS Requirements) development. Rentals are set by the Board. Several leases have been granted on state lands. Lease size is limited to a maximum of 640 acres/7ease.

Any private owner, or holder of a state or federal lease of geotherma 1 resources must first apply for a geothermal resource permit from I.D.W.R. before any drilling operations can begin.

Under the Idaho Geothermal Resources Act, applicants can be required to make an application to appropriate the public waters of the state.

No waste disposal or injection well can be constructed in in Idaho unless a permit has been issued by I.D.W.R. The approval of this permit is contingent upon the approval of the Department of Health and Welfare. The proposed well is reviewed to see if it will unreasonably contaminate or deteriorate the quality of the groundwater below the adopted water quality standards of the state. 
INSTITUTIONAL CONSIDERATIONS - LOCa 1

Institutional

Requirements

Comprehensive

Plan

Zoning Ordinance Subdivision Ordinance
Agency and

Public Attitudes

Franklin County

Planning and

Zoning Commission.

Preston

Planning and

Zoning Commission
Status of Requirements (i.e., EIA/EIS Requirements)

Issues special use permits for non-conforming uses.

Issues special use and subdivision permits within 5 kilometers of the city limits. 


\section{ENVIRONMENTAL FACTORS}

\section{.. CLIMATE (12)}

..Prevailing Winds: From the south, gusting up to $60 \mathrm{mph}$

..Precipitation (Annual): $142 \mathrm{~cm}$ snow, $38 \mathrm{~cm}$ precipitation

..Days of sunshine (annual): 290

..Average Temperature

$\begin{array}{lcc} & \text { January } & \text { JuTy } \\ \text { Minimum: } & -11.5^{\circ} \mathrm{C} & 10.27^{\circ} \mathrm{C} \\ \text { Maximum: } & 0^{\circ} \mathrm{C} & 32.3^{\circ} \mathrm{C}\end{array}$

..Degree Days (Annual): 7075

..Relative Humidity (Seasonal Peaks)

Summer:

Winter:

..AIR QUALITY: High

..GEOLOGIC FACTORS: Blowing dust

..WATER QUALITY: Deep wells can have salinity problems.

..NOISE: LOW noise levels

..ELEVATION: 1467 meters.

\section{TRANSPORTATION AND UTILITIES}

..Utility or Energy Transmission Corridors and Facilities

A $138 \mathrm{kv}$ line is located 20 kilometers north of Preston and owned by Idaho Power Co. and Utah Power and Light.

..Transportation Corridors or Facilities

U.S. Highway 91 at Preston

State Highway 34 at Preston

Union Pacific Railroad at Preston

POPULATION

..General Description of Population

Population of Franklin County is 8,200. Population change from 1970 to 1976 is $16.5 \%$; population per square mile 12.3 .

Population is $44 \%$ urban, $21.5 \%$ rural non-farm, and $34 \%$ rural farm.

Total housing units: 2,465

Major population center: Preston (population 3,600)

.. Economics

The major economic activities are agricultural and major agricultural activities are cattle and hog raising. Major crops are sugar beets, alfalfa and wheat. 
1) U.S. Dept. of Interior, Final Environmental Impact Statement, Vol. 1, Development of Phosphate Resources in Southeastern Idaho, U.S. Geological Survey, April 1976.

2) Ornum, Joel Van, Industrial Waste Heat for Adjacent Communities and Industrial Applications, Rocket Research Co., Report RRC-78-H-181, Pacific Northwest Regional Commission, Dec. 1977. pp. 29-50.

3) U.S. Dept. of Interior, op. cit. p. 332.

4) Ornum, Joel Van, op. cit. p. 29

5) Memorandum: To State Director Idaho BLM, Boise, Idaho; From Conservation Manager, Western Region U.S.G.S.; Subject: Definition and Description of Conda KGRA, Aug. 18, 1978.

6) Mitche11, John C., Geothermal Investigations in Idaho, Part 6, "Geochemistry and Geological Setting of the Thermal and Mineral Waters of the Blackfoot Reservoir Area, Caribou County, Idaho," Idaho Department of Water Resources Water Inf. Bul1. 30, August 1976. 24 p.

7) Armstrong, F. C., and Cressman, E.R., The Bannock Thrust Zone, Southeastern Idaho, U.S. Geol. Survey Prof. Paper 374-J, 1963, p. 22.

8) Mitche11, John C., op. cit. p. 11.

9) Ibid.

10) Mitche11, J. C., Personal communications, JuTy, 1978.

11) Caribou County Comprehensive Land Use Plan 1977, pp. 141-180.

12) N.0.A.A., Climatological Data, Idaho, U.S. Dept. of Commerce, 1978.

13) Young, H.W. and Mitche11, J.C., Geothermal Investigations in Idaho, Part 1, "Geochemistry and Geological Setting of Selected Therma 1 Water," Idaho Dept. of Water Resources Inf. Bu11. 30, 1973.

14) Brott, C.A., Blackwel1, D.D. and Mitchell, J.C., Geothermal Investigations in Idaho, Part 8, "Heat Flow Studies of the Snake River Plain, Idaho;" Idaho Dept. of Water Resources Inf. Bu11. 30, 1976.

15) Idaho Office of Energy Natural Gas Data, Chubbuck Geothermal File, 1977.

16) Idaho Division of Budget, Policy Planning and Coordination, County Profiles of Idaho 1978, State of Idaho. 


\section{REFERENCES}

17) Corey, Lee. Edt., Portneuf Valley Energy Resource Assessment, Idaho State University, Energy Experiment Station Report \#103, Dec. 1976.

18) Forsgren, Klane F., personal communications, March, 1978.

19) Keller, Karen, Director Lava Hot Springs Foundation, personal communications, August 1978.

20) Byington, Mig, Councilwoman, Lava Hot Springs personal communications, June, 1978.

21) Mitche11, John C., Geothermal Investigations in Idaho, Part 5 "Geochemistry and Geological Setting of the Thermal Waters of the Northern Cache Valley Area, Frankl in County, Idaho, Idaho Department of Water Resources Water Inf. Bul1. 30, July 1976. 


\section{APPENDIX $F$ \\ GEOTHERMAL DEVELOPMENT REGION $V$ \\ Northeastern Idaho}

\section{TABLE OF CONTENTS}

Text:

$\underline{\text { Page }}$

INTRODUCTION . . . . . . . . . . . . . . . . . . . . . . . 427

ISLAND PARK AND YELLOWSTONE KGRAS SUB-AREA . . . . . . . . . . 429

MADISON COUNTY SUB-AREA . . . . . . . . . . . . . . . . 442

LEMHI COUNTY SUB-AREA . . . . . . . . . . . . . . . . . . 454

RARE I I CONFLICTS . . . . . . . . . . . . . . . 459

SUMMARY OF LEASING ACTIVITY . . . . . . . . . . . . . . . . 462

REFERENCES ..................... 464

Tables:

Table 1-F, Northeast Idaho, Population by County . . . . . . 428

Table 2-F, Data Summary for Island Park and Yellowstone KGRAs . 432

Table 3-F, Madison County Projections . . . . . . . . . . . 444

Table 4-F, Data Summary for Madison County, Idaho . . . . . . 445

Table 5-F, Data Summary for Lemhi County, Idaho . . . . . . . 455

Table 6-F, RARE II Geothermal Areas . . . . . . . . . . 459

Table 7-F, Leasing Activity . . . . . . . . . . . . . 463 


\section{APPENDIX F}

\section{Geothermal Development Region $V$}

Northeast Idaho

\section{INTRODUCTION}

The Northeast Idaho region encompasses 9 counties: Bonneville, Butte, Clark, Custer, Fremont, Jefferson, Lemhi, Madison, and Teton. The boundaries of this region coincide with the boundaries of the Idaho Falls and Salmon BLM Disiricts and Idaho State Planning Region VI. Three physiographic provinces are evident in the region: the northern intermountain areas, the eastern Snake River Plain, and the Rocky Mountains area. Most of the known regional geothermal occurrences are located in the northern intermounta in area of the Lemhi and Lost River Mountain Ranges and the Island Park area of the eastern Snake River Plain.

The major economic center of this region is Idaho Falls in Bonneville County. Smaller economic centers are Rexburg in Madison County and Salmon in Lemhi County. The principal economic activities are centered in the Snake River Plain near Idaho Falls and Rexburg. The total population of this 9-county region is 114,863 with approximately 86 percent of the population living in the Idaho-Falls-Rexburg growth corridor. See Table 7-F for a 7 ist of county populations for Northeast Idaho. The major emoloyment sectors are government, agriculture, food processing and lumber. Idaho Falls is the center for government research related to the National Reactor Testing Station. The Idaho Falls-Rexburg corridor is the regional center for agricultural activities. St. Anthony and Salmon are centers for logging and milling operations.

Three geothermal areas were examined in the Northeast Idaho Region: the Island Park-Yellowstone KGRA, the Madison County area, and Lemhi County. The majority of the known thermal springs is located in the Island Park area and Lemhi County. Hot springs in the Salmon area have moderate potential for commercial electrical generation. The Madison County area has a large market for direct heat utilization but has undefined resources. The Island Park area has very favorable geological conditions which indicate a geothermal resource, but the area is also considered to be environmentally and politically sensitive. 
TABLE T-F

NORTHEAST IDAHO

POPULATION BY COUNTY

1975

Bonneville

58,123

Butte

3,240

Clark

964

Custer

3,291

Fremont

9,992

Jefferson

13,196

Lemhi

6,395

Madison

17,057

Teton

2,605

Source: County Profiles for Idaho, 1978, (Reference \#1). 
The Island Park and Yellowstone KGRAs are located in Fremont County, and are within the Targhee National Forest. The Island Park KGRA encloses 28,342 acres in the central and western sections of Fremont County. The Yellowstone KGRA enclosed 14,164 acres along the western boundary of Yellowstone National Park. (2)

The total population of Fremont County is approximately 10,000. The principal axis of population and economic activity is along Highway 20 running north and east through the area from Idaho Falls to West Yellowstone, Montana. The communities of Rexburg, St. Anthony, Ashton, Island Park, and West Yellowstone all lie along this route. Twenty-three percent of the county population is classified as rural farm, forty-four percent is rural non-farm and thirty-three percent 7 ive in urban areas. The economy of the area is dependent on farming, potatoes and barley, 1 umber, and recreation. The relative prosperity of the area seems to be improving with a steady increase in per capita income over the last 10 years. The county is projected to have a two percent annual growth rate. (1)

The KGRAs are located at the eastern end of the Snake River Plain. The Island Park area marks a topographic and geologic transition between the Snake River Plain to the west and the Yellowstone Plateau to the east. Both KGRAs are part of the Yellowstone Plateau Volcanic Field. Topography of the area is subdued; elevations range from 1,830 meters to 2,260 meters.

The Yellowstone National Park provides one of the world's greatest displays of geyser and hot springs activity. These phenomena are throught to reflect the presence of a crustal heat source such as a magma body. The main surface geological expression of this magma body is the extensive rhyolite flows and large collapse calderas of Island Park and the Yellowstone Plateau.

The Island Park area is the western portion of the Yellowstone Plateau Volcanic Field. Several cycles of Late Pliocene and Pleistocene volcanism are evident. Eruptions have occurred in cycles beginning two million years ago and ending a few tens of thousands of years ago. Geologically the Island Park area is particularly interesting because of the voluminous sheets of rholitic lava, ash-flow tuff and cyclic caldera collapse, associated with each volcanic cycle. The last recognized occurrence of volcanic activity took place about 70,000 years ago. Although the Island Park area is bounded on the north and east by a very active seismic belt, it is conspicuously aseismic. (3)

So little is known about the geothermal potential of the Island Park and Yel lowstone KGRAs, that it is impossible to evaluate the potential for development. Limited geophysical evidence suggests good drilling possibilities but a general absence of hot or warm springs above $20^{\circ} \mathrm{C}$ (4) suggest a lack of hydrothermal systems. Moderate to high temperature geothermal systems might exist at depth. Permeable fault zones may be encountered at comparatively shallow depths, but the exact nature of a geothermal system in the Island Park and Yellowstone KGRAs. will probably not be known for certain until an exploration drilling program has been completed. 
More than 150 lease applications have been received to explore for geothermal resources in the Island Park area of the Targhee National Forest. (5) The Targhee National Forest is charged with the role of harmonizing geothermal development activities with environmental, social, and economic values within the area. This is a complex task and an environmental impact statement will be prepared prior to issuance of any leases in the Targhee National Forest. Proximity to Yellowstone National Park, critical wildlife habitat requirements, recreational values, and water quality are the major considerations of the environmental statement.

Four major issues which affect geothermal leasing and developments are: designation of protected grizzly bear habitat in the National Forest, designation of roadless areas in the National Forest, access to Harriman State Park, and the continuing residential and commercial development of private lands in the Island Park area. The first two issues pertain to restricting all access to certain areas of the National Forest. The latter two issues are concerned with state and local restrictions to develop on private and state lands. A11 four issues are currently being studied.

A major physical restriction to geothermal development in the Island Park and Yellowstone KGRAs is the characteristically rigorous winter. The severity of the winter is not due so much to prolonged periods of extremely low termperatures, but rather to the presistence of comparatively low temperatures, unsettled weather and frequent snows. Numerous logging roads provide access to remote areas but these roads are often blocked by snow from December through April.

\section{Scenario Projections}

Direct use applications of geothermal. resources in the Island Park KGRA are limited. Present economic development in Fremont County is largely confined to the Rexburg-St. Anthony area. No major industrial activities are located near the KGRA. The major market for direct use of geothermal resources in Island Park is for space heating of homes near Island Park Reservoir. Approximately 600 homes are located in this area. Future industrial development which could occur would be related to the lumber industry. High temperature resources capable of lumber processing could stimulate development of a processing plant on private lands within the KGRA. The Targhee and Gallatin National Forests are currently recovering from a significant insect kill. A large quantity of timber is being salvaged. Annual timber yield from the Targhee National Forest is one hundred and ten million board feet per year. (6) This is an insufficient supply for a major pulp plant but small timber mills are possible.

The thrust of the geothermal interest in the KGRAs is to develop electrica? power capacity. If a significant geothermal resource is discovered, 50 to $550 \mathrm{MW}$ is the realistic range of development that would be allowed.(7). The Island Park KGRA has a greater chance for leasing and development because of its lower environmental sensitivity, better access via logging roads, and the significant amount of private lands within the KGRA.

The Yellowstone KGRA has a low probability for geothermal leasing and development because the area is adjacent to Yellowstone National Park and has a high 
political and environmental sensitivity. Table 2-F is a summary of site specific data regarding the Yellowstone and Island Park KGRAs.

\section{Projections}

Leasing by 1980 , 50 to $100 \mathrm{MW}$ facility by 1995, depending upon geological and environmental conditions, and

Up to a possible 100 to 500 megawatts by 2020 , depending upon resource and environmental factors being favorable.

No direct uses. Insufficient timber supply for pulp. 
TABLE 2-F

DATA SUMMARY FOR THE

YELLOWSTONE AND ISLAND PARK KGRAS, FREMONT COUNTY, IDAHO

SITE LOCATION AND PHYSICAL DESCRIPTION

..Latitude: $44^{\circ} 25^{\prime} 00^{\prime \prime} \mathrm{N}$.

..Longitude: $111^{\circ} 24^{\prime} 00^{\prime \prime} \mathrm{W}$.

- Rectilinear (2):

Island Park: Selected sections in T. 10, 11, 12, N. and R. 42, 43, 44, 45 E. Boise Meridian.

Yellows tone: Sec. $2,3,10,11,14,15,22,26,27,34,35$; in each township; T. $12,13,14 \mathrm{~N}$. and R. $45 \mathrm{E}$. Boise Meridian.

.. County: Fremont.

..Adjacent Counties: Jefferson, Clark, Madison, Teton.

..Topography: Generally subdued; elevations range from between 1,830 meters to 2,260 meters.

..Present Land Use: The major land uses are: timber management, logging, wildlife management, protected habitat recreation.

..Future Land Use Plans: Expansion of roadless areas and wildlife habitat areas.

..Aesthetics: Area is considered one of the most aesthetic areas in the state.

..Geologic Description (8): In very general terms, the Yellowstone and Island Park Known Geothermal Resource Areas lie between two prominent centers of volcanic activity, one still active in the Yellowstone Park area and the other in eastern Idaho now dormant and known as the Island Park Caldera. The Island Park Caldera is an elliptical ring structure 28 by 48 kilometers in diameter that collapsed from the center of a shield volcano composed of rhyolite ash flows of Pleistocene age. The caldera provides a transition to the eastern Snake River Plain graben structure. The western part of the caldera area is well exposed, but the eastern part is completely covered by rhyolite ash flows which extend under the Yellowstone KGRA. These flows are 600,000 years old and emanated from the Yellowstone Park area. The shallow granitic batolith, that was emplaced beneath the Island Park area and responsible for the great outpouring of rhyolite, probably has now solidified. Basaltic volcanism has continued virtually to the present in this area. The source of the basaltic lavas is believed to be from the Upper Mantle. 
In the Yellowstone Park area, the solidification of the shallow granitic batholith has not been completed, and it is for that reason that numerous hot springs and fumaroles and much thermal activity is found in that area. This is in contrast to the Island Park area which has no hot springs. The warmest spring of any kind is a $13^{\circ} \mathrm{C}$ spring in the center of the caldera. It is the close proximity to Yellowstone Park which indicates possible geothermal hot water in the Yellows tone KGRA.

The Yellowstone volcanic field evolved in a region of active extensional tectonism. The principal belt of seismic activity in this portion of the United States passes directly through the Yellowstone Plateau Volcanic Field. The eastern Snake River Plain graben trends northeastward toward the Yellowstone area superimposed on this regional structure which consists of fault blocks bounded by normal and vertical faults. Some minor faulting subparallel to the Snake River fault systems is superimposed on the western rim of the Island Park caldera. Although the Yellowstone area and areas north, east and south of Island Park are part of the very active Intermountain seismic belt, Island Park. is conspicuously aseismic.

..Geologic Hazards (8): The area north of the Yellowstone volcanic plateau area, in the Hebgen Lake area of Montana, has experienced numerous descructive earthquakes in recent times.

1925

1935

1947

1959
6.7 Bozeman, Montana

6.2 Helena, Montana

6.2 Virginia City, Montana

7.1 Hebgen Lake, Montana 
-. Reservoir Temperature (14):

.. Surface: $36^{\circ} \mathrm{C}, 41^{\circ} \mathrm{C}$.

. Subsurface: $120^{\circ} \mathrm{C}, 145^{\circ} \mathrm{C}$.

..Geochemical

.. $\mathrm{SiO}_{2}: 120^{\circ} \mathrm{C}, 145^{\circ} \mathrm{C}$.

.. Na-K-Ca: $85^{\circ} \mathrm{C}, 90^{\circ} \mathrm{C}$.

..Estimated Electric Energy Potential (MWe, 30 years): $550 \mathrm{MW}$.

. Type of Overlaying Rock: Rhyolite, flows, ash and tuff.

..Estimated Depth to Top of Reservoir: 1 to 2 kilometers. 


$\begin{array}{cccc}\begin{array}{c}\text { TOTAL AREA } \\ \text { (Acres) }\end{array} & \text { FEDERAL } & \text { STATE } & \text { PRIVATE } \\ \text { (Acres) } & \text { (Acres) } & \text { (Acres) }\end{array}$

..KGRA: Yellowstone

14,164

14,164

KGRA

Is land Park $\quad 25,539 \quad 25,539$
KGRA

..Land Leased in KGRA: $\quad-0-$

..Tentative Lease Sale Dates: 1979.

..Summary of Leasing Status and Needs: More than 150 separate lease applications have been received to develop geothermal resources in the Island Park area of the Targhee and Gallatin National Forests. No leases have been let on federal lands due to the need for a pre-lease EIS. This statement will be completed by January, 1979. 
..Present Development Status (7) (11): No federal leases have been issued. Over 150 applications have been received for the Island Park and Yellowstone KGRAs. No action will be taken on federal leases until an environmental impact statement has been completed by the Targhee National Forest.

Leases for 12,794 acres have been issued on State of Idaho 1ands to 0ccidental Geothermal Inc. and Warren Barrels.

. Projected or Planned Development (5): The realistic target range being considered by the Targhee National Forest EIS is 50 to 550 megawatts of maximum development. 
.. Federal

Institutional

Requirements

Federal Geotherma?

Resource Lease

(30 C.F.R. 3000)

National Environmental

Policy Act

(42-U.S.C. 4331)

Federal Water Polution

Control Act

(33-U.S.C.A. 1251)

Federal Safe Drinking

Water Act

(42 U.S.C. (A) 300)

..State

Institutional

Requirements

Leases on State lands

(Idaho Code 47-601

et. seq. Chapter 16,

Geothermal Resources)
Agency and

Public Attitudes

Leases are made

pursuant to the

Geotherma 1 Steam

Act of 1970.

(84 Stat. 1566)

(30 USC 1001-1025)

B.L.M.

U.S.G.S.

An EIA is required before leases are issued.

E.P.A.
Status of Requirements (i.e., EIA/EIS Requirements)

Leases within the KGRA are competitive. Special conditions are required in the leases with regard to potential archaeological and historical sites, adjacent roadless areas, and critical habitat areas.

A preliminary EIS is being completed for the exploration and leasing phase. In general an EIA is required for all projects involving exploration and development. An EIS will be required for any major action beyond exploration.

The national goal of this Act is to attain -0- pollution by 1985 .

\section{E.P.A.}

Ground water is included under this Act and the reinjection of geothermal effluent will require permits.

This Act is concerned with protection of underground water sources that could be used for domestic water. E.P.A.

The Act sets standards for wells and well drilling and could influence future geothermal wells.

\section{Status of Requirements \\ (i.e., EIA/EIS Requirements)}

Pubiic Attitudes

The state board of Land Commissioners is authorized to issue leases for geothermal resources underlying state and school lands.
Lease term is 10 years and can be continued with diligent development. Rentals are set by the Board. Several leases have been granted on state lands. Lease size is limited to a maximum of 640 acres/lease. 
..State (continued)

Institutional

Requirements

Geothermal Resource

Permits

(Idaho Code 42-4001

et. seq. Chapter 40,

Geotherma1 Resources)

Water Appropriation

(Idaho Code 42-101

et. seq. Chapter 1,

Water Appropriation)

Injection wells

(Idaho Code 42-3001

et. séq. Chapter 39,

Waste Disposal and

Injection We11s)
. Local

Institutional

Requirements

Fremont County

Comprehensive Plan

Subdivision Ordinance

Building Code
Agency and

Public Attitudes

The regulatory powers of the State Geotherma ' Resource. Act are placed in the Idaho Department of Water

Resources.

The Idaho Department of Water Resources issues water appropriation permits and a water right license.

Permits are issued by the Department of Water Resources.

Status of Requireme (i.e., EIA/EIS Requirements)

Any private owner, or holder of a state or federal lease of geothermal resources must first apply for a geothermal resource permit form I.D.W.R. before any drilling operations can begin.

Under the Idaho Geothermal Resources Act, applicants can be required to make an application to appropriate the public waters of the state.

No waste disposal or injection well can be constructed in Idaho unless a permit has been issued by I.D.W.R. The approval of this permit is contingent upon the approval of the Department of Health and Welfare. The proposed well is reviewed to see if it will unreasonably contaminate or deteriorate the quality of the ground water below the adopted water quality standards of the state.

Agency and Public Attitudes

Fremont County Planning and Zoning Commission
Status of Requirements (i.e., EIA/EIS Requirements)

Special use permits for nonconforming uses are required

Permit to develop a subdivision is required.

Building permits are required. 
..Crimate (10):

..Precipitation (Annual): $507 \mathrm{~cm}$ snow

$73 \mathrm{~cm}$ precipitation

..Days of Sunshire (Annual): 200

..Average Temperature:

January/JuTy

. Minimum: $-16.7^{\circ} \mathrm{C} / 6.0^{\circ} \mathrm{C}$

..Maximum: $\quad-3.6^{\circ} \mathrm{C} / 26^{\circ} \mathrm{C}$

..Degree Days (Annua 7): 10,365.

..Air Quality: High.

..Water Quality: High.

..Noise: Low.

..Elevation: 1,920 meters.

..Biological (12):

..Dominant Flora: Eighty-seven percent of land area is forested; 456,000 acres have as dominant species: lodgepole pine, Douglas fir. The fores $t$ is a Douglas fir-alpine fir climax habitat.

Thirteen percent of land area is open non-forested meadows and grass lands. In 67,000 acres shrubs, grasses and forbes are dominant; as sagebrush, meadow and riparian habitat.

..Dominant Fauna: The main animals of concern are: elk migration, calving and summer range; moose winter and summer and calving range; deer winter, summer and calving range; grizzly bear, den areas, summer and winter range.

...Endangered Species:

..Fauna: The Bald Eagle and grizzly bear are threatened species and habitat areas are critical issues. 
..Utility or Energy Transmission Corridors and Facilities: Power service is limited to the Island Park Reservoir area.

..Transportation Corridors or Facilities: The main trarisportation corridor is U. S. Highway 20, which runs north-south from Rexburg to West Yellowstone, Montana. Numerous logging roads provide access to remote areas. Union Pacific Rail Road service is available at Rexburg, Ashton, Island Park, and West Yellowstone. Track from Ashton to West Yellowstone is in a state of disrepair and is not used. 
Site: Yellowstone and Island Park KGRA

..General Description of Population (1):

..Total population of Fremont County: 10,200.

..Percent Population Change 1970-76: 16.5\%.

..Population Per Square Mile: 5.5

..Percent Population:

..Urban: $33.0 \%$

. Rural Farm: 23.2\%

. Rurar Non-Farm: $44.5 \%$

. Population Centers:

..Ashton:

1,281

..Is land Park: 200

..Newdale: $\quad 300$

..Parker: $\quad 315$

..St. Anthony: 3,260

..Teton: $\quad 500$

..Economics (1): The economy of Fremont County is based on agriculture and timber. Approximately 210,000 acres of Fremont County is agriculturai land. Approximately 400,000 acres of Fremont County is forest 1and. The agricultural economy is centered in the Teton and Rexburg areas of southern Fremont County while the forest industry is centered in St. Anthony. There are 207 business establishments and 3,655 residential housing units in the county. Unemployment is currently $10.2 \%$. 
Madison County has a population of 18,000 and approximately $61 \%$ urban population living in the Rexburg area. Rexburg is located in the growth corridor of northeast Idaho along the southern edge of the eastern Snake River Plain. Rexburg has a population of approximately 11,000 and over 2,000 residential housing units. The growth rate of Rexburg over the last eight years has averaged 24 percent. New housing starts have increased $73 \%$ since 1975 with the Rexburg area recording over 300 new housing units per year. (1). This trend is partically due to growth in the area and reconstruction of flooded areas which were destroyed in the Teton Dam collapse.

Madison County is a major producer of potatoes, barley, oats, sugar beets, and peas. The major crop is potatoes with annual production exceeding 250 million pounds of processed potatoes. Madison County produces over 3,830,000 cwt. of potatoes per year. (14) A major portion of these potatoes are exported for processing and fresh market sales.

The major industries are Rogers Foods Inc. and Sun Glow which are potato processing plants. The major non-industrial business in Madison County is Ricks College. Located in Rexburg, Ricks College has a full-time enrollment of 6,000 and over one million square feet of floor space.

Geologically, the Rexburg area 1 ies in the center of a ring structure which appears to be a caldera complex similar to the Island Park area but without extensive rhyolitic formations. Dacite cones do exist southwest of the city along the endge of the ring structure. The area is part of the Snake River Plain physiographic province and located 80 kilometers southeast of the geothermal activity in Yellowstone National Park. The caldera formation is buried by basalts and sediments of the Snake River Plain. Hot springs of the area appear to be related to this caldera structure. Landstat photos, and recent gravity and magnetic data from the U. S. Geological Survey indicate a sizeable caldera structure centered around the city of Rexburg. (15) Hot springs in the area have surface temperatures of $44^{\circ} \mathrm{C}$. (1)

Fault structures in the area show two major trends. Rexburg is built on the east-west trending fault boundary that marks the southern margin of the Snake River Plain and the north-south trending fault boundary of the Rocky Mountains overthrust belt.

Heat flow studies conducted by Idaho Department of Water Resources indicate twice the normal heat flow from the general area. Probably resources depths indicated for the area 1,000 to 1,200 meters for $90^{\circ} \mathrm{C}$ to $100^{\circ} \mathrm{C}$ temperatures, and 2,000 meters for $150^{\circ} \mathrm{C}$ temperatures. (16)

With these resources temperatures a number of direct use applications could be possible. Rogers Foods Inc. is a major potato processing plant. A major processing function of this plant is dehydration of potatoes. A geothermal resources of $120^{\circ} \mathrm{C}$ could provide 40 to 50 percent of the direct heat energy needs of this plant. The present forms of energy used by Rogers Foods are $0 i 1$ and natural gas. The annual energy need of the company is approximately $230 \times 10^{9}$ BTU/year. (17) Rogers Foods plans to expand its plant by $30 \%$ in the next two years. 
Ricks College has a coal-fired steam/water heating system. The feasibility of conversion to geothermal resources will depend on the water temperature of the resource. A resource of greater than $100^{\circ} \mathrm{C}$ would allow a straight forward retrofit conversion. The annual heat loads of Ricks College are approximately $100 \times 109$ BTU/year.

The City of Rexburg is located between Rogers Foods and Ricks College. The business district and residential area are closely grouped adjacent to the College campus. The estimated annual heat energy needs of Rexburg are approximately $400 \times 109$ BTU/year. The central business district and the residential areas adjacent to the campus are a compact grouping which would be an ideal target for a district heating system.

\section{Projections}

Successful development ventures in Madison County will depend upon deep exploratory drilling proving the resource. Table $3-F$ is a list of estimated geothermal energy development that could be possible by 1985 providing exploration began in 1978 and provide the resource. Table 4-F is a summary of site specific data regarding the Madison County Sub-Area. 
TABLE 3-F

MADISON COUNTY PROJECTIONS

Industrial:

Rogers Foods Inc.

$200 \times 10^{9}$ BTU/year by 1985

Space Heating:

Business and Residential $400 \times 10^{9}$ BTU/year by 1985

Ricks College

$100 \times 10^{9}$ BTU/year by 1985 
.. Latitude: $43^{\circ} 49^{\prime} 00^{\prime \prime} \mathrm{N}$.

.. Longitude: $111^{\circ} 47^{\prime} 00^{\prime \prime} \mathrm{W}$.

..Rectilinear: T. 6 N., R 40 E., Boise Meridian.

... County: Madison.

..Adjacent Counties: Bonneville, Jefferson, Fremont, Teton.

..Topography: Rexburg lies at the border of the Snake River Plain with part of the town built on the up thrusted boundary to the south. Moderate slopes are found south of Rexburg near Ricks College. To the north and southwest is the broad expanse of the almost level Snake River Plain.

..Future Land Use Plans: Continuation of present land uses and expansion of the potato crop.

. Aesthetics: Area is highly aesthetic rural agricultural area.

..Historical/Archaeological Significance: Several historical buildings are located in Rexburg and at Ricks College.

.Geologic Description (1) (16): The city of Rexburg is built across a major east-west trending structure which is related to the southern border of the Snake River Plain. The eastern Snake River Plain is considered a downfaulted structure or graben. The north half of the city lies in the flood plain of the Teton River. The south half of the city is built on the up thrusted boundary that marks the westerm extreme of what is commonly called the Northern Rockies Thrusted Zone. Yellowstone and Island Park calderas are located 80 kilometers to the northeast. Lithologies are dominated by basalts and rhyolite ash from the Yellowstone and Island Park systems.

. Geophysical Summary (15) (16): Recent gravity data has identified what is being designated as the Rexburg caldera complex. The caldera is buried by the volcanic rocks and alluvium of the Snake River Plain. A strong circular gravity low is identifiable on a regional gravity high.

Normal regional heat flow of the Snake River Plain is $3 \mathrm{HFU}$, the heat flow values for the Rexburg area are $4 \mathrm{HFU}$.

Temperature and depth estimates from heat fiow values range from $100^{\circ} \mathrm{C}$ at depths of 1,000 to 1,500 meters and $150^{\circ} \mathrm{C}$ at depths of 1,500 to 2,000 meters. 


\section{RESERVOIR CHARACTERISTICS}

.. Reservoir Temperature (1):

.. Surface: $44^{\circ} \mathrm{C}$.

..Subsurface: $100^{\circ} \mathrm{C}$ to $150^{\circ} \mathrm{C}$ estimated from heat flow.

...Geochemical: $\mathrm{SiO}_{2} 120^{\circ} \mathrm{C}$.

..Escimated Nonelectric Energy Potential (BTU Per Year): $800 \times 10^{9}$ 
.. Site Land Status

. Madison County

FEDERAL STATE PRIVATE OTHER

Total Acres

(Acres)

(Acres)

(Acres)

(Acres)

$60,351 \quad 45,591 \quad 194,818 \quad 1,860$

Total Acres

Leased

666 Unknown

4.00 
..Present Development Status (18): Madison County, Ricks College and Rogers Foods Inc. are actively seeking federal support for exploration drilling. The purpose of geothermal development would be to convert Ricks College and Rogers Foods from natural gas and coal.

..Projected or Planned Development (1):

..Projected Development: Seventy to one hundred percent conversion of Rogers Foods. Inc. One hundred percent conversion of Ricks College. Thirty to forty percent conversion of Rexburg business district and residential areas near Ricks College.

. Total Projected Geothermal Energy Use: $700 \times 10^{9}$ BTU/year. 
..Federal

Institutional

Requirements

National Environmental

Policy Act

(42-U.S.C. 4331)

Federal Water Pollution

Control Act

(33-U.S.C.A. 1251)

Federal Safe Drinking Water Act

(42 U.S.C. (A) 300)
Agency and

Public Attitudes

E.P.A.

The national goal of this Act is to attain -0- pollution by 1985.

E.P.A.

This Act is concerned with protection of underground water sources that could be used for domestic water. E.P.A.
Status of Requirements (i.e., EIA/EIS Requirements)

An EIS could be required for injection.

Ground water is included under this Act and the reinjection of thermal effluent will require permits.

The Act sets standards for wells and well drilling and could influence future geothermal wells. The upper aquifer of the basin is the supply of domestic and irriwater for the area. Reinjection of water for geothermal wells will require permits under this Act.

..State

Institutional

Requirements

Leases on State lands

(I daho Code 47-601

et. seq. Chapter 16,

Geothermal Resources)

Geothermal Resource

Permits

(Idaho Code 42-4001

et. seq. Chapter 40, Geotherma 1 Resources)

Water Appropriation (Idaho Code 42-101 et. seq. Chapter 1, Water Appropriation)
Agency and

The State Board of Land Commissioners is authorized to issue leases for geothermal resources underlying state and school lands.

The regulatory powers of state Geotherma 1 Resource Act are placed in the Idaho Department of Water Resources.

The Idaho Department of Water Resources issues water appropriation permits and a water right license.
Public Attitudes

\section{Status of Requirements (i.e., EIA/EIS Requirements)}

Lease term is 10 years and can be continued with diligent development. Rentals are set by the board. Several leases have been granted on state lands. Lease size is limited to a maximum of 640 acres/lease.

Any private owner, or holder of a state or federal lease of geothermal resources must first apply for a geothermal resource permit from I.D.W.R. before any drilling operations can begin.

Under the Idaho Geothermal Resources Act, applicanis can be required to make an application to appropriate the public waters of the state. 
..State (continued)

Institutional

Requirements

Injection wells

(Idaho Code 42-3001

et. seq. Chapter 39,

Waste Disposal and

Injection Wells)
Agency and Public Attitudes

Permits are issued by the Department of Water Resources.
Status of Requiremen (i.e., EIA/EIS Requirements)

No waste disposal or injection well can be constructed in Idaho unless a permit has been issued by I.D.W.R. The approval of this permit is contingent upon the approval of the Department of Health and Welfare. The proposed well is reviewed to see if it will unreasonable contaminate or deteriorate the quality of the ground water below the adopted water quality standards of the state.

..Loca1: Madison County has no local planning. 
..Climate (10):

.Precipitation (Annual): $137.6 \mathrm{~cm}$ snow

$28.5 \mathrm{~cm}$ precipitation

..Days of Sunshine (Annual): 300

..Average Temperature:

January/JuTy

..Minimum: $-13 / 9^{\circ} \mathrm{C} / 8.61^{\circ} \mathrm{C}$

..Maximum $12.5^{\circ} \mathrm{C} / 30^{\circ} \mathrm{C}$

..Degree Days (Annual): 8,221

..Relative Humidity (Seasonal Peaks):

..Summer: 30

..Winter: 70

..Air Quality: High.

..Water Quality: High.

..Noise: Low.

..Geologic Factors: Periodic flooding.

..Elevation: 1,490 meters. 
..Utility or Energy Transmission Corridors and Facilities: Natural gas service at Rexburg, operatured by Intermountain Gas Co.

. Transportation Corridors or Facilities: Junction of Idaho Highway 30 and $U$. S. Highway 20 is located in Rexburg.

Railroad service at Rexburg operated by Union Pacific Railroad Co. 
..General Description of Population (1):

..Population of Madison County: 18,000 (approximate).

- Major Urban Centers:

. Rexburg, population approximately 11,000.

.. Sugar City, population approximately 800 .

..Percentage Change in Population 1970-76: 16.5\%.

..Population Per Square Mile: 38.1 .

..Percent Population:

..Urban: $61.5 \%$

. Rural Farm: $16.6 \%$

. Rural Non-Farm: $18.1 \%$

..Housing Units: 3,175 .

..New Housing Starts: Rexburg (1976): 276.

..Economics (1): The economy of the area is dependent on agriculture, food processing and Ricks College.

..Percent of Average Unemployment (1976): 10\%

. Total Employment: 5,760

. Total Assessed Valuation (1976): $\$ 24,805,711$

..Median Family Income (1976): $\$ 11,375$

..Number of Business Establishments: 280

..Percent of Families Below Poverty Level: $8 \%$ 
Lemhi County is located along the Idaho-Montana border in northeastern Idaho. The county is a remote rugged mountainous area which supports a population of approximately 6,500. The major population center is Salmon, population 3,200. Over 90 percent of this county's Tand area is owned by the federal government. The major land owner is the National Forest, which controls 78 percent of the 1 and area. There are approximately 2,300 housing units in the county with the majority of these units located in Salmon. Salmon is a major lumber center and supports two lumber mills. The county's major economic activities are farming, logging, and lumber. The fastest growing industry is recreation. (1) The major transportation routes are U. S. Highways 93 and 28 which run northsouth from Salmon to the Snake River Plain.

The geology of the area is dominated by the Beaverhead Mountain Range of the Rocky Mountains to the northeast and the fault block mountains of the Lemh $i$ Range to the southwest. The Lemhi Range is a major northwest trending mountain range which is part of a series of northwest trending fault structures which form the eastern flank of the interior Sawtooth Mountains. Hot springs in this area are isolated, but do occur along a northwest trending curvilinear feature which parallels the regional structure of the faulted mountains. Surface temperatures range from $45^{\circ} \mathrm{C}$ to $93^{\circ} \mathrm{C}$. (4) Quartz and sodium-potassiumcalcium geochemical thermometers show a range of temperatures from $85^{\circ} \mathrm{C}$ to $250^{\circ} \mathrm{C}$. (4) The four major thermal springs are all located on federal land; three are on BLM lands and one is on National Forest lands.

Three of the hot springs have limited commercialization potential for electrical generation providing adequate temperatures and flow rates can be developed. The three hot springs are: Big Creek, Salmon, and Sharkey Hot Springs The three sites are considered developable based on moderate topography, and indicated aquifer temperatures based on geochemical thermometers. Table 5-F is a summary of the known reservoir data concerning these three springs. 
TABLE 5-F

DATA SUMMARY FOR LEMHI COUNTY

RESERVOIR CHARACTERISTICS

Site: Salmon Hot Springs: Sec. 3, T. 20 N., R. 22 E., Boise Meridian.

..Reservoir Temperature (1):

..Surface: $45^{\circ} \mathrm{C}$.

.. Subsurface:

. Geochemical (1):

.. $\mathrm{SiO}_{2}$ : $80^{\circ} \mathrm{C}$.

. Na-K-Ca: $205^{\circ} \mathrm{C}$.

..Flow Rates: $145 \mathrm{gpm}$, from three springs.

..pH: 6.3 .

..Total Dissolved Solids: 649.

..Fluid Chemistry:

$$
\begin{aligned}
& \text {..Si: } \quad 33 \\
& \text {..Ca: } 23 \\
& \text {...Mg: } \quad 11 \\
& \text {..Na: } 190 \\
& \text {.. K: } 28 \\
& \text {.. } \mathrm{HCO}_{3}: 565 \\
& . . \mathrm{CO}_{3} \stackrel{0}{=} 0 \\
& \text {..SO4: } 34 \\
& \text {..P: } \quad .04 \\
& \text {..C1: } 50 \\
& \text {..F: } \quad 1.8 \\
& \begin{array}{ll}
. \mathrm{NO}_{3}: \quad .03 \\
\hline
\end{array}
\end{aligned}
$$

..Geological: Springs are venting from the contact between 01 igocene and underlying tuffaceous rocks. Springs appear to be structurally controlled by a northwest trending fault.

..Environment: The springs are located 12 kilometers south of Salmon, Idaho in an area of moderate slope.

..Elevation: 1,524 meters (approximate).

..Estimated Energy Potential: $50 \mathrm{mw}$.

..Projected Development Date: 2020. 
Site: Big Creek Hot Springs, Lemhi County: Sec. 22, T. 23 N., R. 18 E., Boise Meridian.

. Reservoir Temperature (1):

. Surface: $82^{\circ} \mathrm{C}$ to $93^{\circ} \mathrm{C}$.

. Geochemical:

.. $\mathrm{SiO}_{2}: 160^{\circ} \mathrm{C}$.

.. Na-K-Ca: $175^{\circ} \mathrm{C}$.

..Flow Rates: $75 \mathrm{gpm}$, from fifteen vents.

..pH: 7.5 .

. Total Dissolved Solids: 727 (mg/litre).

..Fluid Chemistry (1): (mg/litre)
Si: $\quad 150$
Ca: $\quad 5.3$
$\mathrm{Mg}: \quad 0.2$
$\mathrm{Na}: \quad 220$
K: $\quad 14$
$\mathrm{HCO}_{3}: \quad 488$
$\mathrm{CO}_{3}: \quad 0$
$\mathrm{SO}_{4}: \quad 53$
P: $\quad 0.05$
Cl: $\quad 29$
F: $\quad 15$
$\mathrm{NO}_{3}: \quad 0.07$

..Geological: Springs venting from altered Cretaceous granitic rocks with possible fault linears in the immediate area. Springs are located in the Salmon River Canyon.

..Environment: Development of this hot spring must consider the environmental sensitivity of the Salmon River which is a major recreation area and a protected fishery habitat.

..Elevation: 1,634 .

..Estimated Energy Potential: $50 \mathrm{mw}$.

..Projected Development Date: 2020.

..Critical Issue: Area is located within a RARE II study area. 
Site: Sharkey Hot Springs, Lemhi County: T 20 N., R. 24 E., Sec. 34, T 20 N., R 24 E., Boise Meridian.

$$
\begin{gathered}
\text {..Reservoir Temperature (1): } \\
\text {..Surface: } 52^{\circ} \mathrm{C} . \\
\text {. Geochemica } 1(1): \\
\text {. SiO2: } 135^{\circ} \mathrm{C} . \\
\text {. Na-K-Ca: } 175^{\circ} \mathrm{C} \text {. }
\end{gathered}
$$

.Flow Rates: $8 \mathrm{gpm}$.

..pH: 7.4 .

..Total Dissolved Solids: 840 (mg/litre).

. Fluid Chemistry (1): (mg/litre)

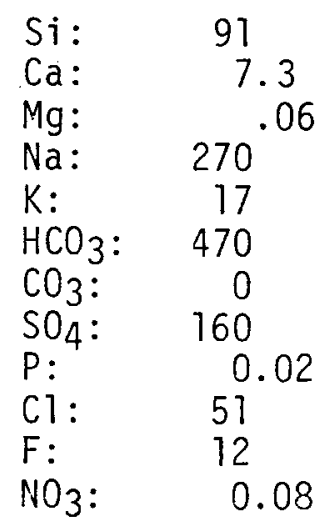

..Geological: Spring is venting from 0ligocene silicic volcanic rocks and is probably structurally controlied by a northwest trending fault, which is found along the base of the Beaverhead Range.

..Topography: Springs are located in an area of moderate topographic relief along the foot of the Beaverhead fault scarp.

... Elevation: 1,691 meters.

...Estimated Energy Potential: $50 \mathrm{mw}$.

..Projected Development Date: 2020. 
Site: Lemhi County, Idaho.

..Climate (10): At Salmon, Idaho.

.Prevailing Winds: $\mathrm{N}-\mathrm{S} 10$ to $20 \mathrm{mph}$, gusting up to 60 .

..Precipitation (Annual): $417 \mathrm{~cm}$ snow

$51 \mathrm{~cm} \cdot$ precipitation

..Days of Sunshine (Annual): 290.

..Average Temperature:

January/July

..Minimum $-14.2^{\circ} \mathrm{C} / 8.3^{\circ} \mathrm{C}$

. Maximum $-7.2^{\circ} \mathrm{C} / 37.5^{\circ} \mathrm{C}$

.. Degree Days (Annual): 7,070.

..Relative Humidity (Seasonal Peaks):

.. Summer: 30

..Winter: 70

...Air Quality: Generally high.

..Water Quality: Generally high, thermal springs do have high flouride.

..Noise: Low.

..Elevation: 1,232 meters. 
Northeastern Idaho has several RARE II areas which have valuable or potentially valuable geothermal resources. Those RARE II areas of greatest concern are located in Fremont County and Lemhi County, where prospects of a commercial geothermal resource are greatest. Table $6-\mathrm{F}$ 1 ists by county the geothermal areas of northeastern Idaho which are located with in or adjacent to RARE II study areas.

TABLE 6-F

RARE II GEOTHERMAL AREAS

Clark County:

Warm Springs Hot Springs

Location: $\quad$ Sec. 25, T. 11 N., R 32 E., Boise Meridian.

Discharge: $\quad 1,920 \mathrm{gpm}$.

Temperature: $\quad 29^{\circ} \mathrm{C}$.

Aquifer Estimate: $60^{\circ} \mathrm{C}$.

RARE II AREA: \#4945, Intalan Peak (Salmon National Forest).

Moderately high geothermal potential.

Area should be studied as to its geothermal potential as part of RARE II.

Custer County:

1. Sunbeam Hot Springs

Location: $\quad$ Sec. 19, T. 11 N., R. 15 E., Boise Meridian.

Disçharge: $\quad 444 \mathrm{gpm}$.

Temperature: $\quad 76^{\circ} \mathrm{C}$.

Aquifer Estimate: $130^{\circ} \mathrm{C}$.

RARE II AREA: \#4551, White Cloud Boulder (Chall is National Forest).

Area has moderate geothermal energy potential.

Areas around springs should be studied.

2. Slate Creek Hot Springs

Location: $\quad$ Sec. 30, T. 10 N., R. 16 E., Boise Meridian.

Discharge: $\quad 185$ pgm.

Temperature: $\quad 50^{\circ} \mathrm{C}$. 
2. Slate Creek Hot Springs (continued)

Aquifer Estimate: $130^{\circ} \mathrm{C}$.

RARE II AREA: \#4551, White Cloud Boulder (Sawtooth National Forest).

Area around spring should be studied for its geothermal energy potential.

\section{Fremont County}

A11 RARE II Areas in Fremont County should be examined as to their geothermal energy potential.

The following RARE II Areas are potentially within the Yellowstone and Island Park KGRAs. (Targhee National Forest).

$\begin{array}{ll}\# 4605 & \text { Headwaters Buffalo River } \\ \# 4606 & \text { Warm River North } \\ \# 4607 & \text { Warm River South } \\ \# 4608 & \text { Warm River East } \\ \# 4609 & \text { Snake River }\end{array}$

Other areas with possible geothermal potential:

\#4603 Reynolds Pass

\#4604 Two Top

\#4962 Mount Jefferson

Lemhi County

1. Big Creek Hot Springs

Location: $\quad 23 \mathrm{~N}$ T $18 \mathrm{E} \mathrm{Sec} .22$.

Discharge: $\quad 75 \mathrm{gpm}$.

Temperature: $\quad 93^{\circ} \mathrm{C}$.

Aquifer Estimate: $160^{\circ} \mathrm{C}$ to $170^{\circ} \mathrm{C}$.

RARE II Areas: \#4506, Jureano; \#4501 Napoleon Ridge (Salmon National Forest).

Big Creek is not in RARE II Area but nearby.

High geothermal potential in this area should be considered in all RARE. II Areas adjacent to Big Creek Hot Springs.

2. No Name

Location: $\quad 16 \mathrm{~N} 21 \mathrm{E}, \mathrm{Sec} .18$.

Discharge: $\quad 20 \mathrm{gpm}$. 
2. No Name (continued)

Temperature: $\quad 46^{\circ} \mathrm{C}$.

Aquifer Estimate: $85^{\circ} \mathrm{C}$ to $165^{\circ} \mathrm{C}$.

RARE II AREA: \#4204 Grouse Peak (Challis National Forest).

Moderately high geothermal energy potential.

Area should be studied as to its geothermal energy potential. 
Leasing activity in Northeastern Idaho is concentrated along the margins of the Snake River Plain. Lease sales in the Island Park and Yellowstone KGRAs are awaiting an environmental report by the Targhee National Forest. Fremont County has the greatest amount of land leased and the largest number of leases pending. No leasing activity has occurred in Lemhi, Custer, and Butte Counties despite the fact that these areas do indicate geothermal potential. This lack of leasing interest is in part due to a lack of information and in part due to the environmental sensitivity of the RARE II issue. Table 7-F is a list of leasing activity in Geothermal Development Region V, Northeastern Idaho. 
..Federal Leasing Activity:

..Bonneville County:

$$
\ldots 2,560 \text { acres - U.S.F.S. Lease - near Palisades. }
$$

..Clark County

. 1,246 acres - B.L.M. Lease - near Liddy Hot Springs.

..Fremont County: Over 150 lease applications are pending, awaiting the final Island Park and Yellowstone KGRAs environmental impact statement.

.. State Leases:

..Bonneville County: 2,489 acres.

..Clark County: 2,553 acres.

..Fremont County: 12,794 acres.

..Madison County: 666 acres. 


\section{REFERENCES}

(1) Idaho Division of Budget, Policy Planning and Coordination, County Profiles of Idaho, 1978, State of Idaho, Office of the Governor.

(2) Memorandum: To the State Director of Idaho BLM, Boise, Idaho; from the Conservation Manager, Western Region USGS; Subject: Definition and Description of Is land Park KGRA and Yellowstone KGRA, March, 1975.

(3) Christiansen, R. L., Origin and Geothermal Potential of Island Park, Eastern Idaho: Geological Soc. of America Abstracts with Programs, Vol. 7, No. 5, 1975, p. 595-597.

(4) Young, H.W. and J. C. Mitche11, Geothermal Investigations in Idaho Part I, "Geochemistry and Geological Setting of Selected Thermal Water", Idaho Dept. of Water Resources, Water Inf. Bul1. 30, 1973.

(5) Bealand, Micky, Targhee National Forest, personal communications, Apri1, 1978.

(6) Bealand, Micky, Targhee National Forest, personal communications, October, 1978.

(7) Bealand, Micky, Targhee National Forest, personal communications, July, 1978.

(8) Christiansen, R. L., Quarternary and Pliocene Vulcanism of the Yellowstone Plateau Region of Wyoming, Idaho, and Montana. Unpublished manuscript, 1975.

(9) Smith, R. B. and M. L. Sbar, Contemporary Tectonic and Seismicity of the Intermountain Seismic Belt: Geological Soc. America Bu11., Vol. $85,1974$.

(10) N.O.A.A., Climatological Data, Idaho, 1978: U. S. Dept, of Commerce.

(11) Idaho Dept. of Lands, Geothermal Lease Files, 1975.

(12) McGee, John M., Biologist, Targhee National Forest, personal communications, October, 1978.

(13) Howard, Richard, U. S. Fish and Wildlife Service, personal communications, February, 1978.

(14) Idaho Crop and Livestock Reporting Service, Idaho Agricuitural Statistics, 1977, Idaho Dept. of Agriculture, Boise, Idaho, 1978.

(15) Mabey, D. R., U. S. Geol. Survey Open File Report 78-382, 1978.

(16) Brott, C. A., D. D. Blackwe11, and J. C. Mitche11, Geothermal Investigations in Idaho, Part 8, "Heat Flow Study of the Snake River Plain Region, Idaho", Idaho Dept. of Water Resources, Water Inf. Bul1. 30, 1976. 
(17) Ornum, Joel Van, Industrial Waste Heat for Adjacent Communities and Industrial Applications, Rocket Research Co., Report RRC-78-H-181, Pacific Northwest Regional Commission, December, 1977, p. 29-50.

(18) Pennock, Robert E., Rodgers Foods, personal communications, July, 1978. 